

\section{REVISTA BRASILEIRA DE POLÍTICAS PÚBLICAS}




\section{REVISTA BRASILEIRA DE POLÍTICAS PÚBLICAS \\ Brazilian Journal of Public Policy}

Programa de Mestrado e Doutorado em Direito do UniCEUB

Centro Universitário de Brasília

Reitor

Getúlio Américo Moreira Lopes

Presidente do Conselho Editorial do UniCEUB

Elizabeth Regina Lopes Manzur

Diretor do ICPD

João Herculino de Souza Lopes Filho

Coordenador do Programa de Mestrado e Doutorado e Editor

Marcelo Dias Varella

\section{Linha editorial}

A Revista Brasileira de Políticas Públicas tem como finalidade constituir instrumento de veiculação de trabalhos científicos e doutrinários relacionados a aspectos ligados a interação entre Políticas Públicas e Direito. Direciona, portanto, seu objeto de interesse a questões referentes a governabilidade, integração, participação cidadã, desenvolvimento e outros temas envolvendo o Estado, a Sociedade e o Direito. Sendo assim, a proposta de linha editorial a ser seguida pela Revista Brasileira de Políticas Públicas é apresentada a partir de três áreas fundamentais, que se subdividem:

1. Políticas de Estado e de Governo e democracia: teoria das políticas públicas, sistema de governo, sistema eleitoral e cidadania, sistema de partidos e reforma constitucional.

2. Políticas Públicas e desenvolvimento econômico e social: políticas de desenvolvimento econômico e produção local/regional, desenvolvimento sustentável e meio-ambiente, desenvolvimento humano e planejamento da ação governamental.

3. Avaliação em políticas públicas: teorias de avaliação em políticas públicas, metodologia de avaliação de políticas públicas e políticas de desenvolvimento, metodologia de analise jurídica de políticas públicas, resultados de analise em políticas públicas, pesquisa em políticas públicas setoriais.

\section{Comitê editorial}

Marie-Pierre Lafranchi, Université d'Aix-en-Provence, França

Frederico Augusto Barbosa, Centro Universitário de Brasília, Brasil

Gilberto Bercovici, Universidade de São Paulo, Brasil

João Maurício Adeodato, Universidade Federal de Pernambuco, Brasil

Jose Adercio Leite Sampaio, Escola Superior Dom Helder Câmara-PUC-MINAS, Brasil

\section{Equipe editorial}

Marcelo Dias Varella

Alice Rocha da Silva

Max Meirelles Gonzaga

Priscila Pereira de Andrade

Layout capa

Departamento de Comunicação / ACC UniCEUB

\section{Diagramação}

S2 Books

\section{Disponível em:}

http://www.rbpp.uniceub.br

\section{Circulação}

Acesso aberto e gratuito

Matérias assinadas são de exclusiva responsabilidade dos autores.

Citação parcial permitida com referência à fonte. 
Revista Brasileira de Políticas Públicas / Programa de Mestrado e Doutorado em Direito do UniCEUB. - vol. 5, n. 3 (jul./dez. 2015) - . Brasília : UniCEUB, 2011

Semestral.

ISSN 2236-1677

Disponível também on-line: www.rbpp.uniceub.br

1. Direito. 2. Políticas Públicas. I. Programa de Mestrado e Doutorado em Direito do UniCEUB

CDU $34+338.26$

Ficha catalográfica elaborada pela Biblioteca Reitor João Herculino 
Crimes de responsabilidade do Presidente da República.............................................. 2 Carlos Ayres Britto

1. A matriz constitucional do tema 2

2. O vínculo operacional lógico entre a Constituição e as matérias veiculadas pelos incisos de I a VII do art. 85 dela própria .................................................................................................................. 3

3. A unidade incindível do artigo constitucional de $\mathrm{n}^{\mathrm{o}}$. 85 e respectivos incisos ................................ 3

4. A democracia como substrato ideológico da unidade incindível do artigo constitucional de $\mathrm{n}^{\circ} .85 \mathrm{e}$

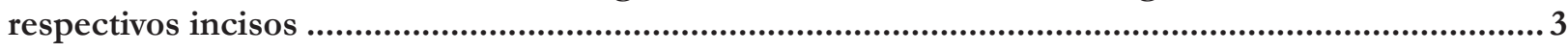

5. A ordem constitucional como o próprio bem jurídico a proteger pela norma incriminadora do art. 85

6. A natureza própria do crime de responsabilidade do Presidente da República, inconfundível com a de qualquer outro ato infracional.....

7. O inteiro significado técnico dos atos constitutivos dos crimes de responsabilidade do Presidente da República 4

8. O necessário pressuposto do mandato fluente, cuidando-se de crimes de responsabilidade do Presidente da República 6

9. A referência constitucional a uma lei de natureza especial, na matéria ..........................................6

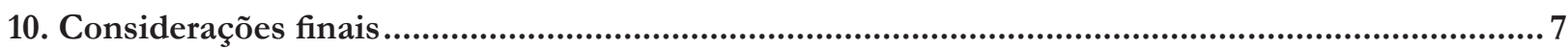

Perda de mandato parlamentar por forÇa de CondenaÇão Criminal na JURisprudênCia do Supremo Tribunal Federal............................................................................ 9

José Levi Mello do Amaral Júnior

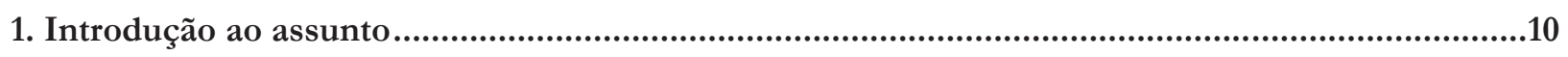

2. Condenação criminal e perda de mandato parlamentar no caso mensalão.....................................10

3. Condenação criminal e perda de mandato parlamentar no caso Donadon.....................................11

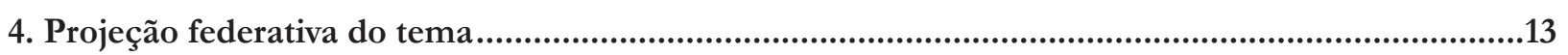

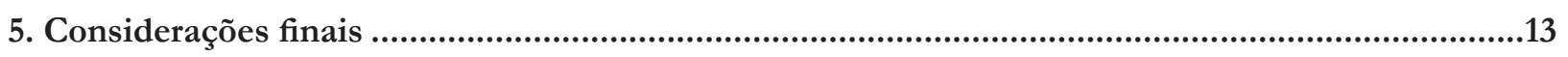

Poder NORMATIVo dAs cortes constitucionais: o CASO BRASILEIRo..................................16 Inocêncio Mártires Coelho

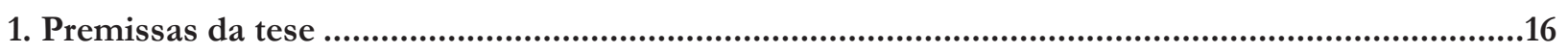

2. O poder normativo da jurisdição constitucional .........................................................................16

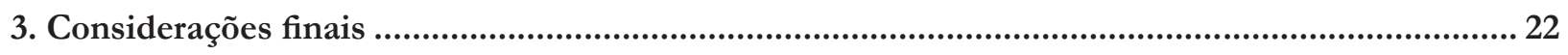

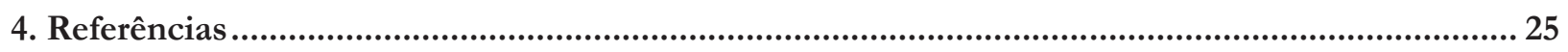


José Levi Mello do Amaral Júnior

1. Municípios na forma federativa de estado brasileira ...................................................................29

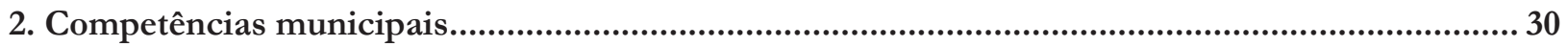

3. A lei municipal no sistema de fontes brasileiro............................................................................. 30

4. A lei orgânica municipal: constituição do Município .........................................................................31

5. Fases da elaboração da lei municipal ................................................................................................31

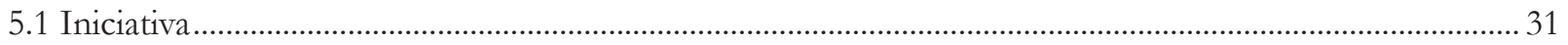

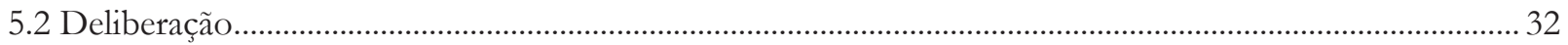

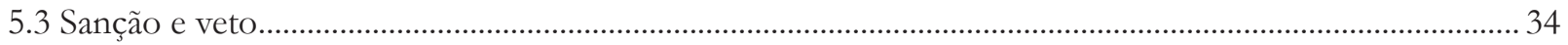

5.4 Promulgação e publicação............................................................................................................................ 34

6. Espécies legislativas no processo legislativo municipal................................................................ 35

7. Considerações finais ............................................................................................................................ 37

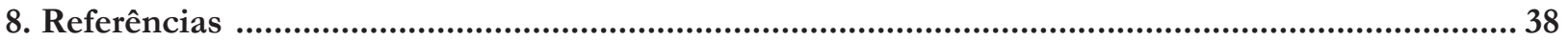

Primeiras linhas Sobre a opÇão POlítico-CRIMINAL da DESERÇão Militar: A NECESSÁRIA CON-

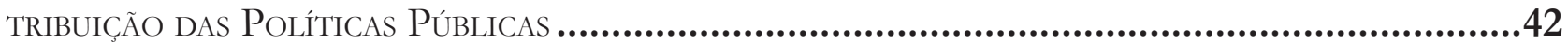

Antonio Henrique Graciano Suxberger e Danilo Gustavo Vieira Martins

1. Intrudução. 43

2. O Direito e sua consideração pelas políticas públicas 45

3. A peculiar conformação dos atores de políticas públicas .......................................................... 46

4. Deserção e sua incidência na justiça militar da união ..................................................................... 48

5. A abertura de novos caminhos pela política criminal..........................................................................51

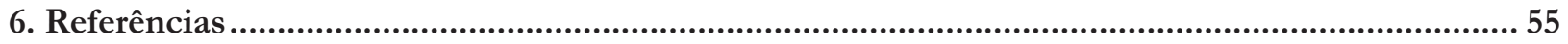

IMPLICAÇÕES DO DIREITO AO VOTO AOS IMIGRANTES: AMEAÇA À SOBERANIA NACIONAL OU EFETIVAÇÃO DE UM DIREITO FUNDAMENTAL? .......................................................................58 Juliana Cleto

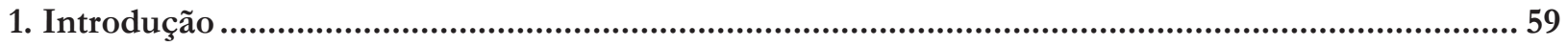

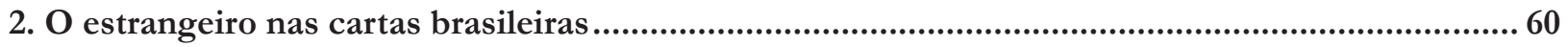

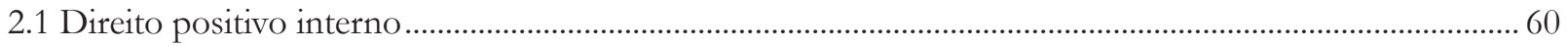

3. A relevância da participação política do estrangeiro no estado democrático de direito ................. 62

3.1 O voto como direito humano fundamental e expressão do povo .................................................................. 63

3.2 Participação política para uma democracia participativa ................................................................................ 64

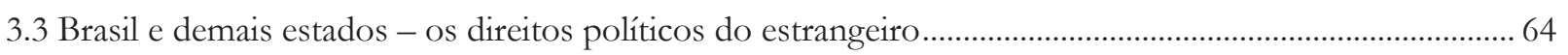

4. Implicações do exercício do voto pelo estrangeiro - direito fundamental ou ameaça? ................. 69

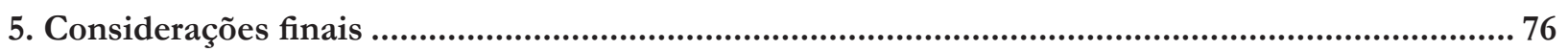


1. Introducción 82

2. Metodología 84

3. Resultados 90

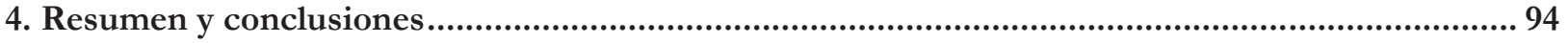

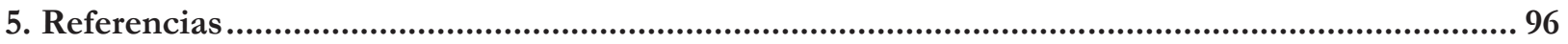

O IMPACTO DE DIFERENTES TIPOS DE REPRESSÃO LEGAL SOBRE AS TAXAS DE HOMICÍDIO ENTRE OS ESTADOS BRASILEIROS .................................................................................. 100

Adolfo Sachsida, Mário Jorge Cardoso de Mendonça e Tito Belchior Silva Moreira

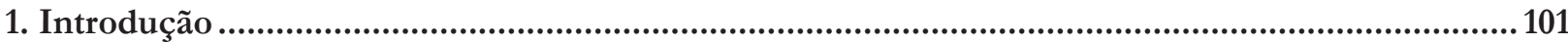

2. Base de dados e evolução da violência ....................................................................................102

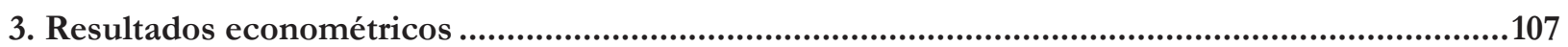

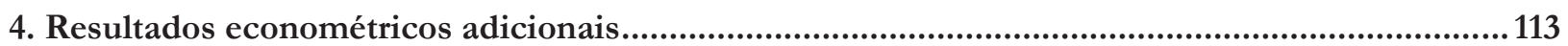

5. Efeitos da mudança na legislação da lei de combate as drogas de 2006 ......................................118

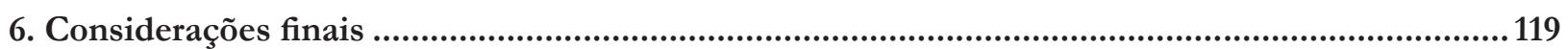

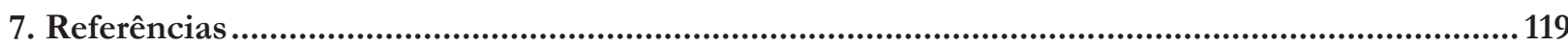

Análise dos impactos diretos e indiretos do Programa de P\&D da ANEEL no setor ELÉTRICO: DIFERENÇAS COM OS EUA.................................................................. 124 Igor Polezi Munhz, Alessandra Cristina Santos Akkari e Neusa Maria Bastos Fernandes dos Santos

1. Introdução

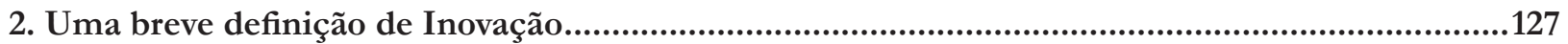

2.1 Panorama da inovação tecnológica no Brasil ............................................................................................. 127

2.2 Panorama da inovação tecnológica nos EUA ………………….................................................................. 130

3. Programa de P\&D da ANEEL no Brasil ...................................................................................132

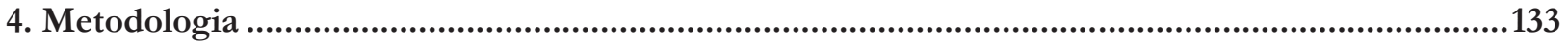

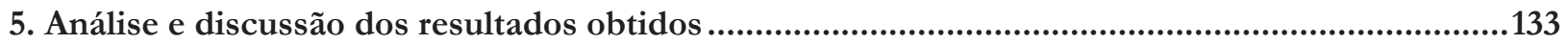

5.1 Análise do Índice ANEEL de Satisfação do Consumidor (IASC) ............................................................... 134

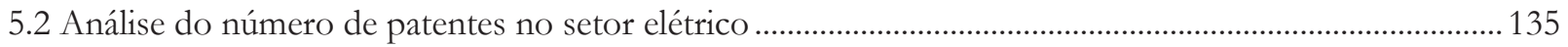

5.3 Análise de correlação entre o número de patentes e a satisfação do consumidor ......................................139

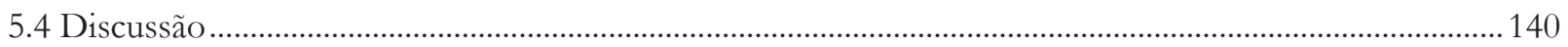

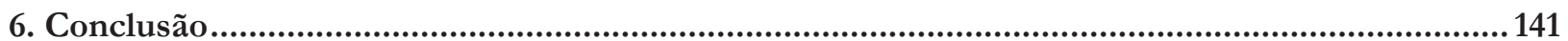

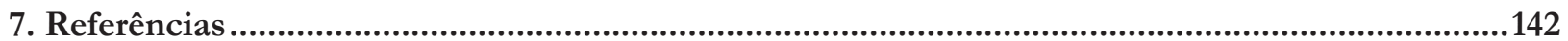


Shango Unchained? State In(Capacity), Urban Bias, and the Power Africa Initiative 146 Tom Brower

1. Introduction 147

2. Empowering development: the impetus for power Africa 149

Shango in chains: the current state of african power 149

Economic, environmental, and social development 151

Powering human rights 153

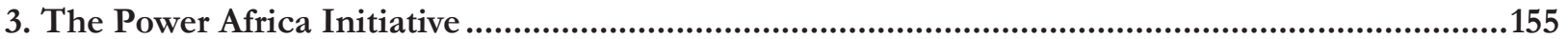

4. A theory of state in(capacity) and electrification ..........................................................................158

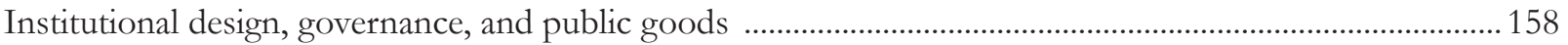

Absolute State Capacity ……………………….................................................................................................... 159

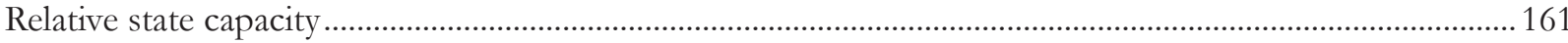

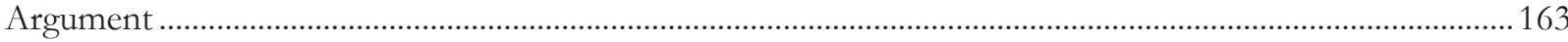

Institutional power and power institutions in sub-Saharan Africa.................................................................... 163

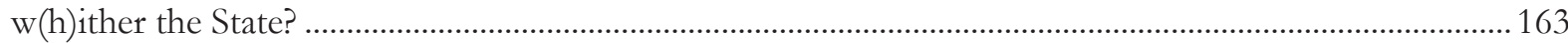

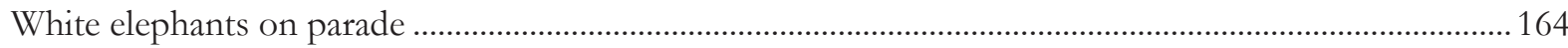

5. When the center holds: intergovernmental relations of the power sector .................................167

6. Regulators, mount up! Power regulation and rural marginalization .........................................169

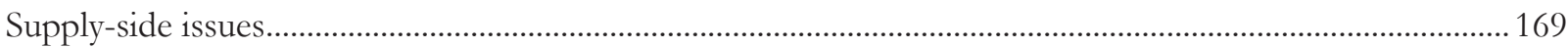

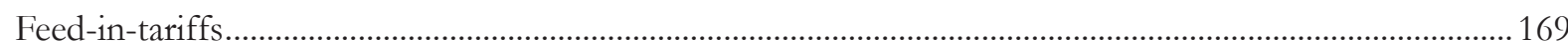

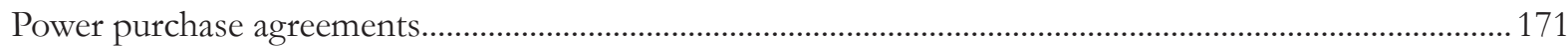

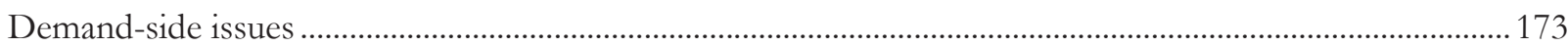

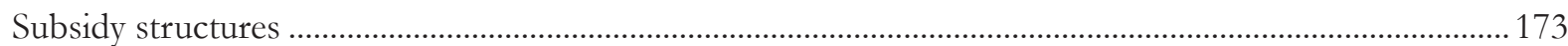

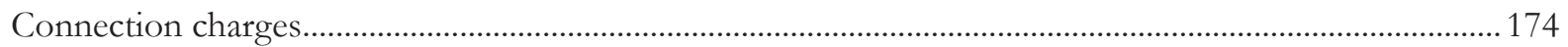

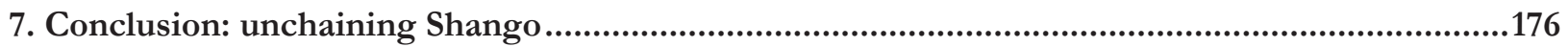

LEVANDO O ORÇAMENTO A SÉRIO COMO INSTRUMENTO DE CONTROLE DE POLÍTICAS PÚBLICAS179 Andre Bogossian

1. Introdução

2. Breves considerações a respeito de políticas públicas ...................................................................182

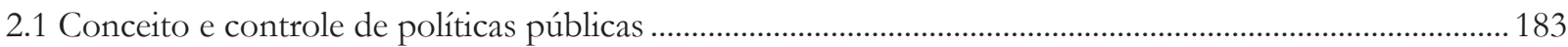

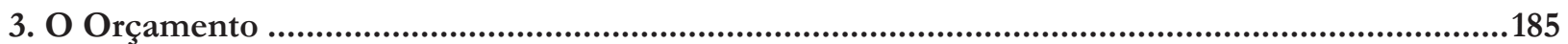

3.1 Planejamento e orçamento: ligação entre sistemas ....................................................................................188

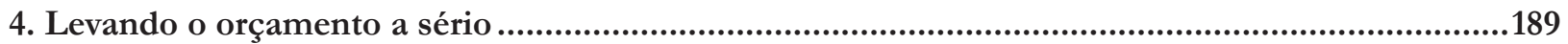

4.1 Orçamento como parâmetro controle da razoabilidade das escolhas alocativas.......................................... 190

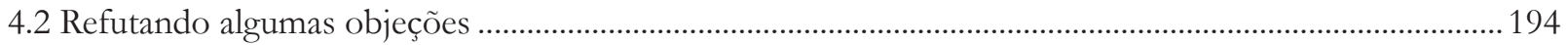

5. Considerações finais ..................................................................................................................195 


\section{ESTIMATIVA DE DEMANDA PELA FORMALIZAÇÃO DA ECONOMIA INFORMAL NO AGRESTE PERNAM-} BUCANO: UMA APLICAÇÃO DO MÉTODO DE VALORAÇÃO CONTINGENTE ...................................200 Monaliza de Oliveira Ferreira e Kelly Samá Lopes de Vasconcelos

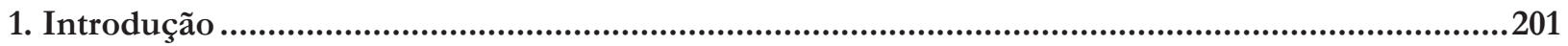

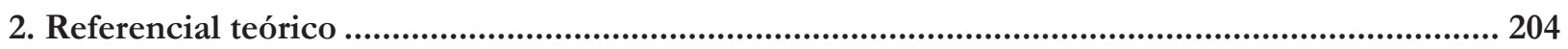

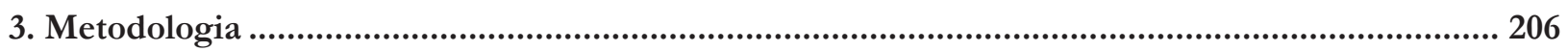

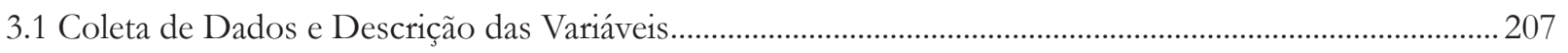

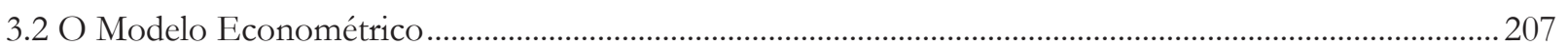

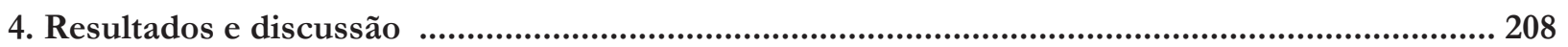

4.1 Caracterização da Economia Informal no Agreste Pernambucano ............................................................. 208

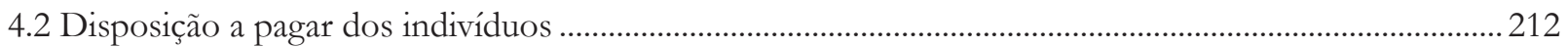

4.2.1 A Demanda pela Formalização da Informalidade em Caruaru..............................................................212

4.2.2 A Demanda pela formalização da informalidade em Santa Cruz do Capibaribe ................................ 214

4.2.3 A Demanda pela formalização da informalidade no agreste pernambucano ....................................... 215

5. Considerações finais .........................................................................................................................216

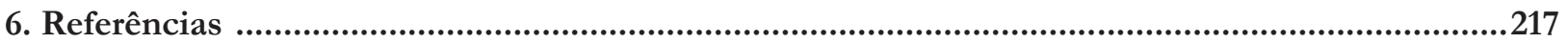

Implicações do Programa Nacional de Alimentação Escolar (PNAE) na renda e orGANIZAÇÃO DE AGRICULTORES FAMILIARES......................................................... 221

Nádia Kunkel Sziwelski, Carla Rosane Paz Arruda Teo, Luciara de Souza Gallina, Fabiula Grahl e Cimara Filippi

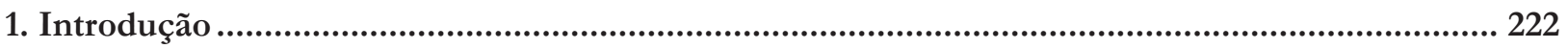

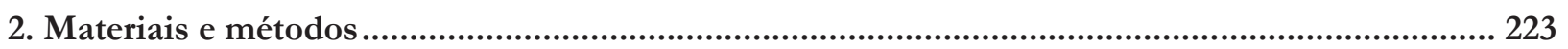

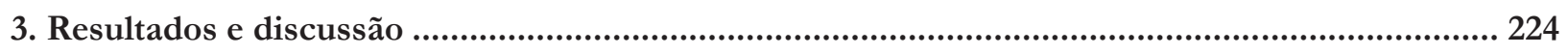

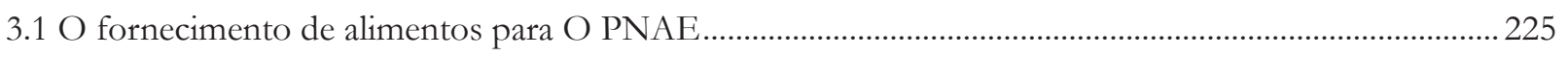

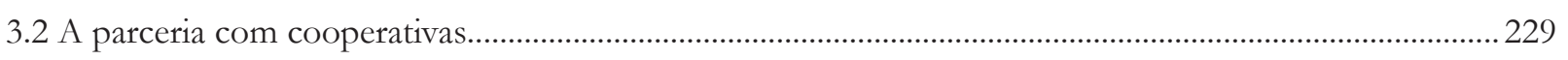

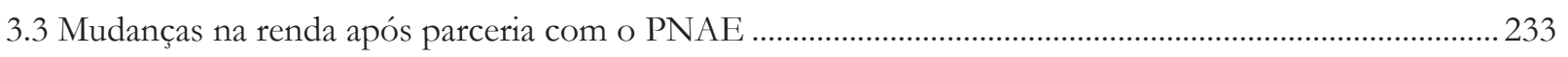

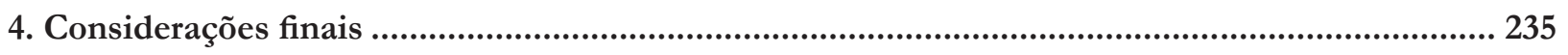

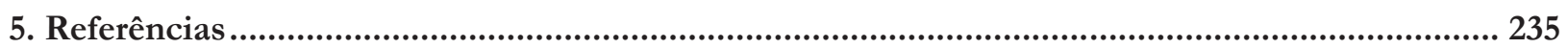

Desenvolvimento das famílias e a POBREza no nORdeste do Brasil............................. 241

Nadja Simone Menezes Nery de Oliveira, Solange de Cassia Inforzato de Souza e Aricieri Devidé Junior

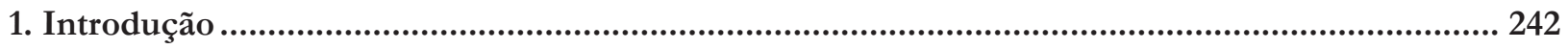

2. Aspectos conceituais e as evidências empíricas sobre a pobreza no Brasil e no Nordeste.......... 243

2.1 Do Caráter Unidimensional ao Multidimensional da Pobreza ..................................................................... 243

2.2 pobreza multidimensional na literatura nacional: evidências empíricas......................................................244 


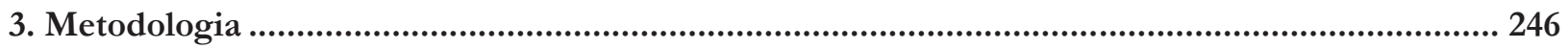

3.1 Composição do Índice de Desenvolvimento das Famílias (IDF) para a Região Nordeste ..................... 246

3.2 Construção do Indicador Sintético Multidimensional.....................................................................................247

4. Análise do desenvolvimento das famílias e a pobreza multidimensional no Nordeste ................. 248

4.1 A pobreza multidimensional no Nordeste e no Brasil para os anos de 2003 e 2012 .............................. 248

4.2 O desenvolvimento das famílias do nordeste segundo as dimensões do IDF ........................................... 249

4.2.1 A Ausência de vulnerabilidade................................................................................................................. 249

4.2.2 As dimensões referentes à Educação, ao trabalho e à renda ................................................................. 250

4.2.3 As Dimensões referentes ao Desenvolvimento Infantil, às Condições Habitacionais e ao Consumo de

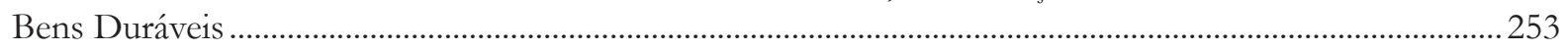

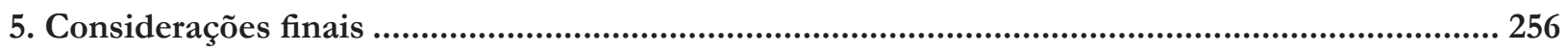

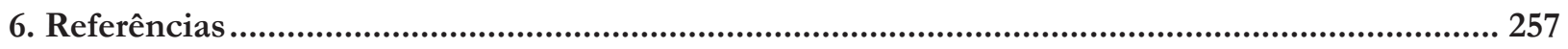

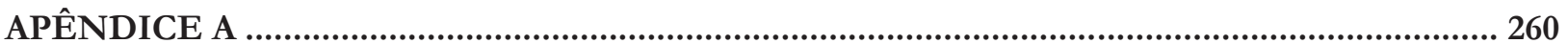

EFEITos Colaterais da MiNERAÇÃo No MEIo AMBIENTE .............................................264

Márcio Oliveira Portella

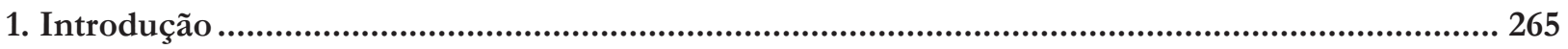

2. Impactos socioambientais da mineração ................................................................................. 265

3. Danos causados pela mineração no meio ambiente ................................................................... 267

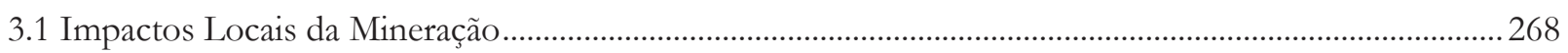

3.2 Análise, prevenção e minimização dos impactos negativos..........................................................................270

4. Compensação financeira pela exploração mineral (CFEM) ..................................................... 273

4.1 O uso sustentável e responsável da CFEM ..................................................................................................274

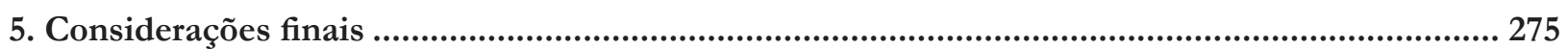

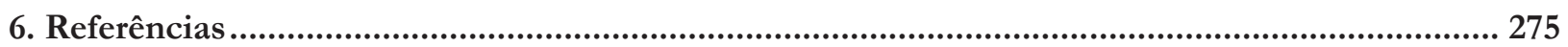

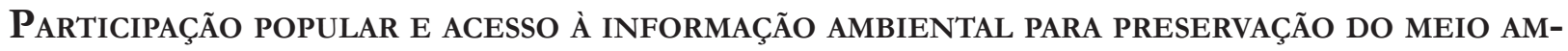

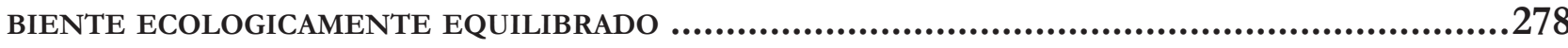
Luciano Marcos Paes

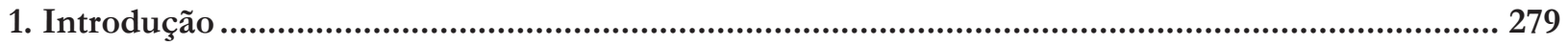

2. Participação popular e acesso à informação ambiental ............................................................... 280

3. Preservação do meio ambiente ecologicamente equilibrado ........................................................ 282

4. Considerações finais ........................................................................................................................ 285

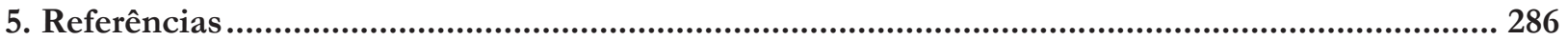


Políticas Públicas Para A FormaÇão e aVAliaÇÃo de magistrados: A CONTRibuiÇÃo Da EDUCAÇÃO JUDICIAL ATRAVÉS DAS ESCOLAS DE MAGISTRATURA .................................................289

Flávio José Moreira Gonçalves

1. Introdução ao tema e à problemática: Estado da arte.

1.1 A formação e avaliação de juízes como objeto de preocupação mundial e as condições históricas de surgimento das escolas judiciais e judiciárias no Brasil 293

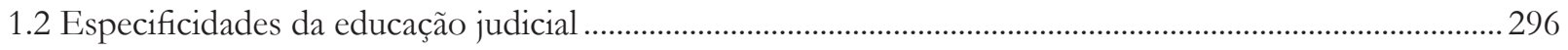

2. Achados da pesquisa realizada com juízes na ESMEC ............................................................. 297

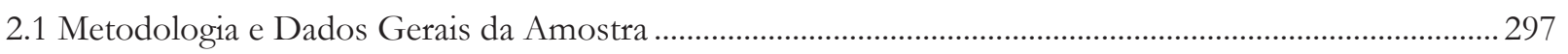

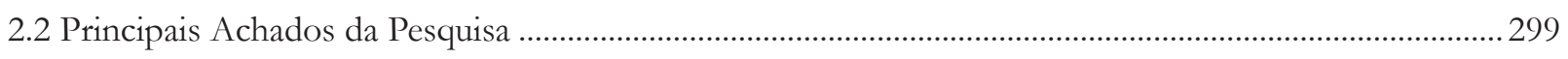

2.2.1 Ausência de preparo adequado para o exercício da magistratura........................................................... 299

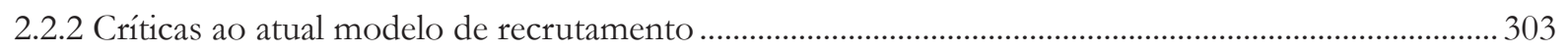

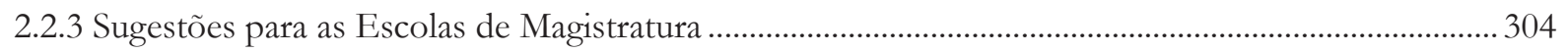

2.2.3.1 Sugestões para melhorar cursos de formação de juízes.........................................................................................304

2.2.3.3 Sugestões de novas disciplinas ou de conteúdos a serem abordados ..................................................................306

2.2.4 Dificuldades em fazer o curso sem afastar-se das funções judicantes, ante a sobrecarga de trabalho.........307

2.2.5 Possibilidades de uso de metodologias de EaD e sua receptividade ...................................................... 308

2.2.6 Valorização da troca de experiência - a Zona de Desenvolvimento Proximal (ZDP) ....................... 309

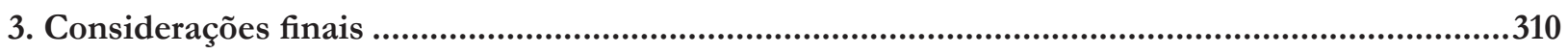

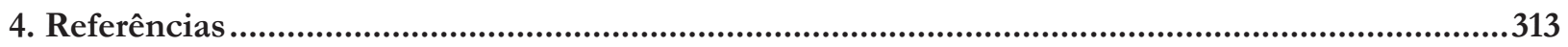

\section{RESENHAS}

Simpler: the future of government, de CAss Sustein ......................................... 316 Veyzon Campos Muniz

Normas EditORIAIS ..............................................................................................320

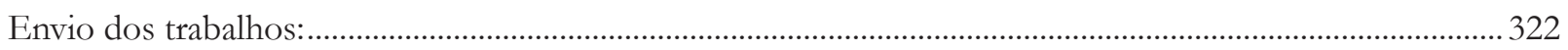


LOSS OF PARLIAMENTARY SEAT AS A CONSEQUENCE OF CRIMINAL CONVICTION: THE BRAZILIAN

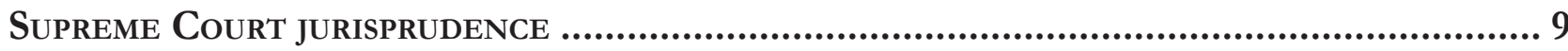

José Levi Mello do Amaral Júnior

Normative Power of Constitutional Courts: THE Brazilian CASE ...............................16 Inocêncio Mártires Coelho

Municipal Legislative Process

José Levi Mello do Amaral Júnior

FIRST LINES ON THE CRIMINAL POLICY OPTION TO MILITARY DESERTION: A REQUIRED CONTRIBUtion from the Public Policy.

Antonio Henrique Graciano Suxberger e Danilo Gustavo Vieira Martins

Implications of Enabling Permanent Residents to Vote - Threat to National SoveREIGNTY OR REALIZATION OF A Fundamental Right? .58 Juliana Cleto

Crime, Unemployment and Economic Activity in Chile .81 Sergio Zuñiga-Jara, Sofía Ruiz Campo e Karla Soria-Barreto

THE IMPACT OF DIFFERENT KINDS OF LEGAL REPRESSION OVER HOMICIDE RATES ACROSS BRAZILIAN STATES 100

Adolfo Sachsida, Mário Jorge Cardoso de Mendonça e Tito Belchior Silva Moreira

ANALYSIS OF DIRECT AND INDIRECT IMPACTS OF ANEEL R \& D PROGRAM IN THE ELECTRICITY SECTOR: DIFFERENCES WITH THE U.S. 124 Igor Polezi Munhz, Alessandra Cristina Santos Akkari e Neusa Maria Bastos Fernandes dos Santos

Shango Unchained? State In(Capacity), Urban Bias, and the Power Africa Initiative 146 Tom Brower 
TAKING THE GOVERNMENT BUDGET SERIOUSLY AS AN INSTRUMENT TO CONTROL PUBLIC POLICIES.179 Andre Bogossian

ESTIMATE DEMAND BY FORMALIZATION OF THE INFORMAL ECONOMY IN THE AGRESTE PERNAMBUCANO: AN APPLICATION OF CONTINGENT VALUATION METHOD

Monaliza de Oliveira Ferreira e Kelly Samá Lopes de Vasconcelos

Programa Nacional de Alimentação Escolar (PNAE) [National School Feeding Program] implications in THE INCOME AND ORgANizATION OF FAMiLy FARMERS

Nádia Kunkel Sziwelski, Carla Rosane Paz Arruda Teo, Luciara de Souza Gallina, Fabiula Grahl e Cimara Filippi

Development of Families and poverty in Northeast of Brazil.

Nadja Simone Menezes Nery de Oliveira, Solange de Cassia Inforzato de Souza e Aricieri Devidé Junior

SIDE EFFECTS OF MINING ON THE ENVIRONMENT .264 Márcio Oliveira Portella

POPULAR PARTICIPATION AND ACCESS TO ENVIRONMENTAL INFORMATION TO ECOLOGICALLY BALANCED ENVIRONMENT PRESERVATION

Luciano Marcos Paes

Public policy relating to magistrate training and EVAluation: JUdicial education CONTRIBUTION THROUGH JUDICIARY SCHOOLS...........................................................289

Flávio José Moreira Gonçalves

\section{Resenhas}

Simpler: the future of government, de Cass Sustein 



\section{REVISTA BRASILEIRA DE POLÍTICAS PÚBLICAS BRAZILIAN JOURNAL OF PUBLIC POLICY}
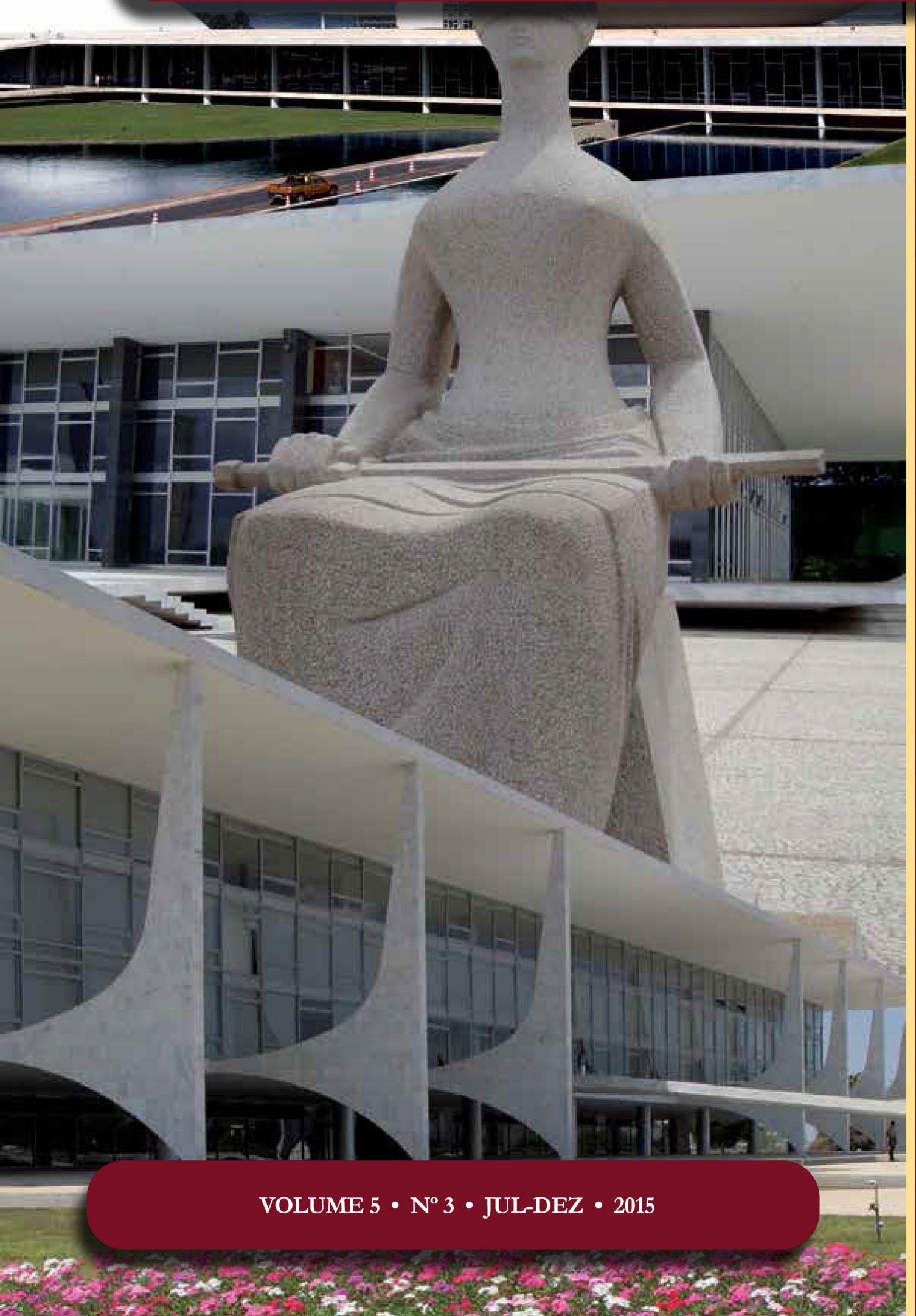

Crimes de responsabilidade do Presidente da República 


\section{Crimes de responsabilidade do Presidente da República*}

Carlos Ayres Britto**

\section{SUMÁRIO}

1. A matriz constitucional do tema. 2. O vínculo operacional lógico entre a Constituição e as matérias veiculadas pelos incisos de I a VII do art. 85 dela própria. 3. A unidade incindível do artigo constitucional de $\mathrm{n}^{\circ} .85 \mathrm{e}$ respectivos incisos. 4. A democracia como substrato ideológico da unidade incindível do artigo constitucional de n. ${ }^{\circ} 85$ e respectivos incisos. 5. A ordem constitucional como o próprio bem jurídico a proteger pela norma incriminadora do art. 85. 6. A natureza própria do crime de responsabilidade do Presidente da República, inconfundível com a de qualquer outro ato infracional. 7. O inteiro significado técnico dos atos constitutivos dos crimes de responsabilidade do Presidente da República. 8. O necessário pressuposto do mandato fluente, cuidando-se de crimes de responsabilidade do Presidente da República. 9. A referência constitucional a uma lei de natureza especial, na matéria. 10. Considerações finais.

\section{A matriz Constitucional do tema}

Vou direto ao ponto: a Constituição brasileira fala de "crimes de responsabilidade" do Presidente da República. É como está na cabeça do seu art. 85, assim vernacularmente posto: "São crimes de responsabilidade os atos do Presidente da República que atentem contra a Constituição e, especialmente, contra [...]”. O que vem de imediato, dos incisos de nos. I a VII, é uma relação de matérias que ela mesma tem como dos seus mais relevantes conteúdos. E que ela mesma tem como dos seus mais relevantes conteúdos, aclaro, porque elementarmente republicanos e federativos. Ou republicano-federativos, assim geminadamente. São eles: "a existência da União", "o livre exercício do Poder Legislativo, do Poder Judiciário, do Ministério Público e dos Poderes constitucionais das unidades da Federação", "o exercício dos direitos políticos, individuais e sociais", "a segurança interna do País", "a probidade na administração", "a lei orçamentária" e "o cumprimento das leis e das decisões judiciais".

** Ministro aposentado do Supremo Tribunal Federal. Doutor em Direito pela Pontíficia Universidade Católica de São Paulo (PUC-SP). Professor do Programa de Mestrado e Doutorado em Direito do Centro Universitário de Brasília (UniCEUB) e Presidente do Centro Brasileiro de Estudos Constitucionais da instituição. E-mail: carlos@ayresbritto.com.br 


\section{O vínCulo operacional lógico entre a Constituição e as matérias Veiculadas Pelos INCISOS DE I A VII DO ART. 85 DELA PRÓPRIA}

Esse vínculo operacional entre a cabeça do art. 85 e respectivos incisos de pronto se vê: a cabeça do artigo fala da Constituição como um continente normativo, os incisos falam de sete dos mais relevantes conteúdos desse continente. Por que assim? Porque tais conteúdos são elementarmente republicano-federativos, torno a ajuizar; ou seja, tais conteúdos são dos mais relevantes do corpo normativo da Constituição porque, neles, a República e a Federação se desdobram. Vão buscar fôlego e sentido. República e Federação que a mesmíssima Constituição brasileira erigiu a forma de governo e a forma de Estado, respectivamente. Pelo que tais conteúdos estão para a República Federativa do Brasil assim como a República Federativa do Brasil está, obviamente, para a Constituição brasileira. Dando-se que entre as duas instituições e a própria Constituição se coloca a democracia, como sequenciadamente demonstro.

\section{A UNIDADE INCINDÍVEL DO ARTIGO CONSTITUCIONAL DE Nº. 85 E RESPECTIVOS INCISOS}

3.1. Novo desdobramento de ideia: os conteúdos veiculados pelos sete incisos do art. 85 compõem com o próprio continente em que a Constituição consiste uma unidade do tipo monolítico ou incindível. Uma só “ordem constitucional”, para me valer da expressão que se lê no inciso XLIV do art. $5^{\circ}$ da mesma Carta Magna, verbis: "constitui crime inafiançável e imprescritível a ação de grupos armados, civis ou militares, contra a ordem constitucional e o Estado Democrático". Tal ordem constitucional a se pôr, em bloco (ao lado do Estado Democrático brasileiro), como o próprio bem jurídico a que visa proteger a norma incriminadora da ação deletéria de grupos armados. Assim como se coloca na eminente posição de bem jurídico a proteger pelo comando do art. 85, compreensivo do caput e incisos de I a VII.

\section{A DEMOCRACIA COMO SUBSTRATO IDEOLÓGICO DA UNIDADE INCINDívEL DO ARTIGO CONSTITUCIONAL DE Nº. 85 E RESPECTIVOS INCISOS}

Ideologicamente, porém, o que responde por essa unidade insuscetível de fratura é o mais denso teor democrático da República Federativa do Brasil. Uma República e uma Federação que se põem, justamente, como anéis de saturno da Democracia brasileira, institucionalmente falando (a Democracia como continente, a República e a Federação como seus imediatos conteúdos institucionais). Como conquista ou signo de civilização avançada. Retrato normativamente falado da epopeia constituinte de 1987/1988. Por isso que atentar contra qualquer das matérias veiculadas pelos incisos de $\mathbf{n}^{\circ}$ s. I a VII dele, art. 85, é atentar contra a Constituição por uma forma que o verbo atentar bem exprime: uma contrariedade acintosa. Uma declaração de inadaptabilidade do Presidente da República aos valores democráticos da Constituição em seu conjunto. Uma contrariedade à própria inteireza da Lei Maior, tão objetivamente grave e subjetivamente censurável que chega às raias da afronta. Da conspurcação ou defraudação da ética da responsabilidade que é de se exigir de um Presidente da República. 


\section{A ORDEM CONSTITUCIONAL COMO O PRÓPRIO BEM JURÍDICO A PROTEGER PELA NORMA INCRIMINADORA DO ART. 85}

Retomo a proposição do tópico de n. 3. Os crimes de responsabilidade do Presidente da República se tipificam por atos atentatórios da Constituição como ordem jurídica em si. Em especial, por aqueles seus aspectos (dela, Constituição) que os sobreditos incisos enunciam. Na base do mexeu com eles, mexeu comigo. Mas atos atentatórios por um modo frontal ou direto à ideia-força em que ela como um todo se traduz. Que ideia-força? A de que a Constituição é a lei nacional de hierarquia máxima. A lei suprema do Estado e de toda a sociedade civil brasileira. A lei que nunca pode deixar de governar quem governa. A lei que, se respeitada em seu primaz e definitivo significado de lei que governa até quem governa, conduz a uma situação de máxima segurança jurídica para todos. Segurança de que, por exemplo, "os objetivos fundamentais da República Federativa do Brasill" (art. $3^{\circ}$ ) serão alcançados e os direitos e garantias dos indivíduos e dos cidadãos, respeitados. Fins constitucionalmente lícitos e meios também constitucionalmente lícitos a andar de braços dados. Que já significa o Estado Constitucional-democrático de Direito em plenitude operacional.

\section{A natureza própria do crime de responsabilidade do Presidente da República, INCONFUNDÍVEL COM A DE QUALQUER OUTRO ATO INFRACIONAL}

O que se tem pelo art. 85, destarte, é a Constituição a se auto-referir. A se auto-referir para se proteger por um modo mais repressivamente drástico. Para ordenar ao Presidente do Brasil que não incorra em atos funcionais atentatórias dela. Que não ouse fazer do Brasil um barco juridicamente à deriva, que é um barco sem o timão dela própria. Sob pena de incidir em crime de responsabilidade, punível, centralmente, com a perda do cargo e a inabilitação para a função pública, por oito anos (parágrafo único do art. 52). É o que prosaicamente se chama de impeachment ou impedimento de prossecução no exercício do mandato presidencial. Mas impeachment pela perpetração de atos infracionais que têm natureza própria ou inconfundível com a de qualquer outra ilicitude: penal, civil, eleitoral, de contas. Por isso que explicitamente chamados de "crimes de responsabilidade", a ter por lógico pressuposto um atentado à Constituição como o específico bem jurídico a que visa proteger a norma incriminadora em que o art. 85 se traduz. Não apenas por si mesmo, porém por efeito do seu parágrafo único (mais abaixo transcrito), que remete sua plena operatividade para lei especial do Congresso Nacional.

\section{O INTEIRO SIGNIFICADO TÉCNICO DOS ATOS CONSTITUTIVOS DOS CRIMES DE RESPONSABILIDADE do Presidente da República}

Antes, porém, da transcrição de tal parágrafo único, o que me cabe é avançar na direção do inteiro significado técnico dos atos constitutivos dos crimes de responsabilidade do Presidente da República. Atos atentatórios da Constituição e "especialmente" daqueles que venho apontando como dos mais relevantes conteúdos dela mesma. Faço-o por modo esquemático, para dizer que:

I - os atos a que se reporta o art. 85 são os de natureza funcional. De natureza funcional, na acepção de que normativamente qualificados como integrantes do rol de competências, prerrogativas e secos deveres do cargo de Presidente da República (os princípios do art. 37 da Constituição, por exemplo, são secos deveres, a que correspondem direitos dos administrados). Mesma exigência que faz a Constituição para as demais formas de responsabilização do Presidente da República pelo cometimento de atos ilícitos distintos do crime de responsabilidade, conforme se vê deste enunciado: "O Presidente da 
República, na vigência do seu mandato, não pode ser responsabilizado por atos estranhos ao exercício de suas funções" ( $\left(4^{\circ}\right.$ do art. 86);

II - cuida-se de atos funcionais praticados no exercício de um mandato presidencial corrente. Atual. Em curso. Não de mandato vencido, conforme um pouco mais adiante explicitarei;

III - são atos afrontosos da ideia mesma de Constituição. Da Constituição para além e também por qualquer dos sete mencionados aspectos ou conteúdos republicano-federativos. Situação que não toma corpo, por evidente, apenas com o episódico ferimento desse ou daquele dispositivo constitucional (tão ocasional quanto isoladamente, então). Quero dizer: não basta agir em desconformidade com esse ou aquele preceito da Constituição, nem da lei, mesmo que da lei de improbidade administrativa ou então da lei orçamentária, para que se tenha como automaticamente deflagrada a hipótese do crime de responsabilidade do Presidente da República. Assim como não basta desatender uma decisão judicial, topicamente considerada, ou negar esse ou aquele direito individual, ou social, ou político, ou ainda que o Presidente da República incorra em atos que também impliquem, pontualmente, um abaixar a cabeşa da União em face de pressões advindas dos Estados-membros, para que se tenha como rotundamente materializadas as respectivas hipóteses de incidências do crime em foco. Não é bem isso. É preciso, para que se dê como ocorrida qualquer das pressuposições de aplicabilidade dos incisos I a VII do artigo constitucional de $\mathrm{n}^{\circ} .85$, que os atos imputados ao Presidente da República atentem contra a ideia em si ou o núcleo duro conceptual de institutos como, exempli gratia: a) "a probidade na administração" enquanto irrestrito dever moral dos administradores públicos e irrenunciável direito da coletividade administrada, além de forma de legitimação da lei quanto ao respectivo modo de aplicação e ainda necessário ponto de encontro entre a legitimidade como pré-requisito de investidura em cargo público e a legitimidade como requisito de desempenho de tal cargo; b) "a lei orçamentária" como peşa-chave da relação político-funcional entre, de uma parte, um Poder Legislativo que parametriza as ações gerais de arrecadação, alocação e dispêndios de dinheiros públicos e, de outra banda, um Poder Executivo que deve se curvar a tais parâmetros, mas sempre na perspectiva do alcance dos "objetivos fundamentais da República Federativa do Brasil" (art. $3^{\circ}$ da Constituição) e das competências materiais da União, em caráter privativo ou já no âmbito das competências comuns aos demais entes federativos (arts. 21 e 23 do Magno Texto Federal); c) o respeito à lei em sentido formal e material como expressão da vontade infraconstitucional do povo e, por isso mesmo, primeiro dos princípios do art. 37 da Constituição e documento jurídico-positivo sem o qual "ninguém será obrigado a fazer ou deixar de fazer alguma coisa [...]", nos termos do inciso II do art. $5^{\circ}$ da mesma Carta Magna; d) o cumprimento das decisões judiciais como expressão da vontade jurídica do Poder constitucionalmente concebido (o Judiciário) para dar a última palavra quanto às controvérsias jurídicas, seja nos processos objetivos ou de aferição abstrata de constitucionalidade, seja nos processos subjetivos ou de aferição em concreto de tais controvérsias; e) a existência da União como pessoa central da Federação que tanto se relaciona em pé-de-igualdade com as outras unidades dessa mesma Federação (art. 18, caput) quanto protagoniza as relações internacionais do Brasil e ainda assegura a defesa nacional (incisos I, II e III do art. 21 da CF). Logo, o de que se trata é de ejetar o raciocínio jurídico para o altiplano da ontologia mesma de cada qual dos incisos de $\mathrm{n}^{\circ} \mathrm{s}$. I a VII do art. 85. Altiplano da própria razão de ser de cada um deles, em bloco ou na inteireza da respectiva compostura jurídica. Na inteireza do regime normativo de cada qual deles, sim, numa específica e democrática estrutura republicano-federativa. O que implica a necessidade da troca do visual interpretativo no varejo pelo visual interpretativo no atacado, pois o bem jurídico ou o valor coletivo que ali comparece como digno de proteção de cada qual de tais incisos não comporta fragmentação conceitual nem trivialização operacional. Numa frase, o que interessa, para a tipificação do crime de responsabilidade do Presidente da República, é saber se os respectivos atos implicam preterição da ideia-força que tanto subjaz à positivação de cada qual desses encarecidos conteúdos quanto compõe o respectivo cerne conceitual-normativo. Numa pergunta, então: os atos presidenciais têm a força de aluir as bases de inspiração e a própria significação objetiva desse ou daquele conteúdo da Constituição, ali figurante dos incisos de I a VII do multicitado art. 85 e para além deles? Se a resposta for afirmativa, aí, por certo, um determinado ato infracional passa a se revestir da extrema gravidade a que corresponde a hipótese de incidência do crime de responsabilidade do Presidente da República;

IV - por último, tais atos foram hipotetizados pela Constituição como crimes de responsabilidade porque reveladores, em última análise, de um como que marginal estilo de governo: o de dar as costas à Constituição. Que é a pior forma de desgoverno. Um estilo ou padrão ou standard ou personalizado jeito de colocar em xeque o axioma de que a Constituição é a lei nacional de hierarquia máxima. Isso a partir 
da reverência mesma que a ela é devida por uma autoridade que acumula as chefias da Administração Pública da União, do governo federal e do Estado brasileiro como um todo. Não por acaso, o único agente público de quem se exige, quando do ato de posse perante uma renovada composição do Congresso Nacional, a prestação do compromisso de "manter, cumprir e defender a Constituição" (Parágrafo único do art. 78). Por conseguinte, autoridade central que não pode jamais colocar o País no terrífico dilema de ter que optar entre o seu Presidente e sua Constituição. Que já é um tipo de ponderação a ser feita pelo Congresso Nacional, valendo-se de sua Câmara dos Deputados como órgão de acusação e pelo Senado como órgão de processo e julgamento (nos precisos termos, respectivamente, do inciso I do art. 51 e do inciso I do art. 52 da Constituição).

\section{O NeCESSÁRIO PRESSUPOSTO do MANDATO FLUENTE, CUIDANDO-SE DE CRIMES DE responsabilidade do Presidente da República}

Já me aproximando do fecho deste breve estudo, ajuízo que o mandato para cujo desempenho se presta o citado compromisso é o conquistado em determinada eleição. Eleição específica, seguida de diplomação, posse e exercício também específicos. Ainda que mandato obtido por uma segunda vez, mas a significar apenas o seguinte: o cargo de presidente é o mesmo; não o mandato. Vale dizer: para o primeiro mandato do Presidente da República, já houve uma anterior eleição, uma anterior diplomação, uma anterior posse, um anterior exercício. Um precedente exercício que não se intercala com o novo (pelo contrário, se intervala), porque mandato novo é exercício que se abre para uma autônoma prova de fidelidade governamental à Constituição. Autônoma prova, a partir de um compromisso virginalmente novo que se presta perante uma determinada composição do Congresso Nacional. Não perante outra composição numérica ou subjetiva. Não um compromisso formal, reitere-se, a se somar ao anterior para fazer dos dois mandatos uma coisa só. Pelo que mandato presidencial vencido sem abertura e julgamento de crime de responsabilidade é, sozinho ou por si mesmo, página virada. Não assim, por evidente, quanto a eventual cometimento de infrações de outra natureza jurídica ainda não prescritas, em especial as infrações penais comuns, as de caráter eleitoral, as situadas no âmbito do dever constitucional da prestação de contas e da lei de improbidade administrativa. Cada qual dessas diferenciadas infrações a demandar processo e julgamento sob formato jurídico inconfundível com aquele concebido pela Constituição para os crimes de responsabilidade do Presidente da República.

\section{A referência constitucional a uma lei de natureza espeCial, Na matéria}

Certo que o parágrafo único do mesmo art. 85 dispõe que os crimes de responsabilidade "serão definidos em lei especial, que estabelecerá as normas de processo e julgamento". Lei de caráter nacional, que é a de $n^{\circ} 1.079$, de 10 de abril de 1950, mas somente passível de boas-vindas pela Constituição na medida em que interpretada conforme à Constituição mesma. Lógico! O que nos parece ter que se ajustar às coordenadas mentais acima lançadas ${ }^{1}$. Coordenadas que tenho como de necessária e fidedigna observância, para evitar que um equivocado trato interpretativo da matéria termine por desaguar num mal disfarçado mecanismo de recall que o sistema constitucional brasileiro não abriga. Assim como não abriga o sistema parlamentar de

1 Falo de coordenadas mentais como o conjunto das reflexões que penso autorizadas pela direta interpretação dos dispositivos constitucionais que pude citar no curso deste breve artigo, de per si e também imersos no todo sistêmico da Constituição. Reflexões que tive a prudência de expor, em primeira mão, para constitucionalistas da minha justificada admiração intelectual, como Eduardo Mendonça e Ademar Borges de Souza Filho, deles obtendo todo estímulo para dar à luz estes escritos. O que não podia fazer sem o presente registro, que é de sincera gratidão. Uma gratidão que estendo aos Drs. Júlio de Melo Ribeiro e Orlando Maia, profissionais e teóricos do Direito que também admiro em grau superlativo e que muito me ajudaram na discussão dos temas central e paralelos desta incursão doutrinária pelo sistema de comandos da Constituição brasileira. 
governo, com seu voto de desconfiança apto a cassar o mandato de quem se encontre à testa do gabinete ministerial-executivo. Cassação tanto individual quanto coletiva, como amplamente sabido.

\section{Considerações finais}

Bem, este é o meu visual do tema. Projetei-o como uma tentativa de contribuir para o aprofundamento de um debate que já se vem travando na esfera política e nos meios jurídicos. Debate que muito promete avançar, numa quadra nacional de intensas perplexidades e visão candentemente partidária das coisas. Por isso que muito me esforcei para manter a serena objetividade que o pensamento científico exige como condição de sua própria identidade. Um pensamento que, para se recobrir assim de pura cientificidade, só pode ter nos escaninhos normativos da Constituição da República Federativa do Brasil o seu necessário ponto de

partida e de chegada. 


\section{REVISTA BRASILEIRA DE POLÍTICAS PÚBLICAS BRAZILIAN JOURNAL OF PUBLIC POLICY}
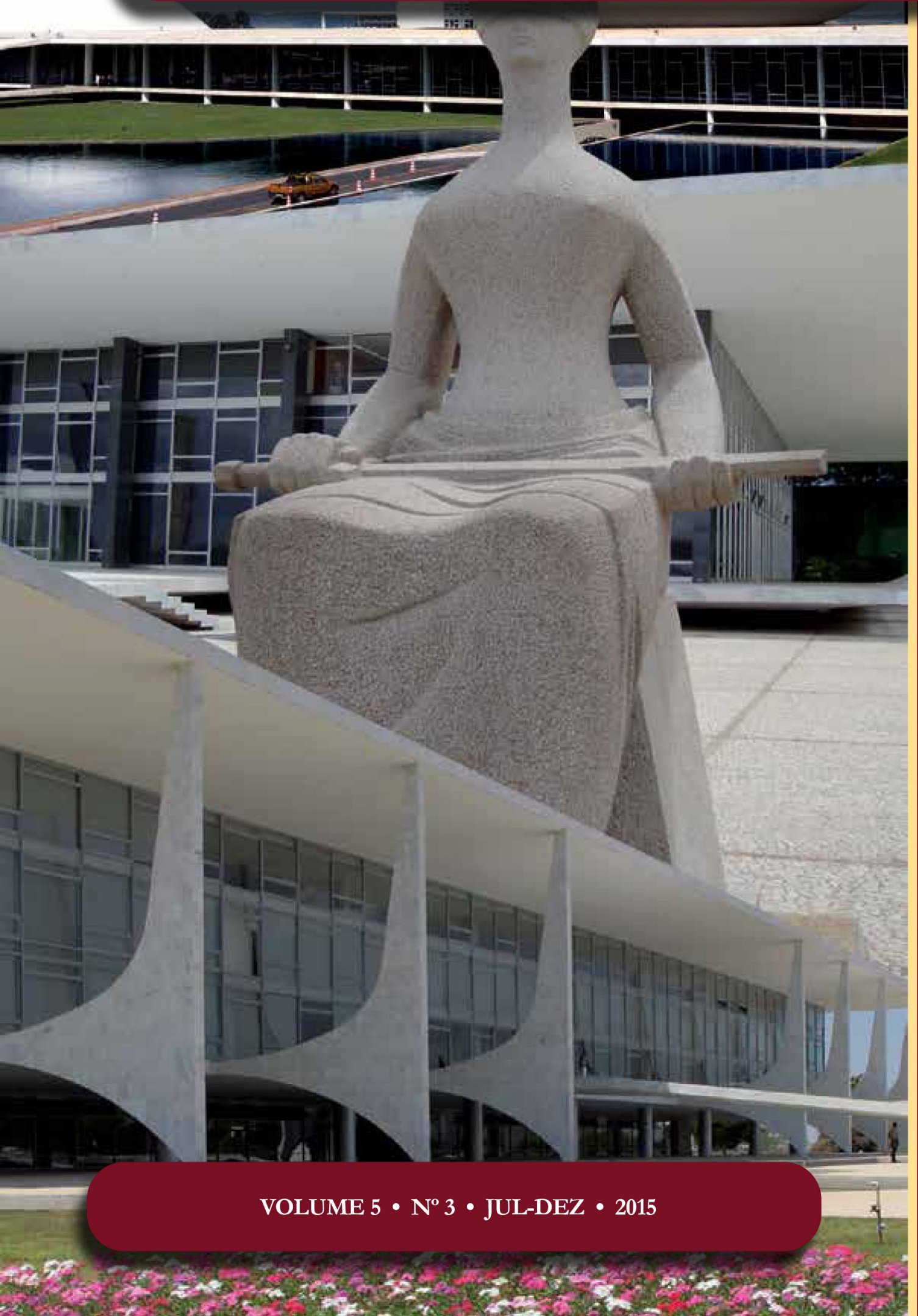

Perda de mandato parlamentar por força de condenação criminal na jurisprudência do Supremo Tribunal Federal Loss of parliamentary seat as a consequence of criminal conviction: the Brazilian Supreme Court jurisprudence

José Levi Mello do Amaral Júnior 


\section{Perda de mandato parlamentar por força de condenação criminal na jurisprudência do Supremo Tribunal Federal*}

\section{Loss of parliamentary seat as a consequence of criminal conviction: the Brazilian Supreme Court jurisprudence}

José Levi Mello do Amaral Júnior**

\section{Resumo}

Este artigo é relativo à prisão de parlamentares nos termos da Constituição brasileira de 1988 e à perda do mandato parlamentar como consequência da condenação criminal definitiva. As disposições constitucionais pertinentes não são claras, são ambíguas e, inclusive, confusas. Por isso mesmo, os precedentes do Supremo Tribunal Federal sobre o tema são hesitantes ou contraditórias, mudam ao longo do tempo e conforme a composição da Corte. Também há importante repercussão sobre membros de parlamentos locais. Seja como for, o importante é que a impunidade tem, hoje, espaço cada vez menor.

PALAVRAS-CHAVE: prisão de parlamentares; perda do mandato; impunidade.

\section{Abstract}

This paper is related to the arrest of parliamentarians under the Brazilian Constitution of 1988 and the loss of parliamentary seat as a consequence of the final criminal conviction. The relevant constitutional provisions are not clear, are ambiguous and even confusing. Therefore, the precedents of the Brazilian Supreme Court on the subject are hesitant or contradictory, change over time and as the composition of the Court. There is also significant impact on members of local parliaments. Anyway, the important thing is that impunity has today less and less space.

KEY WORDS: arrest of parliamentarians; loss of parliamentary seat; impunity.

\section{SUMÁRIO}

1. Introdução ao assunto 2. Condenação criminal e perda de mandato parlamentar no caso mensalão 3. Condenação criminal e perda de mandato parlamentar no caso Donadon 4. Projeção federativa do tema 5. Considerações finais 
A Constituição brasileira de 1988, no que se refere à perda de mandato parlamentar por força de condenação criminal, não adota conjunto normativo muito claro. Duas Ações Penais e um Mandado de Segurança que ensejaram decisões do Supremo Tribunal Federal tornaram ainda mais difícil o problema.

\section{INTRODUÇÃO AO ASSUNTO}

A Constituição brasileira de 1988 veda a cassação de direitos políticos, mas admite sejam eles perdidos ou suspensos em algumas poucas hipóteses, como, por exemplo, a condenação criminal transitada em julgado ${ }^{1}$.

Por outro lado, dentre as hipóteses de perda do mandato parlamentar, estão: (i) a suspensão dos direitos políticos; e (ii) a condenação criminal transitada em julgado, enquanto durarem seus efeitos ${ }^{2}$.

No contexto até aqui narrado talvez pareça evidente que da condenação criminal transitada em julgado - quando relativa a parlamentar - decorra, ao natural (ou seja, como efeito da própria condenação), a perda do mandato parlamentar: isso porque o mandato pressupõe o gozo de direitos políticos, o que não se tem com a suspensão desses advinda do trânsito em julgado da condenação criminal.

No entanto, o próprio texto constitucional faz duas colocações potencialmente conflitantes: (i) no caso de suspensão dos direitos políticos, "a perda será declarada pela Mesa da Casa respectiva"; e (ii) no caso de condenação criminal transitada em julgado, "a perda do mandato será decidida pela Câmara dos Deputados ou pelo Senado Federal"4.

Dito de outro modo: (i) no geral dos casos, em se tratando de suspensão dos direitos políticos, a perda do mandato é automática e será apenas declarada pela Mesa da Casa respectiva; (ii) porém, no caso de condenação criminal transitada em julgado - não obstante dela decorra suspensão dos direitos políticos - a perda do mandado fica sujeita a uma decisão da Câmara dos Deputados ou do Senado Federal.

Essa questão foi enfrentada recentemente pelo Supremo Tribunal Federal nos autos de duas Ações Penais, a Ação Penal n. 565/RO (caso Ivo Cassol) e a Ação Penal n. 470/MG (rumoroso caso "mensalão"), mas que conheceram soluções divergentes dada a ocorrência de variação na composição da Corte no interstício havido entre uma decisão e outra. Em um terceiro caso (caso Donadon), insinua-se, ainda, um desdobramento no mínimo curioso, inclusive porque parece implicar inovação ao Direito aplicável. É o que se passa a examinar.

\section{CondenaÇão Criminal e perda de mandato parlamentar no caso mensalão}

No julgamento da Ação Penal n. 470/MG, Relator o Ministro JOAQUIM BARBOSA, julgada em 17 de dezembro de 2012, relativa a graves crimes contra a Administração Pública, o Relator sustentou que a previsão constitucional acerca de decisão da Câmara ou do Senado sobre perda de mandado de parlamentar condenado criminalmente "justifica-se (...) nas hipóteses em que a sentença condenatória não tenha decretado a perda do mandato pelo parlamentar, seja por não estarem presentes os requisitos legais para tanto (...), seja por ter sido proferida antes da expedição do diploma". Para ele, "o procedimento estabelecido no art. 55 da Constituição da República disciplina as hipóteses em que, por um juízo político, pode ser decretada a perda de mandato eletivo parlamentar. (...) Situação inteiramente diversa, porém, é aquela que envolve a

\footnotetext{
Constituição brasileira de 1988, art. 15, incisos III.

Constituição brasileira de 1988, art. 55, incisos IV e VI.

Constituição brasileira de 1988 , art. 55, \ $3^{\circ}$.

4 Constituição brasileira de 1988 , art. $55, \int 2^{\circ}$.
} 
decretação da perda do mandado eletivo pelo Poder Judiciário, que pode atingir não apenas o parlamentar eleito como qualquer outro mandatário político, seguindo normas específicas de direito penal e processual penal. (...) Condenado o Deputado ou Senador, no curso de seu mandato, pela mais alta instância do Poder Judiciário nacional, inexiste espaço para o exercício de juízo político ou de conveniência pelo Legislativo, pois a suspensão de direitos políticos, com a subsequente perda de mandato eletivo, é efeito irreversível da sentença condenatória (...)".

Por sua vez, o Ministro RICARDO LEWANDOWSKI, funcionando como Revisor, abriu divergência. Para ele, "a condenação criminal (...) configura apenas uma condição necessária, mas não suficiente, para a perda dos respectivos mandatos, a qual depende da instauração do competente processo na Câmara, que não pode deixar de fazê-lo, se devidamente provocada".

A Ministra ROSA WEBER, ao acompanhar a divergência, argumentou que "o juiz competente para julgar sobre o exercício do poder político, do poder de representação, em uma democracia, é o povo soberano, que o faz diretamente (caso de democracias cujas Constituições preveem o instituto do recall) ou por meio de seus representantes (caso da hipótese prevista no art. 55, VI e $\int 2^{\circ}$, da Constituição brasileira)". Para ela, "o mandato se reveste, durante o período para o qual constituído, da qualidade da intangibilidade, somente podendo ser afetado nas hipóteses e segundo os procedimentos expressamente previstos pela Constituição".

O Ministro GILMAR MENDES buscou harmonizar as diversas disposições constitucionais pertinentes. Sustentou que a condenação de parlamentar por crimes contra a Administração Pública - crimes esses que dificilmente deixam de ser considerados atos de improbidade administrativa (e improbidade administrativa também é causa de perda ou suspensão de direitos políticos ${ }^{5}$ ) -, em que o próprio juiz assenta a perda do mandato, impõe-se à Casa parlamentar competente a mera declaração da perda do mandato parlamentar.

O Ministro MARCO AURÉLIO afirmou considerar automáticos os efeitos do art. 15, III, da Constituição brasileira de 1988. Também defendeu que o $\ 2^{\circ}$ art. 55 da Constituição brasileira de 1988 "é reservado a situações concretas em que não se tem, como consequência da condenação, a perda do mandato".

Enfim, o Ministro CELSO DE MELLO disse concordar com a distinção feita pelo Ministro GILMAR MENDES, qual seja, remanescem na esfera das Casas legislativas os casos em que o crime pelo qual foi condenado o parlamentar não contém, como elementar típica do tipo penal, ato de improbidade administrativa. Enfatizou a prevalência de decisão transitada em julgado, que guarda relação com a concepção mesma de Estado Democrático de Direito. Destacou que a Constituição brasileira de 1988 confere ao Supremo Tribunal Federal o monopólio da última palavra em tema de exegese das normas constitucionais. Encerrou afirmando que "a insubordinação legislativa ou executiva ao comando emergente de uma decisão judicial revela-se comportamento intolerável, inaceitável e incompreensível”.

O resultado do julgamento no ponto foi por maioria apertada, cinco votos contra quatro, para decretar a perda do mandato dos parlamentares julgados.

\section{CondenaÇão criminal e perda de mandato parlamentar no caso Donadon}

No julgamento da Ação Penal n. 565/RO, Relatora a Ministra CÁRMEN LÚCIA, julgada em 08 de agosto de 2013, em que figura como réu um Senador ${ }^{6}$, a jurisprudência foi modificada. Dois novos Ministros, TEORI ZAVASCKI e ROBERTO BARROSO, aderiram ao entendimento vencido na Ação Penal n. 470/MG.

5 Constituição brasileira de 1988, art. 15, inciso V.

6 Ivo Cassol, eleito pelo Estado de Rondônia. 
Por outro lado, semanas antes, em 26 de junho de 2013, transitara em julgado a Ação Penal n. 365/RO, Relatora a Ministra CÁRMEN LÚCIA, julgada em 28 de outubro de 2010, em que figurava como réu um Deputado Federal ${ }^{7}$. O parlamentar foi recolhido à penitenciária logo após o trânsito em julgado. Em 28 de agosto de 2013, a Câmara dos Deputados votou a perda do mandato do parlamentar: foram 233 favoráveis à perda, 131 contrários e 41 abstenções, resultado insuficiente para a perda do mandato (que requer voto da maioria absoluta dos membros da Casa ${ }^{8}$, ou seja, 257 votos no caso da Câmara).

Configurou-se, então, a inusitada situação de cidadão detentor de mandato parlamentar preso no cumprimento de decisão transitada em julgado.

Contra a decisão da Câmara dos Deputados, Líder de partido de oposição impetrou o Mandado de Segurança n. 32.326/DF, Relator o Ministro ROBERTO BARROSO. O Relator, em decisão monocrática proferida em 02 de setembro de 2013, concedeu liminar para suspender a deliberação da Câmara dos Deputados que não cassou o parlamentar condenado e preso?.

Para o Relator, "quando se tratar de Deputado cujo prazo de prisão em regime fechado exceda o período que falta para a conclusão de seu mandato, a perda se dá como resultado direto e inexorável da condenação, sendo a decisão da Câmara dos Deputados vinculada e declaratória”.

A propósito, vale conferir os seguintes excertos do despacho:

36. De acordo com a legislação em vigor e a interpretação judicial que the tem sido dada, o preso em regime aberto e semiaberto pode ser autorizado à prestação de trabalho externo, independentemente do cumprimento mínimo de 1/6 da pena. Este tem sido o entendimento pacifico do Superior Tribunal de Justiç, podendo-se citar, exemplificativamente, os acórdãos proferidos no HC 251.107 e no HC 255.781, ambos julgados este ano. Por outro lado, no tocante ao preso em regime fechado, a Lei de Execucões Penais (arts. 36 e 37) não apenas restringe o trabalho externo como exige o cumprimento minimo de 1/6 (um sexto) da pena. Reiterando: o preso em regime fechado tem restrições severas ao trabalho externo, além de não poder prestá-lo antes do cumprimento do sexto inicial da pena.

37. Disso resulta que o condenado em regime inicial fechado, cujo periodo remanescente de mandato seja inferior a 1/6 (um sexto) da pena a que foi condenado - isto é, ao tempo mínimo que terá de permanecer necessariamente na penitenciária (LEP, art. 87) -, não pode conservar o mandato. É que, nessa situação, verifica-se uma impossibilidade jurídica e física para o exercício do mandato. Jurídica, porque uma das condições minimas exigidas pela Constituição para o exercício do mandato é o comparecimento às sessões da Casa (CF, arts. 55, III, e 56, II). E física, porque ele simplesmente não tem como estar presente ao local onde se realizam os trabalhos e, sobretudo, as sessões deliberativas da Casa Legislativa. Vejase, então: o mandato do Deputado Natan Donadon terminaria em 31.01.2015, isto é, cerca de 17 (dezessete) meses após a deliberação da Câmara, que se deu em 28.08.2013. Porém, $1 / 6$ da sua pena de 13 anos, 4 meses e 10 dias corresponde a pouco mais de 26 meses. Logo, o prazo de cumprimento de pena em regime fechado ultrapassa o periodo restante do seu mandato.

O Relator, ao final do despacho, explicita que tomou em consideração "a gravidade moral e institucional (...) de uma decisão política que (...) chancela a existência de um Deputado presidiário”. Também faz expressa referência à "indignação cívica", à "perplexidade jurídica", ao "abalo às instituições" e ao "constrangimento" que a situação gera aos Poderes constituídos, fatores esses que, segundo o Relator, "legitimam a atuação imediata do Judiciário" ${ }^{\text {. }}$.

Parece bastante claro que essa decisão monocrática - abstraindo a circunstância de haver suspendido uma não-decisão: a decisão pela não-perda do mandato de parlamentar preso - decorreu de interpretação bastante construtiva. Tanto isso é verdade que o Ministro GILMAR MENDES afirmou que o despacho implicaria um "mandato salame", de cumprimento fatiado, na medida em que o parlamentar progredisse de regime prisional ${ }^{11}$.

7 Natan Donadon, eleito pelo Estado de Rondônia.

8 Constituição brasileira de 1988 , art. $55, \int 2^{\circ}$.

9 Inteiro teor em: http://www.stf.jus.br/arquivo/cms/noticiaNoticiaStf/anexo/ms32326.pdf

10 Há outras declarações do Ministro Roberto Barroso no sentido de não se deixar influenciar pela "opinião pública". A propósito, entrevista publicada em 03 de novembro de 2013 na revista jurídica virtual Consultor Jurídico (http://www.conjur.com.br).

11 A declaração foi publicada, por exemplo, no jornal Folha de São Paulo, de 04 de setembro de 2013, editoria "Poder". 
Enfim, vale anotar que o Mandado de Segurança n. 32.326/DF foi monocraticamente julgado prejudicado porque sobreveio uma nova deliberação parlamentar que declarou a perda do mandato colocado em questão. O Relator assim reconheceu em despacho de 18 de março de 2014. No ensejo, anotou "que o deferimento da liminar permitiu que o Poder Legislativo fizesse um novo exame da matéria, já à luz dos elementos constitucionais que tornaram inviável, no caso, a manutenção do mandato parlamentar". A seguir, concluiu que o diálogo institucional que se colocou "demonstra que a relação entre o Poder Legislativo e o Supremo Tribunal Federal pode ser marcada por saudável complementariedade, em benefício da efetiva concretização das exigências constitucionais."

Sem dúvida que assim pode e, sobretudo, deve ser. Porém, é essencial que daí não decorra a substituição de um Poder pelo outro. É fundamental que o Supremo Tribunal Federal, ao arbitrar o jogo político, não se substitua aos agentes políticos eleitos, mormente na elaboração de normas legais ou constitucionais.

\section{Projeção federativa do tema}

Importa, também, verificar a repercussão do assunto relativamente a Deputados Estaduais e Vereadores.

Para tanto, é bastante elucidativo despacho do Presidente do Supremo Tribunal Federal, Ministro RICARDO LEWANDOWSKI, proferido em 14 de maio de 2015, nos autos da Suspensão de Liminar n. 864/PR. Foi ajuizada por cidadão que - no curso de mandato de Vereador - viu transitar em julgado contra si uma condenação criminal. A perda de mandato foi colocada em votação pela respectiva Câmara de Vereadores que deliberou pela manutenção do cargo. Então, a resolução da Câmara foi liminarmente sustada pelo Tribunal de Justiça competente, que também determinou a posse do suplente. Daí o requerimento de suspensão de liminar.

De início, destaca que "o ordenamento pátrio não prevê o tratamento simétrico entre os membros do Poder Legislativo". Esclarece que a regra do art. 15, inciso III, da Constituição encontra exceção no art. 55 , inciso VI e $\int 2^{\circ}$, da própria Constituição, exceção essa que reconhece extensível apenas a Deputados Estaduais e Distritais, mas não aos demais detentores de mandatos eletivos, aí incluídos os Vereadores. A propósito, transcreve excerto do Voto que proferiu na Ação Penal n. 470/MG: "A regra da cassação imediata dos mandatos, no entanto, aplica-se, por inteiro e de imediato, aos vereadores, bem como aos prefeitos, governadores e ao próprio Presidente da República, por força do que se contém no referido art. 15, III, da Constituição."

\section{Considerações finais}

A literalidade constitucional não facilita a interpretação das normas envolvidas no assunto examinado. A abordagem mais simples resulta confiar à decisão da Casa parlamentar respectiva a perda do mandato do parlamentar condenado criminalmente com trânsito em julgado. Claro, daí resulta a possibilidade - sim, inusitada - de cidadão (ainda) detentor de mandato parlamentar ser recolhido à prisão para cumprimento de condenação criminal transitada em julgado. Essa é uma possibilidade - já havida na vida prática - que constrange o ideal de higidez das instituições políticas (que evidentemente passa pela firme retidão dos seus membros). Porém, ao mesmo tempo, afirma de modo claro uma característica elementar da república democrática: todos são iguais perante a lei, inclusive os detentores de poder (inclusive de poder eletivo).

Portanto, melhor seria que a perda do mandato parlamentar sempre decorresse de modo automático da condenação criminal transitada em julgado. No entanto, o texto constitucional, no ponto, é ambíguo: em sua literalidade, parece reclamar decisão da Casa parlamentar respectiva. Fora daí, é necessário interpretar 
de modo construtivo, ainda que bastante natural. O Supremo Tribunal Federal, no ponto, tem hesitado em razão de a Constituição efetivamente não ser clara, bem assim por força de flutuações em sua composição (o que é uma contingência natural).

Na prática, é pouco provável que o texto constitucional venha a sofrer alguma modificação formal no ponto, sobretudo para retirar de modo claro a prerrogativa de decisão das Casas parlamentares. Assim, melhor seria que o Supremo Tribunal Federal pacificasse o próprio entendimento sobre o assunto, afirmando o automatismo entre a condenação criminal transitada em julgado e a perda do mandato parlamentar. Essa é a solução que parece mais crível.

De toda sorte, o essencial é que a condenação criminal transitada em julgado seja efetiva, ainda que contra detentor de mandato representativo. Com isso, frustra-se a perniciosa sensação de impunidade e afirma-se a igualdade de todos perante a lei. Esse passo - a efetividade da condenação criminal contra quem quer que seja - já foi dado e repetido na prática brasileira. E é potencialmente seminal de toda uma nova e saudável cultura de retidão. 


\section{REVISTA BRASILEIRA DE POLÍTICAS PÚBLICAS BRAZILIAN JOURNAL OF PUBLIC POLICY}
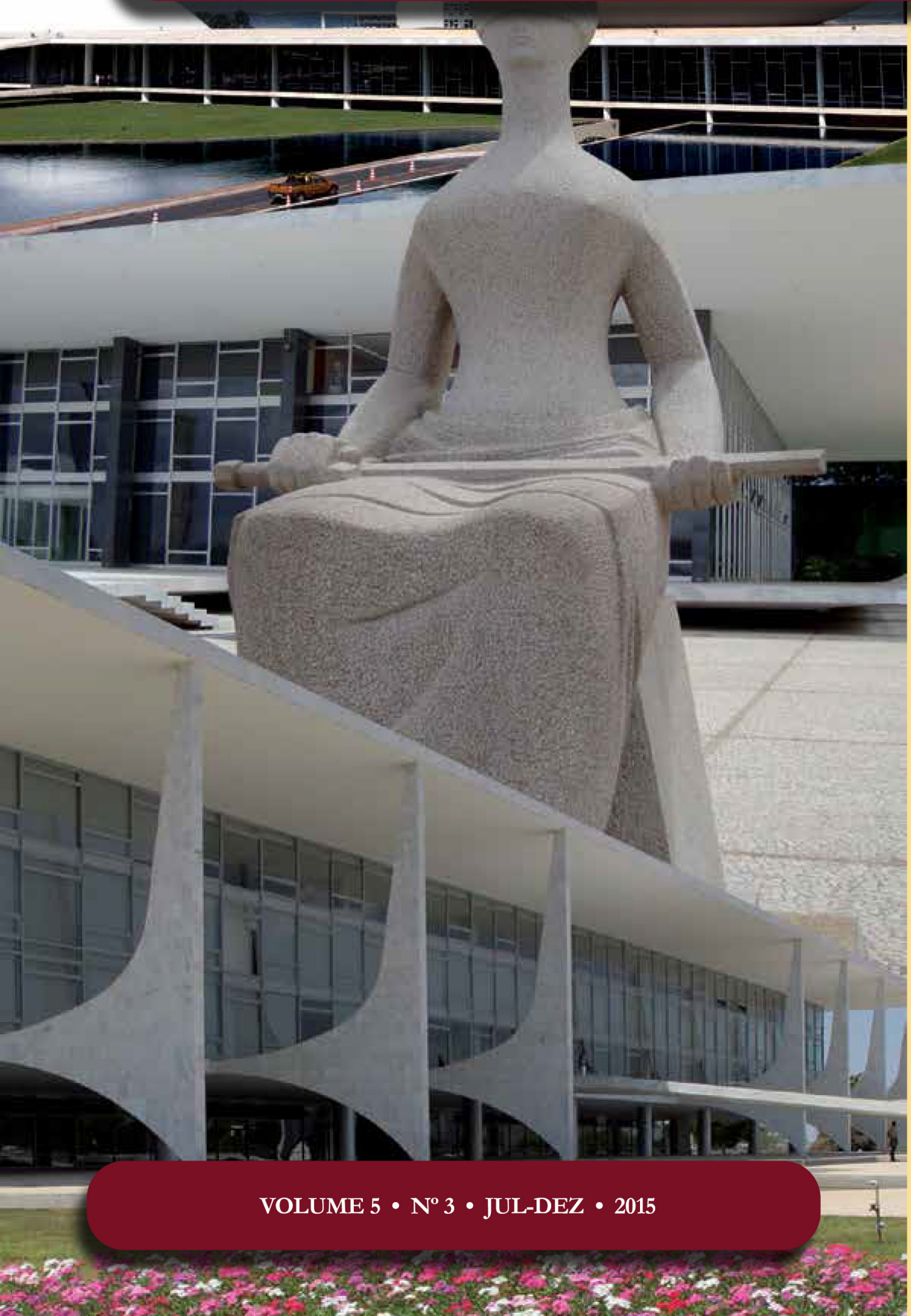

Poder normativo das cortes constitucionais: 0 caso brasileiro Normative power of constitutional courts: the Brazilian case 


\section{Poder normativo das cortes constitucionais: o caso brasileiro*}

\section{Normative power of constitutional courts: the Brazilian case}

Inocêncio Mártires Coelho**

\section{Resumo}

O objetivo deste artigo é ressaltar que, apesar das costumeiras a uma suposta produção legislativa heterônoma e, por isso, ilegítima, das cortes constitucionais, em verdade se trata de uma objeção inconsistente, porque esses tribunais extraordinários, pela sua própria natureza e posição institucional, são a derradeira instância da atividade jurisdicional nos Estados Democráticos de Direito, estando situados fora e acima da tradicional tripartição dos poderes estatais. Disso decorre que as suas decisões são irrecorríveis, embora passíveis de críticas, espraiando-se, normativamente, pelo sistema jurídico de que fazem parte. No Brasil, assumidamente um Estado Democrático de Direito, a situação é idêntica, cabendo ao STF - como órgão de cúpula do nosso sistema jurídico - dar a palavra final sobre qualquer controvérsia jurídica que lhe for submetida, o que significa dizer que essa corte, nalguma medida, também "legisla" naquilo que for objeto dos seus julgados.

Palavras-chave: Estado Democrático de Direito. Jurisdição constitucional. Cortes constitucionais. Poder normativo.

\section{Premissas da tese}

A afirmação, no título desta comunicação, da existência de um poder normativo na jurisdição constitucional, assenta-se pelo menos em duas premissas básicas, a saber:

1. As constituições, como documentos vivos e abertos à ação do tempo, estão sujeitas ao panta rhei, à lei da eterna transformação. Na medida em que disponham de força normativa - por sua própria natureza e função, todas elas possuem esse atributo em alguma medida - , ao mesmo em que se modificam, vão modificando a realidade em que emergem e sobre a qual atuam, numa fecunda interação dialética entre realidade constitucional e texto constitucional, entre âmbito normativo e programa normativo, ou se, quisermos entre infraestrutura e superestrutura. Não seria diferente, portanto, a forma de ser e de existir da nossa Carta Política, que foi promulgada em 5 de outubro de 1988 e até hoje permanece em vigor, graças à nossa vontade de Constituição, ao respeito que lhe devotamos, como a lei suprema que rege a nossa vida em comum; ${ }^{1}$ 
2. As cortes constitucionais, institucionalmente, situam-se fora e acima da tradicional tripartição dos poderes do Estado. A matéria prima com que trabalham esses supertribunais é o texto da Constituição. Esse texto é o mais aberto possível; por isso, comporta as mais diversas leituras, a depender de cada situação hermenêutica, leituras que, pela natureza e função dessas cortes, incorporam-se à Constituição, como se fossem emendas constitucionais, mesmo que esses tribunais não disponham, expressamente, desse "poder constituinte" atípico. Assim, a cada interpretação, a Constituição vai sendo reescrita, por via hermenêutica, e contra isso não há outra saída senão a crítica externa, que inibe, mas não impede, esse comportamento dos órgãos encarregados de dar a última palavra - nem que seja uma última palavra provisória - sobre o sentido e o alcance dos preceitos constitucionais. Nisso consiste o poder normativo da jurisdição constitucional ou a dimensão normativa das suas interpretações. ${ }^{2}$

\section{O PODER NORMATIVO DA JURISDIÇÃO CONSTITUCIONAL}

Lendo, faz alguns anos, a Teoria Geral do Direito e do Estado, de Hans Kelsen, deparei-me com a instigante observação - por ele atribuída a um certo bispo Hoadley -, de que o verdadeiro legislador é aquele que dispõe de autoridade absoluta para interpretar quaisquer normas jurídicas - sejam elas escritas ou faladas e não a pessoa que por primeiro as escreveu ou transmitiu verbalmente, uma assertiva de resto semelhante à que formularam Hobbes e Perelman, para os quais o legislador [rectius ; o atual] não é aquele por cuja vontade se editaram as leis, mas aquele que, podendo revogá-las ou interpretá-las autenticamente, as mantém em vigor com o sentido em que vêm sendo aplicadas. ${ }^{3}$ Idêntico, enfim, é o pensamento de Rousseau ao dizer que a lei de ontem não obriga hoje, mas o consentimento tácito presume-se pelo silêncio e presume-se que o soberano confirma incessantemente as leis que, podendo, ele não ab-rogou; e que tudo o que uma vez declarou querer, quererá sempre, a menos que o revogue. ${ }^{4}$

No desconcertante Nietzsche, por outro lado, choquei-me com a aquela sentença de que não existem fatos, mas, apenas, interpretações de fatos, e tampouco fenômenos morais, mas, apenas, uma interpretação moral dos fenômenos, ainda que se possa dizer - reconhecia o próprio filósofo - , que isso tudo já é uma interpretação. ${ }^{5}$

De outra feita, consultando o fecundo Mauro Cappelletti, fiquei impressionado com a afirmação - que adotamos como uma das premissas desta exposição - de que as cortes constitucionais estão situadas fora e acima da tradicional tripartição dos poderes estatais; que elas não podem ser enquadradas nem entre os órgãos jurisdicionais, nem entre os legislativos, nem muito menos entre os órgãos executivos estatais; e afinal, que esses tribunais extraordinários possuem uma função autônoma de controle constitucional, que não se identifica com nenhuma das funções próprias de cada um dos três poderes tradicionais, antes incide de várias formas sobre todos eles, para reconduzi-los, quando necessário, à rigorosa obediência das normas constitucionais. ${ }^{6}$

Mais adiante, desta feita lendo textos antigos de Francisco Campos sobre o papel institucional do STF e a inevitável criatividade das suas decisões, no exercício da jurisdição constitucional, encontrei-me com as

2 CAPPELLETTT, Mauro. O controle de constitucionalidade das leis no sistema das funções estatais. Revista de Direito Processual Civil, São Paulo, v. 2, n. 3, p. 37-73, jan./jun. 1961. p. 38; HESSE, Konrad. A força normativa da Constituição. Porto Alegre: S. A. Fabris, 1991. p. 19; MENDES, Conrado Hübner. Direitos fundamentais, separação de poderes e deliberação. São Paulo: Saraiva, 2011. Com especial atenção para a Nota 4, p. 216, e para o Apêndice, às páginas 249-254.

3 KELSEN, Hans. Teoría general del derecho y del estado. México: UNAM, 1969. p. 182-183; HOBBES, Thomas. Leviatã. México: Fondo de Cultura Económica, 1996. p. 220; PERELMAN, Chaïm. Ética e direito. São Paulo: M. Fontes, 1996. p. 625.

4 ROUSSEAU, J. J. Do contrato social. Rio de Janeiro: Globo, 1962. (Obras de Jean-Jacques Rousseau, v. 2). p. 81.

5 NIETZSCHE, Friedrich. Fragmentos finais. Brasília: UnB, 2002. p. 157; NIETZSCHE, Friedrich. A vontade de poder. Rio de Janeiro: Contraponto, 2008. p. 153; 260.

6 CAPPELLETTI, Mauro. O controle de constitucionalidade das leis no sistema das funções estatais. Revista de Direito Processual Civil, São Paulo, v. 2, n. 3, p. 37-73, jan./jun. 1961. p.38. 
considerações expostas a seguir, de generalizada aceitação pelos constitucionalistas mais categorizados.

Juiz das atribuições dos demais Poderes, sois o próprio juiz das vossas. O domínio da vossa competência é a Constituição, isto é, o instrumento em que se define e se especifica o Governo. No poder de interpretá-la está o de traduzi-la nos vossos próprios conceitos. Se a interpretação, e particularmente a interpretação de um texto que se distingue pela generalidade, a amplitude e a compreensão dos conceitos, não é operação puramente dedutiva, mas atividade de natureza plástica, construtiva e criadora, no poder de interpretar há de incluir-se, necessariamente, por mais limitado que seja, o poder de formular. O poder de especificar implica margem de opção tanto mais larga quanto mais lata, genérica, abstrata, amorfa ou indefinida a matéria de cuja condensação há de resultar a espécie. ${ }^{7}$ (grifos nossos).

Mais surpreso, ainda, fiquei ao ler um artigo de Lúcio Bittencourt, escrito nos idos de 1942, no qual afirma que, bem vistas as coisas, poder-se-ia dizer que a interpretação é parte integrante do processo legislativo, porque é nesse momento que se completa a nomogênese jurídica, pois só então o seu aplicador reconhece, para os fins de realização direito, que ocorreu, no mundo fático, a hipótese de incidência abstratamente prevista nos enunciados normativos. ${ }^{8}$

Noutra ocasião, compulsando textos do clássico Alexander Pekelis sobre a Constituição norte-americana, surpreendi-me com a passagem a seguir, sempre lembrada pelos admiradores dessa bicentenária carta política.

Devemos recordar que em certo sentido os Estados Unidos não têm uma constituição escrita. As grandes cláusulas da Constituição americana, assim como as disposições mais importantes das nossas leis fundamentais, não contêm senão um apelo à honestidade e à prudência daqueles a quem é confiada a responsabilidade da sua aplicação. Dizer que a compensação deve ser justa; que a proteção da lei deve ser igual; que as penas não devem ser nem cruéis nem inusitadas; que as cauções e as multas não devem ser excessivas; que as investigações ou as detenções hão de ser motivadas; e que a privação da vida, da liberdade ou da propriedade não se pode determinar sem o devido processo legal, tudo isso outra coisa não é senão autorizar a criação judicial do direito, e da própria Constituição, pois a tanto equivale deixar que os juizes definam o que seja cruel, razoável, excessivo, devido ou talvez igual. ${ }^{9}$

Com igual admiração, anotei de Charles Hughes, que foi Governador do Estado de Nova York e, depois, presidente da Suprema Corte dos Estados Unidos, a frase-síntese da experiência constitucional do seu país, a proclamar que os americanos vivem sob uma constituição, mas que essa carta política é aquilo que os seus juizes dizem que ela é. ${ }^{10}$

Estudando, agora, o autodenominado pós-positivismo ou neoconstitucionalismo ${ }^{11}$, sou informado por muitos dos seus estudiosos que esse movimento de idéias, de significativa presença em diversos países, pode caracterizar-se pelos seguintes traços fundamentais - afora outros, que não vem ao caso indicar -, todos eles ligados à chamada interpretação especificamente constitucional.

- $\quad$ mais constituição do que leis;

- $\quad$ mais juízes do que legisladores

- $\quad$ mais princípios do que regras;

- $\quad$ mais ponderação do que subsunção;e

7 CAMPOS, Francisco O Poder Judiciário na Constituição de 1937. In: Direito constitucional. Rio de Janeiro: Forense, 1942 , p. 367.

8 BITTENCOURT, Carlos Alberto Lúcio. A interpretação como parte integrante do processo legislativo. Revista do Serviço Público, São Paulo, v. 4, n. 3, p. 121-127, dez. 1942.

9 PEKELIS, Alexander. La tecla para una ciencia jurídica estimativa. et al. El actual pensamiento jurídico norteamericano. Buenos Aires: Losada, 1951. p. 117-172. p. 125.

10 A frase, frequentemente citada, é referida, entre outros, por Antonio Carrillo Flores. CARRILLO FLORES, Antonio. Prólogo. In: HUGHES, Charles Evans. La suprema Corte de Estados Unidos. Mexico: Fondo de Cultura Economica, 1946. p. 7-8.

11 SOUZA NETO, Cláudio Pereira de; SARMENTO, Daniel. Direito constitucional: teoria, história e métodos de trabalho. Belo Horizonte: Fórum, 2013. p. 202; Nota 65. 
- $\quad$ mais concretização do que interpretação. ${ }^{12}$

Pois bem, vistos em conjunto, e sem necessidade de maiores reflexões, pode-se dizer que esses traços distintivos pretendem configurar e/ou sintetizar uma expressiva mudança de paradigmas ou, se preferirmos, uma autêntica subversão dos esquemas de pensamento do constitucionalismo tradicional, tal como ele surgiu e se desenvolveu desde o final do século XVIII até praticamente todo o século XX.

Para fundamentar esta assertiva de ordem geral, comecemos pela prevalência da Constituição, que antes se considerava como fonte mediata ou, simplesmente, como fonte das fontes do direito, conferindo-se à lei a função de regular de forma direta, imediata e soberana, todas as relações sociais, e ao legislador, a mais ampla liberdade de conformação, sob o entendimento de que a lei - expressão, sempre renovada, da vontade geral -, era congenitamente legítima e os seus autores, como representantes e/ou tradutores dos anseios do povo, não deveriam submeter-se a nenhum controle ou censura estranhos aos parlamentos.

Para o novo constitucionalismo, a Constituição, que no passado era um simples catálogo de competências e de fórmulas exortativas, que não vinculavam o legislador - nesse sentido ela era apenas um texto político, sem pretensão de injuntividade -, assume, agora, a função de norma suprema e de fundamento de validade de todo o ordenamento jurídico, compondo um conjunto de regras e de princípios dotados de normatividade própria e imediatamente eficaz - a força normativa da Constituição -, relegando-se a Lei, antes soberana, à condição de ato infraconstitucional, sujeito a controle de legitimidade, formal e material, em face da Constituição. Esse controle, por outro lado, é confiado a todos os agentes oficiais da sua interpretação/aplicação, desde os órgãos da jurisdição ordinária, que habitualmente a manejam, até as cortes constitucionais, que estão acima dos demais Poderes e, por isso mesmo, desfrutam de prerrogativas infinitamente maiores do que as que eram reconhecidas ao legislador recém-destronado. É precisamente esse o sentido da expressão mais Constituição do que leis, a evidenciar a supremacia e a aplicabilidade direta da Carta Política e não a existência de muitas constituições, o que seria uma rematada tolice, porque todos sabem que em qualquer Estado de Direito existe só uma Constituição e leis as mais diversas.

Como consequência necessária e imediata da supremacia e da aplicabilidade direta dos preceitos constitucionais, tem-se a segunda característica desse novo constitucionalismo - mais juíres do que legisladores -, a sinalizar para o reconhecimento dos julgadores como legítimos criadores do direito e não como simples reveladores de uma suposta e indefinível vontade da lei ou do legislador, que, enquanto tais, não resolvem os problemas suscitados pela convivência humana. Afinal, como ensina Emilio Betti, o intérprete não trabalha com meras suposições, mas apenas com o feito ou o falado. ${ }^{13}$

Quanto à terceira característica desse novo constitucionalismo - mais princípios do que regras -, o que temos diante de nós é a constatação de que, hoje em dia, reconhecida a não correspondência entre texto e norma, os preceitos tidos como genuinamente constitucionais apresentam-se sob a forma de enunciados abertos e, por isso, portadores de múltiplos significados, a serem revelados/atribuídos por seus intérpretes/ aplicadores, em cada situação hermenêutica. Nesse sentido, todo princípio - em verdade todo enunciado jurídico - é plurinormativo, porque dele podemos extrair mais de uma norma, como atestam as mutações normativas ou viragens da jurisprudência.

12 Para uma visão sumária dessa temática, inclusive críticas e confrontos de posições, ver: CARBONELL, Miguel (Org.). Teoría del neoconstitucionalismo. Madrid: Instituto de Investigaciones Jurídicas, 2007; CARBONELL, Miguel. Neoconstitucionalismo(s). Madrid: Trotta, 2005. Sobre o neo-constitucionalismo no Brasil, ver BARROSO, Luis Roberto. Curso de direito constitucional contemporâneo. São Paulo: Saraiva, 2009. p. 306-350; RAMOS, Elival da Silva. Ativismo judicial: parâmetros dogmáticos. São Paulo: Saraiva, 2010. p. 279-288; e HORBACH, Carlos Bastide. A nova roupagem do direito constitucional: neo-constitucionalismo, pós-positivismo e outros modismos. São Paulo: RT, 2007; HORBACH, Carlos Bastide. A nova roupa do direito constitucional: neoconstitucionalismo, póspositivismo e outros modismos. In: ROCHA, Maria Elizabeth Guimarães Teixeira; MEYER-PFLUG, Samantha Ribeiro (Coord.). Lições de direito constitucional em homenagem ao professor Jorge Miranda. Rio de Janeiro: Forense, 2008. p. 291-302. p. 295.

13 BETTI, Emilio. Interpretación de la ley y de los actos jurídicos. Madrid: Revista de Derecho Privado, 1975. p. 28. 
Intimamente ligada a essa terceira nota distintiva, a rigor apenas uma consequência do que nela se contém, a quarta característica do movimento neo-constitucionalista - mais ponderação do que subsunção - ela traduz a singularidade da chamada interpretação especificamente constitucional, enquanto hermenêutica de princípios, em cujo âmbito não poderemos torná-los operativos utilizando o raciocínio silogístico e a técnica da subsunção, pelo simples fato de que tais instrumentos só têm aplicação a preceitos cujas hipóteses de incidência e respectivas consequências jurídicas venham previamente determinadas pelo legislador, conforme o clássico enunciado se $\boldsymbol{A}$, então $\boldsymbol{B}$, no qual o elemento $\boldsymbol{A}$ representa o suposto de fato cuja ocorrência, no mundo real, tem como consequência a atualização do elemento $\boldsymbol{B}$, no mundo do direito.

Como no âmbito dos princípios jurídicos - enquanto pautas axiológicas abertas e indeterminadas - esses elementos não são estabelecidos, desde logo, pelo legislador, até porque traduzem apenas raz̃ôs para que se decida num ou noutro sentido, o modo de aplicá-los exige que os intérpretes/aplicadores avaliem essas razões, optando, afinal, pela solução que se lhes mostre correta e justa, à luz do caso concreto. Por isso é que se diz que, num conflito entre princípios constitucionais, funciona como hipótese de incidência o próprio caso sob apreciação e, como consequência jurídica, o princípio que vier a prevalecer. Nesse sentido, lembrando Carlos Cossio, em citação de Castanheira Neves, dir-se-ia que, à semelhança das leis, é possível aplicar princípios por subsunção, mas só depois de os escolhermos por valoração. ${ }^{14}$

Quanto à quinta e última característica do novo constitucionalismo - mais concretização do que interpretação - para bem compreendê-la devemos ter presente, mais uma vez, a distinção entre regras e princípios. As primeiras a demandarem a descoberta do seu sentido, seja ele o que foi idealizado, subjetivamente, pelo legislador empírico, seja o que, independentemente da sua vontade, ou mesmo à sua revelia, veio a se fixar objetivamente no texto e, como tal, há de ser levado em conta pelos intérpretes/aplicadores; os segundos, os princípios jurídicos, cuja abertura semântica não nos permite falar de apenas um, mas de múltiplos significados, postos à disposição dos seus operadores para que os concretizem à luz das peculiaridades do caso. A propósito, relembremos, com Böckenförde, que enquanto a interpretação é uma indagação sobre o conteúdo e o sentido de algo precedente, já a concretização é o preenchimento criativo de uma pauta que se volta para o futuro e que permite aos seus intérpretes/aplicadores optar pela leitura que lhes parecer mais adequada, em cada caso, à realização da justiça material como referente fundamental da idéia de direito. ${ }^{15}$

Diante disso tudo, parece plenamente justificada a assertiva de Rubio Llorente ao dizer que, atualmente, a doutrina da interpretação é o núcleo essencial da Teoria da Constituição e do Direito Constitucional, assim como da Teoria do Estado e, de alguma forma, até mesmo da própria Teoria do Direito, na medida em que os traços fundamentais desse novo constitucionalismo ou pós-positivismo - a depender do ponto de vista em que os analisarmos - poderão ser vistos como causa ou consequência da chamada interpretação especificamente constitucional. ${ }^{16}$

Pois bem, em que pese à sua aceitação em alguns dos nossos meios acadêmicos, com louvores e/ou ressalvas, do que nos dão conta excelentes textos de Ana Paula de Barcellos, Antonio Cavalcanti Maia, Cláudio Pereira de Souza Neto, Daniel Sarmento, Guilherme Sandoval Góes e do Chef d'École, Luís Roberto Barroso $^{17}$, apesar desse acolhimento doutrinário, o novo constitucionalismo ou pós-positivismo também é alvo de

14 NEVES, A. Castanheira. Metodologia jurídica: problemas fundamentais. Coimbra: Coimbra, 1993. p. 172.

15 BÖCKENFÖRDE, Ernst-Wolfgang. Escritos sobre derechos fundamentales. Baden-Baden: Nomos Verlagsgesellschaft, 1993. p. 126-127.

16 RUBIO LLORENTE, Francisco. La interpretación de la constitución. Madrid: Centro de Estudios Constitucionales, 1984. p. XVII. 17 BARROSO, Luís Roberto; BARCELLOS Ana Paula de. O começo da história: a nova interpretação constitucional e o papel dos princípios no direito brasileiro. In: SILVA, Virgílio Afonso da (Org.). Interpretação constitucional. São Paulo: Malheiros, 2005. p. 271-316; BARROSO, Luís Roberto. Direito, racionalidade e paixão. In: BARCELLOS, Ana Paula de. Ponderação, racionalidade e atividade judicial. Rio de Janeiro: Renovar, 2005. Não paginado; BARROSO, Luis Roberto. Curso de direito constitucional contemporâneo. São Paulo: Saraiva, 2009. p. 265-289; MAIA, Antonio Cavalcanti. Nos vinte anos da Carta Cidadã: do pós-positivismo ao neoconstitucionalismo. In: SOUZA NETO, Cláudio Pereira de; SARMENTO, Daniel; BINENBOJM, Gustavo (Coord.). Vinte anos da Constituição Federal de 1988. Rio de Janeiro: Lúmen Juris, 2009. p. 117-168; SOUZA NETO, Cláudio Pereira de; SARMENTO, Daniel. Direito constitucional: teoria, história e métodos de trabalho. Belo Horizonte: Fórum, 2013. p. 200-206; GÓES, Guilherme Sandoval. Neoconstitucionalismo e dogmática pós-positivista. In: BARROSO, Luis Roberto (Org.). A reconstrução democrática do direito público no 
críticas acerbas de outros juristas de igual estofo, com destaque para o erudito professor Humberto Ávila, a verberar que, aplicado ao Brasil - porque, segundo ele, a nossa Carta Política, ao contrário do que se costuma dizer, é regulatória e não principiológica -, o neoconstitucionalismo está mais para o que se poderia denominar, provocativamente, de uma espécie enrustida de não-constitucionalismo, um movimento ou uma ideologia que, barulhentamente, proclama a supervalorização da Constituição enquanto, silenciosamente, promove a sua desvalorização. ${ }^{18}$

De nossa parte - si parva licet componere magnis -, achamos que ainda é cedo para dizermos se esse neoconstitucionalismo é, mesmo, uma coisa nova ou não passa de um modismo ou de mais um retorno - do eterno retorno ${ }^{19}$-, ainda envergonhado, ao jusnaturalismo velho de guerra...

Afinal, como salienta Mauro Cappelletti, no Direito moderno a Constituição pretende ser uma forma legalista de superar o legalismo; um retorno ao jusnaturalismo com os instrumentos do positivismo jurídico; um jusnaturalismo histórico, vale dizer, nem absoluto, nem eterno nem imutável; enfim, um direito natural vigente, legítimo e plenamente eficaz. ${ }^{20}$

Voltando, agora, ao nosso ponto de partida, anotamos que, independentemente de suportes teóricos como é o caso do neoconstitucionalismo -, não é nova nem esdrúxula a ideia de se admitir a presença de alguma carga de normatividade ou de um poder normativo em toda a interpretação/aplicação judicial do direito, seja ao nível inicial da jurisdição, nas decisões monocráticas, seja no topo da hierarquia judiciária, nos veredictos dos colegiados judicantes, especialmente das cortes constitucionais, cujas decisões, sobre serem irrecorríveis, têm efeito irradiante por todo o sistema jurídico de que fazem parte. Se a tudo isso ainda acrescentarmos o reconhecimento - sincero e corajoso -, de que em, última análise, à luz da experiência, a lei é a sua interpretação, como adverte Reale ${ }^{21}$, ou que a criação do Direito é sempre aplicação do Direito, conforme ensinamento de Kelsen $^{22}$, aí não haverá como negar-se à jurisprudência, ao chamado direito judicial, o status ou a condição de autêntica fonte do Direito. ${ }^{23}$

No âmbito da hermenêutica filosófica, como arte geral do compreender ${ }^{24}$, na qual se fundamenta e de onde provém a particular hermenêutica jurídica - na condição de ancilla philosophiae ${ }^{25}$-, nesse domínio vale lembrar, no dizer de Hans-Georg Gadamer, que é a interpretação que, frequentemente, leva à criação crítica do texto; que toda leitura contém, basicamente, também interpretação; que até a tradução meramente literal é sempre um gênero de interpretação; que mesmo nas artes reprodutivas - na música, por exemplo -, é nítida a singularidade de cada executor; que aquilo a que chamamos leitura é um ler compreensivo; e, enfim, que a compreensão não é jamais um comportamento apenas reprodutivo, antes também produtivo, pois quando se logra compreender, compreende-se sempre de um modo próprio e diferente. ${ }^{26}$ Essa, digamos, é a visão

Brasil. Rio de Janeiro: Renovar, 2007. p. 113-150.

18 ÁVILA, Humberto Ávila. Neoconstitucionalismo: entre a ciência do direito e o direito da ciência. In: SOUZA NETO, Cláudio Pereira de; SARMENTO, Daniel; BINENBOJM, Gustavo (Coord.). Vinte anos da Constituição Federal de 1988. Rio de Janeiro: Lúmen Juris, 2009. p.187-202.

19 SICHES, Luís Recaséns. Iusnaturalismos actuales comparados. Madrid: Universidad de Madrid-Faculdade de Derecho, 1970.p. 7; RADBRUCH, Gustav. Cinco minutos de filosofia do direito. In: p. 211-214. . Filosofia do direito. Coimbra: Arménio Amado, 1961. v. 2.

20 CAPPELLETTI, Mauro. O controle de constitucionalidade das leis no sistema das funções estatais. Revista de Direito Processual Civil, São Paulo, v. 2, n. 3, p. 37-73, jan./jun. 1961. p. 38. p. 56; 129. Sobre o conceito de Constituição normativa, ver LOEWENSTEIN, Karl Teoría de la constitución. Barcelona: Ariel, 1979. p. 217-218. Sobre a força normativa da Constituição, ver HESSE, Konrad. A força normativa da Constituição. Porto Alegre: S. A. Fabris, 1991; HESSE, Konrad. Temas fundamentais do direito constitucional. São Paulo: Saraiva, 2009. p. 123-146.

21 REALE, Miguel. Estudos de filosofia e ciência do direito. São Paulo: Saraiva, 1978. p. 63.

22 KELSEN, Hans. Teoria geral do direito e do Estado. São Paulo: M. Fontes, 1990. p. 137.

23 BRUTAU, José Puig. La jurisprudencia como fuente del derecho. Barcelona: Bosch, [19--?].

24 SCHLEIERMACHER, Friedrich D. E. Herménentique. Alençon: CERF/PUL, 1989. p. 113.

25 COELHO, Inocêncio Mártires. Da hermenêutica filosófica à hermenêutica jurídica: fragmentos. 2. ed. São Paulo: Saraiva, 2015.

26 GADAMER, Hans-Georg. Verdad y método. Salamanca: Sígueme, 1993. v. 1. p. 367; 479; GADAMER, Hans-Georg. Verdady método. Salamanca: Sígueme, 1994. v. 2. p. 26; 329- 330. 
majoritária sobre o papel do sujeito no fenômeno do conhecimento como relação/correlação entre sujeito e objeto, evento em que ao sujeito cognoscente compete apreender o objeto - o que ele faz saindo de sua esfera e ingressando na esfera própria do objeto - enquanto ao objeto corresponde a função de se dar a conhecer ou se deixar apreender pelo sujeito, ao qual transfere as suas propriedades.

$\mathrm{Na}$ teoria marxista do conhecimento, esse protagonismo do sujeito no processo cognitivo é levado ao extremo, porque para o materialismo histórico só o indivíduo humano concreto, percebido no seu condicionamento biológico e no seu condicionamento social, é o sujeito concreto da relação cognitiva. Noutro dizer, para essa corrente de pensamento, o sujeito que conhece não é um espelho, não é um aparelho registrando, passivamente, as sensações geradas pelo meio circunvizinho, antes é precisamente quem dirige este aparelho, quem o orienta, quem o regula, e em seguida transforma os dados que este lhe fornece. ${ }^{27}$ Em síntese, na relação cognitiva - independentemente da autonomia do objeto -, o sujeito é o senhor do conbecimento.

Diante desse papel do sujeito no evento da cognição e do reconhecimento - "transitado em julgado" -, da pré-compreensão como condição de possibilidade de toda a compreensão, não seria de causar surpresa e tampouco reações emocionais ${ }^{28}$, que o Supremo Tribunal Federal - como sujeito institucional, senhor e possuidor da última palavra sobre o significado do texto constitucional -, viesse a ser habilitado, como o foi pela Emenda Constitucional n ${ }^{\circ}$ 45/2004, para, mediante deliberação de dois terços dos seus membros, depois de reiteradas decisões sobre matéria constitucional, aprovar súmula que, a partir de sua publicação na imprensa oficial, terá efeito vinculante - idêntico ao efeito que possuem as leis! -, em relação aos demais órgãos do Poder Judiciário e à administração pública direta e indireta, nas esferas federal, estadual e municipal, bem como proceder à sua revisão ou cancelamento, na forma estabelecida em lei. Por isso, entendemos que tais Súmulas, em relação às instâncias indicadas na Constituição, são instrumentos de hegemonia hermenêutica, destinados a lhes impor a compreensão - em verdade, a pré-compreensão -, do STF sobre todas matérias constantes do texto constitucional.

Excluído da submissão a essas Súmulas restou apenas o Poder Legislativo, pois do contrário já não teríamos Constituição, pelo menos naquele sentido histórico-ideológico, que se espraiou pelo mundo jurídico-político a partir do artigo XVI da Declaração dos Direitos do Homem e do Cidadão, de 1789, cujo teor e substância nunca é demais relembrarmos:

Não tem constituição aquela sociedade em que não estejam assegurados os direitos dos indivíduos, nem separados os poderes estatais. ${ }^{29}$

Assim agindo, o constituinte derivado mais não fez - para o bem ou para o mal - do que sacramentar, em texto expresso, a tese hermenêutica segundo a qual "indicar, previamente, qual a interpretação que julga certa é o mesmo que dizê-lo, a posteriori, de forma irrecorrível", argumento certeiro que fundamentou antiga decisão do Tribunal Superior do Trabalho - mais tarde invalidada pelo STF -, em que essa corte especializada defendeu a constitucionalidade dos seus Prejulgados, por ela considerados tão necessários, legítimos e, por isso, também vinculantes como estas novas Súmulas da nossa corte constitucional, com a única diferença - a favor da Justiça do Trabalho -, de que os seus Enunciados foram concebidos e incorporados à velha CLT há mais de 60 anos. ${ }^{30}$

27 SCHAFF, Adam. História e verdade. São Paulo: M. Fontes, 1987. p. 81-82.

28 STRECK, Lênio Luiz. Súmulas no direito brasileiro: eficácia, poder e função: a ilegitimidade constitucional do efeito vinculante. Porto Alegre: Livraria do Advogado, 1998. p. 287-288: “[...] a imposição de Súmulas isto é, de normas gerais e abstratas (textos jurídicos) pela cúpula do Poder Judiciário às instâncias inferiores, é a própria negação da função da jurisprudência, convertendo-se esse Poder de Estado em um arremedo de legislador, o que, além de tudo, é constitucionalmente ilegitimo".

29 MENDES, Gilmar; COELHO, Inocêncio M.; BRANCO, Paulo G. G. Curso de direito constitucional . 2. ed. São Paulo: Saraiva, 2008. p. 155.

30 BRASIL. Tribunal Superior do Trabalho. Processo no RR - MC - 2.241/68. Supremo Tribunal Federal. Representação n. ${ }^{\circ} 946-D F$, RTJ 82/44-51. 


\section{Considerações finais}

Consolidada a posição das cortes constitucionais, ao menos no mundo ocidental, tornou-se banalidade considerar a jurisprudência desses supertribunais como genuína fonte do direito, cuja legitimidade, ademais, não se deve e, a rigor, sequer se pode questionar, na medida em que os julgados provêm de uma instituição que, sistemicamente, situa-se fora e acima da tradicional tripartição dos poderes estatais e que, no exercício das suas atribuições, está autorizada pela própria Constituição a emitir a última palavra sobre o significado dos preceitos constitucionais, dessas gloriosas ambiguidades, que permitem as mais diversas leituras, a depender de cada situação hermenêutica. ${ }^{31}$

Não por acaso, entre nós e alhures, já se fala até mesmo em constituição "constituenda" e "reinventada" pela jurisdição constitucional ${ }^{32}$; que o direito constitucional deixou ser apenas o que prescreve o texto da Lei Maior, para compreender, também, a bagagem de padrões hermenêuticos desse bloco normativo, incorporada na jurisprudência constitucional.

Casos bem recentes, no Brasil, que tiveram grande repercussão política e social, atestam a atualidade desse entendimento, como as decisões do STF "esclarecendo" que os mandatos dos titulares de cargos eletivos pertencem aos partidos políticos e não aos candidatos eleitos sob as suas legendas, razão por que se estes vierem a trocar de partido estarão sujeitos à perda do mandato, nos casos e condições estabelecidos em legislação judicial ${ }^{33}$; permitindo que se aplicasse às greves no serviço público a legislação existente para o setor privado, enquanto não for aprovada legislação específica, a qual, de resto, até hoje não foi editada ${ }^{34}$; assim como e por derradeiro, a decisão unânime, reconhecendo, como entidade familiar, a união estável entre casais do mesmo sexo. Igualmente emblemática, a merecer o mesmo destaque, foi o julgado do Tribunal Superior Eleitoral que, em pedido de impugnação de candidatura, considerou como cônjuges - para efeito da inelegibilidade prevista no art. $14, \int 7^{\circ}$, da Constituição -, as pessoas do mesmo sexo que vivam em estado de casadas, pois nessa condição, ao menos para esse efeito, devem ser consideradas como unidas por matrimônio. ${ }^{35}$

Nesse contexto, em que figuras do porte de um Elias Díaz já se perguntam - entre perplexos e apreensivos - se o atual Estado constitucional de Direito não é uma simples máscara ideológica, com que se disfarça

31 A expressão gloriosas ambiguidades é de Shirley M. Huffstedler, como informa Mauro Cappelletti. CAPPELLETTI, Mauro. Juízes legisladores? Porto Alegre: S. A. Fabris, 1993. p. 67.

32 CORTÊS, António. Jurisprudência dos princípios. Lisboa: Universidade Católica, 2010. p. 73-74; HÄBERLE, Peter. El concepto de Constitución. Concepción mixta de Constitución. In:____. El_Estado constitucional. México: UNAM, 2001. p. 3-7. p. 3; e SAMPAIO, José Adércio Leite. A Constituição reinventada pela jurisdição constitucional. Belo Horizonte: Del Rey, 2002. p. 208-217.

33 INFORMATIVO STF. Brasília: STF, n. 482, de 01 out. 2007. Disponível em: < http://www.stf.jus.br/arquivo/informativo/ documento/informativo482.htm>. Acesso em: 12 dez. 2015. Omisso o Congresso Nacional em disciplinar esse aspecto crucial da fidelidade partidária, embora tal paralisia viesse se tornando crescentemente incômoda, para dizer o mínimo, a jurisdição constitucional não criou direito novo, apenas "explicitou" — por via de interpretação sistemática —, algo que já se continha no corpo e na alma da Constituição: num regime político em que ninguém pode se eleger sem filiação partidária, os mandatos pertencem aos partidos e não àqueles que se elegem sob as suas legendas. Como essa decisão foi "extraída" do texto constitucional em vigor, caso o Congresso Nacional queira restabelecer o "troca-troca" de partidos sem perda de mandatos, terá de assumir essa "coisa" e emendar a Constituição... Mais recentemente, novamente provocado a dizer o direito, o STF decidiu que essa perda de mandato não se aplica àqueles que se elegeram em votação majoritária, no caso, os Senadores da República.

34 BRASIL. Supremo Tribunal Federal. Mandado de Injunção. MI 689 PB. Tribunal Pleno. Impetrante: Sindicato dos Servidores do Poder Judiciário do Estado da Paraíba. Impetrado: Congresso Nacional. Relator: Min. Eros Grau. Brasilia, 07 de junho 2006. Disponível em: <http://stf.jusbrasil.com.br/jurisprudencia/760369/mandado-de-injuncao-mi-689-pb>. Acesso em: 12 dez. 2015. Ementa: mandado de injunção. Concessão de efetividade à norma inscrita no artigo 37, inciso VII, da Constituição do Brasil. Aplicação da lei federal n. 7.783/89, que rege o direito de greve na iniciativa privada, até que sobrevenha lei regulamentadora.

35 BRASIL. Tribunal Superior Eleitoral. Recurso Especial Eleitoral. REspe 24564 PA. Embargante: Maria Eulina Rabelo de Sousa Fernandes. Embargado: Procuradoria Regional Eleitoral do Para. Relator: Min. Gilmar Mendes. Brasília, 02 de outubro de 2004. Disponível em: <http://www.justicaeleitoral.jus.br/arquivos/tse-recurso-especial-24564> . Acesso em: 12 dez. 2015 . Acórdão publicado em sessão, em 01/10/2004. Registro de candidato. Candidata ao cargo de prefeito. Relação estável homossexual com a prefeita reeleita do município. Inelegibilidade. Art. 14, \ $7^{\circ}$, da Constituição Federal. Os sujeitos de uma relação estável homossexual, à semelhança do que ocorre com os de relação estável, de concubinato e de casamento, submetem-se à regra de inelegibilidade prevista no art. 14, $\int 7^{\circ}$, da Constituição Federal. 
um verdadeiro Estado judicial de Direito ${ }^{36}$, não é "espantosa", portanto, a adoção da Súmula Vinculante, um instituto que, ao se agasalhar no texto constitucional, veio a se converter no emblema mais vistoso da chamada legislação judicial, uma normatividade que, mesmo congênita à atividade de aplicar/dižer o direito, ainda assim deve sujeitar-se a alguma forma de controle externo, de vigilância crítica - e.g. discussões doutrinárias e debates acadêmicos - via da qual a sociedade intenta dialogar com as suas cortes supremas, na esperança de convencê-las da necessidade de modificarem o seu entendimento sobre quaisquer temas, sempre que alterações no prisma histórico-social de realização do direito evidenciarem estar se esgotado o poder de convencimento da sua jurisprudência, até aí dominante. ${ }^{37}$ Afinal, não custa relembrar as lições dos mestres - com destaque para Oliver Wendell Holmes e Miguel Reale -, a nos dizerem que a vida do direito não tem sido a lógica, mas a experiência, e que esse mesmo direito deve ser estável sem ser estático, e dinâmico sem ser frenético. ${ }^{38}$

Nesse cenário avultam de importância esforços como os de Peter Häberle - um jurista para o século XXI ${ }^{39}$ -, em prol da abertura da sociedade dos intérpretes da Constituição e, assim, da institucionalização do diálogo entre os seus tradutores oficiais e todos os segmentos sociais que, nalguma medida, tenham algo de útil a dizer sobre o sentido e o alcance das normas constitucionais.

Embora alçadas à condição de super-leis, porque, em princípio, não são passíveis de alteração ou cancelamento senão a critério do próprio STF, que as "promulga" segundo juízos próprios de conveniência e oportunidade, mesmo assim tais Súmulas - porque vivemos num Estado de Direito ${ }^{40}$-, hão de ser lidas com observância dos métodos e dos princípios da interpretação do direito, em geral, e da chamada interpretação especificamente constitucional, em particular, o que implica dizer que, sendo normas jurídicas, portanto objetos culturais, tais Súmulas possuem substrato e sentido, ou texto e significado. Os primeiros elementos - o substrato ou o texto - são imutáveis em sua configuração linguística; enquanto os outros - o sentido ou significado -, são abertos à ação do tempo e, assim, ficam sujeitos às mudanças de compreensão, que são próprias das formas significativas e ensejam a sua permanente regeneração, como já tivemos oportunidade de escrever, noutro contexto, que ora recordamos:

Uma coisa é preservar-se o corpo físico da lei, o substrato da obra de arte; outra, bem diversa, é regenerar-lhe o espírito, emprestando às suas palavras significados sempre renovados. O texto original da Constituição norte-americana, por exemplo, velho de mais de duzentos anos, permanece intacto e exposto a visitação pública - ao lado do pergaminho da Declaração de Independência -, numa vitrine espessa, que oferece a maior proteção possível contra a ação do tempo... Graças a novas leituras, temporalmente ajustadas, que a Suprema Corte lhe empresta sem cessar, aquele texto vetusto - que foi ditado "à luz de uma vela de sebo" -, continua sendo venerado como a "religião civil" do país, "o supremo direito da terra" e a lei que rege "todas as crises dos negócios humanos" na maior potência econômica e militar do planeta. ${ }^{41}$

Evidenciando-se, assim, que toda decisão judicial contém, por menor que seja, alguma carga de normatividade, então o de que se trata não é de acusar os juízes de agir como legisladores, menos ainda de taxá-los como ativistas irresponsáveis, mas, antes, de instituir mecanismos de controle do direito judicial, dessa legislação

36 DÍAZ, Elias. Curso de filosofía del derecho. Madrid: Marcial Pons, 1998. p. 110.

37 REALE, Miguel. Gênese e vida dos modelos jurídicos: problemas de semântica jurídica. In: O direito como experiência.

São Paulo: Saraiva, 1968. p. 209-218.

38 HOLMES, Oliver Wendell. O direito comum. Rio de Janeiro: O Cruzeiro, 1967. p. 29; REALE, Miguel. A dinâmica do direito numa sociedade em mudança. In: ___ Estudos de filosofia e ciência do direito. São Paulo: Saraiva, 1978. p. 52-57.

39 VALADÉS, Diego. Peter Häberle: un jurista para el siglo XXI. Estudio introductorio. In: HÄBERLE, Peter. El Estado constitucional. México: UNAM, 2001. p. XXI-LXXXIV.

40 GADAMER, Hans-Georg. Verdade e método. Petrópolis: Vozes, 1997. v. 1. p. 488: Assim, para a possibilidade de uma hermenêutica jurídica é essencial que a lei vincule por igual todos os membros da comunidade; quando não é este o caso, como no absolutismo - em que a vontade do senhor absoluto está acima da lei -, já não é possível hermenêutica alguma, "pois um senhor superior pode explicar suas próprias palavras, até contra as regras da interpretação comum".

41 BITAR, Orlando. A lei e a Constituição. Belém: Do Autor, 1951. p. 66; BITAR, Orlando. Obras completas de Orlando Bitar. Rio de Janeiro: Conselho de Federal de Cultura, 1978. v. 2. p. 43; e MARSHALL, John. Decisões constitucionais de Marshall. Rio de Janeiro: Imprensa Nacional, 1903. p. 24/26. 
heterônoma criada pela magistratura, o que só será possível se, institucionalmente, além da usual motivação das suas decisões, os julgadores forem obrigados a revelar o que está por trás dos seus veredictos; de que premissas partiram e porque as elegeram ao invés de outras; numa palavra, só os controlaremos, no sentido próprio dessa expressão, se eles tiverem de justificar as próprias justificacooes, levando a cabo o que já se convencionou chamar de justificação última e profunda, uma justificação que se baseie em outras razões - tais como justiça, razoabilidade, oportunidade e correção -, razões que não derivam diretamente das normas ou dos princípios do ordenamento jurídico, mas que nem por isso deixam de ser objetivas e compreensíveis por todos quantos possam ser afetados, direta ou indiretamente, pelas decisões dos aplicadores do direito. ${ }^{42}$

\section{REFERÊNCIAS}

ÁVILA, Humberto Ávila. Neoconstitucionalismo: entre a ciência do direito e o direito da ciência. In: SOUZA NETO, Cláudio Pereira de; SARMENTO, Daniel; BINENBOJM, Gustavo (Coord.). Vinte anos da Constituição Federal de 1988. Rio de Janeiro: Lúmen Juris, 2009. p. 187-202.

BARROSO, Luis Roberto. Curso de direito constitucional contemporâneo. São Paulo: Saraiva, 2009.

BARROSO, Luís Roberto. Direito, racionalidade e paixão. In: BARCELLOS, Ana Paula de. Ponderação, racionalidade e atividade judicial. Rio de Janeiro: Renovar, 2005.

BARROSO, Luís Roberto; BARCELLOS, Ana Paula de. O começo da história: a nova interpretação constitucional e o papel dos princípios no direito brasileiro. In: SILVA, Virgílio Afonso da (Org.). Interpretação constitucional. São Paulo: Malheiros, 2005. p. 271-316.

BETTI, Emilio. Interpretación de la ley y de los actos jurídicos. Madrid: Revista de Derecho Privado, 1975.

BITAR, Orlando. A lei e a Constituição. Belém: Do Autor, 1951.

BITAR, Orlando. Obras completas de Orlando Bitar. Rio de Janeiro: Conselho de Federal de Cultura, 1978. v. 2.

BITTENCOURT, Carlos Alberto Lúcio. A interpretação como parte integrante do processo legislativo. Revista do Serviço Público, São Paulo, v. 4, n. 3, p. 121-127. dez. 1942.

BÖCKENFÖRDE, Ernst-Wolfgang. Escritos sobre derechos fundamentales. Baden-Baden: Nomos Verlagsgesellschaft, 1993.

BRASIL. Supremo Tribunal Federal. Mandado de Injunção. MI 689 PB. Tribunal Pleno. Impetrante: Sindicato dos Servidores do Poder Judiciário do Estado da Paraíba. Impetrado: Congresso Nacional. Relator: Min. Eros Grau. Brasilia, 07 de junho 2006. Disponível em: <http://stf.jusbrasil.com.br/jurisprudencia/760369/mandado-de-injuncao-mi-689-pb>. Acesso em: 12 dez. 2015.

BRASIL. Supremo Tribunal Federal. Representação n. ${ }^{\circ}$ 946-DF, RTJ 82/44-51.

BRASIL. Tribunal Superior do Trabalho. Processo $n^{\circ} R R-M C-2.241 / 68$.

BRASIL. Tribunal Superior Eleitora. Recurso Especial Eleitoral. REspe 24564 PA. Embargante: Maria Eulina Rabelo de Sousa Fernandes. Embargado: Procuradoria Regional Eleitoral do Para. Relator: Min. Gilmar Mendes. Brasília, 02 de outubro de 2004. Disponível em: < http://www.justicaeleitoral.jus.br/arquivos/tserecurso-especial-24564>. Acesso em: 12 dez. 2015.

BRUTAU, José Puig. La jurisprudencia como fuente del derecho. Barcelona: Bosch, [19--?].

CAMPOS, Francisco O Poder Judiciário na Constituição de 1937. In: Direito constitucional. Rio de Janeiro: Forense, 1942.

42 ORTEGA, Manuel Segura. La racionalidad jurídica. Madrid: Tecnos, 1998. p. 117-118. 
CAPPELLETTI, Mauro. Juizes legisladores? Porto Alegre: S. A. Fabris, 1993.

CAPPELLETTI, Mauro. O controle de constitucionalidade das leis no sistema das funções estatais. Revista de Direito Processual Civil, São Paulo, v. 2, n. 3, p. 37-73, jan./jun. 1961.

CARBONELL, Miguel (Org.). Teoría del neoconstitucionalismo. Madrid: Instituto de Investigaciones Jurídicas, 2007.

CARBONELL, Miguel. Neoconstitucionalismo(s). Madrid: Trotta, 2005.

CARRILLO FLORES, Antonio. Prólogo. In: HUGHES, Charles Evans. La suprema Corte de Estados Unidos. Mexico: Fondo de Cultura Economica, 1946. p. 7-8.

COELHO, Inocêncio Mártires. Da bermenêutica filosófica à hermenêutica jurídica: fragmentos. 2. ed. São Paulo: Saraiva, 2015.

CORTÊS, António. Jurisprudência dos princípios. Lisboa: Universidade Católica, 2010.

DÍAZ, Elias. Curso de filosofía del derecho. Madrid: Marcial Pons, 1998.

GADAMER, Hans-Georg. Verdad y método. Salamanca: Sígueme, 1993. v. 1.

GADAMER, Hans-Georg. Verdad y método. Salamanca: Sígueme, 1994. v. 2.

GADAMER, Hans-Georg. Verdade e método. Petrópolis: Vozes, 1997. v. 1.

GÓES, Guilherme Sandoval. Neoconstitucionalismo e dogmática pós-positivista. In: BARROSO, Luis Roberto (Org.). A reconstrução democrática do direito público no Brasil. Rio de Janeiro: Renovar, 2007. p. 113-150.

HÄBERLE, Peter. El concepto de Constitución. Concepción mixta de Constitución. In: ElEstado constitucional. México: UNAM, 2001. p. 3-7.

HESSE, Konrad. A força normativa da Constituição. Porto Alegre: S. A. Fabris, 1991.

HESSE, Konrad. Temas fundamentais do direito constitucional. São Paulo: Saraiva, 2009. p. 123-146.

HOBBES, Thomas. Leviatã. México: Fondo de Cultura Económica, 1996.

HOLMES, Oliver Wendell. O direito comum. Rio de Janeiro: O Cruzeiro, 1967.

HORBACH, Carlos Bastide. A nova roupa do direito constitucional: neoconstitucionalismo, pós-positivismo e outros modismos. In: ROCHA, Maria Elizabeth Guimarães Teixeira; MEYER-PFLUG, Samantha Ribeiro (Coord.). Lições de direito constitucional em homenagem ao Professor Jorge Miranda. Rio de Janeiro: Forense, 2008. p. 291-302.

HORBACH, Carlos Bastide. A nova roupagem do direito constitucional: neo-constitucionalismo, pós-positivismo e outros modismos. São Paulo: RT, 2007.

INFORMATIVO STF. Brasília: STF, n. 482, de 01 out. 2007. Disponível em: < http://www.stf.jus.br/arquivo/informativo/documento/informativo482.htm>. Acesso em: 12 dez. 2015.

KELSEN, Hans. Teoría general del derecho y del Estado. México: UNAM, 1969.

KELSEN, Hans. Teoria geral do direito e do Estado. São Paulo: M. Fontes, 1990.

LOEWENSTEIN, Karl. Teoría de la Constitución. Barcelona: Ariel, 1979.

MAIA, Antonio Cavalcanti. Nos vinte anos da Carta Cidadã: do pós-positivismo ao neoconstitucionalismo. In: SOUZA NETO, Cláudio Pereira de; SARMENTO, Daniel; BINENBOJM, Gustavo (Coord.). Vinte anos da Constituição Federal de 1988. Rio de Janeiro: Lúmen Juris, 2009. p. 117-168.

MARSHALL, John. Decisões constitucionais de Marshall. Rio de Janeiro: Imprensa Nacional, 1903. 
MENDES, Conrado Hübner. Direitos fundamentais, separação de poderes e deliberação. São Paulo: Saraiva, 2011.

MENDES, Gilmar; COELHO, Inocêncio M.; BRANCO, Paulo G. G. Curso de direito constitucional. 2. ed. São Paulo: Saraiva, 2008.

NEVES, A. Castanheira. Metodologia jurídica: problemas fundamentais. Coimbra: Coimbra, 1993.

NIETZSCHE, Friedrich. A vontade de poder. Rio de Janeiro: Contraponto, 2008.

NIETZSCHE, Friedrich. Fragmentos finais. Brasília: UnB, 2002.

ORTEGA, Manuel Segura. La racionalidad jurídica. Madrid: Tecnos, 1998.

PEKELIS, Alexander. La tecla para una ciencia jurídica estimativa. et al. El actual pensamiento jurídico norteamericano. Buenos Aires: Losada, 1951. p. 117-172.

PERELMAN, Chaïm. Ética e direito. São Paulo: M. Fontes, 1996.

RADBRUCH, Gustav. Cinco minutos de filosofia do direito. In: Filosofia do direito. Coimbra: Arménio Amado, 1961. v. 2. p. 211-214.

RAMOS, Elival da Silva. Ativismo judicial: parâmetros dogmáticos. São Paulo: Saraiva, 2010.

REALE, Miguel. A dinâmica do direito numa sociedade em mudança. In: . Estudos de filosofia e ciência do direito. São Paulo: Saraiva, 1978. p. 52-57.

REALE, Miguel. Estudos de filosofia e ciência do direito. São Paulo: Saraiva, 1978.

REALE, Miguel. Gênese e vida dos modelos jurídicos: problemas de semântica jurídica. In: . $O$ direito como experiência. São Paulo: Saraiva, 1968. p. 209-218.

ROUSSEAU, J. J. Do contrato social. Rio de Janeiro: Globo, 1962. (Obras de Jean-Jacques Rousseau, v. 2).

RUBIO LLORENTE, Francisco. La interpretación de la Constitución. Madrid: Centro de Estudios Constitucionales, 1984.

SAMPAIO, José Adércio Leite. A Constituição reinventada pela jurisdição constitucional. Belo Horizonte: Del Rey, 2002.

SCHAFF, Adam. História e verdade. São Paulo: M. Fontes, 1987.

SCHLEIERMACHER, Friedrich D. E. Herméneutique. Alençon: CERF, 1989.

SICHES, Luís Recaséns. Iusnaturalismos actuales comparados. Madrid: Universidad de Madrid-Faculdade de Derecho, 1970.

SOUZA NETO, Cláudio Pereira de; SARMENTO, Daniel. Direito constitucional: teoria, história e métodos de trabalho. Belo Horizonte: Fórum, 2013.

STRECK, Lênio Luiz. Súmulas no direito brasileiro: eficácia, poder e função: a ilegitimidade constitucional do efeito vinculante. Porto Alegre: Livraria do Advogado, 1998.

VALADÉS, Diego. Peter Häberle: un jurista para el siglo XXI. Estudio introductorio. In: HÄBERLE, Peter. El Estado constitucional. México: UNAM, 2001. p. XXI-LXXXIV. 


\section{REVISTA BRASILEIRA DE POLÍTICAS PÚBLICAS BRAZILIAN JOURNAL OF PUBLIC POLICY}
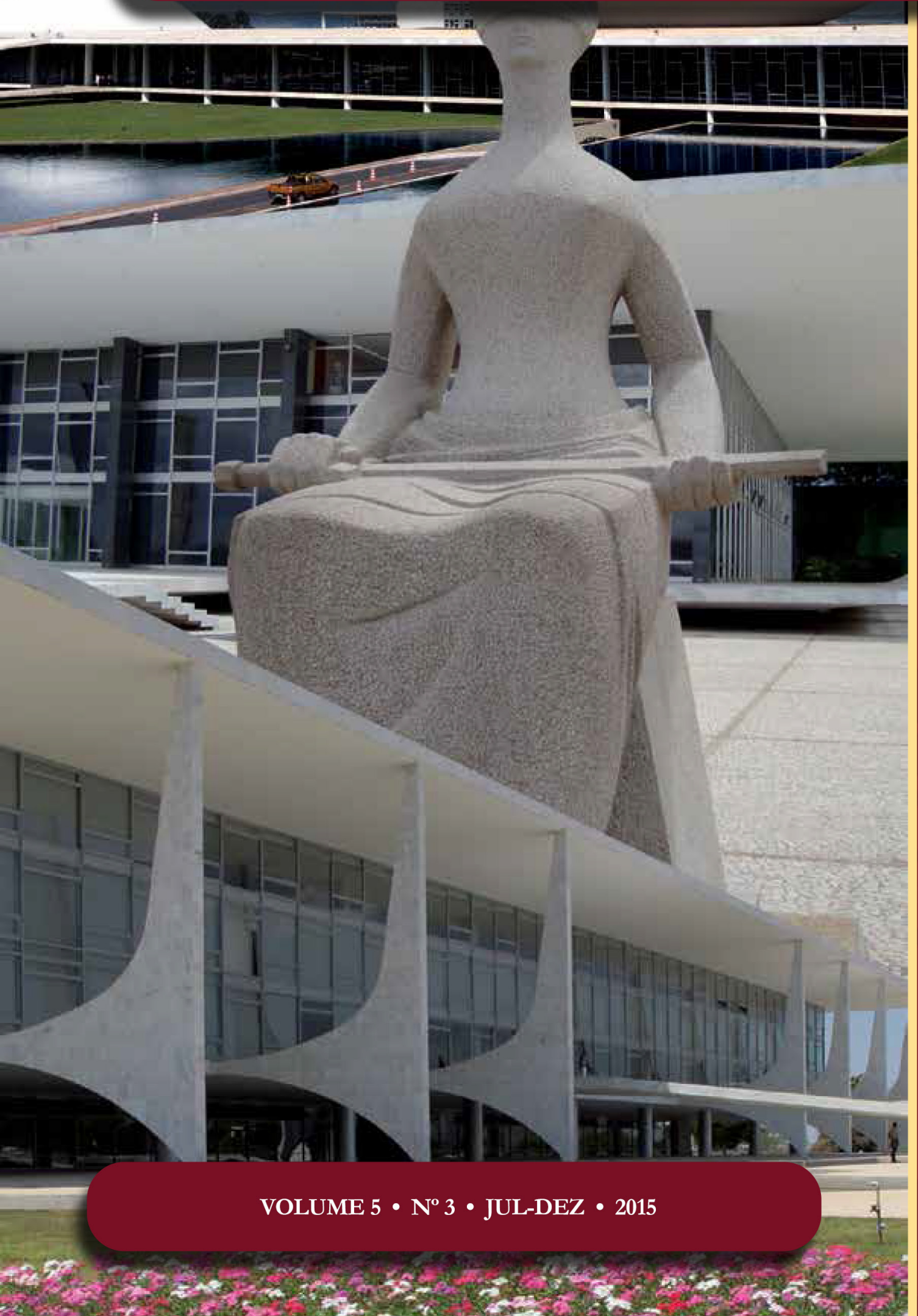

Processo Legislativo Municipal Municipal Legislative Process 


\section{Processo Legislativo Municipal*}

\section{Municipal Legislative Process}

José Levi Mello do Amaral Júnior**

\section{Resumo}

Este artigo é relativo ao processo legislativo nos municípios brasileiros. Ele descreve os direitos e responsabilidades dos municípios na relação com a Constituição, enumerando os poderes que são delegados a eles. A Constituição habilita os municípios a aprovarem a legislação que é expressamente permitida pelos poderes enumerados. Alguns poderes são compartilhados pelos Governos federal e local. O artigo argumenta que municípios podem adotar modos alternativos de criação do Direito local.

Palavras-chave: Federalismo brasileiro. Municípios. Processo legislativo.

\section{Abstract}

This paper is related to the legislative process in Brazilian municipalities. It describes the rights and responsibilities of municipalities in relationship to the Constitution, enumerating the powers delegated to the municipalities. The Constitution allows municipalities to enact legislation that is expressly allowed by the enumerated powers. Some powers are shared by the federal and local governments. The paper argues that municipalities can adopt alternative ways to create local law.

Keywords: Brazilian federalism. Municipalities. Legislative process.

\section{Municípios na forma federativa de eStado brasileira}

A forma federativa de Estado brasileira tem uma peculiaridade: todos os seus Municípios também são entes federados ${ }^{1}$, com igual dignidade federativa gozada pelos demais entes federados ${ }^{2}$.

Em outras palavras, a federação brasileira, o conjunto total do Estado brasileiro, resulta do amálgama - indissolúvel - formado pela União, pelos Estados, pelo Distrito Federal e pelos Municípios. Trata-se de antiga tradição que o processo constituinte de 1988 explicitou Almeida ${ }^{3}$.

* Artigo convidado.

** Professor de Direito Constitucional da Faculdade de Direito da USP. Procurador da Fazenda Nacional. Consultor-Geral da União. E-mail: jose.levi@usp.br
1 BRASIL. Constituição (1988). Constituição da Republica Federativa do Brasil. Arts. $1^{\circ}$ e 18. Disponível em: <http://www.planalto.gov.br/ccivil_03/constituicao/ConstituicaoCompilado.htm>. Acesso em: 10 dez. 2015.

2 FERREIRA FILHO, Manoel Gonçalves. O poder constituinte. 4. ed. São Paulo: Saraiva, 2005. p. 153-154.

3 ALMEIDA, Fernanda Dias Menezes de. Competências na Constituição de 1988. 6. ed. São Paulo: Atlas, 2013. p. 96-97. 
Disso resulta que os Municípios participam da repartição constitucional de competências entre os entes federados.

\section{COMPETÊNCIAS MUNICIPAIS}

Têm, portanto, competências enumeradas: (i) materiais (fazer ou cuidar concretamente de algo); e (ii) legislativas (legislar sobre determinado assunto), competências essas que são apenas deles, Municípios. Constam, em essência, do art. 30 da Constituição da República.

Ademais, participam: (iii) das competências comuns, que têm natureza material e comportam-se de modo cumulativo ${ }^{4}$; bem como (iv) das competências concorrentes, que têm natureza legislativa e comportam-se de modo não cumulativo ${ }^{5}$.

Claro, isso sem prejuízo de outras competências espalhadas ou esmiuçadas em diversas outras normas da Constituição da República, por exemplo, o art. 156 (impostos de competência municipal) e o art. 182 (política urbana).

Do exercício das competências municipais enumeradas e concorrentes decorre o campo temático próprio à lei municipal.

\section{A LEI MUNICIPAL NO SISTEMA DE FONTES BRASILEIRO}

No primeiro caso (exercício de competências legislativas enumeradas aos Municípios), decorre uma lei municipal que tem campo que lhe é próprio e peculiar, inclusive prevalecendo sobre eventuais leis federais e estaduais que, na prática, venham a pretender usurpar competência municipal, malferindo a repartição constitucional de competências. Não há que cogitar, aqui, hierarquia entre leis federais, estaduais e municipais. Têm elas a mesma posição no sistema de fontes brasileiro.

No segundo caso (exercício de competências legislativas concorrentes por parte dos Municípios), decorre uma lei municipal que complementa moldura definida (e, logo, com observância aos respectivos limites estabelecidos) por uma lei nacional de normas gerais, que — do mesmo modo - também submete leis federais e estaduais. Aqui, sim, há hierarquia entre, de um lado, a lei nacional de normas gerais (expressiva da vontade do todo federativo) e, de outro lado, as leis federais, estaduais e municipais que, para (e no âmbito de) cada um desses entes, vêm a complementar a lei nacional de normas gerais ${ }^{6}$.

4 Constituição da República, art. 23. "A cumulativa existe sempre que não há limites prévios para o exercício da competência, ou por parte de um ente, seja a União, seja o Estado-Membro. Claro está que, por um princípio lógico, havendo choque entre norma estadual e norma federal num campo de competência cumulativa, prevalece a regra da União.” (FERREIRA FILHO, Manoel Gonçalves. Comentários à Constituição brasileira de 1988. São Paulo: Saraiva, 1990. v. 1. p. 189). Prevalece, claro, no pressuposto de a competência legislativa correlata ser privativa da União ou concorrente de modo a atribuir à União as normas gerais, hipóteses essas que ocorrem na grande maioria dos casos do art. 23 da Constituição da República (ALMEIDA, Fernanda Dias Menezes de. Competências na Constituição de 1988. 6. ed. São Paulo: Atlas, 2013. p. 116-118).

5 Constituição da República, art. 24, combinado com o art. 30, inciso II. A propósito (ALMEIDA, Fernanda Dias Menezes de. Competências na Constituição de 1988. 6. ed. São Paulo: Atlas, 2013. p. 140-143). Comportam-se de modo não cumulativo porque implicam uma repartição vertical de competências: a União legisla normas gerais, deixando-se aos demais entes a complementação (FERREIRA FILHO, Manoel Gonçalves. Comentários à Constituição brasileira de 1988. São Paulo: Saraiva, 1990. v. 1. p. 189).

6 BRASIL. Constituição (1988). Constituição da Republica Federativa do Brasil. Art. 24, SS $1^{\circ}$ a 4․ Disponível em: <http://www.planalto.gov.br/ccivil_03/constituicao/ConstituicaoCompilado.htm>. Acesso em: 10 dez. 2015. Sobre o assunto, confira-se trabalho clássico: Ataliba, 1980, p. 58-76. 
A lei municipal cumpre, no âmbito do Município, o princípio da legalidade 7 . Trata-se de realizar — também em face do Poder Público municipal — o ideal, próprio ao conceito de Estado de Direito, de que o cidadão é livre na medida em que ele próprio ou um representante seu para tanto eleito participa da formação da lei.

Assim, há um processo legislativo a ser observado também pelos Municípios. Encontra as suas linhas gerais no modelo constitucional de 1988, bem como no respectivo modelo constitucional estadual.

\section{A lei orgânica mUNICIPAL: CONSTITUIÇÃo do MUNICíPIO}

A sua disciplina específica deve constar da lei orgânica municipal, ou seja, deve constar do texto constitucional do Município, atendidos os princípios estabelecidos pela Constituição da República e pela Constituição do respectivo Estado8.

Sem dúvida, a lei orgânica municipal é a Constituição do Município9. Implica manifestação de poder constituinte decorrente, claro, insista-se, atendidos os princípios estabelecidos pela Constituição da República e pela Constituição do respectivo Estado ${ }^{10}$.

\section{FASES dA ELABORAÇÃO dA LEI MUNICIPAL}

Nesse contexto, o processo legislativo municipal deve refletir algumas características essenciais e estratégicas do processo legislativo da Constituição da República, bem como da Constituição do respectivo Estado, em regra diretamente vinculadas à lógica da organização dos poderes e às respectivas salvaguardas recíprocas.

Em suma, assim como se dá com o processo de formação da lei ordinária, espécie legislativa que revela o padrão do processo legislativo na Constituição da República, pode-se afirmar que o processo de formação da lei municipal "apresenta uma fase introdutória, a iniciativa, uma fase constitutiva, que compreende a deliberação e a sanção, e a fase complementar, na qual se inscreve a promulgação e também a publicação."11

\subsection{Iniciativa}

Segundo a melhor doutrina, "a iniciativa não é propriamente uma fase do processo legislativo, mas sim o ato que o desencadeia"12.

\footnotetext{
7 BRASIL. Constituição (1988). Constituição da Republica Federativa do Brasil. Art. $5^{\circ}$, inciso II, combinado com o art. 37, caput. Disponível em: <http://www.planalto.gov.br/ccivil_03/constituicao/ConstituicaoCompilado.htm>. Acesso em: 10 dez. 2015.

8 BRASIL. Constituição (1988). Constituição da Republica Federativa do Brasil. Art. 29. Disponível em: <http://www.planalto.gov.br/ ccivil_03/constituicao/ConstituicaoCompilado.htm>. Acesso em: 10 dez. 2015.

9 Dois exemplos ilustram essa realidade. Primeiro, a Lei Orgânica do Município de Barbacena, Minas Gerais, expressamente se declara "Constituição" do Município. BARBACENA. Lei Orgânica do Município de Barbacena, de 08 de dezembro de 1990. Disponível em: <http://www.barbacena.mg.gov.br/governo/leiorganicadomunicipio.pdf>. Acesso em: 10 dez. 2015. Segundo, a Constituição do Estado de Pernambuco dispõe, em seu art. 61, inciso I, alínea "l”, que compete ao Tribunal de Justiça processar e julgar originariamente "a ação direta de inconstitucionalidade de lei ou ato normativo estadual ou municipal, em face desta Constituição, ou de lei ou ato normativo municipal em face da Lei Orgânica respectiva." (PERNAMBUCO. Constituição (1989). Constituição do Estado de Pernambuco. Disponível em: <http://legis.alepe.pe.gov.br/arquivoTexto.aspx?tiponorma=12\&numero=1989\&complemen to $=0 \& a n o=1989 \&$ tipo $=$ TEXTOORIGINAL $>$. Acesso em: 10 dez. 2015), ou seja, explicitamente reconhece como parâmetro de controle de constitucionalidade da lei municipal a "Lei Orgânica respectiva".

10 “[...] não será absurdo falar num Poder Constituinte municipal, o que certamente arrepiará certos constitucionalistas sempre prontos a denunciar os 'erros' da Carta.” (FERREIRA FILHO, Manoel Gonçalves. O poder constituinte. 4. ed. São Paulo: Saraiva, 2005. p. 154.

11 FERREIRA FILHO, Manoel Gonçalves. Do processo legislativo. 7. ed. São Paulo: Saraiva, 2012. p. 228.

12 FERREIRA FILHO, Manoel Gonçalves. Do processo legislativo. 7. ed. São Paulo: Saraiva, 2012. p. 228.
} 
Transpondo-se a lógica do art. 61 da Constituição da República para o âmbito municipal, claro, com as devidas adaptações, devem ter iniciativa legislativa "geral" qualquer membro ou Comissão da Câmara de Vereadores, o Prefeito e os cidadãos do Município ${ }^{13}$.

Ademais, ainda seguindo o modelo do referido art. 61, certos assuntos deverão ser de iniciativa privativa do Prefeito. É o que entende o Supremo Tribunal Federal relativamente aos Estados:

as regras básicas do processo legislativo federal são de absorção compulsória pelos Estados-membros em tudo aquilo que diga respeito - como ocorre às que enumeram casos de iniciativa legislativa reservada - ao princípio fundamental de independência e harmonia dos poderes, como delineado na Constituição da República. ${ }^{14}$

Claro, essa compreensão também se aplica, ao natural, ao processo legislativo municipal. Logo, devem ser da iniciativa privativa do Prefeito as leis que: (i) fixem ou modifiquem os efetivos das guardas municipais; (ii) disponham sobre: (ii.a) criação de cargos, funções ou empregos públicos na administração direta e autárquica ou aumento de sua remuneração; (ii.b) servidores públicos do Município, seu regime jurídico, provimento de cargos, estabilidade e aposentadoria; (ii.c) criação e extinção de Secretarias e órgãos da administração pública municipal, sem prejuízo de decreto autônomo municipal nos mesmos moldes daquele previsto pelo art. 84, inciso VI, da Constituição da República, ou seja, para dispor sobre: (ii.c.1) organização e funcionamento da administração municipal, quando não implicar aumento de despesa nem criação ou extinção de órgãos públicos; e (ii.c.2) extinção de funções ou cargos públicos, quando vagos.

A Constituição da República fixa, expressamente, uma iniciativa privativa das Câmaras Municipais: a fixação dos subsídios do Prefeito, do Vice-Prefeito e dos Secretários Municipais ${ }^{15}$.

A iniciativa popular, sucedâneo de democracia direta, também deve ser objeto da lei orgânica municipal, precisamente pela participação popular que proporciona. Implica a possibilidade de projeto de lei ser apresentado à Câmara Municipal subscrito por determinado número de eleitores municipais (número esse a ser fixado pela lei orgânica). A rigor, as assinaturas coletadas devem ser conferidas e validadas. Porém, sobretudo para prestigiar projeto de iniciativa popular meritório, nada impede que um Vereador ou uma Comissão da Câmara de Vereadores subscreva o projeto para que siga ele tramitação regular sem maiores dificuldades iniciais. Importa prestigiar a substância de projeto fruto de cidadania participativa, tanto que o inciso IX do art. 252 do Regimento Interno da Câmara dos Deputados dispõe que "não se rejeitará, liminarmente, projeto de lei de iniciativa popular por vícios de linguagem, lapsos ou imperfeições de técnica legislativa, incumbindo à Comissão de Constituição e Justiça e de Cidadania escoimá-lo dos vícios formais para sua regular tramitação". Importa anotar que se trata de uma iniciativa geral, “já que não está adstrita a matérias determinadas. Pela lógica, todavia, não alcança as matérias reservadas". ${ }^{16}$

\subsection{Deliberação}

É a fase principal do processo legislativo, porque "nela e por ela o Legislativo estabelece as regras jurídicas novas". ${ }^{17}$

13 "rigorosamente falando, no Direito brasileiro ninguém possui realmente iniciativa geral. A designação vale simplesmente na medida em que significa propor direito novo sobre qualquer matéria (exceto as reservadas)" (FERREIRA FILHO, Manoel Gonçalves. Do processo legislativo. 7. ed. São Paulo: Saraiva, 2012. p. 229).

14 BRASIL. Supremo Tribunal Federal. Ação Direta de Inconstitucionalidades. ADI 279 AL. Tribunal Pleno. Requerente: Governador do Estado de Alagoas. Requerido: Assembleia Legislativa do Estado de Alagoas. Relator: Min. Sepúlveda Pertence. Brasília, 13 de novembro de 1997. Disponível em: <http://stf.jusbrasil.com.br/jurisprudencia/14699547/acao-direta-de-inconstitucionalidade-adi-276-al>. Acesso em: 10 dez. 2015.

15 BRASIL. Constituição (1988). Constituição da Republica Federativa do Brasil. Art. 29, inciso V. Disponível em: <http://www.planalto.gov.br/ccivil_03/constituicao/ConstituicaoCompilado.htm>. Acesso em: 10 dez. 2015.

16 FERREIRA FILHO, Manoel Gonçalves. Do processo legislativo. 7. ed. São Paulo: Saraiva, 2012. p. 229.

17 FERREIRA FILHO, Manoel Gonçalves. Do processo legislativo. 7. ed. São Paulo: Saraiva, 2012. p. 2012. p. 233. 
Diferentemente do processo legislativo próprio ao Congresso Nacional e a exemplo do que se dá no plano estadual, a deliberação no processo legislativo municipal é unicameral.

A Câmara Municipal poderá ter comissões permanentes e temporárias, com características análogas àquelas previstas pelo art. 58 da Constituição da República, cabendo-lhes discutir e, até mesmo, votar conclusivamente projeto de lei que dispensar, na forma do regimento interno da Câmara, a competência do Plenário, salvo se houver recurso subscrito por determinado número de membros da Casa ${ }^{18}$. Aplicado ao processo legislativo, o trabalho das comissões é denominado pela doutrina "subfase instrutória."19

A possibilidade de apresentação de emendas parlamentares, a maioria (simples ou qualificada) para aprovação de um projeto de lei, o número de turnos de votação etc. são assuntos que a lei orgânica municipal poderá ferir, ficando os pormenores com o regimento da Câmara Municipal.

As emendas parlamentares formalizam as contribuições dos Vereadores aos projetos em tramitação. Cabe ao regimento da Câmara Municipal especificar a tipologia das emendas (aditivas, supressivas, modificativas, aglutinativas etc.), bem como prever, se for o caso, a possibilidade de apresentação de substitutivo ao projeto $^{20}$. Em princípio, cabe à emenda em qualquer projeto. Porém, em se tratando de matéria da iniciativa privativa do Prefeito, importa observar o que dispõe o art. 63, inciso I, da Constituição da República: a emenda será admitia, desde que não implique aumento de despesa (exceto no caso das proposições orçamentárias, nos termos e nos limites dos $\iint 3^{\circ}$ e $4^{\circ}$ do art. 166 da Constituição da República $)^{21}$. Dada a essencialidade da matéria orçamentária, inclusive porque inerente à harmonia entre os poderes, essas disposições expressam princípios que devem ser observados pelos Municípios.

A lei orgânica poderá adotar padrão: (i) de quórum para deliberação; e (ii) de maioria para aprovação, como fez o art. 47 da Constituição da República, verbis:

salvo disposição constitucional em contrário, as deliberações de cada Casa e de suas Comissões serão tomadas por maioria dos votos, presente a maioria absoluta de seus membro. ${ }^{22}$

Na situação padrão e a teor dos respectivos Regimentos Internos e da prática das Casas do Congresso Nacional, em se tratando de projeto de lei ordinária, o parlamentar pode votar "sim", "não", "em branco" ou, simplesmente, registrar "abstenção". Os votos em branco, bem como as abstenções, são computados para efeito de quórum ${ }^{23}$, ou seja, ajudam a sustentar a sessão, diferentemente da ausência (incluída a presença não computada) ou da obstrução, que, no limite, podem derrubar a sessão por falta de quórum.

18 BRASIL. Constituição (1988). Constituição da Republica Federativa do Brasil. Art. 58, § 2º inciso II. Disponível em: <http://www. planalto.gov.br/ccivil_03/constituicao/ConstituicaoCompilado.htm>. Acesso em: 10 dez. 2015.

19 FERREIRA FILHO, Manoel Gonçalves. Do processo legislativo. 7. ed. São Paulo: Saraiva, 2012. p. 2012. p. 233.

20 Que, na prática, "nada mais é do que uma ampla emenda ao projeto inicial". BRASIL. Supremo Tribunal Federal. Ação Direta de Inconstitucionalidades. ADI 2182-6/DF. Tribunal Pleno. Requerente: Partido Trabalhista Nacional. Requerido: Congresso Nacional. Relator: Min. Marco Aurélio. Brasília, 31 de maio de 2000. Disponível em: < http:// redir.stf.jus.br/paginadorpub/paginador. jsp?docTP=TP\&docID=421277>. Acesso em: $10 \mathrm{dez} .2015$.

21 A propósito, Ação Direta de Inconstitucionalidade n. 3.114-7/SP. Esse precedente ainda exige pertinência temática entre o projeto de lei e a emenda a ele apresentada. BRASIL. Supremo Tribunal Federal. Ação Direta de Inconstitucionalidades. ADI 3114 SP. Tribunal Pleno. Requerente: Governador do Estado de São Paulo. Requerido: Assembléia Legislativa do Estado de São Paulo. Relator: Min. Carlos Britto. Brasília, 24 de agosto de 2005. Disponível em: <http://stf.jusbrasil.com.br/jurisprudencia/763435/ acao-direta-de-inconstitucionalidade-adi-3114-sp>. Acesso em: 10 dez. 2015.

22 BRASIL. Constituição (1988). Constituição da Republica Federativa do Brasil. Disponível em: <http://www.planalto.gov.br/ccivil_03/constituicao/ConstituicaoCompilado.htm>. Acesso em: 10 dez. 2015.

23 É o que dispõe, por exemplo, o Regimento Interno da Câmara dos Deputados, art. 183, § 2. BRASIL. Câmara dos Deputados. Resolução ñ 17, de 1989. Disponível em: < http:/ / www2.camara.leg.br/atividade-legislativa/legislacao/regimento-interno-da-camarados-deputados/RICD\%20atualizado\%20ate\%20RCD\%2012-2015.pdf>. Acesso em: 10 dez. 2015. 


\subsection{Sanção e veto}

Parafraseando lição de Manoel Gonçalves Ferreira Filho ${ }^{24}$, completa a fase constitutiva do processo legislativo municipal a apreciação pelo Prefeito do texto aprovado pela Câmara Municipal ${ }^{25}$, resultando em

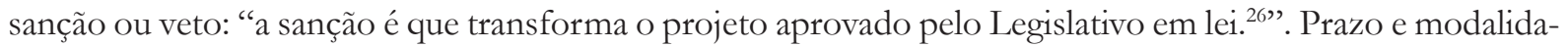
des de sanção (expressa ou tácita) e veto (total ou parcial, por inconstitucionalidade ou por interesse público) devem ser objeto de definição da lei orgânica municipal.

Com efeito, há uma lógica constitucional da sanção e do veto que se revela inerente à principiologia da organização dos poderes e, por isso mesmo, deve ser observada pelos entes federados: (i) "O veto parcial somente abrangerá texto integral de artigo, de parágrafo, de inciso ou de alínea" 27 , porque, do contrário, o veto a palavras isoladas poderia, inclusive, inverter o sentido da deliberação parlamentar ${ }^{28}$; (ii) o mero decurso de prazo implica sanção tácita, não veto (total) tácito ${ }^{29}$, de modo a, justamente, prestigiar a deliberação parlamentar ${ }^{30}$; e (iii) o veto no Direito brasileiro não é absoluto, ${ }^{31}$ mas, sim, sujeita-se à apreciação da Câmara Municipal e pode ser derrubado por ela ${ }^{32}$, pois é próprio da democracia que a última palavra sobre a formação das leis seja dos representantes eleitos do povo ${ }^{33}$.

Enfim, importa registrar que a sanção não convalida vício de iniciativa, ou seja, a sanção (do Prefeito) não torna superada a inconstitucionalidade (formal) decorrente da usurpação de iniciativa privativa do Chefe do Poder Executivo municipal. Trata-se de assunto que foi objeto de polêmica doutrinária ${ }^{34}$ mas que parece pacificado na jurisprudência do Supremo Tribunal Federal, não obstante exista julgado que aplica entendimento anterior (inclusive sumulado ${ }^{35}$ ) por força de analogia com a possibilidade de emenda em matéria de iniciativa exclusiva do Poder Executivo, desde que não implique aumento de despesa ${ }^{36}$.

\subsection{Promulgação e publicação}

A promulgação é uma chancela, um atestado de que o processo legislativo completou-se de modo regular e que, portanto, a lei existe ${ }^{37}$. Tratando-se de processo legislativo de espécie legislativa passível de veto,

24 FERREIRA FILHO, Manoel Gonçalves. Do processo legislativo. 7. ed. São Paulo: Saraiva, 2012.

25 "Completa a fase constitutiva do processo legislativo a apreciação pelo Executivo do texto aprovado pelo Congresso Nacional.” (FERREIRA FILHO, Manoel Gonçalves. Do processo legislativo. 7. ed. São Paulo: Saraiva, 2012. p. 233).

26 FERREIRA FILHO, Manoel Gonçalves. Do processo legislativo. 7. ed. São Paulo: Saraiva, 2012. p. 236.

27 BRASIL. Constituição (1988). Constituição da Republica Federativa do Brasil. Art. 66, \ 2º. Disponível em: <http://www.planalto. gov.br/ccivil_03/constituicao/ConstituicaoCompilado.htm>. Acesso em: 10 dez. 2015.

28 FERREIRA FILHO, Manoel Gonçalves. Do processo legislativo. 7. ed. São Paulo: Saraiva, 2012. p. 247-248.

29 BRASIL. Constituição (1988). Constituição da Republica Federativa do Brasil. Art. 66, \ $3^{\circ}$. Disponível em: <http://www.planalto. gov.br/ccivil_03/constituicao/ConstituicaoCompilado.htm>. Acesso em: 10 dez. 2015.

30 FERREIRA FILHO, Manoel Gonçalves. Do processo legislativo. 7. ed. São Paulo: Saraiva, 2012. p. 236-237.

31 FERREIRA FILHO, Manoel Gonçalves. Do processo legislativo. 7. ed. São Paulo: Saraiva, 2012. p. 246-247.

32 BRASIL. Constituição (1988). Constituição da Republica Federativa do Brasil. Art. 66, \5 4. Disponível em: <http://www.planalto. gov.br/ccivil_03/constituicao/ConstituicaoCompilado.htm>. Acesso em: 10 dez. 2015.

33 BRASIL. Constituição (1988). Constituição da Republica Federativa do Brasil. Art. 1º, parágrafo único. Disponível em: < http:// www.planalto.gov.br/ccivil_03/constituicao/ConstituicaoCompilado.htm>. Acesso em: 10 dez. 2015.

34 FERREIRA FILHO, Manoel Gonçalves. Do processo legislativo. 7. ed. São Paulo: Saraiva, 2012. p. 237-244.

35 BRASIL. Supremo Tribunal Federal. Súmula $n^{0}$ 5. A sanção do projeto supre a falta de iniciativa do Poder Executivo. Disponível em: <http://www.stf.jus.br/portal/jurisprudencia/listarJurisprudencia.asp?s1=5.NUME.\%20NAO $\% 20$ S. FLSV.\&base $=$ baseSumulas $>$. Acesso em: 10 dez. 2015.

36 A propósito, o Voto-Vista do Ministro Moreira Alves na Ação Direta de Inconstitucionalidade n. 266-0/RJ. BRASIL. Supremo Tribunal Federal. Ação Direta de Inconstitucionalidades. ADI 266 RJ. Tribunal Pleno. Requerente: Governador do Estado do Rio de Janeiro. Requerido: Assembleia Legislativa do Estado do Rio de Janeiro. Relator: Min. Octavio Gallotti. Brasília, 18 de junho de 1993. Disponível em: <http://stf.jusbrasil.com.br/jurisprudencia/14707586/acao-direta-de-inconstitucionalidade-adi-266-rj>. Acesso em: 10 dez. 2015.

37 MIRANDA, Francisco Cavalcanti Pontes de. Comentários à Constituição de 1967. São Paulo: Revista dos Tribunais, 1967. t. 3. p. 177. 
a promulgação ocorre juntamente com a sanção ${ }^{38}$. Portanto, no processo legislativo municipal, cabe, em princípio, ao Prefeito, podendo passar ao Presidente da Câmara Municipal no caso de sanção tácita ou de derrubada de veto ${ }^{39}$.

Por sua vez, a publicação tem por objetivo "fazer conhecida a lei" "40 e, a partir da vigência, obrigatória. Isso porque "a publicação é condição de eficácia do ato normativo"41 de modo que, "verificada essa condição, fixa-se o termo em que se há de tornar efetiva a eficácia do ato normativo" "42.

$\mathrm{Na}$ prática do processo legislativo brasileiro, é usual fazer a vigência coincidir com a publicação ${ }^{43}$. Por outro lado, em caso de omissão da lei acerca da sua própria vigência, aplica-se a vacatio legis padrão da Lei de Introdução às Normas do Direito Brasileiro, qual seja, "quarenta e cinco dias depois de oficialmente publicada" 44 .

Fazer publicar as leis é competência privativa do Chefe do Poder Executivo ${ }^{45}$. Na União, realiza-se por meio do Diário Oficial da União. Nos demais entes, pode ocorrer por meio de diário oficial próprio ou por meio de qualquer outra mídia que permita ampla divulgação, inclusive sítio eletrônico certificado na forma da Medida Provisória n. 2.200-2, de 24 de agosto de 2001 (como se dá com a versão eletrônica do próprio Diário Oficial da União $0^{46}$.

\section{EsPÉCIES LEGISLATIVAS NO PROCESSO LEGISLATIVO MUNICIPAL}

O processo legislativo na Constituição da República compreende a elaboração de sete espécies normativas primárias, ou seja, que encontram fundamento de validade diretamente na Constituição ${ }^{47}$ : emenda constitucional, lei complementar, lei ordinária, lei delegada, medida provisória, decreto legislativo e resolução ${ }^{48}$.

A autonomia dos entes federados deveria permitir ampla liberdade de escolha acerca do próprio processo legislativo e respectivas espécies normativas primárias.

No entanto, o Supremo Tribunal Federal impõe aos Estados e aos municípios diversos aspectos do processo legislativo da Constituição da República. É o que se dá, como já examinado, com a iniciativa privativa do Chefe do Poder Executivo.

O mesmo acontece com as próprias espécies normativas primárias. Isso porque o Supremo Tribunal Federal exige coincidência — tendo a Constituição da República como parâmetro — entre as matérias re-

38 MIRANDA, Francisco Cavalcanti Pontes de. Comentários à Constituição de 1967. São Paulo: Revista dos Tribunais, 1967. t. 3. p. 177.

39 BRASIL. Constituição (1988). Constituição da Republica Federativa do Brasil. Art. 66, \ $7^{\circ}$. Disponível em: <http://www.planalto. gov.br/ccivil_03/constituicao/ConstituicaoCompilado.htm>. Acesso em: 10 dez. 2015.

$40 \quad$ MIRANDA, Francisco Cavalcanti Pontes de. Comentários à Constituição de 1967. São Paulo: Revista dos Tribunais, 1967. t. 3. p. 177.

41 FERREIRA FILHO, Manoel Gonçalves. Do processo legislativo. 7. ed. São Paulo: Saraiva, 2012. p. 274.

42 FERREIRA FILHO, Manoel Gonçalves. Do processo legislativo. 7. ed. São Paulo: Saraiva, 2012. p. 274-275.

43 O que se dá pela tradicional cláusula "Esta Lei entra em vigor na data de sua publicação." (que a Lei Complementar n. 95, de 26 de fevereiro de 1998, art. $8^{\circ}$, recomenda reservar "para as leis de pequena repercussão"). BRASIL. Lei Complementar n” 95 , de 26 de fevereiro de 1998. Disponível em: <http://www.planalto.gov.br/ccivil_03/leis/LCP/Lcp95.htm>. Acesso em: 10 dez. 2015.

44 BRASIL. Decreto-Lei no 4.657, de 4 de setembro de 1942. Art. 1. Disponível em: <http://www.planalto.gov.br/ccivil_03/decretolei/Del4657.htm>. Acesso em: 10 dez. 2015.

45 BRASIL. Constituição (1988). Constituição da Republica Federativa do Brasil. Art. 84, inciso IV. Disponível em: <http://www. planalto.gov.br/ccivil_03/constituicao/ConstituicaoCompilado.htm>. Acesso em: 10 dez. 2015.

46 BRASIL. Imprensa Nacional. Diário Oficial da União [versão eletrônica]. Disponível em: <http://www.in.gov.br>. Acesso em: 10 dez. 2015.

47 FERREIRA FILHO, Manoel Gonçalves. Do processo legislativo. 7. ed. São Paulo: Saraiva, 2012. p. 223-226.

48 BRASIL. Constituição (1988). Constituição da Republica Federativa do Brasil. Art. 59. Disponível em: <http://www.planalto.gov.br/ ccivil_03/constituicao/ConstituicaoCompilado.htm>. Acesso em: 10 dez. 2015. 
servadas à lei complementar ${ }^{49}$ nas esferas federal, estadual e municipal:

a inconstitucionalidade dos preceitos impugnados decorre da violação ao princípio da simetria, uma vez que a Constituição do Estado do Piauí exige a edição de Lei Complementar para o tratamento de matérias em relação às quais a Constituição Federal prevê o processo legislativo ordinário. ${ }^{50}$

Esse mesmo entendimento foi aplicado pelo Supremo em circunstância análoga relativamente à Lei Orgânica do Município de Pedranópolis, São Paulo ${ }^{51}$.

Com efeito, a Corte, explicitamente, ainda considera vigente o princípio da simetria que decorria do art. 200 da Constituição de 1967, com a redação da Emenda Constitucional n. 01, de 17 de outubro de $1969^{52}$. Ora, o princípio da simetria parece próprio à lógica centralista de um regime autoritário, mas de nenhum modo é compreensível em um contexto federativo democrático que se pretende amigo das autonomias locais. Na ordem constitucional vigente, seria mais natural o Tribunal reconhecer aos Estados e Municípios a livre definição sobre a adoção ou não da lei complementar, bem como que matérias seriam a ela reservadas, até porque inexiste na vigente Constituição da República disposição similar ao art. 200 da Constituição pretérita.

Por outro lado, em se tratando de lei delegada e medida provisória, o Supremo Tribunal Federal concede liberdade de escolha às Constituições estaduais: poderão optar por prever ou por não prever lei delegada e medida provisória. Vejam-se alguns exemplos. $\mathrm{O}$ art. $5^{\circ}, \mathbb{\Omega} 1^{\circ}$, da Constituição do Estado de São Paulo é rigoroso: "é vedado a qualquer dos Poderes delegar atribuições." ${ }^{53}$. Assim, o Direito Constitucional paulista exclui ambas as espécies. Por outro lado, os Estados do Goiás e de Minas Gerais conhecem prática de lei delegada. Indo além, as Constituições dos Estados do Acre, do Maranhão, da Paraíba, do Piauí, de Santa Catarina ${ }^{54}$ e do Tocantins ${ }^{55}$ permitem, aos respectivos Governadores, a edição de medida provisória.

49 BRASIL. Constituição (1988). Constituição da Republica Federativa do Brasil. Disponível em: <http://www.planalto.gov.br/ccivil_03/constituicao/ConstituicaoCompilado.htm>. Acesso em: 10 dez. 2015. Art. 69: "As leis complementares serão aprovadas por maioria absoluta." Portanto, diferentemente do que se dá quando da votação da lei ordinária, votar "em branco" ou, simplesmente, registrar "abstenção equivale a votar "não".

50 BRASIL. Supremo Tribunal Federal. Ação Direta de Inconstitucionalidades. ADI 2872 PI. Tribunal Pleno. Requerente: Governador do Estado do Piauí. Requerido: Assembleia Legislativa do Estado Piauí. Relator: Min. Eros Grau . Brasília, 01 de agosto de 2011. Disponível em: <http://stf.jusbrasil.com.br/jurisprudencia/20624854/acao-direta-de-inconstitucionalidade-adi-2872-pistf >. Acesso em: 10 dez. 2015. No mesmo sentido: BRASIL. Supremo Tribunal Federal. Medida Cautelar na Ação Direta de Inconstitucionalidade. ADI 1087 PI. Tribunal Pleno. Requerente: Governador do Estado do Rio de Janeiro. Requerido: Assembleia Legislativa do Estado do Rio de Janeiro. Relator: Min. Moreira Alves. Brasília, 01 de fevereiro de 1995. Disponível em: < http://stf. jusbrasil.com.br/jurisprudencia/14704759/medida-cautelar-na-acao-direta-de-inconstitucionalidade-adi-1087-rj>. Acesso em: 10 dez. 2015; BRASIL. Supremo Tribunal Federal. Medida Cautelar na Ação Direta de Inconstitucionalidade. ADI 2314 RJ. Tribunal Pleno. Requerente: Governador do Estado do Rio de Janeiro. Requerido: Assembleia Legislativa do Estado do Rio de Janeiro. Relator: Min. Moreira Alves. Brasília, 25 de abril de 1995. Disponível em: <http://stf.jusbrasil.com.br/jurisprudencia/14751531/ medida-cautelar-na-acao-direta-de-inconstitucionalidade-adi-2314-rj>. Acesso em: 10 dez. 2015.

51 BRASIL. Supremo Tribunal Federal Recurso Extraordinário. RE 383123 SP. Segunda Turma. Recorrente: Prefeito Municipal de Pedranópolis. Recorrido: Presidente da Câmara Municipal de Pedranópolis. Relator(a): Min. Carmen Lúcia. Brasília, 04 de novembro de 2014. Disponível em: < http://stf.jusbrasil.com.br/jurisprudencia/25313098/recurso-extraordinario-re-383123-sp-stf/ inteiro-teor-151824983 >. Acesso em: 10 dez. 2015.

52 "As disposições constantes desta Constituição ficam incorporadas, no que couber, ao direito constitucional legislado dos Estados." BRASIL. Constituição (1988). Emenda Constitucional nº 1, de 17 de outubro de 1969. Disponível em: <http:/ /www.planalto.gov. br/ccivil_03/Constituicao/Emendas/Emc_anterior1988/emc01-69.htm>. Acesso em: 10 dez. 2015.

53 SÃO PAULO. Constituição (1989). Constituição do Estado de São Paulo. Disponível em: <http://www.legislacao.sp.gov.br/legislacao/dg280202.nsf/a2dc3f553380ee0f83256cfb00501463/46e2576658b1c52903256d63004f305a?OpenDocument>. Acesso em: 10 dez. 2015.

54 BRASIL. Supremo Tribunal Federal. Ação Direta de Inconstitucionalidades. ADI 2391 SC. Tribunal Pleno. Requerente: Partido dos Trabalhadores. Requerido: Assembleia Legislativa do Estado de Santa Catarina. Relator(a): Min. Ellen Gracie. Brasília, 16 de agosto de 2006. Disponível em: < http://stf.jusbrasil.com.br/jurisprudencia/759899/acao-direta-de-inconstitucionalidade-adi2391-sc>. Acesso em: 10 dez. 2015.

55 BRASIL. Supremo Tribunal Federal. Ação Direta de Inconstitucionalidades. ADI 425 TO. Tribunal Pleno. Requerente: Partido Do Movimento Democrático Brasileiro. Requerido: Assembleia Legislativa do Estado do Tocantins. Relator: Min. Maurício Corrêa. Brasília, 04 de setembro de 2002. Disponível em: < http://stf.jusbrasil.com.br/jurisprudencia/773148/acao-direta-de-inconstitucionalidade-adi-425-to>. Acesso em: 10 dez. 2015. 
Por sua vez, como visto, as leis orgânicas municipais devem observância aos princípios da Constituição da República e aos princípios da Constituição do respectivo Estado ${ }^{56}$. Precisamente em razão de a Constituição paulista não contemplar a medida provisória, o Tribunal de Justiça do Estado de São Paulo fulminou medidas provisórias editadas pelo Prefeito de Indaiatuba. ${ }^{57}$ Por outro lado, há registro de Municípios paranaenses que preveem medida provisória. ${ }^{58}$ Vale observar que, assim como a Constituição paulista, a paranaense também não adota a espécie.

Enfim, seja como for, para acolher a medida provisória, a lei orgânica deverá observar, ao menos, os seguintes princípios elementares que regem a espécie na Constituição da República: (i) edição apenas em caso de relevância e urgência ${ }^{59}$; (ii) observância às limitações materiais da esfera federal aplicáveis à esfera local ${ }^{60}$; (iii) submissão imediata à apreciação parlamentar para conversão em lei ${ }^{61}$, inclusive com a possibilidade de emendas parlamentares; e (iv) regime de prazos tão rigoroso quanto aquele adotado no plano federal ${ }^{6263}$.

\section{Considerações finais}

Victor Nunes Leal ${ }^{64}$ em obra clássica, afirma: "ao estudarmos a autonomia municipal no Brasil, verificamos, desde logo, que o problema verdadeiro não é o de autonomia, mas o de falta de autonomia, tão constante tem sido, em nossa história, salvo breves reações de caráter municipalista, o amesquinhamento das instituições municipais. ${ }^{65}$

Essa situação agrava-se com a imposição do princípio da simetria, que reduz, consideravelmente, o espaço de criatividade que deveria ser próprio à autonomia dos entes federados.

Não obstante as restrições dele decorrentes, encontram-se soluções político-institucionais originais e interessantes nas diversas esferas da federação brasileira. Porém, ainda assim, seria muito importante à evolução da cultura federativa pátria reconhecer aos municípios a possibilidade de adoção de inovações desvinculadas dos modelos federal e estadual, mormente no que se refere à mecânica de produção do próprio direito, ou seja, no que se refere ao processo legislativo local.

56 BRASIL. Constituição (1988). Constituição da Republica Federativa do Brasil. Art. 29. Disponível em: < http://www.planalto.gov.br/ ccivil_03/constituicao/ConstituicaoCompilado.htm>. Acesso em: 10 dez. 2015.

57 SZKLAROWSKY, Leon Frejda. Medidas provisórias: instrumento de governabilidade. São Paulo: NDJ, 2003. p. 341-347.

58 CLÈVE, Clemerson Merlin. Medidas provisórias. 3. ed. São Paulo: Revista dos Tribunais, 2010. p. 244.

59 BRASIL. Constituição (1988). Constituição da Republica Federativa do Brasil. Art. 62, caput. Disponível em: <http://www.planalto. gov.br/ccivil_03/constituicao/ConstituicaoCompilado.htm>. Acesso em: 10 dez. 2015.

60 BRASIL. Constituição (1988). Constituição da Republica Federativa do Brasil. Art. 62, \ 1º. Disponível em: <http://www.planalto. gov.br/ccivil_03/constituicao/ConstituicaoCompilado.htm>. Acesso em: 10 dez. 2015.

61 BRASIL. Constituição (1988). Constituição da Republica Federativa do Brasil. Art. 62, caput. Disponível em: < http://www.planalto. gov.br/ccivil_03/constituicao/ConstituicaoCompilado.htm>. Acesso em: 10 dez. 2015.

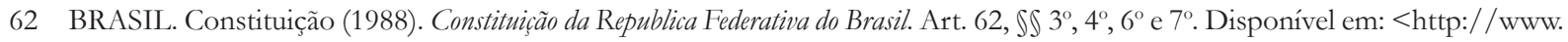
planalto.gov.br/ccivil_03/constituicao/ConstituicaoCompilado.htm>. Acesso em: 10 dez. 2015.

63 Argumentação levada a efeito para avaliar os termos em que é possível a medida provisória estadual (AMARAL JÚNIOR, José Levi Mello do. Medida provisória: edição e conversão em lei, teoria e prática. 2. ed. São Paulo: Saraiva, 2012. p. 209) e considerada correta em doutrina (MENDES, Gilmar Ferreira; BRANCO, Paulo Gustavo Gonet. Curso de direito constitucional. 8. ed. São Paulo: Saraiva, 2013. p. 890-891).

64 LEAL, Victor Nunes. Coronelismo, enxada e voto: o município e o regime representativo no Brasil. 3. ed. Rio de Janeiro: Nova Fronteira, 1997.

65 LEAL, Victor Nunes. Coronelismo, enxada e voto: o município e o regime representativo no Brasil. 3. ed. Rio de Janeiro: Nova Fronteira, 1997. p. 70. 


\section{REFERÊNCIAS}

ALMEIDA, Fernanda Dias Menezes de. Competências na Constituição de 1988. 6. ed. São Paulo: Atlas, 2013.

AMARAL JÚNIOR, José Levi Mello do. Medida provisória: edição e conversão em lei, teoria e prática. 2. ed. São Paulo: Saraiva, 2012.

ATALIBA, Geraldo. Regime constitucional e leis nacionais e federais. Revista de Direito Público, São Paulo, n. 53/54, p. 58-76, 1980.

BARBACENA. Lei Orgânica do Município de Barbacena, de 08 de dezembro de 1990. Disponível em: < http:// www.barbacena.mg.gov.br/governo/leiorganicadomunicipio.pdf>. Acesso em: 10 dez. 2015.

BRASIL. Câmara dos Deputados. Resolução no 17, de 1989. Disponível em: <http://www2.camara.leg.br/ atividade-legislativa/legislacao/regimento-interno-da-camara-dos-deputados/RICD $\% 20$ atualizado $\% 20$ ate\%20RCD\%2012-2015.pdf>. Acesso em: 10 dez. 2015.

BRASIL. Constituição (1988). Constituição da Republica Federativa do Brasil. Disponível em: < http://www.planalto.gov.br/ccivil_03/constituicao/ConstituicaoCompilado.htm>. Acesso em: 10 dez. 2015.

BRASIL. Constituição (1988). Emenda Constitucional no 1, de 17 de outubro de 1969. Disponível em: <http:// www.planalto.gov.br/ccivil_03/Constituicao/Emendas/Emc_anterior1988/emc01-69.htm>. Acesso em: 10 dez. 2015.

BRASIL. Decreto-Lei $n^{0} 4.657$, de 4 de setembro de 1942. Disponível em: <http://www.planalto.gov.br/ccivil_03/decreto-lei/Del4657.htm>. Acesso em: 10 dez. 2015.

BRASIL. Imprensa Nacional. Diário Oficial da União [versão eletrônica]. Disponível em: <http://www.in.gov. br>. Acesso em: 10 dez. 2015.

BRASIL. Lei Complementar no 95, de 26 de fevereiro de 1998. Disponível em: <http://www.planalto.gov.br/ ccivil_03/leis/LCP/Lcp95.htm>. Acesso em: 10 dez. 2015.

BRASIL. Supremo Tribunal Federal. Ação Direta de Inconstitucionalidades. ADI 279 AL. Tribunal Pleno. Requerente: Governador do Estado de Alagoas. Requerido: Assembleia Legislativa do Estado de Alagoas. Relator: Min. Sepúlveda Pertence. Brasilia, 13 de novembro de 1997. Disponível em: <http://stf.jusbrasil. com.br/jurisprudencia/14699547/acao-direta-de-inconstitucionalidade-adi-276-al>. Acesso em: 10 dez. 2015.

BRASIL. Supremo Tribunal Federal. Ação Direta de Inconstitucionalidades. ADI 2182-6/DF. Tribunal Pleno. Requerente: Partido Trabalhista Nacional. Requerido: Congresso Nacional. Relator: Min. Marco Aurélio. Brasília, 31 de maio de 2000. Disponível em: <http://redir.stf.jus.br/paginadorpub/paginador. jsp?docTP=TP\&docID=421277>. Acesso em: 10 dez. 2015.

BRASIL. Supremo Tribunal Federal. Ação Direta de Inconstitucionalidades. ADI 3114 SP. Tribunal Pleno. Requerente: Governador do Estado de São Paulo. Requerido: Assembléia Legislativa do Estado de São Paulo. Relator: Min. Carlos Britto. Brasília, 24 de agosto de 2005. Disponível em: < http://stf.jusbrasil.com.br/ jurisprudencia/763435/acao-direta-de-inconstitucionalidade-adi-3114-sp>. Acesso em: 10 dez. 2015.

BRASIL. Supremo Tribunal Federal. Ação Direta de Inconstitucionalidades. ADI 266 RJ. Tribunal Pleno. Requerente: Governador do Estado do Rio de Janeiro. Requerido: Assembleia Legislativa do Estado do Rio de Janeiro. Relator: Min. Octavio Gallotti. Brasília, 18 de junho de 1993. Disponível em: <http://stf.jusbrasil.com.br/jurisprudencia/14707586/acao-direta-de-inconstitucionalidade-adi-266-rj>. Acesso em: $10 \mathrm{dez}$. 2015. 
BRASIL. Supremo Tribunal Federal. Ação Direta de Inconstitucionalidades. ADI 2872 PI. Tribunal Pleno. Requerente: Governador do Estado do Piauí. Requerido: Assembleia Legislativa do Estado Piauí. Relator: Min. Eros Grau . Brasília, 01 de agosto de 2011. Disponível em: < http://stf.jusbrasil.com.br/jurisprudencia/20624854/acao-direta-de-inconstitucionalidade-adi-2872-pi-stf >. Acesso em: 10 dez. 2015.

BRASIL. Supremo Tribunal Federal. Ação Direta de Inconstitucionalidades. ADI 2391 SC. Tribunal Pleno. Requerente: Partido dos Trabalhadores. Requerido: Assembleia Legislativa do Estado de Santa Catarina. Relator(a): Min. Ellen Gracie. Brasília, 16 de agosto de 2006. Disponível em: < http://stf.jusbrasil.com.br/ jurisprudencia/759899/acao-direta-de-inconstitucionalidade-adi-2391-sc >. Acesso em: 10 dez. 2015.

BRASIL. Supremo Tribunal Federal. Ação Direta de Inconstitucionalidades. ADI 425 TO. Tribunal Pleno. Requerente: Partido Do Movimento Democrático Brasileiro. Requerido: Assembleia Legislativa do Estado do Tocantins. Relator: Min. Maurício Corrêa. Brasília, 04 de setembro de 2002. Disponível em: <http://stf. jusbrasil.com.br/jurisprudencia/773148/acao-direta-de-inconstitucionalidade-adi-425-to $>$. Acesso em: 10 dez. 2015.

BRASIL. Supremo Tribunal Federal. Medida Cautelar na Ação Direta de Inconstitucionalidade. ADI 1087 PI. Tribunal Pleno. Requerente: Governador do Estado do Rio de Janeiro. Requerido: Assembleia Legislativa do Estado do Rio de Janeiro. Relator: Min. Moreira Alves. Brasília, 01 de fevereiro de 1995. Disponível em: $<$ http://redir.stf.jus.br/paginadorpub/paginador.jsp?docTP=AC\&docID=346816>. Acesso em: $10 \mathrm{dez}$. 2015.

BRASIL. Supremo Tribunal Federal. Medida Cautelar na Ação Direta de Inconstitucionalidade. ADI 2314 RJ. Tribunal Pleno. Requerente: Governador do Estado do Rio de Janeiro. Requerido: Assembleia Legislativa do Estado do Rio de Janeiro. Relator: Min. Moreira Alves. Brasília, 25 de abril de 1995. Disponível em: $<$ http://stf.jusbrasil.com.br/jurisprudencia/14751531/medida-cautelar-na-acao-direta-de-inconstitucionalidade-adi-2314-rj>. Acesso em: 10 dez. 2015.

BRASIL. Supremo Tribunal Federal. Recurso Extraordinário. RE 383123 SP. Segunda Turma. Recorrente: Prefeito Municipal de Pedranópolis. Recorrido: Presidente da Câmara Municipal de Pedranópolis. Relator(a): Min. Carmen Lúcia. Brasília, 04 de novembro de 2014. Disponível em: <http://stf.jusbrasil.com.br/jurisprudencia/25313098/recurso-extraordinario-re-383123-sp-stf/inteiro-teor-151824983>. Acesso em: 10 dez. 2015.

BRASIL. Supremo Tribunal Federal. Súmula n 5. A sanção do projeto supre a falta de iniciativa do Poder Executivo. Disponível em: <http://www.stf.jus.br/portal/jurisprudencia/listarJurisprudencia.asp?s1=5. NUME.\%20NAO\%20S.FLSV.\&base=baseSumulas>. Acesso em: 10 dez. 2015.

CLÈVE, Clemerson Merlin. Medidas provisórias. 3. ed. São Paulo: Revista dos Tribunais, 2010.

FERREIRA FILHO, Manoel Gonçalves. Comentários à Constituição brasileira de 1988. São Paulo: Saraiva, 1990. v. 1.

FERREIRA FILHO, Manoel Gonçalves. Do processo legislativo. 7. ed. São Paulo: Saraiva, 2012.

FERREIRA FILHO, Manoel Gonçalves. O poder constituinte. 4. ed. São Paulo: Saraiva, 2005.

LEAL, Victor Nunes. Coronelismo, enxada e voto: o município e o regime representativo no Brasil. 3. ed. Rio de Janeiro: Nova Fronteira, 1997.

MENDES, Gilmar Ferreira; BRANCO, Paulo Gustavo Gonet. Curso de direito constitucional. 8. ed. São Paulo: Saraiva, 2013.

MIRANDA, Francisco Cavalcanti Pontes de. Comentários à Constituição de 1967. São Paulo: Revista dos Tribunais, 1967. t. 3. 
PERNAMBUCO. Constituição (1989). Constituição do Estado de Pernambuco. Disponível em: < http://legis. alepe.pe.gov.br/arquivoTexto.aspx?tiponorma $=12 \&$ numero $=1989 \&$ complemento $=0 \& a n o=1989 \&$ tipo $=\mathrm{T}$ EXTOORIGINAL>. Acesso em: 10 dez. 2015.

SÃO PAULO. Constituição (1989). Constituição do Estado de São Paulo. Disponível em: <http://www.legislacao.sp.gov.br/legislacao/dg280202.nsf/a2dc3f553380ee0f83256cfb00501463/46e2576658b1c52903256d6 3004f305a?OpenDocument>. Acesso em: 10 dez. 2015.

SZKLAROWSKY, Leon Frejda. Medidas provisórias: instrumento de governabilidade. São Paulo: NDJ, 2003. 


\section{REVISTA BRASILEIRA DE POLÍTICAS PÚBLICAS BRAZILIAN JOURNAL OF PUBLIC POLICY}
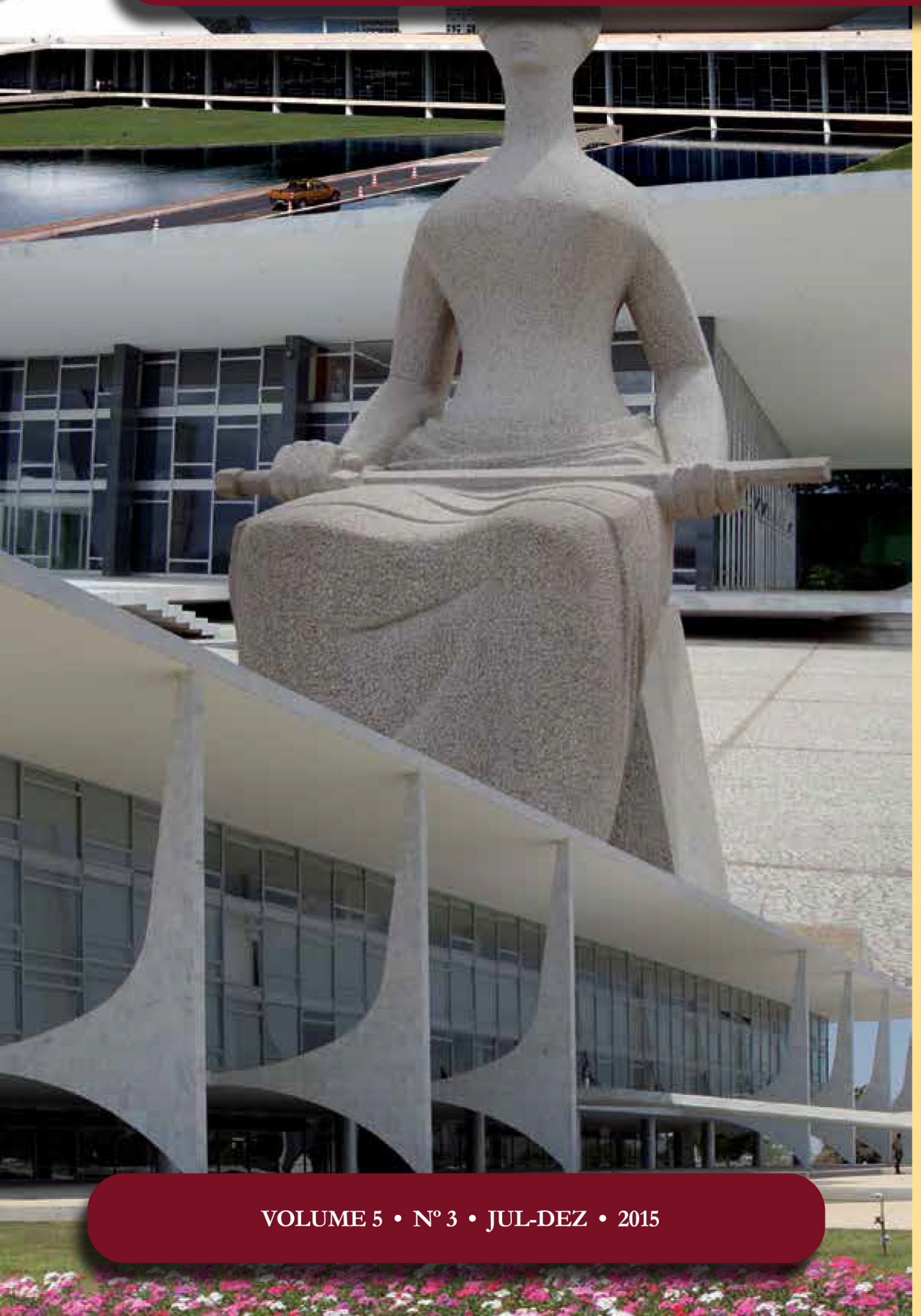

Primeiras linhas sobre a opção político-criminal da deserção militar: a necessária contribuição das Políticas Públicas

First lines on the criminal policy option to military desertion: a required contribution from the Public Policy

Antonio Henrique Graciano Suxberger Danilo Gustavo Vieira Martins 


\section{Primeiras linhas sobre a opção político- criminal da deserção militar: a necessária contribuição das Políticas Públicas*}

\section{First lines on the criminal policy option to military desertion: a required contribution from the Public Policy}

\section{Resumo}

O presente artigo analisa a figura da deserção militar em tempos de paz e o que representa, como opção de política pública, sua previsão como crime no Código Penal Militar. O trabalho revisita as lições próprias da Política Criminal para cotejá-las com a contribuição das Políticas Públicas, especialmente em relação à conformação dos atores das políticas públicas e o processo de agenda setting por meio do qual a deserção se apresenta como problema de política pública para as Forças Armadas. A pesquisa observa revisão bibliográfica e documental e utiliza os dados produzidos pela Pesquisa Institucional sobre condutas criminosas de maior incidência para a Justiça Militar da União, promovida pelo Centro de Estudos Judiciários da Justiça Militar, integrante do Superior Tribunal Militar. A relevância do estudo encontra-se no debate premente sobre a opção criminalizadora da deserção e no que representa tal crime na movimentação da Justiça Militar da União.

Palavras-chave: Descriminalização. Políticas públicas. Deserção. Direito penal militar.

\section{Abstract}

The present article assays the military desertion in peacetime and its significance, as a criminal policy option, to the definition of this conduct as a crime in the Military Criminal Code. The paper considers the most important Criminal Policy standards in comparison to the contribution provided by the Public Policy, especially regarding public policy actors and the agenda setting focused on the military desertion as a problem to the Armed Forces. From a literature review and document analysis about the subject, the paper also analyzes the data produced by the Judiciary Studies Center from Federal Military Justice in a 2014 research titled "Institutional Research about higher incident crimes in the Federal Military Justice". Its relevance lies on the urgent debate about decriminalization of the military desertion in peacetime and what this crime represents in the quantity of cases filed in Federal Military Justice.

\footnotetext{
*** Mestrando em Direito do Centro Universitário de Brasília - UniCEUB. Assessor de Ministro do Superior Tribunal Militar. Professor do Curso de Direito do Centro Universitário Euroamericano - UniEURO/DF. Oficial da Marinha do Brasil.

** Doutor em Direito. Professor do Programa de Mestrado e Doutorado do UNICEUB. Email: suxberger@gmail.com
}

da Marinha do Brasil.

* Artigo convidado. 
Keywords: Decriminalization. Public policy. Desertion. Military criminal law.

\section{SUMÁRIO}

1 Introdução. 2 O Direito e as Políticas Públicas. 3 A conformação dos atores de políticas públicas no presente caso. 4 A incidência da deserção na Justiça Militar da União. 5 A abertura de novos caminhos pela Política Criminal. 6. Referências.

\section{INTRUDUÇÃo}

É sabido que a criminalização de determinada conduta materializa uma opção político-criminal do Estado. O processo de criminalização, assumido como uma construção social, abrange a opção legislativa de tipificação, as interações por meio dos quais os atores e as organizações do sistema de justiça criminal selecionam o fato para fazer incidir a resposta penal do Estado e, por fim, a efetivação da sanção penal eventualmente imposta numa condenação.

A opção estatal de valer-se de sua forma de controle social mais drástica e gravosa - o Direito Penal deve passar, no entanto, pela inarredável conclusão de que possibilidades e meios de controle formal menos gravosos mostraram-se inadequados ou insuficientes. Trata-se, justamente, do postulado da subsidiariedade, que informa a intervenção penal do Estado e reserva essa gravosa forma de controle aos casos de maior relevância e necessária tutela objetiva.

A advertência de que a intervenção penal não é o único ou o primeiro meio de controle social de que dispõe o Estado mostra-se óbvia, mas, frequentemente, esquecida face à expansão desenfreada de novos tipos penais e novos bens jurídicos a receber proteção penal. Há outras formas de controle que, inclusive, devem preceder ao Direito Penal, o qual, pela gravidade de suas consequências, é a ultima ratio do sistema.

A identidade de instrumentos em relação a outras formas de controle social na definição e na correção da conduta desviada - como a norma, a sanção e o processo - permite a assertiva de que a intervenção penal persegue os mesmos fins de resguardo da ordem social ${ }^{1}$, embora ela se valha da opção mais violenta e grave de resposta (como regra, a pena privativa de liberdade) e conte, por isso, com efeitos nefastos que suplantam as razões justificadoras do Direito Penal (o estigma que a resposta penal reserva ao indivíduo). Pablo Milanese destaca que o Direito Penal, hoje, tem se convertido mais num instrumento político de direção social que mecanismo de proteção jurídica subsidiária de outros ramos do ordenamento jurídico. ${ }^{2}$ A lição de Muñoz Conde é precisa sobre a opção política de criminalização:

o que diferencia o direito penal de outras instituições de controle social é, simplesmente, a formalização do controle, liberando-o, dentro do possível, da espontaneidade, da surpresa, do conjunturalismo e da subjetividade própria de outros sistemas de controle social. O controle social jurídico-penal é, além disso, um controle normativo, quer dizer, exerce-se através de um conjunto de normas criadas previamente ao efeito. ${ }^{3}$

Os debates sobre a opção legislativa de criminalização ou descriminalização de condutas têm ocupado

1 SUXBERGER, Antonio Henrique Graciano. Ministério Público e política criminal: uma segurança pública compromissada com os direitos humanos. Curitiba: Juruá, 2012. p. 93.

2 MILANESE, Pablo. El moderno derecho penal y la quiebra del principio de intervención mínima. Revista electrónica de doctrina y jurisprudencia, v. 4, n. 2, fev. 2004. Disponível em: <https://www.unifr.ch/ddp1/derechopenal/articulos/a_20080526_33.pdf>. Acesso em: 20 out. 2015.

3 MUÑOZ CONDE, Francisco. Direito penal e controle social. Trad. Cíntia Toledo Miranda Chaves. Rio de Janeiro: Forense, 2005. p. 6. 
a produção acadêmica dirigida aos temas de Direito Penal, Política Criminal e Criminologia. Entretanto, a escolha pela positivação de novos tipos penais ou pela superação de opções legislativas que se mostrem ultrapassadas, desnecessárias ou, simplesmente, equivocadas, na medida em que reflete a eleição de um modo de abordagem pelo Estado quanto à necessidade de tutela de bens jurídicos, igualmente demanda a compreensão do processo por meio do qual as questões públicas tornam-se problemas de políticas públicas, isto é, passam a merecer abordagem ou, de modo mais preciso, entram na agenda política de discussão sobre a mantença da opção penal ou a busca de outros modos de controle formal diversos da resposta penal.

Trata-se, portanto, do processo de agenda setting, que ocupa a literatura em geral de Políticas Públicas e que interessa às alternativas fixadas para eventual decisão de descriminalização. Se a descriminalização mostra-se como opção a ser acolhida, admita-se por hipótese, quais serão as alternativas para a abordagem da conduta de deserção em tempos de paz pelo Direito Militar e as instituições militares?

As políticas públicas substanciam ações governamentais (mas não somente realizadas no âmbito estatal ou estritamente por atores estatais) dirigidas a resolver determinadas necessidades públicas. Se o ciclo das políticas públicas abrange o processo de formulação, implementação, acompanhamento e avaliação dessas políticas, o debate sobre eventual descriminalização - máxime quando se cuida do crime de maior incidência no sistema de justiça militar, como se verá a seguir - não pode se dissociar da leitura do ciclo próprio da opção estatal de abordagem do fenômeno da deserção nas instituições militares. É dizer: não há como esse debate guardar relevância estritamente com as razões da intervenção penal do Estado. Até porque, para além da opção de criminalização, seguir-se-á, de modo indissociável, o questionamento sobre as alternativas de controle social para o fenômeno então abrangido pelo tipo penal.

O exemplo do crime militar de deserção em tempos de paz, descrito no artigo 187 do Código Penal Militar $^{4}$ (sem descuidar das figuras relacionadas ou assemelhadas estabelecidas nos artigos 188 a 194), traduz possibilidade de abordagem que deve respeitar minimamente a complexa questão das opções de que dispõe o Estado no exercício de suas instâncias de controle social. Hoje, a conduta de deserção observa tipificação jurídico-penal e é responsável pela substancial movimentação do sistema de justiça criminal militar. A opção pela criminalização, contudo, mostra-se a mais acertada para o controle do fenômeno que o tipo penal supostamente enfrenta? Quais os pontos a serem considerados, em termos de políticas públicas, nesse debate?

O tema das políticas públicas requer atenção especial por envolver o sincronismo de diversos ramos do saber, mesclados e concatenados entre si, a fim de permitir que todos os espaços sejam devidamente ocupados. A política pública tem como objetivo maior assegurar o exercício de ações governamentais e, por intermédio delas, concretizar o exercício de cidadania, de forma difusa ou direcionada à determinada parcela da sociedade, em face de suas características sociais, culturais, étnicas ou econômicas. Por isso, interessa o questionamento sobre quem, para quem, por quê, como, onde e quando as políticas públicas se fazem presentes como opção do sistema de justiça militar.

A abordagem de políticas públicas, assim, mostra-se como uma via de mão dupla, em que numa direção seguem as preocupações de elaboração, execução e aperfeiçoamento e, noutra, a atenção sobre quem as recebe, como avaliá-las e como observar o impacto sobre o problema ensejador da intervenção estatal. A elaboração e a execução de políticas públicas não é tarefa solitária dos entes públicos ou privados, pelo contrário, tal atividade há de contar com a efetiva participação da coletividade, uma vez que as ações desenvolvidas a tem como destinatária e, naturalmente, melhor que ela atue conjuntamente com o poder público.

O objetivo do presente artigo, então, consiste em questionar o papel do Direito Militar (e do Direito Penal Militar de modo mais específico) como manifestação de política pública para controle do fenômeno da deserção em tempos de paz nas Forças Armadas. O questionamento quanto à opção de criminalização da deserção mostra-se relevante por força do corrente argumento de sua necessidade à manutenção da hie-

4 BRASIL. Decreto-Lei n. 1.001, de 21 de outubro de 1969. Código Penal Militar. Disponível em: <http://www.planalto.gov.br/ ccivil_03/decreto-lei/Del1001Compilado.htm>. Acesso em: 20 out. 2015. 
rarquia e da disciplina militares. Esses postulados encontram-se no próprio cerne das instituições militares, decerto, mas a opção de intervenção penal reclama cotejo com os dados trazidos pelo censo realizado no ano de 2014 pela Justiça Militar da União ${ }^{5}$ a respeito da relevância da deserção no funcionamento do sistema de justiça criminal militar.

Não se cuidará de questionar a própria demanda de instrumentos para salvaguarda da hierarquia e disciplina militares. Essa demanda de proteção e tutela objetiva ensejou a opção político-criminal de positivação do crime de deserção. A preocupação do presente estudo é diversa: em termos de políticas públicas, a opção de criminalização mostra-se como a mais acertada? O que considerar em relação à ação governamental dirigida a atender essa demanda?

Sua relevância reside no fato de que o crime de deserção mostra-se como o de maior incidência no sistema de justiça criminal militar. Se a razão que justifica a intervenção penal do Estado reside na prevenção de delitos, seja geral, seja específica, mostra-se premente a necessidade de questionar a eficácia da opção jurídico-penal para assegurar a atenção à disciplina e hierarquia militares.

Não se pretende, decerto, apresentar desde logo a solução para o complexo tema da opção político-criminal de criminalização da deserção. Ao revés, busca-se, apenas, prestar instrumental hábil ao aprimoramento do debate e, sobretudo, colaborar ao aprimoramento institucional das Forças Armadas com vistas ao exercício de suas missões constitucionalmente estabelecidas de defesa da Pátria, garantia dos poderes constitucionais e promoção da lei e da ordem.

\section{O DiReito e sua consideração pelas políticas públicas}

Apesar da dificuldade de situar o campo das Políticas Públicas numa área específica do Direito ou de correlacioná-la a uma ou mais disciplinas, Maria Paula Dallari Bucci leciona que o fenômeno do Direito, em relação às políticas públicas, encontra-se envolto pelos valores e pela dinâmica da política. Por isso, definir as políticas públicas como campo de estudos jurídicos faz parte de uma abertura, do Direito, para a interdisciplinaridade. ${ }^{6}$

Naturalmente, o Direito como ciência dinâmica, cujo papel sempre foi acompanhar o modelo social, amoldando-se e fazendo amoldar, tem travado necessária dialética com outras áreas do conhecimento, das quais havia se distanciado desde o ideal positivista iniciado no século XIX. Dado que as políticas públicas possuem estreita ligação com as demandas sociais, cabe aos operadores do Direito aproximar a ordem jurídica do campo de atuação prática. Sob a ótica da atuação concreta do Direito, o conceito de um sistema hierarquizado de normas abarcará não somente a tecnicidade jurídica, na forma de uma pirâmide normativa sistematizada em graus de hierarquia e responsabilidade, mas deve buscar uma expressão formal de cidadania, instrumentalizando a subjetividade política dentro da legitimidade do Direito.

A aplicação do Direito no universo das políticas públicas necessita ser pensada, em termos teleológicos, como espiral de contínua crítica, a fim de permitir a aproximação da vida concreta com os princípios jurídicos destacados no cenário (nacional e internacional).

Diogo Rosenthal Coutinho assevera que o Direito foi alçado ao papel de arranjo institucional, isto é, como interlocutor entre as demandas sociais e as políticas públicas. Por essa razão, há a necessidade de que sua utilidade seja previamente testada pela experiência, e não somente pelo estudo estritamente teórico. Nis-

5 BRASIL. Superior Tribunal Militar. Pesquisa Institucional sobre condutas criminosas de maior incidência para a Justiça Militar da União: Relatório da 1. a fase análise de dados do sistema de acompanhamento de processos da Justiça Militar. Brasília, 2014. Disponível em: <http://www.stm.jus.br/images/CEJUM/pccrim/relatorio_complementar_1a_fase-pcrim.pdf>. Acesso em: 20 out. 2015.

6 O conceito de política pública em direito. In: BUCCI, Maria Paula Dallari. O conceito de política pública em direito. In:

(Org.). Políticas públicas: reflexões sobre o conceito jurídico. São Paulo: Saraiva, 2006. p. 1-50. p. 1. 
so reside importante desafio aos juristas pátrios, cuja formação ,desafortunadamente, negligencia, em geral, a importância da reflexão jurídica sobre as políticas públicas e a investigação aplicada. ${ }^{7}$

O Direito, pois, quando se cuida de políticas públicas, mostra-se de modo inacabado por duas razões. A primeira se refere ao sentido teleológico veiculado pelo Direito de buscar valores que garantam a ordem social e sua aplicabilidade de modo interdisciplinar, observado seu papel de fiel depositário de mandamentos constitucionais. A segunda razão, não menos importante, cuida da conformação do Direito repleta de fluxos e refluxos, os quais, embora construídos sob a encomenda de uma análise sintomática da sociedade, devem ser revistos continuamente, a fim de que o Direito siga pari passu os anseios e as necessidades da coletividade.

\section{A PECULIAR CONFORMAÇÃo dOS ATORES de POLÍtICAS PÚBLICAS}

Quando se pensa em políticas públicas, necessário se faz indagar quem são os atores nesse processo complexo e dinâmico. Por um lado, é preciso definir as iniciativas e suas respectivas atribuições; por outro lado, impõe-se indicar os destinatários dessas políticas, como ordem nominal do contexto sociopolítico no qual estejam inseridos.

Em primeiro momento e de modo quase intuitivo, surge o governo, entendido como a Administração Pública direita e indireta. Essa compreensão encontra lastro no próprio texto constitucional ${ }^{8}$, cujo artigo 175 estabelece que incumbe ao Poder Público, diretamente ou sob regime de concessão ou permissão, a prestação de serviços públicos. O tema dos serviços públicos remete ao capítulo dos Direitos Sociais na Constituição (artigo 6. ${ }^{\circ}$ e seguintes). Os direitos sociais, como expressamente estabelece a Constituição, abrangem o acesso à educação, à saúde, à alimentação, ao trabalho, à moradia, ao lazer, à segurança, à previdência social, a proteção à maternidade e à infância e a assistência aos desamparados. De qualquer modo, conquanto relevante a presença governamental, não é somente o ente público que atua no processo de elaboração de políticas públicas. Outros atores são igualmente capazes de interferir no processo das políticas públicas.

Leonardo Secchi assevera que os atores, em políticas públicas, são os indivíduos, grupos ou organizações que desempenham um papel ativo na arena política e, por isso, têm capacidade de influenciar, direta ou indiretamente, os resultados da política. Tais atores são personagens que conseguem sensibilizar a opinião pública sobre problemas de ordem coletiva. ${ }^{?}$

Um ator pode atuar isoladamente ou em conjunto com os demais atores. Ainda, determinada categoria poderá ser constituída de vários atores, trabalhando em sincronismo. A categorização de atores tem por finalidade somar os que possuem caracteres em comum e, consequentemente, distinguir os que se diferenciam. Os chamados atores individuais são pessoas que agem, intencionalmente, em uma arena política, entre esses encontramos os políticos, burocratas, magistrados, formadores de opinião. Já os atores coletivos são grupos e organizações que agem nessa mesma arena. São exemplos de atores coletivos: partidos políticos, sindicatos, associação de moradores.

Outra categorização de atores refere-se ao papel que exercem em reformas administrativas. Assim, os principais atores de políticas públicas seriam os políticos eleitos e seus designados politicamente, os burocratas selecionados por concurso e a sociedade civil externa à administração pública. A tipologia que considera

7 O direito das políticas públicas. In: COUTINHO, Diogo Rosenthal. O direito nas políticas públicas. In: MARQUES, Eduardo; FARIA, Carlos Aurelio Pimenta de (Org.). Política pública como campo disciplinar. Rio de Janeiro: Fiocruz, 2013. v. 1. p. 181-200. p. 182. 8 BRASIL. Constituição (1988). Constituição da República Federativa do Brasil. Disponível em: <http://www.planalto.gov.br/ccivil_03/constituicao/ConstituicaoCompilado.htm>. Acesso em: 20 out. 2015.

9 SECCHI, Leonardo. Políticas públicas: conceitos, esquemas de análise, casos práticos. 2. ed. São Paulo: Cengage Learning, 2013. p. 99. 
os atores como governamentais e não governamentais inclui, entre os primeiros, os políticos, os designados politicamente, os burocratas e os juízes. Já os atores não governamentais incluiriam os grupos de interesse, partidos políticos, meios de comunicação, think tanks, destinatários das políticas públicas, organizações do terceiro setor e os chamados stakeholders (categoria aberta que incluiria fornecedores, organismos internacionais, comunidades epistêmicas, financiadores, especialistas etc. - partes, estrategicamente, interessadas ou interveniente que, eventualmente, agregassem interesse ou participação). ${ }^{10}$

Os políticos apresentam-se como fundamentais no processo de políticas públicas. Investidos em cargos no Executivo ou no Legislativo, possuem legitimidade para propor e executar políticas públicas de grandes dimensões. Diferenciam-se dos outros por serem representantes do interesse da coletividade, bem assim por se encontrarem investidos de autoridade institucionalizada e, encarnando símbolos, atuam como pessoas públicas. Os designados politicamente ocupam cargos públicos, usualmente indicados pelos políticos eleitos, para servirem em funções de chefia, direção e assessoramento na Administração Pública. $\mathrm{Na}$ arena política, os cargos oferecidos a essa categoria de atores constituem preciosa ferramenta de poder para a política propriamente dita e, para os respectivos partidos que dela participam, não raro configuram moeda de troca destinada a pessoas de confiança e técnicos que colaboram na promoção de uma candidatura ou plataforma, unindo quando, se possível, a tecnicidade profissional e a confiabilidade partidária. Os burocratas são formados pelos agentes que mantêm a Administração Pública em funcionamento, independentemente de quem esteja no exercício do poder político. Possuem características singulares, tais como a estabilidade de emprego, os esquemas de seleção e de promoção fundados em competência técnica e experiência adquirida, além de modelos hierárquicos funcionais. Esses atores detêm recursos importantes que viabilizam a eficácia e a efetividade nas políticas públicas. Por deterem o conhecimento profissional sobre os serviços, aproximam-se dos destinatários das políticas públicas e dominam o funcionamento da própria Administração.

Também os juízes, máxime quando se mencionam os serviços públicos que derivam da positivação dos direitos sociais, apresentam-se como atores de políticas que, de modo angular, ou seja, indiretamente, apresentam singular participação na implementação das políticas públicas, em face do poder legal instituído. Interpretam a aplicação do conjunto normativo em vigor, por parte dos cidadãos ou da administração pública.

Para além do aprofundamento do desenho apresentado aos atores das políticas públicas, essa conformação presta-se, brevemente, à assertiva de que, no tema tratado neste artigo, o problema de política pública menciona conformação subjetiva que refoge do ordinário na abordagem das políticas públicas. Com efeito, ao se questionar o acerto ou desacerto da opção legislativa de criminalização da deserção e quais as alternativas presentes ao controle formal da deserção, para além da resposta penal, dificilmente o problema mostra-se como compartilhado ou vivenciado pelos tradicionais atores das políticas públicas.

O desafio mencionado por Diogo Coutinho, relativamente à dificuldade dos juristas de produzirem conhecimento aplicado, ganha maior relevo quando se cuida de específico e peculiar tema que envolve as Forças Armadas. Isso porque a Constituição é muito clara ao destacar as características que marcam a estrutura militarizada e hierarquizada das Forças Armadas. Também as missões estabelecidas constitucionalmente às Forças Armadas mostram-se claras: estão elas destacadas no artigo 142 da Carta de 1988. Contudo, especialmente nos tempos de paz, não se mostra viável (ou hábil a ensejar interesse) a ampliação do debate a respeito da opção legislativa de formalização do controle estatal dentro das Forças, de modo a assegurar, por um lado, mínima racionalidade ao funcionamento do sistema de justiça criminal militar e, por outro lado, permitir que o Direito cumpra seu papel de exclusivamente tutelar bens jurídicos - no caso, a hierarquia e a disciplina militares - e prevenir ações de deserção nas tropas.

É dizer: o tema das opções e alternativas de controle formal (aqui inserido o controle penal) das ações próprias de deserção frustram a tipologia dos atores de políticas públicas em geral. Isso porque o tema

10 SECCHI, Leonardo. Políticas públicas: conceitos, esquemas de análise, casos práticos. 2. ed. São Paulo: Cengage Learning, 2013. p. 100. 
acaba por interessar, apenas, os diretamente envolvidos no sistema de justiça criminal militar. Com suas características de especificidade e de observância de valores castrenses, o sistema de justiça militar (de modo específico, a Justiça Militar da União) acaba atraindo a atenção e o interesse tão-somente dos próprios integrantes das forças e, eventualmente, daqueles colhidos seja pelo funcionamento das instituições do sistema de justiça ou dos destinatários das normas de controle penal. Isso, decerto, colide com o fato de que a movimentação político-criminal que concretiza a opção de tipificação criminal mostra-se complexa, dado o envolvimento direto do Parlamento, do próprio Executivo e da opção política geral de conformação das Forças Armadas e de seu papel contemporâneo nas sociedades.

Ainda assim, conquanto dissociada da tradicional apresentação dos atores das políticas públicas, as advertências para observância de uma discussão plural, aberta e constituinte no desenho das políticas públicas guardam absoluta aplicabilidade na discussão tratada neste artigo. Nesse nicho específico de interesse substanciado pela discussão das opções de criminalização ou não do sistema de justiça militar, a demanda por uma discussão aberta e de preocupação quanto aos efeitos das soluções alvitradas mostra-se urgente.

Em outras palavras, conquanto a discussão interesse apenas a setores específicos ou atores restritos de políticas públicas atinentes à Justiça Militar da União, as preocupações de abertura política, de embasamento em conhecimento de nítida preocupação aplicada e a necessária consideração de análise e avaliação dessas políticas públicas guardam absoluta pertinência. Caso contrário, corre-se o sério risco de, para além de um nicho específico de políticas públicas, a discussão resulte na produção de soluções dissociadas do contexto social em que se inserem, decerto, todos os tradicionais atores de políticas públicas.

As políticas públicas são dirigidas à sociedade de modo difuso ou a determinado grupo de pessoas, em face de suas características agregativas, que sistematizam determinada parcela da sociedade, para um comportamento social específico. Afinal, conquanto situada em ponto específico do debate, a solução seguramente há de observar a necessária consecução dos fins que justificam a própria existência da especificidade da Justiça Militar.

\section{Deserção e sUa INCIDÊNCIA NA JUSTIÇA MILITAR da UNIÃo}

A abordagem geral das políticas públicas, no que importa à opção político-criminal de tutela penal da disciplina e da hierarquia militares, envolve a própria conformação dos serviços prestados pelo Estado por meio de sua resposta institucional mais solene e gravosa - as Forças Armadas. Incumbe à Justiça Militar da União, em razão do que estabelece o artigo 124 da Constituição, processar e julgar os crimes militares tal como definidos em lei. A lei mencionada no texto constitucional é justamente o Código Penal Militar.

Dirigida à compreensão do universo de processos que movimentam a Justiça Militar da União, a Comissão de Pesquisa Institucional sobre Condutas Criminosas de Maior Incidência para a Justiça Militar da União disponibilizou Relatório ${ }^{11}$ de pesquisa que, valendo-se do Sistema de Acompanhamento de Processos atinentes aos anos de 2002 a 2012 e, posteriormente, por meio de complemento, aos anos de 2013 ao primeiro semestre de 2014, avaliou quantitativa e qualitativamente os processos criminais que movimentaram a Justiça Militar da União no período.

O objetivo principal da pesquisa consistiu em descrever o fluxo dos tipos penais de maior incidência, de modo a permitir ao Superior Tribunal Militar que documentasse as incidências penais e a tipologia desses crimes e, ainda mais, contribuir na formulação de políticas públicas e na execução de seus respectivos programas de ação.

11 BRASIL. Superior Tribunal Militar. Pesquisa Institucional sobre condutas criminosas de maior incidência para a Justiça Militar da União: Relatório da 1. a fase análise de dados do sistema de acompanhamento de processos da Justiça Militar. Brasília, 2014. Disponível em: <http://www.stm.jus.br/images/CEJUM/pccrim/relatorio_complementar_1a_fase-pcrim.pdf>. Acesso em: 20 out. 2015. 
O crime que mais chama a atenção no mencionado relatório, exatamente em relação ao quantitativo geral, é o tipo de deserção, tal como descrito no artigo 187 do Código Penal Militar. Entre os anos de 2002 a 2012, esse tipo penal foi indicado em aproximadamente cinquenta por cento do total de delitos de maior incidência. É dizer: entre os tipos penais de maior incidência, a deserção figurou de modo destacado, respondendo por quase metade de toda a movimento atinente às infrações de estelionato, furto, posse de entorpecente, peculato, lesões leves, abandono de posto, lesão culposa, uso de documento falso, desacato a militar, falsidade ideológica, falsificação de documento, ameaça, receptação e apropriação indébita.

Já entre o período de 2013 e o primeiro semestre de 2014, o delito de deserção apresentou a porcentagem de trinta por cento do total, em relação, também, aos crimes de maior incidência, só que dessa vez em relação ao estelionato, ao furto e a posse de entorpecentes. De qualquer modo, tanto no relatório inicial quanto no seu respectivo complemento, o delito de deserção se destacou como o crime de maior incidência entre os anos de 2002 e 2014.

O Código Penal Militar, composto pelas parte geral e especial, divide-se em três livros. A parte geral ocupa apenas um livro e a parte especial apresenta-se num livro para os crimes militares em tempo de paz e noutro livro para os crimes militares em tempo de guerra. O delito de deserção está descrito nos dois livros $^{12}$, ou seja, o militar poderá praticar esse crime em tempo de paz e, de igual modo, em tempo de guerra. Ressalta-se que, para o militar que deserta na frente do inimigo, em tempo de guerra, a pena prescrita em grau máximo é a de morte.

Interessa ao presente trabalho, de modo mais claro, a deserção em tempos de paz, até porque não se mostra plausível a esta altura a discussão sobre eventual risco de guerra ao país.

A deserção substancia delito formal ou de mera conduta. Isso significa que, para a sua configuração, não há necessidade de resultado materialístico. Sua consumação ocorre quando o militar se ausenta, sem licença, da unidade em que serve ou do lugar em que deve permanecer, por mais de oito dias. É um crime propriamente militar ou de mão própria, pois somente poderá ser praticado por militar. A infração atinge diretamente o serviço e o dever militares, por conseguinte, vulnera a disciplina e a hierarquia castrenses.

Enio Luiz Rossetto destaca que desertar é abandonar definitivamente o serviço militar enquanto está ainda obrigado, ou escapar de seu cumprimento por prazo que a lei presume como abandono, ou não se apresentar para prestá-lo conforme o prazo, ou finalmente agir, fraudulentamente, para se isentar do cumprimento dos deveres decorrentes do serviço militar. ${ }^{13} \mathrm{O}$ tipo básico de deserção ainda contém variações. Por exemplo, há a deserção especial prevista no artigo 189 do Código Penal Militar, de consumação imediata, quando o militar deixa de se apresentar no momento da partida do navio ou aeronave, de que é tripulante, ou do deslocamento da unidade ou força em que serve. Nesse tipo de delito, não se exige o interregno de oito dias para a consumação criminosa.

A maior incidência, contudo, é do tipo penal em sua figura básica, a deserção descrita no artigo 187 do Código Penal Militar, razão pela qual nele se centram as atenções a seguir indicadas.

O delito de deserção afeta, diretamente, a hierarquia e disciplinares militares que, segundo o Estatuto dos Militares, são a base institucional das Forças Armadas. ${ }^{14}$ A responsabilidade e a autoridade dos postos e titulações crescem na medida em que se avança nos graus hierárquicos da carreira. Nos termos do mencionado Estatuto, a hierarquia militar configura-se pela ordenação da autoridade, em níveis diferentes, dentro da estrutura das Forças Armadas. A hierarquia é consubstanciada no espírito de acatamento à sequência de autoridade. Já a disciplina é compreendida como a rigorosa observância e o acatamento integral das leis,

12 Artigos 187 a 194, 391 e 392, todos do Código Penal Militar. BRASIL. Decreto-Lei n. 1.001, de 21 de outubro de 1969. Código Penal Militar. Disponível em: <http://www.planalto.gov.br/ccivil_03/decreto-lei/Del1001Compilado.htm>. Acesso em: 20 out. 2015.

13 ROSSETTO, Enio Luiz. Código penal militar comentado. São Paulo: Revista dos Tribunais, 2012. p. 586.

14 BRASIL. Lei n. 6.880, de 9 de dezembro de 1980. Dispõe sobre o Estatuto dos Militares. Disponível em: <http://www.planalto. gov.br/ccivil_03/leis/16880compilada.htm>. Acesso em: 15 jan. 2015. Artigo 14, parágrafos 1. a 3.‥ 
regulamentos e disposições que fundamentam o organismo militar e coordenam seu funcionamento regular e harmônico. A disciplina traduz-se pelo perfeito cumprimento do dever por parte de todos e de cada um dos componentes desse organismo. A disciplina e o respeito à hierarquia devem ser mantidos em todas as circunstâncias da vida entre militares da ativa e da reserva remunerada e reformados.

Quando um militar decide se ausentar do quartel, sem a devida autorização legal, por mais de oito dias, inicialmente, afronta diretamente a determinação de seu superior hierárquico que, em atenção ao plano de serviço, estabeleceu os dias e horários de expediente normal ou a escala de serviço, quando os militares realizam a atividade de segurança orgânica do quartel. Igualmente, deixa de observar os preceitos legais estatuídos nas normas e regulamentos militares, com abalo à estrutura organizacional militar e, por conseguinte, abalo direto do serviço militar em si.

Nessa situação, o militar, também, malfere a moral que deve orientar a relação entre os companheiros de farda e gera instabilidade entre os combatentes que cumprem seu compromisso com a Força. A visão de um militar que deserta, ainda que em tempos de paz, desperta sentimento natural de reprovação, bem assim a expectativa de que a instituição rigorosamente se posicione para solução desse problema. Do ponto de vista estritamente organizacional, a deserção ainda gera problema administrativo, com desvio de esforços de pessoal e material, para compensação da falta, em prejuízo do serviço a que se destina a unidade militar.

O militar deserta, segundo Artur Vidigal de Oliveira, porque não prioriza a caserna. Age com dolo, sem temor do que poderá lhe acontecer, e falta com o juramento empenhado à pátria, de modo a ensejar vulneração de seu dever militar, sem justificativa plausível para isentá-lo de responsabilidade. ${ }^{15}$

Os militares são preparados, em tempo de paz, para o cumprimento fiel e irrestrito das ordens recebidas de seus superiores hierárquicos. Tais ordens amparam-se em regulamentos militares, que, em caso de necessidade, reclamam do militar o sacrifício da própria vida em favor do cumprimento das missões constitucionais da Força.

Essa observância aos preceitos militares não vem de uma fé cega e impensada; ao contrário, ampara-se na necessária confiança de que seus superiores hierárquicos possuem envergadura moral e capacidade técnica suficientes para direcionar as ações militares para a melhor solução de qualquer questão que envolva a respectiva Força. Ainda, lastreia-se na ideia de que esses comandos, em regra, encontrarão conformidade com os preceitos legais em vigor.

Se em tempo de paz, isto é, em situações de tranquilidade, quando os parâmetros administrativos em expectativa normal e a rotina seguem seu curso programado, a prática da deserção já causa um revés expressivo; imagine-se, em tempo de guerra, no curso de batalha, a gravidade da deserção. À frente do inimigo, quando o combatente, além de defender sua própria vida, age para garantir a segurança de outros militares e a própria higidez do país pelo qual luta. Os militares são preparados em tempo de paz, para que, em guerra, formem corpo uníssono em perfeita sintonia. Por isso, qualquer desrespeito aos superiores e às normas em vigor gera desequilíbrio nefasto com aptidão de influir diretamente a unidade militar e, consequentemente, a própria missão que se propõe realizar.

Em linhas gerais, esses são os reflexos da deserção em torno do ambiente militar. Talvez, para os demais integrantes da coletividade, fora do regime e da unidade castrenses, a falta injustificada de um militar em seu quartel por mais de oito dias não represente um fato de censurabilidade tão severa. A deserção, contudo, seguramente afeta a ordem militar e, por conseguinte, compromete o bom desempenho das funções militares. Malfere, portanto, as manifestações essenciais do valor militar, entre essas encontram-se o patriotismo,

15 O escólio foi veiculado em voto proferido em julgamento de recurso sobre o crime de deserção no Superior Tribunal Militar. Cf. BRASIL. Superior Tribunal Militar. Apelação. Processo n. 26-84.2005.7.01.0201 RJ. Tribunal Pleno. Apelante: Eric Willian ea Silva Nunes. Apelada: Conselho Permanente de Justiça da 2. Auditoria da 1. CJM. Relator: Ministro Artur Vidigal de Oliveira. Brasilia, 08 dez. 2014. Disponível em: < http://www.jusbrasil.com.br/diarios/documentos/156275207/andamento-do-processo-n26-8420057010201-do-dia-08-12-2014-do-stm>. Acesso em: 20 out. 2015. 
o civismo, o culto das tradições históricas, a fé na missão elevada das Forças Armadas, o espírito de corpo, o orgulho pela organização a que serve, o amor à profissão das armas e o entusiasmo necessário com que deve ser exercida. A consideração dessas especificidades mostra-se necessária para evitar que eventual discussão sobre as opções político-criminais na Justiça Militar orientem-se por valores distintos daqueles próprios da disciplina militar.

\section{A ABERTURA De NOVOS CAMINHOS PELA POLÍtICA CRIMINAL}

O Direito Penal busca a uniformidade e a justa aplicação da sanção penal. Nisso reside sua dúplice função protetiva: guarda justificativa na tutela objetiva de direitos fundamentais por meio de tipos penais incriminadores, ou seja, protege a coletividade, ao tempo em que limita o exercício do poder punitivo estatal ao que estabelece prévia, clara e expressamente o preceito sancionatório do tipo penal, ou seja, igualmente protege o indivíduo do poder penal do Estado.

Como fenômeno dinâmico e complexo, a realização da intervenção penal apresenta-se muito além da compreensão isolada e hermética da sistemática jurídica do ordenamento penal. Essa leitura de caráter dogmático, registre-se, guarda inegável relevância, mas nem de longe autoriza única e isoladamente orientar as opções político-criminais de criminalização de condutas.

A dinâmica do sistema de justiça criminal - e o sistema de justiça militar não destoa dessa compreensão - demanda análise multidisciplinar que aborde aspectos sociais, culturais, econômicos e políticos. A intervenção penal do Estado, para além da moldura legal punitiva, deve permitir aprofundamento da questão na ordem de tempo e de espaço, a fim de garantir que as questões submetidas ao sistema de justiça não sejam tratadas com base apenas numa fórmula geral inflexível para casos específicos.

Claus Roxin nos ensina que uma solução diretamente valorativa do problema não fere de modo algum a segurança jurídica e o domínio do material jurídico. Não se pode desprezar os riscos de uma sistemática penal restrita ao uso de fórmulas genéricas, em que o juiz criminal atue, exclusivamente, pelo automatismo dos conceitos teóricos, deixando de observar às peculiaridades do caso real. ${ }^{16} \mathrm{~A}$ política criminal tem por finalidade o enfrentamento da criminalidade pelo uso de métodos racionais, calcados na universalidade multidisciplinar do conhecimento. Cabe a essa política a tarefa social do Direito Penal, ao passo que ao Direito Penal em si, de modo mais particular, compete a função garantidora de assegurar a uniformidade da aplicação do direito e a preservação da liberdade em face do absolutismo individual.

A feição de ciência jurídica do Direito Penal reclama análise sistemática do ordenamento jurídico-positivista e da sua ordenação no sistema social a que esteja inserido. A Política Criminal, por sua vez, atenta para os conteúdos sociais e, mais ainda, aos fins do Direito Penal e, por isso, avança para além dos limites do âmbito jurídico. É esse o ponto de sua interseção com a temática das políticas públicas.

Ao lançar as bases do pensamento funcionalista, de vertente teleológica, Claus Roxin aborda a questão punitiva de modo aberto, ditando que a realidade se impõe em qualquer exame dos fatos da vida. Tal exame, porém, não assegura por si só que se tenha processado, metodologicamente e sistematicamente, de modo satisfatório a realização do próprio poder punitivo. Uma teoria do delito - e, de modo mais amplo, uma teoria da intervenção penal do Estado - que exclui os pontos de vista político-criminais, atendo-se, apenas, a uma abordagem formalista, não autoriza que ao caso receba correção valorativa muitas vezes necessária como medida de Justiça. ${ }^{17}$

16 ROXIN, Claus. Política criminal e sistema jurídico-penal. Trad. Luís Greco. Rio de Janeiro: Renovar, 2002. p. 9.

17 ROXIN, Claus. Política criminal e sistema jurídico-penal. Trad. Luís Greco. Rio de Janeiro: Renovar, 2002. p. 26. 
A construção de um sistema de valores, sob o prisma do Estado democrático, tem sua razão de justificativa na vontade popular proclamada expressamente na Constituição. As opções ético-sociais da comunidade jurídico-política amparada nesses valores fazem parte da realidade social por meio do processo sociopolítico de integração e é exatamente essa confluência autoriza uma dialética entre a Política Criminal e o Direito Penal. Essa interação, decerto, há de refletir os valores consagrados pelo modelo de Estado almejado na Constituição. ${ }^{18} \mathrm{O}$ intérprete, por sua vez, tem papel relevante na construção de soluções axiologicamente orientadas às finalidades de uma intervenção penal que se espera não só legítima mas adequada ao caso concreto.

Assim, no debate sobre eventual opção de criminalização ou descriminalização de tipos já existentes, o caminho a ser trilhado implica deixar que as decisões valorativas do sistema político criminal façam parte do sistema do direito penal positivista, de tal modo que as interações harmônicas e os resultados desse sistema interdisciplinar não fiquem sujeitas, apenas, a um sistema puramente positivista.

Os delitos de deserção, como estudo de caso, representam grande oportunidade para que os atores políticos possam desenvolver alternativas que busquem solução tanto para aquele que venha a infringir a regra legal proibitiva da deserção como para as Forças Armadas. O agente da deserção, destinatário da opção político-criminal, há de receber resposta que se oriente à preocupação de retribuição pelo mal causado e, também, por razão de prevenção (geral e específica) de novos delitos.

A pesquisa institucional realizada pelo Superior Tribunal Militar ${ }^{19}$ indicou a possível relação entre o número de deserções e a remuneração dos recrutas. Em maio de 2004, a remuneração de um recruta era de cento e cinquenta e três reais. O salário mínimo, à época, era de duzentos e sessenta reais. A remuneração do recruta só se aproximou do salário mínimo em 2008, quando este valia quatrocentos e dezessete reais e o recruta recebia quatrocentos e quinze reais. É significativo que o número de deserções observe, justamente, os influxos da pior ou melhor remuneração dos recrutas, especialmente porque a esmagadora consideração dos acusados do crime de deserção ostentam justamente o posto de recruta.

Outro dado relevante, que impacta sensivelmente na situação dos recrutas nas Forças, refere-se aos resultados colhidos pelo Projeto Soldado Cidadão. Criado em 2002 e melhor delineado a partir de sua inclusão no Plano Plurianual de 2004 a 2007, o Projeto objetiva oferecer aos jovens incorporados às fileiras das Forças Armadas cursos profissionalizantes que proporcionem capacitação técnico-profissional básica, formação cívica e ingresso no mercado de trabalho em melhores condições. ${ }^{20}$ A oferta dos cursos, muitas vezes, atrai os jovens que ocupam a mencionada graduação de recruta, mas a prática dos cursos acaba frustrando muitos dos que ali ingressam que culminam por incidir na prática da deserção. ${ }^{21}$

As causas que levam os militares a desertar são as mais variadas possíveis e não há estudos qualitativos que autorizem uma etnografia ou uma abordagem das representações por que seus agentes realizam tal fato delituoso. Apenas de modo ilustrativo, em processo de deserção que tramita no Superior Tribunal Militar, o desertor, um soldado de 21 anos, justificou a deserção no fato de que havia rompido o relacionamento que mantinha com sua namorada. A grande massa de desertores apontados pela pesquisa institucional é composta de cabos, soldados e taifeiros. A faixa etária dos desertores é de jovens adultos, com idade entre 19 a 23 anos. Apresentam grau de instrução que nem sempre alcança a conclusão do ensino médio. A baixa renda, já mencionada, é igualmente fator preocupante.

18 SUXBERGER, Antônio Henrique Graciano. Legitimidade da intervenção penal. Rio de Janeiro: Lumen Juris, 2006. p. 147.

19 BRASIL. Superior Tribunal Militar. Pesquisa Institucional sobre condutas criminosas de maior incidência para a Justiça Militar da União: Relatório da 1. ${ }^{a}$ fase análise de dados do sistema de acompanhamento de processos da Justiça Militar. Brasília, 2014. Disponível em: <http://www.stm.jus.br/images/CEJUM/pccrim/relatorio_complementar_1a_fase-pcrim.pdf>. Acesso em: 20 out. 2015.

20 BRASIL. Câmara dos Deputados. O Projeto Soldado-Cidadão. Brasília, dez. 2007. Disponível em: <http://bd.camara.gov.br/>. Acesso em: 20 out. 2015.

21 BRASIL. Superior Tribunal Militar. Pesquisa Institucional sobre condutas criminosas de maior incidência para a Justiça Militar da União: Relatório da 1. ${ }^{a}$ fase análise de dados do sistema de acompanhamento de processos da Justiça Militar. Brasília, 2014. Item 8. Disponível em: <http://www.stm.jus.br/images/CEJUM/pccrim/relatorio_complementar_1a_fase-pcrim.pdf>. Acesso em: 20 out. 2015. 
Na prática, quando o militar deserta, ao ser capturado ou se apresentar, voluntariamente, fica ele detido à disposição da Justiça pelo prazo de dois meses, por força de preceito legal expresso no Código de Processo Penal Militar ${ }^{22}$, recepcionado pela Constituição Federal de $1988 .{ }^{23}$ A pena para o crime de deserção estatuída pelo artigo 187 do Código Penal Militar é de seis meses a dois anos de detenção. A esmagadora maioria das condenações impõe a pena mínima de seis meses de detenção. O prazo da detenção provisória - dois meses - por si só já representa terço da reprimenda ao final estabelecida. Tal peculiaridade tem autorizado ao longo dos anos a incidências dos sucessivos favores legais estabelecidos nos Decretos presidenciais de indulto natalino.

A atividade legislativa em matéria penal, desenvolvida ao longo das últimas décadas, tem sido marcada por três características principais, quais sejam: a produção de tipos penais cuja legitimação guarda referência a bens jurídicos vagos, a criminalização de estados prévios às lesões efetivas de bens jurídicos e o recrudescimento na imposição de sanções, que muitas vezes revelam-se desproporcionalmente altas e, por sua vez, não dão indícios da diminuição da criminalidade. ${ }^{24}$

Essa constatação não autoriza a conclusão de que os desertores devam, apenas, por isso, isentar-se de responsabilidade penal ou que o tipo penal de deserção deveria sofrer revogação ou superação. Como já demonstrado, o crime de deserção implica sérios danos à ordem militar. O modo pelo qual se processam as persecuções penais de deserção igualmente não se prestam a deslegitimar, por si só, a resposta penal, pois tanto as Auditorias Militares quanto o Superior Tribunal Militar têm dado respostas judiciais com estrita atenção aos postulados mais caros do devido processo legal, especialmente a duração razoável dos processos.

Contudo, a opção de criminalização da deserção em tempos de paz, quando se tem em conta os números que refletem sua incidência ao longo dos anos e o perfil dos jovens que incursionam em tal prática, demanda reflexão a respeito da aptidão que a resposta penal tem, nesse caso, para atender aos valores mais caros às instituições militares e, também, às preocupações que justificam a própria intervenção penal do Estado.

A falência da resposta penal, como instrumento de tutela objetiva dos preceitos fundamentais em testilha - disciplina e hierarquia militares -, é evidenciada pelo elevado número de incursões criminosas que respondem a fatores que pouco se referem aos valores tutelados pela norma incriminadora. É dizer: as deserções pouco dizem sobre eventual frustração ou esvaziamento da hierarquia e da disciplina militares, mas deixam entrever que o problema guarda mais proximidade com o perfil sociofinanceiro dos jovens colhidos pelo sistema de justiça criminal militar.

Faz-se, pois, premente o fomento de uma discussão que permita atender tanto ao Estado, no caso, as Forças Armadas que sofrem os reveses das deserções, como ao próprio desertor, no sentido de que a sanção não seja destinada tão somente à retribuição da deserção, mas sim como medida de orientação e ressocialização do condenado.

As políticas públicas, no caso em questão, a política criminal reflete o estado de consciência da sociedade para o tempo e o lugar específico que se pretende cumprir. A normativa vigente e os programas de ação voltados ao enfrentamento da criminalidade ou à reafirmação das valores tão caros à disciplina e à hierarquia militar devem observar justamente a aptidão que os instrumentos eleitos tenham para os fins almejados.

Nessa linha de ideias, não parece razoável que a resposta penal indelével e imediata surja, por exemplo, nos primeiros casos de incidência da deserção em tempos de paz. Em situações assim, a resposta sancionatória - diversa da tradicional sanção de pena privativa de liberdade - pode mostrar-se mais efetiva para a

22 BRASIL. Decreto-Lei n. 1.002, de 21 de outubro de 1969. Código de Processo Penal Militar. Artigo 451. Disponível em: <http:// www.planalto.gov.br/ccivil_03/decreto-lei/Del1002Compilado.htm>. Acesso em: 20 out. 2015.

23 BRASIL. Constituição (1988). Constituição da República Federativa do Brasil. Artigo 5. ${ }^{\circ}$, inciso LXI. Disponível em: <http://www. planalto.gov.br/ccivil_03/constituicao/ConstituicaoCompilado.htm>. Acesso em: 20 out. 2015.

24 SUXBERGER, Antônio Henrique Graciano. Legitimidade da intervenção penal. Rio de Janeiro: Lumen Juris, 2006. p. 65. 
prevenção de nova prática de deserção. Por exemplo, o incremento da transgressão disciplinar - que abrange as faltas administrativas militares - ou a criação de contravenção disciplinar dirigida a essa prática isolada e dissociada do contexto de vulneração mais patente da disciplina e da hierarquia militares poderiam, de um só golpe, fortalecer a resposta penal, reservando-a propriamente aos casos mais graves e, ao mesmo tempo, atender aos reclamos de continuidade e organização do Poder Público tão prejudicado com a prática da deserção.

Uma resposta gradativa, pois, que conjugue medidas extrapenais e de reforço do ordenamento disciplinar não só atenderia aos já destacados reclamos de Política Criminal, como igualmente responderia positivamente a uma racionalidade gerencial, que conjuga os objetivos e os meios a serem utilizados e guarda proximidade com a temática das políticas públicas. ${ }^{25}$

A título ilustrativo, o Regulamento Disciplinar para a Marinha apresenta um rol de ações que, se praticados por militares, poderão ser tidas como contravenção disciplinar. Por exemplo, o Regulamento prevê a contravenção consistente em "deixar de se apresentar, finda a licença ou cumprimento de pena, aos seus superiores ou a quem deve fazê-lo, de acordo com as normas de serviço da Organização Militar". ${ }^{26}$ Caso a deserção deixasse de guardar estrita previsão de crime, numa primeira incidência, por exemplo, o pretenso desertor poderia receber apenas a sanção atinente à contravenção disciplinar, de modo a atender a falta cometida, assegurar retorno à coletividade pelo prejuízo causado e, assegurando solução mais célere à questão, isso poderia autorizar maior potencial preventivo de reiteração da conduta ou ensejar efeito dissuasório mais efetivo de ações que atinjam as Forças Armadas.

Um ponto, no entanto, é certo: o debate sobre eventual descriminalização do crime de deserção há de observar, concomitantemente, a consideração de propostas de incremento de instrumentos e respostas extrapenais. É dizer: a eventual retirada do preceito incriminador não deve implicar a diminuição ou atenuação dos instrumentos de controle formal estatal sobre a deserção. Ao contrário, deve ensejar, em caso de afastamento da resposta mais gravosa do Estado (sanção penal), maior sofisticação da resposta extrapenal, para assegurar os relevantes valores então tutelados pela intervenção penal do Estado.

O Direito Penal e a Política Criminal não ocupam pontos antagônicos na construção das respostas possíveis aos problemas reconhecidos como de necessária atuação estatal. O Direito Penal há de guardar instrumental hábil a veicular as finalidades reconhecidas pelas políticas públicas como merecedoras da resposta penal sancionatória, tudo em respeito ao papel do Direito como arranjo institucional de vocalização das respostas estatais aos problemas públicos.

Roxin alerta que um divórcio entre a construção dogmática e acertos político-criminais é de plano impossível. Situar o trabalho dogmático-penal e os saberes criminológicos como antagonistas, igualmente, não se mostra postura compatível com a complexidade dos problemas a que se voltam esses campos de conhecimento. Ao revés, a urgência da compreensão dos debates sobre a efetividade da resposta da penal reclama o aproveitamento dos saberes criminológicos para vocalizar exigências político-criminais que venham, se o caso, a se convolar em regras jurídicas. ${ }^{27}$

Pensar o Direito e aplicá-lo às Políticas Públicas na solução dos problemas criminais existentes no âmbito das Forças Armadas, ou na sociedade, demandam a soma da tecnicidade jurídica aliada à experiência pensada sob o prima da materialidade multidisciplinar. Esse, pois, o desafio do jurista, de quem se espera o desenho de alternativas com potencial de aplicabilidade e não de estrita consistência teórica ou abstrata.

25 SOARES, Fabiana de Menezes. Legística e desenvolvimento: a qualidade da lei no quadro de da otimização de uma melhor legislação. Cadernos da Escola do Legislativo, Belo Horizonte, v. 9, n. 14, p. 7-34, jan./dez. 2007. p. 13.

26 BRASIL. Decreto n. 88.545, de 26 de julho de 1983. Aprova o Regulamento Disciplinar para a Marinha e dá outras providências. Artigo 7. ${ }^{\circ}$, item 16. Disponível em: <http://www2.camara.leg.br/legin/fed/decret/1980-1987/decreto-88545-26-julho1983-438491-norma-pe.html>. Acesso em: 20 out. 2015.

27 ROXIN, Claus. Política criminal e sistema jurídico-penal. Trad. Luís Greco. Rio de Janeiro: Renovar, 2002. p. 82. 
Não é missão fácil, decerto, porque essa aplicabilidade demanda tempo, prática e reflexão. Somese a isso a utilização de metodologias que não guardam muita proximidade com o Direito, como a pesquisa qualitativa e as investigações sociojurídicas sobre as demandas do sistema de justiça criminal militar (e do sistema de justiça criminal como um todo). O objetivo é claro: alcançar uma fórmula que se apresente efetiva, isto é, hábil a impactar no problema reconhecido como ensejador de políticas públicos, pelo menos até o ponto em que o modelo social se refaça e, assim lance, por mais uma vez, o desafio de entendê-lo e equalizá-lo por meio do binômio Direito e Políticas Públicas.

\section{REFERÊNCIAS}

BRASIL. Câmara dos Deputados. O Projeto Soldado-Cidadão. Brasília, dez. 2007. Disponível em: <http:// bd.camara.gov.br/>. Acesso em: 20 out. 2015.

BRASIL. Constituição (1988). Constituição da República Federativa do Brasil. Disponível em: < http://www.planalto.gov.br/ccivil_03/constituicao/ConstituicaoCompilado.htm>. Acesso em: 20 out. 2015.

BRASIL. Decreto n. 88.545, de 26 de julho de 1983. Aprova o Regulamento Disciplinar para a Marinha e dá outras providências. Disponível em: <http://www2.camara.leg.br/legin/fed/decret/1980-1987/decreto88545-26-julho-1983-438491-norma-pe.html>. Acesso em: 20 out. 2015.

BRASIL. Decreto-Lei n. 1.001, de 21 de outubro de 1969. Código Penal Militar. Disponível em: <http://www. planalto.gov.br/ccivil_03/decreto-lei/Del1001Compilado.htm>. Acesso em: 20 out. 2015.

BRASIL. Decreto-Lei n. 1.002, de 21 de outubro de 1969. Código de Processo Penal Militar. Disponível em: <http://www.planalto.gov.br/ccivil_03/decreto-lei/Del1002Compilado.htm>. Acesso em: 20 out. 2015.

BRASIL. Lei n. 6.880, de 9 de dezembro de 1980. Dispõe sobre o Estatuto dos Militares. Disponível em: <http://www.planalto.gov.br/ccivil_03/leis/16880compilada.htm>. Acesso em: 15 jan. 2015.

BRASIL. Superior Tribunal Militar. Apelação. Processo n. 26-84.2005.7.01.0201 RJ. Tribunal Pleno. Apelante: Eric Willian ea Silva Nunes. Apelada: Conselho Permanente de Justiça da 2. Auditoria da 1. CJM. Relator: Ministro Artur Vidigal de Oliveira. Brasilia, 08 dez. 2014. Disponível em: <http://www.jusbrasil.com.br/ diarios/documentos/156275207/andamento-do-processo-n-26-8420057010201-do-dia-08-12-2014-dostm>. Acesso em: 20 out. 2015.

BRASIL. Superior Tribunal Militar. Pesquisa Institucional sobre condutas criminosas de maior incidência para a Justiça Militar da União: Relatório da 1. ${ }^{a}$ fase análise de dados do sistema de acompanhamento de processos da Justiça Militar. Brasília, 2014. Disponível em: <http://www.stm.jus.br/images/CEJUM/pccrim/relatorio_ complementar_1a_fase-pcrim.pdf $>$. Acesso em: 20 out. 2015.

BUCCI, Maria Paula Dallari. O conceito de política pública em direito. In: (Org.). Políticas públicas: reflexões sobre o conceito jurídico. São Paulo: Saraiva, 2006. p. 1-50.

COUTINHO, Diogo Rosenthal. O direito nas políticas públicas. In: MARQUES, Eduardo; FARIA, Carlos Aurelio Pimenta de (Org.). Política pública como campo disciplinar. Rio de Janeiro: Fiocruz, 2013. v. 1. p. 181-200.

MILANESE, Pablo. El moderno derecho penal y la quiebra del principio de intervención mínima. Revista electrónica de doctrina y jurisprudencia, v. 4, n. 2, fev. 2004. Disponível em: <https://www.unifr.ch/ddp1/derechopenal/articulos/a_20080526_33.pdf>. Acesso em: 20 out. 2015.

MUÑ OZ CONDE, Francisco. Direito penal e controle social. Trad. Cíntia Toledo Miranda Chaves. Rio de Janeiro: Forense, 2005. 
ROSSETTO, Enio Luiz. Código penal militar comentado. São Paulo: Revista dos Tribunais, 2012.

ROXIN, Claus. Política criminal e sistema jurídico-penal. Trad. Luís Greco. Rio de Janeiro: Renovar, 2002.

SECCHI, Leonardo. Políticas públicas: conceitos, esquemas de análise, casos práticos. 2. ed. São Paulo: Cengage Learning, 2013.

SOARES, Fabiana de Menezes. Legística e desenvolvimento: a qualidade da lei no quadro de da otimização de uma melhor legislação. Cadernos da Escola do Legislativo, Belo Horizonte, v. 9, n. 14, p. 7-34, jan./dez. 2007.

SUXBERGER, Antônio Henrique Graciano. Legitimidade da intervenção penal. Rio de Janeiro: Lumen Juris, 2006.

SUXBERGER, Antonio Henrique Graciano. Ministério Público e política criminal: uma segurança pública compromissada com os direitos humanos. Curitiba: Juruá, 2012. 


\section{REVISTA BRASILEIRA DE POLÍTICAS PÚBLICAS BRAZILIAN JOURNAL OF PUBLIC POLICY}
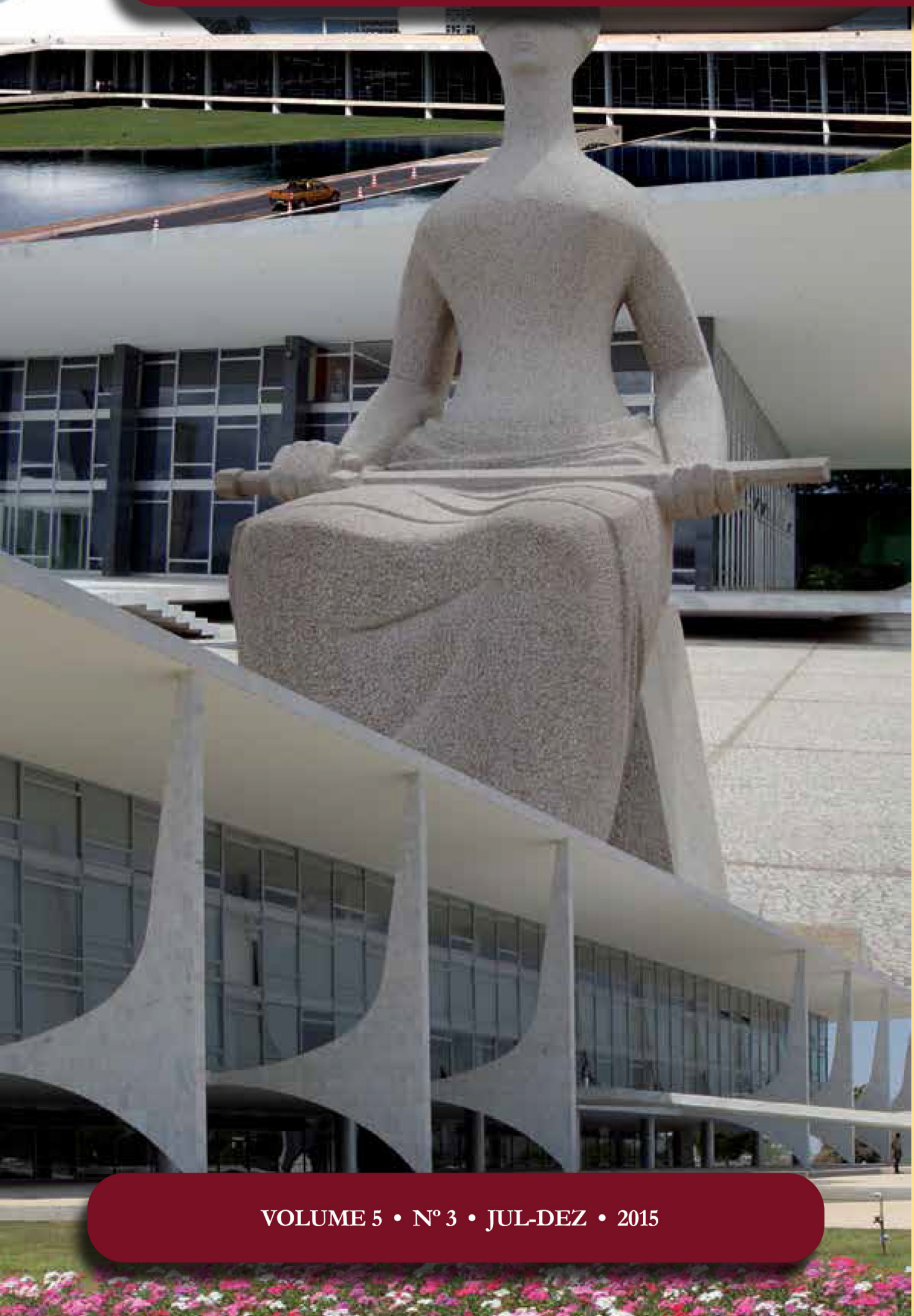

Implicações do direito ao voto aos imigrantes: ameaça à soberania nacional ou efetivação de um direito fundamental? Implications of Enabling Permanent Residents to Vote - Threat to National Sovereignty or Realization of a Fundamental Right? 


\title{
Implicações do direito ao voto aos imigrantes: ameaça à soberania nacional ou efetivação de um direito fundamental? *
}

\author{
Implications of Enabling Permanent \\ Residents to Vote - Threat to National \\ Sovereignty or Realization of a Fundamental \\ Right?
}

Juliana Cleto **

\section{Resumo}

O presente trabalho objetiva questionar a impossibilidade de voto ao estrangeiro no Brasil, independentemente de seu tempo de residência. Atualmente, é necessário, para o alistamento eleitoral, que o indivíduo seja brasileiro nato ou naturalizado, sendo inviável o voto ao estrangeiro. "Aqui vivo, aqui voto" se traduz em uma das campanhas mais relevantes para ressaltar a importância da participação política do imigrante em um Estado democrático de direito. O movimento "no taxation without representation" da nação estadunidense do século XVIII hoje toma uma roupagem distinta, mas que, na essência, carrega a mesma indignação - aqui se vive, pagam-se impostos, respeita-se a lei. Por que, então, não se vota? Quais as implicações decorrentes da abertura do direito ao voto aos imigrantes? Uma vez que o imigrante se torna eleitor, abrem-se diversas outras possibilidades que não lhe seriam possíveis sem o alistamento — doação a partidos políticos, a criação de partidos políticos, a propositura de ações populares, iniciativa popular de projetos de lei, participação em programas de governo. Qual seria, então, o posicionamento mais adequado em relação a esse impasse? Possibilitar o voto ao imigrante apenas em eleições locais ou igualmente a eleições nacionais? Até que ponto a participação política do estrangeiro deixa de ser a efetivação de um direito fundamental e passa a representar ameaça à soberania nacional?

Palavras-chave: Cidadania. Imigrante. Participação política. Direitos humanos.

* Recebido em 01/10/2014 Aprovado em 30/01/2015

** Pós-graduada em Direito Constitucional pela Academia Brasileira de Direito Constitucional (2015). Graduada em Direito pelo Centro Universitário Curitiba (2013). E-mail: julianacleto@live.com

\section{Abstract}

The current final paper aims to question the impossibility for the immigrants to vote in Brazil, regardless of their residence period in the country. Currently, one of the requirements to vote in Brazil is to be Brazilian (native or naturalized), so it is impossible for foreigners to vote. "I live here, thus I vote here" is one of the most relevant campaigns to demonstrate the importance of immigrants' political participation in a democratic state. The 18th century movement "no taxation without representation" comes in a new "drapery" in $21^{\text {st }}$ century Brazil, but keeps its essence - the same non- 
conformity. The immigrants live here, work here, respect the local laws - why, then, are they not allowed to vote? What are the derived implications of enabling permanent residents to vote? Once the immigrants become voters, many other possibilities that would not be possible are now available - donations to political parties, the creation of political parties, the bringing of class actions, popular initiative bills, participation in government programs. What would then be the most suitable position in relation to this subject? Enabling the immigrants to vote only in local elections or also the national elections? To what extent foreign political participation is no longer the realization of a fundamental right and becomes to represent a threat to national sovereignty?

Keywords: Citizenship. Immigrant. Political participation. Human rights.

\section{INTRODUÇÃo}

Muito se tem discutido acerca da condição dos imigrantes, não apenas nas Américas, como principalmente na Europa. Embora o continente europeu se denomine "velho", aparenta não ter conseguido lidar, por enquanto, com a questão da imigração, ao menos nos países com dominância de partidos conservadores.

Nesse sentido, observa-se que tanto a América do Sul quanto a do Norte já estão mais “maduras” em relação ao tratamento dedicado aos imigrantes, seja por fatores históricos ou humanitários.

O Estado Brasileiro, contudo, ainda se mostra como uma das únicas nações latino-americanas que ainda não facultou o alistamento eleitoral aos imigrantes que aqui vivem, razão pela qual estes não se veem representados politicamente.

O que aparenta ser apenas uma questão complementar a um Estado democrático de direito, em verdade, traduz-se num tópico que, implicitamente, é muito mais relevante do que se pensa — o voto consiste, talvez, na expressão máxima da participação política numa democracia. O imigrante, por sua vez, vê-se como um "nada político" em um Estado que o acolhe tão somente como indivíduo e contribuinte, mas não como cidadão.

Com o advento da Constituição Cidadã, consolidou-se que os direitos e garantias nela expressos não excluem outros decorrentes do regime e dos princípios por ela adotados, ou dos tratados internacionais em que o Brasil seja parte.

Desse modo, há que se ressaltar o fato de que o voto constitui direito humano, previsto em tratados internacionais dos quais o Brasil é signatário. Logo, não possibilitá-lo ao imigrante seria violar esse direito ou, ao menos, restringir a dignidade do estrangeiro aqui residente.

Por outro lado, possibilitar o voto, ou seja, o alistamento eleitoral, ao imigrante, seria provê-lo de direitos que interferem diretamente na condução das políticas públicas, atos administrativos, projetos de lei, criação de partidos, dentre outros.

Como, então, garantir ao estrangeiro representatividade política sem que essa participação não ameace a soberania? Essa ameaça realmente existe ou se trata de um discurso exacerbadamente nacionalista?

Com efeito, destaca-se que a pesquisa não se destina a responder esses questionamentos, mas desentranhá-los. Para tanto, o trabalho será baseado em obras doutrinárias e textos legislativos, bem como serão utilizados dados obtidos eletronicamente junto a organizações internacionais e órgãos governamentais. 


\section{O ESTRANGEIRO NAS CARTAS BRASILEIRAS}

Persiste, ainda, no Brasil tendência a considerar a nacionalidade e a cidadania como sinônimos, o que não se traduz numa verdade. Enquanto o primeiro possui forte ligação com o Estado, o segundo comporta qualidades do indivíduo.

Observa-se que o conceito de cidadania, no Brasil, geralmente se correlaciona com o exercício dos direitos políticos, não se abarcando, pela maioria dos doutrinadores, as categorias dos direitos civis e dos direitos sociais.

Porém, necessário questionar — será a cidadania assim tão restrita aos meros direitos políticos ou é capaz de abarcar outros direitos senão o de votar e ser votado? Indo mais além, uma vez que os inalistáveis não podem exercer seus direitos políticos, seriam eles privados da própria cidadania?

Os direitos políticos não estão isolados, mas fazem parte de um conjunto de direitos fundamentais, dentre os quais estão inseridos os direitos civis e os direitos sociais. Em outras palavras, os direitos individuais são pressupostos uns dos outros, numa interligação.

Desse modo, o direito de sufrágio não pode ser confundido com o conceito de cidadania porque aquele significaria tão somente a prerrogativa do voto, enquanto a cidadania em si seria muito mais ampla. O mesmo ocorre com os direitos políticos, que são mais abrangentes do que o direito de sufrágio (podendo-se dizer que o primeiro é um gênero do segundo), porém mais restritos do que a cidadania.

Conclui-se, por conseguinte, que a concepção de cidadania, em suma, do “[...] atributo político decorrente do direito de participar no governo e direito de ser ouvido pela representação política" ", não vem recebendo a devida relevância e destaque, porquanto não é tratada pela maioria dos doutrinadores na sua magnitude.

Não apenas a cidadania envolve os direitos políticos, sociais e civis, mas também engloba a todos, sendo eles pressupostos e, concomitantemente, consequências do fato de ser cidadão — “[...] é evidente que, nesse sentido amplo, todos têm direito à cidadania, independentemente de se estar ou não alistado como eleitor". ${ }^{2}$

Portanto, verifica-se que a cidadania, em sentido amplo, designa o conjunto de direitos e deveres individuais e a possibilidade de exercê-los, enquanto em sentido estrito consistiria na viabilidade de participar politicamente no Estado.

\subsection{Direito positivo interno}

Primeiramente, assevere-se ser a Constituição da República de 1988 de inspiração principalmente portuguesa e espanhola, a representação do "coroamento do processo de transição do regime autoritário em direção à democracia". ${ }^{3}$

Ademais, é indispensável observar uma das principais diferenças entre o Texto Maior vigente e os anteriores - naqueles, os primeiros dispositivos constitucionais tratavam da estrutura do Estado, sendo que somente ao final do texto se abordavam os direitos fundamentais do cidadão.

Em contrapartida, na Carta de 1988, privilegiaram-se os direitos fundamentais inicialmente e apenas ao final se dirigiu o foco à organização estatal.

Em outras palavras, anteriormente se tratava da relevância dos dispositivos constitucionais em ordem decrescente: do Estado, da sociedade e do indivíduo; sendo que nos dias atuais esta ordem foi invertida.

1 SILVA, José Afonso da. Curso de direito constitucional brasileiro. 33. ed. São Paulo: Malheiros, 2010. p. 346.

2 GOMES, José Jairo. Direito eleitoral. 7. ed. São Paulo: Atlas, 2011. p. 41.

3 SARMENTO, Daniel. Por um constitucionalismo inclusivo: história constitucional brasileira, teoria da constituição e direitos fundamentais. Rio de Janeiro: Lumen Juris, 2010. p. 102. 
Elevou-se, em nível de cláusula pétrea (artigo $60, \sqrt{\S} 4^{\circ}, \mathrm{CF}$ ), o sufrágio direto, secreto, universal e periódico, bem como se implantou, definitivamente, o plebiscito, o referendo e a iniciativa popular, institutos essenciais a uma democracia participativa.

Imprescindível, também, destacar a importância que foi reservada aos analfabetos, que, não obstante não dominarem a técnica da escrita, leitura e interpretação, são contribuintes e são capazes de acompanhar os acontecimentos políticos da nação e constituir opinião a partir de experiências vividas.

No que tange aos estrangeiros, observa-se especial tratamento a estes nos dispositivos atinentes à nacionalidade: estes podem se naturalizar basicamente por três formas, sendo que na primeira delas, mais genérica, exige-se período de residência ininterrupta de 15 (quinze) anos ${ }^{4}$ no Brasil, bem como a ausência de condenação penal. Aos portugueses, no entanto, requer-se, apenas, a residência por um ano ininterrupto e idoneidade moral.

A Constituição ainda menciona a naturalização na forma da lei, que, no caso, trata-se do Estatuto do Estrangeiro (Lei no 6.815/1980) - enquadram-se nessa lei todos aqueles indivíduos que não sejam portugueses ou que não desejem requerer a nacionalidade derivada com base no art. 12, inc. II, alínea b.

As condições para a concessão de naturalização estão previstas no art. 112 do Estatuto do Estrangeiro, quais sejam: capacidade civil, possuir visto permanente no Brasil, residência ininterrupta no Brasil por no mínimo 4 (quatro) anos antes do pedido de naturalização, profissão ou posse de bens que assegurem o sustento próprio e da família, bom procedimento, inexistência de denúncia, pronúncia ou condenação no Brasil ou no exterior por crime doloso cuja pena mínima seja a de prisão, abstratamente considerada, superior a 1 (um) ano, e boa saúde .

Ainda, o Estatuto possibilita a redução do período de residência exigido nos seguintes casos, definidos no art. 113:

I - ter filho ou cônjuge brasileiro;

II - ser filho de brasileiro;

III - haver prestado ou poder prestar serviços relevantes ao Brasil, a juízo do

Ministro da Justiça;

IV - recomendar-se por sua capacidade profissional, científica ou artística; ou

V - ser proprietário, no Brasil, de bem imóvel, cujo valor seja igual, pelo menos, a mil vezes o Maior Valor de Referência; ou ser industrial que disponha de fundos de igual valor; ou possuir cota ou ações integralizadas de montante, no mínimo, idêntico, em sociedade comercial ou civil, destinada, principal e permanentemente, à exploração de atividade industrial ou agrícola.

Parágrafo único. A residência será, no mínimo, de um ano, nos casos dos itens I a III; de dois anos, no do item IV; e de três anos, no do item V.

Usualmente, os grandes fluxos migratórios ocorrem em virtude da busca por emprego e melhor qualidade de vida. Muitas vezes os imigrantes chegam a se submeter ao trabalho análogo ao de escravo ${ }^{6}$.

4 Destaque-se que, antes da ECR n ${ }^{\circ}$ 3/94, o período mínimo de residência exigido era de trinta anos. BRASIL. Emenda constitucional de revisão n. 4, de 7 de junbo de 1994. Disponível em: < http://www.senado.gov.br/legislacao/const/con1988/CON1988_13.07.2010/ art_12_.shtm> Acesso em: 28 maio 2015.

5 A comprovação de boa saúde é dispensada a estrangeiros residentes no Brasil há mais de dois anos (cf. art. 112, \$2, Lei 6.815/80).

6 "No que tange ao número de horas semanais trabalhadas, os imigrantes, de um modo geral, estavam inseridos em ocupações que requisitavam uma dedicação elevada. Em 2000, 43,4\% dos imigrantes ocupados tinham jornadas semanais superior a 44 horas, limite máximo estabelecido em lei. Em 2010, essa situação ficou ainda pior, com 52,2\% dessa força de trabalho exposta a jornadas acima do limite legal. Interessante observar que esse incremento absoluto se deu na faixa entre 45 e 49 horas semanais. No extremo oposto, também aumentou de volume a jornada de 15 a 30 horas. Isso indica, por um lado, uma situação de exploração, dada à exposição a jornadas excessivas, e, por outro, o estado de precarização da mão de obra migrante. Em 2000, os trabalhadores imigrantes com jornadas inferiores a 30 horas representavam 39,7\% do total da força de trabalho migrante, passando a 32,7\%, em 2010“. CAVAL- 
Ademais, grande parte dos imigrantes, desde 2010, caracteriza-se como solteira ${ }^{7}$, razão pela qual se conclui ser dificultoso o enquadramento do estrangeiro nos incisos do art. 113.

Dentre as hipóteses de naturalização previstas no Estatuto do Estrangeiro, podem-se encontrar, ainda, duas possibilidades que são oriundas da Carta Constitucional de 1967, quais sejam: i. a do estrangeiro admitido no Brasil até a idade de 5 (cinco) anos, domiciliado definitivamente no território nacional, desde que requeira a naturalização até 2 (dois) anos após atingir a maioridade; e ii. estrangeiro que tenha vindo residir no Brasil antes de atingida a maioridade e haja feito curso superior em estabelecimento nacional de ensino, se requerida a naturalização até 1 (um) ano depois da formatura.

Nesses casos, exigem-se tão somente documento de identidade para estrangeiro, atestado policial de residência contínua no Brasil e atestado policial de antecedentes, passado pelo serviço competente do lugar de residência no Brasil (cf. art. 115, $\mathbb{\Omega} 2^{\circ}$ ).

Por derradeiro, destaque-se que a Carta Constitucional de 1988 manteve vigente a Justiça Eleitoral, instituída em 1932, bem como assegurou os direitos sine qua non a uma democracia política, quais sejam - o direito à liberdade de expressão, de associação política e de direito à informação.

\section{A RelevÂnCia da participação política do estrangeiro no estado democrático de DIREITO}

Muito se questiona acerca da insatisfação da população brasileira em relação ao corpo político-representativo, algo que vem se tornando um aspecto preocupante aos cidadãos brasileiros, que muitas vezes não se veem devidamente representados ${ }^{8}$.

É nesse panorama que se questiona a posição do imigrante — se o cidadão brasileiro, que tem voz ativa politicamente, encontra obstáculos em sua representatividade, o estrangeiro enfrenta problemas maiores, pois não detém a possibilidade de votar nem se vê representado, seja porque a maior parte da classe parlamentar não demonstra preocupação às questões dos imigrantes, seja pela explícita inviabilidade do voto destes, salvo por meio da naturalização.

Acredita-se que a participação política do estrangeiro no Brasil possa inclusive ampliar a conscientização, ainda carente, dos eleitores brasileiros — o imigrante tem uma visão de mundo, muitas vezes, mais ampla e tolerante do que o nacional, o qual fica restrito às questões internas.

Não obstante a Carta Maior de 1988 seja tida, por muitos, como avançada em relação ao Estado brasileiro, em uma espécie de anacronismo, é necessário que se busque esse cenário tão positivo que nela consta. Numa análise sistemática da Constituição brasileira atual, torna-se ininteligível o fato de que esta assegura diversos direitos e garantias, inclusive aos estrangeiros, mas não os provê da possibilidade de votar.

CANTI, Leonardo; OLIVEIRA, Antonio Tadeu; TONHATI, Tânia (Org.) A Inserção dos Imigrantes no Mercado de Trabalho Brasileiro. Cadernos OBMigra, Brasília, v. 1, n. 2, dossiê especial, 2015. p. 59.

7 "Quanto ao estado civil dos imigrantes de última etapa, a estrutura etária mais jovem faz com que sobressaiam as pessoas com status de casados e solteiros e, ao contrário do que observamos entre os imigrantes de estoque, a participação de viúvos e divorciados foi muito pequena. Os fluxos que chegaram na década de 2000 trouxeram um volume maior de solteiros, que foi o estado civil predominante." CAVALCANTI, Leonardo; OLIVEIRA, Antonio Tadeu; TONHATI, Tânia (Org.) A Inserção dos Imigrantes no Mercado de Trabalho Brasileiro. Cadernos OBMigra, Brasília, v. 1, n. 2, dossiê especial, 2015. p. 63.

8 Em pesquisa de 2009 realizada pelo IBOPE (PESQUISA DE OPINIÃO PÚBLICA SOBRE CONFIANÇA EM INSTITUIÇÕES), apenas $5 \%$ do total de entrevistados demonstraram ter "muita confiança" no Congresso Nacional, sendo que 31\% demonstraram "alguma confiança", 26\% "quase nenhuma confiança" e 35\% afirmaram ter "nenhuma confiança". IBOPE. Pesquisa de opinião pública sobre confiança em instituições. Jul. 2009. Disponível em: <http://www.ibope.com.br/pt-br/conhecimento/relatoriospesquisas/Lists/RelatoriosPesquisaEleitoral/OPP $\% 20090979 \% 20-020$ Confian $\%$ C 3 $\%$ A $7 \mathrm{a} \% 20 \mathrm{em} \% 20$ institui $\%$ C 3 $\%$ A7 $\%$ C $3 \%$ B5es. pdf>. Acesso em: 29 maio 2015. 
Não se pode admitir que no seio de tantas lutas reivindicatórias dos direitos das minorias não se inclua a minoria (qualitativa) de imigrantes, que aqui vive, aqui contribui fiscalmente, e aqui não vota. Se os habitantes de uma nação não fazem jus aos direitos positivados e não lutam por uma causa comum, perde-se o encanto com as instituições democráticas, gera-se indiferença diante dos governantes, dos partidos políticos e do próprio País.

\subsection{O voto como direito humano fundamental e expressão do povo}

Não obstante a análise já realizada acerca da história do instituto da cidadania em si, bem como retrospectiva das Cartas Constitucionais brasileiras, relevante se faz destacar o papel do povo na democracia e a urgência em se preservar o voto como um direito humano.

A Declaração Universal de Direitos Humanos contemplou, em seu artigo 21, a democracia como direito humano. Ademais, sabe-se que, de acordo com a Carta Constitucional de 1988, "[...] todo poder emana do povo, que o exerce por meio de representantes eleitos ou diretamente”, conforme artigo $1^{\circ}$, parágrafo único.

Desse modo, o cidadão há de ser visto numa concepção flexível, disposta a se moldar perante as vicissitudes de um mundo pós-moderno. É passada a época em que o cidadão se enquadrava em um rol taxativo de quesitos; trata-se hoje de um rol exemplificativo, aberto a mudanças, à efetivação dos direitos humanos.

O filósofo ARISTÓTELES, embora habitasse uma Grécia marcada pela exclusão de mulheres e escravos, já definia o cidadão em uma concepção ampla:

Como definiremos um cidadão? Ele é mais do que apenas um habitante; direitos privados não são suficientes para definir um cidadão. Ordinariamente, trata-se de alguém que possui poder político; alguém que se senta nos júris e nas assembleia. Mas é difícil encontrar uma definição que se aplique a todos os chamados cidadãos. Defini-los apenas como filhos de cidadãos é um procedimento frívolo. ${ }^{9}$

Muito embora a Constituição Cidadã seja a mais avançada entre todas as Cartas Constitucionais brasileiras, no que diz respeito à proteção da dignidade da pessoa humana, e traga em seu bojo o conceito mais abrangente de cidadania por enquanto, ainda não se vê uma abertura à figura do estrangeiro, visto como “estranho" à participação política.

Exigir que o estrangeiro resida em território brasileiro por quinze anos ininterruptos para somente então ter a possibilidade de se naturalizar, ao menos na hipótese constitucional, e se alistar eleitoralmente, demonstra caráter um tanto nacionalista dos constituintes de 1987.

Uma vez que é responsabilidade do Estado consolidar a cidadania por meio de estratégias que possam implementar " [...] a indivisibilidade e a universalidade dos direitos humanos e o processo de especificação do sujeito de direito"10, cabe igualmente ao Estado adotar medidas que garantam maior (senão mínima) representatividade aos imigrantes aqui residentes.

O Pacto Internacional sobre Direitos Civis e Políticos, do qual o Brasil é signatário, assegura, em seu artigo $2^{\circ}$, que os Estados Partes se comprometem a respeitar e garantir a qualquer indivíduo que se encontre em seu território e que esteja sujeito a sua jurisdição “[...] os direitos reconhecidos no presente Pacto, sem discriminação alguma por motivo de raça, cor, sexo, língua, religião, opinião política ou de outra natureza, origem nacional ou social, situação econômica, nascimento ou qualquer condição" 11 .

9 ARISTÓTELES. Politica. Tradução de Politikón por Pedro Constantin Tolens. São Paulo: M. Claret, 2007. p. 39.

10 PIOVESAN, Flávia. Temas de direitos humanos. 7. ed. São Paulo: Saraiva, 2014. p. 503.

11 BRASIL. Presidência da Republica. Decreto n. 592, de 6 de julho de 1992. Disponível em: < http://www.planalto.gov.br/ccivil_03/ decreto/1990-1994/D0592.htm>. Acesso em: 24 maio 2015. 


\subsection{Participação política para uma democracia participativa}

Quanto maior a proximidade entre o Estado e o cidadão, mais desenvolvido será o regime democrático - em um Estado de direito, o instituto do voto recebe alta relevância, uma vez que se traduz numa das formas mais eficientes de se tomar parte ativamente da esfera política da nação.

Desde Jean-Jacques Rousseau, teoristas republicanos e democratas têm declarado que um sistema adequado de governo deve oportunizar condições de participação política a todos os cidadãos — na visão do autor britânico Anthony BIRCH, o direito de votar em eleições periódicas é a condição mínima que um sistema de governo deve satisfazer, a fim de se qualificar como democrático, sendo que demais cientistas políticos manifestam-se no sentido de que a disponibilização de outras formas de participação política também se fazem necessárias ${ }^{12}$.

O conceito de participação política é muito menos complexo do que o conceito de representação: a participação é uma atividade, e envolve uma ampla camada de civis que participam de um processo no qual líderes políticos são eleitos e políticas governamentais são implementadas ${ }^{13}$.

Não obstante a participação seja um conceito atinente ao comportamento, trata-se de uma concepção de fortes conotações normativas. A minoria dos indivíduos acredita que a participação política tenha implicação negativa emuitos a consagram como um dos fatores de sucesso dos sistemas democráticos ocidentais e, estando satisfeitos com estes sistemas, encontram-se igualmente satisfeitos com o nível e os atributos da participação pública nestes ${ }^{14}$.

Se os cidadãos têm a oportunidade de participar do processo de escolha de seus representantes, de emitir opiniões em assuntos de interesse público e de fiscalizar a atuação dos legisladores, eles estarão mais aptos a aceitar as decisões estatais como legítimas ${ }^{15}$.

Por conseguinte, cumpre esclarecer que a democracia participativa se traduziu num avanço instituído pela atual Constituição Brasileira, quando comparada à Lex Legum imediatamente anterior — adotou-se esse modelo em detrimento de uma democracia indireta ou representativa ${ }^{16}$.

Por derradeiro, não caberia a aplicação de uma forma de governo democrático puramente direto no Estado brasileiro, devido às suas dimensões continentais, tampouco uma espécie plenamente indireta, uma vez que impossibilitaria a atuação dos particulares enquanto cidadãos.

\subsection{Brasil e demais estados - os direitos políticos do estrangeiro}

Há que se distinguir, a princípio, a figura do estrangeiro residente e a do não residente. De acordo com TAVARES ${ }^{17}$, o residente seria o indivíduo que é radicado no país, exercendo neste suas atividades e integrando sua população; por sua vez, o não residente encontrar-se-ia no território nacional apenas por questões turísticas ou temporariamente a negócios.

Não obstante o estrangeiro esteja no Brasil provisória ou definitivamente, devem-lhes ser exigidas certas obrigações e reconhecidos determinados direitos ${ }^{18}$, sendo o grau de proteção em relação a estes dependente da natureza do ingresso ${ }^{19}$.

12 BIRCH, Anthony Harold. The concepts and theories of modern democracy. London: Routledge, 1993. p. 80.

13 BIRCH, Anthony Harold. The concepts and theories of modern democracy. London: Routledge, 1993.

14 BIRCH, Anthony Harold. The concepts and theories of modern democracy. London: Routledge, 1993. p. 81.

15 BIRCH, Anthony Harold. The concepts and theories of modern democracy. London: Routledge, 1993.

16 SLAIBI FILHO, Nagib. Anotações à constituição de 1988: aspectos fundamentais. 2. ed. Rio de Janeiro: Forense, 1989. p. 139.

17 TAVARES, André Ramos. Curso de direito constitucional. 11. ed. São Paulo: Saraiva, 2013. p. 659.

18 TAVARES, André Ramos. Curso de direito constitucional. 11. ed. São Paulo: Saraiva, 2013. p. 659.

19 MAZZUOLI, Valerio de Oliveira. Curso de direito internacional público. 4. ed. São Paulo: Revista dos Tribunais, 2010. p. 661. 
Desde a sessão de Genebra de 1892 do Institut de Droit International, convencionou-se que o ato de admitir e expulsar estrangeiros é discricionário a cada país, em virtude de sua soberania.

No entanto, conforme explana MAZZUOLI, não se conhece Estado “[...] que se utilize dessa prerrogativa teórica para fechar definitivamente suas portas aos estrangeiros, notadamente na época contemporânea" 20 - o Estado brasileiro admite, em tempos de paz, a entrada e permanência do estrangeiro, quando satisfeitas as condições da Lei n ${ }^{\circ}$ 6.815/80.

Ademais, o estrangeiro ingressa no território nacional, em regra, por meio da apresentação do passaporte, documento policial emitido pelo país de origem, o qual servirá como identificação pessoal principal, nele constando o tipo de visto concedido.

$\mathrm{O}$ art. $4^{\circ}$ do Estatuto do Estrangeiro denomina as espécies de visto que poderão ser concedidas (de trânsito, de turista, temporário, permanente, de cortesia, oficial e diplomático) e o ato de entrada, estada ou registro do estrangeiro poderá ser obstado sempre que sua presença no País for tida como inconveniente (art. 26) ou em se configurando qualquer as hipóteses do art. $7^{\text {o21 }}$.

Frise-se que, dentre as espécies de visto concessíveis aos estrangeiros, a que se destaca, para auxiliar o estudo do presente objeto, é o visto permanente - o Estatuto do Estrangeiro, em seu art. 16, disciplina que o visto permanente poderá ser concedido ao estrangeiro que pretenda se fixar definitivamente no Brasil e que preencha os requisitos previstos no art. $5^{022}$.

Complementarmente, a Lei no 6.815/80 dispõe que o estrangeiro ainda deverá satisfazer as exigências de caráter especial previstas nas normas de seleção de imigrantes estabelecidas pelo Conselho Nacional de Imigração, sendo que seu visto poderá ficar condicionado ao exercício de atividade certa e à fixação em região determinada do território nacional, por período não superior a 5 (cinco) anos.

Com efeito, o Conselho Nacional de Imigração, órgão vinculado ao Ministério do Trabalho e Emprego, publicou diversas Resoluções Normativas acerca da concessão do visto permanente ao estrangeiro, dentre as quais serão analisadas as que melhor atinem ao presente objeto de estudo.

Recentemente, a RN-CNIg nº 108/2014 dispôs que o Ministério das Relações Exteriores poderá conceder visto temporário ou permanente, a título de reunião familiar, aos dependentes de cidadão brasileiro ou de estrangeiro temporário ou permanente no Brasil, bem como revogou as antigas RNs sob n 36/1999 e $n^{\circ} 77 / 2008$, as quais disciplinavam sobre o mesmo tema.

Já no ano de 2012 o Brasil tornou-se exemplo de assistência humanitária ao conceder vistos permanentes a nacionais do Haiti, em virtude da ocorrência do terremoto que assolou o país em 12 de janeiro de 2010. Com a vigência da $\mathrm{RN}$ n 97/2012, os haitianos passaram a ter a possibilidade de obter a Cédula de Identidade do Estrangeiro pelo prazo de 5 (cinco) anos, prorrogável sob a comprovação de sua situação laboral no Brasil. Frise-se que esta RN teve seu período de vigência prorrogado até 30 de outubro de 2015 pela RN $n^{\circ} 113 / 2014$.

Além da Resolução mencionada, a qual já se mostrava como exemplo humanitário, o CNIg havia promulgado a $\mathrm{RN} n^{\circ} 93 / 2010$, a qual abriu a possibilidade de concessão de visto permanente às vítimas de tráfico de pessoas, bem como a seus familiares e dependentes, pelo prazo de 1 (um) ano. Durante esse interstício, a vítima poderá decidir se voluntariamente colaborará com eventual investigação ou processo criminal em curso - atuação semelhante possuem os Estados Unidos, porém com critérios mais restritos ${ }^{23}$.

20 MAZZUOLI, Valerio de Oliveira. Curso de direito internacional público. 4. ed. São Paulo: Revista dos Tribunais, 2010. p. 661.

21 "Art. $7^{\circ}$ Não se concederá visto ao estrangeiro: I - menor de 18 (dezoito) anos, desacompanhado do responsável legal ou sem a sua autorização expressa; II - considerado nocivo à ordem pública ou aos interesses nacionais; III - anteriormente expulso do País, salvo se a expulsão tiver sido revogada; IV - condenado ou processado em outro país por crime doloso, passível de extradição segundo a lei brasileira; ou V - que não satisfaça às condições de saúde estabelecidas pelo Ministério da Saúde.”

22 "Art. $5^{\circ}$ Serão fixados em regulamento os requisitos para a obtenção dos vistos de entrada previstos nesta Lei."

23 US CITIZENSHIP AND IMMIGRATION SERVICES. Green card for a victim of trafficking (T Nonimmigrant), 2015. Available at: 
Em outras oportunidades anteriores, o CNIg havia regulamentado a concessão de vistos permanentes às demais categorias de indivíduos, tais como: investidores estrangeiros ( $\mathrm{RN} \mathrm{n}^{\circ}$ 84/2009), estrangeiros designados para administrar entidades sem fins lucrativos ( $\left.\mathrm{RN} \mathrm{n}^{\circ} 70 / 2006\right)$ e administradores, gerentes, diretores e executivos, com poderes de gestão, de sociedade civil ou comercial, grupo ou conglomerado econômico ( $\mathrm{RN} \mathrm{n}^{\circ}$ 62/2004).

Necessário sublinhar, após essas considerações, que o visto de entrada no Estado Brasileiro poderá ser dispensado em caso de tratado bilateral ou por reciprocidade, como ocorre para a maioria dos países latino-americanos e da Europa Ocidental2 ${ }^{24}$. Porém, o ingresso do estrangeiro sem o visto não faz presumir que este será permanente, sendo sempre temporário.

Ademais, embora o Brasil tenha aprovado a Convenção de Direito Internacional Privado de 1928, a qual assegura que os estrangeiros pertencentes aos Estados Partes terão os mesmos direitos civis assegurados aos nacionais no país em que se encontram ${ }^{25}$, o mesmo documento possibilita que cada nação restrinja o âmbito de aplicabilidade desses direitos.

No tocante aos direitos políticos, não obstante haja, por uma parte da doutrina, o entendimento de que o estrangeiro não os detêm no território brasileiro ${ }^{26}$, há quem defenda seu exercício - DIMOULIS apresenta duas possibilidades: i. os portugueses residentes podem exercer todos os direitos reconhecidos aos brasileiros, mesmo sem a naturalização, desde que haja reciprocidade; e ii. a atuação de estrangeiros em partidos políticos ${ }^{27}$.

Embora o caput do art. 17 da atual Carta Constitucional não exija que o indivíduo seja nacional para exercer a atividade partidária, a Lei no 9.096/1995 dispõe, no art. 16, que somente eleitores no pleno gozo dos direitos políticos possam se filiar a partidos, previsão que, segundo DIMOULIS,

decorre de uma criticável concepção dos partidos políticos enquanto quase órgãos estatais que funcionam sob o estrito controle da Justiça eleitoral como mecanismos para a eleição e não como espaços de debate democrático sobre ideias e projetos, independentemente da elegibilidade de cada um de seus membros. Seria necessário que o legislador harmonizasse essa previsão com a ampla determinação da titularidade desse direito político no texto constitucional, permitindo, ao mesmo tempo, ampliar a participação democrática. ${ }^{28}$

Entende-se que a cidadania é um conceito muito mais amplo do que o mero direito de votar e ser votado, envolvendo diversos deveres e direitos do indivíduo perante o Estado a que está vinculado.

No entanto, o exercício da cidadania pelos estrangeiros pode ser tida, por vezes, como certa ameaça à soberania nacional. MAZZUOLI desenvolve o tópico quando aborda a questão de acesso a cargos, empregos ou funções públicas (art. 37, inc. I, CF) - para ele, os estrangeiros residentes e os não residentes devem ter o mesmo tratamento, devendo ser admissível que qualquer um deles tenha acesso à Administração Pública, na forma da lei. Porém, logo em seguida, o autor se manifesta no sentido de que tal possibilidade demonstraria “[...] certo prejuízo à salvaguarda dos interesses nacionais":

[...] parece difícil aceitar a ideia de que alguém que não compõe o espírito nacional, por não estar integrado à nossa sociedade e aos nossos costumes, participe da administração pública praticando atos jurídicos tipicamente administrativos. ${ }^{29}$

\footnotetext{
< http://www.uscis.gov/green-card/other-ways-get-green-card/green-card-victim-trafficking-t-nonimmigrant>. Access on: 02 June 2015. 24 MAZZUOLI, Valerio de Oliveira. Curso de direito internacional público. 4. ed. São Paulo: Revista dos Tribunais, 2010. p. 663.

25 "Art. $1^{\circ}$ Os estrangeiros que pertençam a qualquer dos Estados contratantes gozam, no território dos demais, dos mesmos direitos civis que se concedam aos nacionais. Cada Estado contratante pode, por motivo de ordem pública, recusar ou sujeitar a condições especiais o exercício de determinados direitos civis aos nacionais dos outros, e qualquer desses Estados pode, em casos idênticos, recusar ou sujeitar a condições especiais o mesmo exercício aos nacionais do primeiro.”

26 MAZZUOLI, Valerio de Oliveira. Curso de direito internacional público. 4. ed. São Paulo: Revista dos Tribunais, 2010. p. 665; TAVARES, André Ramos. Curso de direito constitucional. 11. ed. São Paulo: Saraiva, 2013. p. 673.

27 DIMOULIS, Dimitri; MARTINS, Leonardo. Teoria geral dos direitos fundamentais. 5. ed. São Paulo: Atlas, 2014. p. 83.

28 DIMOULIS, Dimitri; MARTINS, Leonardo. Teoria geral dos direitos fundamentais. 5. ed. São Paulo: Atlas, 2014. p. 83.

29 MAZZUOLI, Valerio de Oliveira. Curso de direito internacional público. 4. ed. São Paulo: Revista dos Tribunais, 2010. p. 665; TA-
} 
Os imigrantes e, principalmente, os estrangeiros residentes participam diuturnamente no Estado em que habitam como qualquer outro nacional — não apenas financeiramente, consumindo produtos, contribuindo para o crescimento econômico, pagando tributos, como também socialmente.

Cartas Constitucionais como a Venezuelana autorizam o voto aos estrangeiros com mais de dezoito anos e período mínimo de residência de dez anos no país ${ }^{30}$, disposição semelhante à Constituição do Uruguai, que possibilita o voto aos estrangeiros de boa conduta, com mais de quinze anos de residência no país, e que neste possuam capital ou propriedade, ou ainda alguma profissão $0^{31}$.

Em geral, observa-se que países latino-americanos não possibilitam o voto aos estrangeiros, como apresenta a Tabela 1:

\section{Tabela 1}

\begin{tabular}{|l|l|}
\hline PAÍS & POSSIBILIDADE DE VOTO AO ESTRANGEIRO \\
\hline Argentina & $\begin{array}{l}\text { Sim, nas eleições locais, dependendo da província. Na província de Bue- } \\
\text { nos Aires, os residentes há, pelo menos, dois anos têm a obrigação de } \\
\text { votar nas eleições primárias e gerais. Na de Córdoba, os residentes há, } \\
\text { pelo menos, cinco anos, e com idade superior a dezoito, têm o dever de } \\
\text { votar nas eleições provinciais. }\end{array}$ \\
\hline Bolívia & $\begin{array}{l}\text { Sim, estrangeiros residentes há, pelo menos, dois anos têm o direito de } \\
\text { votar nas eleições municipais. }\end{array}$ \\
\hline Brasil & Não, apenas aos brasileiros natos e naturalizados. \\
\hline Chile & $\begin{array}{l}\text { Sim, estrangeiros residentes há, pelo menos, cinco anos, sem con- } \\
\text { denação penal e maiores de dezoito anos, têm o direito de votar nas } \\
\text { eleições municipais. }\end{array}$ \\
\hline Colômbia & $\begin{array}{l}\text { Sim, estrangeiros residentes há, pelo menos, cinco anos e maiores de } \\
\text { dezoito podem votar nas eleições distritais e municipais. }\end{array}$ \\
\hline Costa Rica & Não, apenas aos costarriquenhos natos e naturalizados. \\
\hline Cuba & Não, apenas aos cubanos natos e naturalizados. \\
\hline Equador & $\begin{array}{l}\text { Sim, estrangeiros residentes há, pelo menos, cinco anos e maiores de } \\
\text { dezesseis podem votar nas eleições seccionais. }\end{array}$ \\
\hline El Salvador & Não, apenas salvadorenhos natos e naturalizados ${ }^{1}$. \\
\hline Guatemala & Não, apenas guatemaltecos natos e naturalizados. \\
\hline Haiti & $\begin{array}{l}\text { Não, apenas haitianos natos e naturalizados (estes devem aguardar cin- } \\
\text { co anos após a naturalização). }\end{array}$ \\
\hline Honduras & Não, apenas hondurenhos natos e naturalizados². \\
\hline México & Não, apenas mexicanos natos e naturalizados. \\
\hline Nicarágua & Não, apenas nicaraguenses natos e naturalizados. \\
\hline Panamá & Não, apenas panamenhos natos e naturalizados. \\
\hline
\end{tabular}

VARES, André Ramos. Curso de direito constitucional. 11. ed. São Paulo: Saraiva, 2013. p. 665.

30 Constitución de la República Bolivariana de Venezuela. "Art. 64 [...] El voto para las elecciones parroquiales, municipales y estadales se hará extensivo a los extranjeros o extranjeras que hayan cumplido dieciocho años de edad, con más de diez años de residencia en el país, con las limitaciones establecidas en esta Constitución y en la ley, y que no estén sujetos a interdicción civil o inhabilitación política." VENEZUELA. Constitución (1999). Constitución de la República Bolivariana de Venezuela. Disponible en: <http://www.cne.gob.ve/web/normativa_electoral/constitucion/indice.php>. Accedido en: 05 jun. 2015.

31 "Artículo 78.- Tienen derecho al sufragio, sin necesidad de obtener previamente ciudadanía legal, los hombres y las mujeres extranjeros, de buena conducta, con familia constituida en la República, que poseyendo algún capital en giro o propiedad en el país, o profesando alguna ciencia, arte o industria, tengan residencia habitual de quince años, por lo menos, en la República." URUGUAY. Constitución (1967). Constitución de La República. Disponible en: <http://www.oas.org/juridico/mla/sp/ury/sp_ury-int-textconst.html>. Accedido en: 05 jun. 2015. 


\begin{tabular}{|c|c|}
\hline Paraguai & $\begin{array}{l}\text { Sim, estrangeiros residentes e maiores de dezoito anos podem votar nas } \\
\text { eleições municipais }{ }^{3} \text {. }\end{array}$ \\
\hline Peru & Não, apenas peruanos natos e naturalizados. \\
\hline $\begin{array}{l}\text { República Cooperativa da Guia- } \\
\text { na }\end{array}$ & $\begin{array}{l}\text { Sim, cidadãos sob o regime da Commonwealth, maiores de dezoito } \\
\text { anos, domiciliados e residentes na Guiana podem votar. }\end{array}$ \\
\hline República Dominicana & Não, apenas dominicanos natos e naturalizados. \\
\hline Uruguai & $\begin{array}{l}\text { Sim, estrangeiros de boa conduta, com, pelo menos, quinze anos de } \\
\text { residência no país. }\end{array}$ \\
\hline Venezuela & $\begin{array}{l}\text { Sim, estrangeiros com mais de dezoito anos, com pelo menos dez anos } \\
\text { de residência no país, podem votar em eleições locais, municipais e esta- } \\
\text { duais. }\end{array}$ \\
\hline \multicolumn{2}{|c|}{$\begin{array}{l}1 \text { "Art. } 97 \text { [...] Los extranjeros que directa o indirectamente participen en la política interna del país pierden el derecho a residir } \\
\text { en él." EL SALVADOR. Constitución (1983). Constitución de la Republica de El Salvador. Disponible en: }<\text { http://www.constitution. } \\
\text { org/cons/elsalvad.htm>. Accedido en: } 11 \text { jun. 2015. } \\
2 \text { "Artículo 32. Los extranjeros no podrán desarrollar en el país actividades políticas de carácter nacional ni internacional, bajo } \\
\text { pena de ser sancionados de conformidad con la Ley." - Constitución Política de 1982. HONDURAS. Constitución (1982). Con- } \\
\text { stitución política. Disponible en: }<\text { http://www.poderjudicial.gob.hn/CEDIJ/Leyes/Documents/Constituci\%CC3\%B3n\%20de\%20 } \\
\text { la\%20Rep\%C3\%Bablica\%20de\%20Honduras\%20\%28Actualizada\%202014\%29.pdf> Accedido en: } 15 \text { jun. } 2015 \text {. } \\
3 \text { "Art. 120. Los extranjeros con radicación definitiva tendrán los mismos derechos en las elecciones municipales." PARAGUAY. } \\
\text { Constitución (1992). Constitución Nacional del Paraguay. Disponible en: < http://www.oas.org/juridico/spanish/par_res3.htm>. } \\
\text { Accedido en: } 15 \text { jun. 2015. }\end{array}$} \\
\hline
\end{tabular}

Fonte: Constituições e Leis Eleitorais dos Estados citados. Vide Referências.

Embora 12 (doze) dos 21 (vinte e um) países integrantes da América Latina não facultem o voto ao estrangeiro residente, entende-se que o Brasil, principalmente devido a fatores históricos, poderia constar da minoria desses Estados.

O Brasil, vale lembrar, é uma nação que tanto as elites quanto o povo vieram de fora. As elites, do sul da Europa, e o povo, predominantemente da África. Os índios, antigos habitantes da terra, quase desaparecerem, ainda que estejam presentes na herança genética. ${ }^{32}$

Teorias de branqueamento ganharam espaço na elite brasileira dos séculos XIX e XX, em virtude de um ideal implícito que pregava a inferioridade dos mestiços em relação a uma suposta raça pura, mas que explicitamente se travestia como uma necessidade imediata de imigração para mão de obra para substituir os escravos.

Ainda hoje não é raro se deparar com indivíduos que afirmam ser a imigração para o Brasil um fenômeno em descontrole e que ocasionará desemprego entre os nacionais, devido ao baixo salário a que os estrangeiros se submetem.

Em verdade, observa-se que o Estado brasileiro não possui uma política migratória bem desenvolvida no que concerne ao manejo de entrada de estrangeiros que aqui desejem se instalar — porém, deve-se ter cuidado especial para não se admitir uma "imigração seletiva"33.

O Estado brasileiro parece dedicar maior relevância aos fluxos emigratórios do que aos imigratórios, ainda numa concepção do início dos anos 2000, quando houve um êxodo populacional do Brasil para outros países como Japão e Estados Unidos. O aumento no número de representações diplomáticas no exterior é apenas um dos aspectos que caracterizam esse fato ${ }^{34}$.

32 OLIVEIRA, Lucia Maria Lippi. Nós e eles: relações culturais entre brasileiros e imigrantes. Rio de Janeiro: FGV, 2005. p. 8.

33 OTAVIO, Chico; GUILAYN, Priscila. Brasil quer facilitar vistos para profissionais estrangeiros. O Globo, Rio de Janeiro; Madri, 15 jan. 2012. Disponível em: <http://oglobo.globo.com/brasil/brasil-quer-facilitar-vistos-para-profissionais-estrangeiros-3671799>. Acesso em: 15 jun. 2015.

34 SICILIANO, André Luiz. A política migratória brasileira: limites e desafios. 2013. 59f. Dissertação (Mestrado em Relações Internacionais) - Instituto de Relações Internacionais, Universidade de São Paulo, São Paulo: 2013. p. 30. Disponível em: <http://www. 
O imigrante sofre não somente em virtude da falta de representação política quando chega a um novo país para ali se instalar - em muitos casos são pessoas desprovidas de recursos financeiros, com baixa escolaridade, que desconhecem a língua do Estado ao qual emigram.

Dito em outras palavras, "o olhar reprovador da comunidade, a obrigação de ser correto demais para dar a impressão de que não são diferentes e opacos" ${ }^{35}$, e a obsessão por uma espécie de "transparência" são alguns dos traços que marcam os imigrantes.

É de se considerar que, ao menos os estrangeiros residentes há quatro anos no Brasil (como sugere a PEC 347), pudessem ter a dignidade de escolher seus representantes, pelo menos os locais.

\section{IMPLICAÇÕES DO EXERCÍCIO DO VOTO PELO ESTRANGEIRO - DIREITO FUNDAMENTAL OU AMEAÇA?}

Ainda há quem considere o estrangeiro uma ameaça à segurança nacional - assim como no longa-metragem Dogville, de Lars von Trier, o imigrante seria um estranho, com costumes exóticos, língua diferente e intenções não muito claras.

No entanto, é necessário um mínimo de empatia para que se visualize a situação do imigrante: ninguém migra por diversão. O estrangeiro que luta por melhores condições de trabalho, pelo sustento próprio e da família, instala-se em um país, ali observa às leis e contribui para seu crescimento econômico merece um mínimo de representação política, mormente em um Estado democrático.

Se analisada detidamente a Assembleia Constituinte de 1987, chegar-se-á à conclusão de que a discussão acerca da participação política do estrangeiro no Brasil foi contida, reprimida.

Logo na Subcomissão da Nacionalidade, da Soberania e das Relações Internacionais, o Sr. Ministro Francisco José Rezek realiza o primeiro comentário relevante, ao menos no tocante ao presente objeto, quando menciona que "na realidade, as distinções que se fazem em favor do estrangeiro gravitam quase todas elas em torno dos direitos políticos"36, ao discutir acerca da nacionalidade de pessoas físicas e jurídicas.

$\mathrm{Na}$ visão do Ministro, o estrangeiro residente que decidisse não se naturalizar em quatro anos, período anteriormente exigido para a nacionalidade derivada, deveria gozar tão somente de direitos civis, mas não de políticos.

Mas é ainda na Comissão da Soberania e dos Direitos e Garantias do Homem e da Mulher que o Sr. Constituinte Costa Ferreira faz uma relevante intervenção:

$[\ldots]$ estrangeiro não tem que criar partido aqui, no Brasil. Acho que cada um deve criar seu partido em sua própria pátria. [...] Precisamos ser autênticos. Seremos amigos de todos, mas não seremos submissos, nem tampouco subservientes. ${ }^{37}$

No mesmo posicionamento nacionalista do Constituinte Costa Ferreira, colocou-se o Sr. Constituinte João Menezes, ao defender que a ideia de estrangeiros poderem ser eleitos no Brasil seria um "absurdo" 38 . Na visão dele, admitir que um indivíduo não naturalizado tivesse direito político passivo seria violar a soberania nacional.

iri.usp.br/documentos/defesa_12-04-19_Andre_Luiz_Siciliano.pdf>. Acesso em: 15 jun. 2015.

35 OLIVEIRA, Lucia Maria Lippi. Nós e eles: relações culturais entre brasileiros e imigrantes. Rio de Janeiro: FGV, 2005. p. 10.

36 BRASIL. Assembleia Nacional Constituinte (Atas de Comissões). Subcomissão da Nacionalidade, da Soberania e das Relações Internacionais. p. 53. Disponível em:<http://www.senado.gov.br/publicacoes/anais/constituinte/sistema.pdf>. Acesso em: 18 jun. 2015. 37 BRASIL. Assembleia Nacional Constituinte (Atas de Comissões). Comissão da Soberania e dos Direitos e Garantias do Homem e da Mulher. p. 65. Disponível em:<http://www.senado.gov.br/publicacoes/anais/constituinte/sistema.pdf>. Acesso em: 18 jun. 2015. 38 BRASIL. Assembleia Nacional Constituinte (Atas de Comissões). Comissão da Soberania e dos Direitos e Garantias do Homem e da Mulher. p. 65. Disponível em:<http://www.senado.gov.br/publicacoes/anais/constituinte/sistema.pdf>. Acesso em: 18 jun. 2015. p. 66. 
Da mesma forma, o Constituinte Luiz Viana Neto considerou a participação política do estrangeiro no Brasil algo "excessivamente liberal", argumentando que o exercício dos direitos públicos políticos deveria ser privativo aos brasileiros.

Pode-se interpretar o caráter um tanto nacionalista da Constituição Cidadã por um viés histórico, segundo o qual o País precisava explicitar sua transição mara um regime democrático e sem intervenções estrangeiras, na tentativa de impedir alinhamentos.

Por outro lado, verifica-se um descompasso entre o cenário mundial de grandes fluxos migratórios com uma Carta Constitucional que priorize politicamente os nacionais, sem sequer fazer menção aos estrangeiros residentes.

Para se considerar o mínimo, é inegável que os estrangeiros residentes em território brasileiro devam contribuir fiscalmente ${ }^{39}$, o que já acarretaria uma discussão semelhante à do movimento no taxation without representation.

A primeira utilização do termo "tributação sem representação é uma tirania" é atribuída ao político e advogado James Otis (1725-1783), de Massachussets. Embora não haja provas materiais disso, Otis posteriormente evidenciou seu posicionamento em relação à tributação sem representação em seu panfleto The Rights of the British Colonies Asserted and Proved (1764), em que ele defendia representação americana no Parlamento Inglês ${ }^{40}$.

Independentemente da origem da expressão em apreço, esta foi utilizada em anos anteriores à Revolução Americana, bem como nos posteriores - as mulheres que reivindicavam o direito ao sufrágio se utilizaram deste slogan, bem como manifestantes contra a falta de representação no Distrito de Columbia, dentre ou$\operatorname{tros}^{41}$.

Contudo, entende-se que, apesar da magnitude desse argumento, ele não deva ser a pedra de toque no que se refere à participação política do estrangeiro residente no Brasil. Várias são as defesas que se pode tomar em prol dessa representatividade: a necessidade de o ser humano participar dos assuntos públicos do Estado em que habita, sua contribuição para o crescimento e desenvolvimento econômico do país, o efetivo exercício da cidadania plena, com a concretização de um direito fundamental indispensável, a possibilidade de se apresentar projetos de lei, de questionar atos administrativos abusivos, de participar ativamente em Conselhos Municipais, para se dizer o mínimo.

É necessário um cuidado especial para que não haja a "demonização do estrangeiro" ${ }^{42}$ no Brasil nos moldes em que se deu na União Europeia, em que a migração tornou-se bode expiatório para justificar a crise econômica e corroborar a vitória de partidos conservadores.

A política contemporânea não se pode mais definir tão somente a partir da soberania estatal, de modo que esta não é mais absoluta — a política deve ser "[...] reavaliada enquanto "política internacional”, pois seus preceitos se sustentam sobre a compreensão dialética de tecnologia/natureza, desenvolvido/em desenvolvimento, centro/periferia" ${ }^{43}$.

39 Lei n ${ }^{\circ}$ 9.718, de 27 de novembro de 1998, art. 12; Medida Provisória no 621, de 8 de julho de 2013, convertida na Lei nº 12.871 , de 22 de outubro de 2013, Instrução Normativa SRF n ${ }^{\circ}$ 208, de 27 de setembro de 2002, art. 2º com as alterações dadas pela Instrução Normativa RFB no 1.008, de 9 de fevereiro de 2010, e Instrução Normativa RFB no 1.383, de 7 de agosto de 2013.

40 MANNING, Martin J; WYATT, Clarence R. Encyclopedia of media and propaganda in Wartime America. Santa Barbara; Denver; Oxford: ABC-CLIO, 2010. v. 1. p. 109.

41 MANNING, Martin J; WYATT, Clarence R. Encyclopedia of media and propaganda in Wartime America. Santa Barbara; Denver; Oxford: ABC-CLIO, 2010. v. 1.

42 VENTURA, Deise; Illes, Paulo. Qual a política migratória do Brasil? Le Monde Diplomatique Brasil, 07 mar. 2012. Disponível em: <http://www.diplomatique.org.br/artigo.php?id=1121>. Acesso em: 18 jun. 2015.

43 JASINSKI, Isabel. A condição de estrangeiro: literatura e exílio em Francisco Ayala. Curitiba: UFPR, 2012. p. 34. 
Outrossim, entende-se desarrazoado o posicionamento estatal de exclusão do estrangeiro na vida política em nome de uma soberania pura. Há que se considerar a situação do estrangeiro e seu interesse por representatividade - o estrangeiro encontra-se como mero objeto do poder político local, em uma condição análoga à de homo sacer, nos moldes estudados por Giorgio Agamben.

Portanto, é inconteste o fato de que, no mundo contemporâneo, há uma grande facilidade para a globalização dos mercados e enormes dificuldades para os seres humanos, "[...] principalmente se não são ricos ou bem-educados" $"$.

No entanto, é preciso lembrar que o estrangeiro, mormente aquele que migra em virtude de subsistência, enfrenta diversos embaraços com os quais um nacional talvez jamais se depare: “[...] o local de origem, as dificuldades da vida na terra natal e os percalços da viagem, os recursos utilizados para encontrar um espaço social na nova sociedade, a mobilidade social, os mecanismos para tentar a integração na nova terra" "45, dentre várias outras resistências e obstáculos típicos de quem vive "entre dois mundos".

Não se mostra razoável a uma nação que acolheu tantos imigrantes no passado uma posição indiferente ao contingente migratório que chega ao Brasil - se antigamente o relevante era estudar a assimilação do estrangeiro no território brasileiro, hoje "[...] importa redimensionar o papel e o lugar dos imigrantes na construção do país" ${ }^{\prime 4}$.

Não são raros os posicionamentos contrários à participação política do imigrante na comunidade local, tampouco na dimensão nacional. Surgem aqui, em grande parte, os aspectos puramente nacionalistas que consideram o imigrante como parte estranha à sociedade, senão como uma ameaça, um inimigo.

Em diversos marcos da história, a correlação entre imigração e segurança nacional serviram de justificativa para políticas restritivas — DOTY esclarece que tal posicionamento já é corrente desde antes de o ataque de 11 de setembro de 2001, talvez a referência maior da ameaça que um estrangeiro possa causar a um país ${ }^{47}$.

No entanto, é necessário desmistificar essa posição, um tanto reducionista, principalmente por dois motivos: i. a ameaça à segurança de uma nação não é causada apenas por estrangeiros, sendo que muitas vezes os próprios nacionais colocam esse bem sob risco ${ }^{48}$; ii. o que se pretende no presente trabalho é a exposição favorável a uma participação política local do imigrante, para tão somente efetivar um direito fundamental à democracia e à dignidade humana.

O tema da segurança nacional começou a ganhar relevância não devido ao imigrante em si, mas principalmente pela suposta ameaça que o comunismo poderia representar aos Estados Unidos em meados da Guerra Fria - a política externa estadunidense passava a ser cada vez mais abrangente e genérica, para o fim de requerer a parceiros e aliados que reprimissem movimentos e partidos que se identificassem minimamente como comunistas ${ }^{49}$.

É a partir dessa ideia do macarthismo, e desse alinhamento com os Estados Unidos, que no Brasil se adotou, no início de 1953, uma nova Lei de Segurança Nacional. Os parlamentares, na época, dividiam-se entre os que defendiam uma democracia "verdadeira", a qual, supunham, não se coadunaria com uma Lei de Segurança Nacional, e aqueles que, como João Mendes, defendiam uma democracia "vigilante”, pois esta precisava "[...] não ser excessivamente tolerante para não ter que ir ao seu extremo oposto: excesso de violência" 50 .

44 OLIVEIRA, Lucia Maria Lippi. Nós e eles: Relações culturais entre brasileiros e imigrantes. Rio de Janeiro: FGV, 2005. p. 18.

45 OLIVEIRA, Lucia Maria Lippi. Nós e eles: Relações culturais entre brasileiros e imigrantes. Rio de Janeiro: FGV, 2005. p. 19.

46 OLIVEIRA, Lucia Maria Lippi. Nós e eles: Relações culturais entre brasileiros e imigrantes. Rio de Janeiro: FGV, 2005. p. $22-23$.

47 DOTY, Roxanne Lynn. The law into their own hands: immigration and the politics of exceptionalism. Arizona: University of Arizona, 2009. p. 53.

48 CARRANCA, Adriana. Por que jovens europeus têm ingressado em grupos terroristas?. Estadão, São Paulo, 11 jan. 2015. Disponível em: <http://internacional.estadao.com.br/blogs/adriana-carranca/por-que-jovens-europeus-tem-ingressado-em-gruposterroristas/>. Acesso em: 24 jun. 2015.

49 REZNIK, Luís. Democracia e segurança nacional: a polícia política no pós-guerra. Rio de Janeiro: FGV, 2004. p. 10.

50 REZNIK, Luís. Democracia e segurança nacional: a polícia política no pós-guerra. Rio de Janeiro: FGV, 2004. p. 16. 
Os instrumentos repressivos, no entanto, existiam antes da nova LSN de 1953 - já no início dos anos 1930, foram criadas as Delegacias Especiais de Segurança Política e Social (Desps), para o fim de apaziguar os movimentos de massa que surgiam (integralismo/fascismo vs. comunismo). Foi a partir da primeira LSN, antidemocrática, e da revolta comunista, movimento popular e legítimo, que se verificou um aumento na repressão pelas Desps ${ }^{51}$.

Para os que se dedicavam ao assunto, segurança nacional significava a preservação dos costumes e tradições da nação, referia-se a um bem-estar coletivo, a aspirações comuns, o que diferenciava os nacionais dos estrangeiros. Caberia, então, ao Estado, formular uma política que preservasse essa "bagagem" cultural, social e econômica, mormente para manter a soberania, a integridade, e a ordem constitucional do País ${ }^{52}$.

O sociólogo e político Alberto Guerreiro Ramos fez uma importante observação ao tema da "segurança nacional" - tanto ele quanto Hermes Lima consideravam todas as significações desse objeto como legítimas, pois se tratavam de construções racionais. Tal posicionamento, no entanto, não o impedia de ter uma visão própria da LSN: "[...] a segurança nacional é eminentemente política e, portanto, ideológica; é uma das modalidades de que se reveste a política geral de um país. Seu conteúdo não é estático, mas historicamente variável”53.

Para Guerreiro Ramos, cada Estado, em cada momento distinto da História, poderia adotar políticas de segurança nacional diferentes, de acordo com as etapas de seu desenvolvimento. Porém, se toda política, para ele, era legítima, não se pode concluir que todas fossem válidas - exemplo prático de que a segurança nacional em si era antidemocrática foi, nos fins dos anos 1930, a Seção de Segurança Nacional, instituída como um órgão auxiliar dos Ministérios ${ }^{54}$.

O órgão era uma espécie de centro de estudos sobre segurança nacional no País, orientando, avaliando e apreciando questões. A Seção também recebia rotineiramente comunicações de diversos Ministérios - do MRE, por exemplo, chegavam notificações acerca do comunismo no exterior; do MTE, dados sobre greves e possíveis manifestações de trabalhadores de determinadas empresas ou regiões ${ }^{55}$.

Imprescindível, ainda, mencionar o Tribunal de Segurança Nacional como, talvez, o órgão mais antidemocrático que poderia ter sido implantado à época. O Tribunal, ad hoc, foi criado em $1936^{56}$, com o fim de punir indivíduos que ameaçassem a segurança externa do País e as instituições políticas, militares e sociais, sob uma visão fascista e opressiva, haja vista a impossibilidade de habeas corpus aos acusados; o TSN deveria ser acionado tão somente em estado de guerra, mesmo que fictício ${ }^{57}$.

De modo geral, observa-se que o TSN teve uma atuação puramente política, sob o comando de um regime integralista em face de uma suposta ameaça comunista. O discurso ideológico suprimiu o jurídico. A legalidade sobrepôs-se à legitimidade. A perseguição política travestiu-se de defesa da segurança nacional, em um tribunal no qual a pena máxima era a de $\operatorname{morte}^{58}$ : "A condição de estrangeiro passava a ser considerada como agravante preponderante na aplicação das penas" 59 .

51 REZNIK, Luís. Democracia e segurança nacional: a polícia política no pós-guerra. Rio de Janeiro: FGV, 2004. p. 24.

52 REZNIK, Luís. Democracia e segurança nacional: a polícia política no pós-guerra. Rio de Janeiro: FGV, 2004. p. 34.

53 REZNIK, Luís. Democracia e segurança nacional: a polícia política no pós-guerra. Rio de Janeiro: FGV, 2004. p. 36.

54 REZNIK, Luís. Democracia e segurança nacional: a polícia política no pós-guerra. Rio de Janeiro: FGV, 2004. p. 40.

55 REZNIK, Luís. Democracia e segurança nacional: a polícia política no pós-guerra. Rio de Janeiro: FGV, 2004. p. 43.

56 TERCIO, Jason. A espada e a balança: crime e política no banco dos réus. Rio de Janeiro: J. Zahar, 2002. p. 61.

57 BALZ, Christiano Celmer. O Tribunal de Segurança Nacional: aspectos legais e doutrinários de um tribunal da era Vargas (19361945). 2009. f. Dissertação (Mestrado) - Centro de Ciências Jurídicas, Universidade Federal Santa Catarina, Florianópolis, 2009. p. 92.

58 Acesso em: 15 jun. 2015. "Art. 18. Os juízes e o Tribunal aplicarão as penas das leis n. 38, de 4 de abril de 1935, e n. 136, de 14 de dezembro de 9935, e de outras que definam crime de sua competência, inclusive a de morte, podendo mandar que as penas temporárias sejam cumpridas em colônias penais agrícolas. Parágrafo único. Considera-se circunstância agravante preponderante a condição de estrangeiro, e agravante ou atenuante conforme o caso, a maior ou menor eficiência do réu na prática do delito." BRASIL. Decreto-Lei n. 88, de 20 de dezembro de 1937. Disponível em: <http://www2.camara.leg.br/legin/fed/declei/1930-1939/decretolei-88-20-dezembro-1937-350832-publicacaooriginal-1-pe.html>.

59 BALZ, Christiano Celmer. O Tribunal de Segurança Nacional: aspectos legais e doutrinários de um tribunal da era Vargas (1936-1945). 
Após a queda do Estado Novo, em 1945, José Linhares, presidente do Supremo Tribunal Federal, à época, que substituiu Vargas até a posse do general Eurico Gaspar Dutra, em janeiro de 1946, teve como um de seus primeiros atos a extinção do Tribunal de Segurança Nacional, “[...] transferindo para a justiça comum o julgamento dos crimes contra a existência, a segurança e a integridade do Estado, bem como a guarda e o emprego da economia popular" ${ }^{\circ 0}$.

A LSN, no entanto, manteve-se vigente mesmo após a queda do Estado Novo e a vigência das Cartas Constitucionais sucessoras. Setores como a Ordem dos Advogados do Brasil e outras entidades democráticas, sempre se opuseram a ela, por ser um instrumento limitador dos direitos individuais, mormente durante o regime militar (1964-1989).

A Lei no 7.170/1983, atualmente vigente, após uma análise detida, sobretudo em relação aos crimes tipificados, mostra-se mais branda do que as anteriores, procurando preservar mais o bem-estar coletivo e a integridade da nação, embora haja determinados artigos consideravelmente abertos ${ }^{61}$, nos quais qualquer indivíduo poderia facilmente ser enquadrado.

O atual governo e a política externa brasileira não demonstram aquela preocupação anterior em relação aos estrangeiros, em viés ideologicamente conservador, no entanto também não buscam aprimorá-la, haja vista a natureza anacrônica do Estatuto do Estrangeiro.

A questão da soberania e da segurança nacional parece afetar, ainda fortemente, os Estados europeus, mormente os governados por partidos conservadores, e os Estados Unidos, pela ameaça do terrorismo.

A preocupação em relação à segurança nacional é, muitas vezes, confundida com a fobia contra os imigrantes, como explica ALEXSEEV ${ }^{62}$ — o discurso do estrangeiro enquanto outro se relaciona mais em relação à pessoa fóbica em si do que ao imigrante — o medo exagerado que o desconhecido, enquanto indivíduo, causa na sociedade é uma questão de como o nacional supervaloriza sua cultura e menospreza as demais.

Ademais, entende-se que a ameaça à soberania ou à segurança nacional derivada da chegada de um imigrante se mostra desproporcional em relação aos reais desafios que a nação deverá enfrentar nessa questão, salvo em casos de guerra iminente e/ou ameaças terroristas.

A Europa hoje enfrenta um dos maiores fluxos migratórios da História, seja por causas ambientais ou bélicas. O continente que na época da Segunda Grande Guerra precisou “importar" trabalhadores do Leste Europeu e dos países ibéricos, agora se mostra extremamente receosa de migrações em massa.

A reação xenofóbica europeia contra muçulmanos e árabes apenas vem crescendo, principalmente após o ataque de 11/9. As similaridades entre o Islamismo e o Cristianismo, religiões que veneram o mesmo Deus e propagam ideias universais, não conseguiram apaziguar a força simbólica dos conflitos pelos quais essas comunidades já passaram: as conquistas muçulmanas em territórios ibéricos, a Batalha de Poitiers, as Cruzadas e a reconquista da Terra Sagrada, a Inquisição e a expulsão dos mouros, a hegemonia otomana sobre a Europa Ocidental, o Cerco de Viena, dentre outros ${ }^{63}$.

A imigração que hoje ocorre na Europa não toma os mesmos moldes do século passado — ela é cada vez maior, chegando a contabilizar porcentagens razoáveis em alguns países: na Áustria, 12,5\% da população é

2009. f. Dissertação (Mestrado) - Centro De Ciências Jurídicas, Universidade Federal Santa Catarina, Florianópolis, 2009 . p. 142.

60 COSTA, Emília Viotti da. O Supremo Tribunal Federal e a construção da cidadania. São Paulo: UNESP, 2006. p. 106.

61 "Art. 23 - Incitar: I - à subversão da ordem política ou social; II - à animosidade entre as Forças Armadas ou entre estas e as classes sociais ou as instituições civis; III - à luta com violência entre as classes sociais; IV - à prática de qualquer dos crimes previstos nesta Lei. Pena: reclusão, de 1 a 4 anos." BRASIL. Lei n. 7.170, de 14 de dezembro de 1983. Disponível em: <http://www.planalto.gov. br/ccivil_03/leis/17170.htm>. Acesso em: 15 jun. 2015.

62 ALEXSEEV, Mikhail A. Immigration phobia and the security dilemma: Russia, Europe, and the United States. United Kingdom: Cambridge Univerity Press, 2005. p. 21.

63 IRELAND, Patrick Richard. Becoming Europe: immigration, integration, and the Welfare State. Pittsburgh: University of Pittsburgh Press, 2004. p. 3. 
estrangeira, na Alemanha esse percentual é de 12,1; nos Estados Unidos, por sua vez, o índice é de 12,3\%. No restante dos países europeus, aproximadamente um em cada dez habitantes é estrangeiro. Cidades como Amsterdã, Londres, Nova York, Bruxelas e Frankfurt apresentam número de estrangeiros residentes que ultrapassa mais de $25 \%$ da população ${ }^{64}$.

Uma vez que a imigração no continente europeu é cada vez maior, bem como grande parte dos trabalhadores é estrangeira, o impacto que isso gera no cenário econômico e político é inevitável ${ }^{65}$. Para tanto, os governos necessitam ponderar a extensão dos direitos a que os imigrantes terão acesso - em países da União Europeia, por exemplo, cidadãos europeus têm a possibilidade de votar em eleições locais do Estado onde habitam, mesmo sem requerer a naturalização ${ }^{66}$.

A Convenção sobre a Participação dos Estrangeiros na Vida Pública ao Nível Local, de 1992, considera inconteste o fato da residência de estrangeiros nos territórios europeus, bem como que aqueles se sujeitam, geralmente, aos mesmos deveres dos cidadãos nacionais, participando ativamente na vida e no desenvolvimento das autarquias locais, sendo necessário melhorar sua integração na comunidade local, por meio de um maior leque de possibilidades de participação nos assuntos públicos locais ${ }^{67}$.

Ademais, referida Convenção dispõe, em seu artigo 4", que “[c]ada Parte diligenciará de forma a que os residentes estrangeiros participem nos inquéritos públicos, nos processos de planificação bem como em outros processos de consulta relativamente às questões locais" - o documento ainda prevê a criação de órgãos consultivos específicos aos estrangeiros residentes e o direito de voto em eleições locais.

Por conseguinte, verifica-se que, se o continente europeu, conhecido pelas políticas restritivas aos imigrantes, já lhes possibilitou o voto nas eleições locais, torna-se difícil, senão impossível, encontrar um fundamento que valide a opção brasileira em não fazer o mesmo.

Não estender o direito de voto em eleições locais aos estrangeiros consiste em uma prática dissonante dos preceitos constitucionais ${ }^{68}$ - o argumento da segurança nacional ${ }^{69}$ não encontra mais respaldo em uma nação que já passou por uma transição para a democracia.

A justificativa para que o estrangeiro residente possa votar nas eleições locais se mostra com maior razoabilidade do que a faculdade de sufrágio em pleitos nacionais - a proximidade do estrangeiro residente e do poder local faz surgir entre estes dois elementos um elo político-legal tão semelhante quanto aquele estabelecido entre o poder local e o cidadão nativo.

Por outro lado, embora os estrangeiros residentes também contribuam para o crescimento econômico nacional e paguem impostos federais, entende-se que o vínculo entre o indivíduo e o Estado federal (território) é típico de uma relação que acaba desencadeando a nacionalidade — para tanto, entende-se que possam se pronunciar acerca das eleições gerais somente as pessoas que desejem assentar-se definitivamente no País - um imigrante pode ser beneficiado por programas como Bolsa Família, Minha Casa Minha Vida, dentre outros, mas não ter a intenção de permanecer no território permanentemente - logo, diferencia-se

64 DANCYGIER, Rafaela M. Immigration and conflict in Europe. United Kingdom: Cambridge University Press, 2010. p. 3.

65 DANCYGIER, Rafaela M. Immigration and conflict in Europe. United Kingdom: Cambridge University Press, 2010. p. 4.

66 DANCYGIER, Rafaela M. Immigration and conflict in Europe. United Kingdom: Cambridge University Press, 2010. p. 33.

67 Convenção sobre a Participação dos Estrangeiros na Vida Pública ao Nível Local. COUNCIL OF EUROPE. Convention on the Participation of Foreigners in Public Life at Local Level. Strasbourg, 1992. (European Treaty Series, n. 144). Disponível em: <http:/ / conventions.coe.int/Treaty/EN/Treaties/PDF/Portuguese/144-Portuguese.pdf> Acesso em: 16 jul. 2015.

68 "[...] o próprio reconhecimento dos direitos políticos como direitos fundamentais já assegura que a interpretação das normas que os contemplam busque resguardar ao máximo o seu exercício." OLIVEIRA, Marcelo Roseno de. Direito eleitoral: reflexões sobre temas contemporâneos. Fortaleza: ABC, 2008. p. 38.

69 "Em suma, a segurança nacional não sabe muito bem quais são os bens que devem ser postos em segurança de qualquer maneira, mas sabe muito bem que é preciso colocá-los em segurança. Ela quer ardentemente e com todas as forças de seu poder físico algo que não sabe muito bem o que é. [...] A segurança nacional talvez não saiba muito bem o que está defendendo, mas sabe muito bem contra quem: o comunismo." COMBLIN, Joseph. A ideologia da segurança nacional: o poder militar na América Latina. Tradução de A. Veiga Fialho. Rio de Janeiro: Civilização Brasileira, 1978. p. 55. 
sobremaneira o visto de permanência da naturalizaçãa $0^{70}$.

Para tanto, imprescindível mencionar o Anteprojeto de Lei de Migrações e Promoção dos Direitos dos Migrantes no Brasil, elaborado pelo Ministério da Justiça junto ao Conselho Nacional de Imigração, à Defensoria Pública da União, à Secretaria de Direitos Humanos da Presidência da República, dentre outros.

$\mathrm{O}$ artigo $54^{71}$ do mencionado anteprojeto prevê a naturalização aos estrangeiros que tenham completado 4 (quatro) anos de residência no País. Tal artigo, cumulado à Proposta de Emenda Constitucional n. $347 / 2013^{72}$, de autoria do Deputado Carlos Zarattini, possibilitaria o direito ao voto aos estrangeiros em eleições locais e gerais.

A PEC 347 foi apensa à PEC n. 119/201173, de autoria do Deputado Roberto Freire, a qual pretende alterar o art. 14 da Constituição atual para facultar a participação de estrangeiro domiciliado no Brasil nas eleições municipais.

Dessa forma, o art. 14, $₫ 2^{\circ}$, da Carta Maior vigente passaria a especificar que nem todos os estrangeiros são inalistáveis, mas somente aqueles que não estejam legalmente regularizados e não tenham residido no Brasil pelo período mínimo de 4 (quatro) anos.

O conceito de cidadania deveria ser revisto em sua magnitude, e desvinculado de concepções como a nacionalidade ou o alistamento eleitoral - mesmo indivíduos que não são cidadãos por um ponto de vista formal, o são materialmente, sendo afetos ao contexto social:

$[\ldots]$ why should democratic participation be the exclusive right of the people achieving social membership? [...] given the democratic idea that power over the government should be vested in the people affected by the gov- ernment, it follows that a person shaped by the social context should be guaranteed political rights. Now, to accept this line of reasoning is virtually to abandon the principle of membership as initially formu- lated and to accept a different idea - the causal interpretation of the all affected principle [...]. membership is not what creates a valid claim for political rights. The basis for the right to vote and other participatory rights is instead found in the extent to which the individual is 'subject to political rule'. ${ }^{74}$

A participação política nada mais é do que um direito humano (o direito de participar no governo traz ideia de democracia e legitimidade), mesmo aos estrangeiros. Logo, a exigência da cidadania, no conceito arcaico do instituto, para exercer a participação política, é restringir a aplicação de um direito humano.

A mobilização pelos direitos políticos dos migrantes não encontra respaldo apenas em Casas de Leis, mas também entre ativistas - o Fórum Social pelos Direitos Humanos e Integração dos Migrantes no Brasil lançou a Campanha "Aqui Vivo Aqui Voto", em março de 2014, na capital paulista, onde participaram do evento quase duas mil pessoas. ${ }^{75}$

70 "The nature of nationality as a matter of domestic jurisdiction does not preclude the existence of rules of international law relating to nationality. As in any other field, the sovereign jurisdiction of the State in matters of nationality may be restricted by the conclusion of treaties concerning nationality, which, to that extent, make the law of nationality a question of conventional international law and, so far as multilateral treaties are concerned, a question of "international legislation". [...] Conceptually and linguistically, the terms "nationality" and "citizenship" emphasize two different aspects of the same notion: State membership. "Nationality" stresses the international, "citizenship" the national, municipal aspect." WEIS, Paul. Nationality and statelessness in international law. United Kingdom: Cambridge University Press, 2014. p. XIII-XIV (preface); 4-5.

71 BRASIL. Anteprojeto de lei de migrações e promoção dos direitos dos migrantes no Brasil. Brasília: Fundação Friedrich Ebert, 2014. Disponível em: <http://library.fes.de/pdf-files/bueros/brasilien/10947.pdf> Acesso em: 16 jul. 2015.

72 BRASIL. Proposta de emenda à Constituição $n$, de 2013. Disponível em: <http://www.camara.gov.br/proposicoesWeb/ prop_mostrarintegra;jsessionid=0C274349B2F8A11B58D26FE30AC87FF2.proposicoesWeb2? codteor=1175684\&filename =P EC+347/2013>. Acesso em: 16 jul. 2015.

73 BRASIL. Proposta de emenda à Constituição n, de 2011. Disponível em: < http://www.camara.gov.br/proposicoesWeb/prop_mos trarintegra?codteor=947592\&filename $=$ PEC+119/2011>. Acesso em: 16 jul. 2015.

74 BECKMAN, Ludvig. The frontiers of democracy: the right to vote and its limits. United Kingdom: Palgrave-Macmillan, 2009. p. 69-70. 75 SÃO PAULO. Secretaria Municipal de Direitos humanos e cidadania. Imigrantes elegem os seus representantes nos Conselhos Participativos Municipais. São Paulo, 30 mar. 2014. Disponível em: <http://www.prefeitura.sp.gov.br/cidade/secretarias/direitos_humanos/ noticias/index.php?p=168815> Acesso em: 16 jul. 2015. 
Cabe, portanto, aos governantes, em nível federal, acatar as reivindicações realizadas há anos, bem como adotar uma postura que avalie a posição anacrônica do Brasil se comparada à média mundial, e substituir o Estatuto do Estrangeiro, com noções ultrapassadas, por uma nova lei da imigração.

Uma legislação contemporânea aos problemas e desafios atuais, que garanta dignidade e um rol mais extenso de direitos aos imigrantes, mormente aos estrangeiros residentes, não só atrairá mão de obra à nação, como também direcionará um tratamento mais humanitário aos migrantes e refugiados.

\section{Considerações finais}

O presente trabalho objetivou questionar a impossibilidade de voto ao estrangeiro no Brasil, tendo-se concluído, em uma primeira análise, que a participação política do imigrante residente, ao menos nas eleições locais, trata-se da efetivação de um direito fundamental, não representando ameaça à soberania/ segurança nacional.

Entendeu-se, igualmente, que a substituição do Estatuto do Estrangeiro, herança do regime militar, por uma legislação que condiga com os novos fluxos migratórios e tenha um caráter humanitário frente aos migrantes e refugiados é urgente - maior facilidade para naturalização e obtenção de vistos, bem como um rol mais extenso de direitos são essenciais à dignidade humana.

Depreendeu-se, também, que a doutrina da segurança nacional é anacrônica à manutenção de um Estado democrático de direito, por ser simples instrumento dos governos que a utilizam como pretexto contra supostas ameaças comunistas.

Ademais, inferiu-se que, embora não haja um número preciso de imigrantes residindo no Brasil, é necessário que estes vejam-se representados politicamente, sobretudo nos municípios em que residem, pela proximidade com os poderes locais.

O presente trabalho não objetivava responder aos questionamentos iniciais, porém esclarecê-los minimamente para uma melhor compreensão do tema, ainda pouco tratado no Brasil.

Por fim, compreendeu-se que a participação do estrangeiro pode trazer mais tolerância à comunidade local, mais instrumentos para fomento, mão de obra qualificada (ou o incentivo à qualificação), crescimento e desenvolvimento econômico e, acima de tudo, mais dignidade ao próprio imigrante.

\section{REFERÊNCIAS}

ALEXSEEV, Mikhail A. Immigration phobia and the security dilemma: Russia, Europe, and the United States. United Kingdom: Cambridge Univerity Press, 2005.

ARISTÓTELES. Politica. Tradução de Politikón por Pedro Constantin Tolens. São Paulo: Martin Claret, 2007.

BALZ, Christiano Celmer. O Tribunal de Segurança Nacional: aspectos legais e doutrinários de um tribunal da era Vargas (1936-1945). 2009. Dissertação (Mestrado) - Centro De Ciências Jurídicas, Universidade Federal Santa Catarina, Florianópolis, 2009.

BECKMAN, Ludvig. The frontiers of democracy: the right to vote and its limits. United Kingdom: Palgrave-Macmillan, 2009.

BIRCH, Anthony Harold. The concepts and theories of modern democracy. London: Routledge, 1993. 
CAMPANHOLE, Adriano; CAMPANHOLE, Hílton Lobo. Constituições do Brasil. 7. ed. São Paulo: Atlas, 1984.

Código Electoral, Panama. Disponivel em: <http://pdba.georgetown.edu/Electoral/Panama/pancode.html>. Acesso em 12 jun 2015.

Código Electoral Provincial de Córdoba. Disponivel em: <http:// wnw.justiciacordoba.gob.ar/jel/pdf/legislacion/L.9571. pdf> Acesso em 11 jun 2015.

COMBLIN, Joseph. A ideologia da segurança nacional: o poder militar na América Latina. Tradução de A. Veiga Fialho. Rio de Janeiro: Civilização Brasileira, 1978.

Constitución de la Republica de Cuba. Disponível em: <http://www.cuba.cu/gobierno/cuba.htm>. Acesso em 11 jun 2015.

Constitucion de la Republica de El Salvador. Disponível em: <http://www.constitution.org/cons/elsalvad. htm>. Acesso em 11 jun 2015.

Constitución de la Republica Dominicana. Disponível em: <http://www.ifrc.org/docs/idrl/751ES.pdf>. Acesso em 11 jun 2015.

Constitución de la República Bolivariana de Venezuela. Disponível em: <http://www.cne.gob.ve/web/normativa_electoral/constitucion/indice.php>. Acesso em 05 jun 2015.

Constitución del Ecuador. Disponível em: <http://www.asambleanacional.gov.ec/documentos/constitucion_de_bolsillo.pdf>. Acesso em 11 jun 2015.

Constitución del Estado Libre Asociado de Puerto Rico. Disponível em: < http:/ /www2.pr.gov/SobrePuertoRico/Documents/elaConstitucion.pdf>. Acesso em 11 jun 2015.

Constitución Nacional del Paraguay. Disponível em: <http://www.oas.org/juridico/spanish/par_res3. htm>. Acesso em 15 jun 2015.

Constitución Política de 1982, Honduras. Disponível em: <http://www.poderjudicial.gob.hn/CEDIJ/ Leyes/Documents/Constituci $\%$ C3\%B3n $\% 20 \mathrm{de} \% 201 \mathrm{a} \% 20$ Rep $\%$ C3\%Bablica $\% 20 \mathrm{de} \% 20$ Honduras $\% 20$ \%28Actualizada\%202014\%29.pdf>. Acesso em 11 jun 2015.

Constitución Política de Honduras, 1982. Disponível em: <http://www.poderjudicial.gob.hn/CEDIJ/ Leyes/Documents/Constituci $\%$ C3\%B3n $\% 20 \mathrm{de} \% 201 \mathrm{a} \% 20$ Rep $\%$ C3\%Bablica $\% 20 \mathrm{de} \% 20$ Honduras $\% 20$ \%28Actualizada\%202014\%29.pdf> Acesso em 15 jun 2015.

Constitución Política de la Republica de Chile. Disponível em: <https://www.camara.cl/camara/media/ docs/constitucion_politica.pdf>. Acesso em 10 jun 2015.

Constitución Política de la Republica de Costa Rica. Disponível em: <http://www.google.com.br/url?sa=t $\& \mathrm{rct}=\mathrm{j} \& \mathrm{q}=\& \mathrm{esrc}=\mathrm{s} \& \mathrm{source}=$ web\&cd $=1 \& \mathrm{cad}=$ rja\&uact $=8 \& \mathrm{ved}=0 \mathrm{CB} 0 \mathrm{QFjAAahUKEwikrZS2j} 4 \mathrm{jGAhU}$ KGIwKHZNQALI\&url=http $\% 3 \mathrm{~A} \% 2 \mathrm{~F} \% 2 \mathrm{Fwww}$.hcostarica.fcs.ucr.ac.cr $\% 2 \mathrm{Fcontenidos} \% 2 \mathrm{Ftextos} \% 2 \mathrm{Fc}$ onstituc.rtf\&ei=RL95VaT7JoqwsASToYGQCw\&usg=AFQjCNEipQi1 rgTi8APpOMuTeDrcQOgdcA\&si g2=ElHH0TrOjzr5g1BwQMmZ4g\&bvm=bv.95277229,d.cWc>. Acesso em 12 jun 2015.

Constitución Política de la Republica de Panama. Disponível em: < http://www.unesco.org/culture/natlaws/media/pdf/panama/pan_constpol_04_spaorof>. Acesso em 12 jun 2015.

Constitución Política del Estado Plurinacional de Bolivia. Disponível em: <http:/ www.harmonywithnatureun.org/content/documents/159Bolivia\%20Consitucion.pdf>. Acesso em 11 jun 2015.

Constitución Política del Peru. Disponível em: < http://www4.congreso.gob.pe/ntley/Imagenes/Constitu/ Cons1993.pdf $>$. Acesso em 11 jun 2015. 
Constitución Política de Nicaragua. Disponível em: <http:/ legislacion.asamblea.gob.ni/Normaweb.nsf/31 33c0d121ea3897062568a1005e0f89/06c0db3b7bcfc75706257307006f6c6d?OpenDocument $>$. Acesso em 11 jun 2015.

Constitution de la République d'Haïti. Disponível em: < http://pdba.georgetown.edu/Constitutions/Haiti/ haiti1987.html>. Acesso em 11 jun 2015.

Constitution of the Co-operative Republic of Guyana Act. Disponível em: <http://parliament.gov.gy/ constitution.pdf>. Acesso em 11 jun 2015.

CORTINA, Adela. Bioética: un impulso para la ciudadanía activa. Revista Brasileira de Bioética, Brasilia, v. 1, n. 4, 2005.

COSTA, Emília Viotti da. O Supremo Tribunal Federal e a construção da cidadania. São Paulo: UNESP, 2006.

DAMATTA, Roberto da et al. Brasileiro: cidadão? 2. ed. São Paulo: Cultura Editores Associados, 1997.

DANCYGIER, Rafaela M. Immigration and conflict in Europe. United Kingdom: Cambridge University Press, 2010.

DIMOULIS, Dimitri; MARTINS, Leonardo. Teoria geral dos direitos fundamentais. 5. ed. São Paulo: Atlas, 2014.

DOTY, Roxanne Lynn. The law into their own hands: immigration and the politics of exceptionalism. Arizona: University of Arizona, 2009.EMERIQUE, Lilian Márcia Balmant. Direito fundamental como oposição política. Curitiba: Juruá, 2008.

FERREIRA FILHO, Manoel Gonçalves. Princípios fundamentais do direito constitucional: o estado da questão no início do século XXI, em face do direito comparado e, particularmente, do direito positivo brasileiro. 2. ed. São Paulo: Saraiva, 2010.

GOMES, José Jairo. Direito eleitoral. 7. ed. São Paulo: Atlas, 2011.

IRELAND, Patrick Richard. Becoming Europe: immigration, integration, and the Welfare State. Pittsburgh: University of Pittsburgh Press, 2004.

JASINSKI, Isabel. A condição de estrangeiro: literatura e exílio em Francisco Ayala. Curitiba: UFPR, 2012.

Jefatura de Gabinete de Buenos Aires. Voto Extranjero. Disponível em: <http://www.gob.gba.gov.ar/portal/subsecretarias/gabinete/provincialelectoral/extranjeros.php>. Acesso em 11 jun 2015.

Ley 1070 de 2006, Congresso de Colombia. Disponível em: <http://www.alcaldiabogota.gov.co/sisjur/ normas/Norma1.jsp?i=20871>. Acesso em 11 jun 2015.

Ley Electoral de 1992, Cuba. Disponível em: < http://www.cubanet.org/htdocs/ref/dis/01070301.htm>. Acesso em 11 jun 2015.

Ley Orgánica de Elecciones, Peru. Disponível em: <http://portal.jne.gob.pe/procesoselectorales/Informacion $\% 20$ Electoral/Materiales $\% 20$ para $\% 20$ evaluaci\%C3\%B3n\%20JEE/Ley $\% 20$ Org $\%$ C3\%A1 nica $\% 20$ de\%20Elecciones.pdf>. Acesso em 12 jun 2015.

LULA, Carlos Eduardo de Oliveira. Direito eleitoral. Leme: Imperium, 2008.

MANNING, Martin J; WYATT, Clarence R. Encyclopedia of media and propaganda in Wartime America. Santa Barbara; Denver; Oxford: ABC-CLIO, 2010. v. 1.

MAZZUOLI, Valerio de Oliveira. Curso de direito internacional público. 4. ed. São Paulo: Revista dos Tribunais, 2010.

Oficina de Educación y Adiestramiento Electoral, Puerto Rico. Disponível em: <http://209.68.12.238/ servicioCEE/educacionElectoral/pdf/TENGODERECHOAVOTAR.pdf>. Acesso em 11 jun 2015. 
OLIVEIRA, Lucia Maria Lippi. Nós e eles: Relações culturais entre brasileiros e imigrantes. Rio de Janeiro: FGV, 2005.

OLIVEIRA, Marcelo Roseno de. Direito eleitoral: reflexões sobre temas contemporâneos. Fortaleza: ABC, 2008. p. 21-48.

PIOVESAN, Flávia. Temas de direitos humanos. 7. ed. São Paulo: Saraiva, 2014.

RAMAYANA, Marcos. Direito eleitoral. 6. ed. Niterói: Impetus, 2006.

RAMOS, André de Carvalho et al. Temas de direito eleitoral no século XXI. Brasília: Escola Superior do Ministério Público da União, 2012.

REZNIK, Luís. Democracia e segurança nacional: a polícia política no pós-guerra. Rio de Janeiro: FGV, 2004.

SARMENTO, Daniel. Por um constitucionalismo inclusivo: história constitucional brasileira, teoria da constituição e direitos fundamentais. Rio de Janeiro: Lumen Juris, 2010.

SILVA, José Afonso da. Curso de direito constitucional brasileiro. 33. ed. São Paulo: Malheiros, 2010.

SLAIBI FILHO, Nagib. Anotações à Constituição de 1988: aspectos fundamentais. 2. ed. Rio de Janeiro: Forense, 1989.

TAVARES, André Ramos. Curso de direito constitucional. 11. ed. São Paulo: Saraiva, 2013.

TERCIO, Jason. A espada e a balança: crime e política no banco dos réus. Rio de Janeiro: J. Zahar, 2002.

VARELLA, Marcelo D. Direito Internacional Público. 5. ed. São Paulo: Saraiva, 2014.

VELLOSO, Carlos Mário da Silva; AGRA, Walber de Moura. Elementos de direito eleitoral. São Paulo: Saraiva, 2009.

WEIS, Paul. Nationality and statelessness in international law. United Kingdom: Cambridge University Press, 2014. 


\section{REVISTA BRASILEIRA DE POLÍTICAS PÚBLICAS BRAZILIAN JOURNAL OF PUBLIC POLICY}
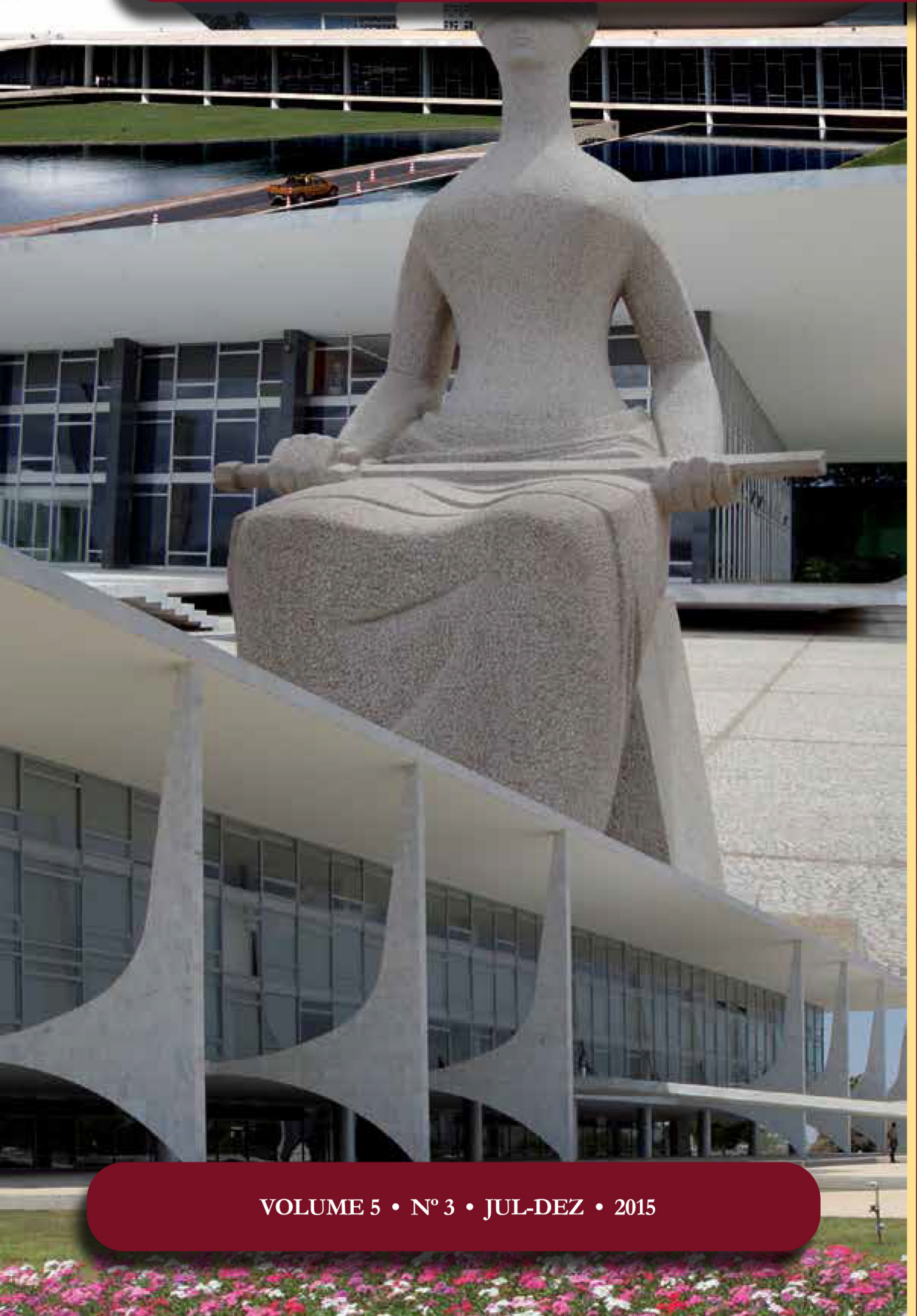

Crimen, Desempleo y Actividad Económica en Chile

Crime, Unemployment and

Economic Activity in Chile

Sergio Zuñiga-Jara

Sofía Ruiz Campo

Karla Soria-Barreto 


\title{
Crimen, Desempleo y Actividad Económica en Chile*
}

\section{Crime, Unemployment and Economic Activity in Chile}

\author{
Sergio Zuñiga-Jara ** \\ Sofía Ruiz Campo *** \\ Karla Soria-Barreto ${ }^{* * * *}$
}

\section{Resumen}

Las tasas de criminalidad en Chile son preocupantes, especialmente si se observan los datos de robos, y con tendencia creciente para los próximos años. Es por ello, que este hecho se ha convertido en un problema primordial desde el punto de vista social, que no ha sido todavía muy estudiado para este país. En este estudio se analizaron los determinantes de la criminalidad en Chile por medio de tres modelos que combinan la relación que existe entre cuatro variables, crimen, desempleo, crecimiento económico y disuasión policial. Los resultados obtenidos sugieren que el crimen puede ser analizado satisfactoriamente en Chile, utilizando una especificación del tipo ARDL. Puntualmente en este estudio se muestra que el crimen se relaciona con la tasa de crecimiento económico, el desempleo y la disuasión policial, y que a su vez, la actividad económica depende del desempleo, pero no tiene relación directa con el acto de crimen. Por último, se muestra que el desempleo depende de las variables crimen y crecimiento económico. Los resultados sugieren que el análisis adecuado de los condicionantes del crimen, pueden considerarse para que las políticas públicas que se diseñen, se anticipen e influyan efectivamente en la reducción de la tasa de delitos.

Palabras clave: Crimen. Disuasión. ARDL. Desempleo. Crecimiento económico.

* Recebido em 24/07/2015

Aprovado em 18/10/2015

** PhD em Economia Financeira. Professor de Economia Financeira na Escuela de Ciencias Empresariales, Universidad Católica del Norte (Chile).E-mail: sz@ucn.cl

*** $\mathrm{PhD}$ em Economia Financeira. Professora de Finanças e Contabilidade na Universidad Católica del Norte (Chile).E-mail: sofi.ruiz00@ gmail.com

**** $\mathrm{PhD}$ em Administração de Empresas. Professora da Universidad Católica del Norte (Chile).E-mail: ksoria@ucn.cl

\section{Abstract}

Crime rates in Chile are worrisome, especially if remarking data of thefts, with a increasing trend for the coming years. It is for this reason that this has become a major problem from the social point of view, not widely studied for this country still. In this study the determinants of crime in Chile through three models that combine the relationship between four variables, crime, unemployment, economic growth and police deterrence were analyzed. The results suggest that crime can be analyzed successfully in Chile, using a ARDL specification type. Specifically this study shows that crime is related to the rate of economic growth, unemployment and police deterrence, and that at the same time, economic activity depends on unemployment, but has no direct relationship to the act of crime. Finally, we show that unemploy- 
ment depends on the variables crime and economic growth. The results suggest that the proper analysis of the determinants of crime, may be considered for public policies designed, anticipate and effectively influence in reducing the crime rate.

Key words: Crime. Deterrence. ARDL. Unemployment. Economic growth.

\section{INTRODUCCIÓN}

El crimen provoca altos costos económicos y psicológicos a la sociedad y al individuo, y puede ser analizado desde diferentes perspectivas. Desde los primeros artículos que estudian la relación entre la actividad criminal y la economía (Fleisher ${ }^{1}$ y Becker $^{2}$ ), se han publicado estudios con distintos enfoques (Detotto y Vannini, ${ }^{3}$ Czabanski, ${ }^{4}$ Lee y Holoviak ${ }^{5}$ y Lambsdorff) ${ }^{6}$. Variables que pueden influir en la tipología del crimen son, por ejemplo, el desempleo, la desigualdad social o económica, el género, la raza, la edad, el nivel educativo y las condiciones del entorno físico (Brand y Price, ${ }^{7}$ Anderson ${ }^{8}$ y Barro 9 ). Un repaso de la literatura de determinantes del crimen en general se puede encontrar en Buonano ${ }^{10} \mathrm{y}$, centrado en el caso chileno Cea et al. ${ }^{11}$

Desde una perspectiva jurídica y moral, Durkheim ${ }^{12}$ considera el crimen como un comportamiento fuera de lo socialmente normado, teniendo por ello que ser sancionado. Desde el punto de vista económico, el crimen se basa en una relación entre el costo y el beneficio marginal que genera, considerando el costo en forma de detención o multa. De esta manera, como indica Becker, ${ }^{13}$ el criminal es un agente racional que maximiza su utilidad decidiendo entre actuar en actividades legales e ilegales. El agente racional considerará la posibilidad de la actividad ilegal si el beneficio logrado, descontado por el valor del castigo o multa, resulta superior al beneficio derivado de la actividad legal. Este enfoque del crimen introduce un agente externo, referido a las políticas públicas, a través de la efectividad policial, judicial y del sistema de sanciones. La eficiencia de estos obliga al delincuente a exigir un mayor beneficio por sus actos.

Desde un enfoque social, el crimen causa daños directos e indirectos a la sociedad. Los directos se derivan de las potenciales pérdidas en vidas y bienes, junto con la reducción de la actividad económica. En cuanto a los daños indirectos, estos pueden ocurrir por el incremento en las primas de riesgos y de seguros, y por la mayor exigencia de medidas de seguridad (mayores costos en vigilancia, sistemas de alarmas o recursos policiales); además de los efectos sobre las inversiones domésticas e internacionales, y sobre los niveles de crecimiento económico y empleo (Sandler y Enders). ${ }^{14}$

\footnotetext{
FLEISHER, B. M. The effect of unemployment on juvenile delinquency. The Journal of Political Economy, 71, 1963, pp. $543-555$. BECKER, G. Crime and Punishment: An Economic Approach. Journal of Political Economy, 76(2), 1968, pp. $169-217$. 
Para Matus, ${ }^{15}$ el análisis de los factores que inciden en el incremento o reducción del crimen no siguen un simple proceso aleatorio, sino que vienen vinculados a causas que pueden ser predeterminadas y conocidas. Tampoco se trata de un proceso estático en el tiempo, ya que cambia a lo largo del año, y de un año a otro. Por ello, este autor establece que interesa analizar los determinantes del crimen para poder identificar las causas y actuar sobre ellas. De aquí, que el diseño de un modelo que facilite explicar relaciones entre diferentes factores de ámbito económico y de eficacia policial, permitiría ofrecer propuestas que colaboren con la predicción y el control de la criminalidad, mediante políticas de intervención pública.

Cantor y Laud ${ }^{16}$ postulan que mucha de la literatura previa en el estudio del crimen no era adecuada, ya que obviaban que existe una relación doble entre crimen y desempleo. Aunque en principio, ante una mayor tasa de desempleo cabe esperar un mayor nivel de criminalidad, también existe otro efecto, ya que se permanece más tiempo en el hogar, con lo que también se reduce la posibilidad de robos y asaltos. Por su parte, Greenberg ${ }^{17}$ critica a los autores anteriores, argumentando que estadísticamente no es posible identificar una relación clara entre ambas variables. Aparentemente sólo se puede concluir que no siempre está claramente identificada la relación este estas variables, ya que va a depender del entorno y de las condiciones en que se realice el análisis.

La relación entre crimen y crecimiento económico puede ser observada desde diferentes ángulos. Buonano et al. ${ }^{18}$ aplican la Curva de Kuznets, ${ }^{19}$ es decir, que la relación entre ingreso y crimen sigue un patrón de U invertida en los Estados Unidos desde 1970: el crimen aumenta con el ingreso hasta alcanzar un nivel máximo, a partir del cual empieza a decrecer. También obtuvieron que los crímenes contra la propiedad tienen más probabilidad de depender de motivaciones económicas que los crímenes violentos, de acuerdo a lo postulado en los modelos clásicos de Becker ${ }^{20}$ y Enrlich. ${ }^{21}$ Pero este resultado muestra cierta ambigüedad, ya que según crece el ingreso, disminuye la necesidad de cometer crímenes. Al mismo tiempo, quienes tienen mayores ingresos son más atractivos para los delincuentes, por lo que un mayor nivel de ingresos motivaría un mayor crimen. Araya y Sierra ${ }^{22}$ observan un traslado de delincuentes desde zonas de alta vulnerabilidad en la Región Metropolitana de Chile a otras de altos índices económicos, mostrando que un mayor crecimiento económico puede no reducir la criminalidad. Levitt ${ }^{23}$ plantea que con el crecimiento económico también crecen las infraestructuras, dotaciones policiales y penitenciarias, lo que debería disuadir al delincuente. En conclusión, la relación de estas variables no está claramente definida, aunque no hay duda de que la tasa de criminalidad en un país sí es afectada por las políticas anticriminales que se establezcan.

La labor policial y judicial tiene una influencia directa en la persuasión al criminal, así como las políticas de reinserción socio-laboral, las que pueden evitar la reincidencia (Fábrega et al. ${ }^{24}$ ). Para el caso de Chile, Rivera et al. ${ }^{25}$ sugieren que existe una doble causalidad separable entre eficiencia policial y criminalidad, y que la eficiencia del poder judicial tiene un efecto disuasorio importante. Además, que una mayor dotación de recursos policiales produce mayor disuasión e incrementa la denuncia de los delitos por parte de las víctimas.

15 MATUS, J. P. ¿Por qué no bajan las tasas de criminalidad en Chile? Revista de Derecho de la Pontificia Universidad Católica de Valparaíso, 26, 2005, pp. 67-92.

16 CANTOR, D.; LAUD, K. C. Unemployment and crime rates in the post World War II United States: A theoretical and empirical analysis. American Sociological Review, 50, 1985, pp. 317-332.

17 GREENBERG, D. F. Time series analysis of crime rates. J. Q. Criminal, 17, 2001, pp. 291-327.

18 BUONANNO, P., FERGUSSON, L.; VARGAS, J. F. The Crime Kurnets Curve. 2014, Documentos

19 KUZNET, S.: Economic growth and income Inequality. The American Economic Review, 45 (1), 1995, pp. 1-28.

20 BECKER, G. Crime and Punishment: An Economic Approach. Journal of Political Economy, 76(2), 1968, pp. 169-217.

21 EHRLICH, I. Participation in Illegitimate Activities: A Theoretical and Empirical Investigation. Journal of Political Economy, 81(3). Estudios de Economía, 1973, 30 (1), pp. 55-85.

22 ARAYA, J.; SIERRA, D. Influencia de factores de riesgo social en el origen de conductas delincuenciales. Serie de Estudios. División de seguridad ciudadana. Ministerio del Interior. Gobierno de Chile, 2002.

23 LEVITT, S. D. Understanding Why Crime Fell in the 1990s: Four Factors that Explain the Decline and Six that Do Not. Financial of Economics Perspectives, 18(1), 2004, pp. 163-190.

24 FÁBregA, J; MORALES, A. M; MUÑOZ, N. Delito y especialización en Cbile. Política criminal, 9(18), 2014, pp. 521-542.

25 RIVERA, J.; NÚÑEZ, J.; VILLAVICENCIO, X. Crimen y disuasión. Evidencia desde un modelo de ecuaciones simultáneas para las regiones de Chile. El Trimestre Económico, 284, 2004, pp. 811-846. 
La acción policial es entonces una variable que influye en el crimen. Algunos estudios han encontrado que esta regla no es generalizable, y que depende de la tipología del crimen (Corman y Mocan ${ }^{26}$, Deadman ${ }^{27}$, y Marvell y Moody ${ }^{28}$. Levitt ${ }^{29}$ postula que se puede considerar que el crimen sería superior con menor vigilancia en lugares públicos. Becker, ${ }^{30}$ Ehnrich ${ }^{31}$ y Imrohoroglu et al. ${ }^{32}$ argumentan que la probabilidad de captura está relacionada inversamente con la tasa de delincuencia, subrayando la importancia de la inversión pública en esta actividad. La relación entre crimen y disuasión ha sido estudiada para el caso chileno por García, ${ }^{33}$ quien obtiene que la relación resultaba inversa entre ambos datos, mientras que en Núñez et al. ${ }^{34}$, a pesar de obtener las mismas conclusiones para delitos económicos (robo, droga y estafa), no coincidió para los delitos pasionales (violación, homicidio y violencia).

Todos los factores mencionados influyen en el desarrollo empresarial de un país o región, ya que las medidas defensivas suponen mayores costos para la empresa, lo que reduce su competitividad, dificulta el acceso a inversión externa, desplaza inversión pública hacia seguridad y lucha contra el crimen.

Como se puede observar, las conclusiones sobre las relaciones entre crimen, desempleo, nivel económico y disuasión no han quedado concluyentemente establecidas en la literatura. El resultado depende, generalmente del método de estudio empleado y de las características del entorno en el que se realice el estudio. Por esto, el presente trabajo presenta un modelo que analiza la relación entre estas variables, con énfasis en los determinantes de la criminalidad en Chile. Para el caso chileno, este estudio supone una innovación en cuanto a metodología, y su contribución radica en incorporar un enfoque estadístico basado en un modelo de rezagos autoregresivos distribuidos (ARDL) ${ }^{35}$ diferente, por ejemplo, a Rivera et al. ${ }^{36}$ quienes emplean ecuaciones simultáneas, o Núñez et al. ${ }^{37}$, que utilizan datos de panel.

El artículo está estructurado de la siguiente manera. Después de esta introducción se explica la metodología empleada. En la siguiente sección se analizan los datos empleados y se muestran los resultados del análisis estadístico, para finalizar con un resumen y conclusiones.

\section{Metodología}

Desde el punto de vista metodológico, el análisis consiste de la formulación y estimación de tres modelos. El primer modelo analiza el crimen en Chile (Gráfico 1) como una función del nivel de desempleo, el crecimiento económico y la disuasión policial, es decir:

26 CORMAN, H.; MOCAN, N. A time-series analysis of crime, deterrence, and drug abuse in New York city. American Economic Review 3, 2000, pp. 584-604.

27 DEADMAN, D. Forecasting residential burglary. International Journal of Forecasting, 19(4), 2003, pp. 567-578.

28 MARVELL, T.; MOODY, C. Specification Problems, Police Levels, and Crime rates. Criminology, 34(4), 1996, pp. 609-646.

29 LEVITT, S. D. Understanding Why Crime Fell in the 1990s: Four Factors that Explain the Decline and Six that Do Not. Financial of Economics Perspectives, 18(1), 2004, pp. 163-190.

30 BECKER, G. Crime and Punishment: An Economic Approach. Journal of Political Economy, 76(2), 1968, pp. 169-217.

31 EHRLICH, I. Participation in Illegitimate Activities: A Theoretical and Empirical Investigation. Journal of Political Economy, 81(3). Estudios de Economía, 1973, 30 (1), pp. 55-85.

32 IMROHOROGLU, A.; MERLO, A.; RUPERT, M. What accounts for the decline in crime? International Economic Review, 45(3), 2004, pp. 707-729.

33 GARCÍA, R. Participación en actividades ilegales: Evidencia empírica del Robo para el caso chileno: Informe final Seminario de Título. Pontificia Universidad Católica de Chile, Instituto de Economía, 1994.

34 NÚÑEZ, J.; RIVERA, J.; VILLAVICENCIO, X.; MOLINA, O. Determinantes socioeconómicos y demográficos del crimen en Chile. Evidencia desde un panel de datos de las regiones chilenas, 2003.

35 ARDL, del inglés Autoregressive Distributed Lag (Modelo de Rezagos Distribuidos). Se trata de una especificación que analiza las relaciones de variables considerando el efecto del tiempo. A los datos de periodos anteriores se los denomina rezagos.

36 RIVERA, J.; NÚÑEZ, J.; VILLAVICENCIO, X. Crimen y disuasión. Evidencia desde un modelo de ecuaciones simultáneas para las regiones de Chile. El Trimestre Económico, 284, 2004, pp. 811-846.

37 NÚÑEZ, J.; RIVERA, J.; VILLAVICENCIO, X.; MOLINA, O. Determinantes socioeconómicos y demográficos del crimen en Chile. Evidencia desde un panel de datos de las regiones chilenas, 2003. 


\section{Crimen Total $=f$ [disuasión policial, crecimiento económico, desempleo $][1]$}

En principio, se esperaría que el crimen disminuyera con mayor disuasión policial (Detotto y Otranto ${ }^{38}$ ), mientras que con el crecimiento económico y el desempleo se puede presentar una relación ambigua, como señalan Detotto y Otranto ${ }^{39}$ o Habibullah y Baharon ${ }^{40}$, quienes aplicaron un modelo ADRL a Malasia, concluyendo que en el largo plazo la economía influye en el crimen, pero no a la inversa. Saridakis ${ }^{41}$ y Mocan et al. ${ }^{42}$ también postulan que la relación entre desempleo y crimen es asimétrica, que un mayor desempleo sí que traía un mayor crimen, aunque ante un descenso del desempleo no se generaba necesariamente una reducción. El crimen podría deberse a varios factores, entre ellos la reinserción social, falta de políticas públicas de prevención, oportunidades laborales o una especialización delictual ${ }^{43}$. Según Morales et al., ${ }^{44}$ existe un incremento de criminales que pueden retornar a la vida cotidiana por faltas de medida disciplinarias y decisiones de tribunales, y aproximadamente un $70 \%$ de los delincuentes será nuevamente formalizado y un $50 \%$ retornará a la cárcel dentro de tres años por una nueva condena. La falta de especialización en un tipo de crimen determinado provoca que cada infractor desarrolle nuevas metodologías delictuales y se favorezca un crecimiento del crimen. Conocer los patrones de especialización delictual permitiría predecir de mejor manera el comportamiento al egreso de la cárcel y facilitar la toma de decisión policial ${ }^{45}$, lo cual podría tener un efecto inverso a la tasa creciente del crimen.

Gráfico 1 - Crimen total en Chile (2001- 2013). Número total de crímenes por año

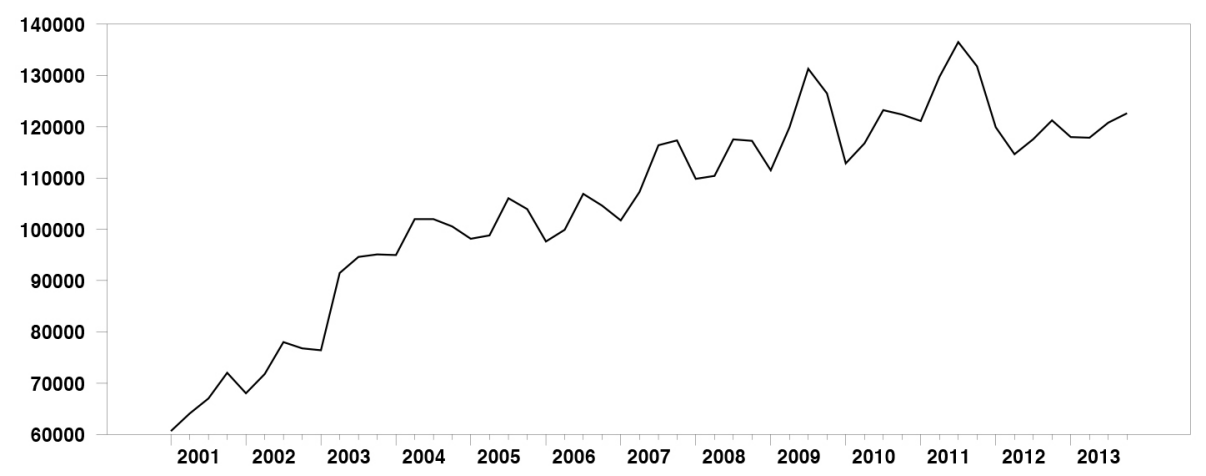

Fuente: Elaboración propia con datos extraídos Ministerio del Interior y Seguridad Pública de Chile

La tasa de disuasión policial en Chile (Gráficos 2 y 3) podría estar afectada por diversos factores, tales como la Reforma Procesal Penal (Ley 19696 del 12 de octubre del 2.000). Con esta ley, adecuada a países desarrollados, la administración de justicia penal es más eficiente y los acusados y víctimas de delitos cuentan con derechos explícitos. Esta nueva normativa podría dar frutos a mediano y/o largo plazo, dado que las conductas y factores socioeconómicos, demográficos, entre otros, no se ajustan inmediatamente.

38 DETOTTO, C.; OTRANTO, E. Cycles in crime and economy: Leading, lagging and coincident behaviours. Journal of Quantitative Criminology, 28, 2012, pp. 295-317.

39 DETOTTO, C.; OTRANTO, E. Does crime affect economic growth?. Kuklos, 63(3), 2010, p. 330-345.

40 HABIBULLAH, M. S; BAHAROM, A. H. Crime and economic conditions in Malaysia. International Journal of Social Economics, 36, 2009, pp. 1071-108.

41 SARIDAKIS, G. Violent crime in the United States of America: a time- series analysis between 1960-2000. European Journal of Law and Economics.18 (2), 2004.

42 MOCAN, N; BILluPS, S.; OVERLAND, J. A Dynamic Model d Differential Human Capital and Criminal Activity. Economica, 72(288), 2005, pp. 655-681.

43 ORTIZ, M.; SEPÚlVEDA, R.; VIANO, C. Análisis de los Programas Jóvenes Infractores de Ley de Prevención, Universidad de Chile, Instituto de Asuntos Públicos, 2005.

44 MORAlES, L.A.; MUÑOZ-DELGADO, J.; SANTILlÁN, A. M., ARENAS, R., PONCE DE LEÓN, F. Perfiles criminológicos: El Arte de Sherlock Holmes en el siglos XXI, 30 (3), 2007, pp. 68-75.

45 FÁBREgA, J; MORALES, A. M; MUÑOZ, N. Delito y especialización en Chile. Política criminal, 9(18), 2014, pp. 521-542. 
Gráfico 2 - Disuasión Policial en Chile (2001- 2013). Total de aprehendidos sobre el total de crímenes por año.

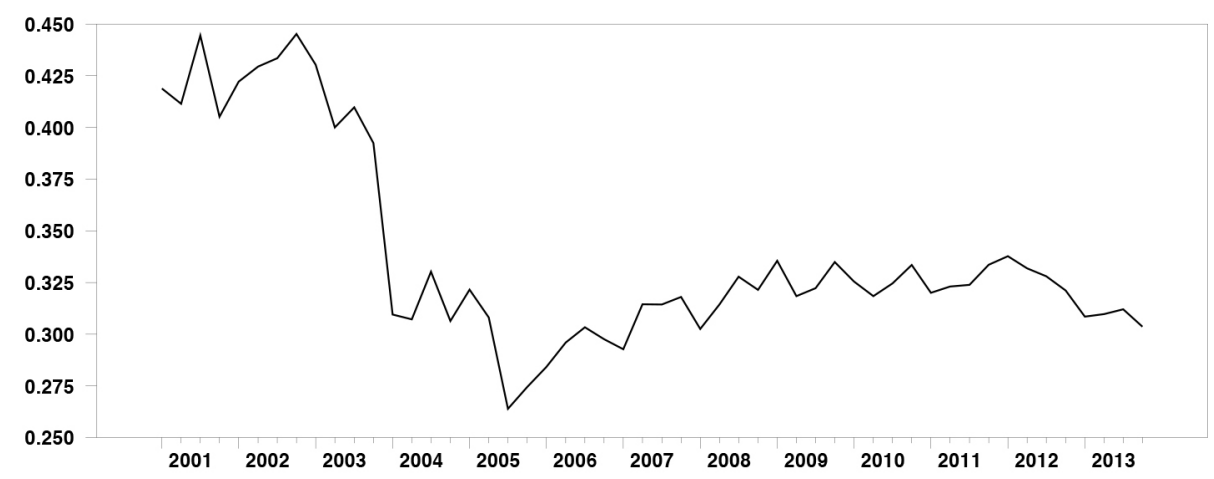

Fuente: Elaboración propia a partir de datos extraídos Ministerio del interior y Seguridad Pública de Chile

Gráfico 3 - Aprehendidos en Chile (2001- 2013).

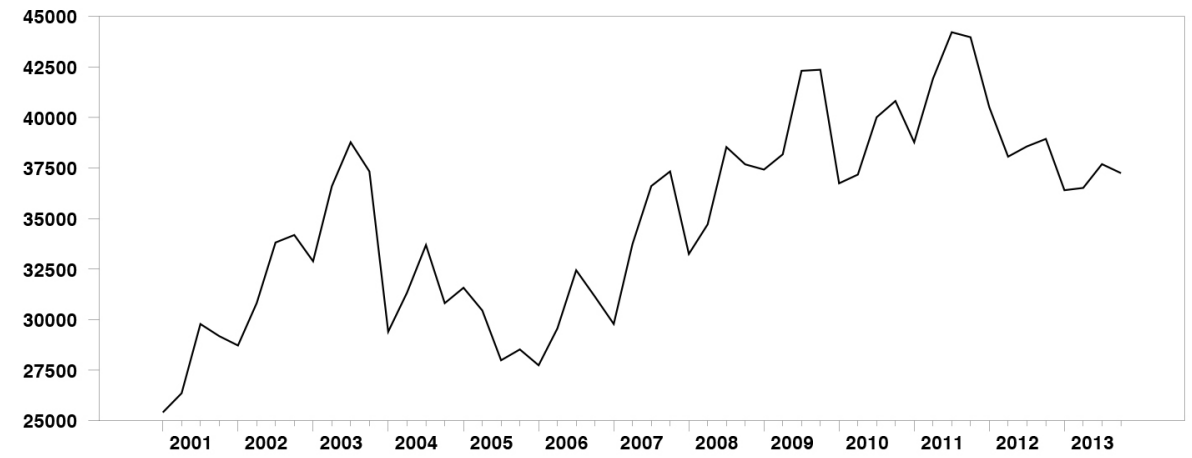

Fuente: Elaboración propia a partir de datos extraídos Ministerio del interior y Seguridad Pública de Chile

El segundo modelo explica el desempleo (Gráfico 4) por parte del crimen y el crecimiento económico, es decir:

En principio, se podría pensar que un mayor crimen traería mayor desempleo, sin embargo, Narayan y Smyth, ${ }^{46}$ con datos de Australia, concluyeron que sólo

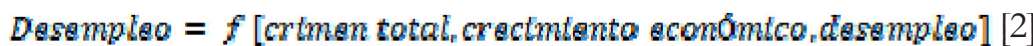

En principio, se podría pensar que un mayor crimen traería mayor desempleo, sin embargo, Narayan y Smyth, ${ }^{47}$ con datos de Australia, concluyeron que sólo algunos delitos (hurtos y robos de autos) causan desempleo en el largo plazo. Mauro, ${ }^{48}$ con un ADRL para Italia, sugiere que el crimen sí que tiene una influencia negativa en el desempleo. Raphael y Winter-Ember ${ }^{49}$ mostraron una relación positiva entre desempleo y crimen (especialmente en delitos contra la propiedad), aunque en otros estudios se defendía que la relación era la contraria (menor desempleo y menor crimen).

46 NARAYAN, P. K.; SMYTH, R. Crime rates, male youth unemployment and real income in Australia: Evidence from Granger causality tests. Applied Economics, 36, 2004, pp. 2079-2095.

47 NARAYAN, P. K.; SMYTH, R. Crime rates, male youth unemployment and real income in Australia: Evidence from Granger causality tests. Applied Economics, 36, 2004, pp. 2079-2095.

48 MAURO, P. Corruption and growth. The Quarterly Journal of Economics, 110, 1995, 681-712.

49 RAPHAEL, S.; WINTER-EMBER, R. Identifying the effect of unemployment on crime, 44 (1), 2001, pp. 259-283. 
Diferentes autores señalan que el desempleo y la tasa de crimen no siempre tienen una relación directa, y que su relación es contradictoria. La profundidad del tema es causa de debate. Modelos estadísticos permiten revelar altas asociaciones entre delito y desempleo (Nagel, ${ }^{50} \mathrm{Jacobs},{ }^{51} \mathrm{Bahl}$ et al. ${ }^{52}$ Carr-Hill y Stern, ${ }^{53}$ y Braith ${ }^{54}$ ). Pero en otros casos aparecen disociaciones casi completas, con correlaciones y regresiones no significativas (Fox, ${ }^{55}$ Long y Witte, ${ }^{56}$ Orsagh,${ }^{57}$ Cantor y Laud, ${ }^{58}$ Wilson y Cook,,${ }^{59}$ Wilson y Hernstein ${ }^{60}$ ).

Gráfico 4 - Desempleo en Chile (2001-2013). Variación por trimestre de la desocupación nacional.

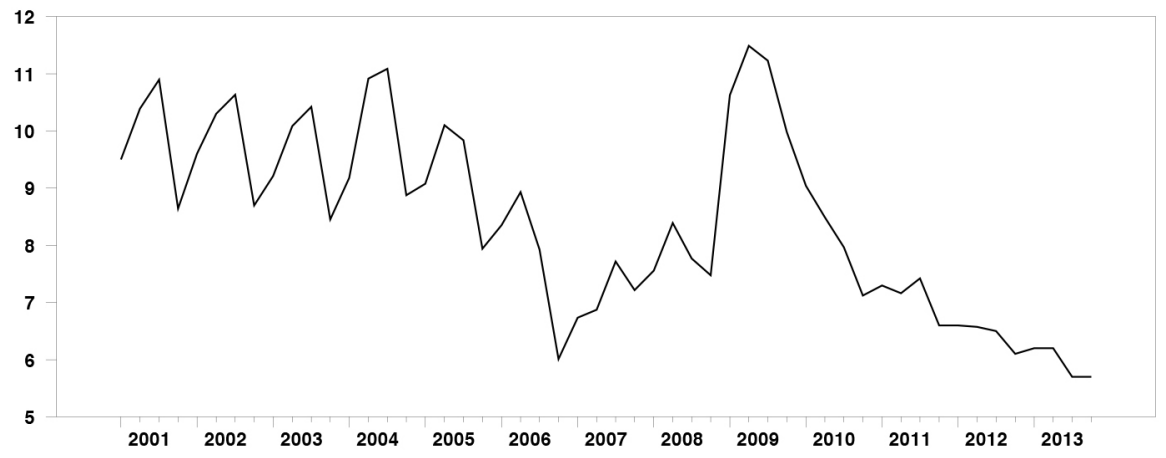

Fuente: Elaboración propia con datos extraídos de Banco Central de Chile

El tercer modelo busca analizar la influencia del crimen y el desempleo en el crecimiento económico (gráfico 5), es decir:

\section{Cractmianto aconómico $=f$ [ontmen total desampleo, oractm. aconómico] [3]}

En este caso, se espera una influencia inversa (Núñez et al.). ${ }^{61}$ Un mayor crimen o un mayor desempleo parecen reducir el crecimiento económico, aunque no todos los estudios coinciden con este resultado (Chen). ${ }^{62}$ La incertidumbre económica en un país podría afectar significativamente a esta variable por varios motivos, entre ellos un alto índice de criminalidad y delincuencia. Esto podría influir en la decisión de un inversionista al decidir exigir mayor rentabilidad por las inversiones y a buscar alternativas más seguras.

50 NAGEL, J. Crime and Incarceration: A Reanalysis, Fels Discussion Paper No12. Philadelphia, University of Pensylvania, School of Public and Urban Policy, 1977.

51 JACOBS, D. Inequality and Police Strength: Conflict Theory and Coercive Control in Metropolitan Areas, American Sociological Review, 44, 1979.

52 BAHL, R; GUSTLEY, R; WASYLENKO, M. The Determinants of Local Government Police Expenditures: A Public Employment Approach, National Tax Journal, 1978.

53 CARR-HILL, R; STERN, N. Crime, the Police and Criminal Statistics. New York, Academic Press, 1979.

54 BRAITH, J. Inequality, Crime and Public Policy Londres, Routledge and Kegan Paul, 1979.

55 FOX, J. Forcasting Crime Data. Lexington, Lexington Books, 1978.

56 LONG, S; WITTE, A. Current Economic Trends: Implications of Crime and Criminal Justice, en Kevin Wright (comp.): Crime and Criminal Justice in a Declining Economy Cambridge, MA, Oelgeschlager, Gunn and Hein, 1981.

57 ORSAGH, T. Unemployment and Crime: An Objection to Professor Brenner's View. Journal of Criminal Law and Criminology, $\mathrm{N}^{\circ} 71$, 1980.

58 CANTOR, D.; LAUD, K. C. Unemployment and crime rates in the post World War II United States: A theoretical and empirical analysis. American Sociological Review, 50, 1985, pp. 317-332.

59 WILSON, J; COOK, P. Unemployment and Crime -What is the Connection”. The Public Interest, No 79, 1985.

60 WILSON, J; HERNSTEIN, R. Crime and Human Nature. Nueva York, Simon and Schuster, 1985.

61 NÚÑEZ, J.; RIVERA, J.; VILLAVICENCIO, X.; MOLINA, O. Determinantes socioeconómicos y demográficos del crimen en Chile. Evidencia desde un panel de datos de las regiones chilenas, 2003.

62 CHEN, S. W. Investigating causality among unemployment, income and crime in Taiwan: Evidence from the bounds test approach. Journal of Chinese Economics and Business Studies, 7, 2009, pp. 115-125. 
Gráfico 5 - PIB en Chile (2001-2013). A precios del año anterior, series empalmadas, referencia 2008 (millones de pesos encadenados).

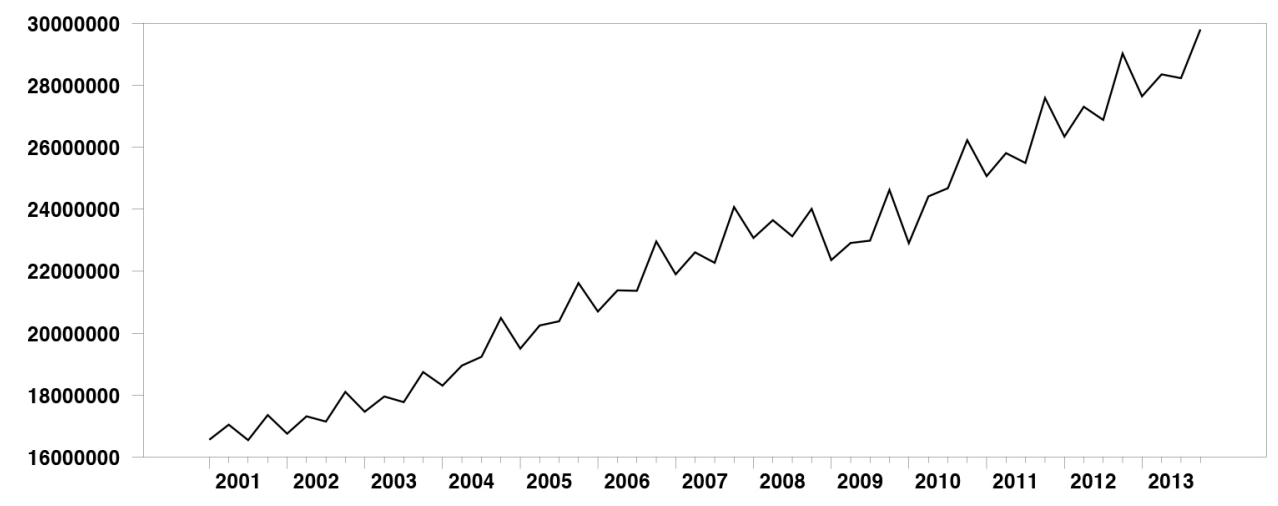

Fuente: Elaboración propia a partir de datos extraídos del Banco Central Chile

La Figura 1 ilustra la forma en que los tres modelos se interrelacionan entre sí. El Modelo 1 (M1) postula que el crimen es explicado por el desempleo, la disuasión y el crecimiento económico. El Modelo 2 (M2) postula que el desempleo es explicado por el crecimiento económico y el crimen. El Modelo 3 (M3) postula que el crecimiento económico es explicado por el desempleo y el crimen. En todos los casos es posible que se incorpore como variable explicativa alguna de las variables del periodo previo en la forma de rezagos.

Figura 1 - Interelaciones de los tres modelos (M1, M2 y M3) empleados para relacionar crimen, disuasión policial, crecimiento económico y desempleo

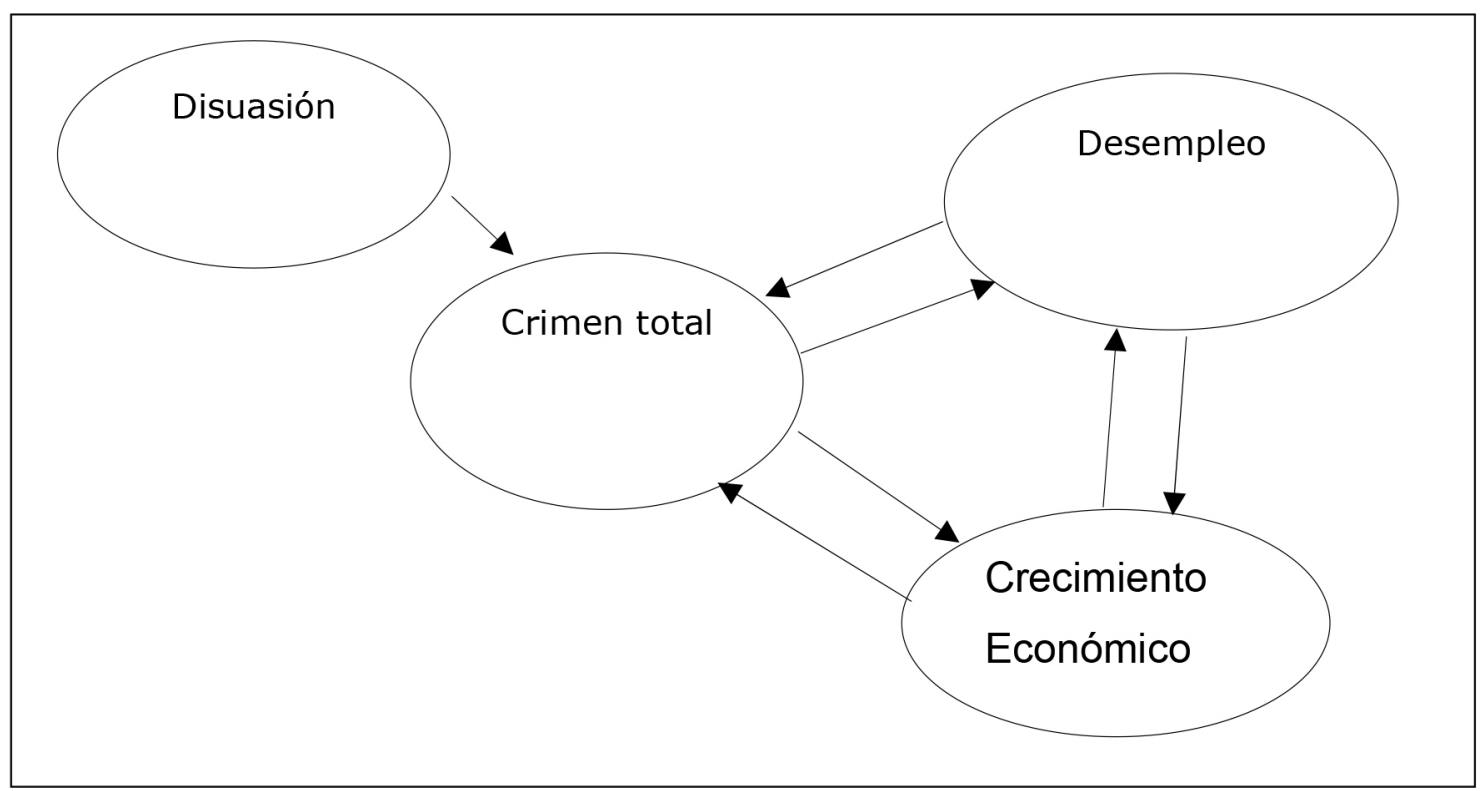

Fuente: Elaboración propia

La Figura 2, muestra las tres etapas del proceso que se ha seguido para lograr los resultados finales del estudio, implementando ARDL y detectando las relaciones de causalidad entre las variables de interés. 
Figura 2 - Pasos seguidos para relacionar crimen, disuasión policial, crecimiento económico y desempleo

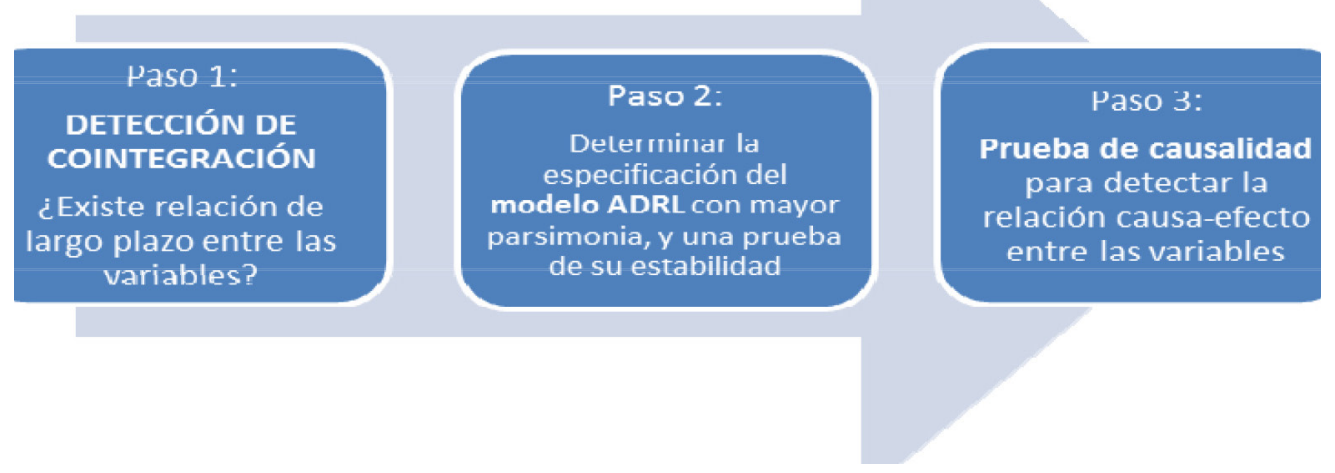

Fuente: Elaboración propia

El primer paso consistió en determinar la existencia de cointegración entre las variables de acuerdo a Pesaran el at. ${ }^{63}$ La hipótesis nula es H0: no existe cointegración. Si se rechaza la hipótesis al nivel de significancia convencional, se concluiría que no existe relación entre las variables a lo largo del tiempo.

El segundo paso consistió en determinar la especificación ARDL con mayor parsimonia, utilizando para ello el criterio $\mathrm{SBC}^{64}$. Esto consiste en ir variando el número de rezagos en la ecuación $(4)^{65}$ hasta obtener el mejor ajuste en cada modelo. Pesaran et al. ${ }^{66}$ utilizan una representación ARDL ${ }^{67}$, que en algunas situaciones es preferible a los métodos más convencionales de análisis de series con posible cointegración, tales como Engle y Granger, ${ }^{68}$ Gregory y Hans ${ }^{69}$ y Johansen ${ }^{70}$. Una ventaja del enfoque de Pesaran et al. ${ }^{71}$ y de Pesaran y $\mathrm{Shin}^{72}$ es que requiere solo de una ecuación para especificar el modelo, haciéndolo más fácil de implementar e interpretar. Además, permite considerar diferentes duraciones de los rezagos en las variables del modelo. Se completa este paso con un test CUSUM de estabilidad de los parámetros, ${ }^{73}$ lo que permite validar tales

63 PESARAN, M. H.; SHIN, Y.; SMITH, R. Bounds testing approaches to the analysis of level relationships. Journal of Applied Econometrics, 16, 2001, pp. 289-326. Los autores proponen una prueba F para los coeficientes de la ecuación (4), la que permite concluir si existe

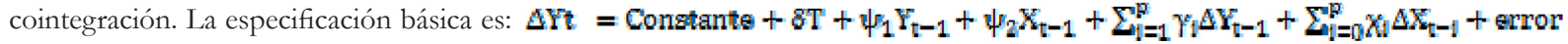
(4) donde $\Delta$ es la tasa de crecimiento de la variable; T es una tendencia temporal, p es el número de rezagos temporales; $\Psi_{i}, y_{i}, x_{i}$ son los parámetros y se completa con el término de error.

64 El criterio SBC (del inglés Schwartz Bayesian Criteria) permite la selección de un modelo, entre un número finito de ellos, considerando el número adecuado de parámetros, para no tener un error en la relación de las variables que origine un modelo con pobre poder predictivo.

65 Véase PESARAN, M. H.; SHIN, Y.; SMITH, R. Bounds testing approaches to the analysis of level relationships. Journal of Applied Econometrics, 16, 2001, pp. 289-326.

66 PESARAN, M. H.; SHIN, Y.; SMITH, R. Bounds testing approaches to the analysis of level relationships. Journal of Applied Econometrics, 16, 2001, pp. 289-326.

67 La especificación ARDL de Pesaran et al. está recomendada cuando el número de datos es limitado, como es en el caso de las series que se emplean en este estudio.

68 ENGLE, R. F.; GRANGER, W. J. Co-integration and Error Correction: Representation, Estimation and Testing, Econometric, 55(2), 1987, pp. 251-276.

69 GREGORY, A. W.; HANS B. E. Practitioners Corner Tests for Cointegration in Models with Regime and Trend Shifts. Oxford Bulletin of Economics and Statistics, 58, 1996.

70 JOHANSEN, S. Statistical Analysis of Cointegrating Vectors. Journal of Economic Dynamics and Control, 12(1), 1988, pp. 231-254.

71 PESARAN, M. H.; SHIN, Y.; SMITH, R. Bounds testing approaches to the analysis of level relationships. Journal of Applied Econometrics, 16, 2001, pp. 289-326.

72 PESARAN M. H.; SHIN, Y. An autoregressive distributed lag modelling approach to cointegration analysis. Chapter 11 in Econometrics and Economic Theory in the 20th Century: The Ragnar Frisch Centennial Symposium, Strom S (ed.). Cambridge University Press: Cambridge, 1999.

73 CUSUM viene del inglés "Cumulative Sum" o suma acumulada. Este test se emplea para determinar los cambios en los coeficientes con el paso del tiempo. 
estimaciones y, sugiriendo que pueden utilizarse para hacer predicciones futuras. La hipótesis nula es H0: los coeficientes son estables.

El paso final consistió en una prueba de causalidad de Granger del modelo de regresión en que se obtuvieron los mejores resultados de entre los pasos anteriores. La prueba consiste en comprobar si los resultados de una variable sirven para predecir los resultados de otra variable. Se trata de una prueba F donde se comparan diferentes especificaciones en los modelos, observando los errores. Detotto y Pulina; ${ }^{74}$ Greenberg; ${ }^{75}$ Witt y Witte; ${ }^{76} \mathrm{O}$ Brien; ${ }^{.7}$ Scorcu y Cellini ${ }^{78}$ han analizado la cointegración entre crimen y otras variables. Narayan y $\mathrm{Smyth}^{79}$ han combinado cointegración con el análisis de la causalidad de Granger.

\section{Resultados}

Las variables analizadas en este estudio son crimen total, disuasión policial, desempleo y crecimiento económico, con datos trimestrales, para el periodo 2001-2013. El crimen total considera todos los tipos de crímenes calculados por el Ministerio del Interior y Seguridad Pública de Chile: robos, hurtos, lesiones, homicidios y violaciones. La variable disuasión policial se calculó como el cociente entre los datos de aprehendidos sobre el total de crímenes denunciados (Ministerio del Interior y Seguridad Pública de Chile). La tasa de desempleo fue calculada como el cociente entre el desempleo y la fuerza laboral. El crecimiento económico se midió por la variación del PIB (Banco Central de Chile). Para eliminar efectos estacionales se calculan variaciones de los datos de un trimestre respecto del mismo trimestre del año anterior (se trabaja con variaciones para el caso de las variables dependientes, Y). Adicionalmente, debido a que las series contienen tendencias temporales, se trabajó con los logaritmos naturales de las variables.

A partir de estos datos se estimaron los tres modelos, siguiendo de cerca el enfoque de Detotto et al. ${ }^{80}$ Como es posible que una variable esté influenciada por periodos anteriores (rezagos), se analizó cuánto tardan las variables en adaptarse a dichos cambios, sea debido a la influencia de la misma variable o por otras. Si hay un rezago, quiere decir que un efecto relevante en la variable ocurre en el trimestre anterior. Para cada uno de los modelos se corrieron diferentes regresiones, con distintas especificaciones, modificando en número de variables explicativas (k) y el número de rezagos (p), buscando el mejor ajuste.

Tabla 1 - Resumen de resultados de las pruebas de cointegración

\begin{tabular}{|c|c|}
\hline MODELO (Variable independiente) & Especificación \\
\hline Modelo 1: Crimen Total & $\mathrm{k}=7 ; \mathrm{p}=0, \mathrm{~F}=6.72 \mathrm{p}$-value $=0.00003$ \\
\hline Modelo 2: Desempleo & $\mathrm{k}=5 ; \mathrm{p}=0 \mathrm{~F}=5.68 \mathrm{p}$-value $=0.0024$ \\
\hline Modelo 3: Crecimiento Económico & $\mathrm{k}=7 ; \mathrm{p}=1 \mathrm{~F}=3.71 \mathrm{p}$-value $=0.021$ \\
\hline
\end{tabular}

74 DETTOTO, C.; PULINA, M. Does more crime mean fewer Jobs and less economic growth? European Journal of Law and Economics, 36(1), 2012, pp. 183-207.

75 GREENBERG, D. F. “Time series”, cit. nota n’ 17.

76 WITT, R.; WITTE, A. Crime, prison and female labour supply. Journal of Quantitative Criminology. 16 (1), 2000 , pp. $69-85$. 77 O'BRIEN, R. Measuring the convergence/divergence of serious crime arrest rates for males and females: 1960 -1995. Journal of Quantitative Criminology, 15, 1999, pp. 97-114.

78 SCORCU, A. E.; CELLINI, R. Economic activity and crime in the long run: An empirical investigation on aggregate data from Italy, 1951-1994. International Review of Law and Economics, 18, 1998, pp. 279-292.

79 NARAYAN, P. K.; SMYTH, R. Crime rates, male youth unemployment and real income in Australia: Evidence from Granger causality tests. Applied Economics, 36, 2004, pp. 2079-2095.

80 DETOTTO, C.; OTRANTO, E. Does crime affect economic growth?. Kuklos, 63(3), 2010, p. 330-345. 
Tabla 2 - Especificación del modelo ARDL resumida. Variables consideradas y signos de la relación entre ellas.

\begin{tabular}{|c|c|c|c|}
\hline MODELO & VARIABLES EXPLICA' & IIVAS & \\
\hline Modelo 1: Crimen Total & (-) Disuasión Policial(4)* & $\begin{array}{l}(+) \text { Crecimiento } \\
\text { Económico }(3)^{*}\end{array}$ & (+) Desempleo(5)* \\
\hline Modelo 2: Desempleo & (-) Crimen Total (3)* & $\begin{array}{l}(+) \text { Crecimiento } \\
\text { Económico }(2)^{*}\end{array}$ & (-) Desempleo(2)* \\
\hline $\begin{array}{l}\text { Modelo 3: Crecimiento } \\
\text { Económico }\end{array}$ & (-) Crimen total (2) & $(+)$ Desempleo $(1)^{*}$ & $\begin{array}{l}(+) \text { Crecimiento } \\
\text { Económico }(1)^{*}\end{array}$ \\
\hline
\end{tabular}

Nota: El signo representa una relación positiva (+) o negativa (-) de la variable considerada y la variable independiente de cada modelo.

Los valores entre paréntesis indican el número de rezagos de la misma en el modelo ((4) quiere decir que presenta el valor de la variable en cuestión 4 trimestres antes)).

* Indica que la hipótesis nula de que las variables $\mathrm{X}$ explican a la variable $\mathrm{Y}$, basada en test $\mathrm{F}$ al 5\% de significancia, ha sido rechazada.

Fuente: Elaboración propia

Tabla 3 - Resultados del Test de Causalidad de Granger

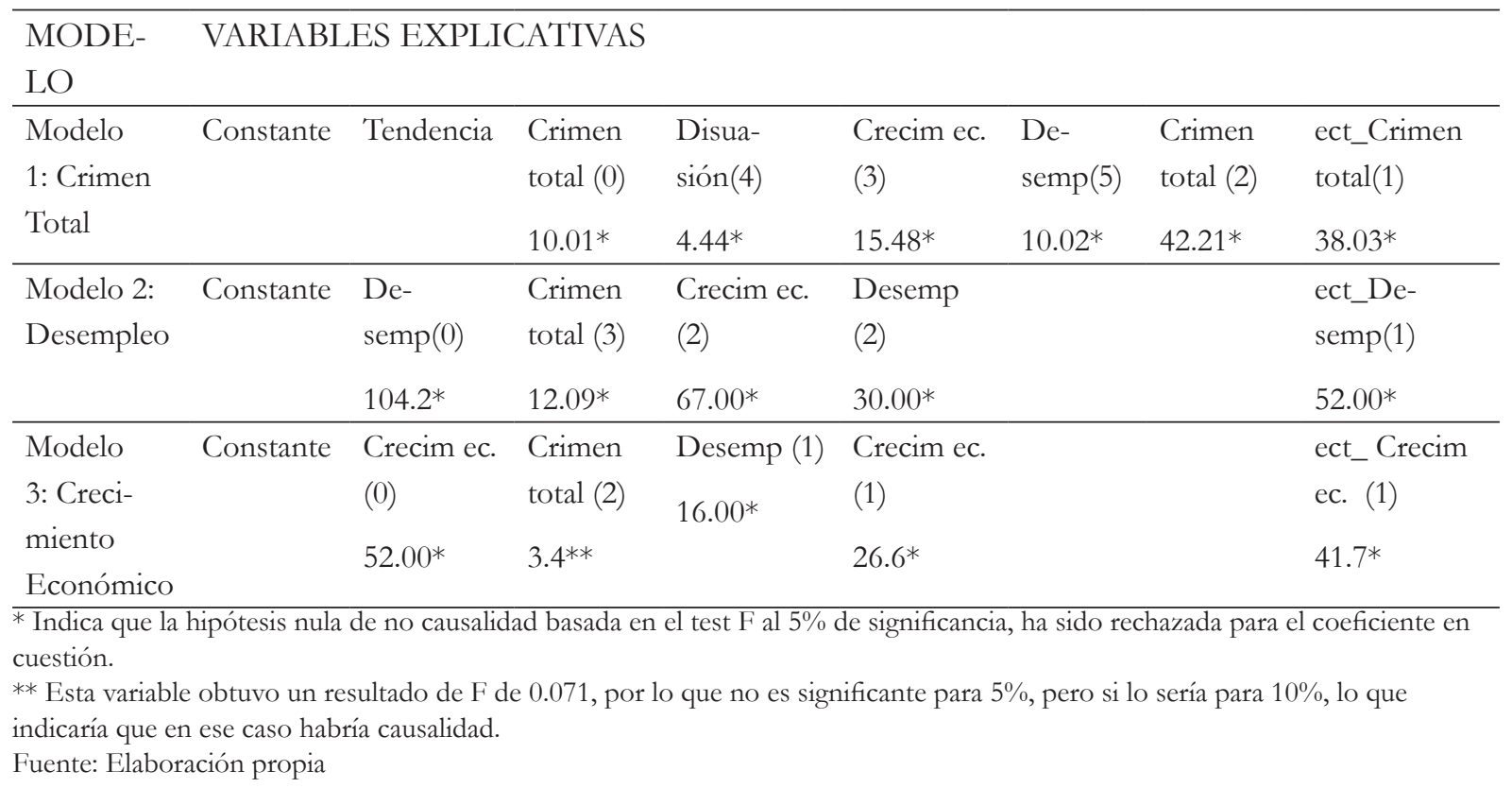

De acuerdo a la Figura 2, el primer paso consistió en determinar si existe cointegración. La Tabla 1 muestra la especificación que arrojó mayor parsimonia y, en cada caso, la cantidad de variables explicativas (k) y de rezagos (p) considerados. La Tabla 1 también muestra el valor de la prueba F y la significancia de esta prueba. El número de rezagos empleados en la búsqueda y referidos a la especificación general ARDL fueron $\mathrm{p}=1$ y 2 , para la variable independiente $(\mathrm{Y})$, y $\mathrm{p}=0,1$ y 2 para las variables explicativas $(\mathrm{X})$. Se varían los rezagos para 12 casos (4 casos para cada uno de los 3 modelos), eligiendo la especificación en base al criterio de parsimonia SBC. Si hay cointegración indica que las variables muestran una relación de largo plazo.

La tabla 1 muestra cual fue la especificación con mayor parsimonia (con el número óptimo de variables y rezagos) para cada uno de los tres modelos. En el caso del Modelo 1, la variación del crimen total es explicada por seis variables y siete $(\mathrm{k})$ parámetros: una constante, una tendencia, el nivel de crimen del mismo periodo, la disuasión policial ejercida cuatro trimestres antes, el crecimiento económico de tres trimestres previos, el nivel de desempleo de cinco trimestres anteriores, la variación en el nivel de crimen, de dos trimestres anteriores, y finalmente, un término de corrección de errores (ect, error correction term), que ha sido 
incluido debido a que para este modelo fue detectada la existencia de cointegración. Para los Modelos 2 y 3 , se utilizan cinco y siete parámetros respectivamente. La tabla también muestra que solo en el caso del Modelo 3 fue necesario incluir la variable explicada (cambio en el crecimiento económico) rezagada un periodo $(\mathrm{p}=1)$. Los estadísticos F y sus p-values indican que las estimaciones de los tres modelos fueron satisfactorias, desde el punto de vista estadístico.

El objetivo del segundo paso es encontrar los tres modelos ARDL con mayor parsimonia, una vez que ya se sabe si existe o no cointegración en cada modelo. Esto implica definir el número correcto de rezagos para cada relación de variables, incluyendo el término corrección errores. La Tabla 2 reporta, en general, modelos bien ajustados, debido a que en casi todos los casos las variables explicativas $(\mathrm{X})$ asociadas a cada modelo resultan explicar individualmente el comportamiento de la variable $\mathrm{Y}$ en cada uno de los tres modelos. Los signos y significancia de cada uno de los coeficientes de estas variables X en la especificación final se muestran en la tabla. El asterisco indica que el parámetro asociado a la variable que corresponde ha sido estimado confiablemente al 5\%. En el Modelo 3, sin embargo, existe una sola variable, el crimen total de dos periodos anteriores (LTC2), que no es confiable al 5\%, aunque si lo es al 10\%. Respecto a los signos de los coeficientes, casi todos los signos coinciden con lo que se podía esperar al comienzo del estudio, como se analiza a continuación.

En el primer modelo, el crimen aparece inversamente relacionado con la tasa de disuasión policial. Especialmente resulta representativa la disuasión en el periodo de un año antes (rezago de cuatro trimestres). Esto podría explicarse por varios factores como la falta de inversión y ejecución de políticas públicas eficientes anti-crimen. Según Rivera et al. ${ }^{81}$ "una mayor dotación de recursos policiales produce mayor disuasión e incrementa la denuncia de los delitos por parte de las víctimas". El modelo también muestra una relación positiva del crimen con el desempleo (especialmente con el rezago de 5 trimestres), lo que significa que ante un incremento del nivel de desempleo, la tasa de crimen aumenta. Sin embargo, el crecimiento económico no se ajusta a lo esperado, ya que el modelo muestra una relación positiva entre este crecimiento y el crimen. En principio, cabría esperar que un mayor crecimiento económico provocara un descenso del crimen, pero no se muestra así. Este resultado no ha sido un caso aislado, ya que ha aparecido en otros estudios, como el de Araya y Sierra ${ }^{82}$ en la Región Metropolitana. En éste se señala que ante un mayor crecimiento económico no tiene porqué reducirse la criminalidad, dado que los delincuentes se trasladan hacia zonas de alto nivel económico. Esta explicación no coincide con otros trabajos como Levitt, ${ }^{83}$ quien concluye que con el crecimiento económico también crecen las infraestructuras, las dotaciones policiales y penitenciarias, lo que debería disuadir al delincuente. Una explicación a esta ambigüedad podría ser, por un lado, según crece el ingreso, el costo de oportunidad de cometer crímenes cae, pero al mismo tiempo, los que tienen mayores ingresos son más atractivos para los delincuentes, por lo que el mayor nivel de ingresos sí provocaría un mayor crimen.

En el segundo modelo (Tabla 2), la tasa de crimen muestra una relación inversa (en el segundo rezago de tres trimestres) con el desempleo. Por su parte, la variable crecimiento económico (rezagada dos trimestres) no parece ajustarse a las expectativas, ya que muestra una variación positiva, es decir, que un mayor crecimiento económico iría ligado a una mayor tasa de desempleo. Becker ${ }^{84}$ señalaba que la relación entre desempleo y crecimiento económico podía mostrar distintos efectos, debido a diferentes situaciones puntuales, como la desigualdad económica o social, el género, la raza, edad, nivel educativo y condiciones del entorno físico. La tercera variable indica que el desempleo en periodos previos también influye en la variable desempleo.

81 RIVERA, J.; NÚÑEZ, J.; VILLAVICENCIO, X. Crimen y disuasión. Evidencia desde un modelo de ecuaciones simultáneas para las regiones de Chile. El Trimestre Económico, 284, 2004, pp. 811-846.

82 ARAYA, J.; SIERRA, D. Influencia de factores de riesgo social en el origen de conductas delincuenciales. Serie de Estudios. División de seguridad ciudadana. Ministerio del Interior. Gobierno de Chile, 2002.

83 LEVITT, S. D. Understanding Why Crime Fell in the 1990s: Four Factors that Explain the Decline and Six that Do Not. Financial of Economics Perspectives, 18(1), 2004, pp. 163-190.

84 BECKER, G. Crime and Punishment: An Economic Approach. Journal of Political Economy, 76(2), 1968, pp. 169-217. 
En el tercer modelo, el modelo de crecimiento económico (Tabla 2), la tasa de crimen muestra una relación inversa, lo que indica que un mayor nivel de crimen va a suponer un descenso en el crecimiento económico. Esta relación podría deberse a con mayor crimen, se requiere un desvío de fondos hacia mayor inversión en seguridad social, gasto policial, seguros, dejándose de lado las inversiones en infraestructura, salud o educación, e incluso reduciéndose la inversión extranjera, por transmitir imagen de inseguridad. Por su parte, el desempleo muestra una relación positiva (con un rezago) con el crecimiento económico, lo que indica que un aumento en el desempleo (en el trimestre anterior) afecta positivamente al crecimiento económico. Esto permite inferir que este cambio podría deberse a la redistribución de riqueza, o bien, a la participación de los gobiernos en desarrollar políticas eficientes para el crecimiento económico, pero deficientes en cuanto a la generación de nuevos empleos. Una posible explicación complementaria a algunos signos no esperados en las ecuaciones anteriores, puede surgir por interrelaciones mutuas entre los modelos, lo que podría implicar un problema de identificación en un sistema de ecuaciones estructurales, dificultando la predicción de todos los datos.

Con las especificaciones anteriores, para verificar la calidad de los modelos, se terminó el paso 2 con la prueba Cusum de estabilidad de parámetros. Este test mostró que para los tres modelos anteriores los parámetros son estables, es decir, la hipótesis nula que H0: los coeficientes son estables, no pudo ser rechazada en ninguno de los tres modelos. Los resultados particulares de este test no son reportados aquí.

En el paso 3, y último, se realizó el test de causalidad de Granger. Para esto, lo que se hace es estimar un modelo que incluye una cierta variable explicativa, reestimar ese mismo modelo pero sin dicha variable, $y$ comparar los resultados globales de ambas regresiones (incluyendo la variable en cuestión vs. excluyéndola). Se trata, entonces, de una prueba F de exclusión. La Tabla 3 presenta los resultados para cada variable explicativa, en cada uno de los tres modelos. Lo que se reporta en cada caso es el valor y significancia de la prueba F. Con asterisco se indica las variables que estadísticamente causan a la variable Y de cada uno de los tres modelos.

Como resultado, en el modelo de crimen todas las variables, por separado, resultan causar significativamente el crimen (Tabla 3). En el caso del modelo de desempleo se cumple lo mismo, es decir, todas las variables causan el desempleo. Sin embargo, en el modelo crecimiento, la única variable que no lo causa es el crimen total. Estos resultados parecen coincidir con los obtenidos en Núñez et al. ${ }^{85}$ en cuanto a las relaciones directas entre tasa de desempleo y eficiencia policial, pero también con numerosos estudios nacionales e internacionales que presentan, con diferentes metodologías, resultados mixtos, a menudo contradictorios, como Torruam y Abur, ${ }^{86}$ Alkimima, ${ }^{87}$ Hald ${ }^{88}$ Sachsida et al., ${ }^{89}$ Narayan y Smyth, ${ }^{90}$ Rivera et al., ${ }^{91}$ Papps y Winkelmann. ${ }^{92}$ En efecto, el resultado del análisis de causalidad y de signos, en el paso dos, parecen apuntar en reforzar las hipótesis básicas e intuitivas a cerca de relaciones, hasta cierto punto esperadas, en tres estas tres variables. Sin embargo, los resultados muestran también el surgimiento de otras relaciones que si bien,

85 NÚÑEZ, J.; RIVERA, J.; VILLAVICENCIO, X.; MOLINA, O. Determinantes socioeconómicos y demográficos del crimen en Chile. Evidencia desde un panel de datos de las regiones chilenas, 2003.

86 TORRUAM, J.; ABUR, C. The Relationship between Unemployment, Inflation and Crime: An Application of Cointegration and Causality Analysis in Nigeria. Journal of Economics and Sustainable Development, 5(4), 2014.

87 ALKIMIMA, A.; CLARKEB K. C.; OLIVEIRAC F. S. Fear, crime, and space: The case of Viçosa, Brazil. Applied Geography, 42, 2005, pp. 124-132.

88 HALD, A. The Rockwool Foundation Research Unit Unemployment and crime: Experimental evidence of the causal effects of intensified ALMPs on crime rates among unemployed individuals. Signe University Press of Southern Denmark. Odense, 2012. 89 SACHSIDA, A.; CARDOSO DE MENDONÇA, M. J.; LOUREIRO, P. R. A.; SARMIENTO, M.B. (2009). Inequality and criminality revisited: further evidence from Brazil. Empir Econ 39, 93-109.

90 NARAYAN, P. K.; SMYTH, R. Crime rates, male youth unemployment and real income in Australia: Evidence from Granger causality tests. Applied Economics, 36, 2004, pp. 2079-2095.

91 RIVERA, J.; NÚÑEZ, J.; VILLAVICENCIO, X. Crimen y disuasión. Evidencia desde un modelo de ecuaciones simultáneas para las regiones de Chile. El Trimestre Económico, 284, 2004, pp. 811-846.

92 PAPPS, K. L.; WINKELMANN. Unemployment and crime: New evidence for an old question. IZA and Centre for Economic Policy Research, 1999, pp. 1-16. 
pueden no ser esperadas, si son soportadas por los análisis estadísticos aquí mostrados. Esto no es sorprendente, por cuanto, como se ha mencionado, un importante cuerpo de literatura extranjero lo corrobora. Lo interesante en este estudio es haber encontrado evidencias del surgimiento de estas relaciones, para el caso chileno reciente.

\section{Resumen y CONCLUSIONES}

América Latina y África tienen las mayores tasas de delincuencia entre las regiones del mundo (Schmidt- Hebbel $^{93}$ ). Aunque Chile aún tiene bajas las tasas de homicidio, no lo son las de robos y hurtos menores, en relación con el resto de América Latina. Este hecho se ha convertido en un problema primordial desde el punto de vista social, ya que se sigue incrementando, con una tendencia creciente en los delitos y sus secuelas en los últimos años, lo que ha hecho que en las encuestas de opinión pública el crimen se haya convertido en una de las principales preocupaciones de los chilenos.

La evidencia científica muestra diferentes motivos por los que la delincuencia podría disminuir, tal como el crecimiento económico, la eficiencia judicial y policial, la prevención social o el bienestar social. En cambio, la delincuencia aumentaría por motivos como el tráfico de estupefacientes, el desempleo, la violencia, la desigualdad social, la concentración del ingreso o el tamaño de las ciudades. En estos casos, la delincuencia tiene costos directos. Schmidt-Hebbe ${ }^{94}$ estima que los costos directos de la delincuencia equivalen al 2,2\% del PIB de Chile. También existen costos indirectos adicionales, psicológicos y sociales, ya que se destruye la confianza del individuo, el ahorro, el emprendimiento y el ocio, reduciendo la calidad de vida y el crecimiento económico. Estos motivos son suficientes para justificar el estudio de esta materia.

El conocimiento de las relaciones entre crimen y crecimiento económico es reducido y, específicamente para el caso chileno, existen referencias (Cea et al., ${ }^{95}$ ) y estudios econométricos (De la Fuente ${ }^{96}$ ) al respecto. Por ello, el presente trabajo se considera un aporte al estudio de los determinantes de la criminalidad en Chile. El trabajo supone una innovación en cuanto a la metodología para el caso chileno, debido a que se utiliza una especificación ARDL (Auto Regresive Distributed Lags) según Pesaran ${ }^{97}$. Se analizaron tres modelos que buscaron relaciones de causalidad mutuas. El primer modelo buscó explicar el crimen mediante disuasión (eficacia policial), crecimiento económico y nivel de desempleo. En este modelo, los resultados muestran que una menor disuasión policial y un mayor desempleo originan un incremento del crimen. Sin embargo, el signo del crecimiento económico que mejor se ajusta al modelo, con 3 trimestres de anterioridad, indicaría que un mayor crecimiento trae un aumento del desempleo. Este resultado no coincide con las expectativas, y otros estudios no ofrecen los mismos signos en las relaciones de las variables. Estos pueden verse influenciados por el entorno en el que se realiza el estudio y la metodología empleada. En Araya y Sierra ${ }^{98}$, basado en la Región Metropolitana, se señala que ante un mayor crecimiento económico no tiene porqué reducirse la criminalidad, dado que los delincuentes se trasladan hacia zonas de alto nivel económico;

93 SCHMIDT-HEBBEL, K. "La tasa de victimización en Chile es muy alta... Eso significa que en esa dimensión somos una sociedad enferma”. La Tercera, ed. Impresa. 24 de junio de 2012.

94 SCHMIDT-HEBBEL, K. "La tasa de victimización en Chile es muy alta... Eso significa que en esa dimensión somos una sociedad enferma”. La Tercera, ed. Impresa. 24 de junio de 2012.

95 CEA, M.; RUIZ, P.; MATUS, J. P. Determinantes de la criminalidad: Revisión bibliográfica. Informe final Seminario de Título. Pontificia Universidad Católica de Chile, Instituto de Economía, 2 (4), 2006, pp. 1-34.

96 DE LA FUENTE, H.; MEJÍAS, C.; CASTRO, P. Análisis econométrico de los determinantes de la criminalidad en Chile. Política Criminal, 6(11), 2011, pp. 192-208.

97 PESARAN, M. H.; SHIN, Y.; SMITH, R. Bounds testing approaches to the analysis of level relationships. Journal of Applied Econometrics, 16, 2001, pp. 289-326.

98 ARAYA, J.; SIERRA, D. Influencia de factores de riesgo social en el origen de conductas delincuenciales. Serie de Estudios. División de seguridad ciudadana. Ministerio del Interior. Gobierno de Chile, 2002. 
aunque esto difiere de otros trabajos como Levitt, ${ }^{99}$ que defiende la importancia de los gastos en infraestructuras o dotación en seguridad y policía para disuadir al delincuente.

En el segundo modelo, el crecimiento económico, el crimen y el desempleo anterior se relacionan al desempleo. En este caso, la variable crecimiento económico (rezagada 2 trimestres) no parece ajustarse a las expectativas, ya que muestra una variación positiva, es decir, que un mayor crecimiento económico iría ligado a una mayor tasa de desempleo. Becker ${ }^{100}$ señalaba que la relación entre desempleo y crecimiento económico podía mostrar distintos efectos, debido a diferentes situaciones, como la desigualdad económica o social, el género, la raza, edad, nivel educativo y condiciones del entorno físico.

El tercer modelo explica el crecimiento económico con el crimen, el desempleo y el crecimiento económico. En este modelo la única variable que no resulta explicativa es el crimen. Justamente, considerando los tres modelos y sus variables explicativas, todas son significativas estadísticamente al 5\%, a excepción de esta variable del Modelo 3. Pero esto no representa, en realidad, un problema relevante debido a que la variable si resulta significativa al 10\%. Es señalable que el desempleo en un periodo previo causa crecimiento económico en el siguiente periodo. Este resultado parece poco intuitivo, sin embargo, existen explicaciones plausibles para esta relación. Una redistribución de riqueza, o bien, la participación de los gobiernos en desarrollar políticas eficientes para el crecimiento económico de un país, pero deficientes en cuanto a la generación y apoyo a nuevos empleos, todas ellas pueden, efectivamente, intervenir en esta relación.

En general, los resultados globales de este estudio parecen coincidir con Núñez et al. ${ }^{101}$ en cuanto a las relaciones directas entre tasa de desempleo y eficiencia policial. También parece coincidir con varios estudios nacionales e internacionales en cuanto que los resultados son mixtos, y a menudo contradictorios, tales como Torruam y Abur, ${ }^{102}$ Alkimima et al., ${ }^{103}$ Andersen, ${ }^{104}$ Sachsida et al., ${ }^{105}$ Narayan y Smyth, ${ }^{106}$ Rivera et al., ${ }^{107}$ Papps y Winkelmann, ${ }^{108}$ confirmando que no existe consenso respecto a las relaciones de causalidad y a sus signos en la literatura del área.

A pesar de que este estudio supone un avance en el conocimiento de las relaciones económicas estudiadas en Chile, es claro que las relaciones causales entre las mismas son complejas, reflejando que existen interdependencias mutuas que dificultan la identificación de los efectos netos y sus signos. Por la importancia de esta temática, desde el punto de vista jurídico y de las políticas públicas, se esperan nuevas investigaciones que exploren otros enfoques y metodologías que permitan seguir avanzando en la dirección planteada por este estudio.

99 LEVITT, S. D. Understanding Why Crime Fell in the 1990s: Four Factors that Explain the Decline and Six that Do Not. Financial of Economics Perspectives, 18(1), 2004, pp. 163-190.

100 BECKER, G. Crime and Punishment: An Economic Approach. Journal of Political Economy, 76(2), 1968, pp. $169-217$.

101 NÚÑEZ, J.; RIVERA, J.; VILLAVICENCIO, X.; MOLINA, O. Determinantes socioeconómicos y demográficos del crimen en Chile. Evidencia desde un panel de datos de las regiones chilenas, 2003.

102 TORRUAM, J.; ABUR, C. The Relationship between Unemployment, Inflation and Crime: An Application of Cointegration and Causality Analysis in Nigeria. Journal of Economics and Sustainable Development, 5(4), 2014.

103 ALKIMIMA, A.; CLARKEB K. C.; OLIVEIRAC F. S. Fear, crime, and space: The case of Viçosa, Brazil. Applied Geography, 42, 2005, pp. 124-132.

104 HALD, A. The Rockwool Foundation Research Unit Unemployment and crime: Experimental evidence of the causal effects of intensified ALMPs on crime rates among unemployed individuals. Signe University Press of Southern Denmark. Odense, 2012. 105 SACHSIDA, A.; CARDOSO DE MENDONÇA, M. J.; LOUREIRO, P. R. A.; SARMIENTO, M.B. (2009). Inequality and criminality revisited: further evidence from Brazil. Empir Econ 39, 93-109.

106 NARAYAN, P. K.; SMYTH, R. Crime rates, male youth unemployment and real income in Australia: Evidence from Granger causality tests. Applied Economics, 36, 2004, pp. 2079-2095.

107 RIVERA, J.; NÚÑEZ, J.; VILLAVICENCIO, X. Crimen y disuasión. Evidencia desde un modelo de ecuaciones simultáneas para las regiones de Chile. El Trimestre Económico, 284, 2004, pp. 811-846.

108 PAPPS, K. L.; WINKELMANN. Unemployment and crime: New evidence for an old question. IZA and Centre for Economic Policy Research, 1999, pp. 1-16. 


\section{Referencias}

ALKIMIMA, A.; CLARKEB, K. C.; OLIVEIRAC, F. S. Fear, crime, and space: the case of Viçosa, Brazil. Applied Geography, 42, 2005, p. 124-132.

ANDERSON, D. The aggregate burden of crime. Journal of Law and Economics, 42, 1999, p. 611-642.

ARAYA, J.; SIERRA, D. Infuencia de factores de riesgo social en el origen de conductas delincuenciales. Serie de Estudios. División de seguridad ciudadana. Ministerio del Interior. Gobierno de Chile, 2002.

BAHL, R; GUSTLEY, R; WASYLENKO, M. The Determinants of Local Government Police Expenditures: A Public Employment Approach, National Tax Journal, 1978.

BARRO, R. Democracy and Growth. Journal of Economic Growth, 1, 1-27.

BECKER, G. Crime and punishment: an economic approach. Journal of Political Economy, 76 (2), 1968, p. 169-217.

BRAITH, J. Inequality, Crime and Public Policy Londres, Routledge and Kegan Paul, 1979.

BRAND, S.; PRICE, R. The economic and social costs of crime, Home Office, 2000.

BUONANNO, P., FERGUSSON, L.; VARGAS, J. F. The Crime Ku₹nets Curve. 2014, Documentos.

CANTOR, D.; LAUD, K. C. Unemployment and crime rates in the post World War II United States: A theoretical and empirical analysis. American Sociological Review, 50, 1985, p. 317-332.

CARR-HILL, R; STERN, N. Crime, the Police and Criminal Statistics. New York, Academic Press, 1979.

CEA, M.; RUIZ, P.; MATUS, J. P. Determinantes de la criminalidad: Revisión bibliográfica. Informe final Seminario de Título. Pontificia Universidad Católica de Chile, Instituto de Economía, 2 (4), 2006, p. 1-34.

CHEN, S. W. Investigating causality among unemployment, income and crime in Taiwan: Evidence from the bounds test approach. Journal of Chinese Economics and Business Studies, 7, 2009, p. 115-125.

CORMAN, H.; MOCAN, N. A time-series analysis of crime, deterrence, and drug abuse in New York city. American Economic Review 3, 2000, p. 584-604.

CZABANSKI, J. Estimates of cost of crime: History, methodologies, and implications, Springer, 2008.

DE LA FUENTE, H.; MEJÍAS, C.; CASTRO, P. Análisis econométrico de los determinantes de la criminalidad en Chile. Política Criminal, 6(11), 2011, p. 192-208.

DEADMAN, D. Forecasting residential burglary. International Journal of Forecasting, 119(4), 2003, p. 567-578.

DETOTTO, C.; VANNINI, M. Counting the cost of crime in Italy. Global Crime, 11(4), 2010, p. 421-435.

DETOTTO, C.; OTRANTO, E. Does crime affect economic growth?. Kuklos, 63(3), 2010, p. 330-345.

DETOTTO, C.; OTRANTO, E. Cycles in crime and economy: Leading, lagging and coincident behaviours. Journal of Quantitative Criminology, 28, 2012, p. 295-317.

DETTOTO, C.; PULINA, M. Does more crime mean fewer Jobs and less economic growth? European Journal of Law and Economics, 36(1), 2012, p. 183-207.

DURKHEIM, E. La división del Trabajo Social. Ed. AKAL, 1987.

EHRLICH, I. Participation in Illegitimate Activities: A Theoretical and Empirical Investigation. Journal of Political Economy, 81(3).Estudios de Economía, 1973, 30 (1), p. 55-85.

ENGLE, R. F.; GRANGER, W. J. Co-integration and Error Correction: Representation, Estimation and Testing, Econometric, 55(2), 1987, p. 251-276.

FÁBregA, J; MORALES, A. M; MUÑOZ, N. Delito y especialización en Chile. Política criminal, 9(18), 2014, 
p. $521-542$.

FLEISHER, B. M. The effect of unemployment on juvenile delinquency. The Journal of Political Economy, 71, 1963, p. $543-555$.

FOX, J. Forcasting Crime Data. Lexington, Lexington Books, 1978.

GARCIA, R. Participación en actividades ilegales: Evidencia empírica del Robo para el caso chileno: Informe final Seminario de Título. Pontificia Universidad Católica de Chile, Instituto de Economía, 1994.

GREENBERG, D. F. Time Series Analysis of Crime Rates. J. Q. Criminal, 17, 2001, p. 291-327.

GREGORY, A. W.; HANS B. E. Practitioners Corner Tests for Cointegration in Models with Regime and Trend Shifts. Oxford Bulletin of Economics and Statistics, 58, 1996.

HABIBULLAH, M.S; BAHAROM, A. H. Crime and economic conditions in Malaysia. International Journal of Social Economics, 36, 2009, p. 1071-108.

HALD, A. The Rockwool Foundation Research Unit Unemployment and crime: Experimental evidence of the causal effects of intensified ALMPs on crime rates among unemployed individuals. Signe University Press of Southern Denmark. Odense, 2012.

HIRSHI, T. Causes of Delinquency Londres, Transaction Publishers, 2002.

IMROHOROGLU, A.; MERLO, A.; RUPERT, M. What accounts for the decline in crime?. International Economic Review, 45(3), 2004, p. 707-729.

JACOBS, D. Inequality and Police Strength: Conflict Theory and Coercive Control in Metropolitan Areas, American Sociological Review, 44, 1979.

JOHANSEN, S. Statistical Analysis of Cointegrating Vectors. Journal of Economic Dynamics and Control, 12(1), 1988, p. 231-254.

KUZNET, S. Economic growth and income Inequality. The American Economic Review, 45 (1),1995, p. 1-28.

LAMBSDORFF, J. How corruption affects productivity. Kylos, 56, 2000, p. 457-474.

LEE, D.; HOLOVIAK, S. Unemployment and Crime: An empirical investigation. Applied Economic Letters, 13 (12), 2006, p. 805-810.

LEVITT, S. D. Understanding Why Crime Fell in the 1990s: Four Factors that Explain the Decline and Six that Do Not. Financial of Economics Perspectives, 18(1), 2004, p. 163-190.

LONG, S; WITTE, A. Current Economic Trends: Implications of Crime and Criminal Justice, en Kevin WRIGHT (comp.): Crime and Criminal Justice in a Declining Economy Cambridge, MA, Oelgeschlager, Gunn and Hein, 1981.

MARVELL, T.; MOODY, C. Specification Problems, Police Levels, and Crime rates. Criminology, 34(4), 1996, p. 609-646.

MATUS, J. P. ¿Por qué no bajan las tasas de criminalidad en Chile? Revista de Derecho de la Pontificia Universidad Católica de Valparaíso, 26, 2005, p. 67-92.

MAURO, P. Corruption and growth. The Quarterly Journal of Economics, 110, 1995, 681-712.

MERTON, R. Teoría y estructura sociales (Cap. VI: Estructura social y anomia). México D.F., Fondo de Cultura Económica, 1964.

MOCAN, N; BILLUPS, S.; OVERLAND J. A Dynamic Model d Differential Human Capital and Criminal Activity. Economica, 72(288), 2005, p. 655-681.

MORALES, L.A.; MUÑOZ-DELGADO, J.; SANTILLÁN, A. M., ARENAS, R., PONCE DE LEÓN, F. Perfiles criminológicos: El Arte de Sherlock Holmes en el siglos XXI, 30 (3), 2007, p. 68-75. 
NAGEL, J. Crime and Incarceration: A Reanalysis, Fels Discussion Paper No12. Philadelphia, University of Pensylvania, School of Public and Urban Policy, 1977.

NARAYAN, P. K.; SMYTH, R. Crime rates, male youth unemployment and real income in Australia: Evidence from Granger causality tests. Applied Economics, 36, 2004, p. 2079-2095.

NÚÑEZ, J.; RIVERA, J.; VILLAVICENCIO, X.; MOLINA, O. Determinantes socioeconómicos y demográficos del crimen en Chile. Evidencia desde un panel de datos de las regiones chilenas, 2003.

O'BRIEN, R. Measuring the convergence/divergence of serious crime arrest rates for males and females: 1960 -1995. Journal of Quantitative Criminology, 15, 1999, p. 97-114.

ORSAGH, T. Unemployment and Crime: An Objection to Professor Brenner's View. Journal of Criminal Law and Criminology, 71, 1980.

ORTIZ, M.; SEPÚLVEDA, R.; VIANO, C. Análisis de los Programas Jóvenes Infractores de Ley de Prevención, Universidad de Chile, Instituto de Asuntos Públicos, 2005.

PAPPS, K. L.; WINKELMANN. Unemployment and crime: New evidence for an old question. IZA and Centre for Economic Policy Research, 1999, p. 1-16.

PESARAN, M. H.; SHIN, Y.; SMITH, R. Bounds testing approaches to the analysis of level relationships. Journal of Applied Econometrics, 16, 2001, p. 289-326.

PESARAN M. H.; SHIN, Y. An autoregressive distributed lag modelling approach to cointegration analysis. Chapter 11 in Econometrics and Economic Theory in the 20th Century: The Ragnar Frisch Centennial Symposium, Strom S (ed.). Cambridge University Press: Cambridge, 1999.

RAPHAEL, S.; WINTER-EMBER, R. Identifying the effect of unemployment on crime, 44 (1), 2001, p. 259-283.

RIVERA, J.; NÚÑEZ, J.; VILLAVICENCIO, X. Crimen y disuasión. Evidencia desde un modelo de ecuaciones simultáneas para las regiones de Chile. El Trimestre Económico, 284, 2004, p. 811-846.

SACHSIDA, A.; CARDOSO DE MENDONÇA, M. J.; LOUREIRO, P. R. A.; SARMIENTO, M.B. (2009). Inequality and criminality revisited: further evidence from Brazil. Empir Econ 39, 93-109

SANDLER, T.; ENDERS, W. Economic consequences of terrorism in developed and developing countries: An overview. In P. Keefer y N. Layza (Eds), Terrorism, economic development and political openness. Cambridge University Press. Cambridge (UK), 2008.

SARIDAKIS, G. Violent crime in the United States of America: a time- series analysis between 1960-2000. European Journal of Law and Economics, 18 (2), 2004.

SCHMIDT-HEBBEL, K. "La tasa de victimización en Chile es muy alta... Eso significa que en esa dimensión somos una sociedad enferma”. La Tercera, ed. Impresa. 24 de junio de 2012. http:// diario.latercera. com/2012/06/24/01/contenido/pais/31-112298-9-klaus-schmidthebbel-la-tasa-de-victimizacion--en-chile-es-muy-alta-eso-significa.shtml. Visitado en: el 2 de enero de 2014.

SCORCU, A. E.; CELLINI, R. Economic activity and crime in the long run: An empirical investigation on aggregate data from Italy, 1951-1994. International Review of Law and Economics, 18, 1998, p. 279-292.

TORRUAM, J.; ABUR, C. The Relationship between Unemployment, Inflation and Crime: An Application of Cointegration and Causality Analysis in Nigeria. Journal of Economics and Sustainable Development, 5(4), 2014.

WILSON, J; COOK, P. Unemployment and Crime -What is the Connection”. The Public Interest, 79, 1985.

WILSON, J; HERNSTEIN, R. Crime and Human Nature. Nueva York, Simon and Schuster, 1985.

WITT, R.; WITTE, A. Crime, prison and female labour supply. Journal of Quantitative Criminology. 16 (1), 2000, p. 69-85. 


\section{REVISTA BRASILEIRA DE POLÍTICAS PÚBLICAS BRAZILIAN JOURNAL OF PUBLIC POLICY}
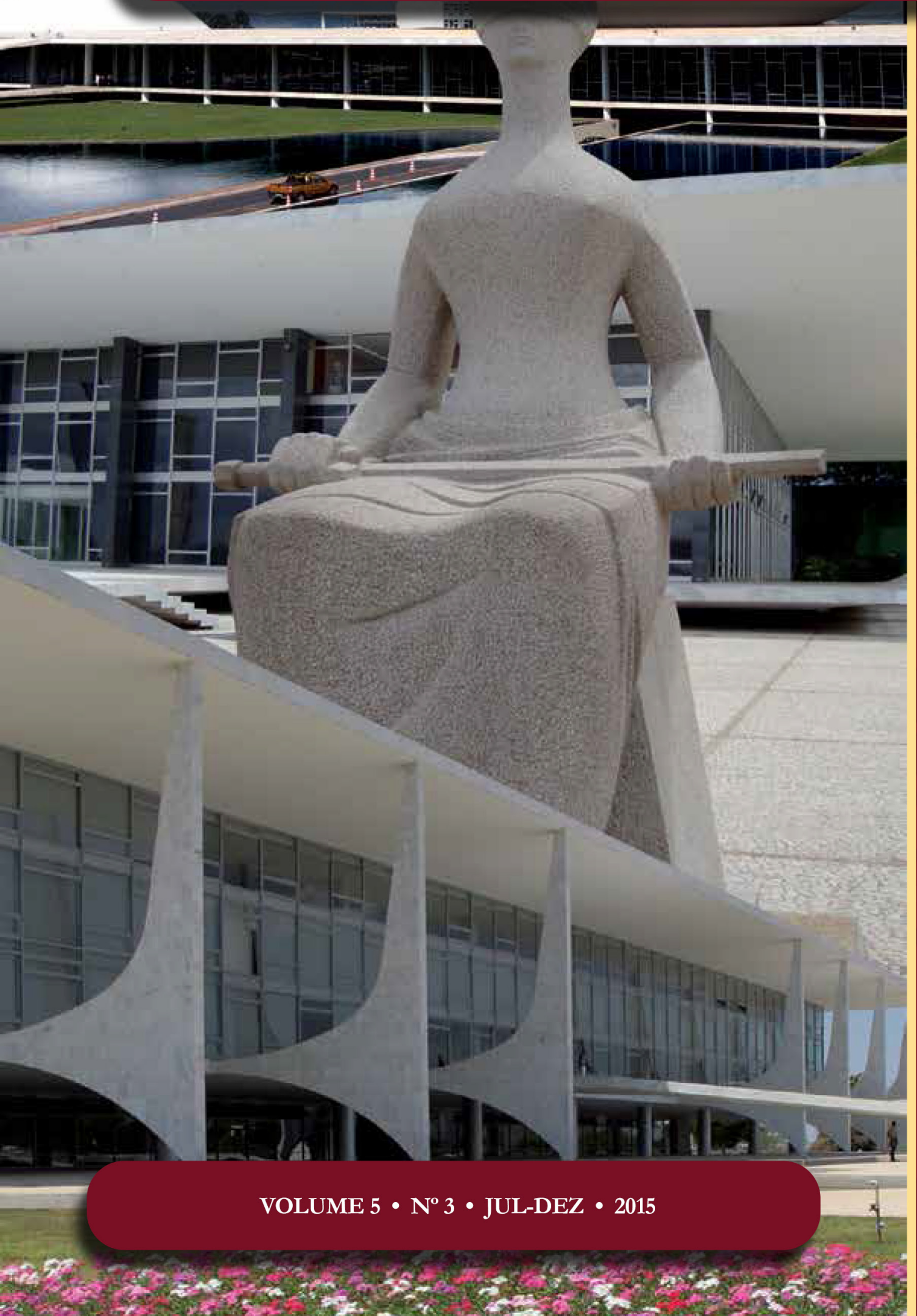

O impacto de diferentes tipos de repressão legal sobre as taxas de homicídio entre os estados brasileiros

The impact of different kinds of legal repression over homicide rates across Brazilian states

Adolfo Sachsida

Mário Jorge Cardoso de Mendonça

Tito Belchior Silva Moreira 


\title{
O impacto de diferentes tipos de repressão legal sobre as taxas de homicídio entre os estados brasileiros*
}

\section{The impact of different kinds of legal repression over homicide rates across Brazilian states}

\author{
Adolfo Sachsida ** \\ Mário Jorge Cardoso de Mendonça *** \\ Tito Belchior Silva Moreira ****
}

\section{Resumo}

Este artigo avalia se as políticas de repressão aos homicídios têm efeitos similares em diferentes estados. As políticas de repressão ao crime podem ser divididas em políticas de incapacitação (encarceramento) e políticas de detenção (taxas de policiamento). Nossos resultados sugerem que diferentes estratégias policiais podem ter impactos distintos no combate ao crime. Além disso, pudemos constatar que a mudança na Lei de Combate as Drogas de 2006 teve como consequência não desejada enfraquecer o impacto da taxa de encarceramento sobre a taxa de homicídios.

Palavras-chave: Criminalidade. Homicídios. Taxa de encarceramento. Taxa de policiais.

JEL: K42, Z18, C23.

* Recebido em 30/04/2015

Aprovado em 08/07/2015

** Doutor em Economia pela Universidade de Brasília (UnB). Pesquisador da Diretoria de Macroeconomia do Instituto de Pesquisa Econômica Aplicada (IPEA). E-mail: sachsida@hotmail.com

*** Técnico de Planejamento e Pesquisa do IPEA desde 1997. PhD (ABD) em Economia pela École des Hautes Études en Sciences Sociales (EHESS) com Mestrado em Economia pela Universidade Federal Fluminense. E-mail: mario.mendonca@ipea.gov.br

**** Doutor em Economia pela UnB. Professor/pesquisador do Departamento de Economia da Universidade Católica de Brasília (UCB). Pesquisador pelo CNPq. E-mail: tito@pos.ucb.br

\section{Abstract}

This article verifies the different effects of legal repression over homicide rates across Brazilian states. We analyze the impacts of two different kinds of legal repression: incapacitation (rate of individuals serving time in jail) and deterrence (rate of police officers). Our econometric results suggest that different police strategies can have different impact over the homicide rate. Furthermore, we find evidence that the new Anti-Drug Law of 2006 had as an unintended consequence the decrease of the impact of incarceration rate over homicide rate.

Key-words: Criminality. Homicide. Incarceration rate. Number of police officers. 


\section{INTRODUÇÃO}

A violência atual que permeia a sociedade brasileira assusta qualquer especialista que se confronta com os dados. Não só a taxa de homicídios atinge níveis alarmantes, como também se mantém nesse patamar sem qualquer sinal de diminuição. A violência no Brasil não é característica de um país que não esteja em guerra civil. As taxas de homicídio superam os 30 homicídios por 100 mil habitantes em diversas localidades brasileiras.

Quando olhamos para um horizonte temporal amplo, vemos que a violência no Brasil tem evoluído com rapidez assustadora. Entre os anos de 1980-84, ocorriam 14,8 homicídios por 100 mil habitantes no Brasil. Mas, de acordo com a pesquisa IDS 2012 (Indicadores de Desenvolvimento Sustentável) elaborada pelo IBGE (Instituto Brasileiro de Geografia e Estatística), em 2009 esse número subiu para incríveis 27,1 por 100 mil habitantes. Isso representa aumento de 83,1\% na taxa de homicídios em 30 anos. Na comparação regional, Alagoas (59,3 assassinatos por 100 mil habitantes), Espírito Santo (56,9) e Pernambuco (44,9) lideram o ranking. Na ponta oposta, Piauí (12,4 assassinatos por 100 mil habitantes), Santa Catarina $(13,4)$ e São Paulo $(15,8)$ são os estados menos violentos. É digno de nota que a taxa de homicídios entre homens é muito superior a de mulheres: a taxa de homicídios por 100 mil habitantes é de 50,7 quando se considera apenas a população masculina, e de 4,4 por 100 mil quando se considera apenas a população feminina.

Contudo, o que já era ruim o bastante, mostrou-se pior ainda. Revendo a metodologia de cálculo dos homicídios ${ }^{1}$, em média, 8.600 homicídios deixaram de entrar por ano na estatística de assassinatos no Brasil no período 1996-2010. Isto é, a taxa de homicídios no Brasil seria 18,3\% superior a oficial, atingindo, assim, a assustadora marca de 62.375 homicídios em 2009.

Este estudo possui dois objetivos principais. Primeiramente, iremos estudar os principais determinantes da taxa de homicídios nos estados brasileiros. Dessa maneira, poderemos verificar se políticas públicas de combate aos homicídios têm efeito similar em diferentes estados da federação. Para tanto, coletamos dados dos estados brasileiros entre os anos de 2003 e 2009. Tal estratégia nos possibilita estimarmos um interessante modelo de dados de painel $^{2}$. Isso nos possibilita a análise de viés gerada em estudos anteriores que usam dados oficiais subregistrados.

Em segundo lugar, verificamos se a nova Lei de Combate às Drogas de 2006 produziu alterações em nossos resultados econométricos. Essa nova lei trouxe importante inovação: aumentou a punição para traficantes. Nossos resultados sugerem que um dos efeitos não intencionais dessa lei consistiu em diminuir a efetividade da taxa de encarceramento no combate à taxa de homicídios. Nesse contexto, ao contrário da intenção original da lei, a polícia passou a classificar usuários como traficantes, gerando penas de prisão para tais usuários. Isso aumentou as taxas de encarceramento sem ter a correspondente redução na taxa de homicídios.

De maneira geral, nossos resultados sustentam o importante papel da polícia no combate ao crime: prender mais criminosos, e aumentar o número de policiais foram estratégias importantes no combate à criminalidade nos estados que conseguiram reduzir sua taxa de homicídios. Isto é, ao contrário do sustentado por alguns especialistas, prender criminosos é fundamental para a redução da violência. Também devemos ressaltar que nosso estudo apresenta evidências de que diferentes estratégias policiais, adotadas pelos estados, fazem diferença nos resultados de redução da criminalidade. Sendo assim, nossos resultados não corroboram os encontrados por Levitt ${ }^{3}$ para os Estados Unidos.

1 CERQUEIRA, Daniel. Mapa dos homicídios ocultos no Brasil. Brasília: IPEA, 2013. (Texto para Discussão, n. 1848).

2 Além disso, depois de realizadas as estimativas com os dados oficiais, usaremos os dados de homicídio corrigidos, produzidos por Cerqueira. CERQUEIRA, Daniel. Mapa dos homicídios ocultos no Brasil. Brasília: IPEA, 2013. (Texto para Discussão, n. 1848).

3 LEVITT, Steven. D.; LOCHNER, Lance. The determinants of juvenile crime. In: GRUBER, Jonathan (Ed.). Risky Behavior among youths: an economic analysis Chicago: University of Chicago Press, Jan. 2001. (NBER Working Paper, n. w7781). p. $327-374$. Available in: <http://www.nber.org/chapters/c10692.pdf>. Access: 17 Nov. 2015. 
Além dessa introdução, apresentamos, na seção 2, breve descrição de nossa base de dados, e também retratamos a evolução da taxa de homicídios, da taxa de encarceramento, e da taxa de policias no Brasil. Na seção 3, apresentamos os resultados econométricos de nosso estudo. $\mathrm{Na}$ seção 4, aplicamos alguns procedimentos para verificar a robustez dos resultados encontrados. A seção 5 analisa os efeitos da mudança na legislação da Lei de Combate as Drogas de 2006 sobre nossos resultados. A seção 6 conclui o trabalho.

\section{BASE DE DADOS E EVOLUÇÃO DA VIOLÊNCIA ${ }^{4}$}

Este artigo faz uso de duas bases de dados. A primeira ${ }^{5}$ utiliza dados oficiais para verificar os determinantes da taxa de homicídios nos estados brasileiros (todas as variáveis estão desagregadas para nível de estados). A segunda base de dados ${ }^{6}$ disponibiliza dados corrigidos referentes à taxa de homicídios. O Quadro 1 descreve as variáveis coletadas para este estudo. Também são informados o período amostral, a fonte dos dados, e sua respectiva descrição.

Quadro 1- Fontes e definições dos dados adotados ${ }^{7}$

\begin{tabular}{|l|l|l|l|}
\hline Variável & Período* & Fonte & Descrição \\
\hline $\begin{array}{l}\text { População total } \\
\text { (pop) }\end{array}$ & 2001-10 & DATASUS & Número total de pessoas residentes no respetivo estado. \\
\hline $\begin{array}{l}\text { Taxa de } \\
\text { Desemprego }\end{array}$ & $2001-09$ & $\begin{array}{l}\text { PNAD/ } \\
\text { IBGE }\end{array}$ & $\begin{array}{l}\text { Taxa de desemprego por 100.000 habitantes do Estado. } \\
\text { Consideraram-se, para tanto, as pessoas que procuraram, } \\
\text { mas não encontraram ocupação profissional remunerada } \\
\text { entre todas aquelas consideradas “ativas" no mercado de } \\
\text { trabalho. Nesse caso, entende-se como "ativas" no mercado } \\
\text { o grupo que inclui todas as pessoas com 10 anos ou mais } \\
\text { de idade que estavam procurando ocupação ou trabalhando } \\
\text { na semana de referência da Pesquisa Nacional por Amostra } \\
\text { de Domicílios (PNAD). }\end{array}$ \\
\hline $\begin{array}{l}\text { Taxa } \\
\text { Desigualdade }\end{array}$ & $2001-09$ & IPEA & $\begin{array}{l}\text { Coeficiente de Gini do estado. Esse índice mede o grau de } \\
\text { desigualdade na distribuição da renda domiciliar per capita } \\
\text { entre os indivíduos. Seu valor pode variar teoricamente } \\
\text { desde 0, quando não há desigualdade, até 1, quando a de- } \\
\text { sigualdade é máxima. Calculado com base nas respostas à } \\
\text { PNAD. }\end{array}$ \\
\hline Taxa Pobreza & 2001-09 & IPEA & $\begin{array}{l}\text { Percentual de pessoas daquele estado com renda domiciliar } \\
\text { per capita inferior à linha de pobreza. A linha de pobreza } \\
\text { considerada nesse contexto é o dobro da linha de extrema } \\
\text { pobreza, uma estimativa do valor de uma cesta de alimentos } \\
\text { com o mínimo de calorias necessárias para suprir adequada- } \\
\text { mente uma pessoa, com base em recomendações da FAO e } \\
\text { da OMS. Calculado com base nas respostas à PNAD. }\end{array}$ \\
\hline
\end{tabular}

4 Uma ampla revisão da literatura sobre os determinantes da taxa de homicídios pode ser encontrada em Sachsida e Mendonça. SACHSIDA, Adolfo; MENDONÇA, Mario Jorge Cardoso de. Evolução e determinantes da taxa de bomicídios no Brasil. Brasília: IPEA, jan. 2013. (Texto para Discussão do IPEA, n. 1808).

5 Fundamentada em Sachsida e Mendonça. SACHSIDA, Adolfo; MENDONÇA, Mario Jorge Cardoso de. Evolução e determinantes da taxa de homicídios no Brasil. Brasília: IPEA, jan. 2013. (Texto para Discussão do IPEA, n. 1808)

6 CERQUEIRA, Daniel. Mapa dos homicídios ocultos no Brasil. Brasília: IPEA, 2013. (Texto para Discussão, n. 1848).

7 Quando faltou determinada informação sobre um ano intermediário, esta foi obtida por interpolação simples. 


\begin{tabular}{|c|c|c|c|}
\hline Variável & Período* & Fonte & Descrição \\
\hline $\begin{array}{l}\text { Taxa Leitos } \\
\text { (TL) }\end{array}$ & $\begin{array}{l}2001-03 \\
2005-09\end{array}$ & DATASUS & $\begin{array}{l}\text { Taxa de leitos hospitalares do estado. De } 2001 \text { a } 2003 \text { tal } \\
\text { taxa corresponde ao número de leitos hospitalares di- } \\
\text { sponíveis no SUS por } 100.000 \text { habitantes. Nesse período } \\
\text { a informação foi disponibilizada pelo Sistema de Infor- } \\
\text { mações Hospitalares do SUS (SIH/SUS). De } 2005 \text { a 2009, } \\
\text { entretanto, tem-se o número de leitos por } 100.000 \text { habitan- } \\
\text { tes, divulgado pelo Cadastro Nacional de Estabelecimentos } \\
\text { de Saúde (CNES). Não há dados para } 2004 \text { em virtude da } \\
\text { implantação do sistema CNES e mudanças nas classifi- } \\
\text { cações de leitos. Para 2005, foi considerada a situação de } \\
\text { dezembro/2005; para os demais anos, foi considerada a } \\
\text { média de janeiro a dezembro. }\end{array}$ \\
\hline $\begin{array}{l}\text { Taxa Ho- } \\
\text { micídios } \\
\text { (Homicídios) }\end{array}$ & 2001-09 & DATASUS & $\begin{array}{l}\text { Taxa de homicídios estadual a cada } 100.000 \text { habitantes. A } \\
\text { taxa de homicídios foi calculada, considerando-se o local de } \\
\text { residência da vítima. Foram contabilizadas tanto as mortes } \\
\text { habitualmente classificadas como homicídios (X85 a Y09 da } \\
\text { CID-10), quanto as mortes por arma de fogo e arma branca } \\
\text { cuja intenção não foi determinada (Y22 a Y24 e Y28 e Y29 } \\
\text { da CID-10). Esse padrão foi o mesmo utilizado no artigo } \\
\text { de Monteiro de Castro, Assunção e Durante (2003). }\end{array}$ \\
\hline $\begin{array}{l}\text { Taxa ho- } \\
\text { micídios } \\
\text { ocultos (Corri- } \\
\text { gido) }\end{array}$ & 1996-10 & $\begin{array}{l}\text { Cerqueira } \\
(2013)\end{array}$ & $\begin{array}{l}\text { Taxa de homicídios estadual a cada } 100.000 \text { habitantes cal- } \\
\text { culada de acordo com a metodologia proposta por Cerquei- } \\
\text { ra (2013). }\end{array}$ \\
\hline $\begin{array}{l}\text { Percentual_ } \\
\text { H18a24 } \\
\text { (H1824) }\end{array}$ & 2001-10 & DATASUS & $\begin{array}{l}\text { Média do percentual de homens de } 18 \text { a } 24 \text { anos residentes } \\
\text { no estado, com relação ao número total de habitantes do } \\
\text { estado. }\end{array}$ \\
\hline $\begin{array}{l}\text { Percentual_Ne- } \\
\text { gros } \\
\text { (pn) }\end{array}$ & 2001-09 & IBGE & $\begin{array}{l}\text { Percentual de pessoas negras, com relação à população to- } \\
\text { tal, no estado. }\end{array}$ \\
\hline $\begin{array}{l}\text { Taxa Presos } \\
\text { (preso) }\end{array}$ & 2003-10 & $\begin{array}{l}\text { INFO- } \\
\mathrm{PEN} / \mathrm{MJ}\end{array}$ & $\begin{array}{l}\text { Número de presos no sistema penitenciário por } 100.000 \\
\text { habitantes no estado. Em } 2003 \text { e } 2004 \text { considera-se, para } \\
\text { tanto, as pessoas presas em regimes fechado, semiaberto, } \\
\text { provisório e sob medida de segurança. A partir de 2005, } \\
\text { acrescenta-se, ainda, aqueles que se encontram em regime } \\
\text { aberto. As informações são disponibilizados pelo Sistema } \\
\text { Integrado de Informações Penitenciárias (InfoPen) do Mi- } \\
\text { nistério da Justiça. }\end{array}$ \\
\hline $\begin{array}{l}\text { Renda Média } \\
\text { Estadual } \\
\text { (renda) }\end{array}$ & 2001-09 & IBGE & $\begin{array}{l}\text { Valor do rendimento médio mensal, em Reais de } 2000 \text {, das } \\
\text { pessoas com } 10 \text { anos ou mais de idade, no Estado. Como as } \\
\text { informações foram obtidas por meio da PNAD, que consi- } \\
\text { dera setembro como o mês base, os salários foram deflacio- } \\
\text { nados por meio do IPCA desse mês. }\end{array}$ \\
\hline
\end{tabular}




\begin{tabular}{|l|l|l|l|}
\hline Variável & Período* & Fonte & Descrição \\
\hline $\begin{array}{l}\text { Taxa_Policia.M } \\
\text { pm) }\end{array}$ & 2001-09 & RAIS & $\begin{array}{l}\text { Taxa de policiais militares por 100.000 habitantes no estado. } \\
\text { Consideraram-se aqueles que exerciam tal função como } \\
\text { atividade principal na semana de referência. As patentes } \\
\text { relacionadas foram: coronéis, tenentes-coronéis, majores, } \\
\text { capitães, tenentes, subtenentes, sargentos, cabos e soldados. }\end{array}$ \\
\hline $\begin{array}{l}\text { Taxa_Policia.C } \\
\text { (pc) }\end{array}$ & 2001-09 & RAIS & $\begin{array}{l}\text { Taxa de policiais civis por 100.000 habitantes no estado. } \\
\text { Consideraram-se aqueles que exerciam tal função como } \\
\text { atividade principal na semana de referência. As funções uti- } \\
\text { lizadas na análise foram: delegados, inspetores e detetives. }\end{array}$ \\
\hline $\begin{array}{l}\text { Taxa_C.bom- } \\
\text { beiros } \\
\text { (bomb) }\end{array}$ & $2001-09$ & RAIS & $\begin{array}{l}\text { Taxa de bombeiros por 100.000 habitantes no estado. Con- } \\
\text { sideraram-se aqueles que exerciam tal função como ativida- } \\
\text { de principal na semana de referência. As patentes relacio- } \\
\text { nadas foram: subtenentes, sargentos, cabos e soldados. }\end{array}$ \\
\hline $\begin{array}{l}\text { Média de Anos } \\
\text { de Estudo } \\
\text { (educ) }\end{array}$ & $2001-09$ & $\begin{array}{l}\text { PNAD/ } \\
\text { IBGE }\end{array}$ & $\begin{array}{l}\text { Média de anos de estudo das pessoas de 25 anos ou mais de } \\
\text { idade no estado. }\end{array}$ \\
\hline
\end{tabular}

O Gráfico 1 mostra a evolução da taxa de homicídios no estado de São Paulo. Apresentamos no Gráfico 1 tanto a taxa de homicídios por 100 mil habitantes oficial do estado de São Paulo (HomSP), que utiliza a base de dados do DATASUS, como também a taxa de homicídios corrigida (CorrSP), elaborada por Cerqueira (2013). Como pode ser observado, é inegável que ocorreu forte redução na taxa de homicídios no estado.

Gráfico 1 - Taxa de homicídios por 100 mil habitantes, São Paulo

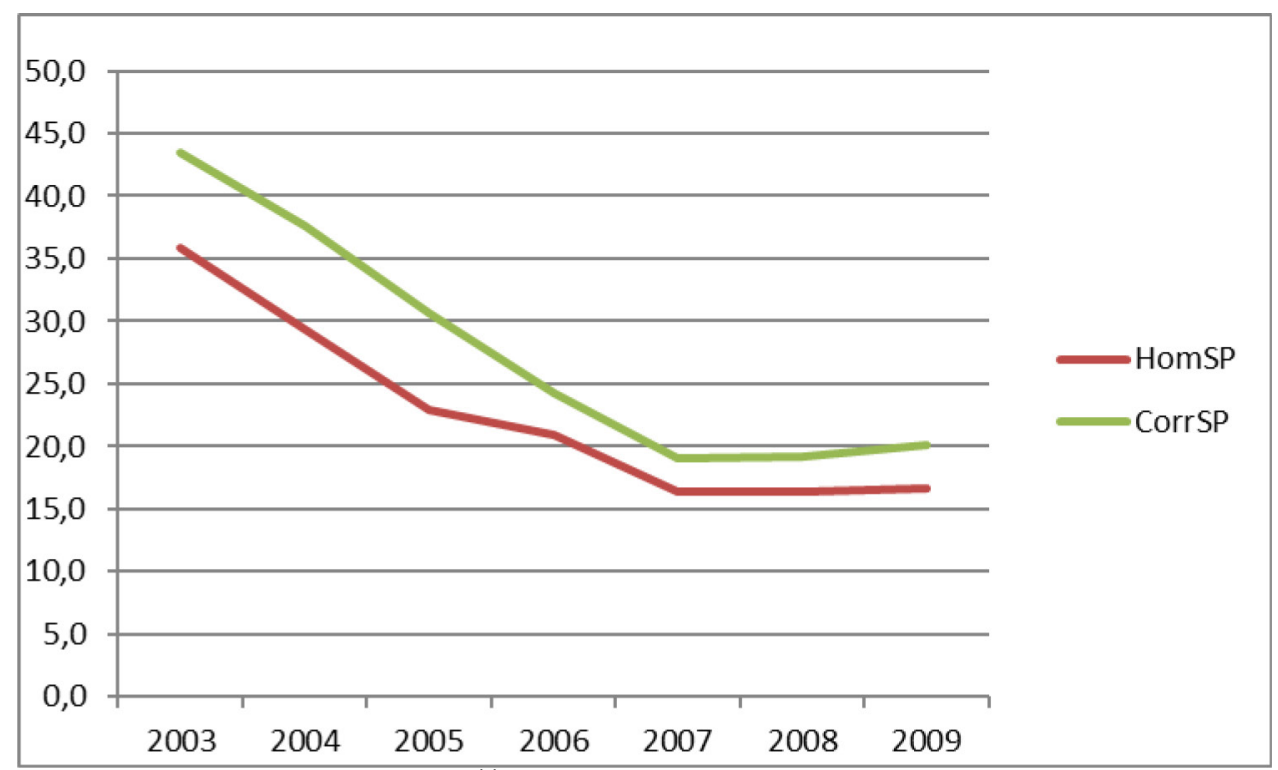

Fonte: DATASUS e Cerqueira ${ }^{8}$

O Gráfico 2 mostra a evolução da taxa de homicídios no estado do Rio de Janeiro. Apresentamos nesse gráfico tanto a taxa de homicídios por 100 mil habitantes oficial (HomRJ), que utiliza a base de dados do DATASUS, como também a taxa de homicídios corrigida (CorrRJ), elaborada por Cerqueira (2013). Apesar de ambas as séries mostrarem tendência decrescente, vemos interrupção dessa tendência na taxa de homicídios corrigida entre 2008 e 2009.

8 CERQUEIRA, Daniel. Mapa dos homicídios ocultos no Brasil. Brasília: IPEA, 2013. (Texto para Discussão, n. 1848). 
Gráfico 2 - Taxa de homicídios por 100 mil habitantes, Rio de Janeiro

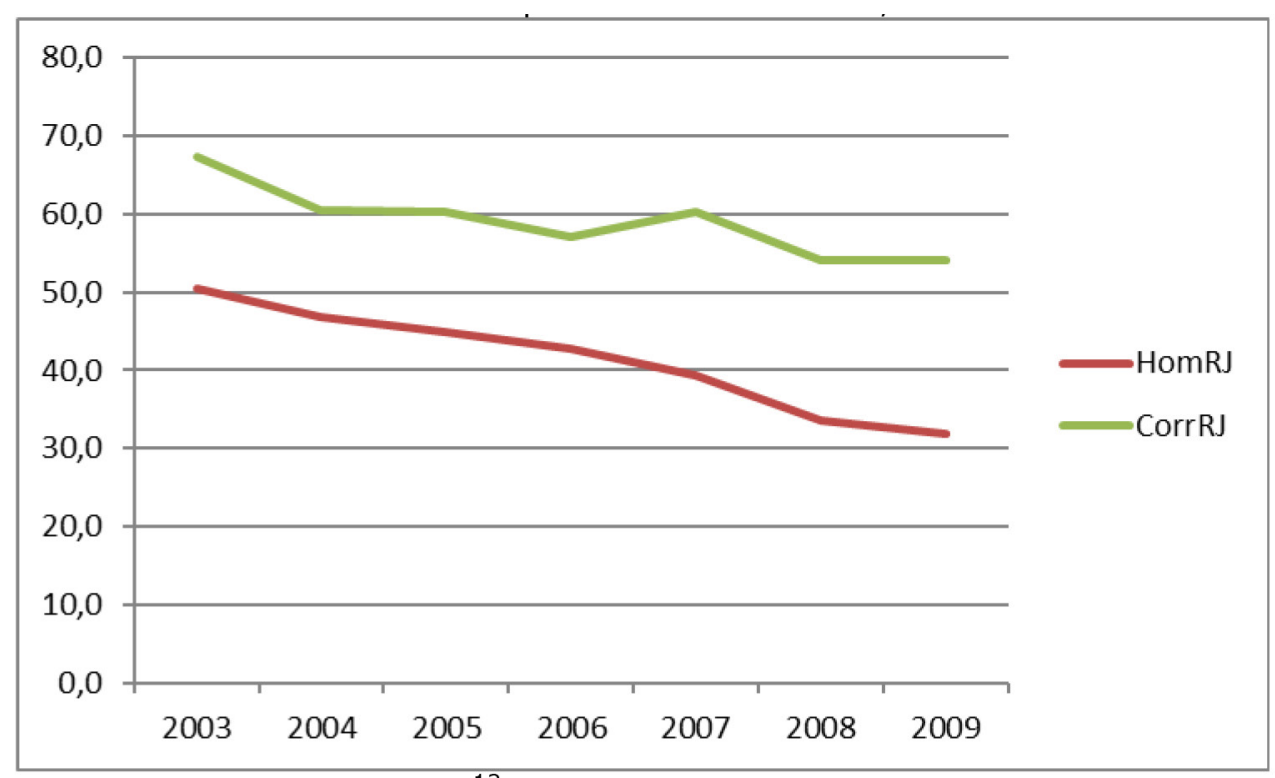

Fonte: DATASUS e Cerqueira ${ }^{9}$

O Gráfico 3 revela a evolução da taxa de homicídios no estado da Bahia. Apresentamos nesse gráfico tanto a taxa de homicídios por 100 mil habitantes oficial (HomBA) como também a taxa de homicídios corrigida (CorrBA). Para a Bahia, podemos verificar expressivo aumento na taxa de homicídios. Contudo, ao utilizarmos os dados corrigidos, verificamos que tal aumento foi bem menos expressivo do que o sugerido pelos dados oficiais. Entre 2003 e 2009, a taxa de homicídios por 100 mil habitantes aumentou em 85,1\% de acordo com os dados do DATASUS. Contudo, esse aumento foi de 67,1\% quando utilizamos os dados corrigidos.

Gráfico 3 - Taxa de homicídios por 100 mil habitantes, Bahia

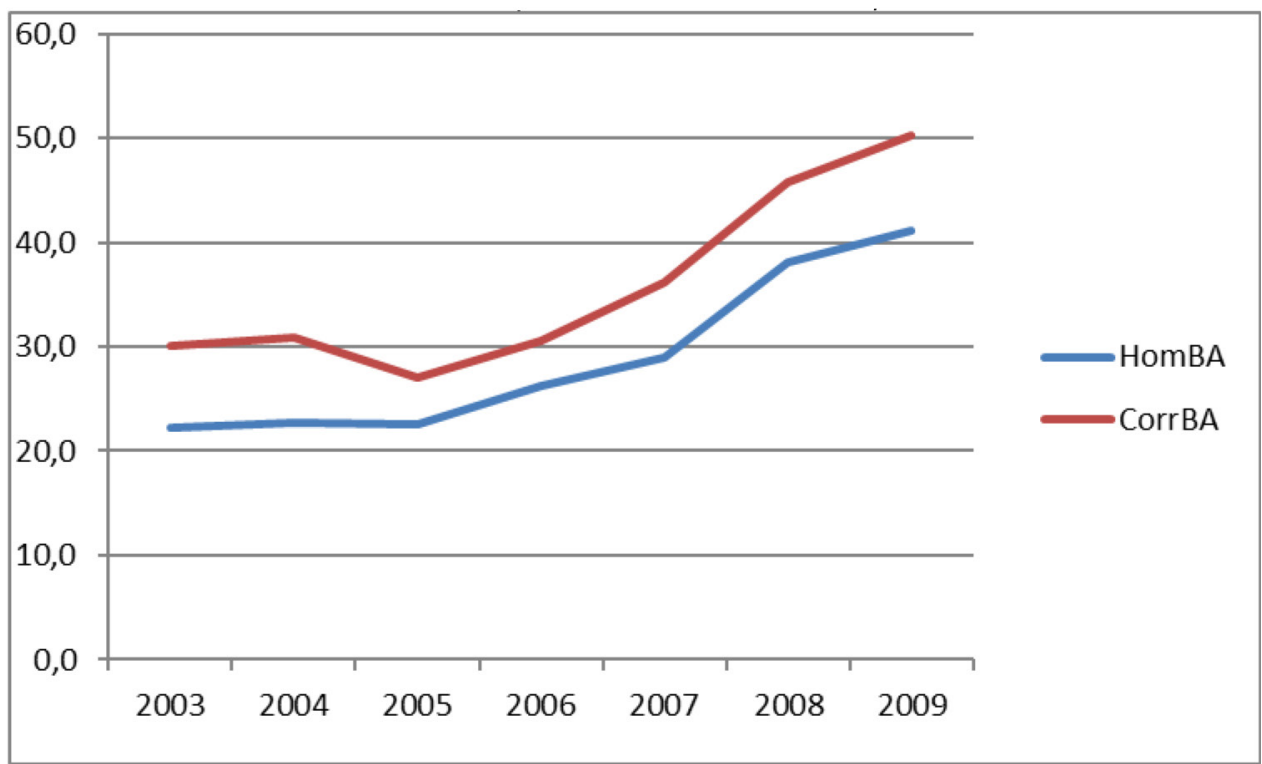

Fonte: DATASUS e Cerqueira ${ }^{10}$

9 CERQUEIRA, Daniel. Mapa dos homicídios ocultos no Brasil. Brasília: IPEA, 2013. (Texto para Discussão, n. 1848).

10 CERQUEIRA, Daniel. Mapa dos homicídios ocultos no Brasil. Brasília: IPEA, 2013. (Texto para Discussão, n. 1848). 
O Gráfico 4 apresenta a evolução das diferenças entre as taxas de homicídios oficiais e as corrigidas. Destaque deve ser dado ao Rio de Janeiro, onde a diferença saltou de 33\% para 69\% no período.

Gráfico 4 - Evolução das diferenças entre as taxas de homicídios oficiais e corrigidas

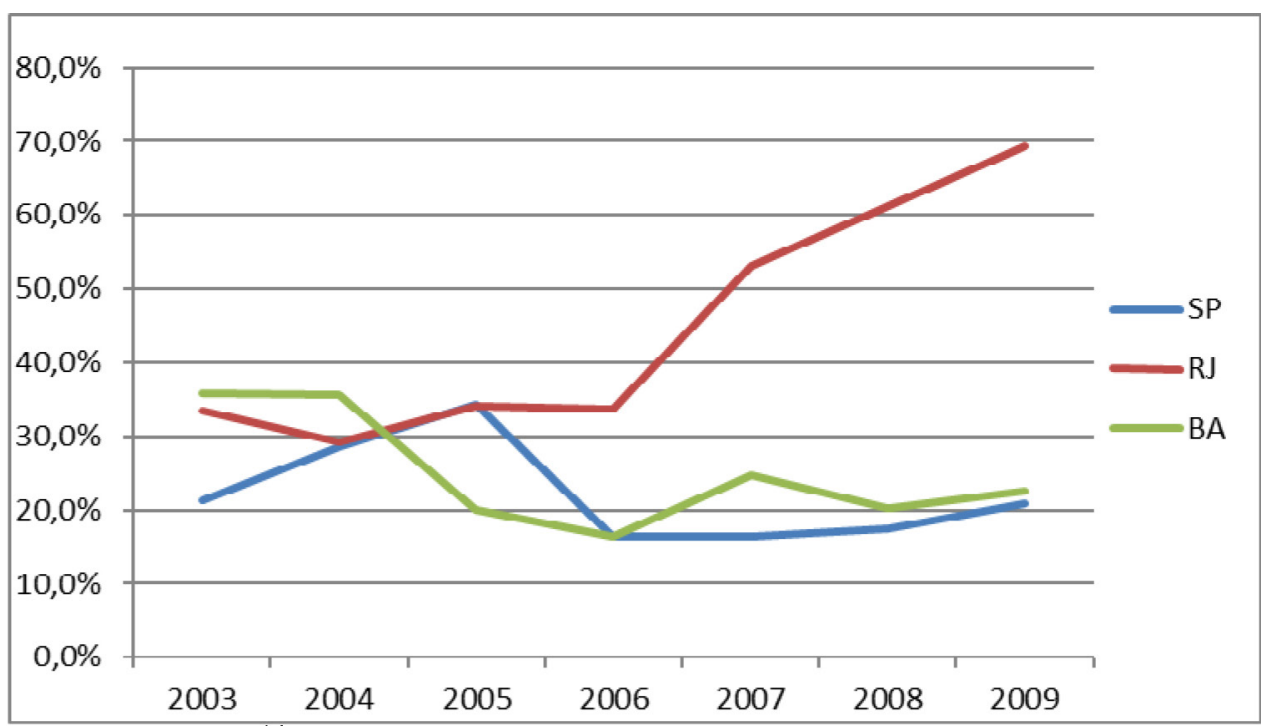

Fonte: Do Autor ${ }^{11}$

A Tabela 1 faz comparação entre os dados das taxas de homicídios oficiais e as estimadas por Cerqueira ${ }^{12}$. A tabela está ordenada em ordem decrescente de acordo com os valores de aumento nas taxas de homicídio estimadas. Sendo assim, podemos ver que o estado do Pará apresentou, no período, aumento de 94\% na taxa de homicídios. Um padrão assustador e que reflete bem a escalada da violência nesse estado. Seja pela taxa estimada ou pela taxa oficial, o estado do Pará apresentou em 2009 taxa de homicídios acima de 40 assassinatos por 100 mil habitantes. Mesmo assim, tal taxa ainda foi inferior à da Bahia (50,3), Alagoas (59,6), Espírito Santo (60), Pernambuco (50,4), e Rio de Janeiro (54), o que demonstra que determinados estados da federação estão próximos a situações de conflito armado.

Ainda na Tabela 1, podemos verificar que, comparando a variação da taxa de homicídios estimada, estado por estado, houve aumento de quase $20 \%$ nessa variável. Se separarmos a amostra entre estados que obtiveram aumento ou redução na taxa de homicídios estimada, veremos que, entre os estados que tiveram aumento na violência, a taxa de homicídios estimada estado por estado cresceu $37,5 \%$, contra redução de $19,6 \%$ nos estados que reduziram a taxa de homicídios estimada ${ }^{13}$.

Tabela 1: Taxas de homicídio oficial e estimada por Cerqueira ${ }^{14}$

\begin{tabular}{c|c|c|c|c|c|c}
\hline Estado & \multicolumn{3}{|c|}{ Taxa de homicídios estimada } & \multicolumn{3}{c}{ Taxa de homicídios oficial } \\
\hline & 2003 & 2009 & Variação & 2003 & 2009 & Variação \\
\hline PA & 21.9 & 42.5 & $94.1 \%$ & 21.4 & 40.7 & $90.2 \%$ \\
\hline PB & 18.2 & 34.5 & $89.6 \%$ & 17.2 & 33.2 & $93.0 \%$ \\
\hline RN & 20.9 & 35.5 & $69.9 \%$ & 15.2 & 31.5 & $107.2 \%$ \\
\hline BA & 30.1 & 50.3 & $67.1 \%$ & 22.2 & 41.1 & $85.1 \%$ \\
\hline
\end{tabular}

11 A partir de CERQUEIRA, Daniel. Mapa dos homicídios ocultos no Brasil. Brasília: IPEA, 2013. (Texto para Discussão, n. 1848). 12 CERQUEIRA, Daniel. Mapa dos homicídios ocultos no Brasil. Brasília: IPEA, 2013. (Texto para Discussão, n. 1848).

13 Vale ressaltar que essa não é a média aritmética da taxa de homicídios, mas apenas a média entre os estados. Isto é, não estamos ponderando pela população estadual.

14 CERQUEIRA, Daniel. Mapa dos homicídios ocultos no Brasil. Brasília: IPEA, 2013. (Texto para Discussão, n. 1848). 


\begin{tabular}{|c|c|c|c|c|c|c|}
\hline \multirow{2}{*}{$\begin{array}{c}\text { Estado } \\
\text { AL }\end{array}$} & \multicolumn{3}{|c|}{ Taxa de homicídios estimada } & \multicolumn{3}{|c|}{ Taxa de homicídios oficial } \\
\hline & 35.8 & 59.6 & $66.5 \%$ & 35.6 & 59.4 & $66.9 \%$ \\
\hline MA & 14.6 & 23.5 & $61.0 \%$ & 13.7 & 22.3 & $62.8 \%$ \\
\hline AM & 19.3 & 27.6 & $43.0 \%$ & 18.5 & 27.1 & $46.5 \%$ \\
\hline PR & 27.1 & 35.9 & $32.5 \%$ & 26.4 & 34.3 & $29.9 \%$ \\
\hline GO & 24.8 & 32.2 & $29.8 \%$ & 25.4 & 32.5 & $28.0 \%$ \\
\hline $\mathrm{CE}$ & 22.5 & 28.8 & $28.0 \%$ & 20.2 & 26.2 & $29.7 \%$ \\
\hline TO & 19.8 & 24.8 & $25.3 \%$ & 16.7 & 23.5 & $40.7 \%$ \\
\hline SE & 29 & 34.7 & $19.7 \%$ & 25.5 & 32.1 & $25.9 \%$ \\
\hline ES & 51.5 & 60 & $16.5 \%$ & 50.2 & 56.6 & $12.7 \%$ \\
\hline RS & 20.3 & 22.8 & $12.3 \%$ & 19.1 & 21.4 & $12.0 \%$ \\
\hline PI & 13.1 & 14.6 & $11.5 \%$ & 10.8 & 12.5 & $15.7 \%$ \\
\hline SC & 13.7 & 14.2 & $3.6 \%$ & 12.2 & 13.6 & $11.5 \%$ \\
\hline $\mathrm{AC}$ & 22.8 & 23.5 & $3.1 \%$ & 22.6 & 22.7 & $0.4 \%$ \\
\hline MG & 23.1 & 23.5 & $1.7 \%$ & 21 & 19 & $-9.5 \%$ \\
\hline DF & 39.1 & 38.6 & $-1.3 \%$ & 33.9 & 33.8 & $-0.3 \%$ \\
\hline MS & 34.1 & 32.4 & $-5.0 \%$ & 31.6 & 31 & $-1.9 \%$ \\
\hline MT & 37.7 & 35.7 & $-5.3 \%$ & 34.7 & 33.6 & $-3.2 \%$ \\
\hline $\mathrm{PE}$ & 57.6 & 50.4 & $-12.5 \%$ & 55.4 & 45.5 & $-17.9 \%$ \\
\hline $\mathrm{AP}$ & 36 & 31 & $-13.9 \%$ & 34.8 & 30.3 & $-12.9 \%$ \\
\hline $\mathrm{RO}$ & 44.1 & 37.5 & $-15.0 \%$ & 39.9 & 35.4 & $-11.3 \%$ \\
\hline $\mathrm{RR}$ & 41.7 & 33.9 & $-18.7 \%$ & 29.4 & 28.2 & $-4.1 \%$ \\
\hline RJ & 67.3 & 54 & $-19.8 \%$ & 50.4 & 31.9 & $-36.7 \%$ \\
\hline $\mathrm{SP}$ & 43.5 & 20.1 & $-53.8 \%$ & 35.8 & 16.6 & $-53.6 \%$ \\
\hline \multicolumn{3}{|c|}{ Média Geral } & $19.6 \%$ & & & $22.5 \%$ \\
\hline \multicolumn{3}{|c|}{ Média dos que aumentaram } & $37.5 \%$ & & & $44.6 \%$ \\
\hline \multicolumn{3}{|c|}{ Média dos que reduziram } & $-16.1 \%$ & & & $-15.1 \%$ \\
\hline
\end{tabular}

Fonte: Do Autor ${ }^{15}$

\section{Resultados ECONOMÉtricos}

Este trabalho faz uso de técnicas de dados de painel. A estrutura dos dados, com diversas unidades cross-section, fornecendo informações ao longo de quase uma década, é condizente com esse procedimento estatístico. Também devemos ressaltar que tal estimador permite melhor tratamento referente a questões de heterogeneidade locais. Num país de dimensões continentais como o Brasil, o uso de estimador capaz de lidar com a diversidade regional constitui vantagem não desprezível ${ }^{16}$.

Devemos ressaltar que, em todas as especificações econométricas, foi adotado o logaritmo das variáveis, de tal maneira que os coeficientes encontrados representam as elasticidades. Além disso, nossa unidade cross-section de referência são as unidades da federação (estados).

15 A partir de CERQUEIRA, Daniel. Mapa dos homicídios ocultos no Brasil. Brasília: IPEA, 2013. (Texto para Discussão, n. 1848). 16 Mais detalhes sobre o estimador de dados de painel podem ser encontrados em: BALTAGI, Badi H. Econometric analysis of panel data. Nova Jersey: J. Wiley \& Sons, 1995; HSIAO, Cheng. Analysis of panel data. Cambridge: Cambridge University, 1986. (Econometric Society Monographs, N. 11); ou DEATON, A. Panel Data from a Series of Repeated Cross-Sections. Journal of Econometrics, v. 30, p. 109-126, 1985. 
Para facilitar a compreensão dos resultados, iremos separar as variáveis utilizadas em três grupos. Os dois primeiros grupos referem-se às variáveis que geralmente aparecem nos estudos sobre criminalidade. Sua análise não faz parte do objetivo principal deste estudo. No primeiro grupo, temos as variáveis socioeconômicas (Taxa de Desemprego da UF e Taxa de Desigualdade de Renda da UF). No segundo grupo, incluímos proxy para os efeitos demográficos (proporção de homens entre 18 e 24 anos em relação à população total). Por fim, no terceiro grupo estão as variáveis de interesse neste estudo, isto é, as variáveis de repressão. As variáveis de repressão dividem-se em: a) variável de incapacitação (Taxa de Encarceramento da UF no período passado); e b) variáveis de detenção (Taxa de Policiais Militares da UF no período passado e Taxa de Policiais Civis da UF no período passado). Cabe destacar que as variáveis de repressão estão sempre defasadas em um período para evitar o problema da endogeneidade entre essas variáveis e a taxa de homicídios.

As Tabelas 2 e 3 apresentam a estimativa inicial do efeito de algumas variáveis sobre a taxa de homicídios da Unidade da Federação (UF). Todas as variáveis neste estudo foram transformadas em logaritmos. Isto é, os coeficientes podem ser interpretados como as elasticidades. Além disso, a unidade cross-section do estimador de painel sempre é a unidade da federação (estado). As Tabelas 2 e 3 também estão divididas em colunas com 6 estimativas diferentes: 1) estimativa feita pelo estimador de efeitos aleatórios, incluindo toda a amostra (Geral, ea); 2) estimativa feita pelo estimador de efeitos aleatórios, incluindo apenas os estados que apresentaram aumento na sua taxa de homicídios estimada por Cerqueira (2013) (Subiu, ea); 3) estimativa feita pelo estimador de efeitos aleatórios, incluindo apenas os estados que apresentaram queda na sua taxa de homicídios estimada (Caiu, ea); 4) estimativa feita pelo estimador de efeitos fixos, incluindo toda a amostra (Geral, ef); 5) estimativa feita pelo estimador de efeitos fixos, incluindo apenas os estados que apresentaram aumento na sua taxa de homicídios estimada (Subiu, ef); e 6) estimativa feita pelo estimador de efeitos fixos, incluindo apenas os estados que apresentaram queda na sua taxa de homicídios estimada (Caiu, ef).

A Tabela 2 faz a análise tomando como variável dependente a taxa de homicídios oficial. Para as variáveis de nosso interesse. Tanto as colunas (Geral, ea) como (Geral,ef) mostram resultados pobres sobre a capacidade das variáveis de repressão combaterem o crime. Ambas as colunas mostram baixo poder explicativo das variáveis independentes. Além disso, estas sinalizam que as variáveis de detenção (taxa de policiais civis e militares) são estatisticamente insignificantes. Enquanto a variável de incapacitação (taxa de presos) mostra-se positivamente correlacionada com a taxa de homicídios oficial.

Explorando melhor a Tabela 2, vemos que há diferença marcante de resultados quando dividimos a amostra entre estados que tiveram aumento/redução na taxa de homicídios estimada. Para os estados que apresentaram aumento na taxa de homicídios estimada, a taxa de encarceramento não foi capaz de reduzir a taxa de homicídios. Por outro lado, nos estados que apresentaram redução na taxa de homicídios estimada, pode-se notar que a taxa de encarceramento funcionou efetivamente para reduzir a taxa de homicídios. Esse resultado se repete para o efeito da taxa de policiais militares sobre a taxa de homicídios. Também é válido notar que o poder explicativo das variáveis independentes aumenta substancialmente quando analisamos os estados que tiveram redução na taxa de homicídios estimada.

Tabela 2 - Determinantes da taxa de homicídio oficial. Dados de painel, 2003-2009*

\begin{tabular}{l|l|l|l|l|l|l}
\hline Variável & Geral, ea & Subiu, ea & Caiu, ea & Geral, ef & Subiu, ef & Caiu, ef \\
\hline Taxa desemprego & .0678 & .1119 & .0649 & -.0069 & .0209 & .0417 \\
$(\mathrm{U})$ & $(, 462)$ & $(, 411)$ & $(, 551)$ & $(, 942)$ & $(, 884)$ & $(, 702)$ \\
\hline Taxa desigualdade & -.0618 & -1.009 & .6117 & -.2054 & -1.164 & .3895 \\
$($ Gini) & $(, 885)$ & $(, 106)$ & $(, 197)$ & $(, 654)$ & $(, 087)$ & $(, 471)$ \\
\hline Percentual_ & .3619 & -.2281 & .6026 & .4664 & -.3621 & .7727 \\
H18a24UF & $(, 310)$ & $(, 712)$ & $(, 099)$ & $(, 205)$ & $(, 581)$ & $(, 059)$ \\
(H1824) & & & & & & \\
\hline
\end{tabular}




\begin{tabular}{|c|c|c|c|c|c|c|}
\hline Variável & Geral, ea & Subiu, ea & Caiu, ea & Geral, ef & Subiu, ef & Caiu, ef \\
\hline $\begin{array}{l}\text { Taxa presos do } \\
\text { período passado }\end{array}$ & $\begin{array}{l}.1440 \\
(, 008) \\
\end{array}$ & $\begin{array}{l}.1409 \\
(, 049)\end{array}$ & $\begin{array}{l}-.2237 \\
(, 023) \\
\end{array}$ & $\begin{array}{l}.1443 \\
(, 025) \\
\end{array}$ & $\begin{array}{l}.1418 \\
(, 078) \\
\end{array}$ & $\begin{array}{l}-.0738 \\
(, 509) \\
\end{array}$ \\
\hline $\begin{array}{l}\text { Taxa Polícia Militar } \\
\text { do período passado }\end{array}$ & $\begin{array}{l}-.0024 \\
(, 951)\end{array}$ & $\begin{array}{l}.0193 \\
(700)\end{array}$ & $\begin{array}{l}-.0677 \\
(, 266)\end{array}$ & $\begin{array}{l}-.0120 \\
(, 775)\end{array}$ & $\begin{array}{l}.0138 \\
(, 790)\end{array}$ & $\begin{array}{l}-.0784 \\
(, 247)\end{array}$ \\
\hline $\begin{array}{l}\text { Taxa Policia Civil do } \\
\text { período passado }\end{array}$ & $\begin{array}{l}-.0172 \\
(, 477)\end{array}$ & $\begin{array}{l}-.0438 \\
(, 179)\end{array}$ & $\begin{array}{l}-.0279 \\
(, 382)\end{array}$ & $\begin{array}{l}-.0130 \\
(, 602)\end{array}$ & $\begin{array}{l}-.0351 \\
(, 289)\end{array}$ & $\begin{array}{l}.0001 \\
(, 996)\end{array}$ \\
\hline Constante & $\begin{array}{l}1.743 \\
(, 048) \\
\end{array}$ & $\begin{array}{l}2.160 \\
(, 160) \\
\end{array}$ & $\begin{array}{l}4.266 \\
(, 000) \\
\end{array}$ & $\begin{array}{l}1.658 \\
(, 080)\end{array}$ & $\begin{array}{l}2.510 \\
(, 129)\end{array}$ & $\begin{array}{l}2.974 \\
(, 019)\end{array}$ \\
\hline Observações & 148 & 97 & 51 & 148 & 97 & 51 \\
\hline Número de grupos & 27 & 18 & 9 & 27 & 18 & 9 \\
\hline Prob $>$ Chi2 & ,1755 & .0240 & .0077 & .2434 & .0196 & .1010 \\
\hline $\begin{array}{l}\text { fraction of variance } \\
\text { due to } u \_i\end{array}$ & .8344 & .8580 & .5829 & .8652 & .8802 & .8054 \\
\hline $\mathrm{R}^{2}$ overall & .0789 & .0126 & .5018 & .0223 & .0000 & .2970 \\
\hline F test that all $u_{-} \mathrm{i}=0$ & - & - & - & $\begin{array}{l}F(26,115) \\
=25.11 \\
(, 000)\end{array}$ & $\begin{array}{l}\mathrm{F}(17,73) \\
=25.76 \\
(, 000)\end{array}$ & $\begin{array}{l}\mathrm{F}(8,36) \\
=12.16 \\
(, 000)\end{array}$ \\
\hline
\end{tabular}

* todas as variáveis estão em logaritmo. Entre parênteses estão os t-prob. ea = efeito aleatório, ef = efeito fixo.

A Tabela 3 repete a análise feita para a Tabela 2. A única diferença é que naquela a variável dependente constitui a taxa de homicídios estimada por Cerqueira (2013). Qualitativamente os resultados são equivalentes, e os resultados presentes na Tabela 3 reforçam os encontrados na Tabela 2.

Tabela 3 - Determinantes da taxa de homicídio estimada. Dados de painel, 2003-2009*

\begin{tabular}{|c|c|c|c|c|c|c|}
\hline Variável & Geral, ea & Subiu, ea & Caiu, ea & Geral, ef & Subiu, ef & Caiu, ef \\
\hline Taxa desemprego & .0455 & .0801 & .0627 & -.0397 & -.0159 & .0087 \\
\hline$(\mathrm{U})$ & $(, 615)$ & $(, 538)$ & $(, 590)$ & $(, 666)$ & $(, 906)$ & $(, 940)$ \\
\hline Taxa desigualdade & -.0955 & -1.064 & .7722 & -.2791 & -1.229 & .4909 \\
\hline (Gini) & $(, 820)$ & $(, 075)$ & $(, 103)$ & $(, 529)$ & $(, 056)$ & $(, 397)$ \\
\hline Percentual_ & .2242 & -.2233 & -.0143 & .3943 & -.3724 & .5302 \\
\hline $\begin{array}{l}\text { H18a24UF } \\
\text { (H1824) }\end{array}$ & $(, 522)$ & $(, 706)$ & $(, 970)$ & $(, 267)$ & $(, 546)$ & $(, 218)$ \\
\hline \multirow{2}{*}{$\begin{array}{l}\text { Taxa presos do } \\
\text { período passado }\end{array}$} & .1504 & .1500 & -.3820 & .1583 & .1582 & -.0878 \\
\hline & $(, 005)$ & $(, 028)$ & $(, 000)$ & $(, 011)$ & $(, 038)$ & $(, 462)$ \\
\hline \multirow{2}{*}{$\begin{array}{l}\text { Taxa Policia Militar } \\
\text { do período passado }\end{array}$} & .0060 & .0188 & -.0183 & -.0039 & .0128 & -.0346 \\
\hline & $(, 879)$ & $(, 694)$ & $(, 769)$ & $(, 924)$ & $(, 793)$ & $(, 629)$ \\
\hline \multirow{2}{*}{$\begin{array}{l}\text { Taxa Policia Civil do } \\
\text { período passado }\end{array}$} & -.0127 & -.0344 & -.0503 & -.0076 & -.0235 & -.0064 \\
\hline & $(, 594)$ & $(, 271)$ & $(, 133)$ & $(, 752)$ & $(, 451)$ & $(, 859)$ \\
\hline \multirow[t]{2}{*}{ Constante } & 2.036 & 2.187 & 6.375 & 1.785 & 2.533 & 3.565 \\
\hline & $(, 019)$ & $(, 137)$ & $(, 000)$ & $(, 051)$ & $(, 104)$ & $(, 009)$ \\
\hline
\end{tabular}




\begin{tabular}{l|l|l|l|l|l|l}
\hline Variável & Geral, ea & Subiu, ea & Caiu, ea & Geral, ef & Subiu, ef & Caiu, ef \\
\hline Observações & 148 & 97 & 51 & 148 & 97 & 51 \\
\hline Número de Grupos & 27 & 18 & 9 & 27 & 18 & 9 \\
\hline Prob > Chi2 & .1286 & .0100 & .0004 & .1110 & .0041 & .4008 \\
\hline $\begin{array}{l}\text { fraction of variance } \\
\text { due to u_i }\end{array}$ & .8304 & .8540 & .4140 & .8815 & .8947 & .8104 \\
\hline $\mathrm{R}^{2}$ overall & .0545 & .0008 & .6404 & .0051 & .0063 & .2979 \\
\hline F test that all u_i $=0$ & - & - & - & $\begin{array}{l}\mathrm{F}(26,115) \\
=26.12 \\
(, 000)\end{array}$ & $\begin{array}{l}\mathrm{F}(17,73) \\
=26.64 \\
(, 000)\end{array}$ & $\begin{array}{l}\mathrm{F}(8,36)= \\
7.83(, 000)\end{array}$ \\
\hline
\end{tabular}

* todas as variáveis estão em logaritmo. Entre parênteses estão os t-prob. ea = efeito aleatório, ef = efeito fixo.

O que os resultados presentes nas Tabelas 2 e 3 evidenciam é que existem importantes diferenças entre as variáveis de repressão: nos estados onde a taxa de homicídios foi reduzida, as variáveis de repressão cumpriram importante papel. Já nos estados que tiveram acréscimo em suas taxas de homicídio, tanto o efetivo policial quanto as taxas de encarceramento tiveram pouco efeito no combate a violência.

Interessante notar que o texto de Levitt ${ }^{17}$ é bem claro ao afirmar que estratégias policiais distintas tiveram pouco efeito na redução da criminalidade nos Estados Unidos. Segundo ele, independentemente das estratégias policiais adotadas, bastava aumentar o efetivo policial e as taxas de encarceramento que a redução na criminalidade seria obtida. Nossos resultados não sustentam essa hipótese para o Brasil.

A Tabela 4 mostra a evolução das taxas de homicídio estimada por Cerqueira ${ }^{18}$ e de encarceramento por estado. Uma conta rápida mostra que, nos estados que apresentaram redução na taxa de homicídios, em 2009, a média de presos por 100 mil habitantes no estado era de 332,4. Por outro lado, nos estados que apresentaram aumento na taxa de homicídios, essa média era de 166,8. Das nove unidades da federação que apresentaram queda na taxa de homicídios estimada, oito apresentaram aumento na taxa de encarceramento do período (o Distrito Federal foi a exceção). Roraima e Rondônia, com aumentos expressivos da taxa de encarceramento, também apresentaram expressivos resultados no combate à taxa de homicídios.

Ainda na Tabela 4, podemos verificar que, das dezoito unidades da federação que apresentaram aumento na taxa de homicídios estimada, apenas Sergipe apresentou redução na taxa de encarceramento. Esses estados apresentaram também expressivos aumentos nas suas taxas de encarceramento, com um crescimento médio de 90,1\% nessas taxas (contra um aumento de 61,3\% nos estados que apresentaram redução da taxa de homicídios). Destaque deve ser dado ao estado de Minas Gerais, que saltou de uma taxa de encarceramento de 29,3 em 2003, para 175,3 em 2009.

Tabela 4 - Evolução das taxas de homicídio estimada e de encarceramento por Estado

\begin{tabular}{c|c|c|c|c|c|c|c}
\hline Posição & Estado & $\begin{array}{c}\text { Presos } \\
2003\end{array}$ & $\begin{array}{c}\text { Presos } \\
2009\end{array}$ & Variação & $\begin{array}{c}\text { Homicídio } \\
2003\end{array}$ & $\begin{array}{c}\text { Homicídio } \\
2009\end{array}$ & Variação \\
\hline 1 & SP & 255.82 & 373.37 & $45.90 \%$ & 43.5 & 20.1 & $-53.80 \%$ \\
\hline 2 & RJ & 124.75 & 144.64 & $15.90 \%$ & 67.3 & 54 & $-19.80 \%$ \\
\hline 3 & RR & 160.37 & 391.7 & $144.20 \%$ & 41.7 & 33.9 & $-18.70 \%$ \\
\hline 4 & RO & 231.61 & 464.52 & $100.60 \%$ & 44.1 & 37.5 & $-15.00 \%$ \\
\hline 5 & AP & 174.08 & 289.18 & $66.10 \%$ & 36 & 31 & $-13.90 \%$ \\
\hline
\end{tabular}

17 LEVITT, Steven. D.; LOCHNER, Lance. The determinants of juvenile crime. In: GRUBER, Jonathan (Ed.). Risky Behavior among youths: an economic analysis Chicago: University of Chicago Press, Jan. 2001. (NBER Working Paper, n. w7781). p. $327-374$. Available in: <http://www.nber.org/chapters/c10692.pdf>. Access: 17 Nov. 2015

18 CERQUEIRA, Daniel. Mapa dos homicídios ocultos no Brasil. Brasília: IPEA, 2013. (Texto para Discussão, n. 1848). 


\begin{tabular}{c|c|c|c|c|c|c|c}
\hline Posição & Estado & $\begin{array}{c}\text { Presos } \\
2003\end{array}$ & $\begin{array}{c}\text { Presos } \\
2009\end{array}$ & Variação & $\begin{array}{c}\text { Homicídio } \\
2003\end{array}$ & $\begin{array}{c}\text { Homicídio } \\
2009\end{array}$ & Variação \\
\hline 6 & PE & 153 & 238.82 & $56.10 \%$ & 57.6 & 50.4 & $-12.50 \%$ \\
\hline 7 & MT & 256.55 & 368.49 & $43.60 \%$ & 37.7 & 35.7 & $-5.30 \%$ \\
\hline 8 & MS & 226.53 & 408.42 & $80.30 \%$ & 34.1 & 32.4 & $-5.00 \%$ \\
\hline 9 & DF & 314.96 & 312.9 & $-0.70 \%$ & 39.1 & 38.6 & $-1.30 \%$ \\
\hline 10 & MG & 29.31 & 175.31 & $498.10 \%$ & 23.1 & 23.5 & $1.70 \%$ \\
\hline 11 & AC & 321.67 & 494.96 & $53.90 \%$ & 22.8 & 23.5 & $3.10 \%$ \\
\hline 12 & SC & 119.37 & 218.02 & $82.60 \%$ & 13.7 & 14.2 & $3.60 \%$ \\
\hline 13 & PI & 45.7 & 82.59 & $80.70 \%$ & 13.1 & 14.6 & $11.50 \%$ \\
\hline 14 & RS & 175.25 & 263.42 & $50.30 \%$ & 20.3 & 22.8 & $12.30 \%$ \\
\hline 15 & ES & 127.01 & 230.45 & $81.40 \%$ & 51.5 & 60 & $16.50 \%$ \\
\hline 16 & SE & 149.05 & 135.76 & $-8.90 \%$ & 29 & 34.7 & $19.70 \%$ \\
\hline 17 & TO & 90.56 & 127.55 & $40.90 \%$ & 19.8 & 24.8 & $25.30 \%$ \\
\hline 18 & CE & 145.87 & 150.59 & $3.20 \%$ & 22.5 & 28.8 & $28.00 \%$ \\
\hline 19 & GO & 62.83 & 166.55 & $165.10 \%$ & 24.8 & 32.2 & $29.80 \%$ \\
\hline 20 & PR & 75.59 & 207.43 & $174.40 \%$ & 27.1 & 35.9 & $32.50 \%$ \\
\hline 21 & AM & 66.77 & 114.19 & $71.00 \%$ & 19.3 & 27.6 & $43.00 \%$ \\
\hline 22 & MA & 36.03 & 53.79 & $49.30 \%$ & 14.6 & 23.5 & $61.00 \%$ \\
\hline 23 & AL & 50.97 & 62.67 & $23.00 \%$ & 35.8 & 59.6 & $66.50 \%$ \\
\hline 24 & BA & 39.56 & 56.16 & $42.00 \%$ & 30.1 & 50.3 & $67.10 \%$ \\
\hline 25 & RN & 60.97 & 120.31 & $97.30 \%$ & 20.9 & 35.5 & $69.90 \%$ \\
\hline 26 & PB & 153.87 & 226.1 & $46.90 \%$ & 18.2 & 34.5 & $89.60 \%$ \\
\hline 27 & PA & 68.78 & 117.56 & $70.90 \%$ & 21.9 & 42.5 & $94.10 \%$ \\
\hline F 210 & & &
\end{tabular}

Fonte: Do Autor ${ }^{19}$

A Tabela 4 nos lança a seguinte pergunta: será que estados que apresentaram aumento nas taxas de homicídio não seriam aqueles que prendiam pouco em 2003? De acordo com os dados presentes na Tabela 4, temos que, em 2003, nos estados que apresentaram queda na taxa de homicídios, tinha-se taxa de detenção média de 210,8 contra taxa média de 101 presos por 100 mil habitantes nos estados que tiveram aumento na taxa de homicídios. Este consiste em mais um indício de que prender criminosos costuma ser estratégia de longo prazo eficiente no combate ao crime.

Verificando a correlação entre taxa de detenção em 2003, e taxa de homicídios em 2009, encontramos que, usando uma linha de corte igual a 100 presos por 100 mil habitantes: a) nos estados que, em 2003, apresentavam taxa de detenção inferior a 100, a correlação entre detenção em 2003 e homicídios em 2009 foi de 0,021 ; e b) nos estados que, em 2003, apresentavam taxa de detenção superior a 100, a correlação entre detenção em 2003 e homicídios em 2009 foi de -0,272. Isto é, estados que no passado tinham taxas de detenção mais alta apresentaram no futuro menores taxas de homicídio.

Infelizmente, nossa série histórica não é grande o bastante para podermos analisar efeitos de tão longo prazo da taxa de detenção sobre a taxa de homicídios. Contudo, nossas análises conjuntas parecem sugerir fortemente que incrementos na taxa de detenção são importantes instrumentos para a redução da taxa de homicídios.

19 CERQUEIRA, Daniel. Mapa dos homicídios ocultos no Brasil. Brasília: IPEA, 2013. (Texto para Discussão, n. 1848). 
Em relação à taxa de policiais, parece que estratégias de policiamento possuem sim importante significado nas políticas de redução ao crime, resultado esse que contradiz o estudo de Levitt ${ }^{20}$ para os Estados Unidos. A Tabela 5 explicita a taxa de policiais e a taxa de homicídios estimada para as diversas unidades da federação. Não deixa de ser interessante notar que, entre as nove unidades da federação que apresentaram redução na taxa de homicídios estimada: a) três delas (São Paulo, Rio de Janeiro e Distrito Federal) apresentaram também redução na taxa de policiais civis e militares; e b) apenas um único estado (Rondônia) aumentou a taxa de policiamento de ambas as policias no período.

Parece ser correto frisar que não apenas a taxa de variação do policiamento é importante, mas, sobretudo, seu número absoluto. Vale a pena ressaltar que a correlação entre a taxa de policias militares em 2003 e a taxa de homicídios em 2009 é de: a) -0,227 para estados que em 2003 mantinham uma taxa de policiais militares igual ou superior a 200 por 100 mil habitantes; e b) 0,822 para estados que em 2003 mantinham uma taxa de policiais militares inferior a 150 por 100 mil habitantes. Isso indica que manter uma força policial reduzida é ineficiente no combate ao crime. Além disso, parece sugerir que abaixo de determinado nível o policiamento militar não é capaz de dissipar o comportamento criminoso no longo prazo.

Tabela 5 - Taxa de policiais e taxa de homicídios estimada*

\begin{tabular}{l|l|l|l|l|l|l|l|l|l}
\hline Estado & 2003 & \multicolumn{3}{l}{ 2009 } & \multicolumn{3}{l}{ Variação (\%) } \\
\hline & Homic. & militar & civil & Homic. & militar & civil & Homic. & militar & civil \\
\hline SP & 43.5 & 187.0 & 61.6 & 20.1 & 171.6 & 43.5 & $-53.8 \%$ & $-8.2 \%$ & $-29.3 \%$ \\
\hline RJ & 67.3 & 251.7 & 71.0 & 54 & 159.1 & 57.2 & $-19.8 \%$ & $-36.8 \%$ & $-19.5 \%$ \\
\hline RR & 41.7 & 262.5 & 41.9 & 33.9 & 247.9 & 41.9 & $-18.7 \%$ & $-5.6 \%$ & $0.0 \%$ \\
\hline RO & 44.1 & 280.2 & 44.2 & 37.5 & 380.9 & 59.6 & $-15.0 \%$ & $35.9 \%$ & $34.8 \%$ \\
\hline AP & 36 & 393.0 & 452.4 & 31 & 795.9 & 42.0 & $-13.9 \%$ & $102.5 \%$ & $-90.7 \%$ \\
\hline PE & 57.6 & 172.2 & 10.2 & 50.4 & 219.8 & 5.5 & $-12.5 \%$ & $27.6 \%$ & $-45.7 \%$ \\
\hline MT & 37.7 & 211.9 & 35.3 & 35.7 & 197.5 & 52.6 & $-5.3 \%$ & $-6.8 \%$ & $48.9 \%$ \\
\hline MS & 34.1 & 118.2 & 73.8 & 32.4 & 194.7 & 51.9 & $-5.0 \%$ & $64.7 \%$ & $-29.7 \%$ \\
\hline DF & 39.1 & 638.6 & 47.6 & 38.6 & 473.6 & 34.4 & $-1.3 \%$ & $-25.8 \%$ & $-27.8 \%$ \\
\hline MG & 23.1 & 179.8 & 33.9 & 23.5 & 267.5 & 14.1 & $1.7 \%$ & $48.7 \%$ & $-58.4 \%$ \\
\hline AC & 22.8 & 494.2 & 73.9 & 23.5 & 505.2 & 57.9 & $3.1 \%$ & $2.2 \%$ & $-21.7 \%$ \\
\hline PC & 13.7 & 261.8 & 70.4 & 14.2 & 214.7 & 19.5 & $3.6 \%$ & $-18.0 \%$ & $-72.3 \%$ \\
\hline RS & 13.1 & 174.2 & 17.4 & 14.6 & 156.6 & 85.0 & $11.5 \%$ & $-10.1 \%$ & $388.2 \%$ \\
\hline ES & 20.3 & 181.9 & 69.4 & 22.8 & 238.0 & 21.3 & $12.3 \%$ & $30.8 \%$ & $-69.4 \%$ \\
\hline SE & 51.5 & 144.4 & 43.3 & 60 & 148.0 & 53.8 & $16.5 \%$ & $2.5 \%$ & $24.2 \%$ \\
\hline TO & 29 & 360.7 & 85.9 & 34.7 & 235.6 & 16.8 & $19.7 \%$ & $-34.7 \%$ & $-80.4 \%$ \\
\hline CE & 22.5 & 194.6 & 17.6 & 24.8 & 314.1 & 34.9 & $25.3 \%$ & $61.4 \%$ & $97.9 \%$ \\
\hline GO & 24.8 & 172.8 & 16.7 & 28.8 & 162.2 & 19.0 & $28.0 \%$ & $-6.2 \%$ & $13.5 \%$ \\
\hline PR & 27.1 & 80.5 & 54.4 & 32.2 & 196.1 & 17.8 & $29.8 \%$ & $7.8 \%$ & $-43.1 \%$ \\
\hline AM & 19.3 & 205.6 & 78.3 & 27.6 & 190.9 & 37.6 & $43.0 \%$ & $-7.1 \%$ & $-52.0 \%$ \\
\hline MA & 14.6 & 68.0 & 27.2 & 23.5 & 126.6 & 14.1 & $61.0 \%$ & $86.1 \%$ & $-48.3 \%$ \\
\hline AL & 35.8 & 235.4 & 15.7 & 59.6 & 271.6 & 34.0 & $66.5 \%$ & $15.4 \%$ & $116.4 \%$ \\
\hline & & & & & & & & & \\
\hline
\end{tabular}

20 LEVITT, Steven. D.; LOCHNER, Lance. The determinants of juvenile crime. In: GRUBER, Jonathan (Ed.). Risky Bebavior among youths: an economic analysis Chicago: University of Chicago Press, Jan. 2001. (NBER Working Paper, n. w7781). p. 327-374. Available in: <http://www.nber.org/chapters/c10692.pdf>. Access: 17 Nov. 2015. 


\begin{tabular}{l|l|l|l|l|l|l|l|l|l}
\hline Estado & \multicolumn{3}{l}{ 2003 } & \multicolumn{3}{l|}{2009} & \multicolumn{3}{l}{ Variação $(\%)$} \\
\hline BA & 30.1 & 204.1 & 33.3 & 50.3 & 190.8 & 21.9 & $67.1 \%$ & $-6.5 \%$ & $-34.3 \%$ \\
\hline RN & 20.9 & 341.4 & 16.2 & 35.5 & 249.5 & 15.6 & $69.9 \%$ & $-26.9 \%$ & $-4.0 \%$ \\
\hline PB & 18.2 & 109.4 & 81.9 & 34.5 & 213.0 & 13.3 & $89.6 \%$ & $94.8 \%$ & $-83.7 \%$ \\
\hline PA & 21.9 & 159.3 & 23.7 & 42.5 & 195.0 & 21.7 & $94.1 \%$ & $22.4 \%$ & $-8.2 \%$ \\
\hline
\end{tabular}

${ }^{*}$ Em 2003 não estavam disponíveis informações sobre a taxa de policiais civis nem para o Amapá e nem para Roraima. Sendo assim usou-se a taxa de 2004 para o Amapá e a de 2005 para Roraima. A taxa de policiais civis para 2009 não estava disponível nem para o Piaú e nem para Roraima, logo adotou-se a taxa de 2007 para o primeiro e a de 2008 para o segundo.

Fonte: Do Autor ${ }^{21}$

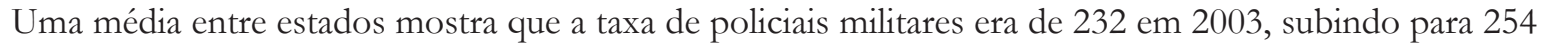
em 2009 (aumento de 9,5\%). Essa mesma taxa entre policiais civis se reduziu de 60,3 em 2003 para 33,8 em 2009 (queda de 43,9\%). Uma linha de pesquisa promissora seria analisar esse comportamento estratégico, adotado por determinados estados, de aumentar o policiamento militar e reduzir o efetivo civil. Vale ressaltar que essa média não consiste na média aritmética, mas na média por estado.

Por fim, 12 dos 27 estados reduziram a taxa de policiais militares. E outros 19 estados reduziram sua taxa de policias civis. Isso pode sugerir que boa parte do atual crescimento da taxa de homicídios no Brasil pode ter sido derivada diretamente dessa escolha de política pública: redução do aparato de policiamento do Estado brasileiro.

\section{Resultados ECONOMÉtRICOS ADICIONAIS}

As Tabelas 6 e 7 incluem amplo conjunto de variáveis para verificar a robustez de nossos resultados. De maneira geral, elas confirmam que existe uma diferença importante entre estados que tiveram redução e aumento na taxa de homicídios. A estratégia policial e a taxa de encarceramento têm efeitos distintos, dependendo do sucesso ou não do combate ao crime.

Tabela 6 - Determinantes da taxa de homicídio oficial. Dados de painel, 2003-2009*

\begin{tabular}{l|l|l|l|l|l|l}
\hline Variável & Geral, ea & Subiu, ea & Caiu, ea & Geral, ef & Subiu, ef & Caiu, ef \\
\hline Taxa desemprego & .0099 & .0519 & .1524 & -.0324 & .0017 & .0023 \\
$(\mathrm{U})$ & $(, 907)$ & $(, 570)$ & $(, 346)$ & $(, 694)$ & $(, 985)$ & $(, 985)$ \\
\hline Taxa desigualdade & .3389 & -.6681 & 1.289 & .3867 & -.5187 & 1.006 \\
$($ Gini) & $(, 443)$ & $(, 193)$ & $(, 003)$ & $(, 396)$ & $(, 331)$ & $(, 205)$ \\
\hline Percentual_ & .5645 & -.3760 & -.2530 & .8974 & -.2709 & 1.316 \\
H18a24UF & $(, 164)$ & $(, 438)$ & $(, 668)$ & $(, 036)$ & $(, 576)$ & $(, 049)$ \\
(H1824) & .2006 & .2474 & .0695 & .1953 & .1879 & -.3050 \\
\hline Pobreza & $(, 184)$ & $(, 145)$ & $(, 600)$ & $(, 265)$ & $(, 301)$ & $(, 342)$ \\
\hline Renda & .0600 & .0875 & -.0641 & -.0243 & .0156 & -.2067 \\
& $(, 288)$ & $(, 122)$ & $(, 600)$ & $(, 713)$ & $(, 809)$ & $(, 092)$ \\
\hline Educação & 1.695 & 2.459 & -.6542 & 2.105 & 2.455 & .1766 \\
& $(, 464)$ & $(, 000)$ & $(, 081)$ & $(, 000)$ & $(, 000)$ & $(, 850)$ \\
\hline
\end{tabular}

21 CERQUEIRA, Daniel. Mapa dos homicídios ocultos no Brasil. Brasília: IPEA, 2013. (Texto para Discussão, n. 1848). 


\begin{tabular}{|c|c|c|c|c|c|c|}
\hline Variável & Geral, ea & Subiu, ea & Caiu, ea & Geral, ef & Subiu, ef & Caiu, ef \\
\hline \multirow[t]{2}{*}{$\%$ Negros } & -.0196 & -.0469 & .2925 & -.0590 & -.0529 & .2217 \\
\hline & $(, 736)$ & $(, 362)$ & $(, 034)$ & $(, 321)$ & $(, 313)$ & $(, 183)$ \\
\hline \multirow[t]{2}{*}{ População } & .0229 & -.0300 & -.0598 & 1.226 & 1.135 & .5552 \\
\hline & $(, 748)$ & $(, 840)$ & $(, 059)$ & $(, 086)$ & $(, 146)$ & $(, 633)$ \\
\hline \multirow{2}{*}{$\begin{array}{l}\text { Taxa presos do } \\
\text { período passado }\end{array}$} & -.0195 & -.1092 & -.2505 & -.0403 & -.1333 & -.1251 \\
\hline & $(, 763)$ & $(, 087)$ & $(, 101)$ & $(, 559)$ & $(, 045)$ & $(, 469)$ \\
\hline \multirow{2}{*}{$\begin{array}{l}\text { Taxa Policia Militar } \\
\text { do período passado }\end{array}$} & -.0044 & .0359 & -.0479 & .0149 & .0484 & -.0280 \\
\hline & $(, 905)$ & $(, 290)$ & $(, 576)$ & $(, 687)$ & $(, 161)$ & $(, 733)$ \\
\hline \multirow{2}{*}{$\begin{array}{l}\text { Taxa Policia Civil do } \\
\text { período passado }\end{array}$} & -.0114 & -.0276 & -.0392 & -.0032 & -.0212 & .0138 \\
\hline & $(, 600)$ & $(, 200)$ & $(, 333)$ & $(, 879)$ & $(, 325)$ & $(, 717)$ \\
\hline \multirow[t]{2}{*}{ Constante } & -1.949 & -1.414 & 8.034 & -21.09 & -18.75 & -4.531 \\
\hline & $(, 277)$ & $(, 624)$ & $(, 000)$ & $(, 055)$ & $(, 112)$ & $(, 801)$ \\
\hline Observações & 147 & 97 & 50 & 147 & 97 & 50 \\
\hline Número de grupos & 27 & 18 & 9 & 27 & 18 & 9 \\
\hline Prob > Chi2 &, 000 &, 000 &, 000 &, 000 &, 000 & ,228 \\
\hline $\begin{array}{l}\text { fraction of variance } \\
\text { due to } u \_i\end{array}$ & .8821 & .9619 & 0 & .9919 & .9929 & .9838 \\
\hline $\mathrm{R}^{2}$ overall &, 0342 &, 0126 &, 7185 &, 0014 &, 0033 &, 0017 \\
\hline F test that all u_i $=0$ & - & - & - & $\begin{array}{l}F(26,109) \\
=\quad 33.70 \\
(, 000)\end{array}$ & $\begin{array}{l}F(17,68) \\
=\quad 61.32 \\
(, 000)\end{array}$ & $\begin{array}{l}\mathrm{F}(8,30)= \\
6.07(, 001)\end{array}$ \\
\hline
\end{tabular}

*Todas as variáveis estão em logaritmo. Entre parênteses estão os t-prob. ea = efeito aleatório, ef = efeito fixo.

Tabela 7 - determinantes da Taxa de Homicídio Estimada. Dados de painel, 2003-2009*

\begin{tabular}{l|l|l|l|l|l|l}
\hline Variável & Geral, ea & Subiu, ea & Caiu, ea & Geral, ef & Subiu, ef & Caiu, ef \\
\hline Taxa desemprego & -.0256 & .0155 & .0500 & -.0719 & -.0360 & -.0147 \\
$(\mathrm{U})$ & $(, 759)$ & $(, 862)$ & $(, 754)$ & $(, 370)$ & $(, 690)$ & $(, 914)$ \\
\hline Taxa desigualdade & .2243 & -.8831 & 1.339 & .1885 & -.7518 & 1.019 \\
(Gini) & $(, 605)$ & $(, 078)$ & $(, 002)$ & $(, 669)$ & $(, 145)$ & $(, 235)$ \\
\hline Percentual_ & .3460 & -.4624 & -.7978 & .6848 & -.3611 & .7801 \\
H18a24UF & $(, 385)$ & $(, 329)$ & $(, 170)$ & $(, 099)$ & $(, 440)$ & $(, 270)$ \\
(H1824) & & & & & & \\
\hline Pobreza & .2669 & .3137 & .0779 & .2708 & .2591 & -.2015 \\
& $(, 069)$ & $(, 057)$ & $(, 552)$ & $(, 112)$ & $(, 141)$ & $(, 560)$ \\
\hline Renda & .0501 & .0963 & -.1075 & -.0248 & .0251 & -.2147 \\
& $(, 364)$ & $(, 081)$ & $(, 372)$ & $(, 698)$ & $(, 688)$ & $(, 105)$ \\
\hline Educação & 1.743 & 2.317 & -.3221 & 2.162 & 2.339 & .4923 \\
& $(, 000)$ & $(, 000)$ & $(, 384)$ & $(, 000)$ & $(, 000)$ & $(, 627)$ \\
\hline
\end{tabular}




\begin{tabular}{|c|c|c|c|c|c|c|}
\hline Variável & Geral, ea & Subiu, ea & Caiu, ea & Geral, ef & Subiu, ef & Caiu, ef \\
\hline \multirow[t]{2}{*}{$\%$ Negros } & -.0160 & -.0466 & .3534 & -.0742 & -.0570 & .0869 \\
\hline & $(, 780)$ & $(, 353)$ & $(, 009)$ & $(, 200)$ & $(, 260)$ & $(, 624)$ \\
\hline \multirow[t]{2}{*}{ População } & .0622 & .0059 & -.0333 & 1.142 & 1.13 & .3502 \\
\hline & $(, 356)$ & $(, 966)$ & $(, 287)$ & $(, 099)$ & $(, 132)$ & $(, 780)$ \\
\hline \multirow{2}{*}{$\begin{array}{l}\text { Taxa presos do } \\
\text { período passado }\end{array}$} & .0172 & -.0611 & -.3560 & .0056 & -.0821 & -.0675 \\
\hline & $(, 785)$ & $(, 326)$ & $(, 018)$ & $(, 933)$ & $(, 197)$ & $(, 717)$ \\
\hline \multirow{2}{*}{$\begin{array}{l}\text { Taxa Policia Militar } \\
\text { do período passado }\end{array}$} & .0044 & .0336 & -.0070 & .0203 & .0455 & .0222 \\
\hline & $(, 904)$ & $(, 311)$ & $(, 934)$ & $(, 574)$ & $(, 172)$ & $(, 802)$ \\
\hline \multirow{2}{*}{$\begin{array}{l}\text { Taxa Policia Civil do } \\
\text { período passado }\end{array}$} & -.0064 & -.0163 & -.0479 & .0026 & -.0094 & .0086 \\
\hline & $(, 766)$ & $(, 438)$ & $(, 231)$ & $(, 898)$ & $(, 649)$ & $(, 835)$ \\
\hline \multirow[t]{2}{*}{ Constante } & -2.52 & -2.05 & 8.95 & -19.93 & -18.88 & -1.44 \\
\hline & $(, 145)$ & $(, 454)$ & $(, 000)$ & $(, 061)$ & $(, 097)$ & $(, 941)$ \\
\hline Observações & 147 & 97 & 50 & 147 & 97 & 50 \\
\hline Número de grupos & 27 & 18 & 9 & 27 & 18 & 9 \\
\hline Prob $>$ Chi2 & ,000 &, 000 &, 000 & ,000 &, 000 &, 5863 \\
\hline $\begin{array}{l}\text { fraction of variance } \\
\text { due to } u \_i\end{array}$ & .8698 & .9583 & 0 & .9907 & .9929 & .9508 \\
\hline $\mathrm{R}^{2}$ overall & ,0568 &, 0045 &, 7586 &, 0030 &, 0051 &, 0380 \\
\hline F test that all $u \_i=0$ & - & - & - & $\begin{array}{l}\mathrm{F}(26,109)= \\
32.53(, 000)\end{array}$ & $\begin{array}{l}\mathrm{F}(17,68)= \\
57.81(, 000)\end{array}$ & $\begin{array}{l}\mathrm{F}(8,30)= \\
4.43(, 001)\end{array}$ \\
\hline
\end{tabular}

* Todas as variáveis estão em logaritmo. Entre parênteses estão os t-prob. ea = efeito aleatório, ef = efeito fixo.

Uma estratégia econométrica alternativa consiste em adotar esse conjunto extra de variáveis como instrumentos da taxa de encarceramento e da taxa de policiamento. Isso foi feito, contudo os resultados qualitativos são equivalentes aos reportados nas Tabelas 2 e 3 . Novamente, têm-se diferenças importantes entre estados que tiveram sua taxa de homicídios aumentada daqueles que tiveram sua taxa de homicídios reduzida ${ }^{22}$.

Vamos agora nos concentrar nos estados onde ocorreram grandes reduções na taxa de homicídios estimada. Vamos analisar separadamente os estados que obtiveram redução superior a 10\% na taxa de homicídios estimada no período (Pernambuco, Amapá, Rondônia, Roraima, Rio de Janeiro e São Paulo). A Tabela 8 mostra o resultado para esses estados. Em geral, pode-se argumentar que nesses estados as variáveis de detenção e repressão apresentaram importantes contribuições para a queda na taxa de homicídios.

Tabela 8 - Resultados para estados com redução superior a 10\% na taxa de homicídios

\begin{tabular}{l|l|l|l|l|l|l}
\hline Variável & $\begin{array}{l}\text { Taxa pre- } \\
\text { sos período } \\
\text { passado }\end{array}$ & $\begin{array}{l}\text { Taxa presos } \\
\text { período } \\
\text { atual }\end{array}$ & $\begin{array}{l}\text { Taxa } \\
\text { Polícia Mi- } \\
\text { litar perío- } \\
\text { do passado }\end{array}$ & $\begin{array}{l}\text { Taxa Polícia } \\
\text { Militar perío- } \\
\text { do atual }\end{array}$ & $\begin{array}{l}\text { Taxa } \\
\text { Polícia Ci- } \\
\text { vil período } \\
\text { passado }\end{array}$ & $\begin{array}{l}\text { Taxa Polícia } \\
\text { Civil período } \\
\text { atual }\end{array}$ \\
\hline Efeito aleatório & $\mathbf{- . 6 9 5 3}$ & & $\begin{array}{l}.1489 \\
(, 128)\end{array}$ & & $\mathbf{- . 0 7 2 3}$ & \\
& $\mathbf{( , 0 0 0 )}$ & & $\mathbf{( 1 0 6 )}$ & \\
\hline
\end{tabular}

22 Por motivos de economia de espaço, tais resultados não estão reportados neste artigo. Para leitores mais curiosos, basta requerer a base de dados diretamente com os autores. 


\begin{tabular}{|c|c|c|c|c|c|c|}
\hline Variável & $\begin{array}{l}\text { Taxa pre- } \\
\text { sos período } \\
\text { passado }\end{array}$ & $\begin{array}{l}\text { Taxa presos } \\
\text { período } \\
\text { atual }\end{array}$ & $\begin{array}{l}\text { Taxa } \\
\text { Polícia Mi- } \\
\text { litar perío- } \\
\text { do passado }\end{array}$ & $\begin{array}{l}\text { Taxa Polícia } \\
\text { Militar perío- } \\
\text { do atual }\end{array}$ & \begin{tabular}{|l|} 
Taxa \\
Polícia Ci- \\
vil período \\
passado
\end{tabular} & $\begin{array}{l}\text { Taxa Polícia } \\
\text { Civil período } \\
\text { atual }\end{array}$ \\
\hline Efeito fixo & $\begin{array}{l}-.0151 \\
(, 917) \\
\end{array}$ & & $\begin{array}{l}-.1044 \\
(, 269) \\
\end{array}$ & & $\begin{array}{l}-.0119 \\
(, 775) \\
\end{array}$ & \\
\hline Aleatório IV & & $\begin{array}{l}-1.069 \\
(, 001)\end{array}$ & & $\begin{array}{l}.0995 \\
(, 581)\end{array}$ & & $\begin{array}{l}-.2265 \\
(, 044)\end{array}$ \\
\hline Fixo IV & & $\begin{array}{l}-.1441 \\
(, 648) \\
\end{array}$ & & $\begin{array}{l}-.1182 \\
(, 861)\end{array}$ & & $\begin{array}{l}.1079 \\
(, 286)\end{array}$ \\
\hline $\begin{array}{l}\text { Aleatório variáveis } \\
\text { de controle extras }\end{array}$ & $\begin{array}{l}.0010 \\
(, 994)\end{array}$ & & $\begin{array}{l}-.2208 \\
(, 064)\end{array}$ & & $\begin{array}{l}.0148 \\
(, 729)\end{array}$ & \\
\hline $\begin{array}{l}\text { Fixo variáveis de } \\
\text { controle extras }\end{array}$ & $\begin{array}{l}.0860 \\
(, 720) \\
\end{array}$ & & $\begin{array}{l}-.1743 \\
(, 436)\end{array}$ & & $\begin{array}{l}-.0287 \\
(, 636)\end{array}$ & \\
\hline
\end{tabular}

${ }^{*}$ Em negrito estão as variáveis estatisticamente significantes.

A Tabela 9 reproduz a Tabela 8 apenas para os estados que tiveram expressivos aumentos em suas respectivas taxas de homicídio estimadas. Isto é, separamos os estados que tiveram incremento superior a $50 \%$ nas taxas de homicídios estimadas no período (Pará, Paraíba, Rio Grande do Norte, Bahia, Alagoas, e Maranhão). Ao contrário dos resultados presentes na Tabela 8, para a Tabela 9 fica evidente que as variáveis de repressão e detenção não foram efetivas para a redução na taxa de homicídios.

Tabela 9 - Resultados para estados com crescimento superior a 50\% na taxa de homicídios

\begin{tabular}{|c|c|c|c|c|c|c|}
\hline Variável & \begin{tabular}{|l} 
Taxa presos \\
período passado
\end{tabular} & $\begin{array}{l}\text { Taxa presos } \\
\text { período } \\
\text { atual }\end{array}$ & \begin{tabular}{|l|} 
Taxa \\
Polícia Mi- \\
litar perío- \\
do passado \\
\end{tabular} & $\begin{array}{l}\text { Taxa } \\
\text { Polícia Mi- } \\
\text { litar perío- } \\
\text { do atual } \\
\end{array}$ & \begin{tabular}{|l} 
Taxa \\
Polícia Ci- \\
vil período \\
passado \\
\end{tabular} & $\begin{array}{l}\text { Taxa Polícia } \\
\text { Civil perío- } \\
\text { do atual }\end{array}$ \\
\hline Efeito aleatório & $\begin{array}{l}-.0096 \\
(, 945) \\
\end{array}$ & & $\begin{array}{l}.1865 \\
(, 166) \\
\end{array}$ & & $\begin{array}{l}-.0265 \\
(, 829) \\
\end{array}$ & \\
\hline Efeito fixo & $\begin{array}{l}.9338 \\
(, 000) \\
\end{array}$ & & $\begin{array}{l}.0372 \\
(, 659) \\
\end{array}$ & & $\begin{array}{l}-.0129 \\
(796)\end{array}$ & \\
\hline Aleatório IV & & $\begin{array}{l}-.1406 \\
(, 534) \\
\end{array}$ & & $\begin{array}{l}.4439 \\
(, 024) \\
\end{array}$ & & $\begin{array}{l}.0367 \\
(, 899) \\
\end{array}$ \\
\hline Fixo IV & & $\begin{array}{l}1.217 \\
(, 000) \\
\end{array}$ & & $\begin{array}{l}.1947 \\
(, 372) \\
\end{array}$ & & \begin{tabular}{|l|}
-.1350 \\
$(, 173)$ \\
\end{tabular} \\
\hline $\begin{array}{l}\text { Aleatório va- } \\
\text { riáveis de contro- } \\
\text { le extras }\end{array}$ & $\begin{array}{l}.0433 \\
(, 862)\end{array}$ & & $\begin{array}{l}-.0592 \\
(, 761)\end{array}$ & & $\begin{array}{l}.0814 \\
(, 590)\end{array}$ & \\
\hline $\begin{array}{l}\text { Fixo variáveis de } \\
\text { controle extras }\end{array}$ & $\begin{array}{l}.0567 \\
(, 944)\end{array}$ & & $\begin{array}{l}.0145 \\
(, 939)\end{array}$ & & $\begin{array}{l}.0688 \\
(, 456)\end{array}$ & \\
\hline
\end{tabular}

${ }^{*}$ Em negrito estão as variáveis estatisticamente significantes. 
As Tabelas 10 e 11 mostram comparações entre os seis estados que mais sucesso tiveram no combate ao crime e os seis estados com menos sucesso. Pela Tabela 10, podemos verificar que o efetivo policial dos estados que tiveram mais sucesso no combate ao crime era bem superior ao dos estados com menos sucesso. E, pela Tabela 11, podemos notar que a taxa de encarceramento também era muito superior nos estados que conseguiram reduzir suas respectivas taxas de homicídio.

Tabela 10 - Comparações entre os estados limites

\begin{tabular}{|c|c|c|c|c|c|c|c|c|c|}
\hline \multirow[t]{3}{*}{ Estado } & \multicolumn{3}{|c|}{2003} & \multicolumn{3}{|c|}{2009} & \multicolumn{3}{|c|}{ Variação $(\%)$} \\
\hline & \multicolumn{9}{|c|}{ Os Seis estados com mais sucesso na redução da taxa de homicídios } \\
\hline & Homic. & militar & civil & Homic. & militar & civil & Homic. & militar & civil \\
\hline SP & 43.5 & 187.0 & 61.6 & 20.1 & 171.6 & 43.5 & $-53.8 \%$ & $-8.2 \%$ & $-29.3 \%$ \\
\hline RJ & 67.3 & 251.7 & 71.0 & 54 & 159.1 & 57.2 & $-19.8 \%$ & $-36.8 \%$ & $-19.5 \%$ \\
\hline $\mathrm{RR}$ & 41.7 & 262.5 & 41.9 & 33.9 & 247.9 & 41.9 & $-18.7 \%$ & $-5.6 \%$ & $0.0 \%$ \\
\hline RO & 44.1 & 280.2 & 44.2 & 37.5 & 380.9 & 59.6 & $-15.0 \%$ & $35.9 \%$ & $34.8 \%$ \\
\hline AP & 36 & 393.0 & 452.4 & 31 & 795.9 & 42.0 & $-13.9 \%$ & $102.5 \%$ & $-90.7 \%$ \\
\hline $\mathrm{PE}$ & 57.6 & 172.2 & 10.2 & 50.4 & 219.8 & 5.5 & $-12.5 \%$ & $27.6 \%$ & $-45.7 \%$ \\
\hline \multirow[t]{2}{*}{ média } & 48.4 & 257.8 & 113.6 & 37.8 & 329.2 & 41.6 & $-22.3 \%$ & $19.2 \%$ & $-25.1 \%$ \\
\hline & \multicolumn{9}{|c|}{ Os seis estados com menos sucesso na redução da taxa de homicídios } \\
\hline MA & 14.6 & 68.0 & 27.2 & 23.5 & 126.6 & 14.1 & $61.0 \%$ & $86.1 \%$ & $-48.3 \%$ \\
\hline $\mathrm{AL}$ & 35.8 & 235.4 & 15.7 & 59.6 & 271.6 & 34.0 & $66.5 \%$ & $15.4 \%$ & $116.4 \%$ \\
\hline BA & 30.1 & 204.1 & 33.3 & 50.3 & 190.8 & 21.9 & $67.1 \%$ & $-6.5 \%$ & $-34.3 \%$ \\
\hline $\mathrm{RN}$ & 20.9 & 341.4 & 16.2 & 35.5 & 249.5 & 15.6 & $69.9 \%$ & $-26.9 \%$ & $-4.0 \%$ \\
\hline $\mathrm{PB}$ & 18.2 & 109.4 & 81.9 & 34.5 & 213.0 & 13.3 & $89.6 \%$ & $94.8 \%$ & $-83.7 \%$ \\
\hline PA & 21.9 & 159.3 & 23.7 & 42.5 & 195.0 & 21.7 & $94.1 \%$ & $22.4 \%$ & $-8.2 \%$ \\
\hline média & 23.6 & 186.3 & 33.0 & 41.0 & 207.8 & 20.1 & $74.7 \%$ & $30.9 \%$ & $-10.4 \%$ \\
\hline
\end{tabular}

Fonte: Do Autor ${ }^{23}$

Tabela 11 - Comparações entre os estados limites

\begin{tabular}{l|c|c|c|c|c|c|c|c}
\hline Posição & Estado & $\begin{array}{c}\text { Presos } \\
2003\end{array}$ & $\begin{array}{c}\text { Presos } \\
2009\end{array}$ & Variação & $\begin{array}{c}\text { Taxa de ho- } \\
\text { micídio 2003 }\end{array}$ & $\begin{array}{c}\text { Taxa de ho- } \\
\text { micídio 2009 }\end{array}$ & Variação \\
\hline & \multicolumn{7}{|c|}{ Os Seis estados com mais sucesso na redução da taxa de homicídios } \\
\hline 1 & SP & 255.82 & 373.37 & $45.90 \%$ & 43.5 & 20.1 & $-53.80 \%$ \\
\hline 2 & RJ & 124.75 & 144.64 & $15.90 \%$ & 67.3 & 54 & $-19.80 \%$ \\
\hline 3 & RR & 160.37 & 391.7 & $144.20 \%$ & 41.7 & 33.9 & $-18.70 \%$ \\
\hline 4 & RO & 231.61 & 464.52 & $100.60 \%$ & 44.1 & 37.5 & $-15.00 \%$ \\
\hline 5 & AP & 174.08 & 289.18 & $66.10 \%$ & 36 & 31 & $-13.90 \%$ \\
\hline 6 & PE & 153 & 238.82 & $56.10 \%$ & 57.6 & 50.4 & $-12.50 \%$ \\
\hline & média & $\mathbf{1 8 3 . 3}$ & $\mathbf{3 1 7 . 0}$ & $\mathbf{7 1 . 5 \%}$ & 48.4 & $\mathbf{3 7 . 8}$ & $\mathbf{- 2 2 . 3 \%}$ \\
\hline 22 & Os seis estados com menos sucesso na redução da taxa de homicídios \\
\hline 23 & MA & 36.03 & 53.79 & $49.30 \%$ & 14.6 & 23.5 & $61.00 \%$ \\
\hline 24 & BA & 50.97 & 62.67 & $23.00 \%$ & 35.8 & 59.6 & $66.50 \%$ \\
\hline 25 & RN & 39.56 & 56.16 & $42.00 \%$ & 30.1 & 50.3 & $67.10 \%$ \\
\hline 26 & PB & 153.87 & 226.1 & $46.90 \%$ & 18.2 & 34.5 & $89.60 \%$ \\
\hline
\end{tabular}

23 CERQUEIRA, Daniel. Mapa dos homicídios ocultos no Brasil. Brasília: IPEA, 2013. (Texto para Discussão, n. 1848). 


\begin{tabular}{c|c|c|c|c|c|c|c}
\hline Posição & Estado & $\begin{array}{c}\text { Presos } \\
2003\end{array}$ & $\begin{array}{c}\text { Presos } \\
2009\end{array}$ & Variação & $\begin{array}{c}\text { Taxa de ho- } \\
\text { micídio 2003 }\end{array}$ & $\begin{array}{c}\text { Taxa de ho- } \\
\text { micídio 2009 }\end{array}$ & Variação \\
\hline 27 & PA & 68.78 & 117.56 & $70.90 \%$ & 21.9 & 42.5 & $94.10 \%$ \\
\hline & média & $\mathbf{6 8 . 4}$ & $\mathbf{1 0 6 . 1}$ & $\mathbf{5 4 . 9 \%}$ & $\mathbf{2 3 . 6}$ & $\mathbf{4 1 . 0}$ & $\mathbf{7 4 . 7 \%}$ \\
\hline
\end{tabular}

Fonte: Do Autor ${ }^{24}$

\section{Efeitos da mudança NA LEGISLAÇão dA LEI DE COMBATE AS DROGAS DE 2006}

Em 2006 a legislação específica referente ao combate às drogas sofreu alterações importantes. A mais importante delas refere-se à extinção da pena de prisão para usuários, com o concomitante aumento da duração da pena para traficantes. A ideia era endurecer a punição para traficantes, e adotar medidas socioeducativas para os usuários de drogas. Mas na prática essa legislação, ao não diferenciar claramente usuário de traficante, acabou gerando aumento da punição tanto para traficantes como também para usuários.

A Tabela 12 mostra os resultados econométricos, dividindo-se nossa amostra em ANTES de 2007 e APÓS 2007. O ano de 2007 constitui o divisor de águas, pois com base, esse ano se deu o efeito completo da nova legislação antidrogas. A Tabela 12 adota apenas o estimador de efeitos aleatórios, pois, em razão da nova divisão amostral, o número de graus de liberdade acaba sendo reduzido. Na primeira parte da tabela, apresentamos os resultados de uma regressão com o conjunto restrito de variáveis (as mesmas da Tabela 2). Os resultados são reveladores. Entre 2003 e 2006, nos estados que apresentaram redução na taxa de homicídios, a taxa de encarceramento foi a principal responsável pela redução na violência. Contudo, após a aprovação da lei antidrogas, a partir de 2007, a redução da violência (nos estados que apresentaram queda na taxa de homicídios) foi obtida por meio de aumento na taxa de policiamento. Isto é, nos estados que reduziram a violência, a partir de 2007, a taxa de encarceramento deixou de ter o efeito redutor de violência que tinha até antes de 2007.

Para verificar a robustez do resultado, incluímos na estimativa conjunto amplo de variáveis (as mesmas da Tabela 6). Novamente, temos resultados semelhantes: entre 2003 e 2006, nos estados que reduziram a taxa de homicídios, a taxa de encarceramento era um importante instrumento de política pública para reduzir a violência. Contudo, após 2007 a taxa de encarceramento deixa de funcionar como redutor da taxa de homicídios. Também podemos verificar indícios de que a estratégia policial adotada por diferentes estados são importantes no resultado final do combate à violência.

Tabela 12 - Efeitos da nova legislação antidrogas de 2006

\begin{tabular}{l|l|l|l|l|l|l|l|l}
\hline & \multicolumn{4}{l}{ Efeito Aleatório - Restrito } & \multicolumn{3}{l}{ Efeito Aleatório - Amplo } \\
\hline & \multicolumn{2}{|l|}{ Antes 2007 } & \multicolumn{2}{l}{ Após 2007 } & \multicolumn{2}{l}{ Após 2007 } \\
\hline Variável & Caiu & Subiu & Caiu & Subiu & Caiu & Subiu & Caiu & Subiu \\
\hline Taxa presos & $\mathbf{- . 5 0 1 3}$ & .0923 & -.0490 & -.1511 & $\mathbf{- . 5 8 8 0}$ & -.0284 & -.1816 & -.1810 \\
$\begin{array}{l}\text { período } \\
\text { passado }\end{array}$ & $\mathbf{( , 0 0 1 )}$ & $(, 238)$ & $(, 711)$ & $(, 322)$ & $\mathbf{( , 0 0 5 )}$ & $(, 715)$ & $(, 234)$ & $(, 177)$ \\
\hline $\begin{array}{l}\text { Taxa Polícia } \\
\text { Militar } \\
\text { período } \\
\text { passado }\end{array}$ & .0961 & -.0078 & $\mathbf{- . 1 4 8 9}$ & .0374 & $\mathbf{. 2 7 5 1}$ & -.0270 & .1311 & $\mathbf{. 0 8 7 0}$ \\
\hline
\end{tabular}

24 CERQUEIRA, Daniel. Mapa dos homicídios ocultos no Brasil. Brasília: IPEA, 2013. (Texto para Discussão, n. 1848). 


\begin{tabular}{l|l|l|l|l|l|l|l|l}
\hline & \multicolumn{4}{|l|}{ Efeito Aleatório - Restrito } & \multicolumn{3}{l}{ Efeito Aleatório - Amplo } \\
\hline & \multicolumn{2}{l|}{ Antes 2007 } & Após 2007 & \multicolumn{2}{l}{ Antes 2007 } & \multicolumn{2}{l}{ Após 2007 } \\
\hline Taxa Polícia & -.0531 & -.0219 & $\mathbf{- . 0 7 1 9}$ & -.0133 & .0211 & -.0348 & $\mathbf{- . 0 9 5 5}$ & -.0368 \\
Civil perío- & $(, 275)$ & $(, 504)$ & $\mathbf{( , 0 7 4 )}$ & $(, 696)$ & $(, 718)$ & $(, 234)$ & $\mathbf{( , 0 2 9 )}$ & $(, 160)$ \\
do passado & & & & & & & & \\
\hline
\end{tabular}

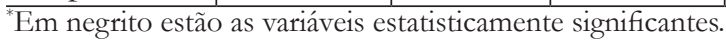

\section{Considerações finais}

Este trabalho verificou o impacto das políticas públicas de repressão sobre a taxa de homicídios no Brasil no período 2003-09. Nossos resultados sugerem que, nos estados que tiveram êxito em reduzir as taxas de homicídio, o aumento na taxa de policiamento e de encarceramento foram variáveis importantes para a redução da violência. Contudo, nos estados onde a taxa de homicídios aumentou, as políticas de repressão demonstraram pouca relevância no período.

Os resultados descritos no parágrafo acima parecem sugerir que diferentes estratégias policiais têm efeitos distintos sobre as taxas de homicídio. Esse resultado contraria o estudo de Levitt ${ }^{25}$ para os Estados Unidos. Sendo assim, parece que, no Brasil, estratégias policiais diferentes podem sim ter impactos diferentes sobre a criminalidade. Também é importante ressaltar que vários estados reduziram seu efetivo policial como proporção da população, isso também pode ter sido um importante motivador do recente incremento nas taxas de violência ocorridas no Brasil.

Por fim, fomos capazes de verificar que a aprovação da nova Lei Antidrogas de 2006 diminuiu a efetividade da taxa de encarceramento no combate à taxa de homicídios. Isso pode ter ocorrido, pois, ao não diferenciar claramente entre usuários e traficantes, a lei acabou tendo efeito diverso do esperado: acabou classificando usuários como traficantes, implicando pena de prisão para usuários de drogas ao invés dos traficantes. Isso aumentou as taxas de encarceramento sem ter a correspondente redução na taxa de homicídios.

\section{REFERÊNCIAS}

ANDRADE, Mônica Viegas; LISBOA, Marcos de Barros. Mortalidade nos estados do Rio de Janeiro, São Paulo e Minas Gerais. Estudos Econômicos, São Paulo, v.31, n.1, p.05-56, 2001.

BALTAGI, Badi H. Econometric analysis of panel data. Nova Jersey: J. Wiley \& Sons, 1995.

BECKER, Gary S. A theory of social interactions. Journal of Political Economy, Chicago, v.82, n. 6, p. 10631093, Nov./Dec.1974.

BECKER, Gary S. Crime and punishment: an economic approach. Journal of Political Economy, Chicago, v. 76, n.2, p. 169-217, Mar./Apr.1968.

BECKER, Gary S.; TOMES, Nigel. An equilibrium theory of the distribuition of income an intergeneretional mobility. Journal of Political Economy, Chicago, v.87, n. 6, p. 1163-1189, Nov./Dec.1979.

BLUMSTEIN, Alfred. Youth violence, guns and the illicit-drug industry. The Journal of Criminal Law and Criminology, Chicago, v. 86, n.1, p. 10-36, 1995.

25 LEVITT, Steven. D.; LOCHNER, Lance. The determinants of juvenile crime. In: GRUBER, Jonathan (Ed.). Risky Bebavior among youths: an economic analysis Chicago: University of Chicago Press, Jan. 2001. (NBER Working Paper, n. w7781). p. 327-374. Available in: <http://www.nber.org/chapters/c10692.pdf>. Access: 17 Nov. 2015. 
BLUMSTEIN, Alfred; ROSENFELD, Richard. explaining recent trens in u.s. homicide rates. The Journal of Criminal Law and Criminology, Chicago, v. 88, n. 4, p. 1175-1216, 1998.

CARNEIRO, Leandro Piquet. Pesquisas de vitimização e gestão da segurança pública. São Paulo em Perspectiva, São Paulo, v. 21, n. 1, p. 60-75, jan./jun. 2007.

CARRERA-FERNANDEZ, José; PEREIRA, Rogério. A criminalidade na região policial da grande São Paulo sob a ótica da economia do crime. In: ENCONTRO REGIONAL DE ECONOMIA, 5., 2000, Fortaleza. Anais... Fortaleza: ETENE, 2000. p. 898-918.

CERQUEIRA, Daniel. Mapa dos homicídios ocultos no Brasil. Brasília: IPEA, 2013. (Texto para Discussão, n. 1848).

CHAIKEN, Jan M.; CHAIKEN, Marcus R. Varieties of criminal behavior: summary and policy implications. Santa Monica: Rand, Aug. 1982.

CHIODA, Laura; MELLO, João Manoel Pinho de; SOARES, Rodrigo Reis. Spillovers from conditional cash transferprograms: Bolsa Família and crime in urban Brazil. Rio de Janeiro: PUC, Feb. 2012. (Texto para Discussão da PUC-RJ, n. 599).

DAVIS, Michael L. Time and punishment: an intertemporal model of crime. Journal of Political Economy, Chicago, v. 96, n. 2, p. 383-390, Apr. 1988.

DEATON, A. Panel Data from a Series of Repeated Cross-Sections. Journal of Econometrics, v. 30, p. 109-126, 1985.

DUBEY, Pradeep; GEANAKOPLOS, John; SHUBIK, Martin. Default and punishment in general equilibrium. Connecticut: Cowles Foundation for Research in Economics at Yale University, May. 2001. (Cowles Foundation Discussion Paper, n. 1304).

EHRLICH, Isaac. Participation in illegitimate activities: a theoretical and empirical investigation. Journal of Political Economy, Chicago, v. 81, n. 3, p. 521-565, May./June, 1973.

EHRLICH, Isaac. The deterrent effect of capital punishment: a question of life and death. American Economic Review, Nashville, v. 65, n.3, p.397-417, Jun. 1975.

FAJNZYLBER, Pablo; LEDERMAN, Daniel; LOAYZA, Norman. What causes violent crime. Washington: World Bank Report, 1998.

FLEISCHER, Belton M. The effect of income on delinquency. America Economic Review, Nashville, v. 56, n. 1/2, p. 118-137, Mar. 1966.

FREEMAN, Richard B. The economis of crime. In: ASHENFELTER, Orley; CARD, David (Ed.). Handbook of labor economis. Amsterdam: Elsevier, 1999. v. 3. p. 3529-3571.

FREEMAN, Richard B.; RODGERS III, William. M. Area economic conditions and the labor market outcomes of young men in the 1990s expansion. Cambridge: NBER, Apr. 1999. (NBER Working Paper, n. 7073)

GLAESER, Edward L.; SACERDOTE, Bruce. Why is there more crime in cities?. Journal of Political Economy, Chicago, v. 107, n. 6, p. S225-S258, Dec. 1999.

GLAESER, Edward L.; SACERDOTE, Bruce; SCHEINKMAN, José A. Crime and social interactions. Quarterly Journal of Economics, Oxford, v. 111, n. 2, p.507-548, May 1996.

GOLDBERGER, Arthur S. A course in econometrics. Cambridge: Havard University Press, 1991.

GREENE, William H. Econometric Analysis. New Jersey: Prentice Hall, 1993.

GROGGER, Jeff. Market wages and youth crime. Journal of Labor Economics, Chicago, v. 16, n. 4, p. 756-791, Oct. 1998. 
GROGGER, Jeffrey. Local violence and educational attainment. The Journal of Human Resources, Madison, v. 32, n. 4, p. 659-682, Aut. 1997.

GYIMAH-BREMPONG, Kwabena; PRICE, Gregory N. Crime and punishment: and skin hue too?" American Economic Review, Nashville, v. 96, n. 2, p. 246-250, May 2006.

HECKMAN, James J. Sample selection bias as a specification error. Econometrica, Ohio, v. 47, n. 1, p. 153161, jan. 1979.

HECKMAN, James J. The common structure of statistical models of truncation, sample selection, and limited dependent variables and a simple estimator for such models. Annuals of Economic and Social Measurement, Cambridge, v. 5, n. 4, p.475-492, Oct. 1976.

HSIAO, Cheng. Analysis of panel data. Cambridge: Cambridge University, 1986. (Econometric Society Monographs, N. 11).

IMAI, Susumu; KRISHNA, Kala. Employment, dynamic deterrence and crime. Cambridge: NBER, 2001. (NBER Working Paper, N.w8281. Available in: <http://papers.nber.org/papers/W8281>. Acess: 17 Nov. 2015.

JOSEPH, Mark. The effect of arrests on the earnings of young men: evidence from the national youth survey. 2001. 36 f. Dissertation (doctorate degree) - Harris Graduate School of Public Policy Studies, University of Chicago, Chicago, 2002.

JUDGE, George G. et al. Introduction to the theory and practice of econometrics. Nova Jersey: J. Wiley \& Sons, 1982.

LEVITT, Steven. D. The effect of prison population size on crime rates: evidence from prison overcrowding litigation. Quaterly Journal of Economics, Oxford, v. 111, n. 2, p. 320-351, May 1996.

LEVITT, Steven. D. Using electoral cycles on police hiring to estimate the effect of police on crime. Cambridge: NBER, 1994. (NBER Working Paper, n. 4991).

LEVIT'T, Steven. D.; LOCHNER, Lance. The determinants of juvenile crime. In: GRUBER, Jonathan (Ed.). Risky Behavior among youths: an economic analysis Chicago: University of Chicago Press, Jan. 2001. (NBER Working Paper, n. w7781). p. 327-374. Available in: <http://www.nber.org/chapters/c10692.pdf>. Access: 17 Nov. 2015.

LOCHNER, Lance. A theoretical and empirical study of individual perceptions of the criminal justice system. New York: University of Rochester, Jun. 2001. Available in: <http://papers.ssrn.com/sol3/papers. cfm?abstract_id=273598>. Access: 17 Nov. 2015.

LOCHNER, Lance; MORET'TI, Enrico. The effect of education on crime: evidence from prison inmates, arrests and self-reports. American Economic Review, Nashville v. 94, n. 1, p. 155-189, Mar.2004.

MARKOWITZ, Sara. An economic analysis of alcohol, drugs, and violent crime in the national crime victimization survey. Cambridge: NBER, Oct. 2000. (NBER Working Paper, n. 7982).

MENEZES, Tatiane Almeida et al. Spatial correlation between homicide rates and inequality: evidence from urban neighborhoods in a brazilian city. Economics Letters, v. 120, n. 1, p. 97-99, Jul. 2013.

NAGIN, Daniel; WALDFOGEL, Joel. The effect of conviction on income through the life cycle. International Review of Law and Economics, Oxford, v. 18, n. 1, p. 25-40, Mar. 1998.

SACHSIDA, Adolfo; MENDONÇA, Mario Jorge Cardoso de evolução e determinantes da taxa de homicídios no Brasil. Brasília: IPEA, jan. 2013. (Texto para Discussão do IPEA, n. 1808).

SAH, Raaj K. Social osmosis and patterns of crime. Journal of Political Economy, Chicago, v. 99, n. 6, p. 12721295, Dec. 1991.

STATA user's guide: realease 6". Texas: Stata Press, 1999. 
WHITE, Halbert. A heteroscedasticity-consistent covariance matrix estimator and a direct test for heteroscedasticity. Econometrica, Ohio, v. 48, n. 4, p. 817-838, May. 1980.

WILLIS, Robert J.; ROSEN, Sherwin. Education and self-selection. Journal of Political Economy, Chicago, v. 87, n. 5, p. S1-S36, Oct. 1979. Part 2: Education and income distribution.

WITTE, Ann Dryden; WITT, Robert. What we spend and what we get: public and private provision of crime prevention and criminal justice. Cambridge: NBER, Apr. 2001. (NBER Working Paper, n. w8204). Available in: <http://papers.nber.org/papers/W8204). Acess: 17 Nov. 2015.

YWATA, Alexandre Xavier de Carvalho et al. Custos das mortes por causas externas no Brasil. Revista Brasileira de Biometria, São Paulo, v.26, n.3, p.23-47, jul./set. 2008. 


\title{
Análise dos impactos diretos e indiretos do Programa de P\&D da ANEEL no setor elétrico: diferenças com os EUA*
}

\author{
Analysis of direct and indirect impacts of \\ ANEEL R \& D program in the electricity \\ sector: differences with the U.S.
}

\author{
Igor Polezi Munhz** \\ Alessandra Cristina Santos Akkari*** \\ Neusa Maria Bastos Fernandes dos Santos****
}

* Recebido em 22/04/2015

Aprovado em 28/07/2015

\begin{abstract}
** Doutorando em Engenharia Mecânica, concentração em Engenharia de Controle e Automação Mecânica, na Escola Politécnica da USP, Mestre em Engenharia Elétrica, Bacharel em Engenharia de Produção (Gestão) e Bacharel em Ciência e Tecnologia pela Universidade Federal do ABC (UFABC). Atualmente é professor da Pontifícia Universidade Católica de São Paulo (PUC-SP) e da Universidade Paulista (UNIP) nos cursos de Engenharia. E-mail: igor. munhoz@usp.br.
\end{abstract}

*** Doutora em Farmacologia / Inovação Farmacêutica (2015), Engenheira de Produção (2014) e Bacharel em Ciência e Tecnologia (2011) pela Universidade Federal do ABC. Atua na área de Gestão de P\&D, Elaboração e Análise de Projetos, Inovação e Propriedade Intelectual. E-mail: alessandra.akkari@ufabc. edu.br.

**** Professora Titular da Pontifícia Universidade Católica de São Paulo. Faculty Research Program Fellow - McGill University, Canadá (1996) / Pós-Doutorado, Doutorado em Controladoria e Contabilidade pela USP (1992), Mestrado em Administração pela USP (1984) e Graduação em Administração de Empresas pela USP (1974). Email: admneusa@pucsp.br.

\section{Resumo}

Há grande interesse na avaliação dos impactos da Pesquisa e Desenvolvimento (P\&D), motivado pela necessidade de compreender os seus efeitos e garantir a manutenção dos recursos destinados a esse fim. No setor elétrico, que é um segmento estratégico da economia brasileira, analisar a efetividade desse tipo de programa e mensurar seus impactos torna-se de grande valia a fim de direcionar as políticas públicas. O objetivo deste trabalho consistiu em estudar se existe correlação entre um dos possíveis resultados mensuráveis dos investimentos em $\mathrm{P} \& \mathrm{D}$ regulamentados pela Agência Nacional de Energia Elétrica (ANEEL), o impacto no número de patentes do setor e os impactos indiretos, sob a visão do consumidor, por meio da satisfação dos clientes. Ademais, desenvolveu-se comparação externa com os EUA, país líder na geração de inovação. Para as análises dos dados secundários, aplicou-se o Método dos Mínimos Quadrados, prevendo cenários futuros, e o Método de Pearson, verificando a existência de correlação. Nos EUA, observou-se forte correlação entre o índice de inovação e a satisfação do consumidor; o que não foi possível constatar para o caso brasileiro, possivelmente devido à satisfação do cliente somente ser percebida em longo prazo, enquanto a exploração do processo de inovação no Brasil é recente. Os resultados contribuem para a manutenção de políticas públicas de estímulo aos investimentos em P\&D no Brasil em longo prazo, prevendo a necessidade de mecanismos capazes de mensurar os resultados dos programas, bem como orientar o setor produtivo e facilitar a interação dos diferentes atores do processo de inovação.

Palavras-chave: P\&D. ANEEL. Políticas públicas. Inovação. Satisfação do consumidor.

\section{Abstract}

The aim of this study is to analyze the correlation between the direct (number of patents) and the indirect (customer satisfaction) impacts of R \& 
$\mathrm{D}$ investments in electrical sector. There is a strong correlation between the innovation rate and customer satisfaction in U.S. However, it isn't possible to verify the same situation in Brazil, possibly due to customer satisfaction only be perceived in a long term, while the innovation process exploration is recent in Brazil. These results contribute to $\mathrm{R} \& \mathrm{D}$ public policies maintenance in Brazil. Nonetheless, it is necessary to provide mechanisms to measure the $\mathrm{R} \& \mathrm{D}$ programs results and to facilitate the interaction between different actors in the innovation process.

Keywords: R\&D. Electric sector. Public policies. Innovation. Customer satisfaction.

\section{INTRODUÇÃO}

Há um grande interesse na avaliação da Pesquisa e Desenvolvimento (P\&D), motivado pela necessidade de compreender os efeitos das políticas e dos programas de P\&D, aprendendo com os fatos passados e servindo de fundamento para a continuidade dessas ações ${ }^{1}$. No cenário brasileiro, existem políticas de investimento em P\&D em diversos setores da economia, como o elétrico, que é o foco deste trabalho. O setor elétrico como objeto de estudo justifica-se por ser um segmento estratégico, bem como atrela-se à necessidade de enfrentar as drásticas alterações climáticas previstas para as próximas décadas, conferindo importância ao melhor entendimento dos processos de inovação nessa área, a fim de otimizar a capacidade da sociedade moderna em lidar com os novos desafios ${ }^{2}$.

No Brasil, o contexto socioambiental tem estimulado empresas do setor público e privado a se adequarem às novas demandas e a ultrapassarem barreiras ocasionadas pela crescente escassez de recursos no mundo ${ }^{3}$. Nesse sentido, há cerca de quinze anos, ocorreu a promulgação da Lei no 9.991 , de 24 de julho de $2000^{4}$, que determinou que empresas concessionárias, permissionárias e autorizadas do serviço público de energia elétrica realizassem investimentos mínimos em P\&D, segundo o regimento da Agência Nacional de Energia Elétrica (ANEEL).

A ANEEL definiu as condições para execução das pesquisas e para a avaliação e o acompanhamento dos resultados dos projetos de P\&D, conforme descrição no Manual do Programa de Pesquisa e Desenvolvimento Tecnológico do Setor de Energia Elétrica ${ }^{5}$, visando estimular as empresas do segmento em atividades de inovação, a fim de lhes contribuir para enfrentar seus desafios tecnológicos e de mercado. Dessa forma, entende-se que o programa tem como objetivo promover e viabilizar o ciclo completo da cadeia da inovação, incentivando a associação de empresas a desenvolver o conhecimento e transformá-lo em resultados práticos, com o intuito de aprimorar o desempenho organizacional e conferir benefícios para a sociedade ${ }^{6}$.

Tem-se que os investimentos das empresas em P\&D geram efeito positivo na eficiência das mesmas, tornando-as tecnicamente superiores a outras organizações que não efetuam desenvolvem a mesma ação.

1 HASEGAWA, Mirian; FURTADO, André Tosi. Avaliação dos impactos de programas de P\&D. Inovaşão Uniemp, Campinas, v.2, n.3, p. 40-41, jul./ago. 2006.

2 JANSEN, Dorothea; OSTERTAG, Katrin; WALZ, Rainer (Ed.). Sustainability innovations in the electricity sector. New York: PhysicaVerlag, 2012.

3 COSTA, Ana Carolina Vital da; ALMEIDA, José Álvaro Jardim de; GOMES, Carla Regina Pása. Investimentos em P\&D no Setor Elétrico Brasileiro: um perfil dos resultados em eco-inovação. Ariús: Revista de Ciências Humanas e Artes, Campina Grande, v. 16, n. 1/2, p. 172-186, jan./dez. 2010.

4 BRASIL. Lei $n^{\circ}$ 9.991, de 24 de julho de 2000. Dispõe sobre realização de investimentos em pesquisa e desenvolvimento e em eficiência energética por parte das empresas concessionárias, permissionárias e autorizadas do setor de energia elétrica, e dá outras providências. Disponível em:<http://www.planalto.gov.br/ccivil_03/leis/19991.htm>. Acesso em: 18 out. 2014.

5 AGÊNCIA NACIONAL DE ENERGIA ELÉTRICA. Manual dos programas de pesquisa e desenvolvimento tecnológico do setor elétrico brasileiro. Brasília: ANEEL, 2001. Disponível em:<http://www.aneel.gov.br/aplicacoes/leitura_arquivo/default.cfm?idaplicacao=56>. Acesso em: 05 ago. 2015.

6 POMPERMAYER, Fabiano Mezadre; NEGRI, Fernanda de; CAVALCANTE, Luiz Ricardo. Inovação tecnológica no setor elétrico brasileiro: uma avaliação do programa de P\&D regulado pela Aneel. Brasília: IPEA, 2011. 
A elevada eficiência adquirida por meio de atividades de P\&D confere a rentabilidade necessária para que esse processo continue, possibilitando que a empresa sobreviva no mercado e, muitas vezes, obtenha lucros extraordinários advindos da proteção da propriedade intelectual (patentes, por exemplo) gerada no processo de inovação ${ }^{7}$.

Os resultados da P\&D podem ser divididos em diretos e indiretos, e os diretos relacionam-se às metas iniciais do programa, gerando impactos econômicos com base na aplicação comercial do novo produto. Os impactos indiretos, denominados spinoffs, escapam do escopo inicial e podem ser definidos como todo produto que não foi prognosticado, abrangendo metodologias e tecnologias novas, alterações na organização, novos serviços, entre outros. Ressalta-se que os spinoffs são possíveis somente pelas competências assimiladas por meio dos programas de P\&D, sendo essas capacitações e conhecimentos resultados intermediários do processo $^{8}$.

$\mathrm{Na}$ abordagem de resultados diretos e indiretos, as inovações tecnológicas podem ser vistas como um resultado direto da P\&D, uma vez que proporcionam impactos econômicos passíveis de mensuração por meio da relação impacto/custo do programa, sendo esta uma das avaliações econômicas possíveis dentre outras metodologias consolidadas para esse tipo de análise, tais como os estudos econométricos ${ }^{9}$, que investigam a função dos custos em P\&D na contabilização do crescimento econômico; surveys ${ }^{10}$, que relacionam a P\&D com a economia por meio da aplicação de questionários para um grupo amostral; e os estudos de caso ${ }^{11}$, que avaliam diretamente o processo de inovação e o ciclo de vida de uma tecnologia.

Diferentemente, é mais difícil mensurar os impactos indiretos do programa, embora estes também sejam essenciais para melhor análise de viabilidade e rentabilidade, uma vez que ilustram uma perspectiva mais abrangente do cenário estudado. Hasegawa e Furtado ${ }^{12}$ constataram que os spinoffs são capazes de gerar um impacto econômico 51 vezes maior que o impacto econômico da inovação principal. Esses resultados expressivos atestam que os spinoffs devem ser considerados na metodologia, a fim de identificar o real impacto e a verdadeira importância dos programas de P\&D. Dessa forma, torna-se de grande valia identificar quais os resultados indiretos e quais seus respectivos impactos, que podem ocorrer na esfera econômica e também na esfera social.

Sob essa perspectiva, esse artigo avaliou a efetividade de programas públicos de incentivo às atividades de P\&D, especificamente o Programa de P\&D da ANEEL, propondo uma metodologia capaz de analisar a correlação entre um dos possíveis resultados mensuráveis dos investimentos em $\mathrm{P} \& \mathrm{D}$, o impacto no número de patentes do setor (impacto direto), e os impactos indiretos, sob a perspectiva do consumidor, por meio de relatórios de satisfação dos clientes. Então, desenvolveu-se comparação externa com os Estados Unidos (EUA), que é um dos países referência em inovação.

7 WINARSKI, Tyson. Protecting Electrical Technology through Patents. IEEE Technology and Society Magazine, Wollongong, v. 29, n. 4, p. 20-29, 2010.

8 HASEGAWA, Mirian; FURTADO, André Tosi. Avaliação dos impactos de programas de P\&D. Inovação Uniemp, Campinas, v.2, n.3, p. 40-41, jul./ago. 2006.

9 CAMPOS, André Luis Sica. Identificação de impactos econômicos a partir da pesquisa acadêmica: um estudo de projetos temáticos da FAPESP. 1999. 93 f. Dissertação (Mestrado) - Instituto de Geociências, Universidade Estadual de Campinas, Campinas, 1999.

10 SALTER, Ammon; MARTIN, Ben. The economic benefits of publicly funded basic research: a critical review. Research Policy, v. 30, n. 3, p. 509-532, mar. 2001.

11 SALTER, Ammon; MARTIN, Ben. The economic benefits of publicly funded basic research: a critical review. Research Policy, v. 30, n. 3, p. 509-532, mar. 2001.

12 HASEGAWA, Mirian; FURTADO, André Tosi. Avaliação dos impactos de programas de P\&D. Inovação Uniemp, Campinas, v.2, n.3, p. 40-41, jul./ago. 2006. 


\section{UMA BREVE DEFINIIÇÃo de INOVAÇÃo}

A inovação pode ser entendida com base em diversos aspectos ou definições. De acordo com Schumpeter ${ }^{13}$, inovar consiste em produzir outras coisas (inovação radical) ou as mesmas coisas de uma forma diferente (inovação incremental) e combinar diferentemente materiais e forças. $\mathrm{Na}$ definição schumpeteriana, a inovação pode ser entendida como o motor do capitalismo. De forma complementar, Alvarez ${ }^{14}$ define inovação como sendo a capacidade de se criar novas formas de gerar e apropriar valor no mercado.

Rosenthal e Moreira ${ }^{15}$, por sua vez, definem a inovação de caráter tecnológico como a aplicação de um novo conjunto de conhecimentos ao processo produtivo, resultando em um novo produto, ou no aprimoramento do produto antigo e/ou no grau de aceitação do produto pelo mercado, conferindo, de maneira geral, um aumento dos lucros e melhor posição da empresa no mercado.

Segundo $\operatorname{Arbix}^{16}$, a inovação pode ser entendida como a primeira comercialização de uma ideia ou projeto, sendo seu locus a empresa. Nesse sentido, observa-se que existe uma diferença entre inovação e invenção, dado que a invenção pode ocorrer em qualquer espaço e não necessariamente possui uma aplicação que será absorvida pelo mercado. Assim, a transformação de uma invenção em uma inovação nem sempre é rápida e exige diferentes tipos de conhecimentos, de capacidade, de habilidade e de recursos. As atividades de P\&D são consideradas a fonte mais importante na geração de novos conhecimentos e o conhecimento pode ser considerado um input e as inovações como um output.

Ainda de acordo com Arbix $^{17}$, o Brasil apresenta políticas de inovação muito orientadas para a pesquisa básica, viés favorável a grandes empresas, enquanto as pequenas e médias ficam marginalizadas e encontram dificuldade em se engajar no processo de inovação, que tem sido a força motora das economias mais desenvolvidas, como os EUA, a Finlândia, a Suécia, o Japão e a Alemanha, que possuem também gastos elevados em P\&D.

Do exposto, constata-se que a inovação tecnológica deve ser resultado de um ambiente que produza ciência de ponta e que influencie, direta e indiretamente, o setor produtivo, especialmente por meio de setores de P\&D implantados nas empresas.

\subsection{Panorama da inovação tecnológica no Brasil}

A expansão, durante as últimas duas décadas, de uma economia globalmente integrada e baseada na inovação está transformando o comércio internacional, as atividades de P\&D e o desenvolvimento da produção industrial, impactando no aumento da competitividade em todo o mundo. Nesse sentido, diferentes países vêm implementando estratégias globais de inovação, a fim de satisfazer os desafios desse novo paradigma, destacando-se a Suiça, o Reino Unido, a Suécia, a Holanda e os EUA, que assumiram as cinco primeiras posições, respectivamente, dentre as regiões mais inovadoras do globo, conforme o relatório da World Intellectual Property Organization (WIPO) - Global Innovation Index 2013.18.

13 SCHUMPETER, Joseph. Capitalismo, socialismo e democracia. Rio de Janeiro: Zahar, 1984.

14 ALVAREZ, Roberto dos R. Inovar é preciso. In: ARBIX, Glauco et al. (Org.) Inovação: estratégia de sete países. Brasília: ABDI, 2010. p. 32-64.

15 ROSENTHAL, David; MOREIRA, Inaldo Lima. Algumas considerações sobre a natureza do processo de capacitação tecnológica: fontes de inovação. Revista de Administração Pública, Rio de Janeiro, v. 26, n. 4, p. 145-160, out./dez. 1992.

16 ARBIX, Glauco. Inovação e desenvolvimento. In: et al. (Org.). Inovação: estratégia de sete países. Brasília: ABDI, 2010, p. 66-91.

17 ARBIX, Glauco. Inovação e desenvolvimento. In: et al. (Org.). Inovação: estratégia de sete países. Brasília: ABDI, 2010, p. 66-91.

18 WORLD INTELLECTUAL PROPERTY ORGANIZATION. Global Innovation Index 2013: The Local Dynamics of Innovation. Genebra, 2013. Disponível em:<http://www.wipo.int/edocs/pubdocs/en/economics/gii/gii_2013.pdf>. Acesso em: 05 ago. 2015 . 
No ranking mundial da $\mathrm{WIPO}^{19}$, o Brasil aparece somente na $64^{\circ}$ colocação dentre os países que mais geram inovação, indicando que ainda há um longo percurso a ser percorrido, existindo muito o que ser aprendido com as experiências mundiais. De fato, Marzano ${ }^{20}$ destaca que a exploração da inovação, no contexto brasileiro, possui história recente, já que a adoção de políticas públicas de inovação, assim como a mensuração dos seus resultados, ocorreu há menos de duas décadas. De acordo com Furtado ${ }^{21}$, historicamente, o desenvolvimento tecnológico mais consistente em empresas brasileiras está associado, primordialmente, a dois fatores: (1) razões de Estado; (2) orientações deliberadas de empresas advindas de acidentes de percurso que permitiram antecipar trajetórias. No mais das vezes, o progresso da tecnologia e a inovação no setor produtivo brasileiro teria ocorrido apenas muito mais tarde ou com uma intensidade muito inferior.

A fim de se observar o panorama da inovação no setor produtivo brasileiro, faz-se válida a análise da Pesquisa de Inovação do IBGE (Pintec) ${ }^{22}$, cuja referência conceitual e metodológica baseia-se no Manual Oslo, que é a principal fonte internacional de diretrizes para coleta e uso de dados sobre atividades inovadoras da indústria, segundo a Organização para a Cooperação e o Desenvolvimento Econômico (OCDE) ${ }^{23}$. Visando a uma avaliação da evolução desses esforços inovativos, observa-se que, entre 2006 e 2008, 38,1\% das indústrias analisadas inovaram em produto e processo, contra 33,4\% no período de 2003 a 2005 . Essa taxa obtida na Pintec 2005 ficou muito próxima do resultado de análise entre o período de 2001 a 2003 $(33,3 \%)$ e acima da apurada para o período 1998-2000 (31,5\%). Assim, percebe-se que, desde 2000, ocorreu aumento da taxa de inovação nas indústrias brasileiras. Contudo, os dados mais recentes indicam que, após esse crescimento, entre 2009-2011 ocorreu declínio para 35,6\%, conforme havia sido previsto pela Agência Brasileira de Desenvolvimento Industrial ${ }^{24}$.

Ainda, os dados chamam atenção para o fato de que, entre 2009-2011, somente 3,7\% e 2,1\% das empresas efetivamente introduziram ao mercado nacional um produto novo ou um processo novo, respectivamente, demonstrando que a maioria das inovações diz respeito ao caráter novo ou substancialmente aprimorado do produto ou processo para a empresa, mas não significando uma novidade para o mercado ${ }^{25}$. Dessa forma, observa-se que há hiato entre as indústrias inovadoras e aquelas que efetivamente implementaram um produto/processo novo ou aprimorado em termos mercadológicos, demonstrando debilidade do setor produtivo brasileiro.

Os resultados da Pintec atestam que modelo de desenvolvimento adotado no Brasil, nas últimas décadas, não criou condições e estímulos para que as indústrias criassem setores de P\&D em sua estrutura organizacional, bem como priorizassem a inovação como diferencial competitivo. De fato, somente em 2004, por meio da Lei de Inovação Tecnológica (Lei Federal n. ${ }^{\circ}$ 10.973, de 02 de dezembro de 2004), o Brasil objetivou criar um ambiente propício para aumentar o envolvimento das empresas no desenvolvimento de projetos

19 WORLD INTELLECTUAL PROPERTY ORGANIZATION. Global Innovation Index 2013: The Local Dynamics of Innovation. Genebra, 2013. Disponível em:<http://www.wipo.int/edocs/pubdocs/en/economics/gii/gii_2013.pdf>. Acesso em: 05 ago. 2015.

20 MARZANO, Fábio Mendes. Politicas de inovação no Brasil e nos Estados Unidos: a busca da competitividade, oportunidades para a ação diplomática. Brasília: Fundação Alexandre de Gusmão, 2011.

21 FURTADO, João. Padrões de Inovação na Indústria Brasileira. Disponível em: <http://www.ifhc.org.br/wp-content/uploads/ apresentacoes/1941.pdf>. Acesso em: 2 abr. 2011.

22 INSTITUTO BRASILEIRO DE GEOGRAFIA E ESTATÍSTICA. Pesquisa de inovação tecnológica -2011. Rio de Janeiro, 2013. Disponível em: <http://www.pintec.ibge.gov.br/downloads/pintec2011\%20publicacao\%20completa.pdf>. Acesso em: 10 jan. 2015.

23 ORGANIZAÇÃO PARA COOPERAÇÃO ECONÔMICA E DESENVOLVIMENTO. Manual de Oslo: diretrizes para coleta e interpretação de dados sobre inovação. 2006. Disponível em: <http://www.uesc.br/nucleos/nit/manualoslo.pdf>. Acesso em: 05 ago. 2015.

24 NEGRI, Fernanda de; CAVALCANTE, Luiz Ricardo. Análise dos dados da PINTEC 2011. Nota técnica DISET, n. 15. Brasília: IPEA, 2013. Disponível em: <http://www.ipea.gov.br/agencia/images/stories/PDFs/nota_tecnica/131206_notatecnicadiset15.pdf>. Acesso em: 10 out. 2014.

25 INSTITUTO BRASILEIRO DE GEOGRAFIA E ESTATÍSTICA. Pesquisa de inovação tecnológica - 2011. Rio de Janeiro, 2013. Disponível em: <http://www.pintec.ibge.gov.br/downloads/pintec2011\%20publicacao\%20completa.pdf>. Acesso em: 10 jan. 2015. 
inovadores. Essa lei pretendia elevar o número de parcerias entre empresas, universidades e institutos científicos e tecnológicos, a fim de estimular o processo inovativo para viabilizar o desenvolvimento tecnológico do país ${ }^{26}$. No entanto, muitas questões complexas não foram tratadas nessa normatização, incluindo a criação de mecanismos que permitam uma real conexão com as políticas industrial e tecnológica, e também a ausência de flexibilidade na gestão das instituições de pesquisa ${ }^{27}$.

Observa-se, ainda, no Brasil desafio de transformar o conhecimento científico em produtos ou serviços, gerando contribuições econômicas. Assim, trata-se de um país que produz ciência, mas que não consegue interagir, em um nível adequado, com o setor produtivo. O resultado dessa baixa incorporação de tecnologia de ponta diretamente nos produtos torna-os pouco competitivos, tanto no mercado interno como no externo. Tem-se a necessidade, então, da criação de condições para que o país consiga avançar de forma consistente no campo tecnológico, exigindo, além de mudança institucional e econômica, também uma mudança cultural ${ }^{28}$. É reconhecido que não basta para um país ter realizações em ciência e tecnologia (C\&T), ou mesmo em P\&D; é preciso transformá-los em novos produtos e processos, ou melhorar os existentes.

Logo, entende-se que o Brasil ainda está nos estágios iniciais de assimilação de competências e geração de inovação, devendo melhor enxergar o processo inovativo como um fator-chave para a alavancagem do país, não apenas com relação aos impactos econômicos, mas seus alcances sob outras perspectivas, uma vez que a inovação mobiliza todos os recursos do país, tanto os humanos como os materiais, permeando as diversas dimensões existentes.

Dessa forma, é importante saber como a inovação é planejada; como ela é implantada; como deve ser acompanha; quais as práticas a serem introduzidas para o caso de correções no trajeto; dentre outros questionamentos que possibilitem conhecer soluções similares que funcionaram em outros países e que, eventualmente, podem ser aplicadas no contexto brasileiro, propiciando novos conhecimentos e possíveis novas soluções.

Alvarez $^{6}$ afirma que a construção do futuro do Brasil passa pela promoção da inovação, a qual deve ser considerada um elemento essencial para o crescimento e para o desenvolvimento do país, possuindo especial importância para o desempenho das organizações, que se encontram em um cenário extremamente competitivo no qual a geração de valor deslocou-se da manufatura para bens intangíveis, compostos por informações e conhecimentos adquiridos. Nesse sentido, o autor afirma que a inovação tecnológica tem fundamento econômico e social para o Brasil, de modo que os alcances e os impactos do processo inovativo vão muito além, necessitando de diferentes maneiras capazes de identificar e de mensurar os tipos de inovação e as suas respectivas perturbações.

Marzano ${ }^{10}$ apresenta no seu trabalho as primeiras tentativas de dimensionar a inovação no Brasil, analisando as infraestruturas disponíveis, conforme segue abaixo:

(1) FINEP (Financiadora de Estudos e Projetos): trata-se de uma agência específica para a inovação, sendo uma empresa de natureza pública, criada em 1967 e vinculada ao Ministério da Ciência e Tecnologia (MCT), cujo orçamento multiplicou-se nos últimos anos e possui estrutura singular, comparável a instituições internacionais.

(2) Lei de Inovação e Lei do Bem: a Lei de Inovação (Lei nº 10.973 de 2004) que incentiva parcerias em P\&D entre universidades, institutos de pesquisa e empresas; regula a transferência de tecnologia; e, entre ou-

\footnotetext{
26 BRASIL. Lei n $n^{\circ}$ 10.973, de 24 de dezembro de 2004. Dispõe sobre incentivos à inovação e à pesquisa científica e tecnológica no ambiente produtivo e dá outras providências. Disponível em: <http://www.planalto.gov.br/ccivil_03/_ato2004-2006/2004/lei/ 110.973.htm>. Acesso em: 05 nov. 2014.

27 PEREIRA, José Matias; KRUGLIANSKAS, Isak. Gestão de inovação: a lei de inovação tecnológica como ferramenta de apoio às políticas industrial e tecnológica do Brasil. RAE Eletrônica, São Paulo, v. 4, n. 2, p. 1-15, jul./dec. 2005.

28 CALMANOVICI, Carlos. A inovação, a competitividade e a projeção mundial das empresas brasileiras. Revista da USP, São Paulo, n. 89, p. 190-203, 2011.
} 
tros aspectos, estabelece subsídios e recursos para as atividades regulamentadas por ela. Essa Lei foi criada para tentar alavancar as parcerias e interações entre a pesquisa e o setor produtivo, que se mostram baixas. A Lei do Bem (Lei no 11.196 de 2005) busca criar incentivos fiscais relacionados à inovação.

(3) PAC da Inovação: lançado em 2007, com orçamento de $\mathrm{R} \$ 41,2$ bilhões, denominado também de PACTI (Plano de Ação de Ciência, Tecnologia e Inovação) 2007-2010, atuando nos segmentos de expansão e consolidação do sistema nacional de C\&T, na implementação da inovação tecnológica nas empresas, na $\mathrm{P} \& \mathrm{D}$ em áreas estratégicas e na C\&T e inovação voltada para o desenvolvimento social.

(4) Incentivos à Educação: Plano de Desenvolvimento da Educação (PDE), gerenciado pelo Ministério da Educação, cujo objetivo é elevar a qualidade da educação básica no Brasil, assim como a educação superior e a educação profissionalizante.

(5) INPI e INMETRO: reestruturação do INPI (Instituto Nacional da Propriedade Intelectual), visando reduzir o atraso na concessão de marcas e patentes no país, pois um fator que limita a aplicação das patentes é o tempo entre a "descoberta" e a divulgação, que pode ser de até 3 ou eventualmente 4 anos. Esse "atraso" é relevante em alguns setores, como nos produtos eletrônicos, que ficam obsoletos em poucos anos e as consequências desse "tempo perdido" são muito sérias, pois o acesso público a essas informações é demorado $^{29}$. Na metrologia também está ocorrendo o reaparelhamento do Instituto Nacional de Metrologia, Normalização e Qualidade Industrial (INMETRO), pois se trata de uma atividade em contínua evolução.

(6) EMBRAPII: criada, em 2013, pelo Ministério da Ciência, Tecnologia e Inovação (MCTI) em parceria com a Confederação Nacional da Indústria (CNI), a Associação Brasileira de Pesquisa e Inovação Industrial (Embrapii) tem como objetivo o fomento a projetos de cooperação entre empresas nacionais e instituições de $\mathrm{P} \& \mathrm{D}$, visando à geração de produtos e processos inovadores ${ }^{30}$.

A análise da infraestrutura brasileira permite inferir que se tratam de iniciativas recentes, que vêm ganhando mais espaço nos últimos anos, com aportes maiores. No entanto, o sistema de inovação brasileiro ainda possui lacunas significativas que atrapalham as relações entre os diferentes atores desse processo, como no caso da interação universidade-indústria, que se mostra incipiente, como ocorria nos EUA até a Segunda Guerra Mundial. O progresso de alguns setores, como o eletrônico, é lento, porque há um gap entre a produção científica, o registro das patentes e a disponibilização desse conhecimento. A capacidade do país é elevada, com recursos naturais e intelectuais; contudo, na visão econômica essa transposição tem se mostrado lenta.

\subsection{Panorama da inovação tecnológica nos EUA}

O sistema norte-americano de inovação está estruturado num profundo e amplo sistema de investimentos governamentais obrigatórios e estabelecidos por leis, sendo estes uma maneira de alavancar os projetos de pesquisa em inovação. O Estado é um tomador de riscos, ou seja, tem um papel fundamental na correção das falhas de mercado, proporcionando um ambiente com riscos reduzidos e atraindo investimentos privados, contribuindo para a aplicação da pesquisa básica na indústria e, consequentemente, para o desenvolvimento de produtos e serviços mais competitivos ${ }^{31}$.

É possível observar ainda que o modelo norte-americano está centrado em três eixos fundamentais, sendo (1) a criação, a manutenção e o aperfeiçoamento de mecanismos independentes e de excelência para

29 ROBINSON, Steve. Management, applied research and the free market paradox. Engineering Management Journal, Indiana, v.6, n.6, p. 261-269, 1996.

30 ASSOCIAÇÃO BRASILEIRA DE PESQUISA E INOVAÇÃO INDUSTRIAL. Informações institucionais. Disponível em: <http://embrapii.org.br/categoria/institucional/quem-somos/>. Acesso em: 05 ago. 2015.

31 MATTOS, Paulo; ABDAL, Alexandre. Estados Unidos: mudanças jurídico-institucionais e inovação. In: ARBIX, Glauco et al. (Org.). Inovação: estratégia de sete países. Brasília: ABDI, 2010. p. 92-120. 
avaliar os resultados dos investimentos em inovação; (2) a criação e a manutenção de um ambiente regulatório claro, estável e flexível, dando importância para aspectos como a participação do setor privado através de dispositivos de transferência de tecnologia; (3) e a redução de riscos, atraindo os investimentos privados ${ }^{18}$.

Esses três eixos estão combinados de maneira que o sistema norte-americano funcione e acarrete bons resultados. Assim, tem-se, na avaliação, instrumento que permite a justificativa da realização dos investimentos em inovação, sendo um quesito essencial para a realização de otimizações no processo e para que as políticas públicas se sustentem por um longo prazo; como também a existência de um ambiente regulatório claro, no qual os riscos são reduzidos, que facilita a interação entre os diferentes atores do processo inovativo de modo a respeitar a atribuição de cada um.

A fim de entender o percurso percorrido pelos EUA, faz-se válido pensar na perspectiva histórica vinculado à formação de seu Ecossistema de Inovação, sendo possível fazer uma linha do tempo com início em 1787, quando o Congresso Constitucional conferiu ao parlamento a autoridade para promover o progresso da Ciência e das artes úteis ${ }^{32}$.

Baseado na própria dinâmica da economia norte-americana, segundo Higgs, a mão-invisível fez com que o Estado ocupasse um papel de tomador de riscos, proporcionando um ambiente favorável ao progresso, e, no século XIX, a inovação já era uma questão totalmente alheia ao Estado. Contudo, devido à instabilidade e tensão resultantes dos períodos de guerra, como a com a Segunda Guerra Mundial (1939-1945) e, posteriormente, a Guerra Fria, a sociedade sentiu a necessidade de aproximação com ao governo federal ${ }^{33}$.

Nesse contexto se criou, em 1958, a Agência de Projetos de Pesquisa Avançada (atualmente denominada Agência de Projetos em Pesquisa Avançada em Defesa), como uma divisão de pesquisa do Departamento de Defesa; e a Agência Nacional Aeronáutica e Espacial (NASA), em 1959. Nesse mesmo ano, visando à rápida formação tecnológica de jovens e pesquisadores, o orçamento da Fundação Nacional de Ciências (NSF) foi elevado em quase US $\$ 100$ milhões, atingindo um total de US $\$ 134$ milhões. Pouco menos de dez anos depois, em 1968, o orçamento da NSF já chegava próximo a US\$500 milhões, representando um crescimento de quase 15 vezes ao longo dessa década. Esses dados demonstram o papel ativo do Estado norte-americano no investimento em pesquisa, fazendo com que os EUA despontasse no cenário tecnológico de modo a culminar no envio do astronauta norte-americano Neil Armstrong à lua, em $1969^{34}$.

Em 1980, surgia um marco legal para o incentivo dos investimentos em inovação nos EUA, estabelecido por meio da lei Stevenson-Wydler Technology Innovation Act e Bayh-Dole Act, que regulamentavam a transferência tecnológica entre empresas privadas e organizações públicas, permitindo que tecnologias geradas em institutos públicos, ou com financiamento público, pudessem ser transferidas para as organizações privadas. Ainda, essas normatizações representavam o estabelecimento de parcerias entre instituições públicas e o setor produtivo, bem como possibilitavam que universidades se tornassem titulares de tecnologias desenvolvidas por meio de investimentos governamentais ${ }^{35}$.

Outros instrumentos de fomento à inovação continuaram a se desenvolver no contexto norte-americano, a partir da década de 80. Em 1982, a Pensilvânia estabeleceu um dos primeiros programas oficiais de estímulo às parcerias público-privadas, o Benjamin Franklin Partnership Program, que representou a suavização das fronteiras de interação entre as universidades, a indústria e o governo. Ainda em 1982, foi promulgada a Lei de Desenvolvimento e Inovação para Pequenas Empresas, como também a Associação Nacional de Incubadoras de Empresas (NBIA), cujo objetivo era fornecer treinamento e ferramentas de auxílio às novas empresas, em 1985. Em 1986 surgiu a Lei Federal de Transferência Tecnológica, que tornou obrigatória a

32 CERQUEIRA, João da Gama. Tratado da propriedade industrial. São Paulo: RT, 1982.

33 HIGGS, Robert. Crisis and Leviathan: Critical Episodes in the Growth of American Government. New York: Oxford University Press, 1987.

34 TASH, William. Evaluating research centers and institutes for success! Fredericksburg: WT \& Associates, 2006.

35 MARINHO, Vera Maria Costa; SEIDL, Peter Rudolf; LONGO, Waldimir Pirró. O papel governamental como ator essencial para a P\&D de medicamentos: um estudo de casos. Química Nova, São Paulo, v. 31, n. 7, p. 1912-1917, 2008. 
promoção de contratos de cooperação em P\&D e transferência tecnológica entre laboratórios públicos e universidades, bem como entre laboratórios públicos e o setor produtivo. Ainda pode-se destacar que a Lei de Cooperação para a Pesquisa (1984) e a Lei de Comércio e Competitivade (1988) ${ }^{18}$.

Nesse cenário a otimização do sistema de propriedade intelectual dos EUA ocorreu, a fim de colaborar para a efetividade dos resultados advindos das normatizações de incentivo à inovação, por meio da proteção e controle de patentes. Como resultado, houve aumento significativo dos royalties, estimulando os inventores. Ainda, em 2000, as indústrias gastavam mais em P\&D do que o governo e, em 2009, o número de membros da NBIA alcançava cerca de 1.900, sendo desses $25 \%$ estrangeiros provenientes de sessenta países ${ }^{10,36}$.

Tem-se, assim, que os EUA estão buscando, continuamente e de diversas formas, assegurar a sua liderança inovadora por meio da capacidade de geração de conhecimento e competências e sua transformação em valor econômico. Ressalta-se ainda o incentiva e a regulamentação de parcerias entre os diferentes atores do processo inovativo, destacando as ações do governo, que influenciam o ritmo e o rumo das mudanças tecnológicas.

Sob essa perspectiva, ao se comparar a estrutura brasileira com a norte-americana, tem-se que o relacionamento bilateral com os EUA é um possível caminho a ser seguido pelo Brasil, retomando o ponto da aprendizagem por meio de experiências de líderes mundiais no cenário da inovação tecnológica.

\section{Programa de P\&D da ANEel no Brasil}

O setor elétrico brasileiro passou por diversas alterações na sua estrutura, desde a sua origem até os dias atuais. Em linhas gerais, pode-se dividir a evolução do setor em três fases principais, conforme descrito abaixo.

Tudo começou com a introdução da eletricidade no país ainda no Império, com a concessão de D. Pedro II a Thomas A. Edison. Na sequência, entre os anos de 1898 a 1929, ocorreu intenso investimento de capital estrangeiro e nacional, oriundos do setor privado; portanto, nessa primeira fase o setor é considerado privado. Em 1929, com a recessão enfrentada pelo Brasil e a instalação de um governo revolucionário nacionalista, deu-se início à segunda fase (1931-1990), que se referiu à estatização do setor. Na fase estatal, o crescimento do segmento ocorreu por meio de endividamentos externos até a crise dos países em desenvolvimento, na década de 80, que causou uma recessão mundial. Durante esses anos, o governo reajustou as tarifas abaixo da inflação como uma medida de controle, o que gerou mais prejuízos financeiros para o país, sendo proposta reformulação no setor. Nesse contexto, iniciou-se a terceira fase (1992-2009), centrada na privatização e nas reformas. Essa reestruturação ocorreu em conjunto com a reforma do papel do Estado, com o governo Fernando Henrique Cardoso. Essas mudanças precisavam ser reguladas e, nesse contexto, é criada a ANEEL, pela Lei 9.427, de 26 de dezembro de $1996^{37}$.

O final da segunda fase e o início da terceira foi marcado por recessões, o que fez o governo reduzir os recursos públicos destinados a P\&D para empregá-los em outros fins mais imediatos e, simultaneamente, a redução pelas empresas privadas, que naquele momento tinham interesses estratégicos de curto prazo com riscos menores. Visando garantir investimentos mínimos em P\&D, foi promulgada a Lei no 9.991, de 2000, definindo os valores percentuais mínimos de gastos com P\&D, sendo uma obrigatoriedade para todas as empresas autorizadas, permissionárias e concessionárias ${ }^{2}$.

36 FEDERAL LABORATORY CONSORTIUM FOR TECHNOLOGY TRANSFER. The Green Book: Federal Technology Transfer Legislation an Policy. 2013. Disponível em: < http://globals.federallabs.org/pdf/FLC_Legislation_and_Policy.pdf>. Acesso em: 14 maio 2014.

37 CENTRAIS ELÉTRICAS BRASILEIRAS. História do setor de energia elétrica no Brasil. Rio de Janeiro, 2015. Disponível em: <http://www.memoria.eletrobras.com.br>. Acesso em: 14 maio 2014. 
Dessa forma, o programa de P\&D da ANEEL, como é denominado, tem como objetivo gerar inovações com base nos investimentos obrigatórios em atividades de P\&D no setor produtivo, desenvolvendo uma cultura inovadora nas organizações e transferindo para as empresas a responsabilidade de gerenciar os projetos, capacitar os funcionários e estabelecer parcerias com institutos de pesquisa. Entre os anos de 2000 e 2007 , foram arrecadados aproximadamente $\mathrm{R} \$ 1,5$ bilhão, alocados em cerca de 2,4 mil projetos ${ }^{38}$.

É interessante ressaltar que o Brasil vem passando por ciclos no setor elétrico, como foi apresentado. Dessa forma, iniciou-se com a concessão no Império para setores privados, que não logrou êxito, seguido da estatização, que também não obteve sucesso e deixou consequências negativas para o ciclo privado que se seguiu. Esse último já começou fadado ao fracasso, pois, além dos impactos deixados pela fase anterior, teve início sem uma regulamentação adequada (a ANEEL foi criada somente em 1996, anos após o início) e sem ações rápidas e eficazes de estímulo à inovação.

Sob o exposto, observa-se que, para que essa trajetória seja revertida, é fundamental focar em P\&D, buscando inovações e conhecendo e avaliando os resultados, a fim de garantir e justificar a continuidade dessas políticas, pois, como citado anteriormente, a inovação é o fator-chave para o sucesso e o crescimento tanto do setor elétrico como do país.

\section{Metodologia}

Realizou-se um estudo exploratório, integrando pesquisa bibliográfica e coleta e análise de dados secundários, abrangendo a satisfação dos consumidores e o número de patentes do setor elétrico. A investigação iniciou-se com a busca de referências em banco de dados nacionais e internacionais, como IEEEXplore, Elsevier, SCielo e outros, assim como o acervo digital de universidades brasileiras.

De forma sistemática, a metodologia empregada contemplou: (1) estudo e levantamento de dados com base em de relatórios de satisfação do cliente no setor elétrico, sendo utilizado o Índice Aneel de Satisfação do Consumidor (IASC), para o caso brasileiro, e American Customer Satisfaction Index (ACSI), para o caso norte-americano; (2) coleta e análise do número de patentes do segmento elétrico, empregando uma base internacional de dados patentários - World Intellectual Property Organization (WIPO); (3) análise bivariada para duas variáveis quantitativas, por meio da aplicação do Método de Correlação de Pearson (teste paramétrico) e análises inferenciais, a fim de verificar possíveis correlações entre os indicadores, bem como desenvolver previsões para os próximos períodos, utilizando-se o software Microsoft Office Excel 2013, pois este apresenta ferramentas de estatística que são úteis para fundamentar as discussões.

\section{ANÁlise E discussão dos RESUltados OBTIDOS}

Considerando-se a importância de uma análise crítica que responda ao objetivo proposto no início do trabalho, essa seção está dividida em quatro partes. A primeira delas introduz o IASC, apresentando os seus resultados e fazendo uma comparação com os dados dos EUA, obtidos por meio da ACSI. Posteriormente, é feita uma avaliação do impacto do programa de P\&D da ANEEL no número de patentes do setor e uma comparação externa. Na terceira parte, buscou-se a correlação entre os itens anteriores, finalizando com uma discussão.

38 AGÊNCIA NACIONAL DE ENERGIA ELÉTRICA. Manual do programa de pesquisa e desenvolvimento do setor de energia elétrica. Brasília, 2008. Disponível em: <http://www.aneel.gov.br/cedoc/aren2008316_2.pdf>. Acesso em: 13 jul. 2014. 


\subsection{Análise do Índice ANEEL de Satisfação do Consumidor (IASC)}

A ANEEL promove anualmente o IASC (Índice ANEEL de Satisfação do Consumidor). Os objetivos principais desse índice, conforme apresentado no Relatório Brasil - IASC 2012, são: 1) avaliar, por meio da percepção dos usuários, o grau de satisfação com as concessionárias distribuidoras de energia elétrica; 2) gerar um indicador que mostre a percepção global no setor; 3) permitir uma análise temporal no período 2002-2012. Para que os objetivos propostos sejam alcançados, é conduzida uma pesquisa de campo com base na aplicação de questionários para uma amostra de, aproximadamente, 20.000 clientes, distribuídos no Brasil. O modelo utilizado para análise é composto por cinco variáveis: 1) satisfação global; 2) qualidade percebida (composto pelos itens informações ao cliente, acesso à empresa e confiabilidade nos serviços); 3) valor percebido (dimensão econômica); 4) confiança no fornecedor; 5) fidelidade (intenção de troca). A ANEEL disponibiliza os resultados da pesquisa na forma de relatórios anuais, dos quais foram retirados os dados que serão utilizados nesse estudo para efeitos comparativos (ANEEL, 2012).

A Figura 1 apresenta a evolução global do IASC, no período 2002-2012, sendo traçada uma linha de tendência polinomial de $5^{a}$ ordem e obtendo-se uma extrapolação para os próximos períodos. O coeficiente de determinação $\left(\mathrm{R}^{2}\right)$ mediu o grau de proximidade entre os valores observados dentro da amostra e os valores previstos pelo modelo adotado, variando de 0 a 1 , sendo que 1 seria o ajuste perfeito.

Gráfico 1 - Índice global de satisfação do consumidor (2002-2012) - Brasil.

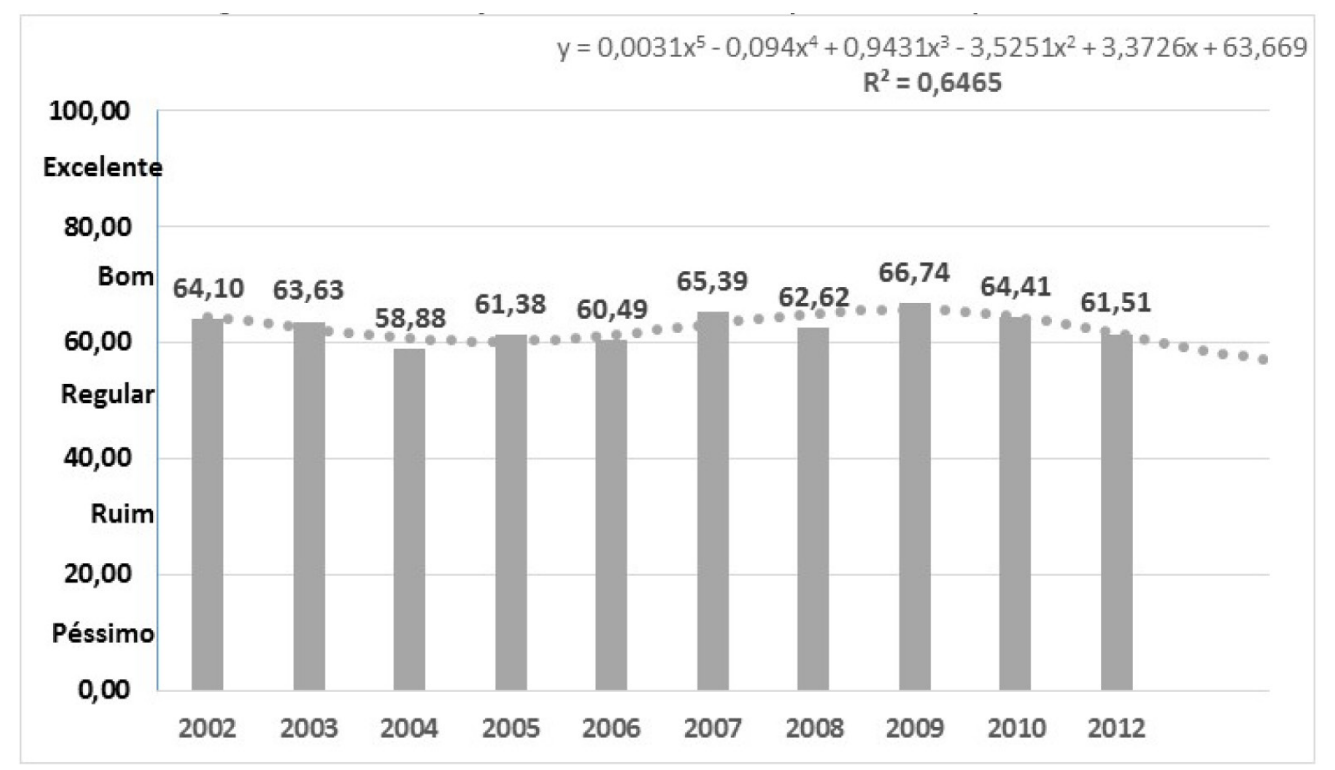

Fonte: Do Autor.

Sob o ponto de vista do consumidor brasileiro, foi possível constatar uma flutuação da satisfação no período avaliado, e especialmente em 2006 e em 2012 o índice encontrava-se na fronteira entre ruim e regular; em 2004 a insatisfação dos clientes foi maior. O índice médio obtido foi de 62,92, permanecendo na faixa considerada entre regular e bom, com tendência para regular e $\mathrm{R}^{2}$ igual a 0,6465 . Não foi constatado um crescimento significativo no índice global, devido à instabilidade nos valores. Ressalta-se que no ano de 2011 não foi publicado o relatório da ANEEL, não sendo possível a obtenção do dado.

Comparativamente, a Figura 2 apresenta a evolução nos EUA, de 2002 a 2012, sendo aferida pela ACSI e disponibilizada em seu sítio eletrônico. 
Gráfico 2 - Índice global de satisfação do consumidor (2002-2012) - EUA.

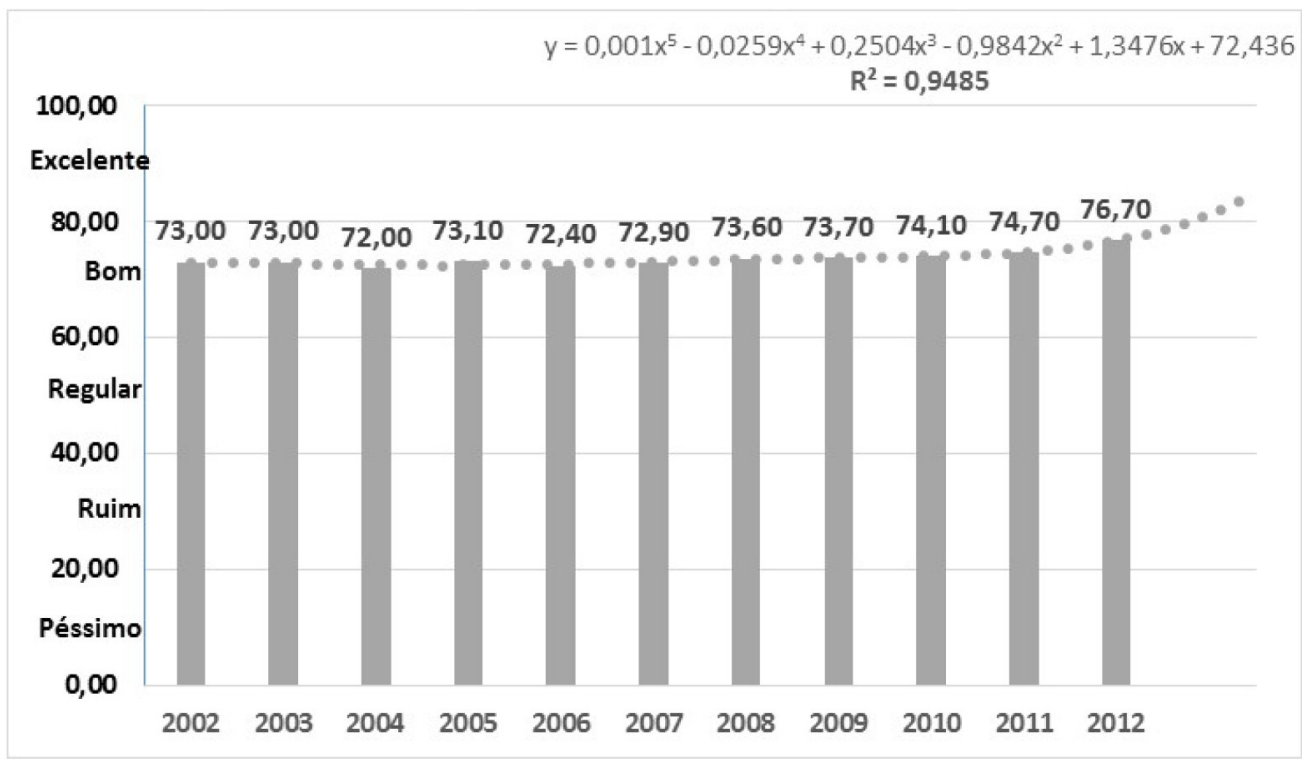

Fonte: Do autor.

No cenário norte-americano, não foi observada flutuação ao longo dos anos, como ocorreu no Brasil, demonstrando sempre uma estabilização da satisfação dos clientes, até 2007 , seguido por uma otimização dos resultados, a partir de 2008. O valor de $\mathrm{R}^{2}$ obtido para o modelo de polinômio de $5^{\mathrm{a}}$ ordem foi de 0,9485 , exibindo maior aderência ao modelo do que o caso brasileiro. Em todo o período avaliado, a amostra permaneceu na faixa entre bom e excelente sob o ponto de vista do consumidor norte-americano, apresentando um índice médio de 73,56. Foi possível observar uma ascensão da linha de tendência e as previsões para os próximos períodos indicaram que um maior aproximação ao nível excelente.

Os valores previstos para ambos os países apresentaram concordância com os recentes relatórios IASC ${ }^{39}$ e $\mathrm{ACSI}^{40}$. Assim, em 2013, realmente houve uma queda no IASC, atingindo 60,41 e ficando na fronteira entre ruim e regular. Em 2014, embora tenha ocorrido uma recuperação na satisfação dos clientes (índice 67,74), há uma manutenção dos valores na faixa regular e bom. No cenário norte-americano, alcançou-se um índice de 77,4, em 2013, e 76,00, em 2014, permanecendo o país na faixa de bom e próximo à fronteira do nível excelente.

\subsection{Análise do número de patentes no setor elétrico}

Os dados utilizados nessa seção foram obtidos no sítio eletrônico da WIPO, também conhecida como Organização Mundial da Propriedade Intelectual (OMPI). Trata-se de uma agência da Organização das Nações Unidas (ONU), sediada em Genebra, responsável pela promoção da proteção da propriedade intelectual no mundo. Sua missão é promover a inovação e a criatividade para o desenvolvimento social, econômico e cultural nos países. Os itens que compõem a propriedade intelectual são a propriedade industrial, que é composta pelas patentes, marcas, desenho industrial e indicações geográficas, os direitos autorais e a proteção sui generis, que abrange os programas de computador, os cultivares e a topografia de circuitos integrados ${ }^{41}$.

39 AGÊNCIA NACIONAL DE ENERGIA ELÉTRICA. Relatório Brasil: IASC 2014. Brasília: ANEEL, 2014. Disponível em: <http://www.aneel.gov.br/arquivos/PDF/RELATORIO_BRASIL_IASC_2014_2.pdf>. Acesso em: 15 jan. 2015.

40 AMERICAN CUSTOMER SATISFACTION INDEX. Customer Satisfaction Benchmarks. Sector: energy utilities. 2015. Disponível em: <http://www.theacsi.org/customer-satisfaction-benchmarks/benchmarks-by-sector>. Acesso em: 22 fev. 2015.

41 WORLD INTELLECTUAL PROPERTY ORGANIZATION. Wipo Overview: 2011 edition. Genebra, 2011. Disponível em: <http://www.wipo.int/export/sites/www/freepublications/en/general/1007/wipo_pub_1007_2011.pdf>. Acesso em: 14 set. 2014. 
Para a análise de correlação que se sucederá na próxima seção, foi escolhida como variável independente o número de patentes, buscando-se verificar, num primeiro momento, se existe algum impacto do programa de P\&D na concessão de patentes do setor. Em seguida, apresenta-se uma comparação com os EUA e a participação do setor elétrico nos pedidos de cada país.

O Manual do Programa de Pesquisa e Desenvolvimento Tecnológico do Setor de Energia Elétrica prevê a propriedade intelectual dos produtos resultantes dos projetos de $\mathrm{P} \& \mathrm{D}$, estimulando a proteção dos direitos de propriedade sobre os produtos gerados, para que a sua comercialização possa contribuir para o desenvolvimento econômico dos agentes participantes desse processo ${ }^{26}$.

Segundo Arbix ${ }^{8}$, o Brasil apresenta atualmente um gasto em P\&D de aproximadamente 1\% do PIB, enquanto nos EUA esse fator era de aproximadamente 2,62\%, em 2006. Winarski ${ }^{4}$ diz que nos EUA a taxa de concessão de patentes no segmente elétrico cresceu significativamente, a partir do ano 2000. Dessa forma, a Figura 3 apresenta o nível de participação do setor elétrico no Brasil, enquanto a Figura 4 ilustra o mesmo cenário para o caso norte-americano.

Gráfico 3 - Pedido de patente por campo tecnológico - Brasil.

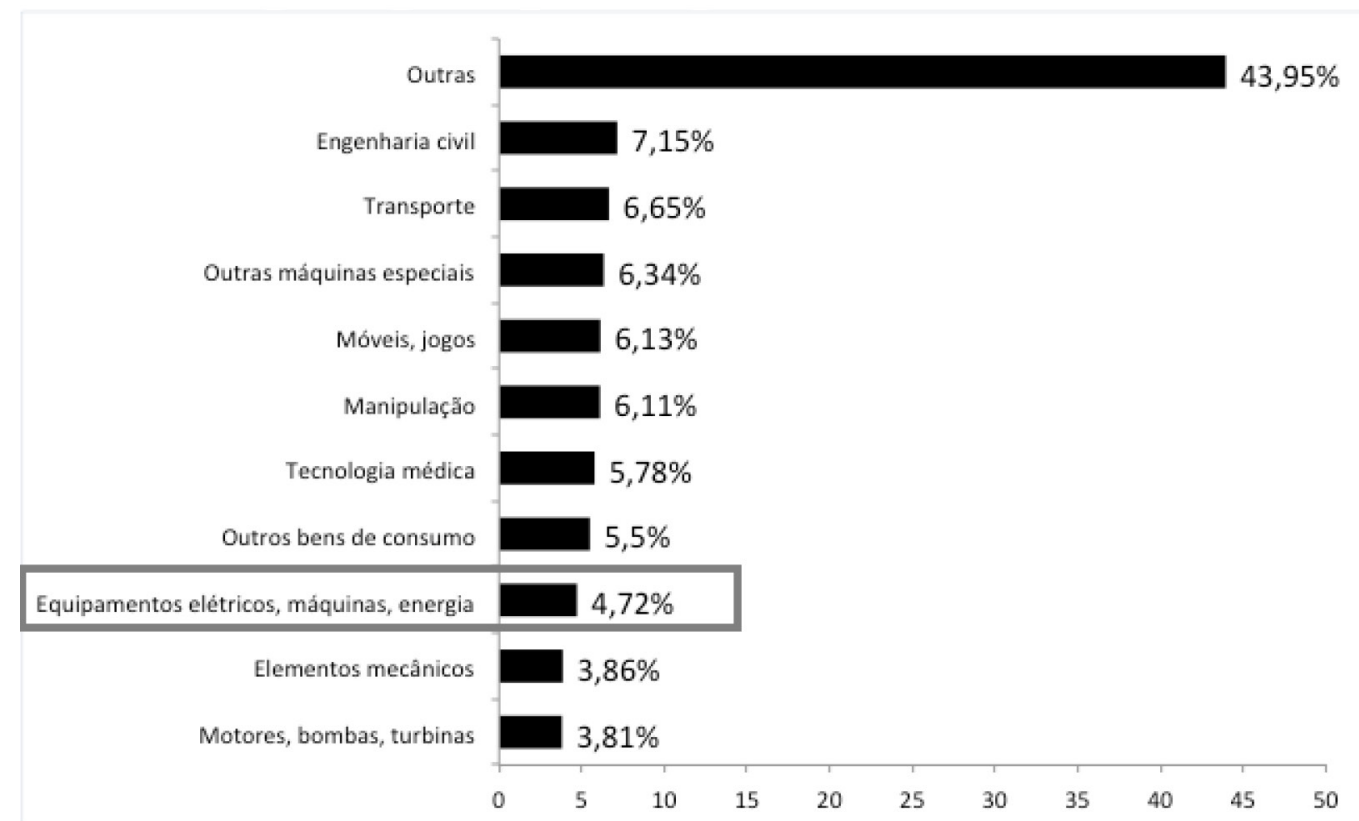

Fonte: adaptado de $\mathrm{WIPO}^{42}$

42 WORLD INTELLECTUAL PROPERTY ORGANIZATION. WIPO statistical country profiles: Brazil. Genebra, 2012. Disponível em: <http://www.wipo.int/ipstats/en/statistics/country_profile/countries/br.html>. Acesso em: 14 set. 2014. 
Gráfico 4 - Pedido de patentes por campo tecnológico - EUA.

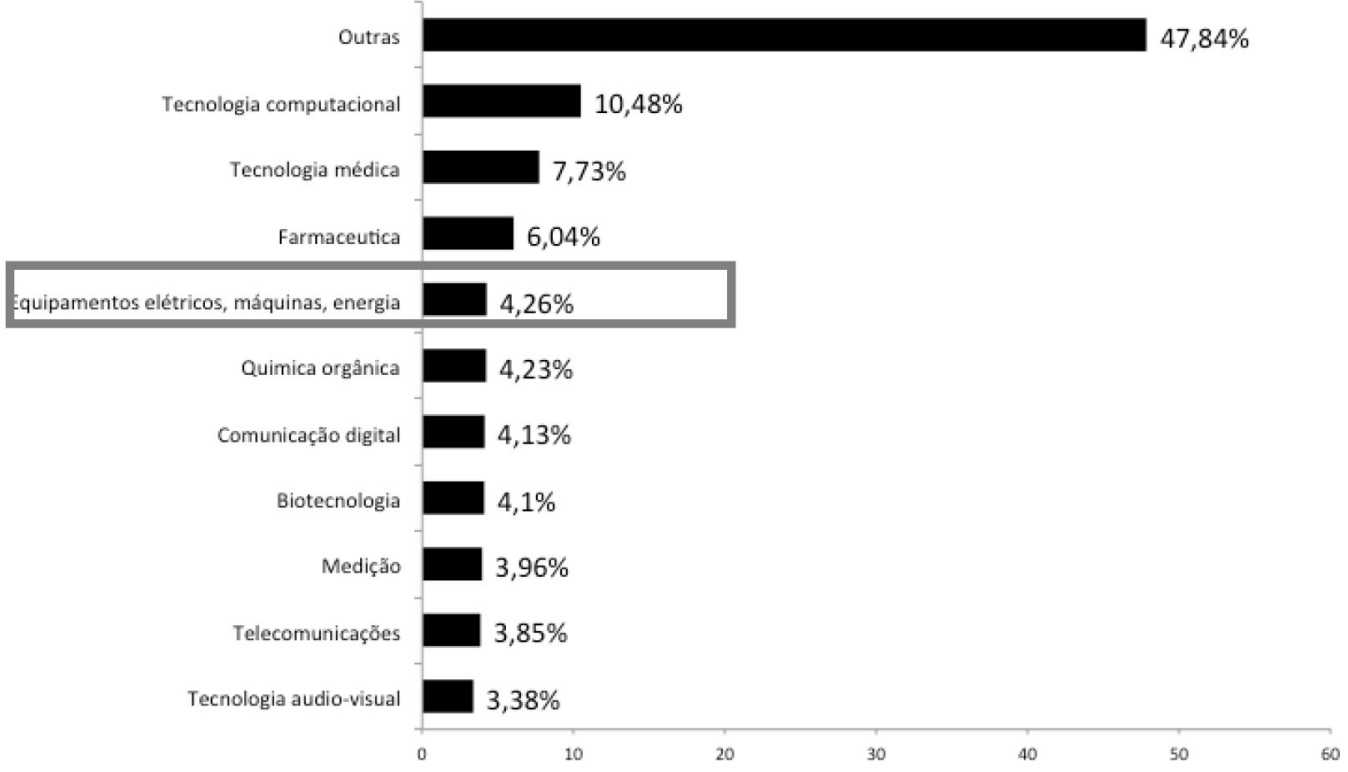

Fonte: adaptado de WIPO ${ }^{43}$

A análise das figuras 3 e 4 demonstra que o Brasil possui um percentual ligeiramente mais elevado de participação do setor elétrico (4,72\%) do que os EUA (4,26\%). Contudo, no contexto brasileiro, esse setor ocupa o $8^{\circ}$ lugar, enquanto nos EUA esse setor desponta em $4^{\circ}$ lugar, apresentando uma importância relativa maior nos EUA do que no Brasil.

As figuras 5 e 6 apresentam o número de patentes publicadas no Brasil e nos EUA, respectivamente, conforme dados da $\mathrm{WIPO}^{44}$. Observa-se que o índice de inovação no Brasil permaneceu instável, com quedas e recuperações constantes, não sendo percebido um crescimento expressivo, de modo que não foi possível evidenciar um impacto efetivo do programa de P\&D da ANEEL, no período analisado. Em valores absolutos, pode-se afirmar que o número de proteções no Brasil é muito baixo, e, em 2011, somente 221 patentes foram obtidas no setor elétrico. Esses dados comprovam o reduzido índice de inovação no setor, bem como a instabilidade do processo inovativo. Contudo, prevê-se aumento no número de proteções brasileiras no segmento elétrico para os próximos anos, tendo como base a linha de tendência polinomial de $5^{\mathrm{a}}$ ordem traçada $\left(R^{2}=0,6758\right)$.

43 WORLD INTELLECTUAL PROPERTY ORGANIZATION. WIPO statistical country profiles: United States of America. Genebra, 2012. Disponível em: <http://www.wipo.int/ipstats/en/statistics/country_profile/countries/us.html>. Acesso em: 14 set. 2014.

44 WORLD INTELLECTUAL PROPERTY ORGANIZATION. WIPO IP statistics data center indicator: 5 patent publications by technology, report type: total count by applicant's origin, year range: 2002-2011, origin: Brazil and United States, technology: electrical machinery, apparatus, energy. 2012. Disponível em: <http://ipstatsdb.wipo.org/ipstatv2/ipstats/patentsSearch>. Acesso em: 14 set. 2014. 
Gráfico 5 - Evolução no número de patentes do setor elétrico - Brasil.

$$
\begin{gathered}
y=0,1545 x^{5}-4,4814 x^{4}+48,35 x^{3}-237,38 x^{2}+513,78 x-160 \\
R^{2}=0,6758
\end{gathered}
$$

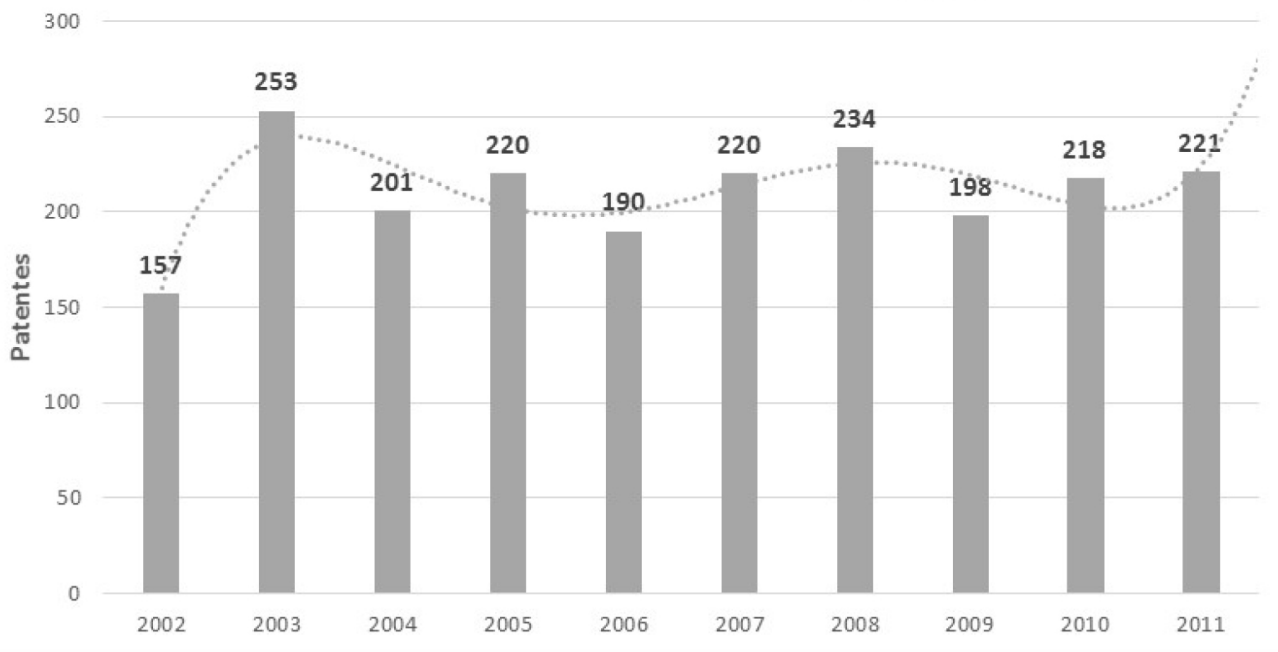

Fonte: Do Autor

De modo distinto, o índice de inovação norte-americano apresentou um discreto crescimento, até 2007, seguido por aumento significativo, em 2008, de modo que o número de proteções saltou de 14.549 (2007) para 15.653 (2008), alcançando 15.782 patentes no setor elétrico, em 2011. Esse comportamento no número de proteções assemelha-se ao observado para o índice de satisfação do cliente, demonstrando que um aumento da inovação no segmento elétrico conferiu maior satisfação do consumidor. Ainda, a linha de tendência polinomial de $5^{a}$ ordem traçada exibiu crescimento, embora modesto, no número de patentes do setor elétrico, para os próximos anos. $\mathrm{O}$ valor de $\mathrm{R}^{2}$ nesse caso foi de 0,9768 , atestando uma alta aderência ao modelo adotado e uma diferença significativa com os dados brasileiros.

Gráfico 6 - Evolução no número de patentes do setor elétrico - EUA.

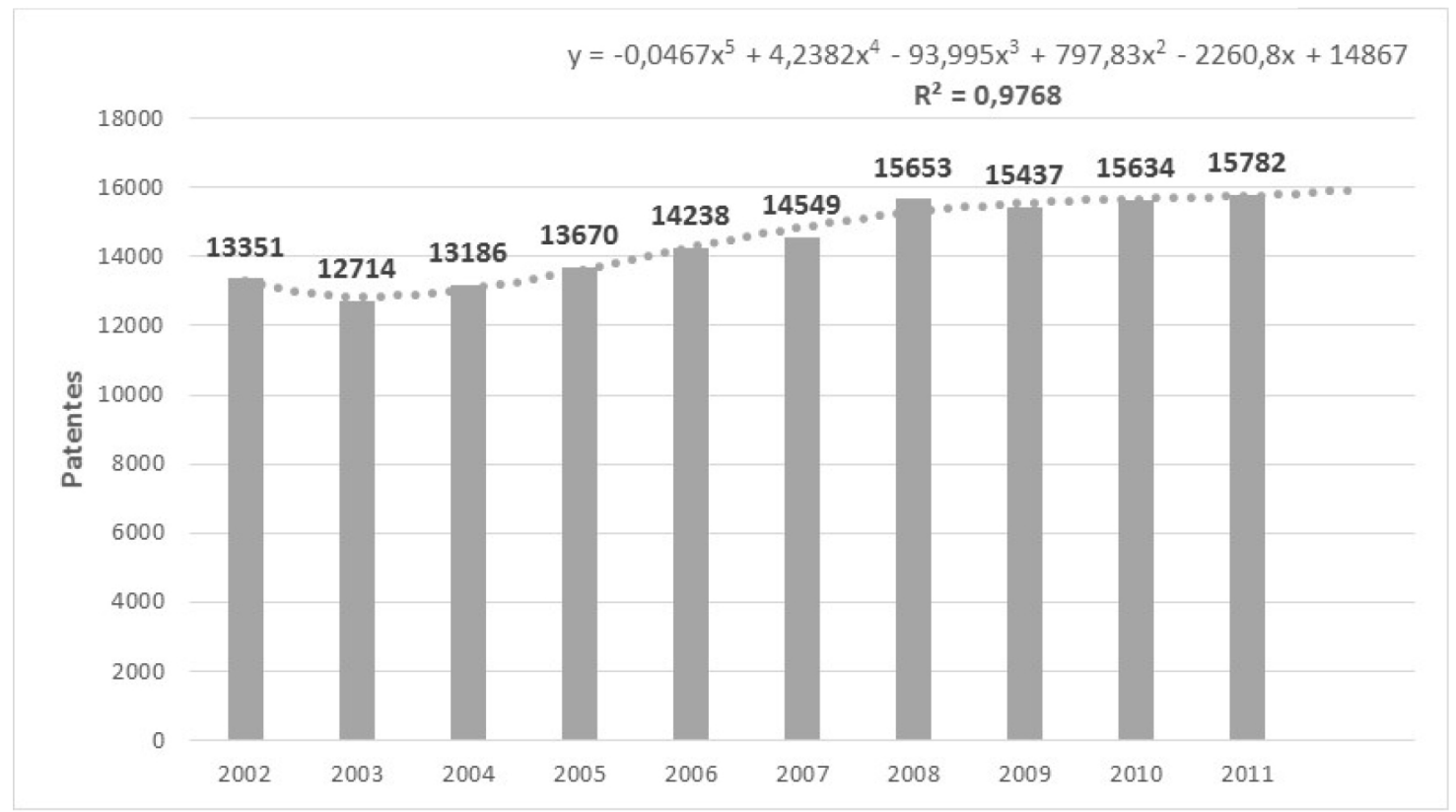

Fonte: Do Autor. 
A diferença entre os números de proteções entre o Brasil e os EUA deve-se, entre outros fatores (como o investimento em P\&D), ao fato de os EUA possuírem uma política de inovação mais consolidada e com forte ligação às ações de $\mathrm{C} \& \mathrm{~T}$, enquanto no Brasil as políticas públicas de inovação, assim como a mensuração de seus resultados, são recentes, sendo inferiores a duas décadas, conforme apresentado no quadro teórico.

\subsection{Análise de correlação entre o número de patentes e a satisfação do consumidor}

A fim de possibilitar análise mais assertiva, o estudo de correlação buscou identificar se existe, e em que grau, associação entre o número de patentes no setor elétrico e o índice de satisfação do consumidor, em cada país. O período avaliado foi 2002-2010, uma vez que a WIPO não apresentou o total patentes referentes à 2012, como também a ANEEL não disponibilizou o índice em 2011, não permitindo, assim, a verificação nesses últimos dois anos.

Nesse artigo, a escolha da análise do coeficiente de correlação de Pearson deve-se ao fato das variáveis de interesse seguirem uma distribuição normal, sendo esta uma condição para a aplicação de testes paramétricos ${ }^{45}$. Ademais, esse método é adotado em cerca de 95\% dos casos para descrever o padrão de relacionamento entre diferentes variáveis ou permitir a realização de inferências pertinentes com base em de dados amostrais ${ }^{46}$.

Dessa forma, aplicou-se o Método de Pearson, sendo $r$ o coeficiente de correlação, que varia entre -1 (correlação perfeita negativa) e 1 (correlação perfeita positiva), que pode ser visto como uma medida da associação linear entre variáveis. O valor 0 (zero) representa que não pode ser constatada correlação, utilizando-se esse modelo. A Tabela 1 mostra as zonas de correlação do modelo e as tabelas 2 e 3 apresentam os dados utilizados na correlação, assim como o resultado para o Brasil e os EUA, respectivamente.

Tabela 1 - Zonas de Correlação do Método de Correlação Pearson

Fonte: Adaptado de Dancey e Reidy (2005)

\begin{tabular}{|c|c|}
\hline $\mathbf{R}^{*}$ & Correlação \\
\hline $0,00-0,30$ & Fraca \\
\hline $0,30-0,70$ & Moderada \\
\hline $0,70-1,00$ & Forte \\
\hline$*$ Os intervalos são equivalentes para valores negativos \\
\hline
\end{tabular}

Tabela 2 - Correlação entre número de patentes e a satisfação dos consumidores (Brasil)

\begin{tabular}{|l|c|c|}
\hline Ano & Patentes (WIPO) & Satisfação (IASC) \\
\hline 2002 & 157 & 64,10 \\
\hline 2003 & 253 & 63,63 \\
\hline 2004 & 201 & 58,88 \\
\hline 2005 & 220 & 61,38 \\
\hline 2006 & 190 & 60,49 \\
\hline 2007 & 220 & 65,39 \\
\hline 2008 & 234 & 62,62 \\
\hline 2009 & 198 & 66,74 \\
\hline 2010 & 218 & 64,41 \\
\hline \multicolumn{3}{|c|}{ r $=\mathbf{0 , 0 4}$} \\
\hline
\end{tabular}

Fonte: Do Autor.

45 ARANGO, Héctor Gustavo. Bioestatística teórica e computacional. 3 ed. Rio de Janeiro: Guanabara Koogan, 2009.

46 CHEN, Peter Y.; POPOVIC, Paula M. Correlation. London: Sage, 2002. 
No cenário brasileiro, não foi constatada uma correlação entre o número de patentes e a satisfação do consumidor $(\mathrm{r}=0,04)$. Esse dado indica que não há uma associação linear entre as variáveis, possivelmente provocado pelas oscilações dos valores já discutidas nos itens anteriores. No entanto, pode haver correlações não lineares, que precisariam ser verificadas em etapas futuras do estudo.

Tabela 3 - Correlação entre número de patentes e a satisfação dos consumidores (EUA)

\begin{tabular}{|c|c|c|}
\hline Ano & Patentes (WIPO) & Satisfação (ACSI) \\
\hline 2002 & 13351 & $\mathbf{7 3 , 0 0}$ \\
\hline 2003 & 12714 & $\mathbf{7 3 , 0 0}$ \\
\hline 2004 & 13186 & $\mathbf{7 2 , 0 0}$ \\
\hline 2005 & 13670 & $\mathbf{7 3 , 1 0}$ \\
\hline 2006 & 14238 & $\mathbf{7 2 , 4 0}$ \\
\hline 2007 & 14549 & $\mathbf{7 2 , 9 0}$ \\
\hline 2008 & 15653 & $\mathbf{7 3 , 6 0}$ \\
\hline 2009 & 15437 & $\mathbf{7 3 , 7 0}$ \\
\hline 2010 & 15634 & $\mathbf{7 4 , 1 0}$ \\
\hline \multicolumn{3}{|c|}{} \\
\hline
\end{tabular}

Fonte: Do Autor.

Nos EUA o resultado mostrou-se diferente, confirmando uma forte correlação positiva entre as variáveis $(\mathrm{r}=0,77)$. Isso significa que existe uma dependência linear entre o número de patentes no setor elétrico e o índice de satisfação do cliente.

\subsection{Discussão}

A partir da contextualização histórica e da análise dos dados, observa-se que o Brasil ainda está dando os primeiros passos no universo da inovação, especialmente no segmento elétrico, iniciando o desenvolvimento das infraestruturas necessárias para esse processo. Uma das maneiras de se evidenciar isso foi por meio da relação entre os investimentos em P\&D, que hoje no Brasil equivalem apenas a 1\% do PIB; e seus respectivos impactos, como a satisfação do cliente e número de patentes no setor. No Brasil o processo de inovação é recente e não está totalmente consolidado, tampouco fortemente inserido no setor produtivo.

Com relação aos impactos diretos, ainda não foi possível perceber um aumento no número de patentes brasileiras no setor elétrico, mesmo com a iniciativa do governo em promover investimentos, por meio do programa de P\&D da ANEEL, cujo objetivo principal é melhorar o desempenho das empresas envolvidas. Corroborando esses resultados, Queiroz ${ }^{47}$ verificou também a não existência de uma relação positiva e estatisticamente significativa entre os gastos com P\&D e o crescimento no lucro de empresas brasileiras analisadas.

Foi possível concluir ainda que, independentemente do país, os retornos econômicos obtidos por meio de investimentos em P\&D geralmente ocorrem em longo prazo e seguem fases, de modo que, inicialmente, deve-se ocorrer o investimento, desenvolvendo novas tecnologias, que, então, serão aplicadas em produtos ou serviços, para, por fim, se obter os retornos econômicos resultantes da comercialização (produto/serviço colocado no mercado).

Ressalta-se ainda que a análise de patentes realizada nesse estudo contemplou um horizonte de tempo de, aproximadamente, dez anos (2002-2011, conforme Figura 5), simultaneamente ao começo do programa

47 QUEIROZ, Odeon. O impacto do crescimento dos gastos em P\&D na taxa de crescimento dos lucros das empresas de acordo com o modelo OJ: um estudo no mercado de capitais brasileiro. In: CONGRESSO ANPCONT, 4., 2010, Natal. Anais... Natal: ANPCONT, 2010. p. 1-16. 
da ANEEL, em 2000. Esse período foi caracterizado pelo investimento e desenvolvimento de projetos tecnológicos, sendo importante determinar os prazos de retorno para cada uma das fases a fim de se avaliar o impacto de cada etapa para o ciclo econômico da inovação.

De maneira mais abrangente, os impactos indiretos da $\mathrm{P} \& \mathrm{D}$ vão além do ciclo econômico da inovação. O impacto indireto adotado como índice nesse trabalho foi a satisfação do cliente. Nesse ponto, até 2012 não foi possível observar um crescimento na satisfação do consumidor brasileiro com base nos dados do IASC. O resultado obtido é uma consequência da satisfação do cliente ser apenas observada após a fase de comercialização, ou seja, quando já houve o investimento, o desenvolvimento e a aplicação da inovação no mercado. Como nesse tempo (2002-2012) não foi possível observar ainda os impactos diretos, também é difícil analisar a correlação com a satisfação do cliente, conforme demonstrado pelo Método de Pearson. Pode-se entender que é cedo para que os clientes percebam os impactos das atividades de P\&D nos serviços cotidianos, considerando-se que essas iniciativas são recentes. No entanto, não basta simplesmente empregar recursos em P\&D; é essencial fiscalizar todo o processo, medir os resultados, fazer ajustes nas políticas, incentivar e orientar o setor produtivo, dentre outras medidas que possibilitem resultados efetivos dos programas de P\&D.

Comparativamente, no que se refere aos EUA, foi possível constatar um crescimento no número de patentes no setor, mesmo sem a identificação, no presente trabalho, de um programa nacional especifico para esse fim no segmento elétrico. Ainda, observou-se uma forte correlação entre o número de proteções no setor e a satisfação dos clientes, podendo ser explicada pelo cenário consolidado existente no país, pois, como essas relações só podem ser evidenciadas no longo prazo, nos EUA existem condições adequadas para que isto ocorra.

\section{ConClusão}

O presente trabalho foi realizado com o objetivo de estudar e avaliar se existe correlação entre um dos possíveis resultados mensuráveis dos investimentos em P\&D regulamentados pela ANEEL, o impacto no número de patentes do setor elétrico, e os impactos indiretos, por meio da satisfação dos clientes expressa na pesquisa IASC. Também, realizou-se uma comparação externa com os EUA.

O estudo demonstrou que, sob a perspectiva do consumidor brasileiro, não foi possível evidenciar uma melhoria no índice IASC, entre 2002 e 2012, permanecendo, em média, na faixa de regular a bom. Foi prevista uma continuação da satisfação dos clientes no nível regular para os próximos períodos. Também não foi constatado o impacto dos investimentos em P\&D no número de patentes do setor elétrico, de modo que o Brasil ainda possui um baixo nível de inovação, especialmente no segmento estudado. Até o presente momento, não foi observada uma relação entre esses gastos em P\&D e a satisfação do consumidor no Brasil.

Comparativamente, nos EUA foi percebido um crescimento no índice de satisfação do cliente, principalmente a partir de 2007. Embora não tenha sido identificado um programa específico para desenvolvimento em $\mathrm{P} \& \mathrm{D}$ no setor elétrico, um mesmo avanço também foi constatado no número de patentes norte-americanas a partir de 2007, indicando uma correspondência entre o índice de inovação e a satisfação do consumidor. De fato, os resultados obtidos por meio da aplicação do Método de Pearson comprovaram uma forte correlação positiva entre essas duas variáveis.

Uma das justificativas para a divergência de resultados entre os países estudados está no fato de a satisfação do cliente somente ser percebida em longo prazo, sendo um resultado do somatório de experiências (positivas ou negativas) vivenciadas pelo consumidor no decorrer do tempo. Nesse sentido, tem-se ainda que o próprio processo de P\&D é longo; as iniciativas do governo brasileiro de incentivo à inovação no setor elétrico são recentes; e, baseado nos indicadores de propriedade intelectual, a geração de patentes e, 
consequentemente, a entrada de novos produtos ou aplicação de novos processos nesse segmento ainda é embrionária, quando comparado aos EUA.

Logo, o presente artigo sugere metodologia capaz de analisar os impactos diretos e indiretos desse tipo de programa, no setor elétrico, e correlacioná-los com os investimentos em P\&D, abrangendo a análise de relatórios de satisfação do consumidor; a busca em banco de dados patentários internacionais; e aplicação de um método de correlação em associação com as inferências pertinentes. Essa sistematização pode ser aplicada para a avaliação da efetividade de outros programas públicos, cabendo, somente, as adequações das variáveis de acordo com o escopo do estudo.

Adotando como exemplo o caso norte-americano, esse estudo sustenta a manutenção de políticas públicas destinadas ao estímulo dos investimentos em P\&D no Brasil no longo prazo, especificamente por meio do Programa de P\&D da ANEEL, a fim de alavancar os índices de inovação no segmento elétrico, bem como aprimorar o padrão de satisfação do consumidor. Contudo, deve-se destacar que a obrigatoriedade de aplicação de recursos em atividades de P\&D por si só não é suficiente, sugerindo fortemente que as políticas públicas desenvolvidas possam prever mecanismos capazes de mensurar os resultados dos programas e de fiscalizar todo o processo no setor produtivo, bem como permitir ajustes e correção de trajeto e facilitar a interação dos diferentes atores envolvidos na inovação.

Vale ressaltar que esse trabalho analisou apenas as correlações lineares entre o número de patentes e a satisfação do cliente. Contudo, pode existir correlações não lineares, que seriam pertinentes para análise em novos trabalhos, assim como buscar um prazo médio de retorno dos investimentos em P\&D, que pode ser utilizado como parâmetros para avaliar e justificar o crescimento dos recursos destinados a esse fim no país.

\section{REFERÊNCIAS}

AGÊNCIA NACIONAL DE ENERGIA ELÉTRICA. Manual do programa de pesquisa e desenvolvimento do setor de energia elétrica. Brasília, 2008. Disponível em: <http://www.aneel.gov.br/cedoc/aren2008316_2.pdf>. Acesso em: 13 jul. 2014.

AGÊNCIA NACIONAL DE ENERGIA ELÉTRICA. Manual dos programas de pesquisa e desenvolvimento tecnológico do setor elétrico brasileiro. Brasilia, 2001. Disponível em: $<$ http://www.aneel.gov.br/aplicacoes/leitura_arquivo/default.cfm?idaplicacao=56>. Acesso em: 05 ago. 2015.

AGÊNCIA NACIONAL DE ENERGIA ELÉTRICA. Relatório Brasil: IASC 2014. Brasília, 2014. Disponível em: <http://www.aneel.gov.br/arquivos/PDF/RELATORIO_BRASIL_IASC_2014_2.pdf>. Acesso em: 15 jan. 2015.

ALVAREZ, Roberto dos R. Inovar é preciso. In: ARBIX, Glauco et al. (Org.) Inovação: estratégia de sete países. Brasília: ABDI, 2010.

AMERICAN CUSTOMER SATISFACTION INDEX. Customer Satisfaction Benchmarks. Sector: energy utilities. 2015. Disponível em: <http://www.theacsi.org/customer-satisfaction-benchmarks/benchmarks-bysector>. Acesso em: 22 fev. 2015.

ARANGO, Héctor Gustavo. Bioestatística teórica e computacional. 3 ed. Rio de Janeiro: Guanabara Koogan, 2009.

ARBIX, Glauco. Inovação e desenvolvimento. In: et al. (Org.). Inovação: estratégia de sete países. Brasília: ABDI, 2010. p.66-91.

ASSOCIAÇÃO BRASILEIRA DE PESQUISA E INOVAÇÃO INDUSTRIAL. Informações institucionais. Disponível em: <http:// embrapii.org.br/categoria/institucional/quem-somos/>. Acesso em: 05 ago. 2015. 
BRASIL. Lei n 9.991, de 24 de julho de 2000. Dispõe sobre realização de investimentos em pesquisa e desenvolvimento e em eficiência energética por parte das empresas concessionárias, permissionárias e autorizadas do setor de energia elétrica, e dá outras providências. Disponível em:<http://www.planalto.gov.br/ ccivil_03/leis/19991.htm>. Acesso em: 18 out. 2014.

BRASIL. Lei n $n^{\circ}$ 10.973, de 24 de dez̧embro de 2004. Dispõe sobre incentivos à inovação e à pesquisa científica e tecnológica no ambiente produtivo e dá outras providências. Disponível em: <http://www.planalto.gov. br/ccivil_03/_ato2004-2006/2004/lei/110.973.htm>. Acesso em: 05 nov. 2014.

CALMANOVICI, Carlos. A inovação, a competitividade e a projeção mundial das empresas brasileiras. Revista da USP, São Paulo, n. 89, p. 190-203, 2011.

CAMPOS, André Luis Sica. Identificação de impactos econômicos a partir da pesquisa acadêmica: um estudo de projetos temáticos da FAPESP. 1999. 93 f. Dissertação (Mestrado) - Instituto de Geociências, Universidade Estadual de Campinas, Campinas, 1999.

CENTRAIS ELÉTRICAS BRASILEIRAS. História do setor de energia elétrica no Brasil. Rio de Janeiro, 2015. Disponível em: <http://www.memoria.eletrobras.com.br>. Acesso em: 14 maio 2014.

CERQUEIRA, João da Gama. Tratado da propriedade industrial. São Paulo: RT, 1982.

CHEN, Peter Y.; POPOVIC, Paula M. Correlation. London: Sage, 2002.

COSTA, Ana Carolina Vital da; ALMEIDA, José Álvaro Jardim de; GOMES, Carla Regina Pása. Investimentos em P\&D no Setor Elétrico Brasileiro: um perfil dos resultados em eco-inovação. Ariús: Revista de Ciências Humanas e Artes, Campina Grande, v. 16, n. 1/2 p. 172-186, jan./dez. 2010.

FEDERAL LABORATORY CONSORTIUM FOR TECHNOLOGY TRANSFER. The Green Book: Federal Technology Transfer Legislation an Policy. 2013. Disponível em: <http://globals.federallabs.org/pdf/ FLC_Legislation_and_Policy.pdf>. Acesso em: 14 maio 2014.

FURTADO, João. Padrões de Inovação na Indústria Brasileira. Disponível em: < http://www.ifhc.org.br/wpcontent/uploads/apresentacoes/1941.pdf>. Acesso em: 2 abr. 2011.

HASEGAWA, Mirian; FURTADO, André Tosi. Avaliação dos impactos de programas de P\&D. Inovação Uniemp, Campinas, v.2, n.3, p. 40-41, jul./ago. 2006.

HIGGS, Robert. Crisis and Leviathan: Critical Episodes in the Growth of American Government. New York: Oxford University Press, 1987.

INSTITUTO BRASILEIRO DE GEOGRAFIA E ESTATÍSTICA. Pesquisa de inovação tecnológica - 2011. Rio de Janeiro, 2013. Disponível em: <http://www.pintec.ibge.gov.br/downloads/pintec2011\%20publicacao\%20completa.pdf>. Acesso em: 10 jan. 2015.

JANSEN, Dorothea; OSTERTAG, Katrin; WALZ, Rainer (Ed.). Sustainability innovations in the electricity sector. New York: Physica-Verlag, 2012.

MARINHO, Vera Maria Costa; SEIDL, Peter Rudolf; LONGO, Waldimir Pirró. O papel governamental como ator essencial para a P\&D de medicamentos: um estudo de casos. Química Nova, São Paulo, v. 31, n. 7, p. 1912-1917, 2008.

MARZANO, Fábio Mendes. Políticas de inovação no Brasil e nos Estados Unidos: a busca da competitividade, oportunidades para a ação diplomática. Brasília: Fundação Alexandre de Gusmão, 2011.

MATTOS, Paulo; ABDAL, Alexandre. Estados Unidos: mudanças jurídico-institucionais e inovação. In: ARBIX, Glauco et al. (Org.). Inovação: estratégia de sete países. Brasília: ABDI, 2010. p. 92-120.

NEGRI, Fernanda de; CAVALCANTE, Luiz Ricardo. Análise dos dados da PINTEC 2011. Nota técnica DISET, n. 15. Brasília: IPEA, 2013. Disponível em: < http://www.ipea.gov.br/agencia/images/stories/PDFs/ 
nota_tecnica/131206_notatecnicadiset15.pdf>. Acesso em: 10 out. 2014.

ORGANIZAÇÃO PARA COOPERAÇÃO ECONÔMICA E DESENVOLVIMENTO. Manual de Oslo: diretrizes para coleta e interpretação de dados sobre inovação. 2006. Disponível em: <http://www.uesc.br/ nucleos/nit/manualoslo.pdf>. Acesso em: 05 ago. 2015.

PEREIRA, José Matias; KRUGLIANSKAS, Isak. Gestão de inovação: a lei de inovação tecnológica como ferramenta de apoio às políticas industrial e tecnológica do Brasil. RAE Eletrônica, São Paulo, v. 4, n. 2, p. 1-15, jul./dec. 2005.

POMPERMAYER, Fabiano Mezadre; NEGRI, Fernanda de; CAVALCANTE, Luiz Ricardo. Inovação tecnológica no setor elétrico brasileiro: uma avaliação do programa de P\&D regulado pela Aneel. Brasília: IPEA, 2011.

QUEIROZ, Odeon. O impacto do crescimento dos gastos em P\&D na taxa de crescimento dos lucros das empresas de acordo com o modelo OJ: um estudo no mercado de capitais brasileiro. In: CONGRESSO ANPCONT, 4., 2010, Natal. Anais... Natal: ANPCONT, 2010. p. 1-16.

ROBINSON, Steve. Management, applied research and the free market paradox. Engineering Management Journal, Indiana, v.6, n.6, p. 261-269, 1996.

ROSENTHAL, David; MOREIRA, Inaldo Lima. Algumas considerações sobre a natureza do processo de capacitação tecnológica: fontes de inovação. Revista de Administração Pública, Rio de Janeiro, v. 26, n. 4, p. 145-160, out./dez. 1992.

SALTER, Ammon; MARTIN, Ben. The economic benefits of publicly funded basic research: a critical review. Research Policy, v. 30, n. 3, p. 509-532, Mar. 2001.

SCHUMPETER, Joseph. Capitalismo, socialismo e democracia. Rio de Janeiro: Zahar, 1984.

SILVA, Evando Mirra Paula e. O significado da pesquisa Mobit. In: ARBIX, Glauco et al. (Org.). Inovação: estratégia de sete países. Brasília: ABDI, 2010. p.24-30.

TASH, William. Evaluating research centers and institutes for success! Fredericksburg: WT \& Associates, 2006.

WINARSKI, Tyson. Protecting Electrical Technology through Patents. IEEE Technology and Society Magazine, Wollongong, v. 29, n. 4, p. 20-29, 2010.

WORLD INTELLECTUAL PROPERTY ORGANIZATION. Global Innovation Index 2013: The Local Dynamics of Innovation. Genebra, 2013. Disponível em:<http://www.wipo.int/edocs/pubdocs/en/economics/gii/gii_2013.pdf>. Acesso em: 05 ago. 2015.

WORLD INTELLECTUAL PROPERTY ORGANIZATION. WIPO IP statistics data center: indicator: 5 patent publications by technology, report type: total count by applicant's origin, year range: 2002-2011, origin: Brazil and United States, technology: electrical machinery, apparatus, energy. 2012. Disponível em: < http:// ipstatsdb.wipo.org/ipstatv2/ipstats/patentsSearch>. Acesso em: 14 set. 2014.

WORLD INTELLECTUAL PROPERTY ORGANIZATION. Wipo Overview: 2011 edition. Genebra, 2011. Disponível em: <http://www.wipo.int/export/sites/www/freepublications/en/general/1007/ wipo_pub_1007_2011.pdf>. Acesso em: 14 set. 2014.

WORLD INTELLECTUAL PROPERTY ORGANIZATION. WIPO statistical country profiles: Brazil. Genebra, 2012. Disponível em: <http://www.wipo.int/ipstats/en/statistics/country_profile/countries/ br.html>. Acesso em: 14 set. 2014.

WORLD INTELLECTUAL PROPERTY ORGANIZATION. WIPO statistical country profiles: United States of America. Genebra, 2012. Disponível em: < http://www.wipo.int/ipstats/en/statistics/country_profile/ countries/us.html>. Acesso em: 14 set. 2014. 


\section{REVISTA BRASILEIRA DE POLÍTICAS PÚBLICAS BRAZILIAN JOURNAL OF PUBLIC POLICY}
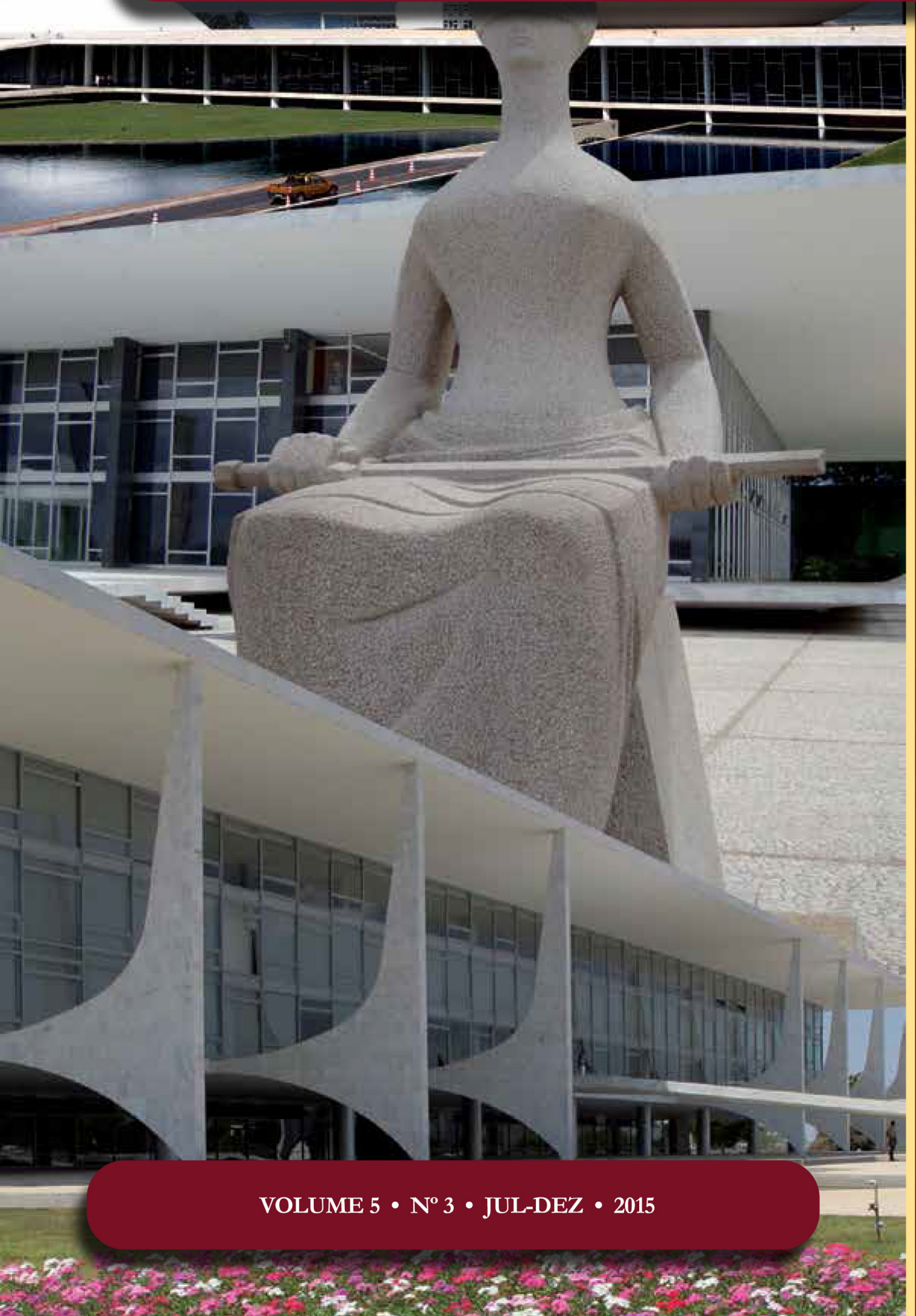

Shango Unchained? State In(Capacity), Urban Bias, and the Power Africa Initiative 


\section{Shango Unchained? State In(Capacity), Urban Bias, and the Power Africa Initiative*}

Tom Brower**

\section{Abstract}

In the midst of an energy crisis, sub-Saharan Africa is a global outlier with respect to power infrastructure and is literally without power. Nearly 600 million Africans - roughly two-thirds of the region-currently lack access to consistent, reliable, and affordable electricity, constituting a significant barrier to economic and social development, the deprivation of a number of socio-economic rights, and a cause of environmental degradation. The Power Africa Initiative, announced in June 2013, seeks to double access to power in sub-Saharan Africa over the next five years through an innovative public-private partnership between United States governmental agencies, private sector energy and infrastructure firms, and six African governments. This paper fills a gap in both the legal and policy literatures by identifying the implementation challenges to Power Africa and the broader theoretical question of the institutional and regulatory obstacles to power sector reform and development in sub-Saharan Africa. Drawing on the political economy and international development literatures, this paper contends that low state capacity and the presence of urban bias in African states represent significant implementation challenges to Power Africa. Specifically, weak and incapacitated state apparatuses and a lack of state autonomy vis-à-vis urban elites have created centralized hybrid power markets and regulatory frameworks that are systematically biased against the extension of electricity into rural areas and have marginalized independent power producers (IPPs) and potential rural consumers. Ultimately, without additional institutional and regulatory reforms, the core goal of Power Africa-rural electrification-will be significantly limited by a lack of commercial sustainability for independent power projects and a lack of consumer affordability to access power.

Keywords: access to electricity, public-private partnership, Power Africa initiative, public policy, public reform

"... And I have to say, those who are involved in this process, they continually tell us the problem is not going to be private-sector financing. The problem is going to be getting the rules right, creating the framework whereby we can build to scale rapidly."

United States President Barack Obama, speaking on electricity access in Africa,

Dar es Salaam, Tanzania, 2013

* Recebido em 02/03/2015 Aprovado em 13/04/2015

** Master of Arts in Political Science, Indiana University (2012). Juris Doctor, University of Virginia School of Law (2015). E-mail: tb2eh@virginia.edu
"There you have it-reforms on unprepared ground, and copied from foreign institutions as well-nothing but harm!"

Fyodor Dostoevsky, The Brothers Karamazov 


\section{INTRODUCTION}

Shango exists in Yoruba ritual thought as the deity of thunder and lightning. Although the patron deity of the Old Oyo Empire was established in the fourteenth century, the potency of the belief in the powers of Shango has continued to present day. A sculpture created in his image stands publicly at the Marina in Lagos, Nigeria, as the symbol of the Power Holding Company of Nigeria, Nigeria's public power utility agency. ${ }^{1}$ Shango would undoubtedly be displeased with the current state of sub-Saharan Africa, as the region is a "global outlier with respect to power infrastructure and is literally without power." The power crisis in sub-Saharan Africa is best conceptualized as a "paradox of plenty."3 Despite being endowed with abundant renewable energy resources, ${ }^{4}$ nearly 600 million people in sub-Saharan Africa-roughly two-thirds of the region-lack access to electricity. ${ }^{5}$ The per capita installed power generation capacity in sub-Saharan Africa is approximately one-third of South Asia's and about one-tenth of Latin America's. ${ }^{6}$ Even compared with other country groups in the same income bracket, sub-Saharan Africa's power generation capacity growth is barely half of that of other developing regions. ${ }^{7}$ Sub-Saharan Africa is the only world region in which per capita consumption of electricity is actually decreasing over time. ${ }^{8}$ Within the region, significant disparities exist between urban and rural access to electricity, with rural electrification rates routinely below $5 \%{ }^{9}$ Despite significant power sector reforms beginning in the 1980 s and the provision of extensive subsidies, electrification rates have not improved, and electrical utilities have operated in a state of persistent dysfunction. ${ }^{10}$ Indeed, access to electricity is a "particularly African problem.."11

In light of the ongoing lack of access to electricity in the region and its significant micro- and macro-economic developmental effects, critics have called for additional reforms to pay explicit attention to institutional and financing mechanisms for increasing access to electricity. ${ }^{12}$ According to the International Energy Agency, sub-Saharan Africa will require more than $\$ 300$ billion in investment to achieve universal electricity

1 See IRELE, Abiola; JEYIFO, Biodun (Ed). The oxford encyclopedia of African thought 334 . Oxford: Oxford University Press, 2010.

2 Anton Eberhard \& Maria Shkaratan, Powering Africa: Meeting the Financing and Reform Challenge, 42 ENERGY POL’Y 9,10 (2012).

3 See generally Terry Lynn Karl, The Paradox of Plenty: Oil Booms and Petro-States (1997) (describing the paradox that countries with natural resource abundances tend to have lower levels of economic growth and worse development outcomes than countries with fewer natural resources).

4 See, e.g., Y. Azoumah et al., Sustainable Electricity Generation for Rural and Peri-Urban Populations of sub-Saharan Africa: the "Flexy-Energy" Concept, 39 Energy Pol’y 131, 132 (2011); Abeeku Brew-Hammond \& Francis Kemausuor, Energy for All in Africa-to be or not to be?!, 1 Current Opinions Envtr. Sustainability 83, 86 (2009), Y.S. Mohammed et al., Status of Renewable Energy Consumption and Developmental Challenges in Sub-Saharan Africa, 27 Renewable \& Sustainably Energy Rev. 453, 45660 (2013); Anton Eberhard et al., Africa’s Power infrastructure: Investment, Integration, Efficiency 1-2, 54 (2011); Uwe Deichman et al., The Economics of Renewable Energy Expansion in Rural Sub-Saharan Africa, 39 EnERgy Pol'y 215, 227 (2011). 5 Int'l Energy Agency (IEA). World Energy Outlook. Available in:

<http://www.worldenergyoutlook.org/resources/energydevelopment/energyaccessdatabase/>. (last visited July 25, 2014) (hereinafter "WEO").

6 EBerhard ET AL., supra note 4, at 2-3.

7 Id. at 3; see generally Tito Yepes et al., Making Sense of Africa's Infrastructure Endowment: A Benchmarking Approach (The World Bank, Policy Research Working Paper No. 4912, 2008).

8 Eberhard et Al., supra note 4, at 6. Notably, sub-Saharan Africa and South Asia were equal in their installed capacities during the 1980s.

9 Theo Chidiezie Chineke \& Fabian M. Ezike, Political Will and Collaboration for Electric Power Reform through Renewable Energy in Africa, 38 Energy PoL'y 678, 683 (2010).

10 See Anton Eberhard et al., Underpowered: The State of the Power Sector in Sub-Sabaran Africa 14-15 (The World Bank, Background Paper No. 6, 2008); Eberhard ET AL., supra note 4, at 79-80, 88-89, 91; Morgan Bazilian et al., Energy Access Scenarios to 2030 for the Power Sector in sub-Saharan Africa, 20 UTIL. PoL'Y 1, 2 (2012).

11 Mimi Alemayehou, Exec. Vice President, Overseas Private Inv. Corp., Testimony before the United States Senate Committee on Foreign Relations at the Hearing on the Power Africa Initiative (Mar. 26, 2014) (hereinafter "OPIC Testimony").

12 See Brew-Hammond \& Kemausuor, supra note 4, at 84; Patricia Nelson, An African Dimension to the Clean Development Mechanism: Finding a Path to Sustainable Development in the Energy Sector, 32 Denv. J. InT'L L. \& POL'y 615, 626 (2004). 
access by $2030 .{ }^{13}$ The Power Africa Initiative (Power Africa or the Initiative), announced in South Africa in June 2013 by President Obama, seeks to double access to power in sub-Saharan Africa by adding more than 10,000 megawatts (MW) of clean, efficient electricity generation capacity over the next five years. ${ }^{14}$ Power Africa aims to extend electrical access to 20 million Africans through an innovative and large-scale public-private partnership that focuses on private sector independent power facilities involving a dozen United States governmental agencies, private sector energy and infrastructure firms, and six African governments.

Testifying before the Senate Foreign Relations Committee's Subcommittee on Africa, Paul Hinks, CEO of Symbion Power and Chairman of the Corporate Council on Africa, noted that " $[t]$ he focus in 2014 should be on addressing some of the significant challenges facing the Power Africa Initiative, in order to pave the way for more private-sector investment in the future." ${ }^{\prime 15}$ Less than a year into Power Africa, African bureaucracies have already been identified as a major obstacle to private sector power investment under Power Africa. ${ }^{16}$ The legal literature has devoted little attention to Power Africa as well as more generally to the issue of electrification and energy generation in sub-Saharan Africa. Although the policy literature has identified a number of institutional and regulatory problems associated with power sectors in sub-Saharan Africa, little attention has been paid to why these obstacles persist.

This paper addresses both the existing gap within the literature on the implementation challenges to Power Africa and the broader theoretical question of the institutional and regulatory obstacles to power sector reform and development in sub-Saharan Africa. Drawing on the political economy and international development literatures, I contend that low state capacity and the presence of urban bias in African states represent significant implementation challenges to Power Africa. Specifically, weak and incapacitated state apparatuses and a lack of autonomy vis-à-vis urban elites have created centralized hybrid power markets and regulatory frameworks that are systematically biased against the extension of electricity into rural areas and have marginalized independent power producers (IPPs) and potential rural consumers. Accordingly, this paper makes two important contributions to the literature by filling an empirical gap through an analysis of the implementation challenges of Power Africa and electrification reform in sub-Saharan Africa, and by introducing a multi-disciplinary theoretical framework to explain the creation of a legal and regulatory framework that is a considerable obstacle to the implementation of Power Africa and power sector reform more broadly.

This paper is organized as follows. Section II provides a background to the power crisis in sub-Saharan Africa and the motivation for Power Africa by reviewing the literature on energy and electrical infrastructure as inputs for economic, environmental, and social development and as a human right. Section III outlines Power Africa and identifies its key actors, goals, and policy mechanisms. Section IV develops a theoretical framework of state capacity and urban bias as causal mechanisms for the creation of hybrid power markets and regulatory frameworks that marginalize IPPs and deter the extension of electrical access to rural areas. Three empirical sections follow. Section V links issues of state capacity and urban bias to the institutional structures of the power sectors and electrical markets in sub-Saharan Africa. Section VI introduces princi-

13 See The White House, Fact Sheet: Power Africa (June 30, 2013), Available in: <http://www.whitehouse.gov/the-press-office/2013/06/30/fact-sheet-power-africa>; EBERHARD ET AL., supra note 4, at 149.

14 U.S. Agency for Int'l Dev. (USAID), Power Africa. Available in: < http://www.usaid.gov/powerafrica> (last visited July 25, 2014).

15 Paul Hinks, Chief Exec. Officer of Symbion Power, Testimony before the United States Senate Committee on Foreign Relations at the Hearing on the Power Africa Initiative (Mar. 26, 2014) (hereinafter "Hinks Testimony").

16 See e.g., Immaculate Karambu, Bureaucracy Frustrating the Work of Power Agency, Daily Nation (Mar. 22, 2014). Available in: <http://www.nation.co.ke/business/Bureaucracy-frustrating-the-work-of-power-agency-/-/996/2254042/-/51jfee/-/index. html > (noting that Earl Gast, USAID's Assistant Administrator for Africa, declared that the pace of private sector investment has been hurt by an unfriendly regulatory environment); Power Africa: Market Reactions to the Obama Initiative, ProjeCt FinANCE NEwswire (Chadbourne \& Parke LLP), Dec. 2013, at 32 (noting that Paul Hinks believes that the big challenge of Power Africa is navigating the bureaucracies of many African countries); Hinks Testimony, supra note 15 (noting the creditworthiness of the power off-taker as a serious concern). 
ples and models of federalism to understand how the centralization of electricity infrastructure deters further rural electrification. Section VII extends this theoretical framework to the regulatory sphere, contending that the existence of urban bias foments a regulatory framework for power that limits the commercial sustainability of private sector power projects and limits rural electrification. Section VIII concludes and offers policy recommendations and implications for future research.

\section{Empowering deVelopment: the impetus for power Africa}

This section identifies the impetus for and importance of the Power Africa Initiative. First, context and background to sub-Saharan Africa's energy crisis is provided, describing both regional trends in a lack of access to electricity and low installation capacity as well as staggering intra-regional differences in access between urban and rural areas. Second, a review of the literature clearly indicates the importance of consistent access to electricity with respect to economic, environmental, and social development, particularly through the mechanisms of macroeconomic growth, firm productivity, improvements to human capital stocks and labor productivities, and lower levels of deforestation and greenhouse gas emissions. Additionally, the human rights literature emphasizes the importance of access to electricity as being integral to the realization of a number of existing socio-economic rights, specifically rights to gender equality and the right to adequate housing.

\section{Shango in chains: the current state of african power}

Crisis and paradox best characterize the state of power infrastructure in sub-Saharan Africa. Nearly half of the 1.2 billion people globally without access to electricity reside in sub-Saharan Africa. ${ }^{17}$ Only $32 \%$ of sub-Saharan Africans have access to electricity, and $79 \%$ still rely on traditional use of biomass for cooking, establishing it as the most power-impoverished region in the world. ${ }^{18}$ By comparison, access to electricity is 65\% in South Asia, ${ }^{19} 90 \%$ in East Asia, ${ }^{20}$ and 95\% in Latin America. ${ }^{21}$ Additionally, sub-Saharan Africa has the lowest power generation capacity of any world region, and capacity growth has stagnated relative to other developing regions. ${ }^{22}$ The combined power generation capacity of sub-Saharan Africa is sixty-eight gigawatts (GW), the equivalent of Spain. ${ }^{23}$ If South Africa is excluded, the total falls to twenty-eight GW, the equivalent of Argentina. ${ }^{24}$ Even this data may be an overstatement because as much as $25 \%$ of installed capacity is operational due to aging power plants and a lack of maintenance. ${ }^{25}$

To paint an even dimmer picture, the lack of access to electricity is significantly disparate between urban and rural areas. ${ }^{26}$ Approximately $60 \%$ of urban populations have access to electricity compared to less than

17 WEO, supra note 5.

18 Id. For citations of similar statistics, see Bazilian et al., supra note 10, at 4; Brew-Hammond \& Kemasuor, supra note 4, at 83; Raffaella Centurelli, Energy Poverty: Can we Make Modern Energy Access Universal? Focus on Financing Appropriate Sustainable Energy Technologies, 22 Colo. J. Int’l Envtl. L. \& Pol’y 219, 221 (2011); Youba Sokona et al., Widening Energy Access in Africa: Towards Energy Transition, 47 EnERgy Pol'y 3, 7 (2012); Eberhard ET AL., supra note 4, at 5.

19 EBERHARD ET AL., supra note 4, at 5.

20 Id.

21 WEO, supra note 5.

22 See Eberhard ET AL., supra note 4, at 1; Sokona et al., supra note 18, at 7.

23 EBerhard ET AL., supra note 4, at at 2.

24 Id.

25 Id.

26 See Abeeku Brew-Hammond, Energy Access in Africa: Challenges Ahead, 38 Energy Pol'y 2291, 2293 (2010); Charles Mooga Haanyika, Rural Electrification Policy and Institutional Linkages, 34 Energy Pol’y 2977, 2977 (2006); Stephen Karekezi \& John Kimani, Status of Power Sector Reform in Africa: Impact on the Poor, 30 ENERGy POL'y 923, 924 (2002). 
$15 \%$ of rural populations in sub-Saharan Africa. ${ }^{27}$ Rural electrification levels routinely fall below $5 \% .{ }^{28}$ Compared to the rest of the world, there are both lower levels of access in absolute terms as well as higher levels of urban-rural disparity. ${ }^{29}$ Consistent with this urban-rural disparity, access to electricity varies significantly based on income. ${ }^{30}$ Only $4 \%$ of the lowest income quintile has access to electricity compared to $74 \%$ of the highest income quintile in sub-Saharan Africa. ${ }^{31}$

In addition to a dearth of access, sub-Saharan Africa's power infrastructure is (in)famously unreliable, as national electricity grids are "generally bedeviled with intermittent power supply and sometimes power rationing." ${ }^{32}$ Manufacturing enterprises experience power outages of fifty-six days per year on average. ${ }^{33}$ For instance, according to World Bank enterprise survey data, firms in Senegal, Tanzania, and Burundi experienced power outages for an average of 45, 63, and 144 days, respectively. ${ }^{34}$ By comparison, a typical power security standard in the United States is one day in ten years. ${ }^{35}$

Unfortunately, the power crisis in sub-Saharan Africa is a worsening problem. Drought has seriously reduced the power available to countries with significant hydropower installments and that are dependent on water as an input to power production. ${ }^{36}$ High and volatile international oil prices have put pressure on oil-importing countries, especially those dependent on diesel and heavy fuel oil for power generation. ${ }^{37}$ Military conflict has severely damaged or destroyed much of the infrastructure in a number of countries, including the Central African Republic, Liberia, Sierra Leone, and Somalia. ${ }^{38}$ With a business as usual approach, $40 \%$ of African countries will not reach the goal of universal access to electricity by $2050 .{ }^{39}$ Sub-Saharan Africa is the only region in which per capita consumption of electricity is dropping over time. ${ }^{40}$ Projecting present electrification rates and population growths, more people in sub-Saharan Africa will be without electricity in 2030 than today. ${ }^{41}$

The paradoxical part of sub-Saharan Africa's power crisis is the significant natural resource endowments that can fuel electric power generation. ${ }^{42}$ Specifically, the literature has focused on the renewable energy potential that is many times the current energy consumption of African states. ${ }^{43}$ Sub-Saharan Africa has sig-

27 Raluca Golumbeanu \& Douglas Barnes, Connection Charges and Electricity Access in Sub-Sabaran Africa 3-4 (The World Bank, Policy Research Working Paper No. 6511, 2013).

28 Chineke \& Ezike, supra note 9, at 683.

29 See Golumbeanu \& Barnes, supra note 27, at 3-4.

30 A. Estache, What do we know about Sub-Saharan Africa's Infrastructure and the Impact on its 1990s Reforms? 33, 40 (The World Bank, Draft Working Paper, 2005).

31 Gisela Prasad, Improving Access to Energy in sub-Saharan Africa, 3 Current Opinions Envtl. Sustainability 248, 249 (2011).

32 Brew-Hammond \& Kemausuor, supra note 4, at 83. See also Eberhard et al., supra note 10, at v, 10-11; EBERHARD ET AL., supra note 4 , at $7-8$.

33 Eberhard et al., supra note 10, at v, 4.

34 EBERHARD ET AL., supra note 4, at 7.

35 Eberhard et al., supra note 10, at v-vi.

36 See Eberhard Et AL., supra note 4, at 12; Eberhard et al., supra note 10, at 13.

37 See id.

38 See Eberhard ET AL., supra note 4, at 12; Eberhard et al., supra note 10, at 13.

39 Golumbeanu \& Barnes, supra note 4, at 4.

40 See EBERHARD ET AL., supra note 4, at 6; Eberhard \& Shkaratan, supra note 2, at 9.

41 Prasad, supra note 31, at 248.

42 See Katharine Gratwick \& Anton Eberhard, An Analysis of Independent Power Projects in Africa: Understanding Development and Investment Outcomes 16 (Mgmt. Program in Infrastructure Reform \& Reg., Working Paper, 2007); EBERHARD ET AL., supra note 4, at 2.

43 See Deichman et al., supra note 4, at 2. 
nificant hydro, ${ }^{44}$ biomass ${ }^{45}$ solar, ${ }^{46}$ geothermal, ${ }^{47}$ and wind resources.${ }^{48}$ For instance, Namibia has an annual potential production of 100 times its current energy consumption, a statistic more driven by high potential production than low consumption. ${ }^{49}$ Median countries, such as Senegal, Sierra Leone, and Benin, have a production capacity of ten-to-twelve times current consumption. ${ }^{50}$ These resources are particularly valuable due to the increasing premium commanded by zero- or low-carbon renewable energies based on their abilities to reduce global greenhouse gas emissions and the cost volatility and geopolitical issues associated with fossil fuels. ${ }^{51}$

\section{Economic, environmental, and social development}

Energy poverty, defined as the "absence of sufficient choice in accessing adequate, affordable, reliable, high quality, safe, and environmentally benign energy services to support economic and human development", ${ }^{2}$ has serious implications for development on both positive economic and normative grounds. Not only does a lack of access to electricity have significant effects on the economic and social development of individuals, households, and businesses, it also undermines the enjoyment of a wide range of human rights, particularly those relating to the improvement of living standards. ${ }^{53}$ It also has significant environmental implications pertaining to forest management and greenhouse gas emissions, critical components of climate change. Over the past twenty years, there has been an abundant and growing literature that has focused on the positive effects of energy and energy infrastructure on economic growth and development. ${ }^{54}$ Although energy has no intrinsic value, access to the products and lifestyle changes that the availability of adequate modern energy services provides has established energy as one of the "essential inputs for socioeconomic development." ${ }^{\prime 5}$ The most evident link between energy infrastructure and income is the productivity effect in a production function framework where an increase in the quantity of infrastructure raises the marginal productivity of other factors. ${ }^{56}$

The literature identifies electrical energy and electric power infrastructure as particularly significant to economic growth and development. Underinvestment in electricity and weak energy infrastructures have caused poor economic performance and constrain future development in sub-Saharan Africa. ${ }^{57}$ Calderón

44 See Azoumah, supra note 4, at 132; Brew-Hammond \& Kemausuor, supra note 4, at 86; Mohammed et al., supra note 4, at 45960; EBERHARD ET AL., supra note 4, at 2.

45 See Brew-Hammond \& Kemausuor, supra note 4, at 86; Mohammed et al., supra note 4, at 456-58; Azoumah et al., supra note 4 , at 132.

46 See Azoumah, supra note 4, at 132; Brew-Hammond \& Kemausuor, supra note 4, at 86; Chineke \& Ezike, supra note 9, at 679; Mohammed et al., supra note 4, at 458-59; EBERHARD ET AL., supra note 4, at 2.

47 See Brew-Hammond \& Kemausuor, supra note 4, at 86; Mohammed et al., supra note 4, at 460; EBERHARD ET AL., supra note 4, at 2 .

48 See Azoumah et al., supra note 4, at 132; Brew-Hammond \& Kemausuor, supra note 4, at 86; EBERHARD ET AL., supra note 4, at 2.

49 Deichman et al., supra note 4, at 2.

$50 \quad I d$.

51 See id.; Sokona et al., supra note 18, at 6.

52 Amulya K.N. Reddy, Energy and Social Issues, in United Nations Development Program, World Energy Assessment: Energy \& The Challenge of Sustainability 44 (2000). Available at: <www.undp.org/energy/activities/wea/drafts-frame.html>.

53 See Jenny Sin-hang Ngai, Energy as a Human Right in Armed Conflict: A Question of Universal Need, Survival, and Human Dignity, 37 Brook. J. INT'L L. 579, 581 (2012).

54 See, e.g., Sokona et al., supra note 18, at 3 (collecting literature); Smail Khennas, Understanding the Political Economy and Key Drivers of Energy Access in Addressing National Energy Access Priorities and Policies: African Perspective, 47 EnERgy POL'y 21, 21 (2012); Mohammed et al., supra note 4, at 453, 455; Vivien Foster \& Jevgenijs Steinbucks, Paying the Price for Unreliable Power Supplies: In-House Generation of Electricity by Firms in Africa 2 (The World Bank, Policy Research Working Paper No. 4913, 2009).

55 Brew-Hammond, supra note 26, at 2291; see also Adrian J. Bradbrook et al., A Human Dimension to the Energy Debate: Access to Modern Energy Services, 26 J. Energy \& NAt. Resources L. 526, 529 (2008) (emphasizing energy services).

56 See Paul Cook, Infrastructure, Rural Electrification, and Development, 15 EnERGY FOR SuSTAINABLE Dev. 304, 305 (2011); Stephen R. Tully, The Contribution of Human Rights to Universal Energy Access, 4 Nw. U. J. InT'L Hum. RTs. 518, 519 (2006). But see Cook, supra note 56, at 306; Deichman et al., supra note 4, at 5 (noting an endogeneity issue).

57 See, e.g., H. Esfahani \& M. Ramirez, Institutions, Infrastructure, and Economic Growth, 70 J. Dev. Econ. 443, 443 (2010). 
finds that if African countries were to catch up with the regional leader, Mauritius, in terms of infrastructure stock and quality, their per capita economic growth rates would increase by an average of $2.2 \%$ per year. ${ }^{58}$ Catching up with the East Asian median country, the Republic of Korea, would bring gains of 2.6\% per year. ${ }^{59}$ Indeed, in sub-Saharan Africa, "the most expensive electricity is no electricity at all."

In addition to productivity increases, access to electricity helps address a plethora of social development goals and helps to build and develop human capital. ${ }^{61}$ Myriad improvements to health outcomes are attributable to access to electricity. ${ }^{62}$ Access to modern forms of energy is essential for the provision of clean water and sanitation. ${ }^{63} \mathrm{~A}$ reduction in the use of biomass for heating and cooking reduces the incidences of eye problems, burns, respiratory illnesses, and cancer associated with combustion of these materials. ${ }^{64}$ Electricity addresses the incidences of HIV/AIDS, malaria, and other diseases by improving the healthcare infrastructure by enabling health clinics and hospitals to refrigerate vaccines, boil water, sterilize equipment, incinerate used syringes, provide light, and transport patients. ${ }^{65}$ Greater access to electricity has been also linked to better educational outcomes such as literacy rates and primary school completion rates. ${ }^{66}$ Higher quality lighting allows for more time for reading and studying in the absence of sunlight. ${ }^{67}$ Additionally, the task of collecting fuel for traditional biomass energy sources or hauling water are time consuming processes that come with a high opportunity cost; access to electricity allows children to greatly reduce or eliminate such chores and spend more time attending school. ${ }^{68}$

Reliance on traditional biomass also has significant and deleterious effects on the environment, particularly when wood and charcoal are used as fuels. Fuel wood collection is a core cause of tropical deforestation. ${ }^{69}$ A number of negative environmental externalities are associated with deforestation, including soil salinization, desertification, and a loss of biological diversity. ${ }^{70}$ Forests play a critical role in climate change by absorbing carbon dioxide; thus, poor forest management in order to support the charcoal industry runs counter to the reducing emissions from deforestation and forest degradation (REDD) mechanism of the United Nations Framework Convention on Climate Change. ${ }^{71}$ Additionally, because of inefficient technology, the incomplete combustion of traditional biomass releases methane, a more potent greenhouse gas than carbon dioxide. $^{72}$ The use of traditional and unsustainable biomass cooking energy fuels has significantly higher greenhouse gas emissions compared to liquefied petroleum gas and biogas. ${ }^{73}$

58 Cesar Calderón, Infrastructure and Growth in Africa iv (The World Bank, Working Paper No. 3, 2008).

59 Id.

60 Bernard Tenenbaum et al., From the Bottom Up: How Small Power Producers and Mini-Grids Can Deliver Electrification and Renewable Energy in Africa 239 (2014).

61 See Stephen Tully, Access to Electricity as a Human Right, 24 Netн. Q. Hum. Rts. 557, 560, 567 (2006); Bas J. van Ruijven et al., Model-based Scenarios for Rural Electrification in Developing Countries, 38 ENERGy 386, 386-87; Haanyika, supra note 26 , at 2977.

62 See Golumbeanu \& Barnes, supra note 27, at 4.

63 See Centurelli, supra note 18, at 222; Tully, supra note 56, at 520.

64 See Jennifer N. Brass et al., Power for Development: A Review of Distributed Generation Projects in the Developing World, 37 AnN. Rev. ENV'T \& Resources 107, 117 (2012); Centurelli, supra note 18, at 225-26.

65 Tully, supra note 56, at 52.

66 See EBERHARD ET AL., supra note 4, at 16, 119 (collecting literature).

67 See Brass et al., supra note 64, at 116, 118; Adrian Bradbrook \& Judith G. Gardam, Placing Access to Energy Services within a Human Rights Framework, 28 Hum. RTs. Q. 389, 395 (2006).

68 Golumbeanu \& Barnes, supra note 27, at 4; Bradbrook \& Gardam, supra note 67, at 395; Tully, supra note 56, at 520; Centurelli, supra note 18, at 227. See also infra notes 100-1.

69 Nogoye Thiam, Towards a Sustainable Energy System for Africa: An African Perspective on Energy Security, in Facing GLOBAL Environmental Change 448 (Hans Günter Brauch et al., eds. 2009).

70 See id.; Nicasius Achu Check, Climate Change and Water Degradation, in Africa in a Changing Global Environment: Perspectives on Climate Change Adaptation and Mitigation Strategies in Africa 14 (Shingirirai Savious Mutanga et al., eds. 2013).

71 See Shakespear Mudombi, Exploring the Challenges and Opportunities for Low Carbon Climate Resilient Development in Africa, in AFrICA in a Changing Global Environment: Perspectives on Climate Change Adaptation and Mitigation Strategies in Africa 154 (Shingirirai Savious Mutanga et al., eds. 2013).

72 Global Energy Assessment, Global Energy Assessment: Toward a Sustainable Future 183 (2012).

73 Id. 
Energy poverty has a disproportionate effect on women, as they are often responsible for collecting firewood, hauling water, and cooking. ${ }^{74}$ As the first female President of an African state, Liberian President Ellen-Johnson Sirleaf, noted,

I'm particularly concerned about the disproportionate impact energy poverty has on women and girls. In many places without power, women and girls are forced to spend hours each day in the time-consuming task of hunting for fuel and firewood_-often a key reason that girls spend less time in school than boys. Women are also disproportionately affected by respiratory illness as a result of indoor air pollution from open fires and kerosene used for cooking, heating, and lighting. Even the simple act of being outdoors becomes fraught with danger for women and girls in some places when the sun goes down and there are no streetlights. ${ }^{75}$

Accordingly, the economic and social benefits of access to electricity provide the greatest private return to women. ${ }^{76}$ There is strong empirical support linking access to electricity with improvements to female labor outcomes ${ }^{77}$ and service-provision, particularly maternal health. ${ }^{78}$

At the firm level, the notorious unreliability ${ }^{79}$ of electricity and the prevalence of outages in the region represent significant welfare losses. ${ }^{80}$ Frequent power outages result in significant losses in terms of foregone sales and damaged equipment. Firms experiencing frequent power outages, defined as more than sixty days per year, lose $10-12 \%$ of their sales, twice as much as firms that have fewer than fifteen outages per year. ${ }^{81}$ Equipment damage traceable to power outages is about twice as high for firms that suffer frequent outages as for firms that suffer few outages. ${ }^{82}$ Loses due to power outages are equivalent to $6 \%$ of turnover on average for firms in the former sector and as much as $16 \%$ of turnover for informal sector enterprises that lack backup generators. ${ }^{83}$

These costs have significant implications for international investment and business development. In most countries in sub-Saharan Africa, infrastructure accounts for 30-60\% of the effect of investment climate on firm productivity. ${ }^{84}$ In half of the countries analyzed, the power sector accounted for $40-80 \%$ of the infrastructure effect. ${ }^{85}$ According to the World Bank, over half of firms in Africa identify poor availability of electricity as a major constraint for doing business. ${ }^{86}$ Ultimately, the extension and provision of reliable electricity serves as a catalyst for increased firm productivity and gross revenue gains. ${ }^{87}$

\section{Powering human rights}

With a more normative focus, the literature has also advocated that access to reliable, sustainable, and affordable electricity be provided as public good as well as conceptualized and incorporated into the human

74 See Ngai, supra note 53, at 581-82; Tully, supra note 56, at 538-39.

75 Ellen-Johnson Sirleaf, Let's Power Africa, Foreign Policy (Aug. 29, 2013), Available in:<http://www.foreignpolicy.com/articles/2013/08/29/let_s_power_africa_ellen_johnson_sirleaf_liberia_energy >.

76 See Chineke \& Ezike, supra note 9, at 683; Brass et al., supra note 64, at 117.

77 See, e.g., Taryn Dinkelman, The Effects of Rural Electrification on Employment: New Evidence from South Africa, 101 Am. EcON. REv. 3078, 3078 (2011).

78 See, e.g., D. Claus, Involving the User: Community Based Management of Solar Home Systems in Indonesia, 2 Refocus 18, 18; Tully, supra note 56 , at 551 .

79 See supra notes 32-35.

80 See Foster \& Steinbucks, supra note 54, at 2; Golumbeanu \& Barnes, supra note 27, at 4.

81 Foster \& Steinbucks, supra note 54, at 13.

82 Id.

83 EBERHARD ET AL., supra note 4, at 7.

84 Id. at $17-18$.

85 Id.

86 Sokona et al., supra note 18 , at 7.

87 See generally C. Kirubi et al., Community-based Electric Micro Grids can Contribute to Rural Development: Evidence from Kenya, 37 WorLD Dev. 1208 (2009). But see Brass et al., supra note 64, at 117 (gathering literature that is skeptical of the relationship between distributed generation provision and new economic opportunities). 
rights framework. ${ }^{88}$ By conceptualizing access to electricity as a human right, pressure could be brought to bear at the national and international level for recognition of access to energy services as integral to the realization of the vast bulk of existing socio-economic rights. ${ }^{89}$ Several states have recognized that electricity access may qualify as a human right. For example, French legislation "contributes to social cohesion by satisfying everyone's right to electricity." South African law imposes duties upon electricity service providers to supply electricity "to every applicant who is in a position to make satisfactory arrangements for payment." 91 This obligation has been interpreted to mean that applicants enjoy a prima facie right entitling them to demand electricity once they have satisfied such supply conditions. ${ }^{92}$

Although the major human rights instruments are silent on the point of access to electricity, the literature argues that it is an implicit attribute of a number of human rights, including non-discrimination, adequate living standards, housing, health, and sustainable development. ${ }^{93}$ This line of argument draws from the International Covenant on Economic, Social and Cultural Rights (ICESCR), which requires that party states "recognize the right of everyone to an adequate standard of living . . . including adequate food, clothing and housing, and to the continuous improvement of living conditions" $" 94$ and the Universal Declaration of Human Rights, which contains an identical list. ${ }^{95}$ The Committee on Economic, Social and Cultural Rights (CESCR), responsible for overseeing the implementation of the ICESCR, expects party states to periodically submit information on household amenities such as heating and electricity. ${ }^{96}$ Within this framework, electricity is principally considered under the right to adequate housing. ${ }^{97}$ For instance, the Special Rapporteur on adequate housing has construed his mandate broadly such that this right includes access to essential civic services such as electricity. ${ }^{98}$ Furthermore, at the national level, the South African Constitutional Court concluded that the right to adequate housing includes "access to services such as water, sewage, electricity and roads." 99

Additionally, access to electricity has been explicitly recognized in the context of eliminating discrimination against women. ${ }^{100}$ Article 14(2)(h) of the Convention on the Elimination of All Forms of Discrimination Against Women (CEDAW) are obligated to "take all appropriate measures to eliminate discrimination against women in rural areas ... and, in particular, shall ensure to such women the right ... to enjoy adequate living conditions, particularly in relation to housing, sanitation, electricity and water supply, transport and communications." 101 Ultimately, given the exigency of energy poverty in sub-Saharan Africa, the positive economic and normative arguments in support of access to electricity, and the lack of initial reform success, developing a new approach to power sector reform is indeed a critical development objective.

88 See Brew-Hammond \& Kemausuor, supra note 4, at 83; Tully, supra note 56, at 518; Tully, supra note 61, at 557; Stephen Tully, The Human Right to Access Electricity, 19 Electricity J., no. 3, 2006, at 30-31; Ngai, supra note 53, at 526.

89 Bradbrook et al., supra note 55, at 529.

90 Electricity Act, art. 1 (2000) (Fr.).

91 Electricity Act 41 of 1987 \$10(1) (1987) (S. Afr.).

92 Tully, supra note 56, at 545 (citing Meyer v Moqbaka Local Municipality, Case No 4008/2003, 24 (S. Afr. High Ct., Orange Free State Provincial Div.) (unreported per Rampai, J.)).

93 Ngai, supra note 54, at 606; Stephen Tully, The Human Right to Access Clean Energy, 3 J. Green Building 140 (2008); Bradbrook \& Gardam, supra note 67, at 405; Tully, supra note 88, at 30, 38.

94 Int'l Covenant on Econ., Soc. \& Cultural Rights, art. 11(1), 993 UNTS 3 (adopted Dec. 16, 1966 and entered into force Jan. 3, 1976).

95 Universal Declaration of Human Rights, art. 25.

96 Committee on Economic, Social and Cultural Rights, Revised General Guidelines Regarding the Form and Contents of Reports to be Submitted by States Parties under Articles 16 and 17 of the ICESCR, I 3, U.N. Doc. E/C.12/1991/1 (June 17, 1991).

97 U.N. Comm. on Econ., Soc. and Cultural Rights (CESCR), General Comment No. 4 on the Right to Adequate Housing Contained in Art XI(1) of the ICESCR, ๆ 8(b), U.N. Doc. E/1992/23 (Dec. 13, 1991).

98 U.N. Commission on Human Rights, Report of the Special Rapporteur on adequate housing as a component of the right to an adequate standard of living, $\uparrow \uparrow$ 35, 46(b), U.N. Doc. E/CN.4/2002/59 (Mar. 1, 2002) (prepared by Miloon Kothari).

99 Gov't of the Republic of S. Afr. v. Grootboom, 2001 (1) SA 46 (CC), 137 (S. Afr.).

100 See Tully, supra note 88, at 38; Ngai, supra note 53, at 606; Lisa R. Pruitt, Deconstructing CEDAW's Article 14: Naming and Explaining Rural Difference, 17 Wм. \& Mary J. Women \& L. 347, 359-60 (2011); Bradbrook et al., supra note 55, at 536-37.

101 Convention on the Elimination of All Forms of Discrimination Against Women, art. 14(2)(h), G.A. Res. 34/180, U.N. GAOR Supp. No. 46, 193, U.N. Doc. A/34/46 (adopted Dec. 18, 1979 and entered into force Sept. 3, 1981). 


\section{The Power Africa Initiative}

President Obama unveiled the Power Africa Initiative on June 30, 2013 in Cape Town, South Africa. ${ }^{102}$ Power Africa seeks to double access to power in sub-Saharan Africa by adding more than 10,000 MW of clean, efficient electricity generation capacity over the next five years. ${ }^{103}$ Drawing on the considerable energy resources of the region, Power Africa seeks to unlock the substantial wind, solar, hydropower, natural gas, and geothermal resources in the region through expanding mini-grid and off-grid solutions, and building out power generation, transmission, and distribution structures. ${ }^{104}$ Accordingly, Power Africa aims to make electricity access available for 20 million people and commercial entities. ${ }^{105}$ In the first phase, Power Africa will partner with six nations: Ethiopia, Ghana, Kenya, Liberia, Nigeria, and Tanzania, the so-called "Power Six". ${ }^{106}$ These countries were selected because they have set ambitious goals in electric power generation, and are making utility and energy sector reforms to pave the way for investment and growth. ${ }^{107}$ Power Africa will also partner with Uganda and Mozambique on responsible oil and gas resources management. ${ }^{108}$ Thus, Power Africa confers a number of environmental benefits by not only moving the region away from traditional biomass that results in deforestation and higher emissions of greenhouse gases, ${ }^{109}$ but also by leveraging the region's copious renewable energy resources that have a considerably lower carbon footprint.

Power Africa stands out as a truly unique and innovative development program due to the leveraging of public, private, and multilateral actors, in addition to an emphasis on collaboration with African governments. The regional headquarters of Power Africa is Nairobi, Kenya, making Power Africa the first Presidential Initiative ever to be based outside the United States. ${ }^{110}$ Over the next five years, the United States plans to direct up to $\$ 7$ billion in government resources; this commitment has already been over-fulfilled with approximately $\$ 7.8$ billion in funding commitments declared by five federal agencies. ${ }^{111}$ The lion's share of the governmental resources will be administered through the Export-Import Bank of the United States (EXIM) to support American exports for the development of power projects. ${ }^{112}$ EXIM's specific mandate in sub-Saharan Africa is to support American job growth by providing American companies with collateral for loans in areas too risky to otherwise operate through two main financial instruments: direct loans and 100\% loan guarantees. ${ }^{113}$ The Overseas Private Investment Corporation (OPIC), the United States Government's development finance institution, has pledged $\$ 1.5$ billion to finance and insure African energy projects. ${ }^{114}$

102 See The White House, supra note 13; USAID, supra note 14; David Nakamura, In Cape Town Speech, Obama to Announce 'Power Africa' Program, WAsh. Post (June 30, 2013, 6:13 A.M.), Available in: <http://www.washingtonpost.com/blogs/post-politics/ wp/2013/06/30/obama-to-announce-electrical-access-program-for-africa/>.

103 See USAID, supra note 14; Morgan Bazilian \& Roger Pielke, Jr., Making Energy Access Meaningful, Issues Sci. \& Tech., Summer 2013, at 77.

104 See USAID, supra note 14; Shamarukh Mohiuddin, Expanding the Role of Microfinance in Promoting Renewable Energy Access in Developing Countries, 11 Geo. Pub. Pol’y Rev. 119, 120 (2005) (noting the synergy between renewable energies and mini-grid and off-grid technologies).

105 See USAID, supra note 14; The White House, supra note 13.

106 See The White House, supra note 13; Tony O. Elumelu, Chairman of Heirs Holdings \& the Tony Elumelu Found., Testimony before the United States Senate Committee on Foreign Relations at the Hearing on the Power Africa Initiative (Mar. 26, 2014).

107 See The White House, supra note 13; Paul Hinks, Chief Exec. Officer of Symbion Power, Comments at Chadborne \& Parke's Fourth Annual Focus on Emerging Markets Conference (Mar. 20, 2014) (hereinafter "Chadbourne Conference”).

108 See The White House, supra note 13.

109 See supra notes 69-73.

110 See Earl Gast, Assistant Adm'r for Afr., U.S. Agency for Int'l Dev., Testimony before the United States Senate Committee on Foreign Relations at the Hearing on the Power Africa Initiative (Mar. 26, 2014) (hereinafter "USAID Testimony"); Yvone Kawira, Nairobi to Host US's Power Africa Project, Daily Nation (Nov. 20, 2013), http://mobile.nation.co.ke/business/Nairobi-to-host-USPower-Africa-project/-/1950106/2081840/-/format/xhtml/-/13kv0m3/-/index.html; Chadbourne Conference, supra note 107.

111 See Kenneth W. Hansen \& Rachel Rosenfeld, Powering Africa, Project Finance Newswire (Chadbourne \& Parke LLP), Aug. 2013, at 8 .

112 See Chadbourne Conference, supra note 107.

113 See id.

114 OPIC Testimony, supra note 11. 
OPIC already has a pipeline of African electricity projects that, if fully committed, would surpass their commitment. ${ }^{115}$ The Millennium Challenge Corporation (MCC) has committed $\$ 1$ billion through its country compacts to encourage new power generation, transmission, and distribution projects. ${ }^{116} \mathrm{MCC}$ will also invest in energy infrastructure, policy and regulatory reforms and host government capacity building. ${ }^{117}$ The United States Agency for International Development (USAID) has pledged $\$ 285$ million to be focused on technical assistance and risk mitigation through mechanisms such as country-specific transaction advisers, as well as encouraging private sector transactions through direct grant financing and loan guarantees through their Development Credit Authority. ${ }^{118}$ OPIC and the United States Trade and Development Agency (USTDA) jointly committed to make available up to $\$ 20$ million in project preparation, feasibility study, and technical assistance grants to support the development of renewable energy projects. ${ }^{119}$ Lastly, the United States African Development Foundation has launched a $\$ 2$ million Off-Grid Energy Challenge to provide grants of up to $\$ 100,000$ to African-owned enterprises. ${ }^{120}$

The private sector focus has distinguished Power Africa as a new model for development in action. ${ }^{121}$ At the time of this paper, the private sector founding partners have pledged to develop nearly ten GW of critical generation projects in five of the Power Africa countries, resulting in over $\$ 14.7$ billion in investment in these countries' power sectors. ${ }^{122}$ Private sector partners are also focused on mini-grid and distributed power services and infrastructure. Commitments sum to 700,000 new households and businesses served and over $\$ 1.1$ billion in investment. ${ }^{123}$ This emphasis on IPPs constitutes an important form of private sector participation in Africa's power sector. With demand outstripping supply in many African countries, independent power projects are becoming a major source of new power generation capacity in these countries. ${ }^{124}$ Additionally, participation of the private sector is important when electrifying remote villages, particularly with stand-alone systems. ${ }^{125}$

Accordingly, the United States has a keen economic interest in Power Africa, namely, that many of the sponsors and developers of these energy and power projects are American companies. Several United States governmental agencies with significant involvement in Power Africa have institutional mandates to specifically support American companies. ${ }^{126}$ Thus, while altruism and developmental goals are important, the potential for successful implementation increases due to the economic stake of American business in Power Africa. However, given the high level of American involvement through a predominantly free-market, private-sector driven approach, Power Africa could simply resemble another example of the broader neoliberal development paradigm that has been critiqued as benefiting developed nations at the expense of developing nations. ${ }^{127}$ For instance, Power Africa has already been criticized for being a mechanism to "grease up" billions of dollars worth of deals for American corporations, such as General Electric. ${ }^{128}$

115 Id.

116 See Hansen \& Rosenfeld, supra note 111, at 9.

117 Id.

118 See Chadbourne Conference, supra note 107.

119 See Hansen \& Rosenfeld, supra note 111, at 9.

120 Id.

121 See USAID Testimony, supra note 110; Chadbourne Conference, supra note 107.

122 U.S. Agency for Int'l Dev., Private Sector. Available in: <http://www.usaid.gov/powerafrica/partners/private-sector>. (last visited July 25, 2014).

123 Id.

124 Karekezi \& Kimani, supra note 26, at 927.

125 Id. See also Int'l Energy Agency (IEA), Comparative Study on Rural Electrification Policies in Emerging Economies 100 (2010).

126 See supra notes 112-14. For instance, the OPIC requires a US nexus in order to qualify for a downstream loan. See Available in:<http://www.opic.gov/sites/default/files/files/040313-callforproposals.pdf>.

127 See generally David Harvey, A Brief History of Neoliberalism (2005); Andre Gunder Frank, Capitalism and Underdevelopment in Latin America (1967); Fernando Henrique Cardoso \& Enzo Faletto, Dependency and Development in Latin America (1979); J. Samuel Valenzuela \& Arturo Valenzuela, Modernization and Dependency: Alternative Perspectives in the Study of Latin American Underdevelopment, 10 Comp. PoL , no. 4, 1978.

128 Christopher Helman, Obama's 'Power Africa' Plan Greases Billions in Deals for General Electric, Forbes (July 1, 2013 , 12:39 P.M.), Available in: <http://www.forbes.com/sites/christopherhelman/2013/07/01/with-power-africa-plan-obama-to-grease-billions- 
Although Power Africa does not require implementing legislation, the Electrify Africa Act of $2013^{129}$ (the Act) was introduced in the House of Representatives days before President Obama's announcement in Cape Town. The purpose of the Act is to "establish a comprehensive United States Government policy to assist countries in sub-Saharan Africa to develop an appropriate mix of power solutions for more broadly distributed electricity access in order to support poverty alleviation and drive economic growth, and for other purposes." ${ }^{130}$ Congress declares that it is the policy of the United States to:

(1) encourage the installation of at least an additional 20,000 megawatts of electrical power in subSaharan Africa by 2020; (2) promote first-time access to electricity for at least 50,000,000 people in subSaharan Africa by 2020 in both urban and rural areas; and (3) promote efficient institutional platforms to provide electrical service to rural and underserved areas. ${ }^{131}$

Although the Act largely provides guidelines to USAID, OPIC, and USTDA that are already underway as part of the Initiative, the Act importantly amends the Foreign Assistance Act of $1961^{132}$ to direct the Board of Directors and the President of OPIC to issue policy guidance that permits significant investment in the electricity sector of the poorest and lowest pollution-emitting countries in a development-driven and environmentally sensitive manner. ${ }^{133}$ This amendment provides OPIC with an exception to invest in energy projects that involve fossil fuels, which otherwise conflicts with OPIC's internal directive that caps the total greenhouse gas emissions in their overall investment portfolio. ${ }^{134}$

At a fundamental level, Power Africa seeks to extend access to reliable, sustainable, and affordable electricity through a concurrent top-down and bottom-up approach that is widely embraced by the literature. ${ }^{135}$ On the centralized track, electrification is undertaken by national governmental entities such as the state-owned national utility, a rural electrification agency (REA), or the ministry of energy, acting alone or together. ${ }^{136}$ Electrification occurs primarily through extension of the national grid. ${ }^{137}$ In contrast, on the decentralized track, electrification is generally carried out through nongovernmental entities such as cooperatives, community user groups, or private entrepreneurs. ${ }^{138}$ The decentralized model incorporates a number of different systems for electricity generation including isolated mini-grids that are a combination of a generating unit and a distribution system that operates separately from the national or regional grids and connected mini-grids that are distribution systems that are connected to, and may draw electricity from, the main grid. ${ }^{139}$ This dual track emphasis, combined with the leveraging of private sector investment in the generation, distribution, and transmission of electricity in order to meet demand, epitomizes the use of non-traditional mechanisms to increase access to electricity, particularly in rural areas that face the highest costs in accessing the national grid. ${ }^{140}$

However, while innovative, the structure of Power Africa is rife with implementation challenges. At the core of this multi-actor public-private partnership are looming concerns with respect to whether African governments can create a favorable and financially sustainable investment climate for private capital, and a legal and regulatory environment that not only allows investments to be profit-generating and commercially

in-deals-for-g-e/>.

129 Electrify Africa Act of 2013, H.R. 2548, 113th Congress (2013).

130 Id.

131 Id. $\int 4$.

132 Foreign Assistance Act of 1961, Pub. L. 87-195, 75 Stat. 424-2 (1961).

133 Electrify Africa Act, supra note 129, \8 8 (c).

134 Bazilian \& Pielke, Jr., supra note 103, at 78; Todd Moss \& Benjamin Leo, Ctr. For Global Dev., Maximizing Access to

Energy: Estimates of Access and Generation for the Overseas Private Investment Corporation’s Portfolio 1-4 (2014).

135 See, e.g., Tenenbaum ET Al., supra note 60, at 1; Sokona et al., supra note 18, at 8; Eberhard ET AL., supra note 4, at 103.

136 See Tenenbaum et al., supra note 60, at 1, 19, 28.

137 Id.

138 Id. at $1,20,28$.

$139 I d$. at 43. Much of the nomenclature for this technology varies by region. Generally speaking, the term "mini-grid" is interchangeable with "small power producer" (SPP) and distributed generation (DG).

140 See Centurelli, supra note 18, at 234-35. 
sustainable, but also provides the proper incentives and policy mechanisms for African households and businesses to afford accessing electricity. Furthermore, the dual centralized/decentralized nature of Power Africa foments questions of the political, legal, policy, and fiscal dynamics between national and subnational governments of African states as the centralized and decentralized electrification tracks are concurrently implemented and balanced. The next section develops these concerns in detail, drawing on the political economy and international development literatures in order to identify how variations of institutional capacity and autonomy present a substantial challenge to the implementation of Power Africa.

\section{A theOry Of State in(CAPACity) AND electrification}

\section{Institutional design, governance, and public goods}

This paper emphasizes the causal link between state capacity, state-society relations, and the creation of institutional and regulatory obstacles that represent significant implementation challenges to Power Africa. There is a considerable and growing literature that focuses on the effects of political regimes and institutional quality on public goods provision. Much of this literature focuses on the effect of regime type on human capital formation and social policies that affect human capital, specifically health and education. The literature overwhelmingly concludes that democratic regimes provide more services that produce improved health and education outcomes ${ }^{141}$ and make larger fiscal commitments to the health and education sectors. ${ }^{142}$ For instance, Stasavage addresses the effects of electoral competition on total, primary, and tertiary education spending in forty-four African nations from 1980 to 1996, finding that the shift to multiparty competition has resulted in increased total education spending by $1.1 \%$ of GDP and $4.4 \%$ of total public expenditures. ${ }^{143}$ More specifically focusing on the quality of formal political institutions, physical capital, and infrastructure, Brower finds a statistically significant and robust relationship between the presence of high-functioning, democratic institutions and road density in sub-Saharan Africa. ${ }^{144}$

Merely a year into Power Africa, African governments have already been identified as a major obstacle to private sector power investment under Power Africa, both in terms of navigating African bureaucracies ${ }^{145}$ and dealing with an unfriendly regulatory environment. ${ }^{146}$ These obstacles speak to the broader issue of governance, which is not only emerging as an international law issue that could take the shape of an erga omnes obligation, ${ }^{147}$ but also a central issue for the implementation of Power Africa specifically and the development of energy infrastructure more broadly in sub-Saharan Africa. ${ }^{148}$ Hyden defines governance as

141 See generally Matthew Baum \& David Lake, The Political Economy of Growth: Democracy and Human Capital, 42 Am. J. Pol. SCI., no. 2, 2003; David Lake \& Matthew Baum, The Invisible Hand of Democracy: Political Control and the Provision of Public Services, 34 Comp. Pol. Stud., no. 6, 2001; Mohsen Fardmanesh \& Nader Habibi, What is Vulnerable During Fiscal Retrenchment?, 12 ECON. \& PoL., no. 1, 2000.

142 See generally David Brown \& Wendy Hunter, Democracy and Human Capital Formation: Education Spending in Latin America, 1980-1997, 37 Comp. Pol. STud., no. 7, 2004; Robert Kaufman \& Alexa Segura-Ubiergo, Globalization, Domestic Politics, and Social Spending in Latin America, 53 World Pol., no. 4, 2001; Barry Ames, Political Survival: Politicians and Public Policy in Latin America (1987).

143 See generally David Stasavage, Democracy and Education Spending in Africa, 49 Am. J. Pol. ScI., no. 2, 2005; David Stasavage, The Role of Democracy in Uganda's Move to Primary Education, 43 J. Modern Afr. Stud., no. 1, 2005.

144 Tom Brower, The Road Less Traveled: Institutional Quality and Road Provision in sub-Saharan Africa 17-19 (Apr. 28, 2012) (unpublished M.A. thesis, Indiana University) (on file with author and Indiana University Library system).

145 See, e.g., supra note 16.

146 Karambu, supra note 16; see also Tenenbaum et AL., supra note 60, at 86.

147 Thomas Franck, Fairness in International Law 83-84 (1995).

148 See Francis N. Botchway, The Role of the State in the Context of Good Governance and Electricity Management: Comparative Antecedents and Current Trends, 21 U. PA. J. INT'L Econ. L. 781, 782-83 (2000) ("the critical variable for the success or failure of government participation is the presence or substantial absence of the tenets of good governance.”). 
that aspect of politics that aims to formulate and manage the rules of the political arena in which state and civil society actors operate and interact to make authoritative decisions. In more operational terms, governance refers to those measures that involve setting the rules for the exercise of power and settling conflicts over such rules. Such rules translate into constitutions, laws, customs, administrative regulations, and international agreements, all of which in one way or the other provide the framework for the formulation and implementation of policy decisions. ${ }^{149}$

However, the concept of governance is murky and typically operationalized in an overbroad fashion, making it an unwieldy concept to subject to focused empirical analysis. Most of the work on governance appears satisfied with a description or provision of a shopping list of ingredients for good governance, such as accountability, transparency, anti-corruption, rule of law, advancement for women, democracy, and decentralization. ${ }^{150}$ Accordingly, this paper draws upon two distinct and interrelated aspects of state capacity in order to provide a more concrete and institution-focused theoretical framework: absolute state capacity, which focuses on the extent to which the state bureaucracy is apolitical and technocratic, and relative state capacity, which focuses on the degree of autonomy that state institutions have vis-à-vis particularistic societal interests. ${ }^{151}$

\section{Absolute State Capacity}

Unsurprisingly, absolute state capacity developed out of the political economy literature that sought to open the "black box" of the state and analytically focus on the institutional structures and dynamics within the state apparatus itself. ${ }^{152}$ Absolute state capacity is "the measure of the ability of a government to implement its policies and accomplish its goals." ${ }^{153}$ The concept of state capacity is multi-dimensional; it is constituted by:

(1) regulatory capacity: the ability of the state to establish and enforce the rules that guide, or regulate, social behavior; (2) administrative capacity: the routine ability to manage the personnel and resources of the state and ensure accountability and efficiency in service delivery; (3) technical capacity: the expertise and knowledge required to make and implement technical decisions. . . as well as the policy tools and instruments necessary to implement those decisions effectively; and (4) extractive capacity, the ability of the state to raise the revenues it needs to pay for the expenses of implementing its policies and goals. ${ }^{154}$

Of these four dimensions, regulatory capacity and administrative capacity are of greatest importance due to the ability of bilateral and multilateral donors to provide technical and financial assistance to overcome a dearth of technological expertise and revenue shortfalls. ${ }^{155}$ This is consistent with USAID's provision of technical assistance and risk mitigation through mechanisms such as country-specific transaction advisers in Power Africa. ${ }^{156}$

Regulatory capacity largely focuses on the promotion of the rule of law. ${ }^{157}$ Although the rule of law is an ex-

149 Goran Hyden, Governance and the Reconstitution of Political Order, in State, Conflict and Democracy in Africa 185 (Richard Joseph ed., 1999). See also Goran Hyden \& Michael Bratton, Governance and Politics in Africa 7 (1993) (defining governance as "the conscious management of regime structures with a view to enhancing the legitimacy of the public realm").

150 See Botchway, supra note 148 , at 161.

151 See D. Michael Shafer, Winners and Losers: How Sectors Shape the Developmental Prospects of States 13-18 (1994).

152 See generally Peter Evans, The State as Problem and Solution: Predation, Embedded Autonomy, and Structural Change, in THE POLITICs OF Economic Adjustment (Stephen Haggard \& Robert Kaufman, eds. 1992); Bringing the State Back In (Peter Evans et al., eds. 1985).

153 Deborah Brautigam, State Capacity and Effective Governance, in AgENDA For Africa's Economic Renewal 83 (Benno Ndulu \& Nicolas van de Walle, eds. 1996).

154 Id.

155 See Tom Brower, Presentation at the Virginia Social Science Association Annual Conference: State Capacity Formation as Functions of Economic Crisis and International Actors: Ghana 1981-1992 (Apr. 5, 2004) (on file with author); EBERHARD ET AL., supra note 4, at 92.

156 See USAID, supra note 14.

157 See Nsongurua J. Udombana, Articulating the Right to Democratic Governance in Africa, 24 Mich. J. INT’2 L. 1209, 1231 (2003)

(contending that " $[\mathrm{g}]$ ood governance ... must also be effective and equitable, in order to promote the rule of law"). 
pansive concept ${ }^{158}$ that can refer to sets of rules that bind governments and individuals, ${ }^{159}$ the presence and quality of specific legal or political institutions, ${ }^{160}$ or the adequate protection of equality or human rights, ${ }^{161}$ at its core, the rule of law has focused on subjecting the government to the same laws as ordinary people. ${ }^{162}$ Thus, the creation of institutional structures and mechanisms that establish a transparent, accountable, and stable state apparatus enhances a state's regulatory capacity. In the context of energy policy, which is characterized by long time horizons and requiring considerable capital investments that are illiquid expost, investors need broad national stability grounded in the rule of law. ${ }^{163}$ Thus, as regulatory capacity decreases, higher incidences of policy reversal and governmental arbitrariness represent significant political risks for private sector investors of Power Africa. If African governments create arbitrary policies that fail to make rural electrification profitable in the long-term for IPPs, Power Africa's chances for successful implementation plummet. Furthermore, because they often operate as off-takers to power purchase agreements (PPAs), the contracts that ensure a reliable stream of income for IPPs, it is essential that African governments remain accountable as contractual partners for Power Africa investors.

Administrative capacity focuses on the extent to which the state bureaucracy is insulated and autonomous from the rest of the politicized, and often particularistic, state apparatus. Accordingly, bureaucracies with high administrative capacity are characterized as apolitical, technocratic, meritocratic, and independent. These institutions ideally approximate the Weberian bureaucracy, the administrative apparatus that ensures the inherent guarantee of reliable formal expectations of the political authority without becoming integrated or identified with the politicians that operates based on legal-rational authority. ${ }^{164}$ The bureaucratic ethic of technical skill and sense of duty over personal views ${ }^{165}$ is an essential requirement for the inevitable regulation of an industry as technical as energy, and has wide ranging national and international implications. ${ }^{166}$ For instance, the International Energy Agency identifies dedicated institutional structures that are independent from political agendas and electrification objectives that are not interfered with according to politicians' personal agendas as preconditions for successful rural electrification policies. ${ }^{167}$ In the context of Power Africa, the state bureaucracy is responsible for establishing the regulatory framework that determines both the price at which energy is purchased from IPPs, how subsidies are structured, and the consumer's cost of connection to the grid. If the bureaucracy is politicized, these regulatory policies may be structured to both be financially unsustainable for IPPs and prevent consumers without access to electricity from gaining it. Politicization additionally further crystallizes existing cleavages and perpetuates existing infrastructural differences, preventing Power Africa from reaching its primary goal of an extension of electricity access.

Technical capacity refers to the skill and expertise required to implement state policy. In the context of energy infrastructure and rural electrification, technical capacity largely rests with the electricity regulators. Electricity regulators make three types of regulatory decisions: economic, technical, and process. ${ }^{168}$ Econo-

158 See Rachel Kleinfeld, Competing Definitions of the Rule of Law, in Promoting the Rule of Law Abroad: In Search of KnowlEDGE 31 (Thomas Carothers, ed. 2006). For a taxonomy of various rule of law concepts, see Richard H. Fallon, Jr., "The Rule of Law" as a Concept in Constitutional Discourse, 97 Colum. L. Rev. 1, 11-24 (1997); see generally William C. Whitford, The Rule of Law, 2000 Wis. L. Rev. 723,724 (2000).

159 Kleinfeld, supra note 158, at 36-44.

160 Id. at 47-48.

161 Id. at 44-46; See Brian Z. Tamanaha, On The Rule of Law: History, Politics, Theory 91-113 (2004) (comparing formalist and substantive theories on the rule of law).

162 See Botchway, supra note 148, at 196; Whitford, supra note 158, at 724 ("The Rule of Law ideal, therefore, has come to mean that government discretion must be bounded by standards that set effective limits on the exercise of that discretion.").

163 See Botchway, supra note 148, at 198.

164 Max Weber, Economy and Society: An Outline of Interpretive Sociology 31(Guenther Roth \& Claus Wittich, eds., Eprhaim Fischoff et al., trans. 1968).

165 Id. at 456-58.

166 See Botchway, supra note 148, at 170.

167 IEA, supra note 125 , at 9.

168 Tenenbaum et AL., supra note 60, at 66, 69. 
mic or commercial decisions gravitate around price setting and identifying the paying entity. ${ }^{169}$ The regulatory decision that is the center of attention is the feed-in-tariff, the price that a grid-connected IPP receives for the power that it sells to the national or regional utility, which is critical for the IPP's economic vitality. A technical decision is usually an engineering decision, such as the technical standards in the interconnection agreement that provide for safe and robust electrical connections between the national utility and a grid-connected IPP. ${ }^{170}$ While technical in substance, these regulatory decisions have important economic impacts. For example, Thailand requires only a few standard relays for interconnection of small induction generators to the national grid, whereas regulators in other countries may require more extensive and expensive protection equipment. ${ }^{171}$ The cost of these technical decisions and the ability of the regulator to make effective choices may seriously affect the commercial viability of energy projects. Lastly, a process decision specifies the process by which the regulator's technical and economic decisions are made and enforced. ${ }^{172}$ Even if the regulator sets a price that ensures economic viability, the regulatory system and underlying transactions may still fail if the specified decision-making process involves too many steps, if government entities ignore their responsibilities, or if the regulator fails to enforce its decisions in a timely manner. ${ }^{173}$ The concern over the regulatory process vis-à-vis Power Africa was evident during President Obama's speech at the Ubungo Symbion Power Plant in Dar es Salaam, Tanzania, where he noted a "sense of urgency" with respect to electrifying African with "more speed" by "cut[ting] through the red tape."174

Lastly, extractive capacity focuses on the state's ability to finance its policies through revenue generation. Compared with other developing regions, sub-Saharan Africa's public financing capabilities are characterized by particularly weak tax revenue collection. Domestic revenue generation of approximately $23 \%$ of GDP trails averages for other developing countries and is the lowest for low-income countries at less than 15\% of GDP a year. ${ }^{175}$ Administrative corruption and tax evasion are among the most pressing problems for many African states, ${ }^{176}$ with, in some cases, more than half of all taxes going uncollected. ${ }^{177}$ Despite high growth rates in the last decade, domestically-raised revenue grew by less than $1.2 \%$ of GDP, suggesting that raising domestic revenue above current levels would require undertaking challenging institutional reforms to increase the effectiveness of revenue collection and broaden the tax base. ${ }^{178}$ As a result, considerable power funding gaps exist in sub-Saharan Africa. The most severe cases are Ethiopia, a "Power Six" country, and the Democratic Republic of Congo, which have annual gaps of $23 \%$ of GDP ( $\$ 2.8$ billion) and 18\% (\$1.3 billion), respectively. ${ }^{179}$ However, in the case of Power Africa, which is driven by private sector investment, the public financing gap is considerably less problematic.

\section{Relative state capacity}

In addition to determining the level of internal state insulation, political institutions also determine the extent to which certain social groups are able to influence policy. Relative state capacity differs from absolute state capacity primarily with respect to its unit of analysis. Relative state capacity comes from the state-socie-

169 Id. at 67.

170 Id. at 66.

171 Id. at 67.

172 Id.

173 Id. at 67-68.

174 The White House, Remarks by President Obama at Ubungo Symbion Power Plant (July 2, 2013, 10:58 A.M. EAT). Available in: <http://www.whitehouse.gov/photos-and-video/video/2013/07/02/president-obama-speaks-ubungo-symbion-powerplant\#transcript>; Hinks Testimony, supra note 15.

175 EBerhard ET AL., supra note 4, at 167.

176 See Robert Klitgand, Controlling Corruption 6 (1988).

177 See Richard M. Bird, The Administrative Dimension of Tax Reform in Developing Countries, in Lessons From TAx ReFORM IN DEveL-

OPING Countries 316 (Malcolm Gillis, ed. 1989).

178 EBERHARD ET AL., supra note 4, at 167.

179 Id. at $164-65$. 
ty relations literature. ${ }^{180}$ Instead of focusing on the internal structure and autonomy of the state apparatus, relative state capacity focuses on the autonomy that the state apparatus has vis-à-vis particularistic societal interests. This paper defines relative state capacity as "the extent to which leaders are organizationally capable of insulting themselves from societal pressures by controlling channels of interest representation and autonomously defining national tasks." 181

One of the most significant characteristics of the energy crisis in sub-Saharan Africa is the significant disparity between urban and rural levels of electrification. ${ }^{182}$ While most tropical African economies are dependent upon the production and export of agricultural products, there is constant pressure to generate higher levels of income and higher standards of living. The natural solution is a shift from an agricultural-based economy to an industrial-based economy that focuses on labor- and capital-intensive goods and services. In addition to furthering this broad development goal, a regime seeks to remain in power to accumulate resources. These two assumptions are at the core of the urban bias problem in sub-Saharan Africa. First developed by Lipton, urban bias describes the pathological practice of government favoring the urban sector in development policy:

[t] he rural sector contains most of the poverty, and most of the low-cost sources of potential advance; but the urban sector contains most of the articulateness, organisation and power. So the urban classes have been able to "win" most of the rounds of the struggle with the countryside; but in so doing they have made the development process needlessly slow and unfair. ${ }^{183}$

Urban areas represent the most exigent threat to a regime's survival due to their geographical concentration and proximity to major government and communication centers, particularly the capital city. These threats manifest in the form of strikes, riots, and military coups. This is juxtaposed to rural areas, which face significant geographical distances and relatively higher collective action costs, and therefore are less likely to effectively organize against the state. ${ }^{184}$ African states face pressure from two sets of actors: urban workers demanding low prices goods; and urban employers, who, when faced with higher prices, must pay higher wages to workers. The fundamental issue driving urban unrest concerns the real value of urban incomes and the erosion of purchasing power. ${ }^{185}$ Accordingly, abating the militancy of urban consumers is a state priority. As a result, African states intervene in major economic markets, creating policies that benefit urban areas, but negatively affect rural areas, namely the agrarian sector. The agrarian sector is consequently squeezed in order to generate the necessary savings for urban-focused investment. ${ }^{186}$ Rural-centric policy is thus paradoxically devised as a means to cope with urban issues. This urban bias extends into the power sector and operates as a core causal mechanism to understanding the obstacles facing the implementation of Power Africa.

Low levels of relative state capacity and the presence of urban bias significantly limit the success of Power Africa through the reification of the extant inequity of access to electricity in sub-Saharan Africa. Motivated by a desire to maintain their purchasing power, urban areas will pressure the government for po-

180 See generally Joel S. Migdal, Strong Societies and Weak States: State-Society Relations and State Capabilities in the Third World (1988); Civil Society and the State in Africa (John Harbeson et al., eds. 1994).

181 Stephan Haggard \& Chung-In Moon, The South Korean State in the International Economy, in THE ANTIMONIES OF INTERDEPENDENCE 141 (John Ruggie, ed. 1983).

182 See supra notes 9, 26-31.

183 Michael Lipton, Why Poor People Stay Poor: Urban Bias in World Development 13 (1977); see also Robert H. Bates, Markets and States in Tropical Africa: The Political Basis of Agricultural Policies 81-95 (1981) (discussing African states' favoritism of urban over rural constituencies); see generally Robert Eastwood, Johann Kirsten, \& Michael Lipton, Premature Deagriculturalisation? Land Inequality and Rural Dependency in Limpopo Province, South Africa, 42 J. Dev. Stud. 1325 (2006) (drawing on recent research). Urban bias overlaps with the notion of ruralism. See Debra Lyn Bassett, Poverty and Global Ruralism, 13 J. Gender Race \& Just. 1, 11 (2009). The distinction is primarily that urban bias theory is aimed specifically at the allocation of resources, whereas ruralism encompasses resource allocation along with discrimination on a broader scale, including a social bias against rural dwellers. See Debra Lyn Bassett, Ruralism, 88 Iowa L. Rev. 273, 280 (2003).

184 See generally Mancur Olson, The Logic of Collective Action and the Theory of Groups (1965); Robert Bates, Towards a Political Economy of Development: A Rational Choice Perspective (1988).

185 Bates, supra note 184, at 346.

186 See generally Michael Todaro, City Bias and Rural Neglect: The Dilemma of Urban Development (1981). 
licies that make electricity as inexpensive as possible, such as uniform national tariffs and high consumption subsidies. In order to deter civil unrest and ensure the survival of the regime, states with low relative state capacity will adopt these policies to placate their urban constituents. In light of the economic cost of these policies and relatively low levels of governmental revenue due to low extractive capacity, governments seek to cover the residual at the expense of rural areas. This bias will be increasingly institutionalized over time as the locus of decision-making authority will be centralized in order to be proximate to urban areas. As a result, rural electrification projects, such as distributed generation (DG), will lack the autonomy to tailor projects to local needs, negatively affecting their viability and long-term success. Furthermore, electrifying rural areas is inherently a more costly endeavor than electrifying urban areas; accordingly, establishing uniform tariffs, though beneficial for urban consumers, effectively marginalizes IPPs focused on rural electrification because they will be unable to sustain long-term profits. Since IPP commercial viability is at the crux of the success of Power Africa, failing to provide the proper economic incentives for IPPs due to a systematic political bias against rural electrification constitutes a significant implementation challenge.

\section{Argument}

This paper contends that low levels of state capacity, evidenced by a lack of bureaucratic insulation within the state apparatus and a lack of state autonomy from particularistic social actors, create institutional structures and regulatory frameworks that represent significant implementation obstacles to Power Africa. Specifically, weak and incapacitated state apparatuses and the presence of urban bias create implementation barriers through three main mechanisms: (1) creating hybrid power markets; ${ }^{187}$ (2) centralizing power sector institutions; and (3) creating unfavorable regulatory frameworks. These mechanisms are systematically biased against the extension of electricity into rural areas, marginalize IPPs, and threaten the commercial sustainability of private sector investments.

Weak institutionalization within the state apparatus has produced neopatrimonial ${ }^{188}$ states with highly politicized bureaucracies and centralized electrical power markets led by inefficient and insolvent parastatal organizations; these present significant risks to IPPs due to their lack of reliability as off-takers. Additionally, the centralization of the power sector deters IPPs and local governments from having political and fiscal autonomy to tailor power projects to local needs, significantly compromising DG projects. Furthermore, due to low state autonomy and urban bias, the hybrid power sector creates a regulatory framework that negatively affects both demand-side and supply-side aspects of rural electrification. The adoption of ineffective subsidy policies and high connection rates deter rural populations from being able to afford electrification. Additionally, suboptimal FITs and poorly structured or nonexistent PPAs threaten the commercial sustainability of IPPs in rural areas. The next three sections take up each of these mechanisms in turn, establishing a causal connection between state capacity and institutional and policy barriers to the implementation of Power Africa.

\section{Institutional power and power institutions in sub-Saharan Africa}

\section{w(h)ither the State?}

One of the most important political legacies of colonialism in Africa has been the reliance on the model of centralized bureaucratic administration, which, like the colonial systems before them, has not effectively

187 A centralized hybrid power market describes a power sector where incumbent state-owned utilities often retain dominant market positions with private sector actors involved on a temporary or highly marginalized basis. See infra notes 203-11.

188 Neopatrimonialism is a system of social organization where patrons utilize state resources in order to secure the support and loyalty of clients in the general population, expressed in terms of an informal patron-client relationship between multiple strata of society. See infra notes 189-94. 
functioned. A considerable literature has assessed the poor institutionalization and lack of absolute state capacity in sub-Saharan Africa. ${ }^{189}$ Additionally, in many sub-Saharan African countries, distinctions between the state realm and civil society are far from clear, evidence of low levels of relative state capacity. ${ }^{190}$ One of the main problems is a loose coupling between the formal bureaucratic structure of these states and neopatrimonial forms of rule that suggest that personal relationships are more important than formal institutions in determining outcomes. ${ }^{191}$ In discussing the neopatrimonial state, Jackson and Rosberg note that" [b]lack Africa's forty-odd states are among the weakest in the world. State institutions and organizations are less developed in the sub-Saharan region than almost anywhere else." ${ }^{192}$ Accordingly, many of Africa's elites lack the capacity to maintain the functions associated with national sovereignty in their territories, such as the maintenance of the rule of law, regulation of borders, and provision of social services. ${ }^{193}$ Thus, some commentators have contended that African states lack the capacity to even be considered states in the empirical sense. ${ }^{194}$ The prevalence of state incapacity in sub-Saharan Africa has had significant implications for the incompleteness of power sector reform in the region and the institutionalization of a public sector-controlled and politicized power sector, discussed in the following section.

\section{White elephants on parade}

Sub-Saharan Africa has gradually conformed to the global trends in power sector reform that began in the 1980s. By 2006, all but a few of the twenty-four countries of sub-Saharan Africa covered by the World Bank's Africa Infrastructure Country Diagnostic had enacted a power sector reform law, three-quarters had introduced some form of private participation in power, two-thirds had corporatized their state-owned power utilities, two-thirds had established some kind of regulatory oversight body, and more than a third had IPPs in operation. ${ }^{195}$ However, reform remains partial and incomplete; rarely in sub-Saharan Africa does one encounter the standard reform model, that is, unbundling, privatization, and wholesale and retail competition. ${ }^{196}$ Although some reform steps have been taken, there have incredulously been few improvements to utilities. ${ }^{197}$ Furthermore, the private sector has also had only limited involvement in reforms thus far. ${ }^{198}$

The incompleteness of power sector reform has been characterized by low levels of administrative capacity of energy regulatory agencies. Independent electricity or energy regulatory agencies have also been established in most sub-Saharan African countries; however, they are now criticized for inconsistent decision-making and for exacerbating regulatory risk. Although these regulatory agencies are de jure independent in their decision-making, regulators are far from independent in a de facto sense. Regulators are often subject

189 See generally Patrick Chabal \& Jean-Pascal Daloz, Africa Works: Disorder as Political Instrument (1999); Jean-François Bayart, The State in Africa: Politics of the Belly (1989).

190 See Ernest Harsch, Accumulators and Democrats: Challenging State Corruption in Africa, 31 J. Modern Afr. Stud. 31 , 34 (1993).

191 See generally Robert H. Jackson \& Carl Rosberg, Personal Rule in Black Africa (1982); Robert H. Jackson \& Carl Rosberg, Personal Rule: Theory and Practice in Africa, 16 Comp. Pol., no. 4, 1984; Chabal \& Daloz, supra note 189.

192 Robert H. Jackson \& Carl Rosberg, Why Africa's Weak States Persist: The Empirical and the Juridical in Statehood, 35 World Pol. 1 , 1 (1982).

193 See Udombana, supra note 157, at, 1215 (2003).

194 See generally Jackson \& Rosberg, supra note 192; Jeffrey Herbst \& Greg Mills, There is No Congo, Foreign Policy (Mar. 18, 2009). Available in: <http://www.foreignpolicy.com/articles/2009/03/17/there_is_no_congo >.

195 Eberhard et al., supra note 10, at vi, 15; EBERHARD ET AL., supra note 4, at 80.

196 See Eberhard et al., supra note 10, at vi, 15; Eberhard ET AL., supra note 4, at 180-81; J.E. Besant-Jones, Reforming Power Markets in Developing Countries: What Have We Learned 22 (Energy \& Mining Sector Board Discussion Paper No. 19, 2006). Uganda is one of the exceptions where generation, transmission, and distribution were fully unbundled. In Kenya, generation (KenGen) has been separated from transmission and distribution (KPLC). Ghana has unbundled its transmission company and has a separate distribution company. Nigeria has technically unbundled its utility, although the separate entities still coordinate with each other. For historical reasons, local governments in Namibia and South Africa assume some responsibility for distribution.

197 See Eberhard et al., supra note 10, at 14-15. This is a confusing result because power sector reform is expected to improve performance.

198 See EBERHARD ET AL., supra note 4, at 79. 
to pressure from governments to modify or overturn decisions. ${ }^{199}$ Turnover among commissioners has been high, with many resigning under pressure before completing their full term. ${ }^{200}$ This is particularly problematic for Power Africa because regulators are responsible for establishing the technical, commercial, and procedural framework in which IPPs operate. ${ }^{201}$ Accordingly, their political independence is cardinal to the commercial viability of power generation and rural electrification. ${ }^{202}$ Low levels of absolute capacity among electricity regulatory agencies have produced a particular institutional structure that threatens the long-term commercial viability of IPPs and deters rural Africans from gaining access to electricity.

Instead of the standard market reform of the power sector, sub-Saharan Africa has seen the emergence of hybrid markets in which incumbent state-owned utilities often retain dominant market positions. ${ }^{203}$ Private sector cooperation is either temporary-for example, a limited-term management contract—or marginal, in the form of IPPs that contract with the state-owned national utility. ${ }^{204}$ These vertically-integrated parastatal ${ }^{205}$ electrical utilities have been observed as highly inefficient. ${ }^{206}$ Thus, like many of the region's state-owned enterprises (SOEs), the electrical utility is a "white elephant." These centralized hybrid power markets have generally been characterized as having low technical capacity, evidenced by poor performance on both technical and commercial fronts. Average distribution losses in Africa are 23\% compared with the commonly-used norm of $10 \%$ or less in developed countries. ${ }^{207}$ Moreover, average collection rates are only $88.4 \%$ compared with best practice of $100 \%{ }^{208}$ The inefficiency of the median utility is equivalent to $50 \%$ of turnover, which means that only two-thirds of revenue is captured. ${ }^{209}$ There are two main implications for the inefficiency of state-owned electrical utilities in hybrid markets. First, because utility managers are forced to forgo maintenance to cover operating deficits, future utility performance is constrained; countries with below-average efficiency have increased electrification rates by only $0.8 \%$ each year compared with $1.4 \%$ for utilities with above-average efficiency. ${ }^{210}$ Second, inefficiency-caused operating deficits render many national utilities commercially insolvent. ${ }^{211}$

Despite low technical capacity and significant commercial performance, the hybrid power market persists along with an underperforming national electrical utility. The literature identifies two main reasons for the persistence of these white elephants. On an ideological front, Fabrikant traces the origin of public enterprises in developing countries to colonialism, pointing out that many former European colonial powers utilized corporations as an arm of their governments for seizing foreign territories. ${ }^{212}$ Upon independence, many developing nations opted for a strategy of economic development based on state ownership and control of much of the industrial sector, which they hoped would bring about structural changes in their economies. ${ }^{213}$ Parastatal organizations have a long and storied history in African economics, beginning in the pre-independence colonial period, and crystallizing under various nationalization schemes of Afro-Marxist regimes. As an expression of socialist/Marxist ideology, public enterprises were a manifestation of national sovereignty and a means to establishing greater equity within society.

199 Id. at 95; Eberhard et al., supra note 10, at 47-48.

200 EBerhard ET AL., supra note 4, at 95; Eberhard et al., supra note 10, at 47-48.

201 See supra notes 168-74.

202 See Haanyika, supra note 26, at 2980, 2989.

203 Eberhard ET AL., supra note 4, at 79; Eberhard et al., supra note 10, at vi, 15; Anton Eberhard \& Katharine Nawaal Gratwick, IPPs in Sub-Saharan Africa, 39 ENERGy POL'y 5541, 5542 (2011).

204 Eberhard et al., supra note 10, at vi, 5.

205 A parastatal organization is defined as having some political authority and serving the state indirectly.

206 See Eberhard ET AL., supra note 4, at 133; Gisela Prasad, supra note 31, at 249; John Turkson \& Norbert Wohlgemuth, Power Sector Reform and Distributed Generation in sub-Saharan Africa, 29 ENERGY POL'y 135, 137 (2001).

207 EBERHARD ET AL., supra note 4, at 134.

208 Id.

209 Id.

210 Id.

211 See id.; Tenenbaum eT AL., supra note 60, at 48, 169, 199.

212 Robert Fabrikant, Developing Country State Enterprises: Performance and Control, 15 Colum. J. TransNAT'L L. 40, 40-56 (1976).

213 See Bertil Walstedt, State Manufacturing Enterprises in a Mixed Economy: the Turkish Case 3-55 (1980). 
The second reason, which is grounded in political economic logic, is consistent with the causal mechanism of state incapacity and the argument of this paper. SOEs were a means to establishing and crystallizing systems of clientelistic reciprocity through political patronage. ${ }^{214}$ SOEs constitute a sizeable amount of national employment and managerial positions within public enterprises that are lucrative and highly desired; accordingly, these positions are a strong form of political capital. Thus, privatization may be resisted to retain the political capital employed by the state apparatus in order to maintain political power and regime stability. In its more nefarious incarnation, the endurance of SOEs operates as "the politics of nonreform" in order to perpetuate patrimonial politics, maintain systems of clientelistic reciprocity, and continue kleptocratic practices. ${ }^{215}$ In the case of the hybrid power market and Power Africa, low levels of absolute state capacity - particularly regulatory and administrative capacities-cause the reform of the power sector to be functionally incomplete in order to retain important political capital. While independent regulatory institutions for the power sector may exist in a de jure sense, in practice, these institutions are highly politicized, technically incapacitated, and commercially unsuccessful. In a de facto sense, the state retains full control of the regulatory decisions that determine the profitability and logistics surrounding rural electrification. However, because these institutions lack political independence, they cease to operate in a technocratic and socially-ameliorative manner, and, instead, promulgate policies guided by a narrow, particularistic logic.

The hybrid power market presents several challenges to the implementation of Power Africa by threatening the long-term commercial sustainability of IPPs. ${ }^{216}$ The first main challenge stems from the internal contradictions of the hybrid power market and a poor understanding of it. Following power sector reform and the creation of the hybrid power market, the responsibilities for planning and procurement of new power infrastructure were often moved to the ministry of energy or electricity. ${ }^{217}$ Due to poor communication and technical disparities between state institutions, plans are often poorly executed, and generation expansion planning has collapsed. ${ }^{218}$ Where still present, planning tends to take the form of outdated, rigid master plans that do not reflect the changes in price and availability of fuel and equipment and the resulting least-cost options. ${ }^{219}$

Similarly, poor understanding of the hybrid power market prevents policymakers from devising clear and transparent criteria for allocating new building opportunities among the state utility and IPPs. ${ }^{220}$ For instance, when the government begins procurements, they may not conduct internationally competitive bidding; this is a problem because a rigorous bidding process provides credibility and transparency and results in more competitively priced power. ${ }^{221}$ Tanzania epitomizes this problem. ${ }^{222}$ It was expected that the Songo Songo project, a sixty MW gas-to-electricity plant project would be up and running within less than a year, despite the significant infrastructure development and financing required. In 1995, despite work on Songo Songo remaining outstanding, a second deal was struck by the Tanzanian government for $100 \mathrm{MW}$ of diesel engines, known as Independent Power Tanzania Limited (IPTL), under a twenty-year PPA. At the time,

214 See generally Nicolas van de Walle, Privatization in Developing Countries: A Review of the Issues, 17 World Dev., no. 5, 1989.

215 See Nicolas van de Walle, The Politics of Nonreform in Cameroon, in Hemmed In: Responses to Africa's Economic DeCLINE 357-97 (Thomas M. Callaghy \& John Ravenhill, eds. 1993); see generally Chabal \& Daloz, supra note 189.

216 See Eberhard ET AL., supra note 4, at 79 (noting that IPPs are introduced on the margin of the sector in in the hybrid power market).

217 Id. at 89.

218 Id.

$219 I d$.

220 Relatedly, " $[\mathrm{w}]$ hat has emerged as a general trend is that the mere presence of a regulator is not in and of itself a defining factor in attracting IPPs. An independent regulator may have positive, negative or no impact on outcomes. If, however, regulatory governance is transparent, fair and accountable, and if regulatory decisions are credible and predictable, there is greater potential for positive outcomes for host country and investor alike." Eberhard \& Gratwick, supra note 203, at 5543.

221 EBERHARD ET AL., supra note 4, at 91.

222 See Katharine Gratwick et al., Generating Power and Controversy: Understanding Tanzania's Independent Power Projects 22-31 (Mgmt. Program in Infrastructure Reform \& Reg., Working Paper, 2007); EBERHARD ET AL., supra note 4, at 91; Gratwick \& Eberhard, supra note 42 , at $35-36$. 
Tanzania could absorb power from one plant, but certainly not two. Gratwick and Eberhard note the impetus for IPTL may be attributed to a host of factors, including alleged corruption. ${ }^{223}$ In the aftermath of the IPTL deal was a lengthy attempt at cancellation and renegotiation of this second plant, as well as temporary postponement of Songo Songo led by the World Bank. ${ }^{224}$ Accordingly, due to a lack of understanding of the hybrid power market, Tanzania had no IPPs in operation rather than two.

A second set of challenges associated with the hybrid power market focus on the off-take arrangement between the IPP and national utility. As previously noted, national utilities are characterized by low levels of technical capacity and significant inefficiencies that have rendered many commercially insolvent. ${ }^{225}$ This commercial insolvency poses considerable risks to IPPs that contract to sell their power to national utilities in order to secure a guaranteed revenue stream. Without this assured revenue, the commercial sustainability of IPPs is considerably threatened. As Paul Hinks noted,

[a]nother serious challenge to the success of power investments in Africa is the creditworthiness, or lack thereof, of the "off-takers" which are usually the government-owned utilities that purchase the electricity from the power producers and distribute it to the consumers. In most instances, the stateowned utility cannot demonstrate a sufficient level of assurance that it will be in a position to pay the private-sector producers or that it will pay promptly and in accordance with the terms of the contract. In practice, if the producers are not paid, they will in turn default on their payments to banks and other financial institutions that help fund the investments that have very little tolerance for non-payment. ${ }^{226}$

Hybrid markets require clarity on the IPP off-take arrangements incumbent national utilities that aggregate demand and average prices for customers. Surprisingly few African countries have explicitly defined their power market structures or procedures for negotiating and contracting PPAs with IPPs. ${ }^{27}$ Some countries have used the single-buyer model with the national utility as the buyer; however, it is unclear whether exclusivity is part of this monopsonistic relationship. Accordingly, both the inherent credit risk associated with the national utility of the off-taker and the lack of clarity with respect to the IPP's potential customers have significant effects on the commercial sustainability of power projects in sub-Saharan Africa. The next section approaches the institutional design of power sectors in sub-Saharan Africa from a different perspective, focusing on the intergovernmental dynamics that arise due to low levels of independence both within the state apparatus and between state and society.

\section{WHEN THE CENTER HOLDS: INTERGOVERNMENTAL RELATIONS OF THE POWER SECTOR}

Due to low absolute and relative state capacity, the endurance of the centralized neopatrimonial state and the centralization of the power sector also have important implications for the implementation of Power Africa due to intergovernmental relations. Power Africa's goal of extending access to electricity in sub-Saharan Africa, combined with the significant urban-rural disparity in access to electricity, suggests a critical role for subnational governments and DG in Power Africa. These intergovernmental relations can be understood as the sets of political, administrative, and fiscal relationships between the autonomous levels of government in a single country. ${ }^{228}$ Weingast, Montinola, and Qian contend that decentralized control over the economy by subnational governments within a common market prevents the central government from interfering with markets. ${ }^{229}$ Additionally, intergovernmental competition over mobile sources of re-

223 Gratwick \& Eberhard, supra note 42, at 35.

224 Id. at 35-36; EBERHARD ET AL., supra note 4, at 91.

225 See supra note 211.

226 Hinks Testimony, supra note 15.

227 See EBERHARD ET AL., supra note 4, at 92.

228 See J. Tyler Dickovick, Decentralization and Recentralization in the Developing World: Comparative Studies from Africa and Latin America and Africa 3 (2011).

229 Gabriella Montinola et al., Federalism, Chinese Style: The Political Basis for Economic Success in China, 48 World Pol. 50, 58 (1995). 
venue also constrains individual subnational governments. ${ }^{230}$ Relatedly, locating decision-making as close to the ground as possible enables a better understanding of the interplay of cultural, institutional, and political factors involved, and will lead to better decisions. ${ }^{231}$ When there is a great deal of economic, environmental, or linguistic heterogeneity in the nature of tax bases or taxpayers, as there is in sub-Saharan Africa, decentralization will be more efficient because it allows an administration to be tailored to local conditions. ${ }^{232} \mathrm{By}$ comparison, advocates for a more centralized approach note that "[a] well-known problem with the decentralization of standard-setting power to local governments is that local authorities are often particularly vulnerable to lobbying by industrial interest groups as a consequence of the controlling role that such groups often play in the socio-economic interests of local communities."233

In the context of Power Africa and the extension of access to electricity, the centralization of formal political institutions and the electrical power infrastructure has two main implications. First, centralization reinforces and further crystallizes the urban bias problem; with the locus of politics and economic policy continuing to be based in the national capital, rural populations will continue to face high collective actions costs and have little capacity to advance their interests. Accordingly, centralization represents the catalyst of a vicious cycle of urban bias and anti-rural policies, including, but not limited to, the power sector. Second, institutional centralization represents a significant deterrent to the development of DG projects in rural areas. Countries with dedicated rural electrification agencies (REAs) or rural electrification funds (REFs) have achieved higher rates of electrification than those that have not. ${ }^{234}$ For instance, the percentage of rural connection is twice as high in countries with both REAs and REFs than countries with neither institution. ${ }^{235}$

Several different mechanisms contribute to the importance of decentralization and higher levels of subnational political and fiscal autonomy to rural electrification. First, the likelihood of poor performance of DG projects is reduced when project planners select technologies that match the social characteristics of the community. ${ }^{236}$ Meeting end users' needs, which vary both across and within communities, also affects the end users' willingness to pay that has clear implications for the financial sustainability of the DG project. ${ }^{237}$ For instance, case study evidence suggests that relatively poor individuals and communities tend to prefer that programs install mini-grids or community-level programs, whereas wealthier individuals tend to implement single-family solar home systems. ${ }^{238}$ Decentralization is typically most effective and efficient at providing information on the local context and the needs, tastes, and preferences of the local end users; ${ }^{239}$ accordingly, a centralized power infrastructure fails to provide the specificity and context necessary to promote successful DG programs in rural areas.

This argument is more generally known as "market-preserving federalism." See Barry R. Weingast, The Economic Role of Political Institutions: Market-Preserving Federalism and Economic Development, 11 J.L. Econ. \& Org. 1, 3 (1995). But see generally Jonathan Rodden \& Susan Rose-Ackerman, 83 Va. L. Rev. 1521 (1997) (critiquing market-preserving federalism).

230 Montinola et al., supra note 229, at 58.

231 Joseph Stiglitz, Senior Vice President \& Chief Economist, The World Bank, Keynote Address at the World Bank Annual Conference on Development Economics: Whither Reform? Ten Years of the Transition (Apr. 28, 1999), http://siteresources. worldbank.org/INTABCDEWASHINGTON1999/Resources/stiglitz.pdf.

232 Paul Smoke, Local Government Finance in Developing Countries: The Case of Kenya 36 (1994).

233 Michael Faure et al., Bucking the Ku₹nets Curve: Designing Effective Environmental Regulation in Developing Countries, 51 Va. J. Int'l L. 95, 120 (2010); see also Rodden \& Rose-Ackerman, supra note 229, at 1532-35.

234 Eberhard et al., supra note 10, at 49; Eberhard et al., supra note 4, at 105, 107-8.

235 Eberhard et al., supra note 4, at 108.

236 See Brass et al., supra note 64, at 120, 131; Eberhard et al., supra note 4, at 120 (emphasizing the importance of community involvement in extending access to electricity).

237 Brass et al., supra note 64 , at 123.

238 See generally Claus, supra note 78; S. Komatsu et al., Are Micro-benefits Negligible? The Implications of the Rapid Expansion of Solar

Home Systems (SHS) in Rural Bangladesh for Sustainable Development, 39 ENERGy POL’y 4022 (2011).

239 See supra notes 230-32. 
Secondly, the principle of collaborative governance ${ }^{240}$ and the ongoing involvement of end users are essential to the success of DG projects. ${ }^{241}$ Empirical research on collaborative governance suggests that participation of end users improves service provision outcomes, such as risk reduction. ${ }^{242}$ Ultimately, "[a] decentralized approach that mobilizes consultation with all stakeholders will ensure that needs and expectations are expressed and the most suitable energy solutions are explored." ${ }^{243}$ In doing so, an enabling environment for the involvement of multiple stakeholders, including provincial governments and local communities, will be created that will facilitate the development of energy projects and the extension of electricity to rural areas. The next section takes up how IPPs and rural consumers are marginalized by these centralized power institutions through a systematically biased regulatory framework.

\section{Regulators, mount up! Power regulation and RURal marginalization}

A dearth of absolute capacity, evidenced by the politicization of the bureaucracy, and relative capacity, evidence by the presence of urban bias, also creates a regulatory framework that represents a significant implementation challenge of Power Africa. Earl Gast, USAID’s Assistant Administrator for Africa, noted that the pace of private sector investment has been hurt by an unfriendly regulatory environment. ${ }^{24}$ State elites, in order to harness political capital and ensure regime survival, create power regulations that concurrently affect the demand-side and supply-side elements of rural electrification. Under Power Africa, IPPs and end users constitute the supply and demand elements, respectively. Specifically, low state capacity constrains the supply of new power projects by not providing a tariff structure that is commercially sustainable and poorly structuring PPAs. On the demand side, regulations make access to electricity cost-prohibitive for many potential end users because of improperly structured subsidies and high, poorly-structured connection rates.

\section{Supply-side issues}

\section{Feed-in-tariffs}

The feed-in-tariff (FIT) typically receives most of the spotlight in the world of energy project development. A FIT is a tariff-support mechanism, typically for renewable energy generators or cogenerators, in which the generator is guaranteed a certain rate of payment for the wholesale power that it sells to the national utility, the national system operator, or other obligated purchaser of its power. ${ }^{245}$ In most instances, FITs for IPPs are set administratively rather than competitively as the outcome of a structured bidding process. ${ }^{246}$ In low-income countries, FITs have the largest effect on DG dissemination. ${ }^{247}$ Accordingly, absence of a FIT is cited as a barrier to distributed models of electrification. ${ }^{248}$

\footnotetext{
240 See Brass et al., supra note 64, at 127 (defining collaborative governance as "a collective decision-making process whereby public-sector agencies engage and deliberate with a variety of nonstate actors, including NGOs, private-sector firms, interest groups, community members, and individuals, to formulate, implement, manage, and regulate public policies, services, and programs").

241 See id. at 120, 124-25, 127 (identifying the prominent themes of collaborative governance and end-user involvement in the DG literature); IEA, supra note 125, at 9, 102 (identifying end-user involvement as a precondition to successful rural electrification).

242 See, e.g., Eberhard \& Gratwick, supra note 203, at 5455.

243 Mohiuddin, supra note 104, at 123.

244 See Karambu, supra note 16 (quoting USAID's Assistant Administrator for Africa Earl Gast: "One of the obstacles we are facing is structuring a deal and attaining financial closure. It is difficult because it involves policy reforms that need implementing, or measures that have been agreed to by the government, but which are dragging.").

245 See Tenenbaum ET AL., supra note 60, at 155, 179-80.

246 Id. at 179.

247 Brass et al., supra note 64, at 130.

248 See id. at 126; see generally A. Yadoo \& H. Cruickshank, The Value of Cooperatives in Rural Electrification, 38 ENERGY POL'Y 2941
} 
There are two main methods for setting FITs in developing countries: (1) the avoided-cost method, which values the FIT based on an estimation of costs that the utility or society will avoid by purchasing power generated from a renewable source; and (2) the standardized, cost-reflective, technology-specific method, which bases the FIT on the estimated cost of generation for each designated renewable energy technology, assuming that the developer has made a least-cost investment and will operate in an efficient manner. ${ }^{249}$ The regulatory regime's choice of FIT has immediate effects on the commercial sustainability of the IPP. If an avoided-cost approach is used, all eligible renewable energy generators receive the same FIT that does not vary based on the generation technology. ${ }^{250}$ Accordingly, not all generation technologies will be equally viable under the avoided-cost approach.

Thus, with a politicized bureaucratic structure with considerable pressures from urban elites, low levels of state capacity marginalize IPPs that focus on technologies that would primarily thrive in rural areas. In countries with tariffs set at the purchasing utility's avoided costs, it is usually the case that only a few projects will be commercially viable, usually larger-scale biomass cogeneration and particularly good small hydropower sites. ${ }^{251}$ Other important renewable energy technologies will not be commercially viable if the FIT is set at the utility's avoided costs. For example, wind power and solar power, which are generally prevalent in rural areas, will be nonviable because their costs will almost always be higher than the utility's avoided-cost-based FIT. ${ }^{252}$ For instance, Tanzania utilizes an avoided-cost FIT. ${ }^{253}$ Based on 2012 tariff rates, estimated fifteen-year cost estimates conclude only hydropower and biomass from agricultural residues will be commercially sustainable, while wind and grown biomass-both resources plentiful in rural areas_-will not be commercial sustainable. ${ }^{254}$

The principal responsibility of the regulator is to optimally set these tariffs — high enough that they will, after a transition period of several years, recover operating costs, capital depreciation, and debt payments, and provide for reserves to deal with emergency repairs and replacements-while concurrently protecting consumers from IPPs that try to exercise monopoly power after receiving a license or permit issued by the regulator. ${ }^{255}$ Three main tariff principles are frequently encountered in sub-Saharan Africa: (1) uniform national tariffs, where all citizens in the same tariff category pay the same tariff for electricity regardless of where they live; (2) avoided-cost tariffs, where an IPP operator is allowed to set tariffs that produce monthly bills to consumers that are equal to or below what the consumers would have been paying on other energy purchases that are now replaced by electricity; and (3) cost-reflective tariffs, tariffs that produce enough revenues to recover the overall capital and operating costs likely to be incurred by an actual or hypothetical IPP operator. ${ }^{256}$ If cost-reflective tariffs are not allowed because the IPP operator's tariffs are capped at a lower level—either by informal political pressures or formal legal requirements—-there will be a financial gap that will render the IPP commercially unsustainable. ${ }^{257}$

However, due to a lack of absolute and relative state capacity, the implementation of cost-reflective tariffs is actively resisted in lieu of de jure or de facto uniform national tariffs. While many of the newer national electricity laws in sub-Saharan Africa require the regulator to set cost-reflective tariffs rather than a uniform national tariff, the current reality is that most retail tariffs are both uniform and too low. ${ }^{258}$ In the most complete survey performed to date on the financial condition of sub-Saharan African utilities, the Africa

(2010).

249 Tenenbaum et AL., supra note 60, at 180-81.

250 Id. at 183.

251 Id.

252 Id.

253 See id. at 190.

254 Id. at 184.

255 Id. at 240.

256 Id.

257 See id. at 10, 240.

258 See id. at 242-43. 
Infrastructure Country Diagnostic concluded that only ten of twenty-one national utilities in sub-Saharan Africa were allowed to charge tariffs that covered their operating costs, and only six of twenty-one national utilities could charge tariffs that covered operating and capital costs. ${ }^{259}$ The underlying mechanism for such policy inertia is urban bias personified:

[t]he reason countries often tolerate and, in some cases, actively resist movement to cost-reflective tariffs may be precisely because the status quo favors the relatively few, better off consumers who are actually connected to the grid. These consumers are mostly urban dwellers with the power to mobilize against governments and manipulate policies for their own benefit. ${ }^{260}$

One high-level African energy ministry official referred to immediate implementation of an overall cost-recovering tariff for the national utility as the equivalent of political suicide, especially when the general public thinks that the national utility is inefficiently run and filled with corrupt employees. ${ }^{261}$ Consequently, uniform national tariffs are rarely allowed to rise to cost-reflective levels, even when legally required under the national energy law.

A uniform national tariff ignores the fact that the real cost of providing electricity in rural areas is almost always higher than providing the same electricity in urban areas due to higher capital cost and higher operating costs. ${ }^{262}$ Accordingly, under a uniform national tariff, IPPs that serve rural communities experience a gap between their costs and revenues. In some cases, the cost-revenue gap arises because a law or regulation prohibits IPPs from charging tariffs that are high enough to cover their costs. ${ }^{263}$ In other cases, IPPs cannot charge cost-recovering tariffs because the national utility operating on the centralized track has created a nationwide de facto price ceiling by charging its customers below-cost retail tariffs, thereby making it seem to potential customers that the electricity provided by the IPP is too expensive. ${ }^{264}$ As a longtime Tanzanian mini-hydro specialist observed:

[i]t costs TANESCO [the Tanzania Electric Supply Company, the national utility] at least 500 shillings/ $\mathrm{kWh}$ [about \$0.33] for operational cost alone, and add management and distribution costs, then power from TANESCO's isolated mini-grids costs something like 800 [about $\$ 0.50$ ] shillings. It is crazy that TANESCO turns around and sells it at 130 shillings [about $\$ 0.08$ ]. No investor can possibly build projects with this situation. And the problem is that everyone now expects electricity at 130 shillings. If someone gets permission to charge a higher price than this, some villagers will go to the power plant and break equipment saying, "you make too much money."265

Ultimately, the political economy that undergirds tariff regulation in sub-Saharan Africa presents a significant barrier to rural electrification and the implementation of Power Africa. As long as uniform national tariffs are maintained - either by formal legal or informal political mechanisms-IPPs serving rural areas will face significant additional costs that will threaten the commercial sustainability of their investments.

\section{Power purchase agreements}

A PPA is the contract that enables an IPP to connect with and sell electricity to a utility-owned grid. ${ }^{266}$ PPAs are critical to the commercial viability of a power project for several reasons. First, PPAs remove a considerable amount of risk and ensure a revenue flow for the IPP by contracting for purchasing electricity

259 Eberhard et al., supra note 10, at 29.

260 Eberhard \& Shkaratan, supra note 2, at 13; see also TenEnBaum ET AL., supra note 60, at 243 ("The stated or unstated rationale for a uniform national tariff is that electricity is seen as a basic right to which all citizens are entitled. For most elected officials, who bave their eyes on the next election, fairness is much more important than cost recovery.").

261 Tenenbaum et al., supra note 60, at 244.

262 See id. at 243-44.

263 Id. at 11.

$264 I d$.

265 Id. at 244.

266 See id. at 6. 
generated by the project. Projected revenues, in turn, comprise the single most important criterion that will render a power generation project bankable and ultimately capable of being on-sold to other investors.

Second, in many developing countries, including sub-Saharan Africa, the state-owned power utility is usually the IPP's only customer and main source of revenue. PPAs also set forth important terms of the transaction between the IPP and the government, including the tariff, the term, and how various risks, such as force majeure, are mitigated and allocated. Ultimately, the PPA is the foundation of a power project's bankability. As a first order issue, PPAs need to actually exist. Although many of the medium-to-large sized power projects in Africa have had a long-term PPA to ensure a market for the power produced and to secure revenue flows for debt and equity providers ${ }^{267}$ not all countries use PPAs. PPAs require a level of technical and legal expertise in order to be successfully executed. In light of the relatively low levels of technical capacity in many African bureaucracies, the utilization of PPAs may be deterred for institutional reasons. However, technical assistance can be supplied by external actors. For instance, the Power Africa team at USAID has prided itself on helping the Government of Ethiopia and a project developer execute the first-ever PPA in the country's history. ${ }^{268}$

If PPAs do exist, issues of absolute capacity—particularly low administrative and technical capacitiescan negatively affect the commercial viability of IPPs through the structure of the PPA. First, the absence of "deemed energy" clauses represents a substantial commercial threat to the commercial viability of IPPs, particularly to small power producers without capacity payments. ${ }^{269}$ Deemed energy refers to a situation in which a main-grid-connected IPP seller is able to produce electricity, but the buyer is unable to receive it. Accordingly, a deemed energy clause in the PPA obligates the buyer to provide compensation for electricity that the IPP was capable of producing but the buyer was unable to receive. ${ }^{270}$ The three most common reasons that prevent a utility from receiving an IPP's energy are (1) insufficient overall generation capacity; (2) insufficient capacity or damage to the local distribution network; and (3) weakness on the receiving utility's transmission grids. ${ }^{271}$ Importantly, each of those reasons can be traced back to poor institutionalization of the power sector, including significant technical and commercial inefficiencies. ${ }^{272}$ Additionally, because national utilities implement uniform national tariff rates that are too low to cover costs in order to secure political support from urban constituents, ${ }^{273}$ they are forced to forego maintenance in order to cover operating deficits. ${ }^{274}$ As inefficiencies persist and operation deficits increase over time, the frequency of the national utility being unable to receive energy and engaging in rolling blackouts should increase over time. Once a disturbance or lack of capacity in the national utility's system occurs, IPPs must shut down in the absence of a deemed energy clause, as they do not have a guaranteed revenue stream as long as the national utility is unable to receive energy.

Even if PPAs with deemed energy clauses are included in power transactions, there is still uncertainty about the reliability of the off-taker. It has already been noted that, unlike most utilities in developed countries and many developing countries, almost all state-owned utilities in sub-Saharan Africa are, at present, commercially insolvent due to systemic inefficiencies caused by a confluence of low technical capacity and the promulgation of suboptimal pricing mechanisms motivated by a lack of relative autonomy from societal

267 Gratwick \& Eberhard, supra note 42, at 43.

268 Hinks Testimony, supra note 15; U.S. Agency for Int'L Dev., What Power Africa Means for Ethiopia. Available in: <http://www. usaid.gov/powerafrica/partners/african-governments/ethiopia>. (last visited July 25, 2014).

269 A capacity payment is a payment made to an IPP that ensures it can recover costs and earn a profit even if its power is not dispatched. See, e.g., Tenenbaum ET AL., supra note 60, at 161.

$270 \quad$ Id. at 162.

271 Id. at $162-63$.

272 See supra notes 206-11.

273 See Tenenbaum et AL., supra note 60, at 244 ("The current reality for most national utilities in Sub-Saharan Africa is that tariffs are both uniform and too low.").

274 See supra note 259. 
interests. ${ }^{275}$ As the national utility often operates as a monopsony for IPPs, the prevailing insolvency raises significant issues with respect to the creditworthiness of the utility as the off-taker under the PPA. Key actors in Power Africa, including Symbion Power, the International Finance Corporation (the finance-arm of the World Bank), and USAID have all expressed concern with respect to the reliability and creditworthiness of the off-taker as a key challenge of Power Africa. ${ }^{276}$ In Tanzania in June 2012, several potential small power project developers complained to the national electricity regulator at a public meeting that the current PPA for grid-connected small power projects (SPPs) was not bankable on a project finance basis by the standards of non-Tanzanian financial institutions. ${ }^{277}$ Among the weaknesses that they pointed to in the current PPA were: (1) currency risk, since the payments would be in Tanzanian shillings, but debt payments would be in hard currencies such as dollars or euros; (2) a lack of indexing for the FIT price floor; and (3) no required payments if the buying utility was unable to receive energy from the SPP because of problems on the buyer's transmission grid. ${ }^{278}$ Ultimately, until IPPs are able to externalize their risk or African institutions establish a more bankable PPA, implementing Power Africa's goals will be challenging.

\section{Demand-side issues}

\section{Subsidy structures}

Even if a commercially sustainable and attractive investment climate and regulatory framework for IPPs is fostered by African governments, access to electricity must not be cost prohibitive for consumers if Power Africa is to be successfully implemented. Consumer or demand-side subsidies are one such mechanism in order to make electricity more affordable and therefore more accessible to those currently without access. In most African countries, tariffs for power are heavily subsidized. On average, power tariffs recover only $87 \%$ of full costs. ${ }^{279}$ Service subsidies amount to as much as $\$ 3.6$ billion per year, or .56\% of Africa's GDP. ${ }^{280}$ These subsidies contribute to the precarious financial state of national utilities. ${ }^{281}$ However, empirical evidence suggests that these subsidies largely bypass low-income households not even connected to services; accordingly, subsidies benefit the nonpoor. The share of subsidies going to the poor is less than half their share in the population, indicating a very pro-rich distribution. ${ }^{282}$ Accordingly, while the usual justification for subsidies is to make services affordable to low-income households, power subsidies are ironically and perversely structured to exclude low-income households from accessing electricity.

At the heart of this perverse logic is the politicization of subsidies through the causal mechanism of urban bias. The social and economic groups that are bypassed by subsidies-low-income households and those not connected to power services-map neatly onto rural populations. Additionally, heavy subsidies to urban consumption of electricity resonate strongly with urban bias theory. Because urban consumers place a significantly high value on their purchasing power, they are likely to pressure the government to provide heavy subsidies to power services in order to retain relatively strong purchasing power. ${ }^{283}$ Due to limited revenue $^{284}$ and the generally high macroeconomic cost of subsidies, ${ }^{285}$ it is unlikely that extending these

275 See supra notes 206-11.

276 See supra note 15.

277 Tenebaum et AL., supra note 60, at 159.

278 Id.

279 EBERHARD ET AL., supra note 4, at 115.

280 Id.

281 See supra note 211.

282 See EberHARD ET AL., supra note 4, at 117 (providing statistics of the distributional incidence of subsidies received by the poor).

283 See supra note 185.

284 See supra notes 175-79.

285 See Eberhard ET AL., supra note 4, at 118. 
subsidies is economically viable. Accordingly, following the script of urban bias, rural areas are squeezed in order to benefit the more politically-active urban sector that are greater threats to the survival of the regime.

A natural solution to overcome this disparity is to implement cross-subsidies, tariff structures where some customers pay more for their costs of supply and other customers pay less than their costs of supply. ${ }^{286}$ Effectively, one group of consumers subsidizes another group by paying different amounts. In the developing world, the three most common forms of cross-subsidies are divided along industrial/residential, high-usage/low-usage, and urban/rural lines. ${ }^{287}$ Despite the widespread approval of cross-subsidies as a policy instrument to further pro-poor, pro-rural electrification, ${ }^{288}$ state executives typically support uniform national tariffs, which, by definition, preclude cross-subsidization. ${ }^{289}$ Cross-subsidies are generally discouraged in policy statements and often statutorily prohibited. ${ }^{290}$ For example, Tanzania's 2008 Electricity Law states that "no customer class should pay more than a licensee than is justified by the costs that it imposes on such a licensee." 291 Although the adoption of cross-subsidies would be beneficial for rural electrification goals, it would come with significant political consequences. Urban consumers' de facto subsidization of rural consumers constitutes an erosion of urban purchasing power, which would not only be politically unpopular, but also illegal in some countries. Implementing cross-subsidies could open African governments to removal via election or other modes of unrest such as protects, strikes, or riots. Accordingly, low state capacity and the presence of urban bias present a significant deterrent to the legal adoption of cross-subsidies that would contribute to the goals of Power Africa.

\section{Connection charges}

Even if a government has created an investment and regulatory climate that allows for IPPs to be commercially sustainable and even has a subsidy structure in place that extends into low-income, rural areas, the lights may still not turn on. Connection charges, "the fee[s] charged to a customer to connect to an established distribution network", ${ }^{292}$ remain the single biggest impediment to expanding electrification in sub-Saharan Africa. ${ }^{293}$ Simply put, "to the unconnected, cheap power is as inaccessible as costly power." ${ }^{294}$ Connection rates are less than 30\% in Africa, compared to 65\% in South Asia and 85\% in Asia and the Middle East. ${ }^{295}$ Furthermore, many of those who remain without a connection live reasonably close to existing networks. ${ }^{296}$ Even when distribution lines are provided to increase access, the percentage of consumers who are able to connect to the network remains extremely low. ${ }^{297}$ The initial rates of connections in villages newly added to the electrical grid are as low as $10-20 \%$ of possible connections, and that number only increases only very slowly over time. ${ }^{298}$

Both the magnitude and structure of the connection charges are identified as characteristics that deter consumer access to electricity. In sub-Saharan Africa, connection charge prices incredulously often exceed

\footnotetext{
286 See Tenenbaum et aL., supra note 60, at 137.

287 Id.

288 See Tully, supra note 88, at 33; TenenBAum ET AL., supra note 60, at 11, 49, 139-41, 258; EBERHARD ET AL., supra note 4, at 103.

289 See Tenenbaum ET AL., supra note 60, at 139; supra notes 256-65.

290 See Tenenbaum et AL., supra note 60, at 137. But see id. at 137-48 (noting that statements and laws are sometimes ignored in practice).

291 Electricity Act of 2008, \$ 23(2)(f) (2008) (Tanz). But see id. \$23(2)(b) (noting that "tariffs should allow licensees to recover a fair return on their investment").

292 Golumbeanu \& Barnes, supra note 27, at 3.

293 Tenenbaum et AL., supra note 60, at 122; see also IEA, supra note 125, at 9, 101; Eberhard \& Shkaratan, supra note 2, at 14.

294 Eberhard et al., supra note 10, at ix; see also IEA, supra note 125, at 101.

295 EBERHARD ET AL., supra note 4, at 104.

296 Id.

297 Golumbeanu \& Barnes, supra note 27, at 2.

298 Id.
} 
a country's annual per capita income. ${ }^{299}$ Sub-Saharan Africa also has the highest number of connection charges in excess of $\$ 100$ per customer of any region in the world. ${ }^{300}$ For instance, in Tanzania, TANESCO, the national utility, sets connection charges to new customers based on distance from existing distribution lines: $\$ 297$ (thirty meters, $\$ 871$ (thirty-one to seventy-one meters), and $\$ 1,288$ (greater than seventy-one meters). ${ }^{301}$ With a per capita gross national income of $\$ 1,560,{ }^{302}$ this alone represents a significant constraint on access to electricity. Additionally, connection charges are typically structured as one-time, upfront fees. ${ }^{303}$ Given the magnitude of the charges, they can constitute a powerful disincentive to people who wish to obtain electricity, no matter how much they desire the service.

Several straightforward and feasible policy instruments have been suggested in order to make connection charges more manageable, such as capital subsidies or amortization schemes where the connection cost is rolled into the tariff or a long-term credit plan. ${ }^{304}$ However, few of these policies have been implemented in sub-Saharan Africa. ${ }^{305}$ This policy inertia is grounded in a political economic logic motivated by the incapacity of the state apparatus. Recall that this paper argues tariffs are set suboptimally low in sub-Saharan Africa in order to placate urban populations by effectively propping up their purchasing power through low electricity prices. ${ }^{306}$ Due to higher capital costs, higher operational costs, and lower economies of scale, providing power to rural areas is more costly than supplying it in urban areas. Accordingly, utilities may fall far short of recovering the expected operating costs in rural areas, particularly if connection charges are high and load factors are relatively low. ${ }^{307}$ If a utility doubts the government will make up the revenue shortfall, it will have an economic incentive to resist expanding service into rural areas. ${ }^{308}$ Accordingly, the high connection charge is an indirect way of discouraging new users from signing up, conceptualized as a form of "passive resistance" among state-owned utilities ${ }^{309}$ Explaining the failure of an electrification program in an African country, a donor memo lamented:

[name of utility] did not make an effort to roll out connections to poor households under this scheme as it had no incentives to connect them, since the actual connection costs were three times higher, and clearly these costs would not be recouped through the lower tariff revenue earned by serving lowincome household. ${ }^{310}$

Thus, connection costs epitomize the negative synergistic effect of low state capacity on demand-side barriers to rural electrification and the implementation of Power Africa. Pressures from both urban populations and the politicized institutions of the state create a regulatory framework characterized by suboptimal tariffs and subsidies that places considerable revenue strain and insolvency on national utilities. As a result of these structural factors, improper incentives exist for national utilities to extend access to electricity into rural areas. However, "getting prices right" would entail the imposition of additional costs on urban populations that come with potentially dire political consequences. Accordingly, connection costs remain high and constitute a significant barrier to the approach and goals of Power Africa.

299 Id. at 6.

300 Id.

301 Id. at 7.

302 The World BANk, GNI per capita PPP (current international \$), http://data.worldbank.org/indicator/NY.GNP.PCAP. PP.CD (last visited July 25, 2014).

303 Golumbeanu \& Barnes, supra note 27, at 2, 4-5.

304 Cook, supra note 56, at 311; Golumbeanu \& Barnes, supra note 27, at 7, 17, 19; TENENBAum ET AL., supra note 60, at 129.

305 But see, e.g., Tenenbaum ET AL., supra note 60, at 131, 136 (discussing Mali’s subsidy policy and Ethiopia's connection-feefinancing program).

306 See supra note 185.

307 Golumbeanu \& Barnes, supra note 27, at 2.

308 Id.; Tenenbaum ET AL., supra note 60, at 22, 126-27.

309 Tenenbaum ET AL., supra note 60, at 127.

310 Id. at 128. 


\section{Conclusion: Unchaining Shango}

Power Africa represents an auspicious and innovative initiative to address sub-Saharan Africa's extant power crisis that had significant implications for social, economic, and environmental development as well as the fulfillment of an implicit attribute of a number of human rights. Characterized by a focus on private sector investment and collaboration between United States governmental agencies, private sector investors and developers, and African governments, Power Africa truly is a new paradigm that has learned from the historical lack of success of traditional, top-down aid paradigms and structural adjustment programs. However, Power Africa faces a number of challenges in order to successfully achieve its goals by creating an attractive and favorable investment climate for long-term private sector investment and commercial sustainability, and providing the proper incentives for those currently lacking access to electricity — typically low-income, rural Africans - to be able to be involved with DG projects and afford access to the central grid. Thus far, the literature has devoted little attention to the challenges facing Power Africa, and the legal literature in particularly has not addressed power sector reform in sub-Saharan Africa.

Although the pervasive economic discourse of "getting prices right" and establishing a strong legal and regulatory framework are essential to the success of Power Africa, this paper has argued that there is an underlying political economic logic that causally explains two distinct yet related challenges of implementing Power Africa. Specifically, the lack of state capacity - evidenced by the politicization of the state bureaucracy and the presence of urban bias-have created institutional structures and a regulatory framework that threaten both the commercial sustainability of private sector power investment and the affordability of access to electricity by new users. State incapacity has produced an incompletely reformed hybrid power sector that is dominated by a vertically-integrated state monopoly and characterized by a centralized structure, insolvent national utilities, and politicized regulators. Lacking autonomy from urban populations, the African states have constructed a regulatory framework that constrains both the supply and demand elements of power access. IPPs are constrained by (1) suboptimal uniform tariff structures that render development of power projects in rural areas commercially unsustainable; (2) PPAs that lack needed clauses that ensure a revenue stream for producers while the national utility cannot receive power; and (3) the general creditworthiness and reliability of the off-taker. Potential new users of electricity are constrained by subsidy structures that bypass low-income, rural households in favor of urban households and expensive, poorly-structured connection charges to the grid.

The implications for future research stemming from this paper are considerable. At the time of this paper, Power Africa is nearing its second anniversary. Evaluating this paper's argument against actual evidence of Power Africa programs is the clearest step forward in this research program. Additionally, extending the theoretical framework of this paper to other developing power markets, such as Latin America and Southeast Asia that have an increased interest in renewable energy, would provide empirical robustness and a strong comparative element to the analysis. Lastly, given the significant differences in the investment mode $^{311}$ and the increasing financial activity of Chinese investment in the developing world, a broader comparative analysis of Power Africa should be undertaken against China's model of foreign assistance and international investment.

As Power Africa moves forward, United States governmental agencies, in addition to supplying African governments with technical assistance and credit enhancement and risk mitigation instruments to investors, must understand the effect that institutional structures and dynamics have on the public-private partnership power transactions that are at the core of Power Africa. Accordingly, this paper suggests a number of institutional and regulatory reforms to complement Power Africa's existing technical assistance. On the institutional front, it is clear that establishing stronger bureaucratic independence from politicized and parti-

311 See, e.g., Deborah Brautigam, The Dragon's Gift: The Real Story of China in Africa (2009). 
cularistic elements of the state apparatus and the state's independence from urban populations are essential for strengthening both absolute and relative state capacities. First, the erosion of urban bias results from the creation of institutional mechanisms that establish stronger links of accountability between state and rural populations. Simply put, a rationally-acting regime would quickly rethink policies systematically biased against rural areas if these populations constituted a threat to the survival of the regime. The establishment and further strengthening of robust democratic institutions, particularly electoral mechanisms, exemplifies a means to overcome urban bias. ${ }^{312}$ Indeed, the literature emphasizes that democracies ${ }^{313}$ with better functioning institutions $\mathrm{s}^{314}$ provide higher levels of public goods.

Decentralization and devolution are also recommended in order to help overcome suboptimal policies caused by state incapacity and urban bias. Given that rural electrification is a primary goal of Power Africa, there is a critical role for subnational governments and DG in Power Africa. Providing more authority and autonomy for subnational governments first and foremost removes the political pressures of urban constituents, a core component of urban bias, from the policy equation. Second, because there is a great deal of economic, environmental, and linguistic heterogeneity in sub-Saharan Africa, decentralization will be more efficient than central control because it allows administration to be tailored to local conditions. ${ }^{315}$ Lastly, DG projects will likely be more successful in the long-run under a decentralized approach because projects will better meet the needs of end users and involve them in the development of the project. Creating and empowering rural electrification agencies and rural electrification funds to oversee rural electrification should complement more macro-institutional reforms.

Additionally, African governments must be encouraged to rethink their current regulatory framework. In order for an extension of access to electricity to become a reality, both the supply-side needs and demand-side needs of electricity must be met. At its core, these two needs focus on making rural electrification commercially sustainable for IPPs and making access to power affordable for consumers. On the supply-side, uniform national tariffs should be replaced with cost-reflective tariffs in order to allow IPPs to charge higher prices to reflect the higher operating costs of providing power to rural areas. More generally, despite the lack of political unpopularity, allowing national utilities to raise prices in order to cover operating costs will address the serious issues of commercial insolvency that plague African power utilities and reduce their credibility as off-takers. Additionally, African governments should continue to be encouraged to utilize and develop PPAs with deemed energy clauses in order to assure IPPs of a revenue stream and limit the political risk associated with their development of energy and power projects.

On the demand-side, African governments must eschew extant subsidy structures that perversely support existing consumers of electricity, often residing in urban areas. Instead, African governments should legalize cross-subsidies of electricity and allow urban consumers to pay relatively higher prices in order for more rural consumers to afford electricity. Lastly, connection charges should be structured in a manner that both allow electricity providers to recoup their costs and potential consumers to afford connecting to the grid. For instance, capital subsidies could be provided by African governments or the development community in order to offset the high costs of connection. Additionally, restructuring connection charges from a one-time, lump sum payment upfront to an amortization scheme where the connection cost is rolled into the tariff or a long-term credit plan would allow for consumers to access the grid (netting the utility an additional customer) while repaying the connection charge in full over time. Ultimately, a broader and deeper understanding of African institutions and political economy can help light the way for powering development under the Power Africa Initiative. Without recognition of the underlying institutional dynamics that structure the African power sector, Shango will continue to be enchained and Power Africa will face an uphill battle.

312 See generally BATES, supra note 183.

313 See supra notes 141-43.

314 See, e.g., supra note 144.

315 See supra notes 230-32. 


\section{Levando o orçamento a sério como instrumento de controle de políticas públicas*}

\section{Taking the government budget seriously as an instrument to control public policies}

Andre Bogossian**

\section{Resumo}

O presente estudo pretende argumentar que o orçamento deve servir como principal instrumento de controle de políticas públicas. Levando-o a sério, os órgãos judiciais respeitam, ao mesmo tempo, as decisões majoritárias advindas do processo democrático e os direitos fundamentais cuja guarda lhes é atribuída pela Constituição. O estudo, que utiliza o método de revisão bibliográfica, se inicia com o exame da natureza e das características das políticas públicas, bem como sua relação com os direitos fundamentais e a possibilidade de controle judicial sobre elas. Aborda-se em seguida o orçamento, seu conceito e natureza jurídica, além de sua relação com o planejamento e com as políticas públicas. Por fim, demonstra-se a importância do orçamento enquanto elo que conecta o sistema político ao jurídico e a importância de se levar as decisões alocativas legitimamente feitas em conta quando do controle de políticas públicas por juízes, havendo espaço para que se faça a proposta de critérios limitativos à interferência jurisdicional na formulação orçamentária de políticas públicas. Nesse sentido, a depender de sua conexão com as propostas eleitorais e destas com os programas político partidários, o orçamento funciona como parâmetro de razoabilidade útil ao controle jurisdicional de políticas públicas.

Palavras-Chave: Políticas públicas. Controle judicial. Planejamento. Orçamento.

* Recebido em 28/03/2015 Aprovado em 24/05/2015

** Mestre em Teoria do Estado e Direito Constitucional pela PUC-Rio; Visiting Research Fellow na Brown University (EUA); Master of Laws (LL.M) candidate na Harvard Law School (2015-2016). E-mail: ambogossian@hotmail. com

\section{Abstract}

This essay argues that government budget should be used as the main instrument to control of public policies. When judicial institutions take it seriously, they respect, at the same time, majoritarian decisions from the democratic process and the fundamental rights they are responsible to guard as imposed by the Constitution. The essay, in a literature review, begins analyzing the nature and characteristics of public policies, and their relation to fundamental rights and the possibility of judicial control over them, which is followed by the public budget, its concept, nature and relation with planning and public policies. Finally, the essay turns to the importance of public budget as a link between the legal and political system and the importance of taking into account allocative decisions legitimately made 
when judges review public policies in concrete cases, therefore a space for a proposal of criteria limiting the judicial interference in the budgetary formulation of public policies: depending on its connection with electoral proposals and of that with political parties' programs in the democratic process, the budget works as a reasonableness parameter usefull to judicial review of public policies

Key-words: Public policies. Judicial review. Planning. Budget

\section{INTRODUÇÃo}

Diante de um texto constitucional claramente compromissório, que procurou atender a múltiplos interesses (típico de uma sociedade pluralista, ou, nas palavras de Diogo de Figueiredo Moreira Neto, uma sociedade policrática $\left.{ }^{1}\right)$, mas que legitimou a intervenção estatal no domínio econômico e social, ficou clara a intenção do Constituinte Originário em garantir o cumprimento dos chamados objetivos fundamentais da República brasileira, consubstanciados no artigo $3^{\circ}$ da Constituição Federal de 1988 (CF/88).

Para tanto, foi imprescindível o reconhecimento da efetividade dos direitos fundamentais ditos prestacionais, exigindo que o próprio Estado proporcione os meios de sua fruição a toda sociedade, indistintamente, por meio de políticas públicas levadas a cabo pelos entes federativos ${ }^{2}$. Estas devem ser formuladas no ambiente de disputa democrática ${ }^{3}$; isto é, a própria ação do Estado, no estabelecimento de prioridades, metas e programas significa criar compromissos financeiros e políticos, gerar equilíbrios e expectativas no enquadramento orçamental que os permita ${ }^{4}$.

Ocorre que a Carta de 1988 arrola tais direitos como direitos subjetivos, sem, contudo, definir exatamente como deve se pautar a atuação estatal na sua prestação, motivo pelo qual, na ausência ou insuficiência da intervenção do Poder Público diante dos casos concretos, tem ocorrido, nos últimos anos, o aumento de demandas em busca de sua tutela judicial. A crescente judicialização de tais questões possuiria, entretanto, viés de insegurança, o que acabaria por levar o Poder Judiciário a tomar decisões em uma seara que foi constitucionalmente atribuída aos Poderes Executivo e Legislativo.

A partir de então, desenvolveu-se extenso debate ${ }^{5}$ acerca da legitimidade da atuação do Poder Judiciário quando este, ao solucionar uma demanda concreta, interfere na execução das políticas públicas, o que acaba por afetar o planejamento orçamentário, seja ordenando que se realize gasto que não fora previsto, seja anulando uma dotação orçamentária destinada a outro setor para que haja verba disponível para efetuar a prestação referente à lide.

1 MOREIRA NETO, Diogo de Figueiredo. Curso de direito administrativo. 15. ed. Rio de Janeiro: Renovar,2009. p.17.

2 JORGE NETO, Nagibe de Melo. O Controle jurisdicional das políticas públicas. Salvador: Jus Podium, 2008. p.53.

3 Não se pretende discutir o conceito ou o valor da democracia; adota-se, portanto, a visão multifacetada de Diogo de Figueiredo Moreira Neto: "A democracia, enquanto conjunto de valores, é um modo de vida; enquanto instituição, conforma um regime político e, enquanto práxis, é uma técnica social para compor interesses diversos”. MOREIRA NETO, Diogo de Figueiredo. Direito da participação política. Rio de Janeiro: Renovar, 1992. p. xvii.

4 GARCIA, Maria da Glória F. P. D. Direito das Políticas Públicas. Coimbra: Almedina, 2009. p.52.

5 Apenas para citar algumas obras versando sobre o tema, em lista longe de ser exaustiva: BARCELLOS, Ana Paula de. Neoconstiucionalismo, direitos fundamentais e controle das políticas públicas. Revista de Direito Administrativo, Rio de Janeiro, n. 240, p.83-103, abr./jun. 2005; BORGES, Alice Gonzalez. Reflexões sobre a judicialização de políticas públicas. Revista Brasileira de Direito Público, Belo Horizonte, v. 7, n. 25, p. 9-44, abr./jun. 2009; D DAL BOSCO, Maria Goretti. Discricionariedade em Políticas Públicas. Curitiba: Juruá, 2007; DIAS, Jean Carlos. O controle judicial de políticas públicas. São Paulo: Método, 2007; FONTE, Felipe Melo. A legitimidade do Poder Judiciário para o controle de políticas públicas. Revista Brasileira de Direito Público, Belo Horizonte, v. 6, n. 20, p. 91-125, jan./mar. 2008; JORGE NETO, Nagibe de Melo. O Controle jurisdicional das políticas públicas. Salvador: Jus Podium, 2008; PALADINO, Carolina de Freitas. Políticas Públicas: considerações gerais e possibilidade de controle judicial. $A \ll C$ : Revista de Direito Administrativo e Constitucional. Belo Horizonte, v. 8, n.32, p. 219-242, abr./jun. 2008; MAURÍCIO JUNIOR Alceu. A revisão judicial das escolhas orçamentárias: a intervenção judicial em políticas públicas. Belo Horizonte: Fórum, 2009; VALLE, Vanice Regina Lírio do. Constitucionalização das Políticas Públicas e seus Reflexos no Controle. Fórum Administrativo, Belo Horizonte, v. 8, n. 85, p. 7-21, mar. 2008; entre outros. 
A questão torna-se ainda mais delicada quando se leva em conta a flagrante escassez de recursos ${ }^{6} \mathrm{em}^{-}$ poder da Administração Pública e a sua impossibilidade em efetuar gastos não previstos nas leis orçamentárias por força de ordem igualmente constitucional ${ }^{7}$. Essa atuação jurisdicional, que ignora qualquer consequência distributiva e de macro justiça ${ }^{8}$, ainda mais em um cenário de judicialização excessiva ${ }^{9}$, causa muitos problemas aos administradores na implementação de políticas públicas de qualidade ${ }^{10}$. $\mathrm{O}$ modo como o Judiciário, em geral, atua no orcamento, fazendo dele uma simples formalidade, uma grande tabela que pode ser emendada e remendada de acordo com a livre convicção de cada juiz em cada vara para solucionar os inúmeros casos concretos não leva o orçamento a sério, não o considera em sua real natureza de instrumento de consecução de uma vontade política legitimamente decidida pelo próprio povo por meio de seus representantes. Não se pode impedir o controle jurisdicional, mas este não pode simplesmente ser feito sem qualquer tipo de parâmetro ou critério objetivo que minimamente resguarde as decisões alocativas feitas legitimamente.

Por outro lado, a própria Carta de 1988 impõe o planejamento como imperativo para o Estado brasileiro (artigo $174 \mathrm{CF} / 88)^{11}$. Ele terá fundamental importância para o presente estudo e norteará a solução a ser desenvolvida. Deve-se compreender que o orçamento constitui o mecanismo orientador de toda a atividade estatal, principal aspecto do processo de ligação entre os sistemas político ${ }^{12}$ e jurídico ${ }^{13}$. Para se defender a legitimidade das políticas públicas, planificadas pelo orçamento, é necessário, portanto, em um primeiro momento, exigir a vinculação daqueles que formulam tais políticas aos projetos que se comprometeram a levar a cabo quando foram eleitos.

Desse modo, desde os processos eleitorais, nos quais as maiorias elegem um ou outro programa de governo que reputam ser mais adequado, deve-se ter como norte o dever de planejar. Um primeiro instrumento para seu balizamento constitui o programa dos partidos políticos, documento indispensável à sua criação e manutenção, de acordo com a Lei no 9.096/95 (a Lei dos Partidos Políticos). Os governantes, eleitos por meio dos partidos, devem atuar de acordo com o respectivo programa, como disposto na Lei $\mathrm{n}^{\mathrm{o}}$ 9.096/95 $5^{14}$. Suas propostas orçamentárias, portanto, devem representar, em razoável medida, as propostas feitas, e estas devem guardar semelhança com o programa partidário.

O presente estudo pretende argumentar que o orçamento deve servir como principal instrumento de controle de políticas públicas, compreendendo-o como processo de decisão coletiva que as viabiliza. Levá-lo a sério significa que o Poder Judiciário deve ser deferente às escolhas alocativas dos agentes representativos do interesse público quando essas escolhas de fato representem o projeto político vitorioso nas urnas. A proposta ora apresentada pretende delimitar o campo de atuação no qual o Judiciário pode legitimamente interferir no nível orçamentário, e, portanto, tem como objetivo minimizar os problemas causados pela

6 A limitação não é apenas financeira, mas também de tempo, mão de obra e outros recursos MAURíCIO JUNIOR, Alceu. $A$ revisão judicial das escolhas orçamentárias: a intervenção judicial em políticas públicas. Belo Horizonte: Fórum, 2009. p.125.

7 AMARAL, Gustavo. Direito, escassez e escolha. 2. ed. Rio de Janeiro: Lúmen Júris. 2009.

8 WANG, Daniel Wei L. Escassez de recursos, custos dos direitos e reserva do possível na jurisprudência do STF. Revista Direito GV, São Paulo, v. 4, n. 2, p. 539-568, jul./dez. 2008. p. 564.

9 BARROSO, Luís Roberto. Da falta de efetividade à judicialização excessiva: Direito à saúde, fornecimento gratuito de medicamentos e parâmetros para a atuação judicial. In: SOUZA NETO, Cláudio Pereira de; SARMENTO, Daniel (Org.) Direitos sociais: fundamentos, judicialização e direitos sociais em espécie. Rio de Janeiro: Lumen Juris, 2008. p. 875-905.

10 Por óbvio que não se está a imputar ao controle jurisdictional a culpa por todas as mazelas no campo de políticas públicas no Brasil. Contudo, é preciso lembrar que as constantes e descoordenadas interferências contribuem sim para o agravamento do problema.

11 Sobre planejamento, vide SOUTO, Marcos Juruena Villela. Direito administrativo da economia. Rio de Janeiro: Lumen Juris, 2003. 12 Seja ele político no sentido partidário, institucionalizado, ou não partidário, num sentido amplo, como atividade de organização do poder na sociedade . (BUCCI, Maria Paula Dallari. Direito administrativo e políticas públicas São Paulo: Saraiva, 2002. p.242).

13 FARIA, Júlio Herman. Políticas Públicas: o diálogo entre o jurídico e o político. A\& : Revista de Direito Administrativo e Constitucional, Belo Horizonte, v. 9, n. 35, p. 157-170, jan./mar. 2009.

14 Lei no 9.096/95: “Art. $5^{\circ}$ A ação do partido tem caráter nacional e é exercida de acordo com seu estatuto e programa, sem subordinação a entidades ou governos estrangeiros.” (grifo nosso). BRASIL. Lei $n^{\circ}$ 9.096, de 19 de setembro de 1995. Disponível em: <http://www.planalto. gov.br/ccivil_03/leis/L9096.htm>. Acesso em: 17 ago. 2015. 
atuação descoordenada entre Judiciário e Executivo. Levar o orçamento a sério significa, em outros termos, respeitá-lo como instrumento de consecução da vontade política manifestada nas urnas e, portanto, mais que mera folha de papel ou simples formalidade que impede a eficácia de direitos fundamentais. Levar o orçamento a sério consiste em tomá-lo como parâmetro minimamente objetivo para o controle da razoabilidade das escolhas alocativas nos casos concretos.

Ao fazê-lo, os órgãos judiciais respeitam ao mesmo tempo as decisões majoritárias advindas do processo democrático e os direitos fundamentais cuja guarda lhes é atribuída pela Constituição. Por esse motivo, o controle judicial deve ser feito pelo orçamento, e não — como se verifica atualmente — no orçamento.

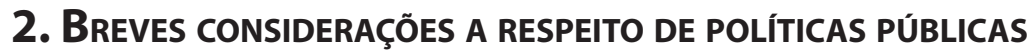

A Constituição e as leis garantem direitos aos cidadãos. Contudo, direitos têm custos, não nascem em árvores ${ }^{15}$; afinal, como indica a célebre frase atribuída a Milton Friedman, não existe almoço grátis ${ }^{16}$. Como demonstrado na paradigmática obra The Cost of Rights ${ }^{17}$, todos os direitos têm custo para sua proteção, até mesmo aqueles que se consideravam "negativos", de abstenção. A escassez de recursos constitui mais um dado inafastável ${ }^{18}$, o que, inclusive, é reconhecido pela Convenção Americana de Direitos Humanos, o conhecido Pacto de São José da Costa Rica (1969), em seu artigo $26^{19}$.

Assim, é utópico pensar que é possível atender sempre a todos. É preciso fazer escolhas trágicas, eis que o direcionamento de recursos para um setor significa retirar (ou ao menos reduzir) recursos para que outros interesses sejam satisfeitos ${ }^{20}$, na tentativa de incrementar o bem-estar dos beneficiários em montante tal que permita compensar a perda de bem-estar dos prejudicados ${ }^{21}$. A própria noção de "interesse público", foco do atuar administrativo, deixa de ser noção abstrata para se tornar constantemente objeto de negociação $0^{22}$. Dessa forma, tanto no microcosmos da decisão alocativa pontual quanto no macrocosmos do planejamento, não existe neutralidade, pois se tratam de escolhas entre várias possibilidades, guiadas por valores políticos e ideológicos possibilitados pelo quadro delineado pelo texto constitucional ${ }^{23}$.

A situação torna-se mais delicada, ainda, se levado em conta o chamado "efeito Buchanan"24, inicialmente verificado para sistemas públicos de saúde, mas que muito bem se aplica a qualquer tipo de demanda em sede de direitos prestacionais. O efeito Buchanan aponta para situação crônica de excesso de demanda, já que o cidadão exprime demanda potencialmente ilimitada, mas o mesmo cidadão, na posição de eleitor

15 GALDINO, Flávio. Introdução à teoria dos custos dos direitos: direitos não nascem em árvores. Rio de Janeiro: Lumen Juris, 2005.

16 FRIEDMAN, Milton. There's no such thing as a free lunch. Chicago: Open Court Publishing, 1975.

17 HOLMES, Stephen; SUNSTEIN, Cass R. The Cost of Rights: Why Libery Depends on Taxes. New York: Norton, 1999.

18 AMARAL, Gustavo. Direito, escassez e escolha. 2. ed. Rio de Janeiro: Lúmen Júris. 2009. p. 182.

19 Capítulo III - DIREITOS ECONÔMICOS, SOCIAIS E CULTURAIS. Artigo 26 - Desenvolvimento progressivo. Os Estados-partes comprometem-se a adotar as providências tanto no âmbito interno como mediante cooperação internacional, especialmente econômica e técnica, a fim de conseguir progressivamente a plena efetividade dos direitos que decorrem das normas econômicas, sociais e sobre educação, ciência e cultura, constantes da Carta da Organização dos Estados Americanos, reformada pelo Protocolo de Buenos Aires, na medida dos recursos disponiveis, por via legislativa ou por outros meios apropriados. (Grifo nosso). COMISSÃO INTERAMERICANA DE DIREITOS HUMANOS. Convenção Americana sobre direitos bumanos. Costa Rica, 22 de novembro de 1969. Disponível em: <http://www.cidh.oas.org/basicos/portugues/c.convencao_americana.htm>. Acesso em: 17 ago. 2015.

20 AMARAL, Gustavo. Direito, escassez e escolha. 2. ed. Rio de Janeiro: Lúmen Júris. 2009. p.150.

21 Assim são eficientes as decisões, segundo o critério de Kaldor-Hicks. GOLDBERG, Daniel K. Controle de Políticas Públicas pelo Judiciário: welfarismo em um mundo imperfeito. In: SALGADO, Lucia Helena; MOTTA, Ronaldo Seroa da (Ed.). Regulação e Concorrência no Brasil: governança, incentivos e eficiência. Rio de Janeiro: IPEA, 2007. p. 43-82. p. 52.

22 GARCIA, Maria da Glória F. P. D. Direito das Políticas Públicas. Coimbra: Almedina, 2009. p. 23.

23 BERCOVICCI, Gilberto. Planejamento e políticas públicas: por uma nova compreensão do papel do Estado. In: BUCCI, Maria Paula Dallari (Org) Políticas Públicas: reflexões sobre o conceito jurídico. São Paulo: Saraiva, 2006. p. 143-161. p. 146.

24 Originalmente apontado por BUCHANAN, James McGill. The inconsistencies of the National Health service. London: Institute of Economic Affairs, 1985. Em AMARAL, Gustavo. Direito, escassez e escolba. 2. ed. Rio de Janeiro: Lúmen Júris. 2009. p. 148. 
e contribuinte, reluta em aceitar as implicações fiscais do próprio comportamento. Em outras palavras, tal efeito verifica algo extremamente pertinente e verdadeiro no cenário brasileiro: muitos (ou todos) querem que o Estado prontamente satisfaça suas demandas, independente do seu custo, enquanto esses mesmos muitos relutam fortemente em contribuir para o próprio sistema, seja por meio da tributação (vide as taxas de sonegação e evasão fiscal), seja por meio da eleição dos projetos políticos que melhor atendam seus interesses particulares.

Como então definir quem, o que, como e quando atender? Nessa perspectiva, as políticas públicas entram em cena como mecanismo democrático institucionalizado capaz de gerar responsividade ${ }^{25}$.

O tema de políticas públicas, quando discutido em qualquer seara (seja no âmbito do direito, da economia, da política ou da administração), é por demais tormentoso. Ele envolve questões desde a compreensão do que é o Estado e quais suas funções (indagação que obviamente não se pretende responder nesta obra ${ }^{26}$ ) até o debate acerca da possibilidade de sua sindicabilidade judicial.

As políticas públicas envolvem um conjunto de ações praticado pelo Estado com a finalidade de dar efeito ao programa político sufragado, tendo em vista a realização dos balizamentos constitucionais. Perpassa a ideia de Estado na qualidade de devedor em uma relação jurídica obrigacional com particulares, os credores. ${ }^{27}$ Trata-se, portanto, de noção de auto-sujeição: o Estado-legislador é quem impõe ao Estado-Administrador quais as prestações a seu cargo, tendo como objetivo último, em regra, a satisfação de direitos fundamentais, não somente aos chamados direitos sociais. Em verdade, servem também aos direitos de primeira dimensão por meio, por exemplo, da política de segurança pública (proteção da propriedade e da liberdade) e aos direitos de terceira dimensão, por meio de políticas públicas para a proteção do meio ambiente. Note-se, entretanto, que não há relação unívoca entre políticas públicas e direitos fundamentais: nem todas as políticas públicas são voltadas a direitos fundamentais.

\subsection{Conceito e controle de políticas públicas}

No campo do direito, durante muito tempo impregnado por uma concepção que rejeitava pontos de interseção com outras áreas do conhecimento, imperou o entendimento de que a decisão quanto aos parâmetros de ação do Estado era terreno próprio e exclusivo da política. Com a abertura metodológica do direito à influência de outros campos do saber, notou-se a reinserção do assunto políticas públicas na pauta de debates. Isso se deve pelo fato de que o tema é, per si, multidisciplinar, devendo ser abordado numa concepção completa, e não fatiada em áreas do saber. Como indica Maria Paula Dallari Bucci, falar em políticas públicas, no direito, é reconhecer e tornar públicos os processos de comunicação, na estrutura burocrática do poder, entre direito e política ${ }^{28}$.

E não se esqueça do elemento técnico - indispensável para o sucesso da política pública. Não basta, para um resultado satisfatório, que a política pública advenha de uma demanda social; ela precisa ser bem planejada e executada. O endêmico fracasso de políticas públicas não pode ser atribuído somente a uma

25 A responsividade constitui conceito chave para a democracia representativa, correspondendo à capacidade do governo para fazer frente e corresponder às preferências dos cidadãos representados. Um governo responsivo é capaz de identificar os desejos e as aspirações dos seus representados e oferecer respostas por meio da adoção de comportamentos apropriados. Para uma abordagem mais aprofundada da noção, veja-se: PETTTIT, Philip. Varieties of public representation. In: SHAPIRO, I. et al. (Ed.). Political representation. Nova York: Cambridge University Press, 2009. p. 61-89; em WILLEMAN, Marianna Montebello. Desconfiança institucionalizada, democracia monitorada e Instituições Superiores de Controle no Brasil. Revista de direito administrativo, Rio de Janeiro, v. 263, p. 221-250, maio/ago. 2013.

26 Remete-se o leitor para a contextualização das políticas públicas neste debate em BUCCI, Maria Paula Dallari. Direito administrativo e políticas públicas São Paulo: Saraiva, 2002. p. 245.

27 SILVA, Alessandra Obara Soares da. Políticas Públicas: Condições e Possibilidades de Controle Judicial. In: CONGRESSO NACIONAL DE PROCURADORES DO ESTADO, 22., 2007, Porto Seguro, v. 1, p. 7.

28 BUCCI, Maria Paula Dallari. Direito administrativo e politicas públicas São Paulo: Saraiva, 2002. p. 241. 
falha econômica, mas também de sua viabilidade política e das opções institucionais ${ }^{29}$.

Nesse aspecto, não é demais notar que não somente a Administração direta implementa políticas públicas em áreas tradicionais como saúde e educação, mas também os órgãos reguladores setoriais independentes, integrantes da Administração Indireta, são responsáveis por inúmeras ações que também se enquadram no conceito de políticas públicas que será apresentado. $\mathrm{Na}$ verdade, uma das grandes vantagens da regulação setorial consiste na especialização técnica ${ }^{30}$, que teoricamente permite políticas mais acertadas.

Há, portanto, um sistema retroalimentável em que as demandas oferecidas pela sociedade são dirigidas ao sistema político, que, em virtude delas, responde por meio de adoção de medidas, como resposta. Sendo infindáveis as demandas, o sistema seria circular, igualmente infindável, pois, a cada demanda, haveria a necessidade de novas respostas. ${ }^{31}$

Partindo desse sistema, poderiam ser identificadas diversas etapas de um processo ${ }^{32}$ :

1. reconhecimento do problema - identifica-se nessa etapa um dado fático (qual seja a situação material a exigir a intervenção estatal) e um dado mais analítico, de reconhecimento de qual seja, descartados os elementos contingentes da situação fática, o efetivo tema em discussão;

2. formação da agenda - compreendendo um mecanismo mais ou menos aberto a agentes não governamentais, de estabelecimento de priorização para as ações públicas, incluindo (ou não) o problema recém-identificado, segundo uma ordem de precedência que reconfigure (ou não) aquela anteriormente estabelecida;

3. formulação da política pública - momento exploratório das várias possibilidades de ação tendo em conta o problema identificado na primeira etapa, a agenda traçada na segunda, e as interrelações entre as várias políticas públicas já em andamento;

4. escolha da política pública a ser implementada - concretiza-se aqui, à vista das alternativas pontadas na etapa anterior, a decisão acerca de qual a linha de ação a ser adotada, a partir (em princípio) da indicação de qual seja aquela que produz a otimização de esforços e/ou benefícios, tendo em conta os recursos disponíveis e mesmo as iniciativas já em andamento;

5. implementação da política pública eleita - etapa de concretização das atividades pontadas na formulação, e especificadas pela escolha;

6. análise e avaliação da política pública executada - na qual se dará a diagnose dos resultados alcançados, com o que se (re)legitima a ação adotada, agregando informações ao capital de conhecimento da Administração, permitindo ainda o redirecionamento de ações futuras. ${ }^{33}$

No direito pátrio, merecem destaque os posicionamentos de Fábio Konder Comparato e Maria Paula Dallari Bucci. Para a autora, políticas públicas são "metas coletivas conscientes", "programas de ação gover-

29 BERCOVICCI, Gilberto. Planejamento e políticas públicas: por uma nova compreensão do papel do Estado. In: BUCCI, Maria Paula Dallari (Org.) Políticas Públicas: reflexões sobre o conceito jurídico. São Paulo: Saraiva, 2006. p. 143-161. p. 144.

30 No Brasil há um número razoavelmente modesto de órgãos reguladores, de modo que sua atuação na formulação e execução de políticas públicas muitas vezes passa despercebida; contudo, em países como os Estados Unidos da América, em que Administração Pública é fortemente aparelhada com agências independentes, é intenso o debate a respeito da sua capacidade e legitimidade na implementação de políticas públicas. Cf. BREYER, Stephen et al. Administrative Law and Regulatory Policy. 4. ed. Nova York: Aspen Law \& Business, 1999. p 145-169.

31 VALLE, Vanice Regina Lírio do. Políticas Públicas, direitos fundamentais e controle judicial. Belo Horizonte: Fórum, 2009 . p. 40.

32 A ideia de conjunto de processos está também presente na doutrina norte-americana, incluindo, pelo menos, (1) a definição da agenda, (2) a especificação das alternativas a partir das quais uma escolha deve ser feita, (3) uma escolha revestida de autoridade, como num voto legislativo ou numa decisão presidencial, e (4) a implementação da decisão. KINGDOM, John. Agendas, alternatives and public policies. New York: Harper Collins College Publishers, 1995. p. 2-3; Em BUCCI, Maria Paula Dallari. O conceito de política pública em direito. In: (Org). Políticas públicas: reflexões sobre o conceito jurídico. São Paulo: Saraiva, 2006. p. 1-49. p. 39. 33 VALLE, Vanice Regina Lírio do. Políticas Públicas, direitos fundamentais e controle judicial. Belo Horizonte: Fórum, 2009. p. $40-41$. 
namental visando coordenar os meios à disposição do Estado e as atividades privadas, para a realização de objetivos socialmente relevantes e politicamente determinados" ${ }^{34}$. Para Fábio Konder Comparato, políticas públicas consistem no " conjunto organizado de normas e atos tendentes à realização de um objetivo determinado”. Para ele, há distinção entre as políticas públicas em si e os atos e normas que lhe dão concretude, afirmando que o juízo de validade de uma política não se confunde nunca com o juízo de validade das normas e atos que a compõem ${ }^{35}$.

Percebe-se, assim, uma faceta dúplice: as políticas públicas são materializadas por atos administrativos e encontram seu substrato na ordem jurídica ao responder a comandos legais ou constitucionais. Fábio Konder Comparato destaca:

a categoria de política pública é inovadora na ordem jurídica porque distingue-se das categorias de normas e atos jurídicos, embora esses elementos sejam partes integrantes dela. A concepção de política pública está mais próxima da de atividade: conjunto organizado de normas e atos tendentes à realização de um objetivo determinado. ${ }^{36}$

A interferência do Judiciário nas políticas públicas desenvolvidas pelo Poder Executivo gera imenso debate. Há inúmeros argumentos favoráveis e contrários às decisões judiciais que, sob o pretexto de assegurar um direito fundamental constitucionalmente garantido (cujos maiores exemplos são saúde e educação), acabam por ordenar a alteração no sistema de prestações estatais. Não constitui o escopo do presente trabalho entrar nos meandros de tamanha discussão. Parte-se da premissa de que o controle judicial de políticas públicas é fato, um dado da realidade. Proibir de forma absoluta o controle por parte do Poder Judiciário pode levar a sérias e desnecessárias situações de violação a direitos fundamentais, enquanto permitir livremente que o Judiciário interfira na execução orçamentária seria um convite à insegurança jurídica e ao decisionismo desenfreado.

Assim, a única solução viável para o problema perpassa pela possibilidade de o Judiciário fazer valer os comandos constitucionais, mas de modo que seja possível controlar a racionalidade de suas decisões. É necessário, portanto, que se imponham parâmetros objetivos a servir de norte para as decisões judiciais, a fim de que não se evite apenas a insegurança jurídica decorrente da possibilidade de decisões contraditórias sobre o mesmo tema, mas também do possível esvaziamento das noções de democracia e separação de poderes.

A seguir será iniciada a exposição da resposta encontrada para a questão suscitada, que será desenvolvida apresentando conceitos necessários como os de orçamento e planejamento, e, ao fim, oferecida a solução encontrada, indicando de qual modo o orçamento pode (e deve) ser levado em conta em sede de controle de políticas públicas pelo Poder Judiciário; ou seja, evitando-se interferências do Poder Judiciário que causem mais problemas no âmbito geral do que geram soluções nos casos concretos.

\section{O OrÇamento}

O orçamento consiste no instrumento pelo qual se positiva toda a atividade financeira do Estado, tendo sua sede na Constituição; “é um ato essencialmente político de caráter jurídico-permissivo, através do qual

34 BUCCI, Maria Paula Dallari. Direito administrativo e políticas públicas São Paulo: Saraiva, 2002. p. 241.

35 COMPARATO, Fábio Konder. Ensaio sobre o juízo de constitucionalidade. Revista de Informação Legislativa. Brasília, v. 35, n. 138, p. 39-48, abr./jun. 1998; em FONTE, Felipe Melo. A legitimidade do Poder Judiciário para o controle de políticas públicas. Revista Brasileira de Direito Público, Belo Horizonte, v 6, n. 20, p. 91-125, jan./mar. 2008. p.99.

36 COMPARATO, Fábio Konder. Ensaio sobre o juízo de constitucionalidade. Revista de Informação Legislativa. Brasília, v. 35, n. 138, p. 39-48, abr./jun. 1998; em COELHO, Helena Beatriz Cesarino Mendes. Condições e Possibilidades do Controle Judicial de Políticas Públicas. In: CONGRESSO NACIONAL DE PROCURADORES DO ESTADO, 22., 2007, Porto Seguro, v. 1, p. 580. 
o Poder Legislativo autoriza, limita e controla as despesas realizadas pelo Poder Executivo.”37. Nada pode ser feito pelo Estado sem que tenha amparo no orçamento, tal qual indicado pelo artigo 167, incisos I e II da $\mathrm{CF} / 88^{38}$.

A discussão acerca da natureza jurídica da lei orçamentária constitui uma das mais clássicas no Direito Financeiro: são dois os entendimentos — o primeiro, tradicional, propugnando pela natureza jurídica de lei formal do orçamento, ou seja, um simples ato-condição que apenas formalmente reveste as características de lei ${ }^{39}$; e o segundo, defendendo sua natureza de lei em seu sentido formal e material, da qual seria possível extrair direitos subjetivos.

Pelo primeiro posicionamento, o orçamento apenas prevê as receitas públicas e autoriza as despesas, sem, entretanto, criar direitos subjetivos para terceiros ou obrigar o Estado a efetuar os gastos autorizados. A falta de previsão da despesa não possibilita sua realização, mas isso não implica o fato de que, havendo a autorização, o administrador esteja obrigado a efetuá-la ${ }^{40}$. Fica evidente, portanto, o caráter autorizativo e não impositivo atribuído ao orçamento. Este foi e é o entendimento predominante no Brasil — ainda que recentes alterações constitucionais mitiguem tal posicionamento. A justificativa para a adoção de tal sistema seria a necessidade de conferir ao Poder Executivo flexibilidade na execução orçamentária, evitando que dotações pudessem vir a ser exigidas judicialmente.

Contudo, como indica Eduardo Mendonça, o orçamento autorizativo, no Brasil, significa o poder de não gastar. Mais que isso, trata-se na verdade de decisão de não gastar naquilo que fora planejado ${ }^{41}$. Isso ocorre porque o Chefe do Executivo, durante o curso da execução orçamentária, não tem liberdade formal para alterar unilateralmente as dotações orçamentárias ${ }^{42}$, mas, por sua vez, tem a possibilidade de contingenciar recursos, ou seja, de não liberar verbas para o destino contemplado no orçamento.

É mais crítico ainda o cenário quando se nota que tais decisões de contingenciamento carecem, em sua maioria, de maior motivação formal. Como se não bastasse a superação de decisão majoritária por ato unilateral (de contingenciamento), tal opção não tem sido acompanhada de motivação que lhe permitisse conferir um mínimo de legitimidade. O sistema orçamentário brasileiro vinha conferindo em geral ao Poder Executivo a faculdade de simplesmente ignorar as previsões orçamentárias, sem nem ao menos indicar os motivos que justificariam tais escolhas. ${ }^{43}$

Ainda, não é possível esquecer que a despesa pública é a contrapartida da receita pública, sendo, em verdade, a razão que justifica a existência dos encargos fiscais. Ora, em última análise, só se legitima a existência de certa carga tributária imposta sobre a população se esta auferir, de algum modo, benefícios daquela. Não faz sentido, portanto, que os representantes instituam certo montante de arrecadação e prevejam investimentos compatíveis com tal decisão, mas seja possibilitado ao Chefe do Executivo ignorar as escolhas feitas

37 CRUZ, Luiz Guilherme de O. Maia. Filosofia Orçamentária: o exercício da Cidadania pela Via do Orçamento. Revista de Direito da Associação dos Procuradores do Novo Estado do Rio de Janeiro, Rio de Janeiro, n. 8, p. 39-67, 2001. p. 42.

38 Art. 167. São vedados:I - o início de programas ou projetos não incluídos na lei orçamentária anual; II - a realização de despesas ou a assunção de obrigações diretas que excedam os créditos orçamentários ou adicionais. BRASIL. Constituição (1988). Constituição da Republica Federativa do Brasil. Disponível em: <http://www.planalto.gov.br/ccivil_03/Constituicao/ConstituicaoCompilado. htm>. Acesso em: 17 ago. 2015.

39 TORRES, Ricardo Lobo. Curso de direito financeiro e tributário. Rio de Janeiro: Renovar, 2008. p. 176.

40 CRUZ, Luiz Guilherme de O. Maia. Filosofia Orçamentária: o exercício da Cidadania pela Via do Orçamento. Revista de Direito da Associação dos Procuradores do Novo Estado do Rio de Janeiro, Rio de Janeiro, n. 8, p. 39-67, 2001. p. 42.

41 MENDONÇA, Eduardo Bastos Furtado de. Da faculdade de gastar ao dever de agir: o esvaziamento contramajoritário de políticas públicas. Revista de Direito do Estado, Rio de Janeiro, v. 3, n. 9, p. 279-326, jan./mar. 2008. p. 282.-285

42 Em que pese a possibilidade de remanejamento de recursos por meios não ordinários, utilizando manobras contábeis, como a proposital subestimação de receitas ou superestimação de despesas para manipulação do limite de abertura de crédito suplementar (previsto no artigo 165, $\int 8^{\circ}$, da CF/88). SIQUEIRA, Vanessa. A Rigidez Orçamentária e a Perda de Discricionariedade do Chefe do Poder Executivo: uma Realidade? São Paulo: Conceito, 2011. p. 110.

43 MENDONÇA, Eduardo Bastos Furtado de. Da faculdade de gastar ao dever de agir: o esvaziamento contramajoritário de políticas públicas. Revista de Direito do Estado, Rio de Janeiro, v. 3, n. 9, p. 279-326, jan./mar. 2008. p. 290. 
pura e simplesmente. O sistema orçamentário, como será visto adiante, deve ser encarado completo, e não apenas como momentos singularmente analisados.

Um segundo entendimento acerca da natureza jurídica do orçamento propugna pela sua compreensão enquanto lei em sentido amplo, ou seja, não apenas revestido de natureza formal legislativa, mas também assim compreendido em sentido material. O orçamento teria o condão de criar direitos, sendo dele, portanto, possível extrair pretensões jurídicas. Seria uma lei em sentido pleno, de conteúdo normativo, com eficácia material constitutiva ou inovadora e com todas as características de valor e força de lei, como a impossibilidade de se derrogarem suas disposições por mero ato normativo, bem como a possibilidade de modificar e até derrogar normas precedentes de hierarquia igual ou inferior ${ }^{44}$.

Entretanto, adotar tal posição in totum poderia levar a um engessamento da atividade financeira do Estado. Havendo dotação prevista para determinado fim, seria exigível que todo o montante previsto fosse utilizado, bastando apenas como condição para tanto que a receita correspondente se concretizasse. Não se aceitaria, portanto, o contingenciamento de recursos, tal qual ocorre, como visto, na percepção autorizativa do orçamento; havendo não a faculdade, mas o dever de gastar naquilo que fora deliberado quando da confeç̧ão da peça orçamentária, restaria inviabilizada ao Poder Executivo a adequação da execução orçamentária durante o seu curso, em que poderiam ocorrer fatores supervenientes que legitimamente demandariam alteração nos gastos estatais, o que, na prática, não é raro.

No Brasil, com a edição da Lei de Diretrizes Orçamentárias (LDO) de 2014, a Lei no 12.919, de 24 de dezembro de 2013, inaugurou-se a adoção parcial do chamado "orçamento impositivo", apenas para as emendas parlamentares ao projeto apresentado pelo Executivo. Essa posição ganhou força e status constitucional com a Emenda Constitucional 86, de 17 de março de 2015. Os dispositivos oriundos da própria proposta do Executivo continuam a se sujeitar à possibilidade de contingenciamento; em contraste, deve-se pagar integralmente as emendas parlamentares (os recursos orçamentários que deputados e senadores incluíram em emendas ao projeto de lei orçamentária submetido pelo Poder Executivo), impedindo o contingenciamento de tais recursos.

Tal inovação no ordenamento brasileiro veio como fruto de impasse institucional entre Congresso e Executivo, como má solução entre ameaças de ambas as partes: em troca da aprovação do Projeto de Lei Orçamentária Anual para 2014, o governo se comprometeu a não vetar o "Orçamento Impositivo" na LDO daquele ano, que originou o "orçamento semi-impositivo" no Brasil. Do mesmo modo, a EC 86/2015 teria vindo para colocar um fim à subserviência do Legislativo em relação ao Governo e, consequentemente, limitar o pouco republicano "balcão de negócios" que tem sido estabelecido em torno da execução orçamentária. Com efeito, o interesse dos parlamentares na realização de determinadas despesas acaba sendo utilizado como meio de troca nas intrincadas articulações políticas com o Poder Executivo. Contudo, pela impositividade restar limitada às emendas individuais acrescentadas por cada parlamentar à lei orçamentária ${ }^{45}$, o restante das dotações continua desvinculado, o que mantém a natureza predominantemente facultativa do orçamento no Brasil.

Enfim, uma posição moderna propugna pela compreensão do orçamento como programa de gestão estatal, ou seja, um plano que expressa em termos financeiros, em determinado período de tempo, o programa de ações governamentais e os seus meios de meios de financiamento. É o chamado orçamento-programa ${ }^{46}$. Toma-se em conta o orçamento em uma finalidade de instrumento da gestão estatal, levando-se em conta sua função econômica, dando-se ênfase aos aspectos financeiros ${ }^{47}$.

44 TORRES, Ricardo Lobo. Curso de direito financeiro e tributário. Rio de Janeiro: Renovar, 2008. p.178.

45 Limitadas a R \$ 16,3 milhões per capita, o que resultará em um gasto global próximo a R \$ 10 bilhões com a "cota pessoal de orçamento", nas palavras de Eduardo Mendonça. MENDONÇA, Eduardo. Constituição e Sociedade: o falso orçamento impositivo. Disponível em: <http://jota.info/constituicao-e-sociedade-o-falso-orcamento-impositivo>. Acesso em: 22 fev. 2015.

46 Cf. SILVA, José Afonso da. Orçamento-programa no Brasil. São Paulo: Revista dos Tribunais, 1973. p. 272.

47 SIQUEIRA, Vanessa. A Rigidez Orçamentária e a Perda de Discricionariedade do Chefe do Poder Executivo: uma Realidade? São Paulo: 


\subsection{Planejamento e orçamento: ligação entre sistemas}

O conceito de planejamento está ligado a uma ideia de racionalização das atividades econômicas. Se sua origem remonta aos países de economia dirigida, sua utilização por países liberais foi aos poucos sendo verificada ao longo do século $\mathrm{XX}^{48}$.

Pode-se compreender planejamento na qualidade de um processo, da atividade de aplicação de sistema racional de escolhas entre um conjunto de alternativas reais de investimentos e outras possibilidades para o desenvolvimento, baseado na consideração dos custos e benefícios sociais. Assim, planejamento é o processo, plano é a concretização ${ }^{49}$, o documento que o formaliza, e planificação é o resultado de tal atividade ${ }^{50}$. Trata-se da expressão da política geral do Estado, um ato de direção política, sempre comprometido axiologicamente com a ideologia constitucional adotada ${ }^{51}$.

A base jurídica do planejamento no país foi delineada pelo Decreto-Lei no 200/67, que o firmou como princípio a ser observado nas atividades administrativas, estabelecendo também que a ação governamental deverá obedecer a planejamento que vise promover o desenvolvimento econômico-social do país e a segurança nacional, norteando-se, segundo planos e programas, e compreendendo a elaboração e atualização de alguns instrumentos básicos, como o plano geral de governo, programas gerais, setoriais e regionais, de duração plurianual, orçamento-programa-anual e a programação financeira de desembolso. ${ }^{52}$

Com a Carta de 1988 o planejamento ganhou status constitucional ${ }^{53}$, eis que, no artigo $174^{54}$, foi transformado de mero ordenador da atividade administrativa em principal instrumento de Estado na atividade econômica ${ }^{55}$. Assim, sendo a Constituição o meio idôneo a legitimar e limitar o poder, se está o Estado autorizado a intervir na seara econômica (e também na social, eis que não são mundos apartados), só deve fazê-lo se houver prévio planejamento ${ }^{56}$. O planejamento deve, por óbvio, configurar a sede primeira dos eventuais conflitos e ponderações a serem realizadas entre os divergentes interesses consagrados na Constituição Federal.

Em que pese a inexistência da lei a qual se refere o artigo 174 da CF/88, percebe-se que a elaboração do planejamento no país se dá por meio da orçamentação de curto, médio e longo prazo ${ }^{57}$. Tal fato corrobora a tese de que é imperioso emprestar nova concepção ao orçamento, de modo que este não seja levado em conta apenas quando da elaboração da lei anual. Em verdade, as atenções devem se voltar ao processo de planejamento que será efetuado desde a elaboração do Plano Plurianual, passando pela Lei de Diretrizes Orçamentárias e, aí sim, chegando às especificações devidas na Lei Orçamentária Anual.

Conceito, 2011. p.131

48 SOUTO, Marcos Juruena Villela. Direito administrativo da economia. Rio de Janeiro: Lumen Juris, 2003. p. 17-20.

49 BERCOVICCI, Gilberto. Planejamento e políticas públicas: por uma nova compreensão do papel do Estado. In: BUCCI,

Maria Paula Dallari (Org.) Politicas Públicas: reflexões sobre o conceito jurídico. São Paulo: Saraiva, 2006. p. 143-161. p. 148.

50 FERREIRA, Sérgio de Andréa. Eficácia jurídica dos planos de desenvolvimento econômico. Revista de direito Administrativo. Rio de Janeiro, n. 140, p. 16-36, abr./jun. 1980.

51 BERCOVICCI, Gilberto. Planejamento e políticas públicas: por uma nova compreensão do papel do Estado. In: BUCCI, Maria Paula Dallari (Org.) Políticas Públicas: reflexões sobre o conceito jurídico. São Paulo: Saraiva, 2006. p. 143-161. p.145.

52 Art $7^{\circ}$ Decreto-Lei no 200/67. BRASIL. Decreto-Lei $n^{\circ}$ 200, de 25 de fevereiro de 1967. Disponível em: < http://www.planalto.gov. br/ccivil_03/decreto-lei/Del0200.htm>. Acesso em: 17 ago. 2015.

53 É possível falar em um "princípio do planejamento", também chamado de "princípio da programação". SIQUEIRA, Vanessa. A Rigidez Orçamentária e a Perda de Discricionariedade do Chefe do Poder Executivo: uma Realidade? São Paulo: Conceito, 2011. p. 47.

54 Art. 174. Como agente normativo e regulador da atividade econômica, o Estado exercerá, na forma da lei, as funções de fiscalização, incentivo e planejamento, sendo este determinante para o setor público e indicativo para o setor privado. BRASIL. Constituição (1988). Constituição da Republica Federativa do Brasil. Disponível em: <http://www.planalto.gov.br/ccivil_03/Constituicao/ ConstituicaoCompilado.htm>. Acesso em: 17 ago. 2015.

$55 \mathrm{Na}$ área econômica, o planejamento deve obedecer aos princípios constitucionais setoriais, sobretudo os que concernem à propriedade privada, à livre iniciativa e à livre concorrência, de forma que não se cogita a rejeição do sistema de mercado. SOUTO, Marcos Juruena Villela. Direito administrativo da economia. Rio de Janeiro: Lumen Juris, 2003. p. 21-22.

56 SOUTO, Marcos Juruena Villela. Direito administrativo da economia. Rio de Janeiro: Lumen Juris, 2003. p. 22

57 BERCOVICCI, Gilberto. Planejamento e políticas públicas: por uma nova compreensão do papel do Estado. In: BUCCI, Maria Paula Dallari (Org) Políticas Públicas: reflexões sobre o conceito jurídico. São Paulo: Saraiva, 2006. p. 143-161. p. 156. 
O que se defende é uma visão do orçamento na qualidade de instrumento jurídico do planejamento econômico e social, demandado pela Constituição. Propugna-se, portanto, por tomar em conta o orçamento em sua dimensão ampla, em relação ao seu processo, e não somente em relação a uma de suas etapas, qual seja, a final: a percepção do orçamento como momento unicamente centrado na confecção da Lei Orçamentária Anual é por demais reducionista. Ele deve ser tomado como o instrumento de ligação entre os sistemas político, social e jurídico.

O início do planejamento se dá com a eleição de determinado projeto político nas urnas. De tempos em tempos, o povo vai às ruas, em um exercício de conteúdo mínimo de democracia formal, para escolher, dentre as diversas propostas, aquela que melhor atende aos seus anseios. A sociedade se organiza politicamente em torno de um Estado Democrático de Direito e lança mão de mecanismos institucionais de seleção de representantes, com a finalidade última de que estes adotem programas de governo que atendam minimamente as mais variadas necessidades de intervenção estatal identificadas por seus componentes. ${ }^{58}$

Em verdade, uma sociedade inserta num ambiente democrático escolhe, em maioria, o programa de governo que pretende ver adotado pelos representantes. Os programas político-partidários e as diretrizes, se cumpridos pelos representantes eleitos do povo, deveriam ser garantia de que as escolhas serão respeitadas. Assim, o planejamento, quando feito com base nesses programas e diretrizes, já nasce com carga de legitimidade advinda da própria sociedade ${ }^{59}$. A cada processo eleitoral, renovam-se as esperanças e cria-se expectativa legítima no seio da sociedade de que aquelas propostas irão sair do papel. Infelizmente, a ideia acima exposta fica bem longe do que se tem visto na prática da política brasileira. O que há, de fato, é a conhecida insinceridade eleitoral. Na realidade, o planejamento confeccionado pelos representantes do povo em pouco se aproxima com o prometido em sede de campanha, e muito em menos do que consubstanciara o programa político-partidário, o que acaba por frustrar as expectativas da sociedade quanto à resolução dos inúmeros problemas sociais.

Trata-se, como visto, de frustração de confiança depositada institucionalmente pelos eleitores naqueles agentes representativos. Não é por outro motivo que o saudoso Marcos Juruena Villela Souto defendia, com absoluta precisão, que a promessa feita ao setor privado contida e consubstanciada no planejamento valeria como direito, de modo que seria forçoso reconhecer ao plano eficácia jurídica ${ }^{60}$.

Assim, aprovado o plano e contabilizadas as ações nas leis orçamentárias, impossível negar o direito de que sejam atendidos os anseios da sociedade, ainda mais pelo fato de terem sido institucionalmente legitimados por meio da elaboração do plano. Tal é a gravidade dessa violação, que o descumprimento de tal planejamento, para o citado autor, caracterizaria crime de responsabilidade (artigo 85, inciso VII CF/88) ${ }^{61}$. Ainda que se considere que as leis orçamentárias possuem natureza meramente autorizativa, não obrigando o Estado a realizar as despesas ali previstas, não há como desconsiderar a natureza de ato jurídico do plano. Isso ocorre porque ele condiciona a elaboração do orçamento, sendo vedadas as ações que não estejam nele previstas.

\section{LEVANDO O ORÇAMENTO A SÉRIO}

Em um mundo pós-moderno, em que se verifica o ocaso de um modelo de democracia meramente for$\mathrm{mal}^{62}$ e a necessidade de sua superação, são os cidadãos fonte e a justificação — e não apenas sujeitos — da

58 FARIA, Júlio Herman. Políticas Públicas: o diálogo entre o jurídico e o político. A\&C: Revista de Direito Administrativo e Constitucional, Belo Horizonte, v. 9, n. 35, p. 157-170, jan./mar. 2009. p. 157.

59 FARIA, Júlio Herman. Políticas Públicas: o diálogo entre o jurídico e o político. A\&C: Revista de Direito Administrativo e Constitucional, Belo Horizonte, v. 9, n. 35, p. 157-170, jan./mar. 2009. p.161.

60 SOUTO, Marcos Juruena Villela. Direito administrativo da economia. Rio de Janeiro: Lumen Juris, 2003, p.29.

61 SOUTO, Marcos Juruena Villela. Direito administrativo da economia. Rio de Janeiro: Lumen Juris, 2003p.30.

62 A democracia, enquanto regime que se afirma na origem individual e inalienável do poder, entrou em crise à medida que se tornava meramente formal, no mero cumprimento de ritos eleitorais para sacramentar o acesso aos cargos de representação política. 
autoridade; são eles que avaliam e que julgam o exercício do poder pelo Estado e por seus governantes ${ }^{63}$. Nesse cenário, o paradigma de controle da atividade estatal é o do resultado e não mais o da mera legalidade ${ }^{64}$, de modo que só se sagrará legítimo o Estado que proporcionar os resultados almejados por aqueles que são fonte de sua autoridade. As políticas públicas são os instrumentos que possuem os governos para tanto e o planejamento constitui requisito indispensável para o sucesso das políticas públicas, sendo o orçamento a principal peça do planejamento. Não se fazem governos sem políticas públicas, não se fazem políticas públicas sem planejamento e não se faz planejamento sem orçamentação.

De fato, se ilegítimo é um governo que atua em sentido contrário aos anseios da sociedade que o elegeu (ilegitimidade corrente), igualmente carente de legitimidade é o governo que não atinge os resultados almejados por aquela sociedade (ilegitimidade finalística) ${ }^{65}$.

Assim, se o controle do atuar administrativo não mais se verifica somente em relação à legalidade, mas à legitimidade — em seu sentido amplo, utilizado nesse contexto —, não é possível impedir que o Poder Judiciário atue em determinados casos concretos, sob pena de legitimar a desídia e a ineficiência de certas esferas do poder estatal em concretizar direitos fundamentais prestacionais. O recurso à via judicial é, na esmagadora maioria das vezes (salvo casos de má-fé, que, infelizmente, não raro ocorrem), o reflexo do resultado insatisfatório da implementação de determinadas políticas públicas, do não atendimento ao resultado esperado pela sociedade, de modo que não se pode simplesmente negar de forma absoluta o recurso ao Judiciário.

De outra monta, não é desejável que se delegue a juízes ampla capacidade decisional nessa seara, sob pena de se chancelar um decisionismo arbitrário, um autoritarismo de juízes que não são Hércules. Não se pode esquecer de que a atuação do Judiciário nas escolhas alocativas é meramente subsidiária ${ }^{66}$, útil apenas quando as instâncias primárias — Executivo e Legislativo — se omitem ou atuam de modo ineficiente. Os argumentos afetos à falta de capacidade técnica e institucional, de legitimidade das instâncias representativas e da escassez de recursos em hipótese alguma podem ser desconsiderados ${ }^{67}$.

Verifica-se, assim, que a única solução apta a produzir resultados efetivos consiste em impor aos juízes parâmetros para que possam decidir quando frente a um caso de efetivação de direitos fundamentais em face de políticas públicas insuficientes, ineficazes ou inexistentes.

De fato, por se tratar de ponderação de interesses, é necessário que ou se criem standards ${ }^{68}$ de ponderação para cada caso ou se defina um método de atuação para a magistratura. Optar-se-á pela segunda possibilidade, lançando mão do orçamento como principal instrumento de controle a disposição do Poder Judiciário.

\subsection{Orçamento como parâmetro controle da razoabilidade das escolhas alocativas}

Não é de hoje que o Poder Judiciário emprega controle constitucional de razoabilidade dos atos administrativos. A razoabilidade é postulado normativo aplicativo ${ }^{69}$, ou seja, é norma que não impõe fim (como os princípios) ou comportamento (como as regras), mas apenas estrutura o dever de realizá-los.

MOREIRA NETO, Diogo de Figueiredo. Direito da participação política. Rio de Janeiro: Renovar, 1992. p.6.

63 WILLEMAN, Marianna Montebello. Desconfiança institucionalizada, democracia monitorada e Instituições Superiores de Controle no Brasil. Revista de direito administrativo, Rio de Janeiro, v. 263, p. 221-250, maio/ago. 2013.

64 Sobre o resultado, vide. MOREIRA NETO, Diogo de Figueiredo. Quatro paradigmas do direito administrativo pós-moderno. Belo Horizonte: Fórum, 2008.

65 MENDONÇA, Eduardo Bastos Furtado de. Mutações do direito público. Rio de Janeiro: Renovar, 2006. p. 29.

66 MAURÍCIO JR., Alceu. A revisão judicial das escolhas orçamentárias: a intervenção judicial em políticas públicas. Belo Horizonte:Fórum, 2009. p. 285.

67 Para um resumo de tais argumentos: MAURÍCIO JR., Alceu. A revisão judicial das escolhas orçamentárias: a intervenção judicial em politicas públicas. Belo Horizonte:Fórum, 2009.

68 GARCIA, Maria da Glória F. P. D. Direito das Políticas Públicas. Coimbra: Almedina, 2009. p. 53.

69 Compreende-se a razoabilidade e a proporcionalidade como postulados normativos, tal qual Humberto Ávila em AVILA, Humberto. Teoria dos princípios: da definição à aplicação dos princípios jurídicos. 9. ed. São Paulo: Malheiros, 2010. 
A magistratura tem utilizado, de forma ainda insuficiente, o orçamento como instrumento de controle de políticas públicas, havendo margem para um aprimoramento institucional. Ora, se é admissível que o Judiciário exerça controle de razoabilidade amplo, não só de atos do Poder Público, mas também das leis, e se é correto considerar o orçamento como instrumento jurídico (que deveria ser) revestido de legitimidade e apto a orientar a execução de políticas públicas, a conclusão que se pretende extrair é a de que devem os juízes extrair do próprio orçamento os balizamentos para o controle da atuação estatal.

Até hoje, como visto, quando se fala em controle de políticas públicas, o que se está a dizer é que os órgãos de controle atuam mesmo como integrantes formuladores de decisões alocativas (como veto-player, verdadeiro centro de regulação positiva ou negativa de políticas públicas, com capacidade de veto e criação de novas políticas pelo remanejamento de dotações $)^{70}$. Ao fazê-lo, na realidade, os magistrados não levam em conta as decisões alocativas realizadas pelas instâncias legitimadas. Trata-se, na prática, de um controle no orçamento, e não de um controle pelo orçamento.

Propugna-se, portanto, pelo respeito ao orçamento como fruto de um planejamento e reflexo de decisão democrática. Já foi mencionado que o orçamento deve representar o conjunto de propostas institucionais vencedor nas urnas; assim, o respeito ao que fora decidido na sede orçamentária não seria um respeito ao administrador ou ao legislador, mas à própria população.

Ocorre que, infelizmente, tais práticas são de difícil verificação no cenário atual brasileiro. É profunda a crise de legitimidade que assola as instâncias representativas, e isso se deve, em grande parte, à conhecida insinceridade eleitoral. Poucos são os partidos políticos no país que têm um projeto, um programa institucional definido, ficando a maioria numa zona de penumbra que, de tanto prometer, acaba por cair em contradição. O chamado "estelionato político" "71 é cometido principalmente pelos próprios partidos e seus filiados, que prometem, durante o período eleitoral, feitos que sabem que serão invariavelmente descumpridos.

Não se pretende ignorar que, muitas vezes, os governantes encontram, no decurso do mandato, situações imprevistas e imprevisíveis, que ensejam a modificação do que haviam prometido e planejado. Antes fosse este o problema. O que se vê, na verdade, é que são raras as agremiações políticas com propostas claras e definidas e que as coloquem em prática quando em posição para tanto.

Assim, pode-se dizer que os problemas verificados numa extremidade do sistema (a execução das políticas públicas) têm raízes profundas noutra extremidade (a da formação da vontade institucionalizada do corpo político soberano). Até que os mecanismos de participação direta da sociedade sejam aprimorados (e não faltam boas propostas para tanto, a começar pelo orçamento participativo, até a inclusão direta da vontade individual na formação das políticas públicas ${ }^{72}$ ).

Não se quer, por óbvio, atribuir aos problemas da insinceridade eleitoral e da crise de representatividade o mérito pelo déficit na prestação de programas estatais de qualidade. Há muitos outros percalços, como a sufocante burocracia, a perversa corrupção, que desvia para cofres particulares astronômicas cifras do erário, a falta de preparo técnico de alguns agentes administrativos, entre tantas outras mazelas que poderiam ser mencionadas, mas que não são objeto do presente estudo.

70 FERREIRA, Camila Duran et al. O Judiciário e as políticas públicas de saúde no Brasil: o caso AIDS. Disponível em: <www.ipea.gov. sobreipea/40anos/estudantes/monografiacamila.doc >. Acesso em: 17 ago. 2015.

71 SOUTO, Marcos Juruena Villela. Direito administrativo da economia. Rio de Janeiro: Lumen Juris, 2003. p. 31.

72 Como no "exercício de futurologia" (em um futuro que não é distante), tal qual nomeado por Diogo de Figueiredo Moreira Neto, com brilhante acuidez, previu, ainda em 1992. Nessa pequena vinheta, ilustra o autor a participação de João e Maria na formação das leis que irão reger suas vidas. Por meio de dispositivos tecnológicos disponíveis em sua casa (a visão do autor não tardará a se concretizar, ante o estágio da automação residencial), o jovem casal de operários tem acesso às questões na pauta diária dos órgãos legislativos local, estadual e federal; com poucos comandos, João e Maria votam em temas como a redução do imposto predial ou o aumento de pena para sequestradores, "sintonizando" e "deixando no computador do Tribunal Regional Eleitoral" suas preferências nessas questões. MOREIRA NETO, Diogo de Figueiredo. Direito da participação política. Rio de Janeiro: Renovar, 1992. p. 1-2. 
O que se pretende demonstrar neste estudo é que há uma solução jurídica e faticamente viável para, ao menos, contribuir para que haja previsibilidade nas decisões judiciais na seara em questão, de modo a conferir maior segurança e estabilidade ao sistema, além de provocar melhoramentos no processo orçamentário. Não se tem a utópica pretensão de sanar definitivamente o problema, que, como visto, é afetado por diversos outros fatores, além do que se está a enfrentar.

A Lei no 9.096/95 — a Lei dos Partidos Políticos — impõe que a ação do partido tenha caráter nacional e seja exercida de acordo com seu estatuto e programa (artigo $5^{\circ}$ ). O programa partidário tem função-chave no sistema, eis que vincula a atuação do partido, devendo também ser registrado junto ao Registro Civil de Pessoas Jurídicas e ao Tribunal Superior Eleitoral, que lhe conferem publicidade ${ }^{73}$. Seu artigo 14 dispõe que os partidos devem fixar seus objetivos políticos no programa, estando livres quanto ao seu conteúdo. Já o artigo 24 impõe que a atuação dos integrantes da bancada partidária se dê de acordo com os princípios doutrinários e programáticos e às diretrizes estabelecidas pelos órgãos de direção partidários.

Em suma, toda a atuação do partido e seus integrantes deve ter como norte as disposições do seu programa, registrado nos órgãos competentes e de conhecimento da sociedade. Assim, também as promessas eleitorais, que virão posteriormente a subsidiar a formatação do planejamento estatal, devem ser feitas de acordo com a orientação programática do partido. Trata-se, como já citado, de manutenção das expectativas criadas nos administrados.

Desse modo, é possível exigir impor um mínimo de coerência institucional à atuação dos partidos. Por exemplo, um partido que se diz liberal não pode, em seu programa, prometer, e muito menos planejar medidas estatizantes.

A solução que se oferece é bastante simples: como visto, o orçamento deve representar o planejamento de governo, que deve ser feito com base no projeto político-institucional vitorioso nas urnas. Se, diante de um caso concreto, um magistrado verificar que as decisões alocativas foram tomadas de acordo com as decisões políticas feitas pela sociedade em um padrão de razoabilidade, então ele não poderá imiscuir-se em tal tarefa e efetuar escolhas realocativas.

É preciso notar que a Carta de 1988 impõe, ela própria, alguns limites mínimos de investimentos a serem efetuados em determinadas áreas, que representam as exceções ao princípio da não vinculação da receita proveniente dos impostos a qualquer fundo, órgão ou despesa. Assim, por exemplo, os Estados, Distrito Federal e Município não podem alocar menos de vinte e cinco por cento da receita resultante de impostos na manutenção e desenvolvimento do ensino (artigo 212 CF/88). Qualquer decisão alocativa abaixo dos limites mínimos impostos pela Constituição dá automaticamente ensejo a intervenção judicial.

Noutros termos: suponha-se que tenha sido politicamente vitorioso um projeto que preze pelo investimento no transporte público. O planejamento de governo deve ser norteado pela proeminência desse setor, eis que foi essa a vontade popular. A confecção das leis orçamentárias deve contemplar investimentos superiores ao que fora alocado nessa área em períodos anteriores, deve revelar uma preocupação com esse projeto eleitoral, sem, contudo, descurar dos limites mínimos impostos pela Constituição Federal em outras áreas, como saúde e educação.

Nesse cenário, duas situações podem advir na prática: a primeira, em que de fato o orçamento elaborado respeita a vontade popular, possuindo intensa carga de legitimidade; e a segunda, em que, ao invés de priorizar o transporte público, se prioriza o investimento em cultura e esportes, por exemplo.

73 Art. $7^{\circ} \mathrm{O}$ partido político, após adquirir personalidade jurídica na forma da lei civil, registra seu estatuto no Tribunal Superior Eleitoral. Art. $8^{\circ} \mathrm{O}$ requerimento do registro de partido político, dirigido ao cartório competente do Registro Civil das Pessoas Jurídicas, da Capital Federal, deve ser subscrito pelos seus fundadores, em número nunca inferior a cento e um, com domicílio eleitoral em, no mínimo, um terço dos Estados, e será acompanhado de: [...]. II - exemplares do Diário Oficial que publicou, no seu inteiro teor, o programa e o estatuto. BRASIL. Lei no 9.096, de 19 de setembro de 1995. Disponível em: <http://www.planalto.gov.br/ ccivil_03/leis/L9096.htm>. Acesso em: 17 ago. 2015. 
No primeiro caso, deve a defesa do ente público demonstrar que há medidas efetivas para alcançar o resultado pretendido pela sociedade - com a efetiva aplicação dos recursos em programas na área beneficiada - ou apresentar razoável motivação para o contingenciamento ${ }^{74}$; de nada adiantaria planejar e formalizar uma peça orçamentária de acordo com o interesse público se toda ou boa parte das verbas forem contingenciadas.

Caso demonstre-se o efetivo ${ }^{75}$ cumprimento do planejamento, diante de uma demanda em que uma pessoa ou um grupo pretenda alguma prestação estatal que envolva custos não previstos, não está autorizado o juiz a remanejar dotações orçamentárias. Isso porque, nessa primeira hipótese, o orçamento atendeu aos anseios populares e as escolhas alocativas foram tomadas de modo legítimo.

A razoabilidade, nessa perspectiva, entra em cena para impedir que abusos sejam cometidos. Ora, dizer que as escolhas alocativas de recursos vão priorizar uma ou outra área não significa dizer que somente essas áreas serão contempladas. A razoabilidade consiste em instrumento utilizado para balizar as decisões, para que estejam sempre em consonância com a vontade popular. Assim, quanto mais próximas forem as escolhas alocativas orçamentárias do projeto eleitoral vitorioso, mais razoáveis elas serão e, portanto, mais contidos devem ser os juízes ao avaliar as políticas públicas decorrentes do planejamento legítimo.

$\mathrm{Na}$ segunda hipótese, ocorreu uma formação patológica no planejamento orçamentário, que irá carecer de legitimidade, estando, portanto, sujeito a intervenções por parte do Judiciário. Mesmo em um caso em que a demanda não envolva os interesses que foram indevidamente negligenciados (no caso transporte público), confere-se ao magistrado o poder de interferir na decisão alocativa.

Não que se defenda que irá o próprio juiz elaborar as escolhas, substituindo-se ao administrador e ao legislador. Em verdade, o magistrado poderá apenas solver o problema que tem em mãos, estando autorizado a interferir em um planejamento (ainda que ilegítimo) apenas na medida necessária para garantir o direito fundamental que tiver em concreto $^{76}$. O que se propõe é que, nesses casos, além da medida de curto prazo, também ele imponha o saneamento da patologia, de modo que na elaboração dos próximos orçamentos seja respeitada a vontade popular ${ }^{77}$.

Uma solução para coibir tais práticas consiste em aceitar, tal qual Maria Goretti Dal Bosco, que os agentes políticos nessas situações patológicas sejam responsabilizados com base na da Lei de Improbidade Administrativa (Lei no 8.429/92), em especial no artigo 11, pela violação ao dever de honestidade e lealdade ${ }^{78}$, e ao princípio da moralidade insculpido no artigo 37 , caput, da CF $/ 88^{79}$.

Esse tipo de controle pode vir a ter como resultado o fortalecimento no Brasil de uma cultura orçamentária, que nada mais é do que a percepção de que a cidadania fiscal não se esgota no dever de pagar tribu$\operatorname{tos}^{80}$. É saudável a aproximação da sociedade, ainda que inicialmente por intermédio do Poder Judiciário, da realidade do planejamento orçamentário, o que sem sombra de dúvidas contribui para a fiscalização do resultado da atuação estatal.

74 Cf. MENDONÇA, Eduardo Bastos Furtado de. A constitucionalização das finanças públicas no Brasil. Rio de Janeiro: Renovar, 2010. 75 Note-se que, apesar de desejável e até sindicável enquanto princípio constitucional (artigo 37, caput, da CF/88), não se faz um juízo de eficiência da política pública, bastando que ela seja efetiva. BRASIL. Constituição (1988). Constituição da Republica Federativa do Brasil. Disponível em: <http://www.planalto.gov.br/ccivil_03/Constituicao/ConstituicaoCompilado.htm>. Acesso em: 17 ago. 2015.

76 Em atenção ao chamado minimalismo judicial (ou minimalismo decisional), as decisões judiciais devem ser "estreitas" e "rasas", ao decidir somente o caso em mãos e apenas na menor profundidade que permita a solução da lide. SUNSTEIN, Cass. One case at a time: judicial minimalism on the Supreme Court. Cambridge: Harvard University Press, 1999. p. 4-10.

77 Solução próxima à aqui desenvolvida é avançada por Alceu Maurício Jr: MAURÍCIO JUNIOR, Alceu. A revisão judicial das escolhas orçamentárias: a intervenção judicial em políticas públicas. Belo Horizonte: Fórum, 2009. p.258.

78 Art. 11. Constitui ato de improbidade administrativa que atenta contra os princípios da administração pública qualquer ação ou omissão que viole os deveres de honestidade, imparcialidade, legalidade, e lealdade às instituições, e notadamente.

79 DAL BOSCO, Maria Goretti. Discricionariedade em Políticas Públicas. Curitiba: Juruá, 2007. p. 426-438.

80 MENDONÇA, Eduardo Bastos Furtado de. Da faculdade de gastar ao dever de agir: o esvaziamento contramajoritário de políticas públicas. Revista de Direito do Estado, Rio de Janeiro, v. 3, n. 9, p. 279-326, jan./mar. 2008. p. 295. 
Ao levar o orçamento a sério e exercer o controle da atividade pública pelo orçamento ao invés de controle no orçamento, as instâncias de controle atuam como contrapoderes democráticos, entendida, nesse contexto, a contrademocracia não como uma antítese do regime democrático, mas um reforço a sofisticar a democracia representativa-eleitoral e a sustenta-la no tempo ${ }^{81}$.

\subsection{Refutando algumas objeções}

Uma primeira objeção que poderia ser feita à tese proposta reside na ineficiência que haveria ao obrigar juízes a olhar para o orçamento e para o projeto político vencedor sempre que surgisse uma demanda, envolvendo direitos prestacionais. Ora, os projetos políticos referenciais somente poderão ser alterados a cada quatro anos, quando da ocorrência de eleições. E não é demais exigir que, a cada ano, os tribunais avaliem a compatibilidade das leis orçamentárias com o planejamento de longo prazo e com o projeto político vencedor, editando súmulas de orientação (não vinculantes, obviamente) para os magistrados, evitando que estes tenham que parar para, caso a caso, efetuar tal verificação. Não se está defendendo neste estudo a criação de nenhum procedimento ou instituto novo, mas apenas a utilização eficiente de mecanismos já existentes na prática jurisdicional para garantir a efetividade das escolhas democraticamente feitas.

Ainda, poder-se-ia argumentar que o exemplo utilizado tomou como base projeto político em que fora definida apenas uma prioridade, o que não condiria com a prática política real. Não se desconsidera que, na maioria das vezes, na prática, os projetos políticos apresentados à população não são tão específicos, fazendo inúmeras promessas em praticamente todas as áreas sociais e econômicas. Tal fato em nada se contrapõe com o que foi estabelecido neste estudo. A maioria dos projetos destaca um ou outro ponto de maior relevância, propondo programas específicos em certas áreas. Em verdade, seria preferível que fossem detalhadas as propostas e que estas indicassem áreas prioritárias, mas na inocorrência de tal detalhamento permanece o raciocínio, pelo que quem muito promete muito terá que cumprir. É possível que a implementação da proposta avançada neste estudo gere mesmo ganhos futuros ao forçar uma maior especificação dos projetos políticos apresentados, o que muito contribuiria para o processo democrático brasileiro.

O mesmo se diga do planejamento e da orçamentação, caso apresentem propostas genéricas em termos confusos, sem que se possa extrair ações concretas nas áreas prioritárias, pois o ônus de descumprir o dever de transparência irá recair naquele que deu causa; ou seja, não pode o Poder Executivo se esconder atrás de artifícios, eis que suas violações aos princípios orçamentários também sofrerão com o controle judicial.

Não se afirme também que o presente estudo ignora os inúmeros problemas sistêmicos encontrados no sistema orçamentário brasileiro ${ }^{82}$. Por óbvio, reconhece-se a imperfeição das regras do jogo orçamentário, mas elas não formam obstáculo às propostas avançadas neste estudo; pelo contrário, crê-se que parte dos problemas endêmicos pode ser combatida com o que foi ora indicado. A solução apresentada, ao vincular a orçamentação às propostas políticas, acaba por exigir maior transparência e coerência nas formulações orçamentárias, e, nesse sentido, pode ser valioso mecanismo de alteração da cultura de corrupção e insinceridade eleitoral.

Uma última questão que pode ser levantada, referente à competência do Poder Judiciário: admite a Constituição o controle proposto? Entende-se que sim, não só pela inafastabilidade da jurisdição, contida no artigo $5^{\circ}$, inciso XXXV da CF/88, que abrange não somente a tutela da lesão, mas também a da ameaça a direito ${ }^{83}$, mas também pelo reconhecimento de que, em última instância, se trata de um controle de razoabilidade — e, portanto, de constitucionalidade, por parte do Poder Judiciário.

81 WILLEMAN, Marianna Montebello. Desconfiança institucionalizada, democracia monitorada e Instituições Superiores de Controle no Brasil. Revista de direito administrativo, Rio de Janeiro, v. 263, p. 221-250, maio/ago. 2013.

82 Alguns deles relatados em SIQUEIRA, Vanessa. A Rigidez. Orçamentária e a Perda de Discricionariedade do Chefe do Poder Executivo: uma Realidade? São Paulo: Conceito, 2011.

83 MAURÍCIO JR., Alceu MAURÍCIO JR., Alceu. A revisão judicial das escolhas orçamentárias: a intervenção judicial em políticas públicas. Belo Horizonte:Fórum, 2009. p.261. 


\section{Considerações finais}

O escopo do presente estudo consistiu na análise do papel do orçamento na formulação e sindicabilidade de políticas públicas, argumentando-se por uma compreensão que leve o orçamento a sério, ou seja, como parâmetro controle da razoabilidade das escolhas alocativas. O respeito ao planejamento orçamentário significa, ao mesmo tempo, o respeito aos direitos fundamentais, cuja guarda é incumbida pela Constituição ao Poder Judiciário, e à democracia. Se há a consciência de que a democracia não pode ser apenas o cumpri-

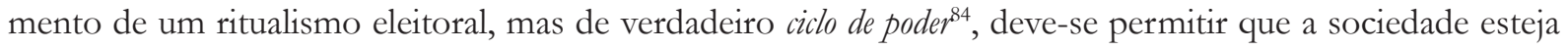
ativa e exerça influência tanto no início quanto no fim desse processo.

Procurou-se demonstrar como o sistema de políticas públicas é complexo e envolve aspectos transdisciplinares, sendo elas o meio adequado a prestar efetividade aos direitos fundamentais prestacionais. Não se quis afastar de modo absoluto a possibilidade de controle jurisdicional de políticas públicas, mas foi preciso reconhecer que não é atribuição do STF formular e implementar políticas públicas, certo que se tratam de tarefas primariamente atribuídas ao Legislativo e Executivo. No entanto, como salientou o ministro Celso de Mello no julgamento da ADPF 45, tais incumbências podem ser atribuídas ao Judiciário "se e quando os órgãos estatais competentes, por descumprirem os encargos político-jurídicos que sobre eles incidem, vierem a comprometer, com tal comportamento, a eficácia e a integridade de direitos individuais e/ou coletivos impregnados de estatura constitucional, ainda que derivados de cláusulas revestidas de conteúdo programático". Portanto, se é necessário reconhecer um poder de garantia de efetividade dos direitos prestacionais ao Judiciário, é igualmente imprescindível - como em qualquer aspecto que envolva o emprego de poder institucionalizado em uma república - pensar em modos de controle, de limitação desse poder. Desse modo, é necessário pensar em parâmetros e condições objetivas sob as quais o Judiciário pode exercer tal controle.

Assim, procurou-se oferecer critério de análise para que os magistrados, diante de casos concretos, possam decidir segura e legitimamente. A previsibilidade das decisões constitui elemento fundamental para conferir segurança ao ordenamento e o controle de políticas públicas pode, sim, ser feito pelo orçamento, e não no orçamento. Avançando a correlação do orçamento com o planejamento para a deste com as promessas eleitorais e destas com os programas político-partidários, pretende-se combater a chamada insinceridade eleitoral, que representa verdadeira fraude ao processo majoritário e frustração ao ciclo de formulação de políticas públicas.

Para que seja legítimo, deve o planejamento orçamentário ser reflexo das escolhas políticas e institucionais realizadas pela população nos momentos eleitorais. Sendo este o caso, somente assim estariam as decisões alocativas imunes à interferência do Poder Judiciário, eis que revestidas de forte carga de legitimidade; em hipótese diversa, na ocorrência de estelionato político, seria permitido o controle por parte do Poder Judiciário daquele planejamento indevido e despido de legitimidade. Desse modo, espera-se que a proposta apresentada neste estudo, além de contribuir para a redução dos casos patológicos de estelionato eleitoral, seja útil ao aprimoramento das instituições republicanas e ao cumprimento por todos os Poderes Constituídos do dever compartilhado e constitucionalmente imposto de efetividade dos direitos fundamentais.

\section{REFERÊNCIAS}

AMARAL, Gustavo. Direito, escassez, e escolha. 2. ed. Rio de Janeiro: Lúmen Júris. 2009.

AVILA, Humberto. Teoria dos princípios: da definição à aplicação dos princípios jurídicos. 9. ed. São Paulo: Malheiros, 2010.

84 Segundo Diogo de Figueiredo Moreira Neto, o ciclo do poder começa pela sua destinação, passa por sua atribuição, pelo seu exercício, pela sua distribuição e pela sua contenção, até chegar a seu último aspecto, a detenção. MOREIRA NETO, Diogo de Figueiredo. Direito da participação política. Rio de Janeiro: Renovar, 1992. p. 7. 
BALEEIRO, Aliomar. Introducão à ciência das finanças. Rio de Janeiro: Forense, 1994.

BARCELLOS, Ana Paula de. Neoconstiucionalismo, direitos fundamentais e controle das políticas públicas. Revista de Direito Administrativo, Rio de Janeiro, n. 240, p.83-103, abr./jun. 2005.

BARROSO, Luís Roberto. Da falta de efetividade à judicialização excessiva: Direito à saúde, fornecimento gratuito de medicamentos e parâmetros para a atuação judicial In: SOUZA NETO, Cláudio Pereira de; SARMENTO, Daniel (Org.) Direitos sociais: fundamentos, judicialização e direitos sociais em espécie. Rio de Janeiro: Lumen Juris, 2008. p. 875-905.

BARROSO, Luís Roberto. Neoconstitucionalismo e constitucionalização do direito: o triunfo tardio do direito constitucional no Brasil. Revista da EMERJ, Rio de Janeiro, v. 9, n. 33, p. 43-92, 2006.

BERCOVICCI, Gilberto. Planejamento e políticas públicas: por uma nova compreensão do papel do Estado. In: BUCCI, Maria Paula Dallari (Org.) Políticas Públicas: reflexões sobre o conceito jurídico. São Paulo: Saraiva, 2006. p. 143-161.

BORGES, Alice Gonzalez. Reflexões sobre a judicialização de políticas públicas. Revista Brasileira de Direito Público, Belo Horizonte, v. 7, n. 25, p. 9-44, abr./jun. 2009.

BRASIL. Constituição (1988). Constituição da Republica Federativa do Brasil. Disponível em: < http:/ /www.planalto.gov.br/ccivil_03/Constituicao/ConstituicaoCompilado.htm>. Acesso em: 17 ago. 2015.

BRASIL. Decreto-Lei n ${ }^{\circ}$ 200, de 25 de fevereiro de 1967. Disponível em: < http:/ /www.planalto.gov.br/ccivil_03/ decreto-lei/Del0200.htm>. Acesso em: 17 ago. 2015.

BRASIL. Lei ñ 9.096, de 19 de setembro de 1995. Disponivel em: <http://www.planalto.gov.br/ccivil_03/leis/ L9096.htm>. Acesso em: 17 ago. 2015.

BRASIL. Supremo Tribunal Federal. Arguição de Descumprimento de Preceito Fundamental. ADPF 45-9/ DF. Tribunal Pleno. Arguente: Partido da Social Democracia Brasileira. Arguido: Presidente da República. Rel. Min. Celso de Mello. Brasilia, 29 de abril de 2004. Disponível em: <http:/ /www.sbdp.org.br/arquivos/ material/343_204\%20ADPF\%202045.pdf>. Acesso em: 22 fev. 2015.

BREYER, Stephen et al. Administrative Law and Regulatory Policy. 4. ed. Nova York: Aspen Law \& Business, 1999.

BUCCI, Maria Paula Dallari. Direito administrativo e políticas públicas São Paulo: Saraiva, 2002.

BUCCI, Maria Paula Dallari. O conceito de política pública em direito. In: (Org). Políticas públicas: reflexões sobre o conceito jurídico. São Paulo: Saraiva, 2006. p. 1-49.

COELHO, Helena Beatriz Cesarino Mendes. Condições e Possibilidades do Controle Judicial de Políticas Públicas. In: CONGRESSO NACIONAL DE PROCURADORES DO ESTADO, 22., 2007, Porto Seguro, v. 1.

COMISSÃO INTERAMERICANA DE DIREITOS HUMANOS. Convenção Americana sobre direitos humanos. Costa Rica, 22 de novembro de 1969. Disponível em: <http://www.cidh.oas.org/basicos/portugues/c. convencao_americana.htm>. Acesso em: 17 ago. 2015

COMPARATO, Fábio Konder. Ensaio sobre o juízo de constitucionalidade. Revista de Informação Legislativa. Brasília, v. 35, n. 138, p. 39-48, abr./jun. 1998.

CRUZ, Luiz Guilherme de O. Maia. Filosofia Orçamentária: o exercício da Cidadania pela Via do Orçamento. Revista de Direito da Associação dos Procuradores do Novo Estado do Rio de Janeiro, Rio de Janeiro, n. 8, p. 39-67, 2001.

DAL BOSCO, Maria Goretti. Discricionariedade em Políticas Públicas. Curitiba: Juruá, 2007 
DIAS, Jean Carlos. O controle judicial de políticas públicas. São Paulo: Método, 2007.

FARIA, Júlio Herman. Políticas Públicas: o diálogo entre o jurídico e o político. A\&C: Revista de Direito Administrativo e Constitucional, Belo Horizonte, v. 9, n. 35, p. 157-170, jan./mar. 2009.

FERREIRA, Camila Duran et al. O Judiciário e as políticas públicas de saúde no Brasil: o caso AIDS. Disponível em: <www.ipea.gov.sobreipea/40anos/estudantes/monografiacamila.doc>. Acesso em: 17 ago. 2015.

FERREIRA, Sérgio de Andréa. Eficácia jurídica dos planos de desenvolvimento econômico. Revista de direito Administrativo. Rio de Janeiro, n. 140, p. 16-36, abr./jun. 1980.

FONTE, Felipe Melo. A legitimidade do Poder Judiciário para o controle de políticas públicas. Revista Brasileira de Direito Público, Belo Horizonte, v. 6, n. 20, p. 91-125, jan./mar. 2008.

FONTE, Felipe Melo. Políticas públicas e direitos fundamentais. São Paulo: Saraiva, 2013.

FRIEDMAN, Milton. There's no such thing as a free lunch. Chicago: Open Court Publishing, 1975.

GALDINO, Flávio. Introdução à teoria dos custos dos direitos: direitos não nascem em árvores. Rio de Janeiro: Lumen Juris, 2005.

GARCIA, Maria da Glória F. P. D. Direito das Políticas Públicas. Coimbra: Almedina, 2009

GOLDBERG, Daniel K. Controle de Políticas Públicas pelo Judiciário: welfarismo em um mundo imperfeito. In: SALGADO, Lucia Helena; MOTTA, Ronaldo Seroa da (Ed.). Regulação e Concorrência no Brasil: governança, incentivos e eficiência. Rio de Janeiro: IPEA, 2007. p. 43-82.

HOLMES, Stephen; SUNSTEIN, Cass R. The Cost of Rights: Why Libery Depends on Taxes. New York: Norton, 1999.

JORGE NETO, Nagibe de Melo. O Controle jurisdicional das politicas públicas. Salvador: Jus Podium, 2008.

KINGDOM, John. Agendas, alternatives and public policies. New York: Harper Collins College Publishers, 1995.

KRELL, Andreas J. Direitos Sociais e controle judicial no Brasil e na Alemanha. Porto Alegre: S. A. Fabris, 2002.

MAURÍCIO JUNIOR., Alceu. A revisão judicial das escolhas orçamentárias: a intervenção judicial em políticas públicas. Belo Horizonte: Fórum, 2009.

MENDONÇA, Eduardo Bastos Furtado de. A constitucionalização das finanças públicas no Brasil. Rio de Janeiro: Renovar, 2010.

MENDONÇA, Eduardo Bastos Furtado de. Da faculdade de gastar ao dever de agir: o esvaziamento contramajoritário de políticas públicas. Revista de Direito do Estado, Rio de Janeiro, v. 3, n. 9, p. 279-326, jan./ mar. 2008.

MENDONÇA, Eduardo Bastos Furtado de. Legitimidade e discricionariedade. 4. 2. ed. Rio de Janeiro: Forense, 2001.

MENDONÇA, Eduardo Bastos Furtado de. Mutações do direito público. Rio de Janeiro: Renovar, 2006.

MENDONÇA, Eduardo. Constituição e sociedade: o falso orçamento impositivo. Disponível em: < http://jota. info/constituicao-e-sociedade-o-falso-orcamento-impositivo>. Acesso em: 22 fev. 2015.

MOREIRA NETO, Diogo de Figueiredo. Curso de direito administrativo. 15. ed. Rio de Janeiro: Renovar,2009.

MOREIRA NETO, Diogo de Figueiredo. Direito da participação política. Rio de Janeiro: Renovar, 1992.

MOREIRA NETO, Diogo de Figueiredo. Quatro paradigmas do direito administrativo pós-moderno. Belo Horizonte: Fórum, 2008. 
PALADINO, Carolina de Freitas. Políticas Públicas: considerações gerais e possibilidade de controle judicial. $A \& C$ : Revista de Direito Administrativo e Constitucional. Belo Horizonte, v. 8, n.32, p. 219-242, abr./ jun. 2008.

PETTIT, Philip. Varieties of public representation. In: SHAPIRO, I. et al. (Ed.). Political representation. Nova York: Cambridge University Press, 2009.

SILVA, Alessandra Obara Soares da. Políticas Públicas: Condições e Possibilidades de Controle Judicial. In: ANAIS DO CONGRESSO NACIONAL DE PROCURADORES DO ESTADO, 22., 2007, Porto Seguro, v. 1.

SILVA, José Afonso da. Orçamento-programa no Brasil. São Paulo: Revista dos Tribunais, 1973.

SIQUEIRA, Vanessa. A Rigidez Orçamentária e a Perda de Discricionariedade do Chefe do Poder Executivo: uma Realidade? São Paulo: Conceito, 2011.

SOUTO, Marcos Juruena Villela. Direito administrativo da economia. Rio de Janeiro: Lumen Juris, 2003.

SUNSTEIN, Cass. One case at a time: judicial minimalism on the Supreme Court. Cambridge: Harvard University Press, 1999.

TORRES, Ricardo Lobo. Curso de direito financeiro e tributário. Rio de Janeiro: Renovar, 2008.

VALLE, Vanice Regina Lírio do. Constitucionalização das Políticas Públicas e seus Reflexos no Controle. Fórum Administrativo, Belo Horizonte, v. 8, n.85, p. 7-21, mar. 2008.

VALLE, Vanice Regina Lírio do. Políticas Públicas, direitos fundamentais e controle judicial. Belo Horizonte: Fórum, 2009 .

WANG, Daniel Wei L. Escassez de recursos, custos dos direitos e reserva do possível na jurisprudência do STF. Revista Direito GV, São Paulo, v. 4, n. 2, p. 539-568, jul./dez. 2008.

WILLEMAN, Marianna Montebello. Desconfiança institucionalizada, democracia monitorada e Instituições Superiores de Controle no Brasil. Revista de direito administrativo, Rio de Janeiro, v. 263, p. 221-250, maio/ ago. 2013. 


\section{REVISTA BRASILEIRA DE POLÍTICAS PÚBLICAS BRAZILIAN JOURNAL OF PUBLIC POLICY}
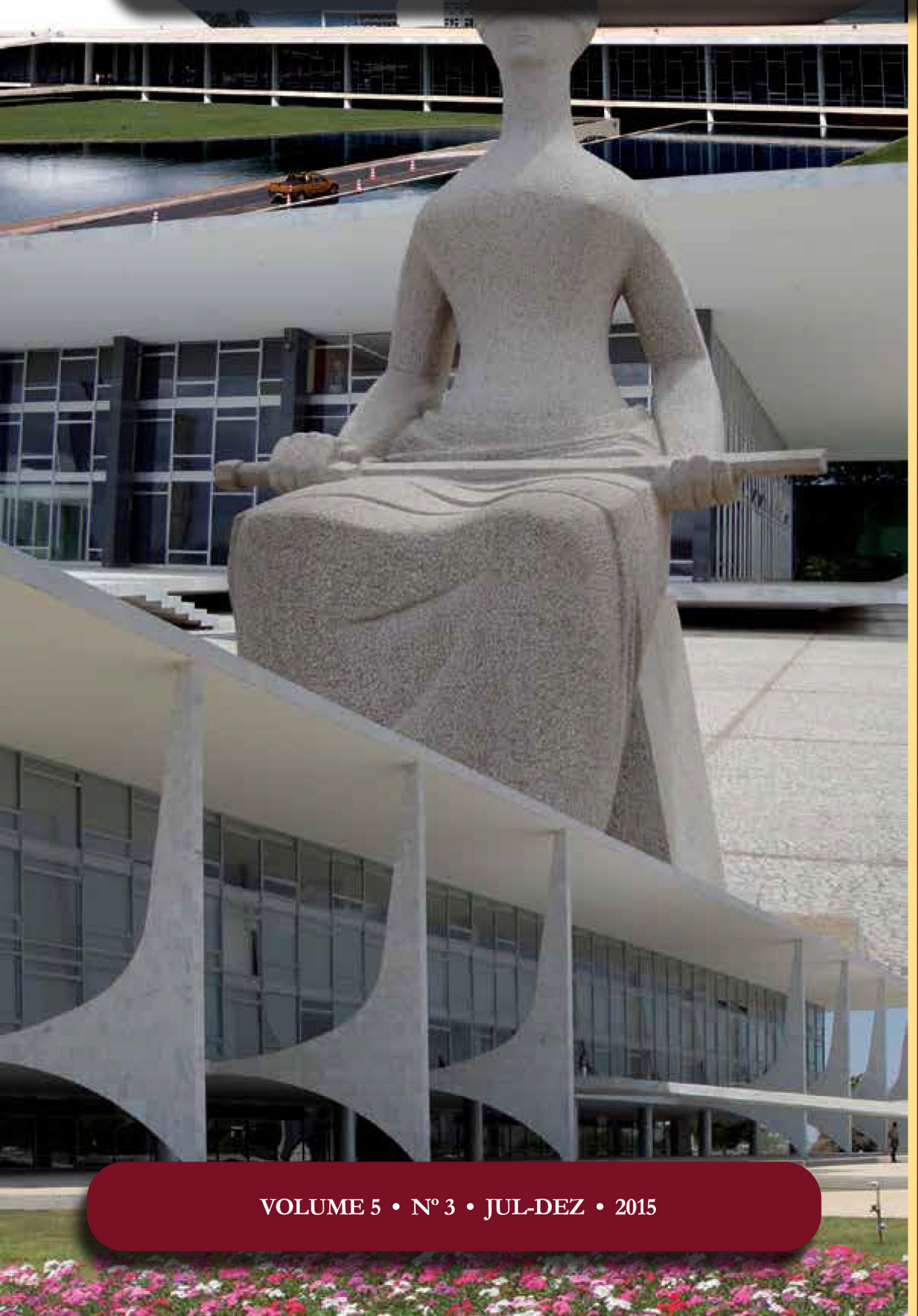

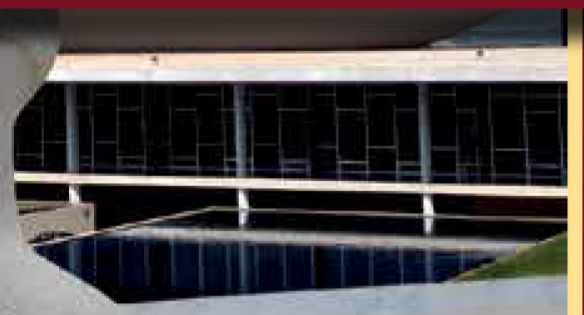

Estimativa de demanda pela formalização da economia informal no agreste pernambucano: uma aplicação do método de valoração contingente

Estimate demand by formalization of the informal economy in the agreste pernambucano: an application of contingent valuation method

Monaliza de Oliveira Ferreira Kelly Samá Lopes de Vasconcelos 


\section{Estimativa de demanda pela formalização da economia informal no agreste pernambucano: uma aplicação do método de valoração contingente*}

\author{
Estimate demand by formalization of \\ the informal economy in the agreste \\ pernambucano: an application of contingent \\ valuation method
}

Monaliza de Oliveira Ferreira**

Kelly Samá Lopes de Vasconcelos ${ }^{* * *}$

\section{Resumo}

O principal efeito da expansão da economia informal sobre a economia formal está relacionado à redução na receita tributária, reduzindo a quantidade e qualidade do fornecimento de serviços e bens públicos. Ademais, do ponto de vista da empresa, tem-se que a produtividade no setor informal é menor que a produtividade no setor formal. O objetivo desta pesquisa consiste em realizar uma estimativa da demanda potencial pela formalização da economia informal, utilizando o método de valoração contingente. Após a aplicação do modelo, observou-se que os microempresários do Polo de Confecções do Agreste Pernambucano estão dispostos a pagar, em média, $\mathrm{R} \$ 0,08$ mensais em Caruaru e nada em Santa Cruz do Capibaribe. O método procura obter o preço sombra da formalização da economia informal para cada agente contribuidor. Os valores obtidos indicam que os feirantes que se encontram inseridos na economia informal, não estão muito dispostos a pagar para inserirem-se na economia formal, ou pelo fato de que acreditam já pagar muitos impostos ou porque acreditam estarem confortáveis com seus rendimentos sem ter de prestar contas sobre isso com o Estado ${ }^{1}$. Ou seja, como o valor obtido foi desprezível, conclui-se que os feirantes não têm interesse pela formalização da economia informal, independentemente das vantagens apontadas.

Recebido em 16/03/2015
Aprovado em 08/07/2015

** Doutora em Economia, Universidade Federal de Pernambuco (UFPE-PIMES). Professora do Programa de Pós-Graduação em Economia - PPGECON/UFPE/CAA. Coordenadora do Grupo de Pesquisa em Economia Aplicada e Desenvolvimento Sustentável -GPEAD. E-mail: monaliza.ferr@gmail.com.

*** Mestranda - Programa de Pós-Graduação em Economia - PPGECON/UFPE/ CAA / Membro do GPEAD. Universidade Federal de Pernambuco (UFPE-CAA). E-mail: kellydevasconcelos@ig.com.br.
Palavras-chave: Economia informal. Firma. Mercado de trabalho. Valoração contingente
1 Embora Estado seja um conceito maior que Governo (uma das instituições que compõem o Estado), nesse contexto esses termos serão tratados como sinônimos. Os dois termos serão considerados como o agente planejador central, aquele que cria e regula as políticas públicas. 


\section{Abstract}

The main effect of the expansion of the informal economy to the formal economy is related to the reduction in tax revenues, reducing the quantity and quality of provision of public services and goods. In addition, the company's point of view, it follows that productivity in the informal sector is less than productivity in the formal sector. The objective of this research is to accomplish an estimate of the potential demand for the formalization of the informal economy, using the contingent valuation method. After applying the model it was observed that micro entrepreneurs on Polo of Pernambuco Agreste Clothes are willing to pay an average of $\mathrm{R} \$ 0.08$ monthly in Caruaru and nothing in Santa Cruz do Capibaribe. The method seeks the shadow price of the formalization of the informal economy for each contributor agent. The values obtained indicate that the sellers that are inserted in the informal economy are not very willing to pay to be inserted in the formal economy, or the fact that many believe already pay taxes or because they believe they are comfortable with their income without having to account for it with the state. That is, as the value was negligible, it is concluded that the sellers have no interest for the formalization of the informal economy, regardless of the advantages pointed out.

Keywords: Informal economy. Firm. Labor market. Contingent valuation

\section{INTRODUÇÃO}

Mesmo em um momento de expansão da economia brasileira, a dificuldade de encontrar emprego tem levado muitas pessoas para o mercado de trabalho informal. Isso garante a sobrevivência de parte da população por meio do autoemprego. O setor informal é formado por trabalhadores que não conseguiram inserir-se de forma plena nos vários setores do mercado formal, principalmente nos países em desenvolvimento e não constitui fenômeno recente. De outro lado, há pessoas que poderiam sair da informalidade, mas preferem permanecer como estão, tratam-se dos microempresários que não se legalizam para auferirem lucros maiores em seus negócios.

O microempresário que está na condição de informal depara-se com algumas desvantagens, dentre elas aquelas oportunidades de negócios que requerem provas de regularidade fiscal, perda de vendas por exigência de nota fiscal, licitações públicas e privadas de que não pode participar, bem como exportações diretas, empréstimos no mercado livre de crédito para pessoas jurídicas etc. Com a alta carga tributária e exigências de documentos para registrar, o empresário acredita que irá decidir espontaneamente pela formalização de seu negócio apenas quando os custos da regularização são cobertos pela atividade. Contudo, na verdade, a regularização deverá acontecer quando os benefícios dessa formalização sejam eles diretos ou indiretos, superarem os custos da regularização, uma vez que as reduzidas receitas do negócio informal ('supostas reduzidas receitas') também constituem um dos fatores para a não legalização de microempresas².

Quando a empresa não é competitiva, existem alguns fatores que impulsionam sua entrada e permanência na informalidade, em que os custos da regularização acabam constituindo-se o principal fator. As barreiras para o desenvolvimento das micros e pequenas empresas devem ser eliminadas, principalmente, quando se fala em acesso a linhas de crédito, qualificação de microempresários, agilização de canais de comercialização, criação de regimes especiais fiscais etc. As organizações informais assemelham-se quanto à escassez de capital, ao uso de tecnologias obsoletas e à falta de organização. Mas a lógica de funcionamento é idêntica à de qualquer firma que objetiva maximizar o lucro em seus negócios ${ }^{3}$.

2 Serviço Brasileiro de Apoio às Micro e Pequenas Empresas. Economia informal urbana: julho de 2005. Goiania: Observatório SEBRAE, 2015.

3 CACCIAMALLI, M. C.; SILVA, M. F. J. Mais informalidade, menos cidadania, os efeitos criados por esse circulo vicioso sobre 
Fato semelhante ocorre com a capacidade de investimento. Quando acontece de as empresas não investirem, o país não gera empregos formais em volume suficiente para atender a demanda. Com menos oportunidades de empregos, a renda das pessoas diminui, fazendo com que comprem menos. Com o consumo em baixa, mais empresas formais são obrigadas a aderir à informalidade, das formas mais variadas e em diversos graus, sendo uma questão de sobrevivência para muitos ${ }^{4}$.

A informalidade da unidade produtiva ocorre, entre outros aspectos, em virtude da inexistência de documentos legais que comprovem sua existência ou funcionamento. Esse aspecto constitui componente importante do direito de propriedade de um negócio produtivo. Um pequeno empreendedor, que tem comprovado o seu negócio, garante que a exploração da atividade não será violada por outra pessoa. Além disso, enquanto os empreendedores informais enfrentam altos custos para elaborar e assegurar os contratos, o que reduz o acesso a mercados; as empresas formais têm melhor acesso aos fornecedores, aos compradores, ao mercado de crédito, à tecnologia e aos serviços de infraestrutura, sem falar que, atuando 'fora da lei', é possível a maquiagem dos números de empregos gerados, o que foi produzido e comercializado, o lucro obtido 5 .

De forma atípica, entretanto, as cidades parecem precisar desse mercado informal, viabilizando a conexão entre setores aparentemente opostos, ou seja, formal contra informal. Esse estranhamento deve-se ao fato de que, mesmo no setor formal, podem-se perceber práticas informais, tais como a extensão da forma de trabalho, a falta de registros profissionais dos empregados e assim por diante ${ }^{6}$.

Se a economia informal cresce, dá-se uma redução na receita dos tributos e, consequentemente, menor quantidade de bens e serviços públicos estarão disponíveis à sociedade, reduzindo o bem-estar da sociedade. Afinal, a infraestrutura pública constitui a base econômica para o desenvolvimento do País e o elemento-chave para o crescimento econômico?

Não raras vezes, a literatura apresenta o setor informal com produtividade inferior ao formal. Na maioria das vezes, está se referindo à produtividade do trabalho. Em estudo bastante recente, Squeff ${ }^{8}$ discute a evolução da produtividade do trabalho nos setores formal, informal e de outras unidades familiares segundo atividade econômica e verifica que a produtividade agregada cresceu 7\% entre 2001 e 2009, em decorrência do setor formal — uma vez que as atividades informais contribuíram negativamente.

A ideia de economia informal está geralmente associada à baixa produtividade, ilegalidade, evasão de impostos, corrupção e, sobretudo a um contingente de pessoas excluídas dos sistemas de proteção social. Trabalhadores que não conseguem posição no mercado formal acabam realizando trabalhos por conta própria ou responsabilizando-se por pequenas tarefas. O mercado de trabalho, entretanto, constitui apenas um lado da economia informal. A exemplo de Filártiga ${ }^{9}$, este artigo tem a firma/feirante como objeto de estudo. Ou seja, a firma é entendida nesse contexto como unidade produtiva e tecnológica, cujos empreendedores tomam decisões estratégicas sob incerteza, comprometendo-se em investimentos de longo prazo. Em suas relações constam os demais agentes econômicos, ou seja, as outras firmas, os consumidores, trabalhadores e Governo.

Nessa perspectiva, formal ou informal tornam-se mais qualidades das transações do que dos agentes econômicos. Uma firma pode ser registrada, ser grande ou pequena, comprar insumos nos mercados for-

a formulação da política social na América Latina. Cadernos Prolam/USP, São Paulo, v. 02, n. 2, p. 4-24, 2003.

4 CACCIAMALLI, M. C.; SILVA, M. F. J. Mais informalidade, menos cidadania, os efeitos criados por esse circulo vicioso sobre a formulação da política social na América Latina. Cadernos Prolam/USP, São Paulo, v. 02, n. 2, p. 4-24, 2003.

5 FONTES, A.; PERO, V. Determinantes do desempenho dos microempreendedores no Brasil. 2009. Disponível em: < http://www.ie.ufrj. $\mathrm{br} /$ datacenterie/pdfs/seminarios/pesquisa/texto0906.pdf>. Acesso em: 10 ago. 2015.

6 FILÁRTIGA, G. B. Custos de transação, instituições e a cultura da informalidade no Brasil. Revista do BNDES, Rio de Janeiro, v. 14, n. 28, p. 121-144, dez. 2007.

7 NERI, M. Informalidade. Ensaios econômicos, Rio de Janeiro, n. 635, p. 1-40, dez. 2006.

8 SQUEEF, G. C. Produtividade do trabalho nos setores formal e informal no Brasil: uma avaliação do período recente. Rio de Janeiro: IPEA, 2015. (Texto para Discussão, n. 2084).

9 FILÁRTIGA, G. B. Custos de transação, instituições e a cultura da informalidade no Brasil. Revista do BNDES, Rio de Janeiro, v. 14, n. 28 , p. 121-144, dez. 2007. 
mal e informal, assinar a carteira de um trabalhador e outro não. Essas escolhas são inerentes às análises de custo-benefício de cada empresa, nas quais os custos de transação e as instituições são levados em conta. Certamente, a redução nesses custos de transação leva a aumentos nas margens de lucro dos empresários. Afinal, transações realizadas por meio de instituições informais evitam pagamentos de impostos e obrigações trabalhistas; reduzem dos custos das taxas e do tempo dedicado ao cumprimento de procedimentos administrativos para obtenção de autorização, licenças, certidões e registros; evitam os custos do cumprimento de padrões de contabilidade, qualidade, entre outras vantagens competitivas que, em alguma medida, traduzem-se em aparentes ganhos de competitividade frente os concorrentes ${ }^{10}$.

Se as cidades dos países em vias de desenvolvimento crescem rapidamente, não significa que se terá aumento dos postos de trabalho, ou seja, os postos de emprego não crescem na mesma proporção que a evolução tecnológica, muito pelo contrário, são perdidos rapidamente e para serem inseridos novamente no mercado levam algum tempo, favorecendo a informalidade. Esse efeito pode ser evidenciado nos pequenos negócios de confecções realizados nas cidades dos Polos de Confecções do Agreste Pernambucano - Caruaru, Toritama e Santa Cruz do Capibaribe.

A tradicional Feira da Sulanca surgiu entre as décadas de 1950 e 1960. No primeiro momento, a matéria-prima utilizada para confecção foram os retalhos trazidos das fábricas têxteis da capital pernambucana, Recife, tendo como costureiras as mulheres moradoras da zona rural. Os vendedores ambulantes eram os tropeiros e os sulanqueiros eram os feirantes itinerantes e divulgadores dos produtos da Sulanca. Em seguida foram aproveitados os retalhos de helanca (fibra sintética em voga no período de 1960/1970) vindos de São Paulo. Por essa razão surgiu o nome "sulanca" (junção de sul mais lanca). É a partir dos anos 2000 que esforços para a regulação, formalização e reestruturação do comércio e atividades na Feira da Sulanca levaram-na a fazer parte do referido Polo de Confecções do Agreste Pernambucano, sendo o principal símbolo desta ${ }^{11}$. Ressalte-se que o movimento não ocorreu de forma sincronizada no tempo e no espaço com os outros municípios do Polo.

Em Toritama e Santa Cruz, esse processo foi um pouco depois, a partir de 2001 ${ }^{12}$. Enquanto Caruaru produz 'de tudo um pouco', Toritama especializou-se na produção de jeans, respondendo por 16\% da produção nacional; enquanto Santa Cruz do Capibaribe voltou-se mais para a produção lingeries e camisolas, ainda que a produção de produtos diversos seja comum a todas as feiras do circuito. Santa Cruz constitui o maior caso de sucesso dos três, na cidade inexiste desemprego, ainda que se verifique grande concentração de renda. No final de 2006, Santa Cruz do Capibaribe surge não apenas com um centro de compras, mas transfere toda a Feira da Sulanca para o Moda Center Santa Cruz, sendo o único do Agreste a possuir uma feira organizada e coberta. A costureira mais antiga da cidade, Dona Petronila Senhorinha dos Santos, 88 anos, é uma das fundadoras da Feira da Sulanca de Santa Cruz do Capibaribe, sendo da época em que vendia tudo que costurava no chão do centro da cidade. Caruaru, todavia, tem mais expressividade e conhecimento nacional, em virtude de sua importância no setor de comércio, turismo (principalmente em virtude das festividades juninas) e cultura popular, destacando-se o Alto do Moura, considerado pela UNESCO como o "maior Centro de Artes Figurativas das Américas". Inclusive a Feira de Caruaru é conhecida como a maior feira popular do Brasil. Em 2006, a referida Feria recebeu o título de "Patrimônio Cultural Imaterial Brasileiro", concedido pelo Ministério da Cultura, por meio do Instituto do Patrimônio Histórico e Artístico Nacional (Iphan). Por sua importância econômica para a Região, a cidade é conhecida também como a "Capital do Agreste".

10 FILÁRTIGA, G. B. Custos de transação, instituições e a cultura da informalidade no Brasil. Revista do BNDES, Rio de Janeiro, v. 14, n. 28, p. 121-144, dez. 2007.

11 BURNET'T, A. A saga dos retalheiros: um estudo sobre a instituição da feira da sulanca no Agreste pernambucano. Século XXI: Revista de Ciências Sociais, v. 3, n. 2, p. 09-40, jul./dez. 2013.

12 OLIVEIRA OLIVEIRA, R. V.; BRAGA, B. M. Território comercial de Toritama: persistência e metamorfoses da informalidade. Revista de Ciências Sociais Política \& Trabalbo, João Pessoa, n. 41, p. 193-225, out. 2014. p. 193-225. 
Dessa forma, este artigo tem por objetivo realizar uma estimativa da demanda potencial pela formalização da economia informal, utilizando o método de valoração contingente, com base na análise dos pequenos negócios de confecções no Agreste Pernambucano.

Antes um método aplicado apenas para problemas ambientais, o método de valoração contingente, passou a ser usado em outros contextos, inclusive na economia da cultura. A aplicação do método na economia da cultura busca usualmente mensurar o quanto determinada população está disposta a pagar por um dado bem cultural, a exemplo dos ativos ambientais. As pesquisas são implementadas na forma de questionários que incluem uma situação hipotética, sendo a terminologia "contingente" referente ao mercado simulado que se apresenta ao entrevistado. Os estudos de valoração contingente apresentam a grande vantagem de captar os valores de existência, opção e legado; valores de "não uso" que possuem particular importância no contexto das artes. Uma crítica bastante comum que especialistas em arte colocam em relação aos estudos econômicos é que estes captam apenas a quantidade de arte, e não a qualidade. A valoração contingente prova a falsidade dessas críticas. O número de visitas a um teatro, museu ou monumento não importa tanto quanto o valor que as pessoas atribuem a essas visitas ${ }^{13}$. Com essa mesma lógica, o método foi utilizado neste estudo.

Além dessa introdução, o artigo apresenta ainda uma seção de referencial teórico, outra de metodologia, os resultados do artigo e uma última seção à guisa de conclusões.

\section{Referencial teórico}

As escolas de pensamento econômico têm tomado várias posições para explicar a informalidade. A teoria clássica considera que a economia está em pleno emprego e apresenta ajuste automático para o equilíbrio entre oferta e demanda, de forma que não há desemprego ou mesmo informalidade. A teoria neoclássica apresenta a informalidade compreendida como efeito do crescimento perturbador do mercado competitivo. Os estruturalistas (neoestruturalistas) reconhecem que a informalidade tem origem na desigualdade de distribuição de riqueza e oportunidades de acesso ao crédito ${ }^{14}$.

Assim, o conceito de informalidade tem evoluído ao longo dos tempos. Em termos teóricos, estão em Boeke $^{15}$, Lewis ${ }^{16}$, Harris e Todaro ${ }^{17}$ as questões conceituais mais voltadas à relação entre informalidade e pobreza. Já Hirschman ${ }^{18}$, Mincer ${ }^{19}$ e De Soto ${ }^{20}$ relacionaram a informalidade mais com a desobediência às leis ${ }^{21}$.

Insta ressaltar que as instituições do mercado de trabalho no Brasil jamais alcançaram universalmente as massas de trabalhadores e constituíram um conjunto muito pobre de direitos. Desde os primórdios da formação de um mercado de trabalho livre no país, parcela considerável da população jamais conseguiu se incorporar ao mercado de trabalho e mesmo sob os auspícios de uma economia industrial, a regulamentação desse mercado deixou de fora os trabalhadores rurais e muitas categorias de trabalhadores urbanos ${ }^{22}$.

13 FREY, Bruno. La economía del arte: una visión personal, y Las falsificaciones en arte: ¿qué falsificaciones? Barcelona: La Caixa, 2000. (Estudios Económicos, 18).

14 CAMARGO, A. L.; MORA, H. G. C. La economía informal em Villavicencio. Finanzas y Politica Económica, Bogota, v. 3, n. 2, p. 83-104, jul./dez. 2011. p. 83-104.

15 BOEKE, J. Economics and economic policy of dual societies: as exemplified by Indonesia. New York: International Secretariat Institute of Pacific Relations, 1953.

16 LEWIS, A. The Dual Economy revisited. The Manchester School, Hoboken, v. 47, n. 3, p. 211-229, Sept. 1979.

17 HARRIS, J.;TODARO, M. Migration, unemployment and development: a two-sector Analysis. American Economic Review, Pittsburgh, v. 60, n. 1, p. 126-142, 1970.

18 HIRSCHMAN, A. Exit, Voice and loyalty: responses to decline in firms, organizations, and states. Cambridge: Harvard University Press, 1970.

19 MINCER, J. Unemployment Effects of Minimum Wages. Political Economy, London, v. 84, n. 4, p. s87-s104, Aug. 1976. Part 2:

Essays in Labor Economics in Honor of H. Greg.

20 SOTO, H. de. El otro sendero: la revolución informal. Bogotá: Oveja Negra, 1987.

21 PERRY, G. Et al. Informality: Exit and Exclusion. Washington: The World Bank, 2007.

22 COSTA, M. S. Trabalho informal: um problema estrutural básico no entendimento das desigualdades na sociedade brasileira. 
As mudanças institucionais e econômicas da sociedade brasileira, nas quatro décadas de crescimento deslanchadas pela política de substituição de importações, não lograram ampliar o padrão de renda-consumo e bem-estar da população irrestritamente, nem muito menos alcançaram o compromisso mais sólido de uma política de pleno emprego. Essa realidade se agravou na década de 1990, com as mudanças estruturais da economia brasileira e seus efeitos sobre o mercado de trabalho. A abertura econômica e as privatizações pressionaram o processo de reestruturação produtiva sistêmica, de modo a afetar não apenas o nível do emprego, mas também a sua qualidade, com a flexibilização dos vínculos e dos regimes de trabalho ${ }^{23}$. Portanto, independente do conceito de informalidade adotado, há que se considerar a incapacidade do agente público de dotar todas as pessoas das condições mínimas de sobrevivência, quer seja pela presença de grande estrato de desempregados na economia ou mesmo pela presença dos ditos subempregos.

Nesta seção far-se-ão alguns comentários acerca do referencial teórico e serão apresentados alguns conceitos importantes para o estudo. Nesse sentido, o conceito de trabalho informal pode ser analisado por duas vertentes.

A primeira delas é apresentada pela Organização Internacional do Trabalho (OIT) ${ }^{24}$, que classifica o trabalho informal como a unidade econômica, caracterizada pela produção em pequena escala, pelo reduzido emprego de técnicas e pela quase inexistente separação entre o capital e o trabalho. Tais unidades também se caracterizam pela baixa capacidade de acumulação de capital e por oferecerem empregos instáveis e reduzidas rendas. Ou seja, é formado por trabalhadores por conta própria, inclusive empregadores e empregados de pequenas firmas, de baixa produtividade ${ }^{25}$.

A concepção seminal de setor informal no trabalho da OIT ocasionou a definição da dicotomia formal/informal segundo uma abordagem denominada subordinação. As atividades do setor informal ocupariam nichos do mercado não preenchidos pela atividade tipicamente capitalista. Lembrando que, o setor informal não pode ser entendido de modo geral como subemprego, ou uma alternativa temporária em razão da falta de oportunidade no setor formal, o setor informal absorve aquelas pessoas que não têm carteira assinada, ou vínculo empregatício e não são recolhidos impostos referentes à ocupação destes. Com o desenvolvimento da esfera produtiva, a atividade, até então espaço para o setor informal, tornar-se-ia atraente para a atividade capitalista, levando-a a ocupar, por meio da concorrência, o lugar preenchido pelas unidades produtivas informais ${ }^{26}$.

O setor informal pode ser delimitado com base em unidades econômicas orientadas para o mercado, destacando-se o fato de que quem detém o negócio exerce simultaneamente as funções de patrão e empregado, tem a posse dos instrumentos de trabalho e além do mais, a colaboração do trabalho familiar, ou ainda, de alguns ajudantes e de não existir separação entre as atividades de gestão e produção ${ }^{27}$.

O trabalho informal pode se apresentar ainda como estratégia de sobrevivência diante da perda de uma ocupação formal ou por opção de vida para alguns trabalhadores que optam por desenvolverem suas atividades em seu próprio negócio (para auferir lucros maiores). O conceito de informalidade também não está condicionado ao local onde é desenvolvida a atividade produtiva, à utilização de ativos fixos, à duração das atividades das empresas (permanente, sazonal ou ocasional) e ao fato de tratar-se da atividade principal ou secundária do proprietário da empresa ${ }^{28}$.

Caderno CRH, Salvador, v. 23, n.58, p.171-190, jan./abr. 2010.

23 COSTA, M. S. Trabalho informal: um problema estrutural básico no entendimento das desigualdades na sociedade brasileira. Caderno CRH, Salvador, v. 23, n.58, p.171-190, jan./abr. 2010.

24 ORGANIZAÇÃO INTERNACIONAL DO TRABALHO. Organização Internacional do Trabalho: promovendo o trabalho decente. Disponível em: <http://www.oitbrasil.org.br/content/o-que-e-trabalho-decente>. Acesso em: 10 ago. 2015.

25 MILHOMEM, A. V. Trabalho informal: precarização do trabalho e exclusão social em Goiás e no Brasil. Revista Anhanguera, São Paulo, v. 4, n. 1, p. 139-155, jan./dez. 2003.

26 MACHADO, A. F.; OLIVEIRA, A. M. H.C.; ANTIGO, M. Evolução do diferencial de rendimentos entre setor formal e informal no Brasil: O papel das características não observadas. Revista Economia Contemporânea, Rio de Janeiro, v. 12, n. 2, p. 355-388, maio/ago. 2008.

27 CACCIAMALLI, M. C. Setor informal urbano e formas de participação na produção. 1983. 172f. Tese (Doutorado) - Universidade de São Paulo, São Paulo, 1983; CACCIAMALLI, M. C. Globalização e processo de informalidade. São Paulo: IPE/USP, 2000. (Texto para Discussão, 01).

28 BORGES, A.; FRANCO, A. Economia informal da RMS: verdades e mitos. Babia Análise e Dados, Salvador, v. 9, n. 3, p. 68-89, 
A segunda definição revela principalmente que as atividades de produção não são executadas de acordo com a lei. A ideia de economia informal está geralmente associada à baixa produtividade, ilegalidade, evasão de impostos, corrupção e, sobretudo, a um contingente de pessoas excluídas dos sistemas de proteção social. O trabalho informal consiste naquele que, em geral, foge da regulação do Estado. Trabalhadores que não conseguem uma posição no mercado formal caminham entre empregos formais e informais, realizando trabalhos por conta própria ou por pequenas tarefas e acrescentando ainda os trabalhadores sem carteira assinada e os que não são remunerados. Essa condição dificulta a contribuição previdenciária, com conseqüências para o próprio trabalhador, mas também para a sociedade, que assume custos previdenciários e de assistência social para os quais não houve poupança ${ }^{29}$.

Embora a transição para a economia formal sejam objetivos desejados, há de se colocar que existem diferentes pontos de vista sobre o que se entende por formalização e como ele pode ser alcançado. Alguns acreditam que se trata de expandir a capacidade e alcance das instituições, especificamente resolver a situação de emprego assalariado no setor formal. Outras vezes pode ser limitada apenas ao registro e sanções punitivas em caso de descumprimento da lei. Tal abordagem é susceptível de ser contra-produtivo, uma vez que não considera várias outras facetas da informalidade. Além disso, as políticas para a adesão à formalização devem ser apresentar incentivos, considerando-se, inclusive, melhorias de infraestrutura e, principalmente, cultura de divulgação para se adequar as condições específicas da economia informal à economia formal. Obviamente, esse processo de transição gera custos no curto prazo para o Estado, ou melhor, para a sociedade ${ }^{30}$.

\section{Metodologia}

O objeto de estudo desta pesquisa é constituído pelas unidades produtivas informal, cuja abordagem conceitual que mais se ajusta é a da pequena produção mercantil, tal como apresentada no estudo de Rosa e Caste$\operatorname{lar}^{31}$, que compreende as seguintes categorias analíticas: os proprietários dispõem de um mínimo de capital fixo, utilizam poucos trabalhadores, familiares ou assalariados não registrados, e participam diretamente da produção, sem serem caracterizados como assalariados; não existe uma completa divisão do trabalho e o proprietário do negócio participa na produção sob as formas de patrão e empregado; dispõem de instalações com aparência pouco sólida, semipermanentes, temporárias ou móveis (ambulantes); não participam do sistema de crédito formal e mantêm relação mínima com as instituições financeiras; dirigem e preservam sua atividade, muito mais, em virtude do emprego e do fluxo de renda gerados do que da busca de uma taxa de rentabilidade competitiva; as relações patrão, empregado e clientes são pessoais e a forma como serão exercidas dependerá da cultura, experiência de vida, personalidade e condições de vida do proprietário; o processo de produção poderá sofrer descontinuidades ou intermitência, em virtude das características do próprio negócio, do mercado ou do produtor; a situação financeira do negócio está fortemente vinculada à situação financeira da família, ou seja, não há uma separação clara entre as finanças do negócio e da família; a capacitação é obtida, em grande parte, por meio da experiência e do conhecimento do negócio do que da educação formal; a quantidade de unidades produtivas é determinada pela renda média auferida e pelo tamanho do mercado. Dessa forma, se os negócios estiverem favoráveis, outros agentes tendem a ingressar na atividade, reduzindo a renda média até o limite em que aquele espaço econômico não será mais atrativo para a entrada de novas microempresas.

dez. 1999.

29 FILÁRTIGA, G. B. Custos de transação, instituições e a cultura da informalidade no Brasil. Revista do BNDES, Rio de Janeiro, v. 14, n. 28, p. 121-144, dez. 2007.

30 INTERNATIONAL LABOR CONFFERENCE. Transition from the informal to the formal economy. Geneva: International Labor Office, 2014.

31 ROSA, A. L. T.; CASTELAR, L. I. M. Demanda por microcrédito em Fortaleza: uma análise do método de avaliação contingente. Fortaleza: Universidade Federal do Ceará. Curso de Pós-Graduação em Economia - CAEN, 1998. (Texto para Discussão, n. 174/98). 


\subsection{Coleta de Dados e Descrição das Variáveis}

Em princípio, o processo de amostragem escolhido é o de amostragem aleatória de múltiplos estágios. No primeiro estágio, a escolha dos grupos formados por comerciantes dos Pólos de Confecção de Caruaru, Santa Cruz do Capibaribe e Toritama. Nesses casos, a unidade de observação não está centrada na pessoa, mas no grupo, que é facilmente identificável; no segundo estágio, foram selecionados quais os subgrupos que seriam considerados, ou seja, os não lojistas ou feirantes. Esse grupo foi escolhido em razão da maior caracterização das atividades informais; por fim a amostra considerada em cada um dos municípios correspondeu ao limite mínimo de 5\% da população de feirantes em cada caso. Dessa forma, entrevistou-se 390 pessoas em Caruaru, 300 em Santa Cruz e 65 em Toritama.

\subsection{O Modelo Econométrico}

Objetivando-se estudar a disposição a pagar (DAP) ${ }^{32}$ dos feirantes da economia informal para entrarem na economia formal, revelada por meio da avaliação contingente, será especificado um modelo econométrico de estimação logit. O modelo de regressão logística especificado apresenta como variável dependente binária a disposição a pagar (DAP) dos indivíduos, em que a variável dependente assume o valor "1" se o entrevistado disse estar disposto a pagar para entrar no mercado formal e "0", caso contrário.

Considerando-se " $\mathrm{X}$ " o vetor com os valores das variáveis explicativas e " $\beta$ " um vetor de parâmetros, o modelo admite que a probabilidade de a pessoa feirante esteja disposta a pagar para entrar no mercado formal, definida neste estudo, como formalização da economia informal, pode estar relacionada com um grupo de variáveis preditoras ou explicativas.

O modelo é baseado na função de distribuição logística (curva em formato de S) e garante que as estimativas de probabilidade situem-se entre 0 e 1, em que os valores positivos (negativos) do parâmetro indicam que a probabilidade de disposição a pagar aumenta (diminui) à medida que o valor da variável explicativa aumenta (diminui). O vetor de variáveis independentes (explicativas ou preditoras) contém diversas variáveis, especificadas no parágrafo a seguir.

Seja $\pi_{i}=\operatorname{Prob}(\mathrm{DAP}=1)$, com $0 \leq \pi_{\mathrm{i}} \leq 1$, a probabilidade do i-ésimo indivíduo estar disposto a pagar para a formalização da economia informal. Dessa forma, a probabilidade $\pi_{\mathrm{i}}$ está relacionada com as seguintes variáveis explicativas: Sexo: variável binária que assume valor " 1 " se a pessoa for do sexo masculino e " 0 ", caso contrário; IDADE: anos de idade do feirante entrevistado; Escolari: variável categórica em que (0) Nunca estudou; (1) Fundamental I completo; (2) Fundamental I incompleto; (3) Fundamental II completo; (4) Fundamental II incompleto; (5) Médio completo; (6) Médio incompleto; (7) Superior completo e (8) Superior incompleto; TamFam: variável categórica em que (1) Mora só; (2) 2; (3) 3; (4) 4; (5) 5; (6) 6; (7) 7; (8) 8; (9) 9 e (10) 10; TemRam: Há quantos anos o feirante trabalha com confecção; NumFun: Quantidade de funcionários que o entrevistado possui; NumMaq: variável categórica em que (0) não tenho — apenas revende; (1) não tenho - facção ${ }^{33}$; (2) até 4; (3) entre 5 e 8; (4) entre 9 e 12 e (5) mais que 12; RegCon: variável dummy em que (0) sim e (1) não; FatMens: faturamento mensal do feirante, medido em moeda corrente (R\$).

32 A variável disposição a pagar é usualmente utilizada na literatura sobre valoração contingente. E mesmo em situações onde não o usuário não tenha intenção de pagar pelo ativo econômico em questão, o termo utilizado é o mesmo, o que pode parecer estranho ao leitor. Na verdade, sabe-se que o usuário não está disposto a pagar com base no valor obtido no modelo, quando é muito baixo. Enfim, a análise dos resultados deve ser realizada com cautela.

33 Facção é o nome dado às unidades de confecção que prestam serviços para outras empresas do ramo. Realizam pequenas etapas da produção; geralmente trabalhos de corte, montagem e acabamento de peças do vestuário para as outras confecções. Trata-se de um serviço de terceirização, portanto. 


\section{Resultados e discussão}

Antes de se iniciar a discussão sobre a disposição a pagar, convém breve explanação a respeito da informalidade no Pólo de Confecções do Agreste Pernambucano, que é constituído principalmente pelos Municípios de Caruaru, Santa Cruz do Capibaribe e Toritama.

\subsection{Caracterização da Economia Informal no Agreste Pernambucano}

O Pólo de Confecções do Agreste Pernambucano concentra grande volume de pequenos fabricos caseiros. Esse setor é muito forte na economia da Região, garantindo o sustento de várias famílias, muitas vezes, sem amparo social ou legal. O empreendimento denominado como "Feira da Sulanca", que contempla o chamado mercado de trabalho informal, absorve pessoas desempregadas, que começam sem nenhuma qualificação e em pouco tempo de prática já estão adaptadas as atividades desempenhadas $\square$ aprendem, na maioria das vezes, no dia a dia do trabalho ${ }^{34}$ e não em cursos específicos.

As feiras recebem semanalmente número considerável de consumidores dos mais variados tipos de classes sociais, em busca dos artigos de confecção, que apresentam o preço baixo como principal elemento de competição com outras regiões do País. Os produtos comercializados nas feiras tornam-se substitutos com os comercializados no mercado formal, acrescentando-se ainda a concorrência dos vestuários oriundos da China.

No Gráfico 1, pode-se verificar por meio da variável sexo (X1), que a maior parte dos trabalhadores são do gênero feminino - 51,54\% em Caruaru; 60,33\% em Santa Cruz e; 52,31\% em Toritama. Essas mulheres assumem o banco nos dias das feiras enquanto seus maridos e outros membros da família desempenham outras atividades, incluindo a parte de costura, que também é realizada pelos homens.

Gráfico 1 - Caracterização da Economia Informal no Agreste Pernambucano, segundo o. Perfil dos Feirantes (\%)

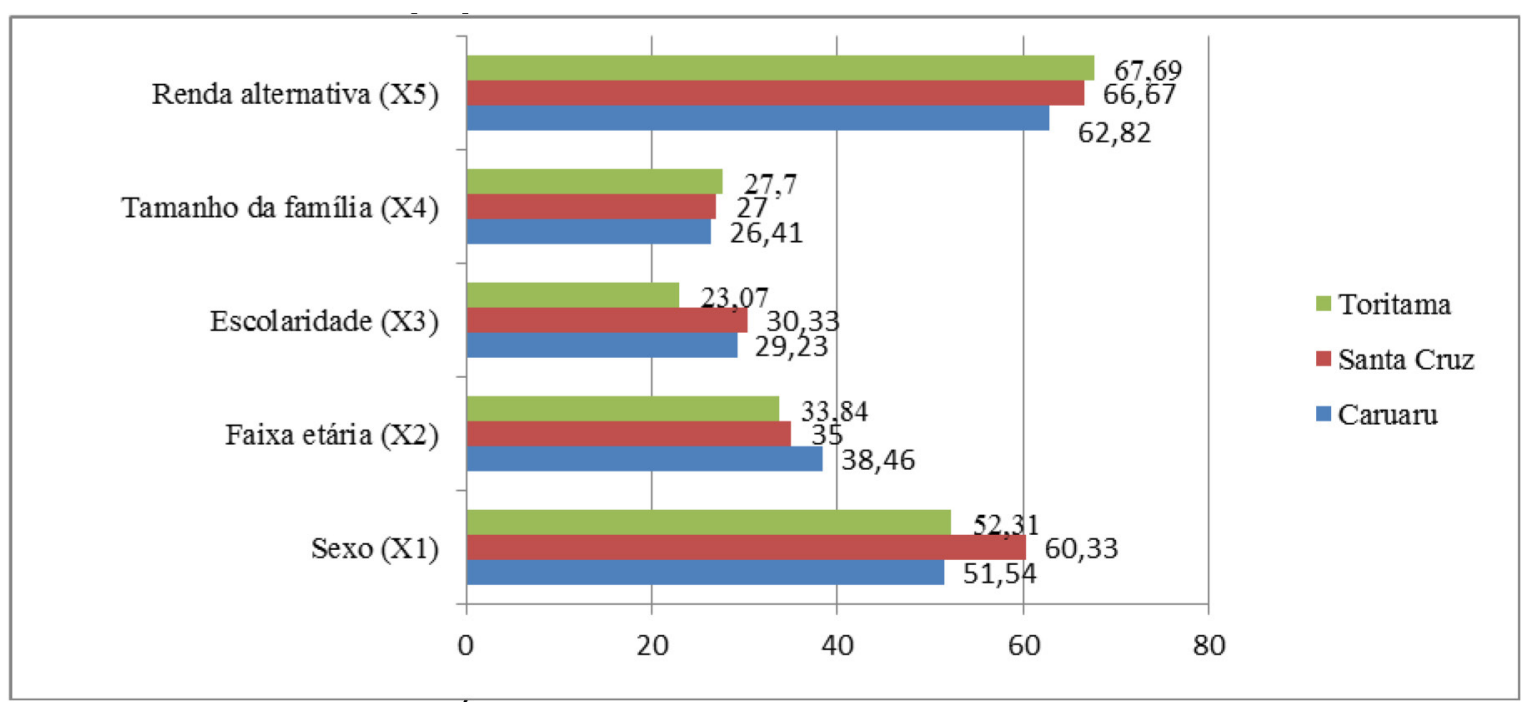

NOTA: LEGENDA DAS VARIÁVEIS: (X1) - Feminino; (X2) - 26 a 35 anos; (X3) - Ensino Médio completo / Fundamental II incompleto; (X4) - 03 pessoas / 04 pessoas; (X5) - Não possuem.

FONTE: Do autor.

A observação da variável faixa etária (X2) revela que as pessoas as quais procuram ocupação nas feiras são principalmente adultas, nas três cidades a faixa etária majoritariamente está entre 26-35 anos, com (38,46\%) em Caruaru, 35\% dos entrevistados de Santa Cruz do Capibaribe e 33,84\% dos entrevistados de

34 Em Economia, chama-se a isso de learnin by doing. 
Toritama. Essas pessoas estão ou convivem com a atividade desde a infância, mas não necessariamente com a feira propriamente dita. Iniciam-se auxiliando no processo produtivo, desde a retirada dos pelos dos tecidos, até o processo de embalagem da mercadoria.

A variável escolaridade (X3) revela que boa parte dos entrevistados possui Ensino Médio completo 29,23\% em Caruaru e 30,33\% em Santa Cruz 30,33\% . Mesmo assim ainda sofrem com a ausência de formação técnica na área. Já em Toritama 23,07\% dos feirantes de não possuem sequer o Ensino Fundamental II completo. Esse percentual sugere que sejam direcionadas políticas públicas urgentes para a melhor qualificação desses trabalhadores, com o intuito de direcioná-los para novos postos de trabalho. Nesse sentido, um apelo constante entre os entrevistados consiste na necessidade de formação de cursos profissionalizantes, o que ajudaria no redirecionamento de algumas dessas pessoas para o mercado formal de trabalho.

Sobre os resultados de escolaridade, convém frisar que a Região conta com cursos frequentes por parte do SENAC. E que tem, desde 2006, a presença das Universidades Federal e Estadual de Pernambuco além do Instituto Federal de Pernambuco, com centros em Caruaru. E não raras vezes o Polo de Confecções tem sido objeto de estudo desses pesquisadores, a exemplo deste. Também cursos de extensão têm sido oferecidos para tais agentes econômicos. Inclusive, já houve cursos de especialização criados especificamente para esse estrato populacional e não houve interesse da parte deles. Convém considerar, todavia, que o nível de escolaridade apresentado não dá o alcance real de escolaridade desses agentes econômicos. Isso porque em muitas das vezes, independente do grau de escolaridade apresentado, essas pessoas são analfabetos funcionais. Em alguns casos, esse déficit educacional só será reduzido com as próximas gerações, aquelas que usufruirão de melhores escolas e que terão a oportunidade de cursar essas universidades, agora presentes na Região.

Não existe um padrão único de tamanho da família, com ressalva a variável (X4), mas em 26,41\% das famílias de Caruaru existem 03 pessoas por família. Em Santa Cruz, também existem 04 pessoas por família para 27\% dos entrevistados e em Toritama esse percentual é de 27,70\%. Quando a pergunta referiu-se à existência ou não de renda alternativa, indicada pela variável renda alternativa (X5), a maioria dos entrevistados nas três cidades respondeu que não possuem — Caruaru (62,82\%), Santa Cruz (66,67\%) e Toritama $(67,69 \%)$.

No Gráfico 2, pode-se observar dos dados referentes à variável empresa familiar. Verifica-se que a grande maioria dos feirantes não possui trabalhadores, contando com a ajuda dos familiares para o desenvolvimento das atividades do empreendimento - 69,74\% em Caruaru, 73,66\% em Santa Cruz e 80\% em Toritama. Essa situação persiste seja com a pequena produção ou apenas com a revenda do produto nos bancos das respectivas feiras. Quando existem funcionários ou ajudantes (Y2) — como os entrevistados preferem — a maioria tem no máximo 03 funcionários. Isso ocorre em 18,98\% dos empreendimentos entrevistados em Caruaru, em 13,34\% em Santa Cruz e 10,77\% em Toritama. 
Gráfico 2 - Caracterização da Economia Informal, segundo a Estrutura Organizacional dos Feirantes $(\%)$

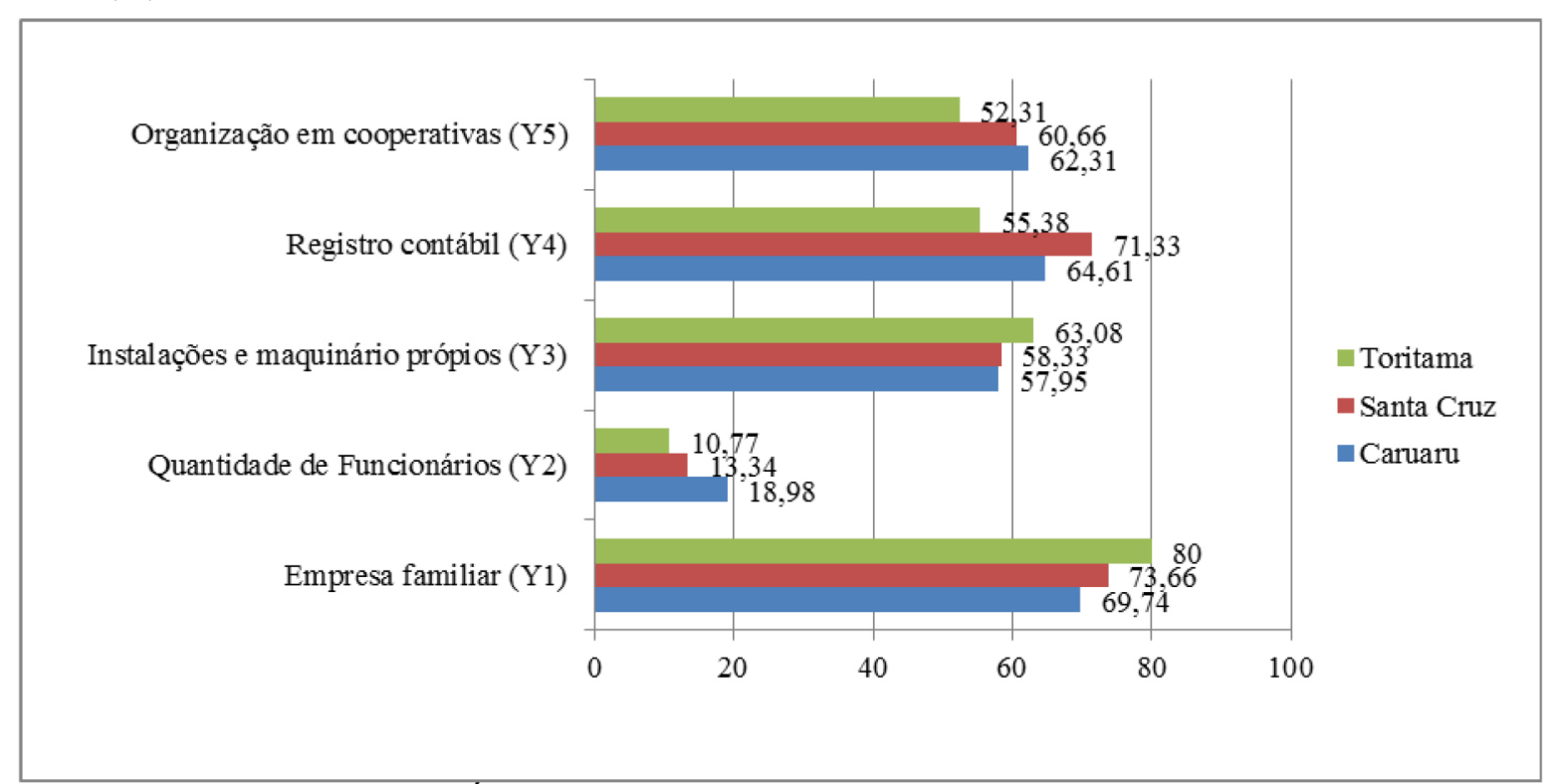

NOTA: LEGENDA DAS VARIÁVEIS: (Y1) - apenas família;/ (Y2) - 01 a 03 funcionários; (Y3) - Sim; (Y4) - Sim; (Y5) Não/ Sim.

FONTE: Do autor.

Ao se verificar o quesito instalações e maquinários próprios (Y3), percebe-se que, na maioria dos empreendimentos, isso ocorre - Caruaru (57,95\%), Santa Cruz (58,33\%) e Toritama (63,08\%). Nesse contexto, convém ressaltar a importância e o que vem a ser fação que, segundo a definição de alguns entrevistados, é a produção por partes. Ou seja, suponha-se que um tecido seja deixado em determinada residência para que fique responsável pelo corte; depois seguirá para outro destino para que se costure; na sequência vai para as pessoas que irão bordar e assim por diante; até o produto volte finalizado para o feirante comercializar. Esse formato de produção na Região é recente, tem mais ou menos cinco anos, segundo alguns feirantes.

Quanto ao registro contábil (Y4), os feirantes foram questionados sobre a existência de algum tipo de registro contábil, mesmo que seja em um simples caderno. As respostas foram positivas para a maioria dos entrevistados — Caruaru (64,61\%), Santa Cruz (71,33\%) e Toritama (55,38\%). De qualquer forma, existe controle da movimentação financeira. Quando isso não ocorre, segundo os entrevistados, "é porque é feito de cabeça mesmo".

Analisando-se as respostas dos entrevistados quando se pergunta a respeito de uma possível organização em cooperativas (Y5), observa-se que, na cidade de Caruaru, há resistência a esse tipo de organização (62,31\%), o que também ocorre em Santa Cruz (60,66\%). Já em Toritama as respostas foram positivas $52,31 \%$. A razão pode dever-se ao fato de esses trabalhadores fazerem parte da Associação dos Feirantes de Toritama, ou seja, já se encontram organizados de alguma forma. Alguns feirantes até ressaltaram que o cooperativismo seria de grande utilidade, pois comprariam o tecido 'jeans' no caso deles, em grande quantidade, diminuindo assim o custo, recebendo, consequentemente, lucro maior em relação ao atual.

A variável (Z1) mostra, no Gráfico 3, como são formulados os preços dos produtos nas três cidades. A maioria dos entrevistados apontou o custo de produção como principal fator para a formação dos preços Caruaru (71,02\%); Santa Cruz (70\%) e Toritama (75,38\%). O que alguns dos entrevistados declararam foi o fato de se ter preço baixo: "se não for dessa forma, o cliente procura a concorrência e eu perco a venda. É melhor ganhar pouco e vender, do que voltar pra casa com a mercadoria". 


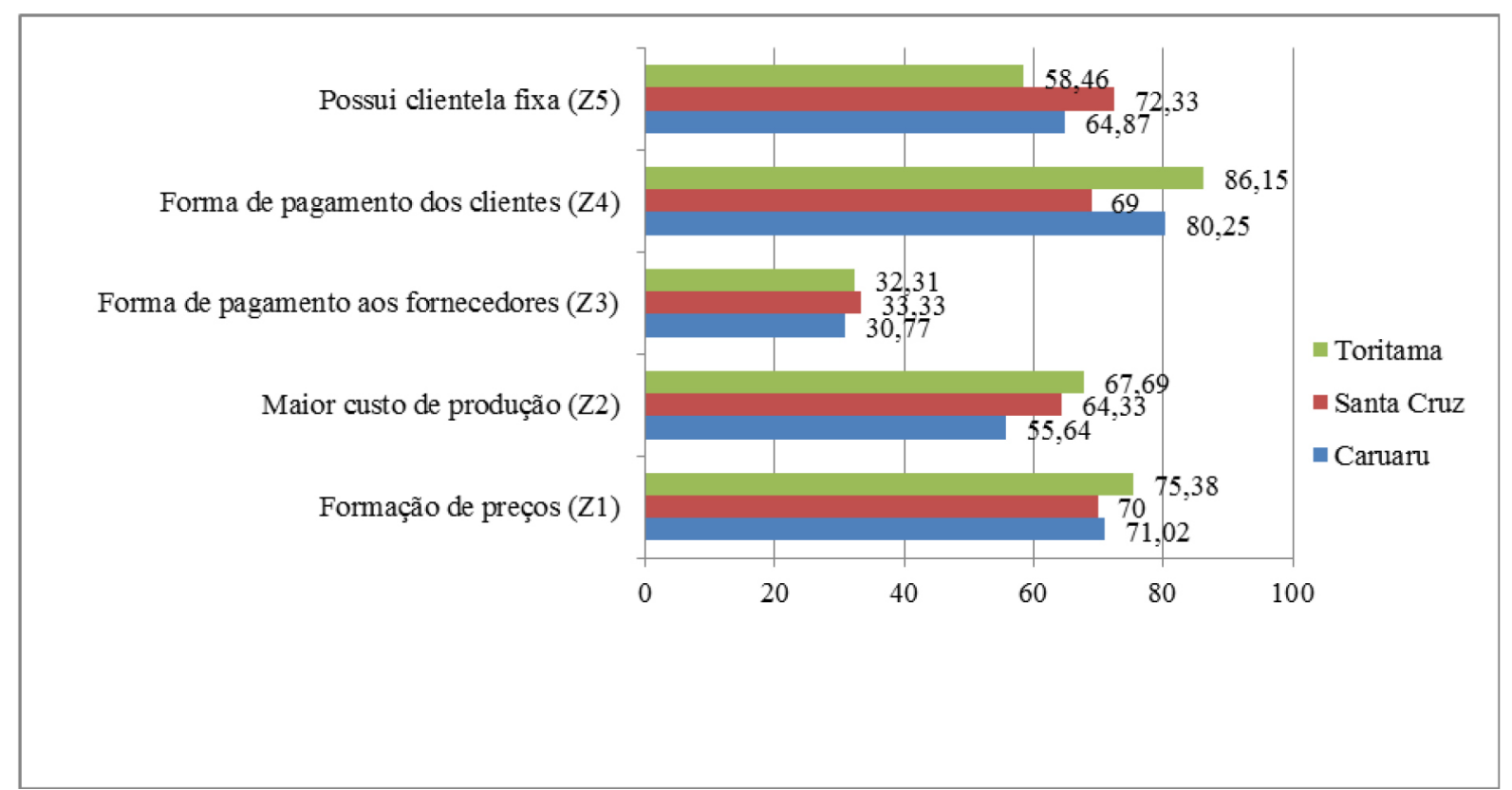

NOTA: LEGENDA DAS VARIÁVEIS: (Z1) - custo de produção; (Z2) - matéria-prima; (Z3) - à vista/as duas formas; (Z4) - à vista; (Z5) - sim.

FONTE: Do autor.

Já a variável (Z2) mostra qual o item que tem maior peso na composição do custo de produção. O estudo demonstra que a maioria dos entrevistados apontou a matéria-prima como o elemento definidor na formação dos custos de produção - Caruaru (55,64\%), Santa Cruz (64,33\%) e Toritama (67,69\%). No caso das férias de confecção, o custo de aquisição do tecido constitui o principal fator na composição dos custos dos feirantes que produzem.

A variável (Z3) revela disparidade quanto à forma de pagamento aos fornecedores pelos feirantes. Em Caruaru, 30,77\% dos entrevistados pagam à vista aos fornecedores e, em Santa Cruz, ocorre o mesmo, 33,33\%; já em Toritama, 32,31\% dos entrevistados utilizam as duas formas de pagamento.

Já a forma de pagamento dos clientes pelas confecções adquiridas (Z4) é feita à vista para 80,25\% dos entrevistados de Caruaru, 69\% dos entrevistados de Santa Cruz e 86,15\% dos entrevistados de Toritama. Isso caracteriza bem a informalidade do setor. Não recebem cheques e raramente aceitam cartões de crédito. Contudo, o preço baixo acaba atraindo o consumidor.

Por essa razão, preço baixo, o consumidor acaba tornando-se fiel. A variável (Z5) mostra a fidelidade dos clientes - Caruaru (64,87\%), Santa Cruz (72,33\%) e Toritama (58,46\%). No caso de Caruaru, a feira é tradicional e os feirantes têm locais fixos para o comércio de seus produtos. Em Santa Cruz, a situação é semelhante, mas é favorecida pela organização e facilidade de acesso e circulação dentro do empreendimento denominado "Moda Center Santa Cruz". Convém ressaltar que a organização dessa feira permite maior volume nas vendas (alguns feirantes chegam a negociar toda a produção da semana para um único cliente. Isso ocorre com consumidores que vêm de outras regiões do País, no intervalo de quinze dias a um mês). Já em Toritama essa percentagem é menor, pois os feirantes mudam-se com maior freqüência do local e, a depender do dia da feira, também participam das feiras de Caruaru e Santa Cruz, alugando o espaço de origem para outra pessoa comercializar.

A variável (W1), demonstrada no Gráfico 4, indica a satisfação do feirante em relação ao seu faturamento mensal. A maioria dos entrevistados em Caruaru (62,05\%) diz-se satisfeita com o faturamento, em Santa Cruz essa percentagem fica em torno de 61\% e em Toritama corresponde a 61,54\%. Para alguns deles, o lucro da feira seria apenas complemento da renda familiar, o que não é o caso da maioria, como mencionado anteriormente. 
Gráfico 4 - Caracterização da Economia Informal, segundo a Orientação para a Formalização (\%)

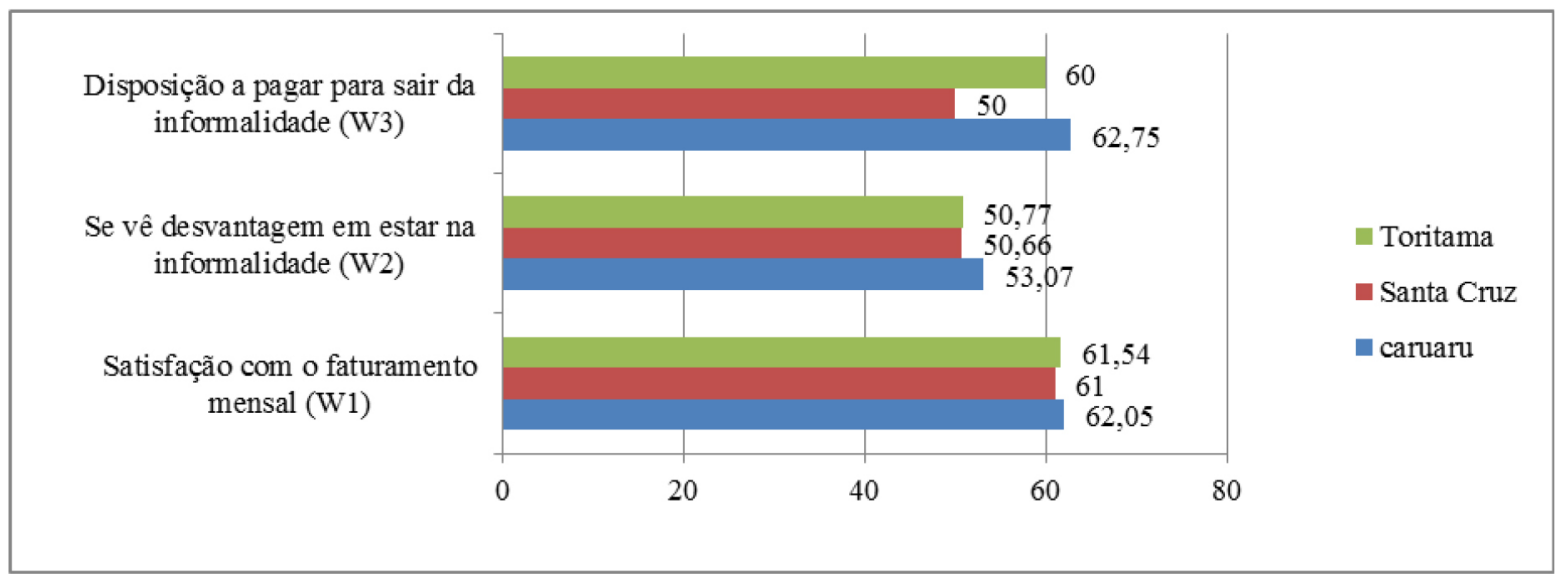

NOTA: LEGENDA DAS VARIÁVEIS: (W1) - Sim / (W2) - Sim - Não / (W3) - Dividido/ Não.

FONTE: Do autor.

A pesquisa inquiriu sobre a percepção dos entrevistados sobre estar na informalidade (W2). Dos entrevistados, $(50,77 \%)$ dos feirantes de Toritama não veem desvantagem em estar na economia informal. Já em Santa Cruz, 50,66\% dos entrevistados acreditam estar em desvantagem por se encontrarem na economia informal, assim como $(53,07 \%)$ em Caruaru. Eles alegaram que já perderam vendas por estarem na informalidade, já que não podem emitir notas fiscais, nem participar de financiamentos para ampliar o negócio.

A variável (W3) mostra a disposição dos entrevistados em pagar algum tipo de imposto para estar na formalidade. Em Santa Cruz, as respostas foram bastante divididas, 50\% estão dispostos e a outra metade não está disposta. Em Toritama, 60\% e Caruaru com 51,79\% dos entrevistados disseram que não estão dispostos a pagar qualquer tipo de imposto para fazer parte do mercado formal. Mas o resultado econométrico demonstrará que, na verdade, as pessoas não estão dispostas a arcar com parte dos custos da formalidade.

\subsection{Disposição a pagar dos indivíduos}

O método de elicidação utilizado foi o open-ended, em que se pergunta diretamente o quanto a pessoa está disposta a pagar em termos monetários ou em percentagem da renda. Dessa forma, os resultados encontrados revelam que a média da disposição a pagar (DAP) média mensal encontrada para Caruaru foi de R\$ 0,08 e para Santa Cruz do Capibaribe foi zero. Para Toritama esse valor não foi calculado ${ }^{35}$, haja vista que as variáveis não foram significativas, muito provavelmente em virtude de pequeno tamanho da amostra. Obviamente esse valor de $\mathrm{R} \$ 0,08$ é desprezível, o que pode ser lido como não disposição a pagar do usuário pela formalização da economia informal.

\subsubsection{A Demanda pela Formalização da Informalidade em Caruaru}

A análise descritiva dos dados apresentada na TABELA 1 revela que, na média, a pessoa que se encontra na economia informal e trabalha na Feira de Caruaru tem 35 anos, menos de 10 anos no ramo, conta com um funcionário assalariado e ganha em torno de $\mathrm{R} \$ 1.586,58$ mensais.

35 A amostra foi calculada em cima do número total de feirantes do Município. No caso de Toritama, em virtude do reduzido número de observações, os resultados mostraram-se sem significância estatística, de forma que se optou pela sua exclusão nesta análise. 
TABELA 1 - análise Descritiva dos Dados em Caruaru

\begin{tabular}{cccccc}
\hline \hline Variável & Mínimo & Máximo & Média & $\begin{array}{c}\text { Desvio- } \\
\text { padrão }\end{array}$ \\
\hline \hline IDADE & 18 & 77 & 35,31 & 14,05 \\
\hline TAMFAM & 1 & 10 & 3,61 & 1,39 \\
\hline TEMPRAM & 1 & 36 & 9,48 & 6,61 \\
\hline NUMFUN & 0 & 18 & 1,08 & 2,45 \\
\hline FATMENS & 300 & 15.000 & $1.586,58$ & $1.675,31$ \\
\hline \hline
\end{tabular}

Fonte: do autor.

Uma análise preliminar dessas variáveis pode demonstrar algumas relações esperadas. Acredita-se, em princípio, que agentes com maior idade, maior tamanho da família, maior tempo de negócio estabelecido, com empreendimentos com maior número de funcionários e maior faturamento mensal estariam mais interessados em formalizar o negócio, haja vista maiores vantagens que poderiam ser adquiridas com essa regularização. Nesse sentido, é de se supor que esses empreendedores estariam mais interessados em pagar por essa formalização. Todavia, o que se verificou nas entrevistas foi que quanto mais estabelecida está a pessoa ou a firma, menos interessada ela está em 'mudar o que está dando certo'. Ou seja, é questão cultural na Região, a informalidade, a feira do jeito que é, durante a madrugada, para eles, parece ser o natural. E quebrar essa resistência necessitará de grande mobilização do poder público, principalmente no concernente à ampla divulgação dos benefícios adquiridos com o processo de formalização.

Nesse sentido, foi procedida a análise das variáveis que influenciam a DAP, seguindo o modelo de variável dependente binária exposto anteriormente. As variáveis idade, tempo no ramo e faturamento mensal mostraram-se significativas para explicar a DAP. Assim, gerou-se o seguinte Modelo Logit de Variável Dependente Binário ${ }^{36}$.

TABELA 2 - variáveis do modelo mais ajustado em Caruaru

\begin{tabular}{|c|c|c|c|c|c|c|}
\hline Variável & $\overline{\bar{\beta}}$ & $\overline{\text { S.E. }}$ & TWald & $\overline{\mathrm{df}}$ & Sig. & $\overline{\operatorname{Exp}(\beta)}$ \\
\hline NUMFUN & $\overline{-0,303}$ & $\overline{0,132}$ & $\overline{5,283}$ & $\overline{1}$ & $\overline{0,022}$ & 0,738 \\
\hline FATMENS & $-0,001$ & 0,000 & 41,640 & 1 & 0,000 & 0,999 \\
\hline Constante & 1,989 & 0,259 & 59,078 & 1 & 0,000 & 7,311 \\
\hline $\mathrm{N}=389$ & & & & & & \\
\hline
\end{tabular}

Fonte: do autor.

Em Caruaru, as variáveis consideradas estatisticamente relevantes para a disposição a pagar pela formalização da economia informal foram número de funcionários e faturamento mensal. Os parâmetros ou coeficientes do modelo logístico apresentam-se como: DAP = 1,989-0,303 (NUNFUN) - 0,001(FATMENS)

36 Foram realizados testes para detectar a presença de multicolinearidade das variáveis com o auxílio do Software SPSS. Donde, pode-se afirmar com precisão estatística que não existe colinearidade entre as variáveis. A estatística qui-quadrado dos resíduos informa que os coeficientes para as variáveis que não estão no modelo são significativamente diferentes de zero, ou seja, nenhuma das variáveis excluídas do modelo contribuiria de forma significativa para o poder preditivo do modelo. O teste de Wald, aplicado individualmente, demonstrou que existem evidências suficientes de que os coeficientes de $\beta$ estimados são diferentes de zero para um nível de significância de 5\%, o que significa que as variáveis são estatisticamente significantes como fatores de risco em potencial para a ocorrência da disposição a pagar. 
O fato de a constante ter-se apresentado positiva, significa que o ambiente propicia uma probabilidade positiva de disposição a pagar pela formalização da economia informal. A percentagem global (overall percentage) de classificação correta do modelo alcançou 74,6\%, indicando que este é considerado satisfatório para a realização de predições futuras. Quanto à razão de chances (odds ratio), as variáveis número de funcionários (NUNFUN) e faturamento mensal (FATMENS) apresentam valores inferiores a unidade, 0,738 e 0,999, respectivamente. Isso significa que à medida que os previsores aumentam, as chances de disposição a pagar diminuem.

As variáveis apresentam-se significativas, mas com sinais negativos. Isso reflete a realidade em que se encontram os feirantes da economia informal. Em alguns casos, os feirantes da economia informal apresentam faturamento mensal alto com a informalidade $(\mathrm{R} \$ 15.000,00)$. Situação que, às vezes, perdura há mais de trinta anos. Como convencer essa pessoa a mudar? Mudar para que? É o que ele questiona.

Uma limitação do estudo refere-se à ausência de maiores explicações para o comportamento das variáveis, o que se daria por meio da comparação com a literatura sobre o assunto. Mas não se tem conhecimento de trabalhos similares que tenham tratado o tema sob essa abordagem e com esse método. Nesse sentido, o que consiste em limitação, de outro lado, também pode se configurar como pioneirismo.

\subsubsection{A Demanda pela formalização da informalidade em Santa Cruz do Capibaribe}

A análise descritiva dos dados apresentada na Tabela 3 revela que, na média, a pessoa que se encontra na economia informal e trabalha na Feira de Santa Cruz do Capibaribe tem 34 anos, menos de 10 anos no ramo, conta com um funcionário e ganha em torno de $\mathrm{R} \$ 1.568,63$ mensais.

Tabela 3 - análise descritiva dos dados em Santa Cruz do Capibaribe

\begin{tabular}{l|r|r|r|r}
\hline \hline Variável & Mínimo & Máximo & Média & \multicolumn{1}{c}{$\begin{array}{c}\text { Desvio-pa- } \\
\text { drão }\end{array}$} \\
\hline IDADE & \multicolumn{1}{c|}{14} & 68 & 34,12 & 10,69 \\
\hline TEMPRAM & 1 & 35 & 9,82 & 7,09 \\
NUMFUN & 0 & 18 & 1,15 & 2,66 \\
FATMENS & 155 & 12.000 & $1.568,63$ & $1.766,68$ \\
\end{tabular}

Fonte: do autor.

De mesma forma, foi realizada a análise das variáveis que influenciam a DAP, seguindo o mesmo modelo. As variáveis idade, escolaridade, tempo no ramo e faturamento mensal mostraram-se significativas para explicar a DAP. Assim, gerou-se o seguinte Modelo Logit de Variável Dependente Binário.

Tabela 4 - variáveis do modelo mais ajustado em Santa Cruz do Capibaribe

\begin{tabular}{|c|c|c|c|c|c|c|}
\hline Variável & $\overline{\bar{\beta}}$ & S.E. & Wald & $\overline{\mathrm{Df}}$ & Sig. & $\overline{\operatorname{Exp}(\beta)}$ \\
\hline$\overline{I D A D E}$ & $\overline{0,037}$ & $\overline{0,016}$ & $\overline{5,361}$ & & $\overline{0,021}$ & $\overline{1,037}$ \\
\hline ESCOLARI & $-0,231$ & 0,095 & 5,885 & & 0,015 & 0,793 \\
\hline TEMPRAM & $-0,046$ & 0,022 & 4,158 & & 0,041 & 0,955 \\
\hline FATMENS & $-0,001$ & 0,000 & 34,119 & & 0,000 & 0,999 \\
\hline
\end{tabular}




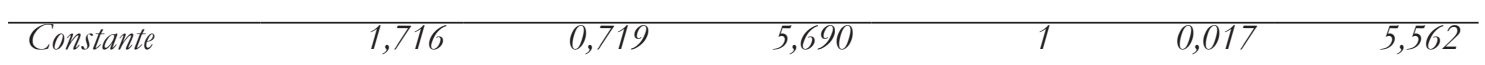

$\mathrm{N}=299$

Fonte: do autor.

Em Santa Cruz, as variáveis consideradas estatisticamente relevantes para a disposição a pagar pela formalização da economia informal foram idade, escolaridade, tempo de permanência no ramo e faturamento mensal. Os parâmetros ou coeficientes do modelo logístico apresentam-se como: DAP = 1,716 + 0,037 (IDADE) - 0,231 (ESCOLARI) - 0,046 (TEMPRAM) - 0,001(FATMENS).

O fato de a constante ter-se apresentado positiva, significa que o ambiente propicia uma probabilidade positiva de disposição a pagar pela formalização da economia informal. A percentagem global de classificação correta do modelo alcançou $71,9 \%$, indicando que este é considerado satisfatório para a realização de predições futuras.

$\mathrm{Na}$ análise da razão de chances, as variáveis escolaridade, tempo de permanência no ramo e faturamento mensal apresentaram valores inferiores a unidade: $0,793,0,955$ e 0,999, respectivamente. Isso significa que à medida que os previsores aumentam as chances de disposição a pagar diminuem. No caso da variável idade, para cada ano da pessoa existe 1,037 chance dele tornar-se disposto a pagar pela formalização da economia informal.

Esperava-se que a variável escolaridade (ESCOLARI) apresentasse sinal positivo, pois se acredita que pessoas com maior instrução tenham maior capacidade para entender a importância de se criar mecanismos de redução da economia informal, por isso, acreditava-se que essa variável se relacionasse positivamente com a variável DAP. Um sinal diferente do esperado, em princípio, indicaria a presença de multicolinearidade entre os dados. Mas essa hipótese foi rejeitada após o teste de diagnóstico de colinearidade. Portanto, admite-se que possa haver algum erro de especificação do modelo não identificado no estudo.

Da mesma forma, as demais variáveis apresentam-se com sinais negativos. Na realidade, isso reflete a realidade em que se encontram os feirantes da economia informal. Quanto mais tempo eles têm no ramo, mais funcionários possuem e maior o faturamento mensal, mais estabelecidos esses feirantes estão no negócio e, portanto, não têm reais pretensões de sair da informalidade, ou seja, querem manter o 'status quo'.

\subsubsection{A Demanda pela formalização da informalidade no agreste pernambucano}

Foi procedida a análise das variáveis que influenciam a DAP, seguindo o modelo exposto anteriormente, considerando a amostra conjunta dos três municípios ${ }^{37}$. As variáveis escolaridade, tempo de permanência no ramo e faturamento mensal mostraram-se significativas para explicar a DAP.

Tabela 5 - variáveis do modelo mais ajustado para o agreste pernambucano

\begin{tabular}{l|l|c|c|c|c|r}
\hline \hline Variável & $\beta$ & S.E. & Wald & df & Sig. & Exp $(\beta)$ \\
\hline \hline ESCOLARI & $-0,222$ & 0,056 & 12,923 & & 0,000 & 0,817 \\
& & & & & & \\
\hline NUMFUN & $-0,258$ & 0,076 & 11,420 & 1 & 0,001 & 0,773 \\
& & & & & & 0,000 \\
\hline FATMENS & $-0,001$ & 0,000 & 66,359 & 1 & & 0,999 \\
\hline
\end{tabular}

37 As dummies locacionais não se apresentaram significantes e por isso foram retiradas do modelo, bem como outras variáveis consideradas inicialmente, possibilitando assim um melhor ajuste do modelo. 


\begin{tabular}{lllllll} 
Constante & 2,514 & 0,286 & 77,115 & 1 & 0,000 & 12,354 \\
& & & & & & \\
\hline $\mathrm{N}=755$ & & &
\end{tabular}

Fonte: do autor.

Considerando-se o agreste pernambucano completo, as variáveis consideradas estatisticamente relevantes para a disposição a pagar pela formalização da economia informal foram escolaridade, número de funcionários e faturamento mensal. Os parâmetros ou coeficientes do modelo logístico apresentam-se como: DAP $=$ 2,514 - 0,222 (ESCOLARI) - 0,258 (NUMFUN) - 0,001(FATMENS).

As variáveis apresentam valores inferiores a unidade [ESCOLARI $(0,817)$, NUMFUN $(0,773)$ e FATMENS $(0,999)]$, quanto à análise da razão de chances. Isso significa que, à medida que os previsores aumentam, as chances de disposição a pagar diminuem.

Grosso modo, os resultados comprovam o ocorrido para a análise isolada dos municípios. Os sinais negativos encontrados refletem o pouco interesse em sair da informalidade à medida que os feirantes estejam mais bem estabelecidos em seus negócios, ou seja, com maior número de funcionários e maior faturamento mensal, corroborando a hipótese inicial de que uma parcela importante das pessoas que se encontram na informalidade não o faz por ausência de oportunidades no mercado formal, mas por considerarem mais atrativos os ganhos adquiridos na informalidade.

\section{Considerações finais}

Em momentos de expansão da economia, espera-se aumento do emprego formal. De outro modo, em períodos de crises, imagina-se aumento nos empregos informais. Nas feiras de confecção do agreste pernambucano, mesmo com o recente histórico de crescimento do País, observa-se grande proporção de trabalhadores e microempresários voltados para a informalidade.

As informações coletadas e analisadas demonstraram que o perfil dos feirantes é principalmente formado pelo gênero feminino; os empreendimentos atuam com a ajuda de familiares; a clientela é fixa e o principal elemento de competição é o baixo preço dos produtos. Essa informação preocupa, na medida em que o desenvolvimento da economia informal traz redução para a arrecadação do Governo, o que compromete os investimentos em bens e serviços públicos, notoriamente necessários para o pleno desenvolvimento da Região.

Do ponto de vista da firma, há que se atentar para o fato de que nem sempre a pessoa está na informalidade por falta de oportunidade no mercado formal. Alguns estão por opção, porque acreditam ser mais vantajoso quando calculam a relação benefício-custo. Mesmo ficando de fora de algumas benesses ofertadas pelo Governo, o fato de não pagar impostos, parece ser mais vantajoso para esse grupo empresarial.

Especialmente pela estrutura de mercado em que se inserem, concorrência monopolística — livre entrada e saída de firmas no mercado; grande número de demandantes e ofertantes; produto diferenciado e com algum tipo de substituibilidade, o que garante algum poder de determinar preço - esses negociantes precisam estar atentos ao fator competitividade. Têm que inovar em termos de mercadoria e de infraestrutura, além de manterem preços atrativos.

Entretanto, percebe-se que os feirantes não estão muito propensos a pagarem para aderirem ao setor formal, haja vista os valores encontrados no estudo, $\mathrm{R} \$ 0,08$ mensais em Caruaru e zero em Santa Cruz do Capibaribe. Os motivos evidenciados vão desde o fato de que acreditam já pagar muitos impostos até e, principalmente, pelo fato de estarem confortáveis com seus rendimentos sem ter de prestar contas sobre isso com o Estado. 
Esse resultado corrobora os principais resultados do estudo de Moura e Barbosa Filho ${ }^{38}$. Para os referidos autores, a informalidade no Brasil é maior nas regiões não metropolitanas e o principal fator explicativo seria o maior nível de informalidade nessas regiões. Além disso, o resultado de que a maior queda de informalidade estaria relacionada ao estrato com maior nível de escolaridade, chegando a explicar $60 \%$ da queda da informalidade no país, poderia explicar porque, no polo de confecções do agreste pernambucano, não há interesse aparente em sair da informalidade, haja vista as pessoas terem baixo nível de escolaridade, considerando-se as especificidades daquele nicho de negócios (pequenos fabricos de fundo de quintal).

O que se observa é que as feiras acabam sendo o principal empregador local e independentemente de as pessoas estarem no mercado formal ou informal, o certo é que se constitui, na principal atividade econômica da Região, contemplando pessoas como proprietárias (feirantes) ou como familiares de feirantes, ou ainda, em menor escala, como trabalhadores remunerados. Contudo, para o desenvolvimento local, a arrecadação é fundamental. A alta informalidade existente no Pólo de Confecções acaba sendo elemento inibidor do crescimento mais igualitário na Região, onde toda a sociedade acaba perdendo. Cabe, portanto, uma intervenção do poder público no sentido de criar mecanismos que levem a essa formalização, tendo em vista que a demanda pela formalização não virá dos feirantes informais.

Contudo, à guisa de conclusão, há que se colocar que uma análise mais detalhada do desempenho econômico do Pólo de Confecções é prejudicada pela escassez de dados com base municipal. Além disso, existem problemas como descontinuidade nos recenseamentos econômicos, além da dificuldade se aferir, tomando-se por base os dados oficiais, qualquer informação sobre a informalidade. Esses problemas foram relatados no relatório do $\mathrm{SEBRAE}^{39}$ e, passados tantos anos, continuam os mesmos. Isso porque os censos demográficos ainda contêm poucas informações econômicas; a RAIS registra apenas os dados das empresas formalizadas (o que compromete sua utilidade para o estudo do Pólo de Confecções do Agreste Pernambucano, cujo índice de informalidade corresponde a mais de 80\%); e as estimativas dos PIBs municipais do IBGE não estão atualizadas, sendo as mais recentes relativas a 2012. Por isso mesmo, as informações de campo foram especialmente importantes para a caracterização do referido Polo.

Uma sugestão para trabalhos futuros seria observar se os programas de transferência de renda estariam impactando na decisão dos empreendedores informais quanto à formalização do setor. Em princípio, com os elementos investigados neste estudo, acredita-se que não. Isso porque não seriam esses agentes econômicos pessoas pobres, usuárias do sistema de bolsas assistencialistas. Pelo menos não é o perfil da maioria, mas em ciência todas as possibilidades devem ser investigadas, ainda mais em se tratando de assunto tão pouco explorado na literatura econômica.

\section{REFERÊNCIAS}

BOEKE, J. Economics and economic policy of dual societies: as exemplified by Indonesia. New York: International Secretariat Institute of Pacific Relations, 1953.

BORGES, A.; FRANCO, A. Economia informal da RMS: verdades e mitos. Babia Análise e Dados, Salvador, v. 9, n. 3, p. 68-89, dez. 1999.

BURNETT, A. A saga dos retalheiros: um estudo sobre a instituição da feira da sulanca no Agreste pernambucano. Século XXI: Revista de Ciências Sociais, v. 3, n. 2, p. 09-40, jul./dez. 2013.

38 MOURA, R. L.; BARBOSA FILHO, F.H. Evolução recente da informalidade no Brasil: uma análise segundo características de oferta e demanda de trabalho. In: ENCONTRO NACIONAL DE ECONOMIA, 41., 2013, Foz do Iguaçu-PR. Anais... Foz do Iguaçu: ANPEC, 2013.

39 Serviço Brasileiro de Apoio às Micro e Pequenas Empresas. Estudo da caracterização econômica do Polo de Confecções do Agreste Pernambucano: relatório final apresentado ao SEBRAE-PE. Recife: FADE/UFPE, maio de 2003. 
CACCIAMALLI, M. C. Globalização e processo de informalidade. São Paulo: IPE/USP, 2000. (Texto para Discussão, 01).

CACCIAMALLI, M. C. Setor informal urbano e formas de participação na produção. 1983. 172f. Tese (Doutorado) - Universidade de São Paulo, São Paulo, 1983.

CACCIAMALLI, M. C.; SILVA, M. F. J. Mais informalidade, menos cidadania, os efeitos criados por esse circulo vicioso sobre a formulação da política social na América Latina. Cadernos Prolam/USP, São Paulo, v. 02, n. 2, p. 4-24, 2003.

CAMARGO, A. L.; MORA, H. G. C. La economía informal em Villavicencio. Finanzas y Política Económica, Bogota, v. 3, n.2, p. 83-104, jul./dez. 2011.

COSTA, M. S. Trabalho informal: um problema estrutural básico no entendimento das desigualdades na sociedade brasileira. Caderno CRH, Salvador, v. 23, n. 58, p.171-190, jan./abr. 2010.

FILÁRTIGA, G. B. Custos de transação, instituições e a cultura da informalidade no Brasil. Revista do BNDES, Rio de Janeiro, v. 14, n. 28, p. 121-144, dez. 2007.

FONTES, A.; PERO, V. Determinantes do desempenho dos microempreendedores no Brasil. 2009. Disponível em: <http://www.ie.ufrj.br/datacenterie/pdfs/seminarios/pesquisa/texto0906.pdf>. Acesso em: 10 ago. 2015.

FREY, Bruno. La economía del arte: una visión personal, y Las falsificaciones en arte: ¿qué falsificaciones? Barcelona: La Caixa, 2000. (Estudios Económicos, 18).

HARRIS, J.;TODARO, M. Migration, unemployment and development: a two-sector Analysis. American Economic Review, Pittsburgh, v. 60, n. 1, p. 126-142, 1970.

HIRSCHMAN, A. Exit, Voice and loyalty: responses to decline in firms, organizations, and states. Cambridge: Harvard University Press, 1970.

INTERNATIONAL LABOR CONFFERENCE. Transition from the informal to the formal economy. Geneva: International Labor Office, 2014.

LEWIS, A. The Dual Economy revisited. The Manchester School, Hoboken, v. 47, n. 3, p. 211-229, Sept. 1979.

MACHADO, A. F; OLIVEIRA, A. M. H.C.; ANTIGO, M. Evolução do diferencial de rendimentos entre setor formal e informal no Brasil: O papel das características não observadas. Revista Economia Contemporânea, Rio de Janeiro, v. 12, n. 2, p. 355-388, maio/ago. 2008.

MILHOMEM, A. V. Trabalho informal: precarização do trabalho e exclusão social em Goiás e no Brasil. Revista Anhanguera, São Paulo, v. 4, n. 1, p. 139-155, jan./dez. 2003.

MINCER, J. Unemployment Effects of Minimum Wages. Political Economy, London, v. 84, n. 4, p. s87-s104, Aug. 1976. Part 2: Essays in Labor Economics in Honor of H. Greg.

MOURA, R. L.; BARBOSA FILHO, F.H. Evolução recente da informalidade no Brasil: uma análise segundo características de oferta e demanda de trabalho. In: ENCONTRO NACIONAL DE ECONOMIA, 41., 2013, Foz do Iguaçu-PR. Anais... Foz do Iguaçu: ANPEC, 2013.

NERI, M. Informalidade. Ensaios econômicos, Rio de Janeiro, n. 635, p. 1-40, dez. 2006.

OLIVEIRA, R. V.; BRAGA, B. M. Território comercial de Toritama: persistência e metamorfoses da informalidade. Revista de Ciências Sociais Politica \& Trabalho, João Pessoa, n. 41, p. 193-225, out. 2014.

ORGANIZAÇÃO INTERNACIONAL DO TRABALHO. Organização Internacional do Trabalho: promovendo o trabalho decente. Disponível em: <http://www.oitbrasil.org.br/content/o-que-e-trabalho-decente>. Acesso em 10 ago. 2015. 
PERRY, G. Et al. Informality: Exit and Exclusion. Washington:The World Bank, 2007.

RAMOS, Lauro (ed.). Mercado de trabalho: conjuntura e análise. Brasília: IPEA, maio 2009. (Boletim, 39). Disponível em: <http://www.ipea.gov.br/agencia/images/stories/PDFs/mercadodetrabalho/BMT39_completo.pdf>. Acesso em: 10 ago. 2015.

ROCHA, M. E. B. Economia informal cearense: uma caracterização. In: VIANNA, P. J.; ROSA, A. L. T. (Org.). Economia do Ceará em Debate. Fortaleza: IPECE, 2006. p. 136-156.

ROSA, A. L. T.; CASTELAR, L.I.M. Demanda por microcrédito em Fortaleza: uma análise do método de avaliação contingente. Fortaleza: Universidade Federal do Ceará. Curso de Pós-Graduação em Economia CAEN, 1998. (Texto para Discussão, n. 174/98).

Serviço Brasileiro de Apoio às Micro e Pequenas Empresas. Economia informal urbana: julho de 2005. Goiânia: Observatório SEBRAE, 2015.

Serviço Brasileiro de Apoio às Micro e Pequenas Empresas. Estudo da caracterização econômica do Polo de Confeções do Agreste Pernambucano: relatório final apresentado ao SEBRAE-PE. Recife: FADE/UFPE, maio de 2003.

SOTO, H. de. El otro sendero: la revolución informal. Bogotá: Oveja Negra, 1987.

SQUEEF, G. C. Produtividade do trabalho nos setores formal e informal no Brasil: uma avaliação do período recente. Rio de Janeiro: IPEA, 2015. (Texto para Discussão, n. 2084). 


\section{REVISTA BRASILEIRA DE POLÍTICAS PÚBLICAS BRAZILIAN JOURNAL OF PUBLIC POLICY}
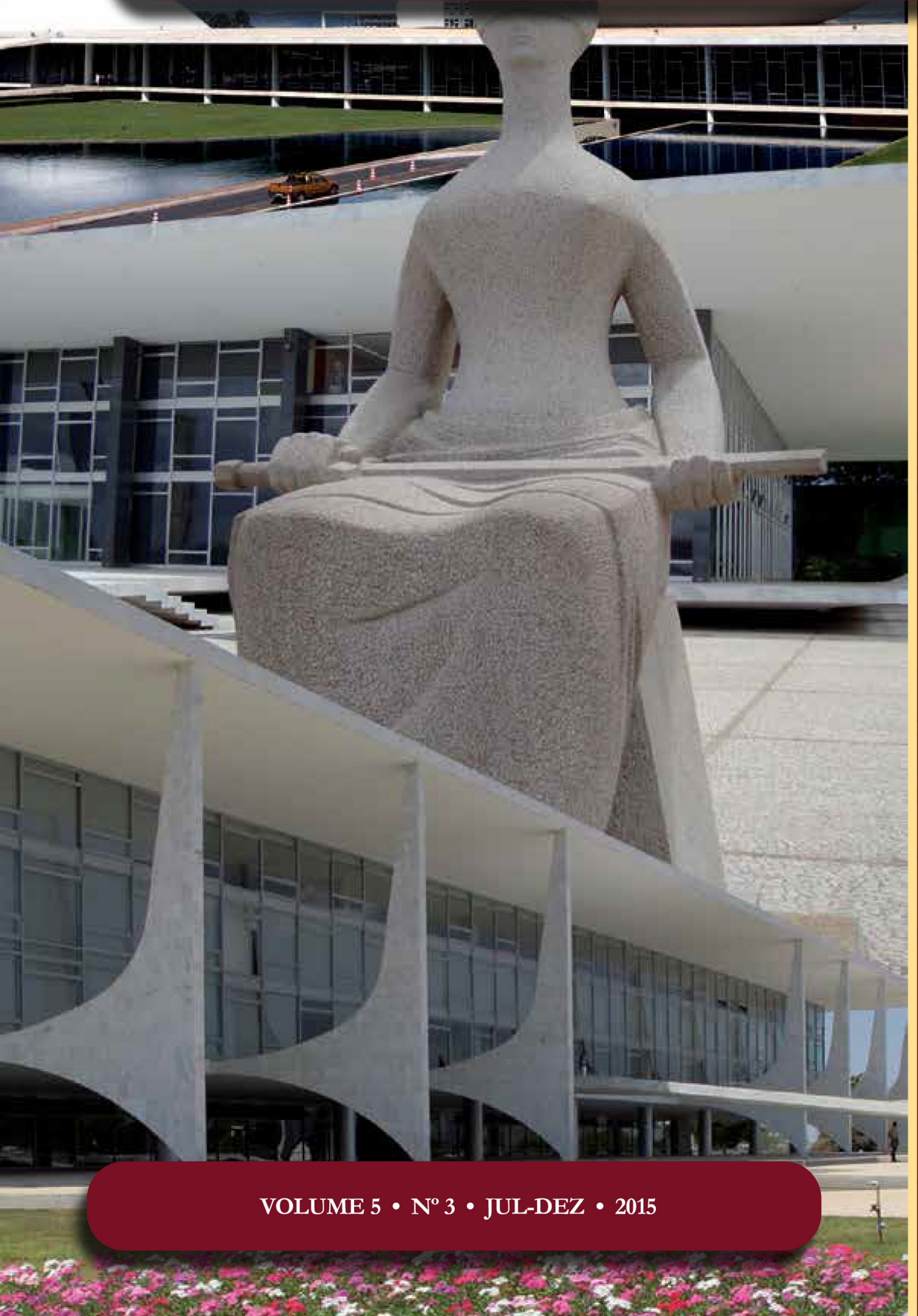

Implicações do Programa Nacional de Alimentação Escolar (PNAE) na renda e organização de agricultores familiares

Programa Nacional de Alimentação Escolar (PNAE) [National School Feeding Program] implications in the income and organization of familly farmers

Nádia Kunkel Szinwelski

Carla Rosane Paz Arruda Teo

Luciara de Souza Gallina

Fabiula Grahl

Cimara Filippi 


\section{Implicações do Programa Nacional de Alimentação Escolar (PNAE) na renda e organização de agricultores familiares*}

\author{
Programa Nacional de Alimentação Escolar \\ (PNAE) [National School Feeding Program] \\ implications in the income and organization \\ of family farmers
}

* Recebido em 25/03/2015

Aprovado em 08/07/2015

** Nutricionista - Docente do curso de Nutrição da Universidade Comunitária da Região de Chapecó - SC. E-mail: nadiaks@unochapeco.edu.br.

*** Nutricionista - Docente do Programa de Pós-Graduação em Ciências da Saúde.da Universidade Comunitária da Região de Chapecó SC.E-mail: carlateo@unochapeco.edu.br.

**** Nutricionista - Docente do Curso de Nutrição da Universidade Comunitária da Região de Chapecó -SC. E-mail: luciara@unochapeco.edu.br.

***** Acadêmica do curso de Nutrição -Bolsista do Núcleo de Iniciação Científica em Promoção da Alimentação Saudável nas Escolas, financiado pelo Art. 170 da Constituição do Estado de Santa Catarina. E-mail: fabiulagrahl@ unochapeco.edu.br.

****** Acadêmica do curso de Nutrição -Bolsista voluntária do Núcleo de Iniciação Científica em Promoção da Alimentação Saudável nas Escolas, financiado pelo Art. 170 da Constituição do Estado de Santa Catarina. Email: cimaraa@unochapeco.edu.br.

\author{
Nádia Kunkel Sziwelski ** \\ Carla Rosane Paz Arruda Teo *** \\ Luciara de Souza Gallina ****
}

Fabiula Grahl *****

Cimara Filippi******

\section{Resumo}

O Programa Nacional de Alimentação Escolar (PNAE) consiste na transferência de recursos financeiros do Governo Federal aos estados, Distrito Federal e municípios, para aquisição de gêneros alimentícios para a alimentação escolar, e 30\% desses recursos devem ser destinados à compra de alimentos da agricultura familiar. Este estudo buscou conhecer as modificações referidas por agricultores familiares de Seara - SC em termos de renda e organização, após iniciar fornecimento de alimentos para o PNAE. Foram realizadas entrevistas com agricultores familiares que entregam alimentos para o Programa, cujas respostas foram submetidas à análise de conteúdo. O PNAE, além de melhorar a qualidade das refeições servidas nas escolas, traz melhoria de renda aos agricultores. Também há avanço na organização destes, já que a associação em cooperativas promove trabalho em equipe e apoio profissional.

Palavras-chave: Alimentação escolar. Renda. Agricultura familiar.

\section{Abstract}

The Programa Nacional de Alimentação Escolar (PNAE) [National School Feeding Program] consists in the transference of financial resources from the Federal Government to the states, Federal District and cities, for the acquisition of food for school feeding, which $30 \%$ of these resources should be intended for the buying of food from family agriculture. The objective of the study was to know the changes mentioned by the family farmers from Seara - SC in terms of income and organization, after starting the food supply to the PNAE. Interviews were held with family farmers that delivered food to the Program which answers were submitted to analysis of 
content. The PNAE brings positive changes to the interviewees, since it not only improves the quality of the meals served in schools but also brings better income to the farmers. There is also improvement in the organization of the farmers, since the association in cooperatives promotes team work and professional support.

Key words: School feeding. Income. Family agriculture.

\section{INTRODUÇÃO}

O Programa Nacional de Alimentação Escolar (PNAE) consiste na política pública de alimentação mais antiga do Brasil e um dos maiores programas de alimentação escolar em nível mundial. O embrião do atual Programa foi instituído em 1955, com a criação da Campanha da Merenda Escolar ${ }^{1}$, que, inicialmente, contou com o financiamento de Organizações Internacionais. Atualmente, o Programa consiste na transferência de recursos financeiros do Governo Federal, de forma suplementar, aos estados, Distrito Federal e municípios, para a aquisição de gêneros alimentícios destinados à alimentação escolar. ${ }^{2}$

O PNAE constitui-se em importante estratégia para garantia da Segurança Alimentar e Nutricional (SAN), já que promove o Direito Humano à Alimentação Adequada (DHAA) por meio da alimentação escolar. ${ }^{3}$ É o único programa brasileiro de cunho alimentar que possui atendimento universalizado. ${ }^{4}$

A verba utilizada para a alimentação escolar é proveniente de recursos federais e repassada pelo Fundo Nacional de Desenvolvimento da Educação (FNDE) para estados e municípios de acordo com o número de estudantes da educação básica que cada município possui. ${ }^{5}$

O artigo $2^{\circ}$, inciso V da Lei n ${ }^{\circ} 11.947 / 2009$, que dispõe sobre o atendimento da alimentação escolar, trata do apoio ao desenvolvimento sustentável, e nele está enfatizada a inserção da agricultura familiar no âmbito do PNAE já que se afirma que deve haver incentivo à aquisição de gêneros alimentícios variados, produzidos em âmbito local e de preferência pela agricultura familiar ou empreendedores familiares rurais, com prioridade às comunidades tradicionais indígenas e quilombolas. Ainda na mesma legislação, em seu artigo 14, especifica-se que, no mínimo, 30\% do total dos recursos repassados pelo FNDE deverão ser destinados à aquisição de alimentos diretamente do agricultor ou empreendedor familiar rural ou de suas organizações, dando prioridade aos assentamentos da reforma agrária, comunidades tradicionais indígenas e quilombolas. ${ }^{6}$ Com isso, o programa passa a apoiar o desenvolvimento local, incentivando aquisição de alimentos diversificados e produzidos na própria região, proporcionando maior adequação aos seus hábitos alimentares. ${ }^{7}$

1 BRASIL. Câmara dos Deputados. Decreto n. 37.106, de 31 de março de 1955. Institui a Campanha de Merenda Escolar. Disponível em: <http://www2.camara.leg.br/legin/fed/decret/1950-1959/decreto-37106-31-marco-1955-332702-publicacaooriginal-1-pe. html>. Acesso em: 29 jun. 2015.

2 BRASIL. Lei n. 11.947, de 16 de junho de 2009. Dispõe sobre o atendimento da alimentação escolar e do Programa Dinheiro Direto na Escola aos alunos da educação básica. Disponível em: < http://www.planalto.gov.br/ccivil_03/_ato2007-2010/2009/lei/ 111947.htm>. Acesso em: 10 jul. 2014.

3 VILLAR, Betzabeth Slater et al. Situação dos municípios do estado de São Paulo com relação à compra direta de produtos da agricultura familiar para o Programa Nacional de Alimentação Escolar (PNAE). Revista Brasileira de Epidemiologia, São Paulo, v. 16, n. 1, p. 223-226, mar. 2013.

4 TRICHES, Rozane Márcia; SCHNEIDER, Sergio. Alimentação Escolar e Agricultura Familiar: reconectando o consumo à produção. Saúde e Sociedade, São Paulo, v. 19, n. 4, p. 933-945, out./dez. 2010.

5 SARAIVA, Elisa Braga et al. Panorama da compra de alimentos da agricultura familiar para o Programa Nacional de Alimentação Escolar. Ciência e Saúde Coletiva, Rio de Janeiro, v. 18, n. 4, p. 927-936, abr. 2013.

6 BRASIL. Lei n. 11.947, de 16 de junho de 2009. Dispõe sobre o atendimento da alimentação escolar e do Programa Dinheiro Direto na Escola aos alunos da educação básica. Disponível em: <http://www.planalto.gov.br/ccivil_03/_ato2007-2010/2009/lei/ 111947.htm>. Acesso em: 10 jul. 2014.

7 VILLAR, Betzabeth Slater et al. Situação dos municípios do estado de São Paulo com relação à compra direta de produtos da agricultura familiar para o Programa Nacional de Alimentação Escolar (PNAE). Revista Brasileira de Epidemiologia, São Paulo, v. 16, n. 1, p. 223-226, mar. 2013. 
A aquisição de alimentos para o programa auxilia a reintegrar a cidade e o campo, podendo colaborar para o enfrentamento de problemas no consumo e produção de alimentos. Essa iniciativa integra "políticas de direito à alimentação, relacionadas à saúde e à nutrição da população de escolares e [...], criam mercados para os agricultores familiares onde não existiam ou eram muito débeis". ${ }^{8}$ Isso significa que o dispositivo legal do PNAE o aproxima da agricultura familiar e essa aproximação é favorável ao fortalecimento da agricultura familiar, colaborando para sua sustentabilidade e para a soberania alimentar. ${ }^{9}$

As evoluções ocorridas na gestão do programa, como a descentralização e obrigatoriedade na compra de alimentos básicos foi fundamental para fortalecer o programa e a agricultura familiar. ${ }^{10}$ Ressalta-se que, de acordo com a Lei no 11.947/2009, gêneros alimentícios básicos são aqueles imprescindíveis à promoção da alimentação saudável.

Orientações como as descritas na Resolução/CD/FNDE n 26/2013 de limitar a compra de alimentos restritos - enlatados, embutidos, doces, alimentos semiprontos ou prontos para o consumo, alimentos concentrados com teor elevado de sódio ou gordura saturada - a 30\% dos recursos destinados ao Programa e de, logicamente, utilizar o restante para a compra de alimentos básicos, sendo no mínimo 30\% diretamente da agricultura familiar, auxiliam em seu fortalecimento, além de promover alimentação adequada aos escolares. ${ }^{11}$

É importante salientar que, até o ano de 1994, a maioria dos alimentos oferecidos pelo PNAE não se adaptavam aos hábitos dos estudantes, pelo fato de que os cardápios eram padronizados em nível nacional, sendo o processo de aquisição de alimentos centralizado. Muitas vezes os alimentos chegavam às escolas impróprios para o consumo, o que aumentava o desperdício. A partir de 1994, houve a descentralização da gestão do programa, sendo designada aos municípios, o que propiciou melhor adequação ao hábito alimentar da população atendida. ${ }^{12}$

Com base no contexto de obrigatoriedade da aquisição de alimentos para o PNAE diretamente do pequeno agricultor, o presente estudo propõe-se a conhecer as modificações referidas por agricultores familiares de um município catarinense de pequeno porte, em termos de renda e organização, após sua inserção no mercado institucional representado pela alimentação escolar.

\section{MateriaIS e mÉtodos}

A pesquisa foi realizada com agricultores familiares do município de Seara - SC, que realizam entrega de gêneros alimentícios para o PNAE. O primeiro contato com os agricultores ocorreu por meio da nutricionista Responsável Técnica da Secretaria da Educação do referido município.

8 TRICHES, Rozane Márcia; SCHNEIDER, Sergio. Reconstruindo o “elo perdido": a reconexão da produção e do consumo de alimentos através do Programa de Alimentação Escolar no município de Dois Irmãos (RS). Segurança Alimentar e Nutricional, Campinas, v. 17, n. 1, p. 1-15, jan./jun. 2010. p. 2.

9 TEO, Carla Rosane Paz Arruda; MONTEIRO, Carlos Augusto. Marco legal do Programa Nacional de Alimentação Escolar: uma releitura para alinhar propósitos e práticas na aquisição de alimentos. Revista de Nutrição, Campinas, v. 25, n. 5, p. 657-668, set./ out. 2012.

10 SARAIVA, Elisa Braga et al. Panorama da compra de alimentos da agricultura familiar para o Programa Nacional de Alimentação Escolar. Ciência e Saúde Coletiva, Rio de Janeiro, v. 18, n. 4, p. 927-936, abr. 2013.

11 BRASIL. Ministério da Educação. Fundo Nacional de Desenvolvimento da Educação. Resolução FNDE/CD n 26, de 17 de junho de 2013. Dispõe sobre o atendimento da alimentação escolar aos alunos da educação básica no âmbito do Programa Nacional de Alimentação Escolar - PNAE. Brasília, 2013. Disponível em: <https://www.fnde.gov.br/fndelegis/action/UrlPublicasAction. php?acao $=$ abrirAtoPublico\&sgl_tipo $=$ RES\&num_ato $=00000026 \& s e q \_a t o=000 \& v l r \_a n o=2013 \& s g l \_$orgao $=$FNDE $/ \mathrm{MEC}>$. Acesso em: 23 nov. 2014.

12 TRICHES, Rozane Márcia; SCHNEIDER, Sergio. Alimentação Escolar e Agricultura Familiar: reconectando o consumo à produção. Saúde e Sociedade, São Paulo, v. 19, n. 4, p. 933-945, out./dez. 2010. 
O estudo é descritivo e exploratório de natureza qualitativa, seguindo o método de amostragem por saturação teórica, definido como a suspensão de inclusão de novos participantes quando os dados obtidos passam a apresentar, na avaliação do pesquisador, certa redundância ou repetição, não sendo considerado relevante persistir na coleta de dados. ${ }^{13}$

Foi realizado um pré-teste com dois agricultores familiares que não fizeram parte do grupo de participantes do estudo para verificar a adequação do instrumento de coleta de dados aos objetivos da pesquisa.

Os dados foram coletados por meio de entrevista semiestruturada gravada e posteriormente transcrita. As entrevistas foram agendadas previamente e realizadas pelas pesquisadoras em local de escolha do entrevistado. Após esclarecimento sobre os objetivos e procedimentos da pesquisa, os agricultores familiares deveriam manifestar aceite de participação com base na assinatura do Termo de Consentimento Livre e Esclarecido (TCLE) e do Termo de Consentimento para Uso de Voz.

As respostas das entrevistas foram submetidas à análise de conteúdo, que consiste em operação de classificação de elementos constitutivos de um conjunto, por diferenciação e por reagrupamento segundo a analogia. ${ }^{14}$

A análise dos dados pautou-se pelas seguintes categorias: o fornecimento de alimentos para o PNAE; a parceria com cooperativas; e as mudanças na renda após parceria com o Programa.

O estudo foi aprovado pelo Comitê de Ética em Pesquisa, envolvendo Seres Humanos da Universidade Comunitária da Região de Chapecó (Unochapecó) sob o Protocolo de Pesquisa no 290/13.

\section{Resultados E discussão}

Foram entrevistados 10 agricultores familiares do município de Seara-SC que fornecem alimentos para o PNAE. A idade dos agricultores variou entre 38 e 76 anos, o que permite identificar que há predominância de adultos e idosos nas atividades rurais, corroborando um relativo envelhecimento do setor rural, dado o intenso deslocamento dos jovens para os centros urbanos frente à incapacidade das atividades agrícolas assegurarem a ocupação e o sustento de todos os membros das famílias. ${ }^{15}$

Esse panorama tem sido reportado na literatura e apontado como desfavorável à reprodução social do setor, pois são os jovens que podem dar continuidade às atividades de produção de alimentos para garantir suprimento das necessidades da população. Em estudo realizado por Silva ${ }^{16}$, que investigou os fatores limitantes à participação de agricultores familiares no fornecimento de produtos para o PNAE, também foi observado que os entrevistados apresentaram idade entre 34 e 75 anos, condizendo com o encontrado no presente estudo.

Esse quadro atual de envelhecimento da população na agricultura é preocupante ${ }^{17}$, pois resulta em baixa capacidade de renovação desse segmento. ${ }^{18}$ Nesse contexto, tem sido apontado que as iniciativas de revitali-

13 FLICK, Uwe. Uma introdução à pesquisa qualitativa. Porto Alegre: Bookman, 2004.

14 BARDIN, Laurence. Análise de conteúdo. Lisboa: Edições 70, 2011.

15 MARCONDES, Tabajara. Mudanças no espaço rural de Santa Catarina. In: VIEIRA, Luiz Marcelino (Org). Sintese Anual da Agricultura de Santa Catarina 2009-2010. Florianópolis: EPAGRI, 2010. p. 12-24.

16 SILVA, Cláudia Hein da. Produtos da agricultura familiar na alimentação escolar do município de Arroio dos Ratos - RS. 2013.66 f. Trabalho de Conclusão de Curso (Graduação) - Faculdade de Ciências Econômicas, Universidade Federal do Rio Grande do Sul, Arroio dos Ratos, 2013.

17 SCHNEIDER, Armildo. A participação da agricultura familiar no Programa Nacional de Alimentação Escolar no município de São Lourenço do Sol. 2013. 39 f. Trabalho de Conclusão de Curso (Graduação) - Faculdade de Ciências Econômicas, Universidade Federal do Rio Grande do Sul, São Lourenço do Sul, 2013.

18 MATTEI, Lauro. Novo retrato da agricultura familiar em Santa Catarina. In: VIEIRA, Luiz Marcelino (Org.). Sintese Anual da Agricultura de Santa Catarina 2009-2010. Florianópolis: EPAGRI, 2010. p. 25-35. 
zação da agricultura familiar devem conferir especial atenção à juventude rural, considerada como ator social central nesse processo em razão de algumas peculiaridades, como a curiosidade, a criatividade, a afinidade por processos inovadores e dinâmicos, a facilidade de aderir a novos canais de comunicação, assegurando que novos conhecimentos sejam gerados e incorporados ao setor. Além disso, a juventude rural representa o futuro da agricultura familiar. ${ }^{19}$ Nesse sentido, a inserção de produtos da agricultura familiar no PNAE pode ser estratégia de enfrentamento desses desafios, contribuindo para a permanência dos jovens na atividade rural e, assim, para a reprodução intergeracional do setor.

Segundo Tomasetto, Lima e Shikida ${ }^{20}$, "a agricultura familiar, como forma de diversificação da produção, vem se desenvolvendo em todos os pontos do mundo e tem como característica a predominância da mão de obra e gerenciamento por membros da família." Dessa maneira, Ribeiro, Ceratti e Broch ${ }^{21}$ veem o PNAE como importante estratégia de incentivo ao trabalho familiar, prevenindo o êxodo rural.

Para Reis e Gonçalves Neto ${ }^{22}$, o desemprego no campo é fomentado pelas monoculturas e sua mecanização promove o êxodo rural. Em contrapartida, a agricultura familiar conta com mão de obra familiar e casualmente com a ajuda de terceiros. A agricultura familiar e a produção de alimentos diversificados são importantes tanto para a alimentação dos brasileiros quanto para a empregabilidade no campo.

De acordo com Saraiva et al. ${ }^{23}$, a aproximação dos agricultores familiares com os consumidores promove integração que além de diminuir o êxodo rural, contribui para a diminuição da pobreza tanto no nível rural quanto urbano.

Em relação ao tempo de fornecimento de gêneros alimentícios para o Programa pelos agricultores familiares entrevistados, houve variação entre dois e cinco anos, e o Programa teve início no município há aproximadamente cinco anos.

Para cada categoria de análise do conteúdo das entrevistas, foram definidas categorias de significado que serão discutidas nos tópicos correspondentes.

\subsection{O fornecimento de alimentos para O PNAE}

De acordo com os sentidos que emergiram das percepções dos agricultores entrevistados sobre o fornecimento de alimentos para o PNAE, foram estabelecidas novas categorias de significado: produtos mais frescos e saudáveis aos escolares, o apoio da prefeitura às agroindústrias, a compra direta dos agricultores familiares, a logística de entrega adotada no município estudado e a melhoria da renda/renda fixa como pontos positivos, e a pouca quantidade de alimentos comprada e o custo de embalagens/rótulos como pontos negativos.

De acordo com o FNDE ${ }^{24}$, o orçamento do PNAE, para o ano de 2014, foi de R 3,5 bilhões, para beneficiar 43 milhões de estudantes da educação básica e de jovens e adultos, e o correspondente a 30\% desse

19 FOOD AND AGRICULTURE ORGANIZATIONS OF THE UNITED NATIONS. The state of food and agriculture: Innovation in family farming. Rome: FAO, 2014.

20 TOMASETTO, Mariza Zeni de Castro; LIMA, Jandir Ferrera de; SHIKIDA, Pery Francisco Assis. Desenvolvimento local e agricultura familiar: o caso da produção de açúcar mascavo em Capanema/Paraná. Interações, Campo Grande, v. 10, n. 1, p. 21-30, jan./jun. 2009. p. 22.

21 RIBEIRO, Ana Lúcia de Paula; CERATTI, Silene; BROCH, Djulia Taís. Programa Nacional de Alimentação Escolar (PNAE) e a participação da agricultura familiar em municípios do Rio Grande do Sul. Revista Gestão e Desenvolvimento em Contexto, Cruz Alta, v.1, n. 1, p. 36-49, 2013.

22 REIS, Luá Cristine Siqueira; GONÇALVES NETO, João da Cruz. Produção de alimentos: agricultura familiar x cultura de exportação no Brasil, sob a perspectiva da sustentabilidade. Revista Brasileira de Políticas Públicas, Brasília, v. 4, n. 1, p. 89-98, 2014.

23 SARAIVA, Elisa Braga et al. Panorama da compra de alimentos da agricultura familiar para o Programa Nacional de Alimentação Escolar. Ciência e Saúde Coletiva, Rio de Janeiro, v. 18, n. 4, p. 927-936, abr. 2013.

24 BRASIL. Ministério da Educação. Fundo Nacional de Desenvolvimento da Educação. Aquisişão de produtos da agricultura familiar para a alimentação escolar. Disponível em: <http://www.fnde.gov.br/programas/alimentacao-escolar/agricultura-familiar>. Acesso em: 10 jul. 2014. 
valor — R \$ 1,05 bilhão — deve ser utilizado para a compra diretamente de agricultores familiares, visando promover o desenvolvimento econômico e sustentável.

Segundo Oliveira ${ }^{25}$, a produção familiar consiste em uma das atividades principais de muitas famílias em diversas regiões do Brasil e deve ser fortalecida, gerando mais oportunidades aos agricultores e aumentando emprego e renda. Os dados do Censo Agropecuário de 2006 tabulados pelo IBGE mostram que o valor anual da produção da agricultura familiar é de apenas 54,5 bilhões de reais (33,2\% do total) e o da agricultura não familiar é 109,5 bilhões $(66,8 \% \text { do total })^{26}$.

Com base na publicação da Lei no $11.947 / 2009^{27}$, a agricultura familiar ganhou grande incentivo. Para Turpin ${ }^{28}$, “o FNDE induz o respeito à cultura alimentar local e ao uso de produtos in natura, típicos da agricultura familiar" quando estabelece que o cardápio deve conter alimentos básicos e quando recomenda a utilização de produtos da região.

O PNAE é um mercado institucional que aproxima produção e consumo de alimentos, que une o apoio à produção familiar de alimentos a uma melhora nos aspectos nutricionais. Esse programa constitui uma estratégia que auxilia a enfrentar problemas relacionados à produção e consumo de alimentos, contribuindo no que diz respeito a aspectos econômicos, sociais e nutricionais. ${ }^{29}$ Ou seja, o Programa auxilia a reduzir a pobreza e a insegurança alimentar, a reorganizar as comunidades, incentiva a organização e associação de famílias agricultoras, dinamiza as economias locais, além de ampliar a oferta de alimentos de qualidade e valorizar a produção familiar.

O encontro da agricultura familiar com a alimentação escolar promove mudanças importantes na alimentação dos estudantes por proporcionar o consumo diário de alimentos saudáveis produzidos por agricultores familiares da região, como foi relatado por um agricultor entrevistado para o presente estudo:

“[...] a prefeitura começou [...] pegar produto fresco, assim que sai da agricultura, do dia-a-dia e é bem mais saudável para quem vai comer, os alunos, com certeza, o produto é sempre melhor” (A1).

Os agricultores entrevistados por Leite et al. ${ }^{30}$ expuseram interesse em vender seus produtos para o PNAE, pois, além de melhoria e garantia de renda para a família, os alunos estão recebendo um alimento mais saudável.

Triches e Schneider ${ }^{31}$ perceberam com seu estudo que a compra de alimentos da agricultura familiar proporcionou modificações nas concepções e práticas alimentares das crianças atendidas e que foi relatado por merendeiras entrevistadas que os produtos recebidos são mais frescos, variados, de qualidade melhor, o que determina melhor aceitação da alimentação pelos alunos, sendo relatados, ainda, maior frequência de frutas e verduras na alimentação e maior consumo desses alimentos pelos estudantes.

25 OLIVEIRA, Luan Lustosa Nicolau de. Programa Nacional de Alimentação Escolar. 2013. 37 f. Relatório Final de Estágio Supervisionado (Graduação em Gestão do Agronegócio) - Universidade de Brasília, Brasília, 2013.

26 HOFFMANN, Rodolfo. A agricultura familiar produz $70 \%$ dos alimentos consumidos no Brasil? Seguranca Alimentar e Nutricional, Campinas, v. 21, n. 1, p. 417-421, 2014.

27 BRASIL. Lei n. 11.947, de 16 de junho de 2009. Dispõe sobre o atendimento da alimentação escolar e do Programa Dinheiro Direto na Escola aos alunos da educação básica. Disponível em: <http://www.planalto.gov.br/ccivil_03/_ato2007-2010/2009/lei/ 111947.htm>. Acesso em: 10 jul. 2014.

28 TURPIN, Maria Elena. A alimentação escolar como fator de desenvolvimento local por meio do apoio aos agricultores familiares. Segurança Alimentar e Nutricional, Campinas, v. 16, n. 2, p. 20-42, jul./dez. 2009. p. 26.

29 PAULA, Márcia Maria de; KAMIMURA, Quésia Postigo; SILVA, José Luís Gomes da. Mercados institucionais na agricultura familiar: dificuldades e desafios. Revista de Politica Agricola, Brasília, v. 23, n. 1, p. 33-43, jan./mar. 2014.

30 LEITE, Cássia Roberta de Melo et al. Projeto EDUCOAGRO (Educação Cooperativa e Agroecológica) fomentando a Agricultura Familiar e apoiando a implantação do Programa Nacional de Alimentação Escolar (PNAE) no município de Jupi/ PE, Brasil. Cadernos de Agroecologia, v. 6, n. 2, dez. 2011. Disponível em: <http://www.aba-agroecologia.org.br/revistas/index.php/cad/ article/view/11884/8255>. Acesso em: 17 ago. 2015.

31 TRICHES, Rozane Márcia; SCHNEIDER, Sergio. Alimentação Escolar e Agricultura Familiar: reconectando o consumo à produção. Saúde e Sociedade, São Paulo, v. 19, n. 4, p. 933-945, out./dez. 2010. 
Salienta-se que, de acordo com a Portaria Interministerial n 1.010/2006, a alimentação saudável precisa ser percebida como direito humano, cujo padrão atenda às necessidades biológicas, sociais e culturais das pessoas, conforme as fases do curso da vida. ${ }^{32}$

Para Campos ${ }^{33}$, o PNAE consiste em "um programa bom para os agricultores familiares, bom para as escolas que possuem melhor alimentação escolar, bom para o desenvolvimento do município e para a população que fixa residência e tem suas necessidades atendidas".

De acordo com Dias e Chiffoleau ${ }^{34}$, o Programa proporciona, desde a educação infantil, aproximar quem produz e quem vai consumir o alimento, e assim, estimula a consciência sobre o local de produção como um local onde são produzidas memórias, saberes e identidade.

Turpin ${ }^{35}$ constatou, em seu estudo, que, dentre os principais benefícios citados pela parceria entre agricultura familiar e alimentação escolar, estão o fortalecimento da economia local, maior produção com maior diversidade de produtos, diminuição do êxodo rural, melhora na qualidade de vida e garantia de renda aos agricultores, mais investimentos na produção dos alimentos, e maior formalização de agricultores por meio de cadastro e adesão ao Programa além da participação de cooperativas e associações.

O PNAE constitui ótima oportunidade para revitalizar a economia local e aproximar o produtor e o consumidor por meio das compras públicas. É um exercício de solidariedade e de reciprocidade. Os alunos têm a possibilidade de conhecer a origem do alimento que estão consumindo e essa reflexão pode ser levada para a sala de aula por meio de ações de educação. ${ }^{36}$

Outro ponto positivo destacado por um agricultor neste estudo foi o apoio da prefeitura às agroindústrias:

"É assim, é positivo, é bom que eles começaram, por que um tempo atrás não pegavam quase, era tudo produto de fora, então a gente também ficou contente que a prefeitura começou dar apoio para as agroindústrias, [...]” (A1).

Segundo Campos $^{37}$, o apoio da gestão pública municipal à agricultura familiar auxilia o agricultor a aumentar sua produtividade, gerando renda. Assim, ocorre maior arrecadação de impostos para o município para consequente utilização desses recursos em benefício à população.

De acordo com Carvalho ${ }^{38}$, muitos municípios da região sul do Brasil adquiriram produtos orgânicos

32 BRASIL. Ministério da Saúde. Portaria Interministerial n. 1.010, de 8 de maio de 2006. Institui as diretrizes para a promoção da alimentação saudável nas escolas de educação infantil, fundamental e nível médio das redes públicas e privadas, em âmbito nacional. Disponível em: <http://dtr2001.saude.gov.br/sas/PORTARIAS/Port2006/GM/GM-1010.htm>. Acesso em: 07 dez. 2014.

33 CAMPOS, Rafael Albuquerque. Agricultura familiar e políticas públicas: avaliação do Programa Nacional de Alimentação Escolar - PNAE no município de Campina da Lagoa/PR. 2011. 53 f. Monografia (Especialização) - Pós Graduação Gestão Pública Municipal, Universidade Tecnológica Federal do Paraná, Curitiba, 2011.

34 DIAS, Juliana; CHIFFOLEAU, Monica. PNAE: um exercício de reciprocidade entre produtor e consumidor a partir da Lei de Alimentação Escolar. In: ENCONTRO NACIONAL DE ESTUDOS DO CONSUMO, 7.; ENCONTRO LUSO-BRASILEIRO DE ESTUDOS DO CONSUMO, 3.; ENCONTRO LATINO-AMERICANO DE ESTUDOS DO CONSUMO, 1., 2014, Rio de Janeiro. Mercados Contestados: as novas fronteiras da moral, da ética, da religião e da lei. Rio de Janeiro: Puc-Rio, 2014. Disponível em: <http://www.estudosdoconsumo.com.br/artigosdoenec/ENEC2014-GT08-Dias_Chiffoleau-PNAE_\%20um_exercicio_de_reciprocidade_entre_produtor_e_consumidor.pdf $>$. Acesso em: 17 ago. 2015.

35 TURPIN, Maria Elena. A alimentação escolar como fator de desenvolvimento local por meio do apoio aos agricultores familiares. Segurança Alimentar e Nutricional, Campinas, v. 16, n. 2, p. 20-42, jul./dez. 2009.

36 DIAS, Juliana; CHIFFOLEAU, Monica. PNAE: um exercício de reciprocidade entre produtor e consumidor a partir da Lei de Alimentação Escolar. In: ENCONTRO NACIONAL DE ESTUDOS DO CONSUMO, 7.; ENCONTRO LUSO-BRASILEIRO DE ESTUDOS DO CONSUMO, 3.; ENCONTRO LATINO-AMERICANO DE ESTUDOS DO CONSUMO, 1., 2014, Rio de Janeiro. Mercados Contestados: as novas fronteiras da moral, da ética, da religião e da lei. Rio de Janeiro: Puc-Rio, 2014. Disponível em: <http://www.estudosdoconsumo.com.br/artigosdoenec/ENEC2014-GT08-Dias_Chiffoleau-PNAE_\%20um_exercicio_de_reciprocidade_entre_produtor_e_consumidor.pdf $>$. Acesso em: 17 ago. 2015.

37 CAMPOS, Rafael Albuquerque. Agricultura familiar e políticas públicas: avaliação do Programa Nacional de Alimentação Escolar - PNAE no município de Campina da Lagoa/PR. 2011. 53 f. Monografia (Especialização) - Pós Graduação Gestão Pública Municipal, Universidade Tecnológica Federal do Paraná, Curitiba, 2011.

38 CARVALHO, Daniela Gomes de. Licitações sustentáveis, alimentação escolar e desenvolvimento regional: uma discussão 
para a alimentação escolar de agricultores familiares da própria região, e essa prática auxilia no fortalecimento da economia municipal e estadual.

A compra direta da agricultura também foi vista como ponto positivo como fica evidente na fala a seguir:

"Positivo é que, por exemplo, assim, a gente tem uma vantagem que a compra é direta de nós agricultores, e daí o valor é um pouco maior, [...]" (A10).

Além disso, a logística de entrega adotada pelo município também foi citada como ponto positivo:

“[...] agora que eles colocaram aquele negócio lá do CTG, central da merenda, aí fica melhor entregar lá” (A2).

O município do presente estudo criou um local que é chamado Central da Merenda, localizado em um Centro de Tradição Gaúcha (CTG), onde os agricultores realizam a entrega dos produtos, sem haver necessidade de se deslocar para fazer as entregas em cada escola. Junto a esse CTG funciona uma escola que também recebe produtos dos agricultores familiares.

A logística de distribuição dos produtos hortifrutigranjeiros para as escolas foi um dos problemas encontrados no estudo de Barbosa e Almeida ${ }^{39}$, além de inadequação de produtos processados pelos agricultores familiares quanto aos aspectos sanitários, pouca disponibilidade de produtos processados, adequação das cozinhas e dos depósitos nas escolas para receber os produtos in natura, vindos da agricultura familiar, a diversidade na produção e a adequação de cardápios aos alimentos disponibilizados pelos agricultores familiares. Tomando-se por base esse problema foi organizado um espaço para a entrega de produtos da agricultura familiar. A disponibilização desse local pode favorecer a aquisição de produtos das cooperativas de agricultores familiares.

Agricultores familiares fornecedores de alimentos para o PNAE foram entrevistados por Leite (2013) e citaram a logística utilizada para entrega dos produtos como favorável, já que a cooperativa é responsável por buscar a produção diretamente nas propriedades e realizar a entrega.

Já em um dos municípios avaliados no estudo de Prado et al. ${ }^{40}$, a entrega foi ponto importante dos problemas de logística, sendo alegado que os agricultores realizavam a entrega dos alimentos nas escolas em carros de passeio, tornando o transporte ineficiente, tendo a necessidade de realizar muitas viagens para finalizar a entrega, gerando atrasos e comprometendo a qualidade dos produtos, podendo ocorrer até a falta de entrega.

Segundo Schneider ${ }^{41}$, é necessário que a logística em relação à coleta e à distribuição dos alimentos seja eficaz para que os produtos sejam consumidos em tempo adequado. Também Prado et al. ${ }^{42}$ citam que, na aquisição de alimentos, a logística de abastecimento é essencial para que o valor nutricional da alimentação servida nas escolas seja mantido.

A melhoria na renda da família também foi citada pelos agricultores familiares entrevistados como ponto positivo da parceria com o PNAE, porém, como esse assunto merece destaque, será discutido em um tópico específico a seguir.

sobre o poder de compra governamental a favor da sustentabilidade. Revista Planejamento e Políticas Públicas, n. 32, p. 115-148, jan./ jun. 2009.

39 BARBOSA, Natália Ferreira; ALMEIDA, Luiz Manoel de Moraes Camargo. Gestão da alimentação escolar em Goiânia: uma análise do Comitê de Apoio à Agricultura Familiar no Programa Nacional de Alimentação Escolar em Goiás. Revista Eletrônica de Educação da Faculdade Araguaia, Goiânia, v. 4, n. 4, p. 242-254, 2013.

40 PRADO, Tatiana Resende et al. Agricultura familiar na alimentação escolar: estudo de caso em dois municípios de Minas Gerais. Nutrire, São Paulo, v. 38, n. 3, p. 256-268, dez. 2013.

41 SCHNEIDER, Armildo. A participação da agricultura familiar no Programa Nacional de Alimentação Escolar no município de São Lourenço do Sol. 2013. 39 f. Trabalho de Conclusão de Curso (Graduação) - Faculdade de Ciências Econômicas, Universidade Federal do Rio Grande do Sul, São Lourenço do Sul, 2013.

42 PRADO, Tatiana Resende et al. Agricultura familiar na alimentação escolar: estudo de caso em dois municípios de Minas Gerais. Nutrire, São Paulo, v. 38, n. 3, p. 256-268, dez. 2013. 
Poucos pontos negativos foram citados pelos agricultores, incluindo a pouca quantidade de alimentos adquirida pelo Programa e o custo com embalagens/rótulos:

"Negativo, só é pouca a venda, podia ser mais né” (A2).

“[...] por outro lado, às vezes a gente produz e vai sobrando aí é difícil pra gente dar a volta" (A6).

“[...] mas a gente também tem dificuldade porque, o custo também das embalagens se tornou caro, porque é tudo comprado, pra tu poder vender tem que ter rótulo, rótulo é uma coisa assim, que também tem custo, então tudo envolve [...]" (A1).

Foi relatado pelas nutricionistas entrevistadas por Prado et al. ${ }^{43}$ que os agricultores familiares locais não conseguem entregar ao município a quantidade necessária de alimentos demandada pelo PNAE, e que nem o mínimo de 30\% é atingido com agricultores locais, sendo necessário recorrer a agricultores da região que, segundo as autoras, estão localizados a uma distância de até $600 \mathrm{~km}$.

O presente estudo vislumbrou a possibilidade de aumentar a quantidade de alimentos adquiridos diretamente da agricultura familiar do município estudado, pois todos os agricultores entrevistados referiram ter capacidade de entregar volumes maiores ao Programa. É importante dizer que, de acordo com a nutricionista Responsável Técnica do PNAE no município em que foi desenvolvido este estudo, aproximadamente 50\% dos recursos recebidos do FNDE no ano de 2013 para a compra de gêneros alimentícios para o Programa foram utilizados para a aquisição de alimentos diretamente da agricultura familiar.

Salienta-se que essa região - oeste catarinense — tem estruturação econômica fortemente influenciada pela agropecuária. Com a inserção da criação de aves de corte e de agroindústrias frigoríficas, viabilizou-se a vocação da região para a pecuária de pequeno porte e a agricultura familiar, potencializando a mão de obra local que é abundante. ${ }^{44}$ De acordo com Giacomolli ${ }^{45}$, a região oeste de Santa Catarina teve ocupação marcada "pelo predomínio de minifúndios e a intensa atividade agropecuária".

Cabe referir, que, no momento que os dados desta pesquisa foram coletados, o limite individual de venda do agricultor familiar para a alimentação escolar deveria respeitar o valor máximo de $\mathrm{R} \$ 20.000,00$ (vinte mil reais)/ano. Em abril de 2015, uma nova resolução ${ }^{46}$ permite que esse valor possa ser praticado por Entidade Executora, ou seja, o agricultor pode vender esse valor para vários municípios.

\subsection{A parceria com cooperativas}

As seguintes categorias de significado serão analisadas a seguir: a burocracia, o trabalho conjunto, a redução dos custos e o apoio técnico dado pelas cooperativas como pontos positivos, e a burocracia também como ponto negativo.

Segundo Castellano ${ }^{47}$, "o cooperativismo se trata de um modelo de gestão que busca maior justiça social

43 PRADO, Tatiana Resende et al. Agricultura familiar na alimentação escolar: estudo de caso em dois municípios de Minas Gerais. Nutrire, São Paulo, v. 38, n. 3, p. 256-268, dez. 2013.

44 SEARA (SC). Prefeitura Municipal. Aspectos econômicos do município de Seara. Disponível em: http://www.seara.sc.gov.br/arquivos_internos/index.php?abrir=secretaria_agricultura>. Acesso em: 24 set. 2014.

45 GIACOMOLLI, Marcio. O papel da CRESOL CREDISEARA no financiamento e apoio aos pequenos agricultores rurais em Seara (SC) e municípios vizinhos. In: ENCONTRO DE GRUPOS DE PESQUISA, 5. Agricultura, desenvolvimento regional e transformações socioespaciais. Disponível em: <http://w3.ufsm.br/gpet/engrup/vengrup/anais/5/Marcio\%20Giacomolli_Estudos\%20 da $\% 20$ Dinamica $\% 20$ Regional $\% 20 \mathrm{e} \% 20 \mathrm{de} \% 20$ Processo.pdf $>$. Acesso em: 17 ago. 2015. p. 2.

46 BRASIL. Ministério da Educação. Fundo Nacional de Desenvolvimento da Educação. Resolução n. 4, de 2 de abril de 2015. Altera a redação dos artigos 25 a 32 da Resolução/CD/FNDE n. 26, de 17 de junho de 2013, no âmbito do Programa Nacional de Alimentação Escolar (PNAE). Disponível em: <https://www.fnde.gov.br/fndelegis/action/UrlPublicasAction. php?acao $=$ abrirAtoPublico\&sgl_tipo $=$ RES\&num_ato $=00000004 \& s e q \_a t o=000 \& v 1 r \_a n o=2015 \& s g l \_o r g a o=C D / F N D E /$ MEC>. Acesso em: 30 jun. 2015.

47 CASTELLANO, Flora de Oliveira. Condições para ampliação da comercialização de produtos orgânicos da agricultura familiar na grande Florianópolis/SC: estudo sobre a organização de uma central de reunião e distribuição de produtos. 2012. 63 f. Trabalho de Conclusão 
e econômica", e seu atual desafio consiste em manter estratégias para assegurar que pequenos produtores tenham espaço em um sistema que busca primeiramente o lucro.

Ainda segundo o mesmo autor, com base na formação de associações e cooperativas, pequenos produtores com dificuldades semelhantes conseguem melhores condições para colocar seus produtos no mercado. ${ }^{48}$ A organização em cooperativas constitui uma alternativa para a inclusão da agricultura familiar na alimentação escolar especialmente em mercados institucionais grandes. ${ }^{49}$

No município em estudo, todos os entrevistados são associados a cooperativas e afirmam que, mesmo antes de fornecer alimentos para o Programa, já eram associados. Essa associação é vista como importante para todos os agricultores entrevistados:

"[...] é que nem fosse uma família, a gente se une todos, todas as agroindústrias, cada um com o seu produto, e vai discutindo, defendendo, [...] com reuniões a gente se sai bem, contente, e é um trabalho junto, mais familiar" (A1).

"[...] se não tivesse a cooperativa, seria pior pra, desde o financiamento, orientação, o grupo se ajuda" (A2).

Também Schneider ${ }^{50}$ constatou em seu estudo que a maioria dos agricultores familiares que fornecem alimentos para o PNAE participam de alguma associação ou cooperativa e que essa parceria traz benefícios aos agricultores. Para os agricultores entrevistados por Leite ${ }^{51}$, a forma de organização cooperativada também é considerada importante para que a comercialização se desenvolva.

Em contrapartida, a maioria dos agricultores entrevistados por Silva ${ }^{52}$ não são associados a cooperativas, mas admitem querer participar dessas associações, pois acreditam que isso possibilitaria a garantia de comercialização de seus produtos.

Percebe-se que o trabalho em equipe realizado com base na parceria com as cooperativas é de grande importância para os agricultores entrevistados:

"Os positivos que se tu tiver algum problema eles sentam todo mundo pra resolver, [...]" (A7).

"É com certeza o trabalho em conjunto facilita muito, a parte burocrática, diminui custo, é um trabalho muito interessante que tem as experiências de uma filial, às vezes contribui com os problemas de outro" (A8).

Segundo Nerling e Abreu ${ }^{53}$, a cooperativa a que os agricultores familiares entrevistados são associados tem o objetivo de promover desenvolvimento das famílias associadas e suas respectivas comunidades por meio da produção e industrialização de seus produtos.

de Curso (Graduação) - Centro de Ciências Agrárias da Universidade Federal de Santa Catarina, Florianópolis, 2012.

48 CASTELLANO, Flora de Oliveira. Condições para ampliação da comercialização de produtos orgânicos da agricultura familiar na grande Florianópolis/SC: estudo sobre a organização de uma central de reunião e distribuição de produtos. 2012. 63 f. Trabalho de Conclusão de Curso (Graduação) - Centro de Ciências Agrárias da Universidade Federal de Santa Catarina, Florianópolis, 2012.

49 BARBOSA, Natália Ferreira; ALMEIDA, Luiz Manoel de Moraes Camargo. Gestão da alimentação escolar em Goiânia: uma análise do Comitê de Apoio à Agricultura Familiar no Programa Nacional de Alimentação Escolar em Goiás. Revista Eletrônica de Educação da Faculdade Araguaia, Goiânia, v. 4, n. 4, p. 242-254, 2013.

50 SCHNEIDER, Armildo. A participação da agricultura familiar no Programa Nacional de Alimentação Escolar no município de São Lourenço do Sol. 2013. 39 f. Trabalho de Conclusão de Curso (Graduação) - Faculdade de Ciências Econômicas, Universidade Federal do Rio Grande do Sul, São Lourenço do Sul, 2013.

51 LEITE, Cármen Elisete Caceres. Análise da importância do PAA e PNAE como impulsionadores do desenvolvimento local - o caso da COPTIL em Hulha Negra/RS. 2013. 56 f. Trabalho de Conclusão de Curso (Graduação) - Faculdade de Ciências Econômicas da UFRGS, São Lourenço do Sul, 2013.

52 SILVA, Cláudia Hein da. Produtos da agricultura familiar na alimentação escolar do município de Arroio dos Ratos - RS. 2013 . 66 f. Trabalho de Conclusão de Curso (Graduação) - Faculdade de Ciências Econômicas, Universidade Federal do Rio Grande do Sul, Arroio dos Ratos, 2013.

53 NERLING, Daniele; ABREU, Lucilene de. Agroecologia e agricultura familiar: relato do estágio de vivência ativa da Unochapecó em Seara - SC 2007. Revista Brasileira de Agroecologia, Cruz Alta, v. 2, n. 1, p. 1222-1225, fev. 2007. 
Antes de haver a possibilidade de os agricultores familiares fornecerem gêneros alimentícios para a alimentação escolar, eles atuavam apenas como produtores de alimentos. Juntamente com a oportunidade de entrega de seus produtos para a alimentação escolar foram exigidas alterações e, em razão delas, os agricultores encontravam dificuldades para participar do programa, dentre as quais, a obrigatoriedade de licitar todos os recursos utilizados para as compras e a adequação das formalidades para comprovação de padrões de qualidade dos produtos. ${ }^{54}$

Atualmente o processo licitatório é dispensado para a compra de alimentos provindos da agricultura familiar, desde que os valores sejam semelhantes aos demais do mercado local e que os produtos tenham a qualidade necessária. A aprovação da Lei que tornou obrigatória a aquisição de gêneros alimentícios de agricultores familiares auxilia estes a comercializarem seus produtos sem participar de processos licitatórios. ${ }^{55}$

Mesmo o processo licitatório sendo dispensado, existem documentos necessários para que os produtores forneçam alimentos para o Programa, envolvendo aspectos burocráticos. Nesse sentido, a parceria com cooperativas também foi vista como fundamental:

"Com a cooperativa é bom por que a gente não precisa correr muito atrás de nota fiscal, tem a funcionária que faz as notas fiscais, enfim, o que é necessário para a comercialização" (A6).

“[...] A cooperativa que faz todo o projeto, faz a nota, faz as encomendas em si, ela faz toda a organização da entrega da produção, toda a logística a cooperativa faz" (A10).

De acordo com Camargo, Baccarin e Silva ${ }^{56}$, embora existam dificuldades, o PNAE permite a inserção e maior participação dos agricultores na economia local, o que contribui para que os hábitos alimentares locais culturalmente estabelecidos sejam valorizados e mantidos.

O apoio técnico dado pelas cooperativas foi citado pelos agricultores entrevistados como ponto positivo da parceria:

"Muito bom a organização, já é engenheira de alimentos, já é contador junto, trabalhamos tudo junto assim, daí diminui gastos" (A4).

"Nós temos uma ONG que dá toda a assessoria daí, o código de barras, contador, engenheira de alimentos, tudo que precisa eles tem [...]" (A5).

“[...] tem toda a parte da burocracia que é feita pela ONG, parte de contabilidade, marca e código de barra e tudo mais que nós temos apoio disso aî" (A9).

Conforme afirma Ramos ${ }^{57}$, muitos documentos precisam ser criados para permitir a organização dos agricultores e seus produtos com as escolas. Dentre eles estão: "chamadas públicas, projetos de venda, contratos de fornecimento, termos de recebimento, notas fiscais e pagamentos." Como os agricultores não estão habituados com esse trabalho, é fundamental a existência de entidade articuladora e de profissional responsável por atuar na parte administrativa.

No estudo de Prado et al. ${ }^{58}$ " "a falta de treinamento técnico dos agricultores é um fator importante, que dificulta todo o processo logístico desde a colheita até a entrega”. O treinamento possibilita capacitar os

54 TRICHES, Rozane Márcia; SCHNEIDER, Sergio. Alimentação Escolar e Agricultura Familiar: reconectando o consumo à produção. Saúde e Sociedade, São Paulo, v. 19, n. 4, p. 933-945, out./dez. 2010.

55 SARAIVA, Elisa Braga et al. Panorama da compra de alimentos da agricultura familiar para o Programa Nacional de Alimentação Escolar. Ciência e Saúde Coletiva, Rio de Janeiro, v. 18, n. 4, p. 927-936, abr. 2013.

56 CAMARGO, Regina Aparecida Leite de; BACCARIN, José Giacomo; SILVA, Denise Boito Pereira da. O papel do Programa de Aquisição de Alimentos (PAA) e do Programa Nacional de Alimentação Escolar (PNAE) no fortalecimento da agricultura familiar e promoção da segurança alimentar. Revista Temas de Administração Pública, v. 8, n. 2, 2013. Disponível em: < http://seer.fclar. unesp.br/temasadm/article/view/6846>. Acesso em: 07 dez. 2014.

57 RAMOS, Mariana Oliveira. As crianças estão se sentindo importantes: avanços na alimentação escolar a partir da lei 11.947/2009 e da compra da agricultura familiar. Revista Trajetória Multicursos, Osório, v.2, n. 2, p. 4-19, ago. 2011. Edição Especial. p. 15.

58 PRADO, Tatiana Resende et al. Agricultura familiar na alimentação escolar: estudo de caso em dois municípios de Minas Gerais. Nutrire, São Paulo, v. 38, n. 3, p. 256-268, dez. 2013. p. 265. 
agricultores para atividades que demandem nível de conhecimento maior em assuntos específicos, "como novas tecnologias de produção, logística e gestão".

Agricultores entrevistados por Schneider ${ }^{59}$ para seu estudo, se mostraram satisfeitos com o fornecimento de alimentos para o PNAE, pois, com isso, têm a oportunidade de participar de palestras e cursos referentes ao seu trabalho, havendo a possibilidade de aumentar sua renda em razão das informações recebidas, renda essa utilizada pela maioria dos agricultores para manter a família e investir em sua propriedade.

Os agricultores entrevistados para o presente estudo não referiram a participação em palestras ou cursos, sendo esta uma estratégia interessante de ser aplicada, pois informações importantes são tratadas nessas intervenções. Cabe ressaltar que os entrevistados citaram ter auxílio de diversos profissionais, o que se dá por meio das parcerias com as cooperativas.

Quando questionados sobre pontos negativos da relação com a cooperativa, os agricultores demonstram estar satisfeitos, pois não apontam problemas:

"Bom, tem essa questão da cooperativa pra nós, não tem pontos negativos, todos eles são pontos positivos" (A10).

Apenas um agricultor cita a burocracia como um ponto negativo:

“... e daí também tem os pontos negativos, que às vezes tem que correr atrás de várias coisas, tudo com nota, senão, não dá nada certo, a gente não consegue nada [...]” (A1).

Porém, em outras falas citadas anteriormente os entrevistados afirmam que toda a parte burocrática é realizada pela própria cooperativa, além de outras entidades que dão apoio aos agricultores.

Em estudo realizado por Campos $^{60}$, os entrevistados também apontaram a burocracia na documentação para o Programa como uma dificuldade, além de referirem não receber informações suficientes a respeito disto dos órgãos competentes. No presente estudo, todos os agricultores afirmaram receber apoio das cooperativas para resolver seus problemas.

Entre os documentos exigidos para o fornecimento ao PNAE, estão o Extrato da Declaração de Aptidão ao Pronaf (DAP), CPF/CNPJ, projeto de venda e declaração de que os gêneros alimentícios a serem entregues são produzidos pelo agricultor ou associados relacionados no projeto de venda. A lista completa de documentos por agricultor individual ou grupos de agricultores está disponível na Resolução/CD/ FNDE $n^{\circ} 26 / 2013^{61}$.

Um desafio e, simultaneamente, incentivo promovido pela lei 11.947/2009, encontrado pelos agricultores familiares consistem na organização para, por exemplo, realizar a entrega dos gêneros alimentícios dentro dos prazos estabelecidos, mesmo com os imprevistos em razão do clima. Assim, a parceria com instituições que forneçam apoio e informação aos agricultores é fundamental para o processo de organização. ${ }^{62}$

Percebe-se que a associação às cooperativas é fundamental para os agricultores entrevistados, em virtude

59 SCHNEIDER, Armildo. A participação da agricultura familiar no Programa Nacional de Alimentação Escolar no município de São Lourenço do Sol. 2013. 39 f. Trabalho de Conclusão de Curso (Graduação) - Faculdade de Ciências Econômicas, Universidade Federal do Rio Grande do Sul, São Lourenço do Sul, 2013.

60 CAMPOS, Rafael Albuquerque. Agricultura familiar e políticas públicas: avaliação do Programa Nacional de Alimentação Escolar - PNAE no município de Campina da Lagoa/PR. 2011. 53 f. Monografia (Especialização) - Pós Graduação Gestão Pública Municipal, Universidade Tecnológica Federal do Paraná, Curitiba, 2011.

61 BRASIL. Ministério da Educação. Fundo Nacional de Desenvolvimento da Educação. Resolução FNDE/CD n. 26, de 17 de junho de 2013. Dispõe sobre o atendimento da alimentação escolar aos alunos da educação básica no âmbito do Programa Nacional de Alimentação Escolar - PNAE. Brasília, 2013. Disponível em: https://www.fnde.gov.br/fndelegis/action/UrlPublicasAction. php?acao $=$ abrirAtoPublico\&sgl_tipo $=$ RES\&num_ato $=00000026 \& s e q \_a t o=000 \& v l r \_a n o=2013 \& s g l \_$orgao $=$FNDE $/ \mathrm{MEC}>$. Acesso em: 23 nov. 2014.

62 RAMOS, Mariana Oliveira. As crianças estão se sentindo importantes: avanços na alimentação escolar a partir da lei 11.947/2009 e da compra da agricultura familiar. Revista Trajetória Multicursos, Osório, v.2, n. 2, p. 4-19, ago. 2011. Edição Especial. 
do apoio prestado por elas aos associados. Corrêa ${ }^{63}$ também constatou com seu estudo que as cooperativas estão muito envolvidas em dar apoio aos agricultores familiares, auxiliando na divulgação e acesso ao PNAE.

\subsection{Mudanças na renda após parceria com o PNAE}

Para as mudanças percebidas na renda após parceria com o Programa, foram estabelecidas como categorias de significado o aumento na renda, renda insuficiente e renda complementar.

Políticas públicas de compras institucionais, como é o caso do PNAE, têm alcançado resultados positivos na sustentabilidade econômica dos agricultores, assim como na estruturação dos grupos a que estes estão associados. ${ }^{64}$

Neste estudo, foram unânimes os relatos em relação à renda como ponto positivo do fornecimento de produtos para o Programa:

"Olha, o positivo, renda garantida, sempre certinho, paga certo também" (A4).

“[...] o pagamento é em dia, não tem atraso, no dia marcado a gente recebe" (A10).

"Ah, é um ponto positivo é que a gente tem uma renda a mais [...] além do que a gente entrega no município e nos mercados" (A3).

"É o ponto positivo é que tu tem todo ano uma quantidade [...]" (A7).

Os agricultores entrevistados no estudo realizado em Campina da Lagoa/PR também referiram receber pagamento correto pelos produtos fornecidos ao PNAE, além de referirem que o Programa incentiva a diversificação no cultivo, e de terem certeza que os alimentos produzidos serão vendidos e o valor correspondente será recebido. ${ }^{65}$

Barbosa e Almeida ${ }^{66}$ também observaram, em seu estudo, realizado em Goiânia que a parceria da agricultura familiar com a alimentação escolar proporciona garantia de mercado para os agricultores comercializarem seus produtos, além de possibilitar inclusão socioeconômica desses sujeitos, aspectos considerados positivos para os agricultores.

Neste estudo percebeu-se que a renda provinda do fornecimento de alimentos para o PNAE não se caracteriza como a principal renda de nenhuma das famílias entrevistadas, sendo, portanto, insuficiente para o sustento da família e complementar aos recursos obtidos de outras vendas e atividades realizadas. Porém, todos os agricultores têm intenção de continuar fornecendo alimentos para o Programa.

Para garantir o sustento da família, todos os agricultores entrevistados para este estudo fornecem alimentos em outros locais, como mercados, feira, casa colonial, fruteiras e dois deles têm outra renda além da produção de alimentos, sendo um professor aposentado e um proprietário de madeireira. Nas falas a seguir evidencia-se o exposto:

"Não é a renda principal não, temos que correr atrás de outras coisas. [...] tem que aproveitar outros pontos e correr atrás, colocar na casa colonial, em outros mercados, a gente tem, em outros lugares que

63 CORRÊA, Edilene dos Santos. Programa Nacional de Alimentação Escolar: um canal de comercialização da agricultura familiar em São Lourenço do Sul. 2011. 62 f. Trabalho de Conclusão de Curso (Graduação) - Faculdade de Ciências Econômicas, Universidade Federal do Rio Grande do Sul, São Lourenço do Sul, 2011.

64 GONÇALVES, Daniel Bertoli. Os desafios da agricultura familiar frente aos programas de compras públicas de alimentos: um estudo sobre agricultores da região sudoeste do estado de São Paulo. Revista da Universidade Vale do Rio Verde, Três Corações, v. 12, n. 1, p. 604-613, jan./jul. 2014.

65 CAMPOS, Rafael Albuquerque. Agricultura familiar e políticas públicas: avaliação do Programa Nacional de Alimentação Escolar - PNAE no município de Campina da Lagoa/PR. 2011. 53 f. Monografia (Especialização) - Pós Graduação Gestão Pública Municipal, Universidade Tecnológica Federal do Paraná, Curitiba, 2011.

66 BARBOSA, Natália Ferreira; ALMEIDA, Luiz Manoel de Moraes Camargo. Gestão da alimentação escolar em Goiânia: uma análise do Comitê de Apoio à Agricultura Familiar no Programa Nacional de Alimentação Escolar em Goiás. Revista Eletrônica de Educação da Faculdade Araguaia, Goiânia, v. 4, n. 4, p. 242-254, 2013. 
a gente tá" (A1).

"Na verdade não vendemos tanto pra eles (PNAE). Vende pra outros também" (A4).

"Pela venda que se faz nesse programa, com certeza não (é suficiente), mas isso ajuda, é um complemento que ajuda as demais vendas" (A8).

No estudo de Schneider ${ }^{67}$, os agricultores entrevistados relataram melhorias em suas propriedades e na qualidade de vida após iniciarem fornecimento de alimentos para o PNAE, porém nenhum deles consegue se manter somente com essa venda, sendo dependentes de outras rendas para melhorar o orçamento da família, o que vem ao encontro do presente estudo.

Os agricultores entrevistados por Campos ${ }^{68}$ replicaram que o PNAE é um bom programa, já que auxilia no aumento da renda do agricultor familiar. Além de expressarem a certeza de que, por se tratar de programa federal, não haverá problemas de não recebimento do valor correspondente aos produtos fornecidos, desde que sejam cumpridas as exigências. Portanto, o agricultor complementa sua renda e tem recebimento garantido.

Também em estudo realizado por Silva ${ }^{69}$ os agricultores afirmaram que a renda extra proporcionada pelo fornecimento de alimentos para o PNAE constitui uma vantagem, assim como as melhorias realizadas em suas propriedades e a oportunidade de permanecer no campo.

Campos $^{70}$ concluiu ainda que o PNAE consiste em um programa de complementação de renda para agricultores familiares e que no município em que realizou sua pesquisa o Programa é de grande importância para os participantes e para a alimentação escolar, já que por meio dele os agricultores podem aumentar a produtividade de suas propriedades, gerando trabalho e renda para a própria família.

$\operatorname{Costa}^{71}$ realizou seu estudo acerca de uma agroindústria familiar de panificação em Tiradentes do Sul/RS e constatou que políticas públicas como o PNAE são de fundamental importância para a manutenção do negócio, pois proporcionam garantia de comercialização dos produtos e consequentemente de renda para as famílias envolvidas, já que mais de $50 \%$ dos produtos fabricados na referida agroindústria são comercializados para o PNAE e o Programa de Aquisição de Alimentos (PAA) ${ }^{72}$.

Para os agricultores familiares, o fornecimento de produtos ao PNAE propicia valorização, desenvolvimento econômico da região e garantia da venda que incentiva a continuidade da produção, além de que estimula sua organização, formalização e cooperação, aumentando a renda, diminuindo o êxodo rural e aproximando produtores e consumidores. ${ }^{73}$

67 SCHNEIDER, Armildo. A participação da agricultura familiar no Programa Nacional de Alimentação Escolar no município de São Lourenço do Sol. 2013. 39 f. Trabalho de Conclusão de Curso (Graduação) - Faculdade de Ciências Econômicas, Universidade Federal do Rio Grande do Sul, São Lourenço do Sul, 2013.

68 CAMPOS, Rafael Albuquerque. Agricultura familiar e políticas públicas: avaliação do Programa Nacional de Alimentação Escolar - PNAE no município de Campina da Lagoa/PR. 2011. 53 f. Monografia (Especialização) - Pós Graduação Gestão Pública Municipal, Universidade Tecnológica Federal do Paraná, Curitiba, 2011.

69 SILVA, Cláudia Hein da. Produtos da agricultura familiar na alimentação escolar do município de Arroio dos Ratos - RS. $2013.66 \mathrm{f}$. Trabalho de Conclusão de Curso (Graduação) - Faculdade de Ciências Econômicas, Universidade Federal do Rio Grande do Sul, Arroio dos Ratos, 2013.

70 CAMPOS, Rafael Albuquerque. Agricultura familiar e políticas públicas: avaliação do Programa Nacional de Alimentação Escolar - PNAE no município de Campina da Lagoa/PR. 2011. 53 f. Monografia (Especialização) - Pós Graduação Gestão Pública Municipal, Universidade Tecnológica Federal do Paraná, Curitiba, 2011.

71 COSTA, Alexandre Moreira da. Estudo de caso de uma agroindústria familiar de panificação no município de Tiradentes do Sul-RS. 2013. 56 f. Trabalho de Conclusão de Curso (Graduação) - Faculdade de Ciências Econômicas, Universidade Federal do Rio Grande do Sul, Três Passos, 2013.

72 O PAA (Programa de Aquisição de Alimentos) é um instrumento de política pública instituído pelo artigo 19 da Lei n. 10.696, de 2 de julho de 2003, e regulamentado pelo Decreto n. 4.772, de 02 de julho de 2003, o qual foi alterado pelo Decreto nº 5.873 , de 15 de agosto de 2006.

73 BRASIL. Ministério da Educação. O papel do nutricionista no Programa Nacional de Alimentação Escolar (PNAE): manual de instruções operacionais para nutricionistas vinculados ao PNAE. 2. ed. Brasília: MEC, 2012 


\section{Considerações finais}

Neste estudo percebeu-se que, embora a renda provinda da venda de gêneros alimentícios para o PNAE não seja a principal de nenhuma das famílias, ela contribui para a melhoria de sua qualidade de vida, por aumentar os ganhos da família e mantê-la unida nas atividades do campo.

A vocação agrícola do município pesquisado e da região em que está localizado permite a aquisição de grande quantidade de alimentos diretamente do pequeno agricultor. Assim, é importante que, além do PNAE, outros programas como o Programa de Alimentação do Trabalhador (PAT) ${ }^{74}$, por exemplo, incentivem o desenvolvimento local por meio da aquisição de alimentos produzidos por agricultores do município.

A compra garantida de alimentos dos agricultores familiares faz com que estes mantenham-se produzindo alimentos, melhorando a qualidade da alimentação da população, já que consumidor e produtor estarão mais próximos, podendo ser comercializados produtos mais frescos.

Quanto à cooperativa, houve aprovação da parceria pelos agricultores, já que esta presta assistência em relação a aspectos antes vistos como dificuldades pelos agricultores, como a documentação exigida para realizar o fornecimento de alimentos para o Programa. Essas entidades dispõem, ainda, de parceria com outros profissionais para auxiliar os agricultores familiares a enfrentarem os desafios encontrados e continuarem a produzir. Pode-se dizer que a agricultura familiar no município estudado está melhor organizada em virtude do apoio dado pelas cooperativas.

Para Oliveira ${ }^{75}$, "as compras institucionais do governo são uma das alternativas à comercialização dos produtos agrícolas vindos da agricultura familiar, que dá aos agricultores destino da produção nos períodos de safra, ajuda a regular os preços de mercado e garantir renda aos produtores", assegurando o retorno de investimentos realizados e preço justo pelos produtos, fazendo com que outros agricultores familiares dediquem-se à produção de alimentos.

Com o PNAE, agricultores, que por muito tempo não viam oportunidade de algo novo, estão confiantes e dispostos a desafiar-se a novas experiências de grupo, assumir compromissos e se envolver com as escolas. Veem um mercado garantido para os seus produtos, a possibilidade de aumento em sua renda e de receber preços mais justos pelo seu trabalho. Além disso, as crianças que vão crescer sentindo o sabor dos alimentos de sua região, conhecendo a diversidade de sabores de frutas, verduras e tubérculos, são novos agricultores que estão em processo de formação e terão cada vez mais orgulho e respeito por serem familiares ou amigos dos agricultores que produzem os alimentos da sua merenda. ${ }^{76}$

Foi percebido com base nos dados levantados que o PNAE contribui positivamente com a agricultura familiar, propiciando aos agricultores, garantia de venda de seus produtos, melhorando sua renda, assim como suas condições de vida e de produção dos alimentos.

\section{REFERÊNCIAS}

BARBOSA, Natália Ferreira; ALMEIDA, Luiz Manoel de Moraes Camargo. Gestão da alimentação escolar em Goiânia: uma análise do Comitê de Apoio à Agricultura Familiar no Programa Nacional de Alimentação

74 O Programa de Alimentação do Trabalhador - PAT foi instituído pela Lei n. 6.321, de 14 de abril de 1976 e regulamentado pelo Decreto n. 5, de 14 de janeiro de 1991, que priorizam o atendimento aos trabalhadores de baixa renda, isto é, aqueles que ganham até cinco salários mínimos mensais.

75 OLIVEIRA, Luan Lustosa Nicolau de. Programa Nacional de Alimentação Escolar. 2013. 37 f. Relatório Final de Estágio Supervisionado (Graduação em Gestão do Agronegócio) - Universidade de Brasília, Brasília.

76 RAMOS, Mariana Oliveira. As crianças estão se sentindo importantes: avanços na alimentação escolar a partir da lei 11.947/2009 e da compra da agricultura familiar. Revista Trajetória Multicursos, Osório, v.2, n. 2, p. 4-19, ago. 2011. Edição Especial. 
Escolar em Goiás. Revista Eletrônica de Educação da Faculdade Araguaia, Goiânia, v. 4, n. 4, p. 242-254, 2013.

BARDIN, Laurence. Análise de conteúdo. Lisboa: Edições 70, 2011.

BRASIL. Câmara dos Deputados. Decreto n. 37.106, de 31 de março de 1955. Institui a Campanha de Merenda Escolar. Disponível em: <http://www2.camara.leg.br/legin/fed/decret/1950-1959/decreto37106-31-marco-1955-332702-publicacaooriginal-1-pe.html>. Acesso em: 29 jun.2015.

BRASIL. Lei n. 11.947, de 16 de junho de 2009. Dispõe sobre o atendimento da alimentação escolar e do Programa Dinheiro Direto na Escola aos alunos da educação básica. Disponível em: <http://www.planalto.gov. br/ccivil_03/_ato2007-2010/2009/lei/111947.htm>. Acesso em: 10 jul. 2014.

BRASIL. Ministério da Educação. Fundo Nacional de Desenvolvimento da Educação. Resolução n. 4, de 2 de abril de 2015. Altera a redação dos artigos 25 a 32 da Resolução/CD/FNDE n. 26, de 17 de junho de 2013, no âmbito do Programa Nacional de Alimentação Escolar (PNAE). Disponível em: <https:// www.fnde.gov.br/fndelegis/action/UrlPublicasAction.php?acao=abrirAtoPublico\&sgl_tipo=RES\&num_ ato $=00000004 \&$ seq_ato $=000 \& v l r \_a n o=2015 \& s g 1 \_$orgao $=C D / F N D E / M E C>$. Acesso em: 30 jun. 2015.

BRASIL. Ministério da Educação. Fundo Nacional de Desenvolvimento da Educação. Resolução FNDE/ CD n. 26, de 17 de junbo de 2013. Dispõe sobre o atendimento da alimentação escolar aos alunos da educação básica no âmbito do Programa Nacional de Alimentação Escolar - PNAE. Brasília, 2013. Disponível em: $\quad<$ https://www.fnde.gov.br/fndelegis/action/UrlPublicasAction.php?acao=abrirAtoPublico\&sgl_ tipo $=$ RES\&num_ato $=00000026 \&$ seq_ato $=000 \& v l r \_a n o=2013 \& s g l \_o r g a o=F N D E / M E C>$. Acesso em: 23 nov. 2014.

BRASIL. Ministério da Educação. Fundo Nacional de Desenvolvimento da Educação. Aquisição de produtos da agricultura familiar para a alimentação escolar. Disponível em: <http://www.fnde.gov.br/programas/alimentacao-escolar/agricultura-familiar>. Acesso em: 10 jul. 2014.

BRASIL. Ministério da Educação. Fundo Nacional de Desenvolvimento da Educação. Programas/ PNAE. Disponível em: < http://www.fnde.gov.br/programas/alimentacao-escolar/alimentacao-escolar-apresentacao>. Acesso em: 22 out. 2014.

BRASIL. Ministério da Educação. O papel do nutricionista no Programa Nacional de Alimentação Escolar (PNAE): manual de instruções operacionais para nutricionistas vinculados ao PNAE. 2. ed. Brasília: MEC, 2012.

BRASIL. Ministério da Saúde. Portaria Interministerial n. 1.010, de 8 de maio de 2006. Institui as diretrizes para a promoção da alimentação saudável nas escolas de educação infantil, fundamental e nível médio das redes públicas e privadas, em âmbito nacional. Disponível em: < http://dtr2001.saude.gov.br/sas/PORTARIAS/ Port2006/GM/GM-1010.htm>. Acesso em: 07 dez. 2014.

CAMARGO, Regina Aparecida Leite de; BACCARIN, José Giacomo; SILVA, Denise Boito Pereira da. O papel do Programa de Aquisição de Alimentos (PAA) e do Programa Nacional de Alimentação Escolar (PNAE) no fortalecimento da agricultura familiar e promoção da segurança alimentar. Revista Temas de Administração Pública, v. 8, n. 2, 2013. Disponível em: <http://seer.fclar.unesp.br/temasadm/article/view/6846>. Acesso em: 07 dez. 2014.

CAMPOS, Rafael Albuquerque. Agricultura familiar e politicas públicas: avaliação do Programa Nacional de Alimentação Escolar - PNAE no município de Campina da Lagoa/PR. 2011. 53 f. Monografia (Especialização) - Pós Graduação Gestão Pública Municipal, Universidade Tecnológica Federal do Paraná, Curitiba, 2011.

CARVALHO, Daniela Gomes de. Licitações sustentáveis, alimentação escolar e desenvolvimento regional: uma discussão sobre o poder de compra governamental a favor da sustentabilidade. Revista Planejamento $e$ Politicas Públicas, n. 32, p. 115-148, jan./jun. 2009.

CASTELLANO, Flora de Oliveira. Condições para ampliação da comercializaçãao de produtos orgânicos da agricultura 
familiar na grande Florianópolis/SC: estudo sobre a organização de uma central de reunião e distribuição de produtos. 2012. 63 f. Trabalho de Conclusão de Curso (Graduação) - Centro de Ciências Agrárias da Universidade Federal de Santa Catarina, Florianópolis, 2012.

CORRÊA, Edilene dos Santos. Programa Nacional de Alimentação Escolar: um canal de comercialização da agricultura familiar em São Lourenço do Sul. 2011. 62 f. Trabalho de Conclusão de Curso (Graduação) - Faculdade de Ciências Econômicas, Universidade Federal do Rio Grande do Sul, São Lourenço do Sul, 2011.

COSTA, Alexandre Moreira da. Estudo de caso de uma agroindústria familiar de panificação no município de Tiradentes do Sul-RS. 2013. 56 f. Trabalho de Conclusão de Curso (Graduação) - Faculdade de Ciências Econômicas, Universidade Federal do Rio Grande do Sul, Três Passos, 2013.

DIAS, Juliana; CHIFFOLEAU, Monica. PNAE: um exercício de reciprocidade entre produtor e consumidor a partir da Lei de Alimentação Escolar. In: ENCONTRO NACIONAL DE ESTUDOS DO CONSUMO, 7.; ENCONTRO LUSO-BRASILEIRO DE ESTUDOS DO CONSUMO, 3.; ENCONTRO LATINOAMERICANO DE ESTUDOS DO CONSUMO, 1., 2014, Rio de Janeiro. Mercados Contestados: as novas fronteiras da moral, da ética, da religião e da lei. Rio de Janeiro: Puc-Rio, 2014. Disponível em: <http:// www.estudosdoconsumo.com.br/artigosdoenec/ENEC2014-GT08-Dias_Chiffoleau-PNAE_\%20um_ exercicio_de_reciprocidade_entre_produtor_e_consumidor.pdf>. Acesso em: 17 ago. 2015.

FLICK, Uwe. Uma introdução à pesquisa qualitativa. Porto Alegre: Bookman, 2004.

FOOD AND AGRICULTURE ORGANIZATIONS OF THE UNITED NATIONS. The state of food and agriculture: Innovation in family farming. Rome: FAO, 2014.

GIACOMOLLI, Marcio. O papel da CRESOL CREDISEARA no financiamento e apoio aos pequenos agricultores rurais em Seara (SC) e municípios vizinhos. In: ENCONTRO DE GRUPOS DE PESQUISA, 5. Agricultura, desenvolvimento regional e transformações socioespaciais. Disponível em: <http://w3.ufsm.br/gpet/ engrup/vengrup/anais/5/Marcio\%20Giacomolli_Estudos\%20da\%20Dinamica\%20Regional\%20e \%20 de\%20Processo.pdf>. Acesso em: 17 ago. 2015.

GONÇALVES, Daniel Bertoli. Os desafios da agricultura familiar frente aos programas de compras públicas de alimentos: um estudo sobre agricultores da região sudoeste do estado de São Paulo. Revista da Universidade Vale do Rio Verde, Três Corações, v. 12, n. 1, p. 604-613, jan./jul. 2014.

HOFFMANN, Rodolfo. A agricultura familiar produz $70 \%$ dos alimentos consumidos no Brasil? Segurança Alimentar e Nutricional, Campinas, v. 21, n. 1, p. 417-421, 2014.

LEITE, Cármen Elisete Caceres. Análise da importância do PAA e PNAE como impulsionadores do desenvolvimento local: o caso da COPTIL em Hulha Negra/RS. 2013. 56 f. Trabalho de Conclusão de Curso (Graduação) Faculdade de Ciências Econômicas da UFRGS, São Lourenço do Sul, 2013.

LEITE, Cássia Roberta de Melo et al. Projeto EDUCOAGRO (Educação Cooperativa e Agroecológica) fomentando a Agricultura Familiar e apoiando a implantação do Programa Nacional de Alimentação Escolar (PNAE) no município de Jupi/ PE, Brasil. Cadernos de Agroecologia, v. 6, n. 2, dez. 2011. Disponível em: $<$ http://www.aba-agroecologia.org.br/revistas/index.php/cad/article/view/11884/8255>. Acesso em: 17 ago. 2015 .

MARCONDES, Tabajara. Mudanças no espaço rural de Santa Catarina. In: VIEIRA, Luiz Marcelino (Org). Sintese Anual da Agricultura de Santa Catarina 2009-2010. Florianópolis: EPAGRI, 2010. p. 12-24.

MATTEI, Lauro. Novo retrato da agricultura familiar em Santa Catarina. In: VIEIRA, Luiz Marcelino (Org.). Sintese Anual da Agricultura de Santa Catarina 2009-2010. Florianópolis: EPAGRI, 2010. p. 25-35.

NERLING, Daniele; ABREU, Lucilene de. Agroecologia e agricultura familiar: relato do estágio de vivência ativa da Unochapecó em Seara - SC 2007. Revista Brasileira de Agroecologia, Cruz Alta, v. 2, n. 1, p. 1222-1225, 
fev. 2007.

OLIVEIRA, Luan Lustosa Nicolau de. Programa Nacional de Alimentação Escolar. 2013. 37 f. Relatório Final de Estágio Supervisionado (Graduação em Gestão do Agronegócio) - Universidade de Brasília, Brasília, 2013.

PAULA, Márcia Maria de; KAMIMURA, Quésia Postigo; SILVA, José Luís Gomes da. Mercados institucionais na agricultura familiar: dificuldades e desafios. Revista de Política Agrícola, Brasília, v. 23, n. 1, p. 33-43, jan./mar. 2014.

PRADO, Tatiana Resende et al. Agricultura familiar na alimentação escolar: estudo de caso em dois municípios de Minas Gerais. Nutrire, São Paulo, v. 38, n. 3, p. 256-268, dez. 2013.

RAMOS, Mariana Oliveira. As crianças estão se sentindo importantes: avanços na alimentação escolar a partir da lei 11.947/2009 e da compra da agricultura familiar. Revista Trajetória Multicursos, Osório, v. 2, n. 2, p. 4-19, ago. 2011. Edição Especial.

REIS, Luá Cristine Siqueira; GONÇALVES NETO, João da Cruz. Produção de alimentos: agricultura familiar x cultura de exportação no Brasil, sob a perspectiva da sustentabilidade. Revista Brasileira de Políticas Públicas, Brasília, v. 4, n. 1, p. 89-98, 2014.

RIBEIRO, Ana Lúcia de Paula; CERATTI, Silene; BROCH, Djulia Taís. Programa Nacional de Alimentação Escolar (PNAE) e a participação da agricultura familiar em municípios do Rio Grande do Sul. Revista Gestão e Desenvolvimento em Contexto, Cruz Alta, v. 1, n. 1, p. 36-49, 2013.

SARAIVA, Elisa Braga et al. Panorama da compra de alimentos da agricultura familiar para o Programa Nacional de Alimentação Escolar. Ciência e Saúde Coletiva, Rio de Janeiro, v. 18, n. 4, p. 927-936, abr. 2013.

SCHNEIDER, Armildo. A participação da agricultura familiar no Programa Nacional de Alimentação Escolar no município de São Lourenço do Sol. 2013. 39 f. Trabalho de Conclusão de Curso (Graduação) - Faculdade de Ciências Econômicas, Universidade Federal do Rio Grande do Sul, São Lourenço do Sul, 2013.

SEARA (SC). Prefeitura Municipal. Aspectos econômicos do município de Seara. Disponível em: <http://www. seara.sc.gov.br/arquivos_internos/index.php?abrir=secretaria_agricultura >. Acesso em: 24 set. 2014.

SILVA, Cláudia Hein da. Produtos da agricultura familiar na alimentação escolar do município de Arroio dos Ratos - RS. 2013. 66 f. Trabalho de Conclusão de Curso (Graduação) - Faculdade de Ciências Econômicas, Universidade Federal do Rio Grande do Sul, Arroio dos Ratos, 2013.

TEO, Carla Rosane Paz Arruda; MONTEIRO, Carlos Augusto. Marco legal do Programa Nacional de Alimentação Escolar: uma releitura para alinhar propósitos e práticas na aquisição de alimentos. Revista de Nutrição, Campinas, v. 25, n. 5, p. 657-668, set./out. 2012.

TOMASETTO, Mariza Zeni de Castro; LIMA, Jandir Ferrera de; SHIKIDA, Pery Francisco Assis. Desenvolvimento local e agricultura familiar: o caso da produção de açúcar mascavo em Capanema/Paraná. Interações, Campo Grande, v. 10, n. 1, p. 21-30, jan./jun. 2009.

TRICHES, Rozane Márcia. Reconectando a produção ao consumo: a aquisição de gêneros alimentícios da agricultura familiar para o Programa de Alimentação Escolar. 2010. 297 f. Tese (Doutorado) - Universidade Federal do Rio Grande do Sul, Porto Alegre, 2010.

TRICHES, Rozane Márcia; SCHNEIDER, Sergio. Reconstruindo o "elo perdido": a reconexão da produção e do consumo de alimentos através do Programa de Alimentação Escolar no município de Dois Irmãos (RS). Segurança Alimentar e Nutricional, Campinas, v. 17, n. 1, p. 1-15, jan./jun. 2010.

TRICHES, Rozane Márcia; SCHNEIDER, Sergio. Alimentação Escolar e Agricultura Familiar: reconectando o consumo à produção. Saúde e Sociedade, São Paulo, v. 19, n. 4, p. 933-945, out./dez. 2010. 
TURPIN, Maria Elena. A alimentação escolar como fator de desenvolvimento local por meio do apoio aos agricultores familiares. Segurança Alimentar e Nutricional, Campinas, v. 16, n. 2, p. 20-42, jul./dez. 2009.

VILLAR, Betzabeth Slater et al. Situação dos municípios do estado de São Paulo com relação à compra direta de produtos da agricultura familiar para o Programa Nacional de Alimentação Escolar (PNAE). Revista Brasileira de Epidemiologia, São Paulo, v. 16, n. 1, p. 223-226, mar. 2013. 


\section{REVISTA BRASILEIRA DE POLÍTICAS PÚBLICAS BRAZILIAN JOURNAL OF PUBLIC POLICY}
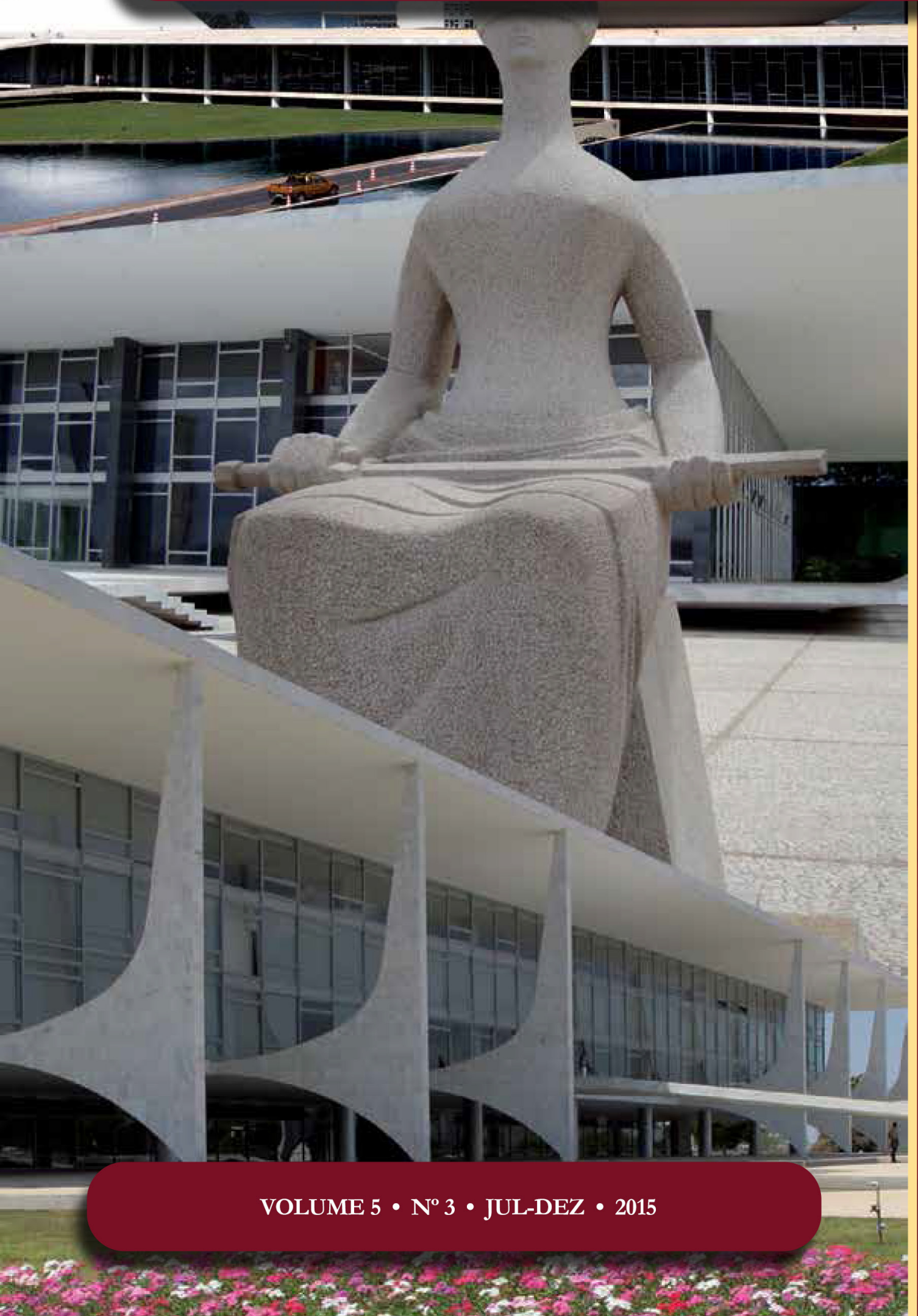

Desenvolvimento das famílias e a pobreza no nordeste do Brasil Development of families and poverty in Northeast of Brazil

Nadja Simone Menezes Nery de Oliveira

Solange de Cassia Inforzato de Souza Aricieri Devidé Junior 


\section{Desenvolvimento das famílias e a pobreza no nordeste do Brasil*}

\section{Development of families and poverty in Northeast of Brazil}

\author{
Nadja Simone Menezes Nery de Oliveira ** \\ Solange de Cassia Inforzato de Souza *** \\ Aricieri Devidé Junior ****
}

* Recebido em 06/05/2015

Aprovado em 08/07/2015

** Doutoranda do Programa de Pós-graduação em Desenvolvimento Regional e Agronegócio (PGDPRA) da Universidade do Oeste do Paraná (UNIOESTE). Bacharel em Ciências Econômicas pela Universidade Federal da Paraíba (UFPB). Mestre em Economia Regional pela Universidade Estadual de Londrina (UEL). E-mail: nadja_menezes@hotmail.com

*** Professora associada do Mestrado em Economia Regional da UEL/Pr. Doutora em Educação: história, política, sociedade, pela PUC/SP. E-mail: solangecassia@uol.com.br

**** Doutor em Economia pela Universidade Federal do Ceará (UFC). Professor adjunto do Departamento de Economia da Universidade Estadual de Londrina. E-mail: aridjr@gmail. com

\section{Resumo}

Este artigo tem por objetivo analisar as evidências da pobreza nordestina brasileira sob a perspectiva multidimensional, com base nos microdados da PNAD (Pesquisa Nacional por Amostra de Domicílios) e cálculo do Índice de Desenvolvimento da Família (IDF) para 2003 e 2012. Os resultados revelaram uma sensível diminuição na pobreza multidimensional do Nordeste, em processo mais favorável do que o Brasil como um todo. O desenvolvimento das famílias no Nordeste está associado à ausência de vulnerabilidade, desenvolvimento infantil e condições habitacionais e de acesso aos bens de consumo. Destaque positivo também para os indicadores da disponibilidade de recursos: redução da extrema pobreza e da proporção de famílias nordestinas cuja maior parte da renda familiar é originada de transferências. Os problemas detectados estão no acesso ao trabalho, especialmente na remuneração do trabalho e na qualidade do posto do trabalho. O pior resultado foi o acesso ao conhecimento, associado, negativamente, ao ensino superior, apesar da contribuição do ensino fundamental e médio para a redução das carências das famílias nordestinas, bem como da qualificação profissional dos trabalhadores. $\mathrm{O}$ índice de pobreza, restrito à renda per capita, unidimensional, cresceu mais do que o apontado pelo índice sintético global, medido nesta pesquisa, o que reforça a escolha da abordagem multidimensional para subsidiar as ações públicas.

Palavras-chave: Pobreza multidimensional. Índice de desenvolvimento da família. Nordeste.

\section{Abstract}

This article aims to analyze the evidence of the northeastern poverty in the multidimensional perspective, from the microdata of PNAD (National Survey by Household Sampling) and to calculate the Family Development Index (IDF), 2003 and 2012. The results revealed a significant decrease in multidimensional poverty in the Northeast, in a more favorable process than Brazil as a whole. The development of families in the Northeast is associated with the absence of vulnerability, child development and housing conditions and access to consumer goods. Highlights also include the positive in- 
dicators of the availability of resources: reducing extreme poverty and proportion of families whose income originated by transfers. Problems are detected in access to work, especially in labor compensation and the quality of the job. The worst result was the access to knowledge, negatively associated to higher education, despite the contribution of the primary and secondary to the reduction of shortages of Northeastern families as well as the professional qualifications of workers. The poverty rate restricted to per capita income, one-dimensional, grew more than appointed by global synthetic index, measured in this study, which reinforces the choice of multidimensional approach to subsidize public actions.

Keywords: Multidimensional poverty. Family Development Index. Northeast.

\section{INTRODUÇÃO}

A pobreza constitui tema amplo, multifacetado e objeto de estudos das diferentes áreas do conhecimento científico. No Brasil, é um problema que decorre, em grande parte, das desigualdades de renda, cujas origens são históricas e agravaram-se pelo modelo de desenvolvimento econômico concentrador e pelas diferenças regionais perceptiveis num país de magnitude continental.

A primeira década de 2000 revelou, especialmente a partir de 2003, que os marcadores da pobreza reduziram no Brasil e nas macrorregiões brasileiras, materializados por melhorias na condição de vida da população brasileira. A região Nordeste, no entanto, ainda concentrava grande parcela de pobres brasileiros, mantendo, assim, um forte descompasso com a sua participação na população total do país ${ }^{1}$.

Do ponto de vista conceitual, a intensificação dos debates e as críticas quanto ao caráter unidimensional da pobreza deu-se tomando-se por base os trabalhos publicados pelo economista indiano Amartya Sen. A pobreza deve ser compreendida como privação de capacitações básicas, da ausência de oportunidades para realizar alguns níveis mínimos de funcionamentos, que vão desde pontos essenciais como, por exemplo, ter acesso a uma boa nutrição e apresentar boa saúde, até questões bem mais complexas quanto ser feliz, possuir respeito próprio e ter vida social ${ }^{2}$.

No Brasil e na esfera regional nordestina, os estudos empíricos sobre o tema evoluíram, nas últimas décadas, tanto no que se referem ao caráter unidimensional quanto aos que avançam na perspectiva multidimensional, sumarizados neste artigo. Nessa última, metodologia e base de dados diferentes têm tratado o tema que podem auxiliar na definição de políticas públicas em todas as esferas governamentais.

A presente pesquisa busca desenvolver uma análise da evidência da pobreza na região do Nordeste brasileira, tendo como base os dados da Pesquisa Nacional por Amostra de Domicílios (PNAD) para 2003 e 2012. Para isso, calculou-se o Índice de Desenvolvimento da Família (IDF) ${ }^{3}$ adaptado para a pesquisa.

Além dessa introdução, o presente artigo divide-se em mais três seções. Na primeira discutem-se os aspectos conceituais e a literatura econômica empírica sobre a pobreza no Brasil e no Nordeste. Na segunda seção, apresenta-se a metodologia para o cálculo do Índice de Desenvolvimento da Família (IDF) para, na seção 3, discutir os resultados da pesquisa.

1 ROCHA, S. Pobreza no Brasil: a evolução de longo prazo (1970-2011). Rio de Janeiro: XXV Fórum Nacional, 2012.

2 SEN, A. K. Development: which way now? The Economic Journal, v. 93, 1983. SEN, A. K. Resources, values and development. Oxford: Brasil Blackwell, 1984.

3 BARROS, R. P.; CARVALHO, M.; FRANCO, S. O Índice de desenvolvimento da família (IDF). Rio de Janeiro: IPEA, 2003. 
2. Aspectos conceituais e as eVIDÊnCias empí́ricas SObre a pobreza no Brasil e no NORDESTE

\subsection{Do Caráter Unidimensional ao Multidimensional da Pobreza}

Com base na visão da pobreza como insuficiência de renda, emergem definições relevantes para a sua operacionalização. Para alguns pesquisadores, a pobreza se classifica em: pobreza absoluta, relativa e subjetiva ${ }^{4}$. Na pobreza absoluta, considera-se pobre a pessoa que possui menos que o mínimo objetivamente definido, o que remete à abordagem tradicional da subsistência. A pobreza relativa define como pobre a pessoa que possui menos que os outros na sociedade e faz referência ao padrão de vida, ao contexto social e ao padrão de consumo médio predominante na sociedade. Já a pobreza subjetiva caracteriza o pobre como aquele que sente que não possui o suficiente para continuar, o que remete ao fator de exclusão social.

As pesquisas sobre pobreza ainda estabelecem essencialmente duas vertentes: uma que relaciona a renda indispensável capaz de satisfazer exclusivamente as necessidades de caráter nutricional, denominada de linha de indigência ou de pobreza extrema, e outra que abrange um conjunto mais amplo de necessidades individuais, como saúde, educação, habitação, transporte, entre outros. Essa segunda linha, é denominada de linha de pobreza.

Cinco decisões são importantes na fixação da linha de pobreza: ${ }^{5}$ a primeira consiste em decidir se esta será baseada na renda ou no consumo; na segunda determinar a unidade a ser estudada: a pessoa, a família, o domicílio, per capita ou adulto-equivalente; a terceira decidir se a análise consistirá em uma única linha de pobreza ou na divisão entre linha de pobreza rural e urbana, ou ainda em diferentes regiões; a quarta se a linha de pobreza será concebida de forma científica, política, subjetiva ou por mera conveniência; e, finalmente, a quinta definição diz respeito a como poderão ser usados outros indicadores além da renda e consumo.

A ocorrência de determinadas linhas de pobreza também pode ser tratada como: absoluta, relativa, subjetiva e dual ${ }^{6}$. Encontra-se a linha de pobreza absoluta ao se estimar o custo de uma quantidade de bens considerados necessários que irão suprir as necessidades básicas de consumo. As pessoas com renda inferior a essa linha podem ser denominados definitivamente pobres ou indigentes. A linha de pobreza relativa avalia as necessidades a serem satisfeitas, levando em consideração o padrão de consumo médio predominante na sociedade, de maneira a diminuir as disparidades existentes em meio aos agentes. Os países em desenvolvimento têm a sua atenção voltada à linha de pobreza absoluta, ao passo que países desenvolvidos focam na linha de pobreza relativa, uma vez que o mínimo essencial à subexistência é assegurado.A combinação simples de duas linhas de pobreza irá resultar em uma linha de pobreza dual ou híbrida.

Entre os critérios utilizados para definição dessas linhas de pobreza, são considerados o rendimento pessoal em dólar, o rendimento per capita domiciliar, tendo por base o salário mínimo, o consumo de calorias essenciais à subsistência, ou a cesta básica convertida em renda. Apesar disso, embora as linhas de pobreza e indigência possam se constituir o ponto de vista mais estimado na preleção e, nos métodos de quantificação da pobreza pelos pesquisadores do tema, ainda é possível se observar fragilidades e restrições.

Duas outras linhas teóricas podem ser acrescentadas, a das necessidades básicas e das capacidades ${ }^{7}$. A abordagem das necessidades humanas básicas vai além de questões relativas à alimentação e incorpora uma

4 KAGEYAMA, A.; HOFFMANN, R. Pobreza no Brasil: uma perspectiva multidimensional. Economia e Sociedade, Campinas, v. 15, n. 1, p. 79-112, jan./jun. 2006.

5 FILDS, G. S. Distribution and Development: a new look at the developing world. New York: Russel Sage Foundation, 2001.

6 RAVALLION, M. Poverty Comparisons: a guide to concept and method. Washington: The World Bank. (LMMS Working Paper, n. 88), 1992. 7 DUCLOS, J. Y.; ARAAR, A. Economic Studies in Inequality Social Exclusion and Well-Being. In: ___. Poverty and Equity: Measurement, Policy and Estimation With Dad. [S.1.]: Springer e International Development Research Centre, 2006. v. 2. p. 3-18. LOPES, H. M.; MACEDO, P. B. R.; MACHADO, A. F. Indicador de pobreza: aplicação de uma abordagem multidimensional ao caso brasileiro. Belo Horizonte: CEDEPLAR/UFMG, 2003. 
maior gama dessas necessidades humanas, como educação, saneamento e habitação. Essa abordagem é capaz de captar outros aspectos da vida cotidiana das pessoas, que não sejam apenas as questões nutricionais e, do ponto de vista econômico, é extremamente benéfica, uma vez que eleva a produtividade da pessoa. Ao serem assim considerados, esses aspectos introduzem o caráter multidimensional nas pesquisas relacionadas à pobreza.

Segundo a teoria das capacitações ${ }^{8}$, a pobreza está associada às privações de necessidades básicas sofridas pelas pessoas, na inexistência de oportunidades para se realizar alguns níveis mínimos de funcionamentos. Esses funcionamentos, por sua vez, vão desde questões fundamentais de como estar bem nutrido, possuir uma boa saúde até questões mais complexas como ser feliz, possuir respeito próprio e a participação da vida social. Nesse sentido, as capacitações consistem na liberdade de uma pessoa para realizar combinações alternativas de funcionamentos. A pobreza, nessa visão, é constituída por diferentes dimensões, que agrega os elementos que se referem ao enfoque das necessidades básicas, como também destaca a capacidade das pessoas no que concerne às escolhas em relação ao bem-estar e os meios de atingi-los. Além disso, essa abordagem acrescenta ao entendimento da pobreza no sentido de mostrar qual qualidade de vida as pessoas avaliam para si, e essa qualidade de vida escolhida não se resume a dotação de renda que essas pessoas possuem, mas ainda de outras condições de vida.

De forma genérica, são entendidos como pobres as pessoas desprovidas de capacidades, elementos básicos para se agir em sociedade, além de chances para atingir graus consideráveis de concretizações e conquistas. Essa abordagem torna real o reconhecimento da inserção de variáveis tão importantes para a determinação de pobreza, além da renda, ao buscar inserir a escassez de capacitações como complemento de análise. Assim, a pobreza está relacionada à privação de liberdade das pessoas de serem capazes de eleger uma vida melhor e mais satisfatória que lhes rendam um maior bem-estar, no sentido em que lhes seja possível saber decidir o que comer a fim de poderem prover suas carências nutritivas, e o que vestir, onde morar, o acesso à saúde, à educação e à justiça, garantindo-lhes exercer inteiramente suas liberdades sociais e políticas e de serviços públicos.

\section{2 pobreza multidimensional na literatura nacional: evidências empíricas}

$\mathrm{Na}$ literatura nacional, estudos buscaram descrever a temática da pobreza sob o enfoque multidimensional. Alguns autores adotaram o julgamento de pobreza sob o aspecto das necessidades básicas e das capacitações para estabelecer um índice escalar multidimensional de pobreza familiar, o IDF, Índice de Desenvolvimento da Família, cujo benefício é a probabilidade de desagregar os dados e, de tal modo, ser facultado o poder de dimensioná-los para grupos demográficos?

Esse mesmo índice fora calculado por outra pesquisadora ${ }^{10}$ para verificar a pobreza multidimensional no estado do Paraná ${ }^{11}$ nos anos de 1995 e 2009 e detectou expressiva proporção de pobres em meio à população paranaense, mais significativa na região rural, principalmente para as dimensões demografia e saneamento. Também foi constatada a ocorrência de profundas reduções na vulnerabilidade dos domicílios analisados. Na comparação com os resultados alcançados com base na análise unidimensional, o indicador de pobreza e extrema pobreza multidimensional revelou uma pobreza maior para os domicílios.

8 SEN, A. K. Development: which way now? The Economic Journal, v. 93, 1983. SEN, A. K. Resources, values and development. Oxford: Basil Blackwell, 1984.

9 BARros, R. P.; CARVAVAlHO, M.; FRANCO, S. O indice de desenvolvimento da família (IDF). Rio de Janeiro: IPEA, 2003. ALENCAR, P. L. A. Pobreza Multidimensional no Nordeste Brasileiro: uma análise do período 2001 a 2009. EPECON, 1., 2012, Anais... Recife, 2012.

10 ALBUQUerQue, Marcela Ribeiro. Pobręa sob o enfoque multidimensional no Paraná: 1995 e 2009. Dissertação (Mestrado em Economia) - Universidade Estadual de Maringá, Maringá, 2011.

11 LOPES, H. M.; MACEDO, P. B. R.; MACHADO, A. F. Análise de pobreza com indicadores multidimensionais: uma aplicação para o Brasil e Minas Gerais. Revista de Economia Contemporânea, Rio de Janeiro, v. 9, n. 1, p. 125-152, 2005. 
Um índice de pobreza multivariada também foi construído e, para tanto, o autor contempla as condições domiciliares, de saneamento, de mercado de trabalho e de educação, para os anos de 1995 e 2004. Os resultados dessa análise indicam que indicadores de pobreza multivariada possuem uma ordem bastante diferente para os Estados do Brasil ${ }^{12}$, quando confrontados com a ordem do indicador de pobreza fundamentado na escassez de renda, principalmente para o ano de 2004.

Pela abordagem das capacitações e com a técnica dos Conjuntos Fu₹ży, tornou possível o cálculo de um indicador para $n$ dimensões relevantes e agregação em um escalar para o indicador-síntese de pobreza multidimensional ${ }^{13}$ nos estados do Brasil em 1992 e 2002. Como forma de reduzir o grau de arbitrariedade na escolha das dimensões de pobreza consideradas, os autores adotam como referência os objetivos e as metas referentes aos Objetivos do Desenvolvimento do Milênio (ONU 2001) ${ }^{14}$. Com base de diferentes bases de dados, os principais resultados da pesquisa indicam que há demarcação espacial bem definida no Brasil, com os dez piores índices localizados nas regiões Norte e Nordeste, e com menores índices de pobreza multidimensional se encontram os estados das regiões Sul e Sudeste.

A pobreza nordestina sob o enfoque multidimensional foi estudada em várias ocasiões ${ }^{15}$. Na perspectiva das capacitações de Sen, com base nos dados do Censo Demográfico ${ }^{16}$ de 2010 sobre os municípios da região Nordeste e a aplicação da técnica da Teoria dos Conjuntos Fu₹:yy, calculou-se Índice Fu₹:y de Pobreza ${ }^{17}$ por 19 indicadores distribuídos em quatro capacitações: educação, saúde, condições habitacionais e renda. Houve ocorrência de maior pobreza com relação à dimensão renda, mas as capacitações educação e saúde também apresentaram importância no indicador de pobreza multidimensional. Chama a atenção dos formuladores de políticas públicas para os indicadores de acesso ao ensino fundamental e ensino médio e ao acesso aos serviços de saneamento básico, coleta de lixo e rede de água ${ }^{18}$.

A análise fatorial de correspondências múltiplas também foi utilizada para estudo, com variáveis qualitativas escolhidas com base na PNAD em anos selecionados ${ }^{19}$. Concluiu-se que, no tratamento da pobreza por uma única dimensão, há negligência da pobreza real, dado que para os anos analisados os indicadores multidimensionais não foram harmônicos com os indicadores unidimensionais. Outro trabalho ${ }^{20}$ utilizou dados de 2009 para mapear a pobreza no Nordeste no que se refere à ausência de itens de consumo e habitação e realizam uma comparação com a insuficiência de renda. Chegam à conclusão de que a região nordestina apresentou um dos mais elevados percentuais de domicílios sem acesso a itens de habitação e consumo, e ainda apresentou o pior desempenho em termos absolutos comparativamente as demais regiões.

Com base nos dados da POF (Pesquisa de Orçamento Familiar) para os anos de 2008-2009, e do modelo ACM (Análise de correspondência múltipla), uma investigação construiu dois índices para medir a pobreza não monetária da Região Nordeste: índice normalizado de altura-por-idade como um proxy para o indica-

12 NEDER, H. D. Um estudo sobre a pobreza rural com abordagem multivariada. In: Congresso da Sociedade Brasileira de Economia, Administração e Sociologia Rural, 46., 2008, Rio Branco. Anais... Rio Branco: SOBER, 2008.

13 DINIZ, B. M.; DINIZ, M. M. Um indicador comparativo de pobreza multidimensional a partir dos objetivos do desenvolvimento do milênio. Economia Aplicada, v. 13, n. 3, 2009.

14 Para maiores detalhes, ver ONU. Technical Report, Organização das Nações Unidas, 2001.

15 SILVA, M. C. P.; BARROS, R. P. Pobreza multidimensional no Brasil. In: Encontro Nacional de Economia da Associação Nacional dos Centros de Pós-graduação em Economia, 34., Salvador, 2006. Anais... Salvador: ANPEC, 2006.

16 QUINTELA, M. D.; ALVES, J. E. D.; SILVA, D. B. N. A Pobreza no Nordeste Brasileiro em 2000 e 2010: uma aplicação do índice de pobreza multidimensional PNUD/ONU. In: ENCONTRO NACIONAL DA ASSOCIAÇÃO BRASILEIRA DE ESTUDOS REGIONAIS E URBANOS , 11., 2013, Foz do Iguaçu. Anais... ENABER, 2013.

17 OTTONELLI, Janaina. Pobreza multidimensional na região Nordeste: uma aplicação da teoria dos conjuntos Fuž̃y (em 2010$) .2013$. 127 f. Dissertação (Mestrado em Economia) - Universidade Federal do Rio Grande do Norte, Natal, 2013.

18 BANGOLIN, I. P.; ÁVILA, R.; P. Poverty distribution among the brasilian states: a multidimensional analysis using capabilities and needs approaches. In: Encontro Nacional da Associação Nacional dos Centros de Pós-Graduação em Economia, 34., 2006, Salvador. Anais... Salvador: ANPEC, 2006.

19 SILVA, A. M. R. Um estudo sobre pobreza multidimensional na região Nordeste do Brasil. Uberlândia: UFU, 2009.

20 CALDAS, R. M.; SAMPAIO, Y. S. B. Pobreza no nordeste brasileiro: uma análise multidimensional. Fortaleza: Fórum BNB de Desenvolvimento, 2012. 
dor de saúde, tendo como referência os valores sugeridos pela ONU (Organização das Nações Unidas); e um índice de bens, que serve como uma proxy do acesso aos bens básicos da economia. Evidenciaram-se a não dominância estocástica significativa para o domínio das linhas de pobreza nutricional e de acesso a bens básicos, porém foi observada evidência estatística de que há dominância estocástica significativa para subconjuntos dos domínios das linhas de pobreza. Seja na análise de dominância unidimensional ou bidimensional, não ocorreu dominância de nenhum estado sobre o outro para o domínio de linhas de pobreza nutricional ou de bens, somente para os seus subconjuntos ${ }^{21}$. A mesma metodologia foi aplicada com dados da PNAD 2009, Análise de Correspondência Múltipla (ACM) e do Índice Multivariado de Pobreza (IMP) ${ }^{22}$, e observou-se que o percentual de pobres calculado unicamente pela abordagem da insuficiência de renda mostrou-se menor do que a proporção no qual a análise seguiu a concepção multidimensional. Em números, a pobreza multidimensional na região nordeste foi de $44,5 \%$, ao passo que a pobreza sob o aspecto unidimensional foi de $33,55 \%$ para o ano de 2009.

Em 2014, a pobreza nordestina pelo aspecto unidimensional e multidimensional foi mensurada com base nos dados fornecidos pela PNAD 2009 e 2012, ainda com base na abordagem do Índice Multivariado de Pobreza (IMP) e técnica de Análise de Correspondência Múltipla (ACM). Como resultado, se verifica que, sob o prisma multidimensional a pobreza, na região Nordeste, atingiu aproximadamente $57 \%$ de sua população em 2009, ao passo que, para a análise da pobreza unidimensional alcançou 35,55\% da população nordestina para o mesmo ano ${ }^{23}$. O índice de pobreza calculado com a análise multidimensional para os anos de 2009 e 2012 foram maiores que os resultados obtidos com a análise unidimensional no mesmo período.

As evidências empíricas que tratam da pobreza multidimensional do Nordeste, apresentadas até este ponto, reforçam a importância do contínuo estudo da pobreza nessa região, visto que, quando confrontada com as demais regiões, independentemente da metodologia utilizada, o Nordeste apresenta os piores resultados e, quando comparada a pobreza sob um enfoque unidimensional com a pobreza de cunho multidimensional, essa última é maior.

\section{Metodologia}

\subsection{Composição do Índice de Desenvolvimento das Famílias (IDF) para a Região Nordeste}

Os dados utilizados no presente estudo foram extraídos da Pesquisa Nacional por Amostra de Domicílios (PNAD), realizada pelo Instituto Brasileiro de Geografia e Estatística (IBGE). Foram utilizadas 32.858 observações, que expandidas, representaram 12.641.485 de domicílios nordestinos no ano de 2003, e 32.294 observações que representaram 16. 472. 674 de domícilios do Nordeste no ano de 2012. Realizou-se um recorte espacial da região Nordeste desses dados para os anos de 2003 e 2012.

O procedimento metodológico adotado foi a construção do Índice de Desenvolvimento da Família $(\mathrm{IDF})^{24}$, dividido em sete dimensões de pobreza, avaliadas com base nas informações da PNAD e sintetiza-

21 BARroso, M. V.; SALVATO, M. A.; MATIAS, J. S. Análise multidimensional da pobreza no Nordeste Brasileiro. In: ENCONTRO DA ASSOCIAÇÃO NACIONAL DOS CENTROS DE PÓS-GRADUAÇÃO EM ECONOMIA, 40., 2012, Porto de Galinhas. Anais... Porto de Galinhas: ANPEC, 2012. ASSELIN, L. M. Composite Indicator of Multidimensional Poverty. CECI, jun. 2002. Disponível em: <http://www.researchgate.net/publication/265568282_Composite_Indicator_of_Multidimensional_ Poverty>. Acesso em 20/09/2015.

22 ARAÚJO, J. A.; TABOSA, F. J. S.; MORAIS, G. S. Pobreza Multidimensional no Nordeste do Brasil. In: ENCONTRO NACIONAL DA ASSOCIAÇÃO BRASILEIRA DE ESTUDOS REGIONAIS E URBANOS, 11., 2013, Foz do Iguaçu. Anais... Foz do Iguaçu: ENABER, 2013.

23 BARROS, F. F. R. Análise da pobreza unidimensional e multidimensional no Nordeste do Brasil em 2009 e 2012. Fortaleza: ANPEC, 2014. 24 BARROS, R. P.; CARVALHO, M.; FRANCO, S. O indice de desenvolvimento da família (IDF). Rio de Janeiro: IPEA, 2003. BAR- 
das no indicador multidimensional, a saber: ausência de vulnerabilidade domiciliar, acesso ao conhecimento, acesso ao trabalho, disponibilidade de recursos, desenvolvimento infantil, condições habitacionais e consumo de bens duráveis. Cada uma das sete dimensões representa, em parte, o acesso aos meios necessários para que as famílias sejam capazes de satisfazer as suas necessidades, e outra parte a consecução de fins, ou seja, a efetiva satisfação de tais necessidades.

A análise é voltada à unidade domiciliar e as sete dimensões se estendem em componentes que, ao seu turno, demandam diferentes indicadores para representá-los. Os componentes que definem as sete dimensões de análise, bem como os indicadores que os representam são descritos no Quadro 1 em apêndice.

Neste trabalho serão consideradas crianças as pessoas dentro do recorte etário de 0 a 9 anos; criança e adolescente de 0 a 17 anos; criança, adolescente e jovem de 0 a 24 anos e idosos, as pessoas com idade de 60 anos ou mais. Considerou-se adultos as pessoas com idade entre 25 e 59 anos. Com relação à alfabetização, foi levado em conta que o adulto analfabeto era aquele que não sabia ler e escrever e o adulto analfabeto funcional aquele com menos de 4 anos de estudo.

Para o acesso ao trabalho, foram considerados membros em idade ativa as pessoas com 10 anos ou mais de idade. As linhas de pobreza utilizadas foram de $\mathrm{R} \$ 311,00$ e $\mathrm{R} \$ 84,00$, respectivamente e corresponderam a $1 / 2$ de salário mínimo no ano vigente. As linhas de extrema pobreza foram de $R \$ 155,50$ e $R \$ 42,00$ em 2012 e 2003, correspondendo a $1 / 4$ de salário mínimo em cada ano analisado.

\subsection{Construção do Indicador Sintético Multidimensional}

Utilizou-se o indicador sintético $\mathrm{S}$ derivado de uma série de indicadores básicos ${ }^{25}$. Os pesos dados às dimensões e a seus componentes correspondentes são simétricos, por não ser possível saber as preferências e os gostos da população que se analisa. Uma vez que para as variáveis de um mesmo componente são atribuídos pesos iguais, e às variáveis pertencentes a uma mesma dimensão e até mesmo essas últimas também recebam pesos idênticos, se se alteram tanto a quantidade de componentes como o número de variáveis por componentes, o peso aplicado para as variáveis de componentes distintos não obedece à regra de que será sempre o mesmo.

O grau de pobreza para cada domicílio se situa entre 0 e 1 . A variabilidade igual a 0 do grau de pobreza representa aqueles domicílios absolutamente pobres, ao passo que a variabilidade do grau de pobreza igual a 1 representa os domicílios sem qualquer traço de pobreza.

O indicador sintético global multidimensional de pobreza $(S)$ pode ser representado de acordo com a seguinte especificação:

$$
S=\frac{1}{7} \sum_{K=1}^{7}\left(\frac{1}{m_{k}} \sum_{j=1}^{m k}\left(\frac{1}{n_{j k}} \sum_{i=1}^{n j k} B_{j k i}\right)\right)
$$

em que $B_{j k i}$ diz respeito ao i-ésimo indicador básico do j-ésimo componente da k-ésima dimensão, $m_{k}$ o número de componentes da k-ésima dimensão, $n_{j k}$ a quantidade de indicadores do j-ésimo componente da k-ésima dimensão.

Isto é, o indicador sintético de cada componente, $S_{j k}$, corresponde à média aritmética dos indicadores utilizados para a representação desse componente. Do mesmo modo, o indicador sintético de cada dimensão, $S_{k}$, é a média aritmética dos indicadores sintético dos seus componentes. E, finalmente o indicador sintético global, $S$, é a média aritmética dos indicadores sintéticos das sete dimensões que o compõem.

ROS, R. P.; CARVALHO, M.; FRANCO, S. Pobreza multidimensional no Brasil. Rio de Janeiro: IPEA, 2006.

25 BARROS, R. P.; CARVALHO, M.; FRANCO, S. O indice de desenvolvimento da família (IDF). Rio de Janeiro: IPEA, 2003. 


\subsection{A pobreza multidimensional no Nordeste e no Brasil para os anos de 2003 e 2012}

A Tabela 1 mostra os resultados sumarizados para o indicador de pobreza calculado para o Nordeste e para o Brasil nos anos de 2003 e 2012. O grau de desenvolvimento dos domicílios nordestinos encontra-se abaixo da média dos domicílios brasileiros em 2003 e 2012, mas a despeito disso, há um processo mais favorável em direção aos primeiros.

O grau de desenvolvimento das famílias nordestinas teve uma sensível melhora na evolução das dimensões da disponibilidade de recursos e acesso aos bens duráveis que superaram esses resultados para o país. Os piores indicadores da pobreza nordestina se concentraram nas dimensões de acesso ao conhecimento e acesso ao trabalho. Apesar do baixo desenvolvimento das famílias brasileiras no acesso ao conhecimento, os resultados apresentados pelo Nordeste nos dois anos foram inferiores aos apresentados para o Brasil.

Para a dimensão acesso ao trabalho, os resultados obtidos para o Brasil nos dois anos foram relativamente bons, mas, para o Nordeste, foi sofrível, em que se configurou em uma diferença de 12 pontos percentuais menor em relação à média brasileira. As maiores diferenças entre os níveis de desenvolvimento dos domicílios do Brasil e do Nordeste em 2003 encontram-se no acesso ao trabalho, na disponibilidade de recursos e no consumo de bens duráveis; em 2012, tais diferenças se reproduzem, com exceção da melhoria da situação nordestina em relação ao acesso aos bens duráveis.

As condições habitacionais, o desenvolvimento infantil, a ausência de vulnerabilidade e o acesso ao conhecimento, são aspectos em que as diferenças nos índices de pobreza entre o Brasil completo e a região Nordeste são menos pronunciadas. Nos três primeiros aspectos, os indicadores são favoráveis, mas, em relação à educação, o país e a região padecem de problemas histórico-estruturais não resolvidos.

Tabela 1 - Indicadores multidimensionais da pobreza no Nordeste e Brasil, 2003 e 2012

\begin{tabular}{|c|c|c|c|c|c|}
\hline \multicolumn{2}{|l|}{ Descrição } & 2003 & 2012 & $\begin{array}{l}\text { Variação } \\
\text { (p.p.) }\end{array}$ & $\begin{array}{c}\text { Variação } \\
(\%)\end{array}$ \\
\hline \multicolumn{2}{|l|}{ Brasil } & 0,74 & 0,78 & 4 & 5,41 \\
\hline \multicolumn{2}{|l|}{ Nordeste } & 0,68 & 0,73 & 5 & 7,35 \\
\hline \multirow{2}{*}{$\begin{array}{l}\text { Dimensão1 - Ausência de Vulnerabilida- } \\
\text { de }\end{array}$} & Brasil & 0,69 & 0,79 & 10 & 14,49 \\
\hline & Nordeste & 0,66 & 0,77 & 11 & 16,67 \\
\hline \multirow{2}{*}{ Dimensão 2 - Acesso ao Conhecimento } & Brasil & 0,36 & 0,37 & 1 & 2,78 \\
\hline & Nordeste & 0,34 & 0,33 & -1 & $-2,94$ \\
\hline \multirow{2}{*}{ Dimensão 3 - Acesso ao Trabalho } & Brasil & 0,67 & 0,67 & 0 & 0 \\
\hline & Nordeste & 0,55 & 0,57 & 2 & 3,64 \\
\hline \multirow{2}{*}{$\begin{array}{l}\text { Dimensão } 4 \text { - Disponibilidade de Recur- } \\
\text { sos }\end{array}$} & Brasil & 0,82 & 0,87 & 5 & 6,10 \\
\hline & Nordeste & 0,67 & 0,77 & 10 & 14,93 \\
\hline \multirow{2}{*}{ Dimensão 5 - Desenvolvimento Infantil } & Brasil & 0,83 & 0,86 & 3 & 3,61 \\
\hline & Nordeste & 0,80 & 0,84 & 4 & 5 \\
\hline \multirow{2}{*}{ Dimensão 6 - Condições Habitacionais } & Brasil & 0,89 & 0,91 & 2 & 2,25 \\
\hline & Nordeste & 0,84 & 0,87 & 3 & 3,57 \\
\hline \multirow{2}{*}{$\begin{array}{l}\text { Dimensão } 7 \text { - Consumo de Bens } \\
\text { Duráveis }\end{array}$} & Brasil & 0,92 & 0,98 & 6 & 6,52 \\
\hline & Nordeste & 0,81 & 0,95 & 14 & 17,28 \\
\hline
\end{tabular}

Fonte: Elaboração própria com base nos dados da PNAD (2003, 2012). 


\subsubsection{A Ausência de vulnerabilidade}

O objetivo dessa dimensão consiste em medir a vulnerabilidade familiar no que se refere ao montante adicional requerido pelas famílias para satisfazer as necessidades essenciais destas. A presença, por exemplo, de gestantes e crianças faz aumentar a vulnerabilidade das famílias, pois aumenta o volume de recursos necessários para a satisfação de suas necessidades, assim como a presença de idosos, ausência do cônjuge, a ausência da mãe são também aspectos relevantes para a compreensão das vulnerabilidades das famílias.

O componente com os menores índices de desenvolvimento apresentados nos dois anos foi o relativo à atenção e cuidados especiais com crianças adolescentes e jovens que mede a ausência de criança, adolescente ou jovem no domićlio (Tabela 2).

No que se refere à dependência econômica, houve redução da presença do cônjuge na família. Esse resultado pode ser explicado pelo visível crescimento das famílias de estrutura monoparental. A diminuição na presença do cônjuge nas famílias nordestinas foi compensada pelo aumento das pessoas em idade ativa dessas famílias, estabilizando o componente da dependência econômica.

O componente que, apesar de alto, se reduziu, foi o da atenção e cuidados especiais com idosos, que podem ser atribuídos ao aumento da expectativa de vida do brasileiro ao nascer. O envelhecimento da população exige gastos adicionais com os idosos, o que contribui para o problema de desenvolvimento nas famílias nordestinas.

Tabela 2 - Dimensão 1: indicadores dos componentes da dimensão ausência de vulnerabilidade no IDF Nordeste, 2003 e 2012

\begin{tabular}{|c|c|c|c|c|}
\hline \multirow{4}{*}{ Ausência de vulnerabilidade } & \multicolumn{4}{|c|}{ IDF da dimensão } \\
\hline & \multicolumn{2}{|c|}{ Nordeste } & \multicolumn{2}{|c|}{ Brasil } \\
\hline & 2003 & 2012 & 2003 & 2012 \\
\hline & 0,66 & 0,77 & 0,69 & 0,79 \\
\hline \multirow{2}{*}{ Componente } & \multicolumn{4}{|c|}{ IDF do componente } \\
\hline & \multicolumn{2}{|c|}{2003} & \multicolumn{2}{|c|}{2012} \\
\hline Fecundidade & \multicolumn{2}{|c|}{0,48} & \multicolumn{2}{|c|}{0,94} \\
\hline $\begin{array}{l}\text { Atenção e cuidados especiais com crianças, adolescentes } \\
\text { e jovens }\end{array}$ & \multicolumn{2}{|c|}{0,36} & \multicolumn{2}{|c|}{0,47} \\
\hline Atenção e cuidados especiais com idosos & \multicolumn{2}{|c|}{0,73} & \multicolumn{2}{|c|}{0,70} \\
\hline Dependência econômica & \multicolumn{2}{|c|}{0,78} & \multicolumn{2}{|c|}{0,78} \\
\hline Presença de mãe & \multicolumn{2}{|c|}{0,97} & \multicolumn{2}{|c|}{098} \\
\hline
\end{tabular}

A redução da fecundidade foi importante para a redução da pobreza. Os indicadores para o ano de 2012 revelam que em 96,66\% dos domicílios pertencentes à amostra estudada para a região Nordeste não havia presença de mulher que tivesse tido filho nascido vivo no último ano, e em 92,17\% desses domicílios não há presença de mulher que tenha tido filho nascido vivo nos últimos dois anos. Isso mostra a realidade da redução da taxa de fecundidade no Brasil que, de acordo com o IBGE, dados do Censo Demográfico de 2000 revelavam uma taxa de 2,38 filhos por mulher, passando a ser de 1,9 filhos por mulher de acordo com o Censo Demográfico de 2010. O maior decréscimo na taxa fecundidade entre as cinco regiões geográficas do Brasil ocorreu na região Nordeste, que passou de 2,69 filhos por mulher em 2000 para 2,06 filhos por mulher em 2010, apesar de se manter acima da taxa de fecundidade nacional. 
Essa baixa taxa de fecundidade pode ser explicada por novo perfil observado na mulher brasileira, tendo alcançado maior participação e ocupação no mercado de trabalho. A crescente busca por melhor qualificação educacional e profissional feminina consiste em mais um motivo para se entender a diminuição da fecundidade da mulher brasileira, o que acaba postergando a maternidade. Programas sociais direcionados ao planejamento familiar são relevantes para esses resultados.

Destaque também para a presença da mãe nos domicílios como indicador favorável ao desenvolvimento familiar. Crianças que estão sendo criadas por terceiros têm maiores chances de estar desprotegidas e, dessa forma, podem trabalhar em atividades penosas e insalubres, ficar fora da escola ou doentes sem atendimento médico adequado, entre outros problemas. A ausência da mãe no domicílio aumenta a vulnerabilidade das famílias.

No Brasil, políticas sociais ressaltam a importância da presença da mãe como, por exemplo, o programa Bolsa família, quando concedem às mães a responsabilidade de receber e gerir o benefício. Relevantes também são as condicionalidades que visam manter o acompanhamento da saúde e educação das crianças.

\subsubsection{As dimensões referentes à Educação, ao trabalho e à renda}

Entre os meios que uma família pode dispor para satisfazer as necessidades desta, o acesso ao conhecimento se encontra entre os mais importantes. No entanto, entre todas as sete dimensões, essa foi a que apresentou tanto pior resultado no nível de desenvolvimento familiar nos dois anos quanto pior desempenho entre os anos estudados.

No ano de 2003, a proporção dos domicílios nordestinos com membros adultos analfabetos foi de 71,53\% e em 2012 essa proporção foi de 76,13\% (Tabela 3). Indicou, também, que 57,8\% dos domicílios contavam com adulto analfabeto funcional no ano de 2003, e em 2012 essa proporção foi de 68,5\%, assinalando a pobreza no nordeste.

Tabela 3 - dimensão 2: indicadores dos componentes da dimensão acesso ao conhecimento no IDF Nordeste, 2003 e 2012

\begin{tabular}{l|c|c|c|c}
\hline \multirow{2}{*}{ Acesso ao conhecimento } & \multicolumn{3}{|c}{ IDF da dimensão } \\
\cline { 2 - 4 } & \multicolumn{2}{|c|}{ Nordeste } & \multicolumn{2}{c}{ Brasil } \\
\cline { 2 - 4 } & 2003 & 2012 & 2003 & 2012 \\
\cline { 2 - 4 } Componente & 0,34 & 0,33 & 0,36 & 0,37 \\
\hline Analfabetismo & \multicolumn{3}{|c|}{ IDF do componente } \\
\cline { 2 - 4 } & \multicolumn{2}{|c|}{2003} & 2012 \\
\hline Escolaridade & \multicolumn{2}{|c|}{0,35} & 0,28 \\
\hline Qualificação profissional & \multicolumn{2}{|c|}{0,43} & 0,32 \\
\hline
\end{tabular}

Fonte: Elaboração própria com base nos dados da PNAD (2003, 2012).

É possível perceber quão grave é a questão do analfabetismo na região nordestina, pois, mesmo com a redução da taxa de analfabetismo nos anos recentes, tanto no âmbito nacional quanto no âmbito regional, como divulgada pelas pesquisas brasileiras ${ }^{26}$, a região Nordeste mantém a temática como problema que afeta desfavoravelmente o nível de desenvolvimento das famílias.

Em 2012, 50,29\% dos domicílios da amostra contavam com a presença de pelo menos um adulto com o nível fundamental completo, uma melhora em 22,96 pontos percentuais em comparação com o ano 2003.

26 INSTITUTO BRASILEIRO DE GEOGRAFIA E ESTATÍSTICA (IBGE). Pesquisa Nacional por Amostra de Domicílios (PNAD 2003, 2012). 
Em 38,57\% desses domicílios tinha ao menos um adulto com ensino médio completo em 2012 contra uma proporção de $22,02 \%$ no ano de 2003.

O componente escolaridade foi o que apresentou pior desempenho em relação à dimensão acesso ao conhecimento, com queda de 11p.p. do seu índice no ano de 2012 em comparação ao ano de 2003, explicado pelos resultados do ensino superior.

É amplamente difundido o aumento tanto na criação de novas Instituições de Ensino Superior, da oferta de vagas nessas instituições, assim como o aumento do número de alunos matriculados nas universidades brasileiras. Vários programas federais atendem essa finalidade, como o Programa Universidade para Todos (Prouni) criado pelo governo federal brasileiro em 2004, com o objetivo de conceder bolsas de estudos integrais ou parciais em cursos de graduação de instituições de ensino superior privadas.

A distribuição regional das matrículas no ensino superior ${ }^{27}$, nos anos de 2012 e 2003, mostra que elas obtiveram incremento mais que proporcional na região Nordeste. Observa-se que esse crescimento mais acentuado nessa região foi impulsionado pelo setor de Instituições de Ensino Superior (IES) privadas. Vale destacar que em 2003 as IES públicas lideravam as matrículas na região Nordeste, realidade oposta observada em 2012.

Dotar as famílias de meios sem garantir que elas possam efetivamente utilizá-los para a satisfação de suas necessidades não constitui política eficaz. Tão importante quanto assegurar que as famílias tenham acesso a esses meios é conceder-lhes a oportunidade de utilizá-los. Por exemplo, se não é dada a determinada pessoa a oportunidade de realizar determinada função que lhe foi conferida os conhecimentos necessários para desempenhá-la. Privar as pessoas do conhecimento é também privá-las do acesso ao mercado de trabalho.

Vale ressaltar, enfim, que, mesmo com o índice de escolaridade baixo nos dois anos analisados, no ano de 2012, esta pesquisa atesta a contribuição do ensino fundamental e médio para a redução das carências das famílias nordestinas, bem como da qualificação profissional dos trabalhadores.

Quanto aos indicadores da dimensão acesso ao trabalho nos dois anos analisados, estes tiveram resultado relativamente baixo em comparação aos indicadores das demais dimensões (Tabela 4). Em 2003 o indicador da pobreza nordestina no que se refere ao acesso ao trabalho foi de 0,55 e no ano de 2012 esse mesmo indicador foi de 0,57 , isso significa que no ano de análise mais recente, $43 \%$ da população nordestina tem dificuldade no mercado de trabalho. O indicador, no entanto, evoluiu em 3,64\%, e foi melhor que o resultado para o Brasil.

Os componentes que mais contribuem para o baixo índice apresentado por essa dimensão para dois anos considerados foram o referente à remuneração do trabalho e a qualidade do posto do trabalho.

Tabela 4 - dimensão 3: indicadores dos componentes da dimensão acesso ao trabalho no IDF Nordeste, 2003 e 2012

\begin{tabular}{l|c|c|c|c}
\hline \multirow{2}{*}{ Acesso ao trabalho } & \multicolumn{3}{|c}{ IDF da dimensão } \\
\cline { 2 - 4 } & \multicolumn{2}{|c}{ Nordeste } & \multicolumn{2}{c}{ Brasil } \\
\cline { 2 - 4 } & 2003 & 2012 & 2003 & 2012 \\
\cline { 2 - 4 } Componente & 0,55 & 0,57 & 0,67 & 0,67 \\
\hline Disponibilidade de trabalho & \multicolumn{3}{|c}{ IDF do componente } \\
\hline Qualidade do posto de trabalho & \multicolumn{2}{|c|}{0,93} & 2012 \\
\hline Remuneração & \multicolumn{2}{|c|}{0,44} & 0,95 \\
\hline Fonte: Elaboração própria com base nos dados da PNAD (2003,2012). & \multicolumn{2}{|c|}{0,29} & 0,48 \\
\hline
\end{tabular}

27 INSTITUTO NACIONAL DE ESTUDOS E PESQUISAS EDUCACIONAIS ANÍSIO TEIXEIRA (INEP). Disponível em: <http://portal.inep.gov.br/>. Acesso em: 20 mar. 2014. 
A literatura sobre mercado de trabalho no Brasil ${ }^{28}$ reforça a recuperação do mercado de trabalho ligada à redução da informalidade no país e aumento dos ocupados em atividades não agrícolas, confirmados nesta pesquisa. Todavia, a região nordeste mantém o problema da não formalização do trabalho, já que em apenas 30\% dos domićlios nordestinos possuem pelo menos um ocupado formalizado. A remuneração do trabalho que, de modo geral, sofre também inflexão positiva no país após 2004, não está confirmada nesta pesquisa para a região nordeste.

Em 2003 somente 40,34\% dos domicílios do Nordeste contava com pelo menos um ocupado com rendimento superior a 1 salário mínimo, essa mesma proporção em 2012 foi de 37,9\% desses domicílios, ou seja, reduziu-se em 2,44 pontos percentuais. Ainda, apenas 18,6\% dos domicílios nordestinos contavam com pelo menos um ocupado que tinha rendimento superior a 2 salários mínimos no ano de 2003 e, para o ano de 2012, essa proporção foi de 15,31\% desses domicílios. Assim, também se observa uma piora nesse indicador em menos 3,29 pontos percentuais, o que mostra que o rendimento do trabalho ainda constitui um obstáculo para as famílias do Nordeste.

O destaque positivo está na disponibilidade do trabalho no Nordeste, pois aproximadamente $92 \%$ das famílias estão ocupadas e 98\% está, há mais de 6 meses, na mesma ocupação. A reorganização do mercado de trabalho brasileiro nos anos 2000, diferentemente da década de 1990, significou demanda de trabalho maior e redução da rotatividade no emprego, conforme discute a literatura econômica sobre o mercado de trabalho. Desse modo, esta pesquisa mostra os efeitos favoráveis no Nordeste para a absorção dos trabalhadores e tempo no trabalho.

A quarta dimensão, disponibilidade de recursos, se refere aos domicílios que se encontram acima da linha de extrema pobreza ou de indigência, da linha de pobreza e daqueles nos quais a maior parte da renda domiciliar não advém de transferências de renda.

A renda familiar per capita consiste em um recurso fundamental já que grande parte das necessidades básicas de uma família pode ser satisfeita pela aquisição de bens e serviços no mercado. Ainda que a procedência dos recursos possa ser relevante para satisfazer as necessidades de uma família, a sustentabilidade e o grau de independência dela dependem da parcela que é gerada autonomamente e da parte que é recebida como transferências de outras famílias ou do governo.

No ano de 2003, cerca de 77,22\% das famílias nordestinas possuía renda familiar per capita superior à linha de extrema pobreza; essa proporção em 2012 fora de 83,61\%, ou seja, o índice desse indicador melhorou em $8,27 \%$. Resultado semelhante ocorreu para o indicador dos domićlios com renda superior a linha de pobreza, sendo de 51,4\% das famílias da região Nordeste em 2003 com renda familiar per capita superior à linha de pobreza e de 58,59\% desses domicílios em 2012, o que representou um incremento de 7,19 p.p (Tabela 5).

Mesmo com a melhora observada dos índices dos componentes da dimensão disponibilidade de recursos, a proporção de pobres e extremamente pobres ainda constitui um grave problema na região Nordeste, já que $41,41 \%$ da população nordestina ainda possui rendimento familiar per capita inferior à linha de pobreza e 16,39\% têm renda familiar per capita inferior à linha de extrema pobreza.

28 POCHMANN, M. Mercado geral de trabalho: o que há de novo no Brasil? Revista Parcerias Estratégicas, CGEE, n. 22 , jun. 2006. RAMOS, L. O desempenho recente do mercado de trabalho brasileiro: tendências, fatos estilizados e mudanças estruturais. Rio de Janeiro: IPEA, 2007. CARDOSO JUNIOR, C. De volta para o futuro? As fontes de recuperação do emprego formal no Brasil e as condições de sua sustentabilidade temporal. Brasília: IPEA, 2007. 
Tabela 5 - dimensão 4: indicadores dos componentes da dimensão disponibilidade de recursos no IDF Nordeste, 2003 e 2012

\begin{tabular}{l|c|c|c|c}
\hline \multirow{2}{*}{ Disponibilidade de recursos } & \multicolumn{3}{|c}{ IDF da dimensão } \\
\cline { 2 - 4 } & \multicolumn{2}{|c|}{ Nordeste } & \multicolumn{2}{c}{ Brasil } \\
\cline { 2 - 4 } & 2003 & 2012 & 2003 & 2012 \\
\cline { 2 - 4 } Componente & 0,67 & 0,77 & 0,82 & 0,87 \\
\hline Extrema pobreza & \multicolumn{3}{|c|}{ IDF do componente } \\
\cline { 2 - 4 } Pobreza & \multicolumn{2}{|c|}{0,77} & 2003 \\
\hline Capacidade de geração de renda & \multicolumn{2}{|c|}{0,51} & 0,84 \\
\hline Fonte: Elaboração própria com base nos dados da PNAD $(2003,2012)$. & \multicolumn{2}{|c}{0,73} & 0,87 \\
\hline
\end{tabular}

Um resultado bastante expressivo foi observado para o indicador que mede a parcela da renda domiciliar que advém de transferências, que mostrou que $73,26 \%$ da renda dos domicílios analisados para a amostra da região Nordeste não era originada de transferências em 2003 e de 87,49\%, no ano de 2012, o que se configurou em um incremento de 19,42\% desse indicador.

Verifica-se a redução da proporção de famílias nordestinas cuja maior parte da renda familiar é originada de transferências, pois 12,51\% do rendimento familiar dos domićlios do Nordeste advinham de transferências em 2012 e essa proporção fora de 26,74\% em 2003, isto é, a proporção das famílias nordestinas nessa situação caiu 14,23 pontos percentuais no período analisado.

Os dados mostram que os indicadores mais relevantes foram a redução da extrema pobreza e o aumento na capacidade de geração de renda. Os programas sociais de transferências de renda condicionadas mantiveram importante participação para o incremento de grau de desenvolvimento das famílias do Nordeste, porém, ao seu lado, outras fontes de renda das famílias ganharam mais espaço, especialmente associadas às aposentadorias e pensões, conforme discutem pesquisadores da área ${ }^{29}$.

\subsubsection{As Dimensões referentes ao Desenvolvimento Infantil, às Condições Habitacionais e ao Consumo de Bens Duráveis}

Na composição do IDF para o Nordeste, as dimensões que tratam do desenvolvimento infantil, das condições habitacionais e do consumo de bens duráveis foram mais significativas e favoráveis para o Nordeste. Os dados mostram que foi garantida a oportunidade de pleno desenvolvimento para $84 \%$ das crianças do Nordeste em 2012, um incremento de 4 p.p. em comparação ao ano de 2003 (tabela 6), com melhor performance nos indicadores dos componentes, sejam os que se referem ao trabalho precoce, acesso à escola e progresso escolar.

Um ponto que merece destaque no sentido de compreender melhor a realidade mostrada nos índices consiste no impacto de programas sociais, como o Bolsa Família, por exemplo, na matrícula e permanência dessas crianças na escola, bem como o seu progresso escolar. Uma vez que esse programa exige que todas as crianças e adolescentes entre 6 e 15 anos de idade estejam devidamente matriculadas e que tenham frequência escolar mínima de 85\% de carga horária ao mês, já os estudantes de 16 a 17 anos de idade devem ter frequência de carga horária mensal de no mínimo $75 \%$.

29 FERREIRA, C. R.; SOUZA, S. C. I. Contribuição das parcelas do rendimento domiciliar per capita na distribuição da renda das macro-regiões brasileiras: 1981 a 2009. In: ENCONTRO NACIONAL DA ASSOCIAÇÃO BRASILEIRA DE ESTUDOS REGIONAIS E URBANOS, 9., 2011, Natal. Anais..., Natal: ENABER, 2011. HOFFMANN, R. Transferências de renda e a redução da desigualdade no Brasil e cinco regiões entre 1997-2004. Econômica, Rio de Janeiro, v. 8, n. 1, p. 55-81, 2006. 
Tabela 6 - dimensão 5: indicadores dos componentes da dimensão desenvolvimento infantil no IDF Nordeste, 2003 e 2012

\begin{tabular}{|c|c|c|c|c|}
\hline \multirow{4}{*}{ Desenvolvimento Infantil } & \multicolumn{4}{|c|}{ IDF da dimensão } \\
\hline & \multicolumn{2}{|c|}{ Nordeste } & \multicolumn{2}{|c|}{ Brasil } \\
\hline & 2003 & 2012 & 2003 & 2012 \\
\hline & 0,80 & 0,84 & 0,83 & 0,86 \\
\hline \multirow{2}{*}{ Componente } & \multicolumn{4}{|c|}{ IDF do componente } \\
\hline & \multicolumn{2}{|c|}{2003} & \multicolumn{2}{|c|}{2012} \\
\hline Trabalho precoce & \multicolumn{2}{|c|}{0,94} & \multicolumn{2}{|c|}{0,98} \\
\hline Acesso à escola & \multicolumn{2}{|c|}{0,65} & \multicolumn{2}{|c|}{0,70} \\
\hline Progresso escolar & \multicolumn{2}{|c|}{0,81} & \multicolumn{2}{|c|}{0,84} \\
\hline
\end{tabular}

Fonte: Elaboração própria com base nos dados da PNAD (2003, 2012).

Outro destaque favorável é o que se refere ao trabalho precoce. O PETI (Programa de Erradicação do Trabalho Infantil) visa à retirada de crianças e adolescentes com idade inferior a 16 anos do trabalho considerado perigoso, penoso, insalubre ou degradante, isto é, qualquer trabalho que ponha em risco a saúde e a segurança desses jovens e adolescentes. Esse programa pode ser apontado como um dos principais responsáveis pelo bom desempenho desse componente. Porém, 1,22\% das crianças do Nordeste com menos de 14 anos ainda trabalhavam e 2,71\% das crianças nordestinas com menos de 16 anos também trabalhavam em 2012.

A sexta dimensão trata das condições habitacionais dos domicílios. Por ter íntima relação com as condições de saúde, mensuradas, sobretudo, pelos indicadores dos componentes acesso a saneamento básico e acesso à coleta de lixo domiciliar, essa dimensão pode ser considerada como uma das mais importantes em captar as condições de vida de uma família (Tabela 7).

Tabela 7 - dimensão 6: indicadores dos componentes da dimensão condições habitacionais no IDF Nordeste, 2003 e 2012

\begin{tabular}{|c|c|c|c|c|}
\hline \multirow{4}{*}{ Condições habitacionais } & \multicolumn{4}{|c|}{ IDF da dimensão } \\
\hline & \multicolumn{2}{|c|}{ Nordeste } & \multicolumn{2}{|c|}{ Brasil } \\
\hline & 2003 & 2012 & 2003 & 2012 \\
\hline & 0,84 & 0,87 & 0,89 & 0,91 \\
\hline \multirow{2}{*}{ Componente } & \multicolumn{4}{|c|}{ IDF do componente } \\
\hline & \multicolumn{2}{|c|}{2003} & \multicolumn{2}{|c|}{2012} \\
\hline Propriedade & \multicolumn{2}{|c|}{0,82} & \multicolumn{2}{|c|}{0,80} \\
\hline Déficit habitacional & \multicolumn{2}{|c|}{0,72} & \multicolumn{2}{|c|}{0,83} \\
\hline Abrigabilidade & \multicolumn{2}{|c|}{0,94} & \multicolumn{2}{|c|}{0,97} \\
\hline Acesso a abastecimento de água & \multicolumn{2}{|c|}{0,99} & \multicolumn{2}{|c|}{0,87} \\
\hline Acesso à energia elétrica & \multicolumn{2}{|c|}{0,92} & \multicolumn{2}{|c|}{0,99} \\
\hline Acesso a saneamento & \multicolumn{2}{|c|}{0,78} & \multicolumn{2}{|c|}{0,86} \\
\hline Acesso à coleta de lixo & \multicolumn{2}{|c|}{0,70} & \multicolumn{2}{|c|}{0,77} \\
\hline
\end{tabular}

Fonte: Elaboração própria com base nos dados da PNAD $(2003,2012)$.

Os índices para essa dimensão apresentaram evolução de 3,57\%, em termos de pontos percentuais essa melhoria foi de 3 p.p.. Esses resultados significam que 84\% das famílias do Nordeste em 2003 e $87 \%$ das famílias em 2012 tinham condições de vida adequadas.

Os componentes que tiveram maior impacto nesse bom resultado foram o de déficit habitacional, que melhorou em 15,28\% no ano de 2012 e o de acesso a saneamento que também obteve melhora em 10,26\% 
no mesmo período, ou seja, em 2012 contava-se com 10,26\% domićlios a mais com acesso a serviços de esgotamento sanitário no Nordeste.

Os componentes que apresentaram pior evolução foram os relativos ao abastecimento de água, cujo resultado mostra que $99 \%$ das famílias do Nordeste tinham acesso adequado ao abastecimento de água em 2003, e essa proporção foi de 87\% em 2012, ou seja, houve uma piora do índice desse componente em 12 p.p.. Outra piora observada para essa dimensão foi para o componente propriedade que apresentou índice de 0,82 em 2003 e 0,80 em 2012, ou seja, o índice desse componente foi reduzido em 2 p.p.. Esse resultado mostrou que em 2012 mais famílias do Nordeste deixaram de ter propriedade sobre os seus domicílios.

No que diz respeito ao acesso adequado ao abastecimento de água, 99,61\% das famílias nordestinas tinham acesso adequado à água no ano de em 2003, em 2012 esse percentual correspondeu a 86,98\% das famílias nordestinas contavam com acesso adequado à água, isto é, ocorreu uma piora desse indicador em 12,63 pontos percentuais em 2012. Outro ponto que merece destaque foi que, no ano de 2003, apenas $53,73 \%$ das famílias dessa região tinham acesso a serviços de esgotamento sanitário e em 2012 em apenas $66,60 \%$ das famílias da região Nordeste esse acesso.

A sétima dimensão faz referência ao consumo de bens duráveis, como fogão e geladeira, pelas famílias nordestinas nos anos analisados, 2012 e 2003 (Tabela 8). Essa dimensão apresentou aumento em 14 p.p. entre os dois anos. O consumo de geladeira pelas famílias do Nordeste em 2012 aumentou em 34,78\%. No ano de 2003, 63\% dos domicílios nordestinos possuíam geladeira, ao passo que, em 2012 esse percentual foi de $93 \%$ desses domicílios. Em 93,31\% das famílias nordestinas contavam com fogão em suas residências.

Tabela 8 - dimensão 7: indicadores dos componentes da dimensão consumo de bens duráveis no IDF Nordeste, 2003 e 2012

\begin{tabular}{l|c|c|c|c}
\hline \multirow{2}{*}{ Consumo de bens duráveis } & \multicolumn{3}{|c}{ IDF da dimensão } \\
\cline { 2 - 4 } & \multicolumn{2}{|c|}{ Nordeste } & \multicolumn{2}{c}{ Brasil } \\
\cline { 2 - 4 } & 2003 & 2012 & 2003 & 2012 \\
\cline { 2 - 4 } Componente & 0,81 & 0,95 & 0,92 & 0,98 \\
\hline Acesso a fogão & \multicolumn{3}{|c}{ IDF do componente } \\
\cline { 2 - 4 } & \multicolumn{2}{|c|}{2003} & 2012 \\
\hline Acesso à geladeira & \multicolumn{2}{|c|}{0,93} & 0,97 \\
\hline
\end{tabular}

Fonte: Elaboração própria com base nos dados da PNAD $(2003,2012)$.

O Gráfico 1 ilustra a evolução do indicador multidimensional de pobreza calculado para a região Nordeste nos anos de 2003 e 2012 para cada uma das sete dimensões. 
Gráfico 1 - Indicadores multidimensionais de pobreza no Nordeste, 2003 e 2012

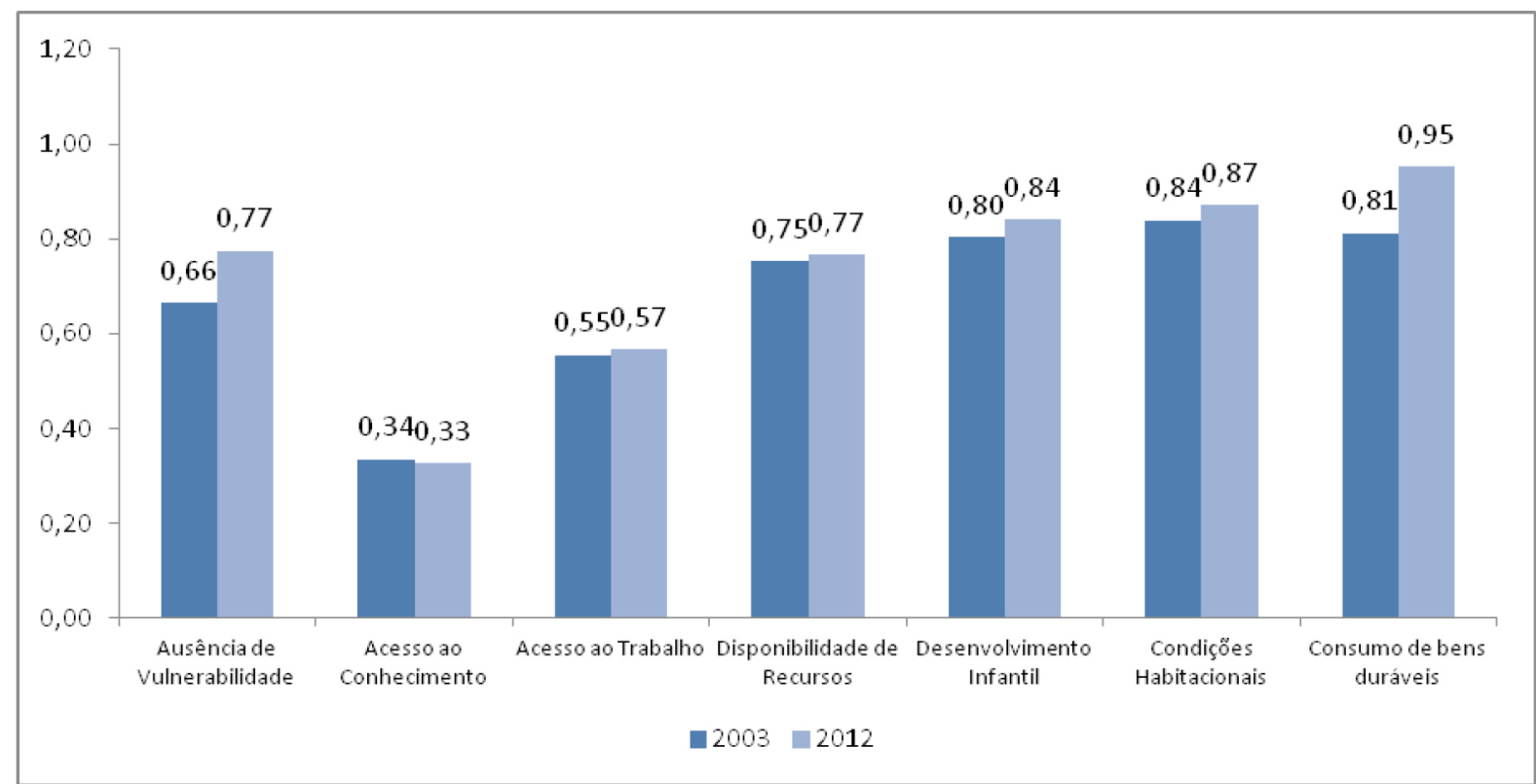

Fonte: Elaboração própria com base nos dados da PNAD (2003, 2012).

\section{Considerações finais}

A redução da pobreza no Brasil e no Nordeste após 2003 está documentada na literatura, especialmente naquela relacionada à abordagem unidimensional. Neste trabalho, a desagregação do grau de desenvolvimento das famílias segundo as sete dimensões selecionadas permite enriquecer o conhecimento e a magnitude desse fato.

Comparadas ao Brasil, todas as dimensões da pobreza foram problemáticas para o Nordeste e tiveram seus índices inferiores em relação ao país para os dois anos, apesar do bom desempenho no período. A pesquisa revela uma sensível diminuição na pobreza multidimensional do Nordeste, principalmente em relação à disponibilidade de recursos e acesso aos bens duráveis, e a despeito do menor desenvolvimento das famílias residentes na região Nordeste em relação às famílias brasileiras, há um processo mais favorável em direção às primeiras.

O cálculo do IDF para a região permitiu afirmar que os bons resultados para o desenvolvimento das famílias no Nordeste estão ligados à ausência de vulnerabilidade, desenvolvimento infantil e condições habitacionais e de acesso aos bens de consumo. No primeiro aspecto, ausência da vulnerabilidade das famílias, vale mencionar a dependência econômica, a redução da fecundidade e a presença da mãe nos domicílios. A diminuição na presença do cônjuge nas famílias nordestinas explicada pelo crescimento de famílias monoparentais foi compensada pelo aumento das pessoas em idade ativa dessas famílias, estabilizando o componente da dependência econômica. O novo perfil econômico da mulher brasileira, bem como programas sociais direcionados ao planejamento familiar e políticas sociais que ressaltam a presença da mãe e as condicionalidades, como o programa Bolsa Família, podem explicar a situação.

O desenvolvimento infantil decorreu da melhor performance nos indicadores do trabalho precoce, acesso à escola e progresso escolar. Novamente, programas sociais como o Bolsa Família e o PETI podem ser responsáveis por esse bom desempenho. Os componentes relativos às condições habitacionais que captam as condições de vida da população evoluíram, com exceção dos componentes relativos à propriedade e o acesso ao abastecimento de água. $\mathrm{O}$ acesso aos bens de consumo duráveis colaborou para o desenvolvimen- 
to das famílias.

Destaque positivo para os indicadores da disponibilidade de recursos, medida pela renda familiar per capita. A melhora se deu na redução da extrema pobreza e na redução da proporção de famílias nordestinas cuja maior parte da renda familiar é originada de transferências.

Todavia, os problemas são detectados nesta pesquisa. Primeiro, os resultados relativamente baixos da dimensão acesso ao trabalho, em comparação aos indicadores das demais dimensões. Apesar da evolução e do melhor resultado se comparados com o país, os componentes que mais contribuem para o baixo índice foram a remuneração do trabalho e a qualidade do posto do trabalho. A despeito da recuperação do mercado de trabalho documentada na literatura econômica, a região nordeste mantém o problema da não formalização do trabalho. A remuneração do trabalho que, de modo geral, sofre também inflexão positiva no país após 2004, não está confirmada nesta pesquisa para a região nordeste. O aspecto positivo está na disponibilidade do trabalho no Nordeste, que mostra os efeitos favoráveis no Nordeste para a absorção dos trabalhadores e tempo no trabalho.

Além disso, a preocupação está no acesso ao conhecimento, pois, entre todas as sete dimensões, esta foi a que apresentou tanto pior resultado no nível de desenvolvimento familiar nos dois anos, quanto pior desempenho entre os anos estudados, associados em grande parte ao ensino superior. Por outro lado, a pesquisa atesta a contribuição do ensino fundamental e médio para a redução das carências das famílias nordestinas, bem como da qualificação profissional dos trabalhadores.

Por fim, os ganhos em relação ao desenvolvimento familiar, do ponto de vista exclusivamente da renda per capita, foram maiores do que os relacionados às outras dimensões da pobreza. $\mathrm{O}$ índice de pobreza restrito à renda, unidimensional, cresceu mais do que o apontado pelo índice sintético global, medido nesta pesquisa.

O exposto reforça a importância de se compreender a pobreza sob o ponto de vista multidimensional, pois, apesar da importância dos recursos monetários para a redução da pobreza, eles por si só não são capazes de garantir às pessoas a não privação de suas liberdades. O aprofundamento dos estudos sobre as divergências espaciais no que se referem ao urbano/rural e regiões metropolitanas e não metropolitanas no Nordeste do país contribuirão ainda mais para o entendimento da realidade da pobreza no país e podem subsidiar as ações públicas endereçadas aos segmentos problemáticos para que se tenha maior grau de desenvolvimento das famílias nordestinas.

\section{REFERÊNCIAS}

ALBUQUERQUE, Marcela Ribeiro de. Pobreza sob o enfoque multidimensional no Paraná: 1995 e 2009. 2011. Dissertação (Mestrado em Economia) - Universidade Estadual de Maringá, Maringá, 2011.

ARAÚJO, J. A.; TABOSA, F. J. S.; MORAIS, G. S. Pobreza Multidimensional no Nordeste do Brasil. In: ENCONTRO NACIONAL DA ASSOCIAÇÃO BRASILEIRA DE ESTUDOS REGIONAIS E URBANOS, 11., 2013, Foz do Iguaçu. Anais... Foz do Iguaçu: ENABER, 2013.

ASSELIN, L.M. Composite Indicator of Multidimensional Poverty. CECI, jun. 2002. Disponível em: <http://www.researchgate.net/publication/265568282_Composite_Indicator_of_Multidimensional_Poverty>. Acesso em 20/09/2015.

BANGOLIN, I. P.; ÁVILA, R.; P. Poverty distribution among the brasilian states: a multidimensional analysis using capabilities and needs approaches. In: Encontro Nacional da Associação Nacional dos Centros de Pós-Graduação em Economia, 34., 2006, Salvador. Anais... Salvador: ANPEC, 2006. 
BARROS, F. F. R. Análise da pobreza unidimensional e multidimensional no Nordeste do Brasil em 2009 e 2012. Fortaleza: ANPEC, 2014.

BARros, R. P.; CARVALHO, M.; FRANCO, S. Pobreza multidimensional no Brasil. Rio de Janeiro: IPEA, 2006.

BARROS, R. P.; CARVALHO, M.; FRANCO, S. O Índice de desenvolvimento da família (IDF). In: TEXTO para Discussão. Rio de Janeiro: IPEA, 2003.

BARROS, R. P.; CARVALHO, M.; FRANCO, S. O Impacto do crescimento econômico e de reducões no grau de desigualdade sobre a pobreza. Rio de Janeiro: IPEA, 1997.

BARROS, R. P.; CARVALHO, M.; FRANCO, S. A evolução do bem-estar, pobreza e desigualdade no Brasil ao longo das últimas três décadas: 1960/90. Pesquisa e Planejamento Econômico, Rio de Janeiro, v. 25, n. 1, p. 115-164, 1995a.

BARROS, R. P.; CARVALHO, M.; FRANCO, S. Os determinantes da desigualdade no Brasil. Brasília: IPEA, 1995b.

BARROS, R. P.; HENRIQUES, R.; MENDONÇA, R. A estabilidade inaceitável: desigualdade e pobreza no Brasil. Rio de Janeiro: IPEA, 2001.

BARROS, R. P.; MACHADO, A. F.; MENDONÇA, R. A. Desigualdade da pobreza: estratégias ocupacionais e diferenciais por gênero. Rio de Janeiro: IPEA, 1997.

BARROS, F. F. R. Análise da pobreza unidimensional e multidimensional no Nordeste do Brasil em 2009 e 2012. Fortaleza: ANPEC, 2014.

BARROSO, M. V.; SALVATO, M. A.; MATIAS, J. S. Análise multidimensional da pobreza no Nordeste Brasileiro. In: ENCONTRO DA ASSOCIAÇÃO NACIONAL DOS CENTROS DE PÓS-GRADUAÇÃO EM ECONOMIA, 40., 2012, Porto de Galinhas. Anais... Porto de Galinhas: ANPEC, 2012.

BRASIL. Lei No 8.069, de 13 de julho de 1990. Dispõe sobre o Estatuto da Criança e do Adolescente e dá outras providências. Diário Oficial [da] República Federativa do Brasil, Brasillia, 16 jul. 1990, p. 13563.

CALDAS, R. M.; SAMPAIO, Y. S. B. Pobreza no Nordeste Brasileiro: uma análise multidimensional. Fortaleza: Fórum BNB de Desenvolvimento, 2012.

CARDOSO JUNIOR, C. De volta para o futuro? As fontes de recuperação do emprego formal no Brasil e as condições de sua sustentabilidade temporal. Brasília: IPEA, 2007.

CODES, A. L. M. A trajetória do pensamento científico sobre a pobreza: em direção a uma visão complexa. Brasília: IPEA, 2008.

DINIZ, B. M.; DINIZ, M. M. Um indicador comparativo de pobreza multidimensional a partir dos objetivos do desenvolvimento do milênio. Economia Aplicada, v. 13, n. 3, 2009.

DUCLOS, J. Y.; ARAAR, A. Economic Studies in Inequality Social Exclusion and Well-Being. In: DUCLOS, J. Y.; ARAAR, A. Poverty and Equity: Measurement, Policy and Estimation With Dad. [S.1.]: Springer e International Development Research Centre, 2006. v. 2. p. 3-18.

FERREIRA, C. R.; SOUZA, S. C. I. Contribuição das parcelas do rendimento domiciliar per capita na distribuição da renda das macro-regiões brasileiras: 1981 a 2009. In: ENCONTRO NACIONAL DA ASSOCIAÇÃO BRASILEIRA DE ESTUDOS REGIONAIS E URBANOS, 9., 2011, Natal. Anais..., Natal: ENABER, 2011.

FILDS, G. S. Distribution and Development: a new look at the developing world. New York: Russel Sage Foundation, 2001. 
HOFFMANN, R. Transferências de renda e a redução da desigualdade no Brasil e cinco regiões entre 19972004. Econômica, Rio de Janeiro, v. 8, n. 1, p. 55-81, 2006.

HOFFMANN, R. Distribuição de renda: medidas de desigualdade e pobreza. São Paulo: Universidade de São Paulo, 1998.

INSTITUTO BRASILEIRO DE GEOGRAFIA E ESTATÍSTICA (IBGE). Censo Demográfico 2000. Disponível em: <www.ibge.gov.br>. Acesso em: 15 nov. 2013.

INSTITUTO BRASILEIRO DE GEOGRAFIA E ESTATÍSTICA (IBGE). Censo Demográfico 2010. Disponível em: <www.ibge.gov.br>. Acesso em: 15 nov. 2013.

INSTITUTO BRASILEIRO DE GEOGRAFIA E ESTATÍSTICA (IBGE). Pesquisa Nacional por Amostra de Domicílios (PNAD). Disponível em: <www.ibge.gov.br>. Acesso em: 10 jul. 2013.

INSTITUTO DE PESQUISA ECONÔMICA APLICADA (IPEA/IPEADATA). Social. Disponível em: < http://www.ipeadata.gov.br/ >. Acesso em: 20 mar. 2014.

INSTITUTO NACIONAL DE ESTUDOS E PESQUISAS EDUCACIONAIS ANÍSIO TEIXEIRA (INEP). Disponível em: <http://portal.inep.gov.br/>. Acesso em: 20 mar. 2014.

KAGEYAMA, A.; HOFFMANN, R. Pobreza no Brasil: uma perspectiva multidimensional. Economia e Sociedade, Campinas, v. 15, n. 1, p. 79-112, jan./jun. 2006.

LOPES, H. M.; MACEDO, P. B. R.; MACHADO, A. F. Análise de pobreza com indicadores multidimensionais: uma aplicação para o Brasil e Minas Gerais. Revista de Economia Contemporânea. Rio de Janeiro, v. 9, n. 1, p. 125-152, 2005.

LOPES, H. M.; MACEDO, P. B. R.; MACHADO, A. F. Indicador de pobreza: aplicação de uma abordagem multidimensional ao caso brasileiro. Belo Horizonte: CEDEPLAR/UFMG, 2003.

NEDER, H. D. Um estudo sobre a pobreza rural com abordagem multivariada. In: Congresso da Sociedade Brasileira de Economia, Administração e Sociologia Rural, 46., 2008, Rio Branco. Anais... Rio Branco: SOBER, 2008.

ORGANIZAÇÃO DAS NAÇÕES UNIDAS. Nações Unidas Declaração do Milênio. Nova York: Technical Report, 2001.

OTTONELLI, Janaina. Pobreza multidimensional na região Nordeste: uma aplicação da teoria dos conjuntos Fuгzy (em 2010). 2013. 127 f. Dissertação (Mestrado em Economia) - Universidade Federal do Rio Grande do Norte, Natal, 2013.

POCHMANN, M. Mercado geral de trabalho: o que há de novo no Brasil? Revista Parcerias Estratégicas, CGEE, n. 22, jun. 2006.

QUINTELA, M. D.; ALVES, J. E. D.; SILVA, D. B. N. A Pobreza no Nordeste Brasileiro em 2000 e 2010: uma aplicação do índice de pobreza multidimensional PNUD/ONU. In: ENCONTRO NACIONAL DA ASSOCIAÇÃO BRASILEIRA DE ESTUDOS REGIONAIS E URBANOS , 11., 2013, Foz do Iguaçu. Anais... ENABER, 2013.

RAMOS, L. O desempenho recente do mercado de trabalho brasileiro: tendências, fatos estilizados e mudanças estruturais. Rio de Janeiro: IPEA, 2007.

RAVALLION, M. Poverty Comparisons: a guide to concept and method. Washington: The World Bank, 1992. ROCHA, S. Pobreza no Brasil: a evolução de longo prazo (1970-2011). Rio de Janeiro: XXV Fórum Nacional, 2012. 
ROCHA, S. Pobreza no Brasil, afinal do que se trata? 3. ed. Rio de Janeiro: FGV, 2006.

ROCHA, S. Pobreza no Nordeste: A década de 1990 vista de perto. Revista Econômica do Nordeste, Fortaleza, v. 34, n. 1, p. 7-41, jan./mar. 2003.

ROCHA, S. Pobreza no Brasil, afinal do que se trata? Rio de Janeiro: FGV, 2003.

ROCHA, S. Desigualdade regional e pobreza no Brasil: a evolução, 1981/95. Brasília: IPEA, 1998.

ROCHA, S. Pobreza no Brasil: parâmetros básicos e resultados empíricos. Pesquisa e Planejamento Econômico, Rio de Janeiro, v. 22, p. 541-560, dez. 1992.

ROWNTREE, B. S. Poverty: a study of town life. London: MacMillan, 1901.

SEN, A. K. Desenvolvimento e Liberdade. Lisboa: Gradiva, 2003.

SEN, A. K. Desenvolvimento como Liberdade. São Paulo: Cia das Letras, 2000.

SEN, A. K. Resources, values and development. Oxford: Basil Blackwell, 1984.

SEN, A. K. Development: which way now? The Economic Journal, v. 93, 1983.

SILVA, A. M. R.; NEDER, H. D. Abordagem das capacitações: um estudo empírico sobre pobreza multidimensional no Brasil. In: Conferência Latino Americana e Caribenha sobre Abordagem das Capacitações e Desenvolvimento Humano, 3., 2010, Porto Alegre. Anais... Porto Alegre, 2010.

SILVA, A. M. R. Um Estudo sobre pobrez̧a multidimensional na região Nordeste do Brasil. Uberlândia: UFU, 2009.

SILVA, M. C. P.; BARROS, R. P. Pobreza multidimensional no Brasil. In: Encontro Nacional de Economia da Associação Nacional dos Centros de Pós-graduação em Economia, 34., Salvador, 2006. Anais... Salvador: ANPEC, 2006.

\section{APÊNDICE A}

Quadro 1 - definição dos componentes e variáveis do Indicador Multidimensional de Pobreza

\begin{tabular}{|l|l|}
\hline Componentes & Variáveis \\
\hline \multicolumn{2}{|l|}{ Dimensão 1: ausência de vulnerabilidade } \\
\hline Fecundidade & $\begin{array}{l}\text { V1. Nenhuma mulher teve filho nascido vivo no último ano } \\
\text { V2. Nenhuma mulher teve filho nascido vivo nos últimos } \\
\text { dois anos }\end{array}$ \\
\hline \multirow{2}{*}{$\begin{array}{l}\text { Atenção e cuidados especiais com } \\
\text { crianças, adolescentes e jovens }\end{array}$} & V3. Ausência de criança \\
& V4. Ausência de criança ou adolescente \\
\hline Atenção e cuidados especiais com idosos & V6. Ausência de idoso \\
\hline & V7. Presença de cônjuge \\
Dependência econômica & V8. Mais da metade dos membros encontra-se em idade \\
& ativa \\
\hline Presença da mãe & V9. Não existe criança no domićlio cuja mãe tenha morrido \\
& V10. Não existe criança no domicílio que não viva com a \\
\hline Dimensão 2: acesso ao conhecimento & mãe \\
\hline
\end{tabular}




\begin{tabular}{|c|c|}
\hline \multirow{2}{*}{ Analfabetismo } & E1. Ausência de adulto analfabeto \\
\hline & E2. Ausência de adulto analfabeto funcional \\
\hline \multirow{3}{*}{ Escolaridade } & $\begin{array}{l}\text { E3. Presença de pelo menos um adulto com fundamental } \\
\text { completo }\end{array}$ \\
\hline & $\begin{array}{l}\text { E4. Presença de pelo menos de um adulto com ensino } \\
\text { médio completo }\end{array}$ \\
\hline & $\begin{array}{l}\text { E5. Presença de pelo menos um adulto com alguma edu- } \\
\text { cação superior }\end{array}$ \\
\hline Qualificação profissional & $\begin{array}{l}\text { E6. Presença de pelo menos um trabalhador com qualifi- } \\
\text { cação média ou alta }\end{array}$ \\
\hline \multicolumn{2}{|l|}{ Dimensão 3: Acesso ao Trabalho } \\
\hline \multirow[b]{2}{*}{ Disponibilidade de trabalho } & $\begin{array}{l}\text { T1. Mais da metade dos membros em idade ativa encontra- } \\
\text { se ocupada }\end{array}$ \\
\hline & $\begin{array}{l}\text { T2. Presença de pelo menos um trabalhador há mais de seis } \\
\text { meses no trabalho atual }\end{array}$ \\
\hline Qualidade do posto de trabalho & $\begin{array}{l}\text { T3. Presença de pelo menos um ocupado no setor formal } \\
\text { T4. Presença de pelo menos um ocupado em atividade não } \\
\text { agrícola }\end{array}$ \\
\hline \multirow{2}{*}{ Remuneração } & $\begin{array}{l}\text { T5. Presença de pelo menos um ocupado com rendimento } \\
\text { superior a } 1 \text { salário mínimo }\end{array}$ \\
\hline & $\begin{array}{l}\text { T6. Presença de pelo menos um ocupado com rendimento } \\
\text { superior a } 2 \text { salários mínimos }\end{array}$ \\
\hline \multicolumn{2}{|c|}{ Dimensão 4: disponibilidade de recursos } \\
\hline Extrema pobreza & $\begin{array}{l}\text { R1. Renda familiar per capita superior à linha da extrema po- } \\
\text { breza }\end{array}$ \\
\hline Pobreza & R2. Renda familiar per capita superior à linha de pobreza \\
\hline Capacidade de geração de renda & $\begin{array}{l}\text { R3. Maior parte da renda familiar não advém de transferên- } \\
\text { cias }\end{array}$ \\
\hline \multicolumn{2}{|c|}{ Dimensão 5: desenvolvimento Infantil } \\
\hline \multirow{3}{*}{ Trabalho precoce } & D1. Ausência de criança com menos de 14 anos trabalhando \\
\hline & D2. Ausência de criança com menos de 16 anos trabalhando \\
\hline & D3. Ausência de criança até 6 anos fora da escola \\
\hline \multirow[t]{3}{*}{ Acesso à escola } & D4. Ausência de criança de 7-14 anos fora da escola \\
\hline & D5. Ausência de criança de 7-17 fora da escola \\
\hline & $\begin{array}{l}\text { D6. Ausência de criança de até } 14 \text { anos com mais de } 2 \text { anos } \\
\text { de atraso }\end{array}$ \\
\hline \multirow[t]{2}{*}{ Progresso escolar } & D7. Ausência de adolescente de 10 a 14 anos analfabeto \\
\hline & D8. Ausência de jovem de 15 a 17 anos analfabeto \\
\hline \multicolumn{2}{|c|}{ Dimensão 6: condições habitacionais } \\
\hline \multirow{2}{*}{ Propriedade } & H1. Domicílio próprio \\
\hline & H2. Domić́lio próprio ou cedido \\
\hline Déficit habitacional & H3. Densidade de até dois moradores por dormitório \\
\hline
\end{tabular}




\begin{tabular}{|ll|} 
Abrigabilidade & H4. Material de construção permanente \\
Acesso a abastecimento de água & H5. Acesso adequado à água \\
Acesso à energia elétrica & H6. Acesso à eletricidade \\
& H7. Esgotamento sanitário adequado \\
& H8. Presença de banheiro no domicílio ou na propriedade \\
Acesso a saneamento & H9. Uso do banheiro ou sanitário é destinado exclusivamen- \\
& te ao domicílio \\
Acesso à coleta de lixo & H10. Lixo é coletado \\
\hline Dimensão 7: consumo de bens duráveis & C1. O domicílio possui fogão \\
\hline Acesso a fogão & C2. O domićlio possui geladeira \\
Acesso à geladeira & Fonte: Elaboração própria com base nos dados da PNAD (2003,2012).
\end{tabular}




\section{REVISTA BRASILEIRA DE POLÍTICAS PÚBLICAS BRAZILIAN JOURNAL OF PUBLIC POLICY}
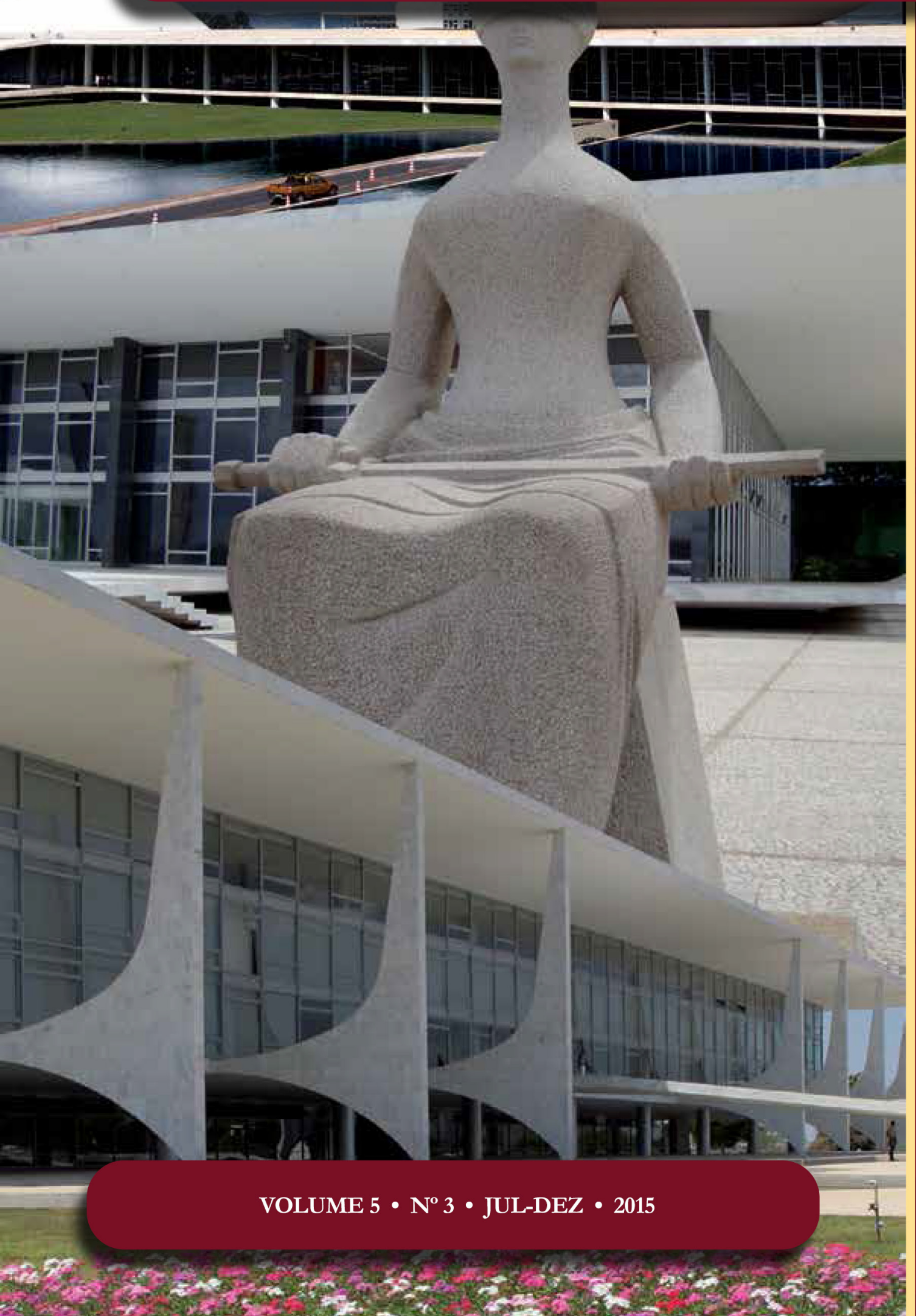

Efeitos colaterais da mineração no meio ambiente

Side effects of mining on the environment 


\section{Efeitos colaterais da mineração no meio ambiente*}

\section{Side effects of mining on the environment}

Márcio Oliveira Portella**

\section{Resumo}

O desenvolvimento do tema proposto tem por objetivo propiciar uma visão panorâmica e didática acerca dos danos causados pela atividade mineradora ao meio ambiente. Inicialmente, o trabalho irá traçar aspectos doutrinários no que diz respeito aos impactos socioambientais dos empreendimentos minerários sobre a sociedade, criando dependência dos recursos gerados e despreparo por parte dos agentes públicos no que concerne a falta de planejamento para a continuidade do desenvolvimento econômico futuro após o encerramento das atividades extrativistas. No segundo momento, o trabalho irá expor e individualizar os danos e os impactos advindos da mineração no meio ambiente, por meio de conceituação legal, estudos elaborados e inerentes a respeito do tema, bem como ações de prevenção e minimização dos danos. Finalmente, será analisada a Compensação Financeira pela Exploração Mineral (CFEM), mecanismo legal criado para buscar amenizar os problemas gerados aos municípios pela atividade de extração ou exploração dos recursos minerais.

Palavras-chave: Mineração. Meio ambiente. Danos. Impactos socioambientais. Compensação financeira pela exploração mineral.

\section{Abstract}

The development of the proposed theme aims to provide an overview and didactic view about the damage caused by mining activities on the environment. Initially, the work will draw doctrinal aspects with regard to social and environmental impacts of mining projects on society, creating a dependence on resources generated and unpreparedness on the part of public officials regarding the lack of planning for continued future economic development after the close of extractive activities. In the second phase, the work will expose and individualize the damage and arising from mining impacts on the environment through legal concepts, elaborate studies and inherent on the subject as well as prevention and minimization of damage. Finally, it will analyze the Financial Compensation for Mineral Exploration (CFEM), legal mechanism created to seek alleviate the problems caused to municipalities for the extraction activity or exploitation of mineral resources.

Keywords: Mining. Environment. Damage. Social and environmental impacts. Financial compensation for mineral exploration. 


\section{INTRODUÇÃo}

A exploração dos recursos minerais corre numa velocidade bastante acentuada e está comprometendo o futuro da sociedade como um todo. Inegavelmente, a atividade minerária traz benefícios financeiros e desenvolvimento para as regiões onde as jazidas se encontram, porém o bônus vem acompanhado de um ônus que reflete e se materializa com o decorrer dos anos.

A extração dos minérios desencadeia grande volume de problemas socioeconômicos futuros, acompanhados de danos que agridem diretamente a natureza e a qualidade de vida das pessoas. Pelas análises de vários autores, fica demonstrado que se não houver planejamento adequado por parte dos agentes públicos, quanto ao desenvolvimento sustentável das regiões minerarias após o término das atividades de extração, ensejará no declínio financeiro da população em torno da região e enorme passivo ambiental.

Essas ações futuras têm de ser pensadas e idealizadas antes do início do empreendimento extrativista, tendo espaço de tempo suficiente para a sua implementação e adequação. A busca pela qualidade de vida das pessoas e a prevenção quanto aos danos ambientais, não pode ser instalada depois dos problemas acontecerem.

A responsabilidade do gestor público no processo de construção de um desenvolvimento sustentável nas regiões extrativistas torna-se imperioso para tentar solucionar ou equacionar as questões relativas aos impactos ambientais, sociais, econômicos e culturais para esta e para as gerações futuras. A conscientização desses problemas futuros levará ao progresso de maneira sustentável, bem como à diminuição das agressões causadas pela mineração ao meio ambiente.

\section{IMPACTOS SOCIOAMBIENTAIS DA MINERAÇÃO}

Não há discordância no sentido de que a mineração constitui atividade predatória ao meio ambiente. Apesar de trazer inicialmente benefícios econômicos nos países ou nas regiões extrativistas, existem inúmeros estudos que demonstram que a abundância de recursos minerais prejudica o desenvolvimento futuro desses lugares depois do término das atividades de extração pelas empresas mineradoras, além de danos irreversíveis ao meio ambiente.

O desempenho socioeconômico das economias mineradoras demonstra-se aquém se comparado ao das economias não mineradoras, comprovando que as primeiras têm muito mais custos do que benefícios. Nesse enfoque inicial, Maria Amélia Enríquez, introdutoriamente, em sua obra, aduz que:

A mineração é uma das mais antigas atividades produtivas exercidas pela humanidade. Não é casual que a história da civilização adote as suas diferentes modalidades como marcos divisórios de suas eras: idade da pedra lascada (paleolítico), idade da pedra polida (neolítico) e idade dos metais (cobre, bronze e ferro). Consciente ou inconscientemente, o consumo de bens minerais está presente em quase todos os setores da vida moderna: de insumos para agricultura até os sofisticados materiais para indústria eletroeletrônica; de bens de consumo aos grandes equipamentos industriais; da produção de medicamentos e cosméticos até a indústria aeroespacial, entre tantos outros usos. Não obstante a sua importância histórica e atual, há muita polêmica quanto ao efetivo papel da mineração para o desenvolvimento dos espaços territoriais onde ela ocorre ${ }^{1}$.

Segundo o entendimento de Lewis $\mathrm{Jr}^{2}$, no âmbito econômico, os países ricos em recursos minerais não

1 ENRÍQUEZ, Maria Amélia. Mineração: maldição ou dádiva? Os dilemas do desenvolvimento sustentável a partir de uma base mineira. São Paulo: Signus, 2008. p. 25.

2 LEWIS JUNIOR, Stephen. Development problems of the mineral-rich countries. In: SYRQUIN, Moshe; TAYLOR, Lance; WESTPHAL, Larry E. (Eds). Economic structure and performance: essays ind the honor of Hollis B. Chenery. Orlando: Academic Press, 1984. 
têm 'vantagens', mas sim 'problemas' para alcançar o desenvolvimento econômico, pois a pujança da mineração acaba dificultando o desempenho de outras atividades. As dificuldades provêm de várias características intrínsecas à atividade mineradora.

Frequentemente, os indicadores de economias de base mineira revelam má distribuição da renda, pouca diversificação econômica, ganhos das exportações concentrados apenas nos produtos primários, além de taxas de crescimento de seus setores econômicos não mineiros inferiores aos das outras economias não mineradoras, entre outros. Além disso, a mineração gera mercado de trabalho monopsônico, ou seja, uma única grande companhia constitui a principal responsável direta e indireta (por intermédio de suas empresas contratadas) pela absorção de uma força de trabalho pulverizada e exerce um papel importante, porém servil, de captador de divisas para financiar o desenvolvimento industrial em outras regiões do mesmo país.

Lewis Jr. ${ }^{3}$ chama de 'maldição dos recursos' esse conjunto de efeitos negativos típicos das economias de base mineradora. As causas dessa 'maldição' estariam relacionadas às características específicas do setor mineral, tais como: existência de renda diferencial proveniente da qualidade das jazidas; baixa participação dos salários no valor adicionado; grande parte das rendas mineiras destina-se às empresas multinacionais ou ao governo, o que gera problemas de intermediação financeira e de alocação de poupança; a instabilidade da receita mineral, devida às flutuações do mercado internacional (volátil por natureza), o que faz com que muitas vezes as companhias mineradoras trabalhem no vermelho, por causa da inelasticidade da produção em curto prazo.

Também, nesse raciocínio, Graham Davis aponta os seguintes fatores que contribuem para que a mineração seja encarada como "atividade maldita", que são:

a) fortes variações dos preços dos produtos minerais, provocada pela instabilidade da demanda, o que gera também instabilidade no fluxo de receitas públicas;

b) natureza "colonial" da mineração, devido ao controle do mercado mineral por multinacionais;

c) mercado de trabalho monopsônico (uma única companhia);

d) antigas regiões produtoras acabaram degenerando para uma situação de ultra subdesenvolvimento, devido à exaustão das minas ${ }^{4}$.

Conforme Shafer ${ }^{5}$, conhecer esses aspectos, dentre outros, é importante porque eles revelam as diferentes estruturas e competências do Estado e sua consequente capacidade de promover a necessária reestruturação em sua base produtiva, para não ficar dependente exclusivamente da atividade mineral. Portanto, a possibilidade de empreender a reestruturação econômica é uma condição fundamental para os setorialistas ${ }^{6}$.

Reestruturação significa um esforço deliberado do Estado para realocar recursos e reorientar a atividade econômica por intermédio das mudanças na composição setorial da economia, com o objetivo de reduzir a vulnerabilidade do país aos riscos associados ao principal setor exportador, ou ampliar a assegurar oportunidades presentes em outros setores, ou ambos? ${ }^{7}$.

Quanto ao setor mineral, o autor sugere que até mesmo os governos mais responsáveis e perspicazes de economias mineiras já partem em desvantagem na "corrida" rumo ao desenvolvimento. Isso acontece porque o setor mineral e os seus componentes moldam a capacidade institucional do Estado para monitorar,

3 LEWIS JUNIOR, Stephen. Development problems of the mineral-rich countries. In: SYRQUIN, Moshe; TAYLOR, Lance; WESTPHAL, Larry E. (Eds.). Economic structure and performance: essays ind the honor of Hollis B. Chenery. Orlando: Academic Press, 1984.

4 DAVIS, Graham A. The mineral sector, sectoral analysis, and economic development. Resources Policy, v. 24, n. 4, p. 217-228, Dec. 1998. p. 217-228.

5 SHAFER, David Michael. Winners and Losers: how sectors shape the developmental prospects of states. Ithaca: Cornell University Press, 1994.

6 Vertente de estudiosos que têm na análise dos setores produtivos o seu principal objeto de investigação.

7 SHAFER, David Michael. Winners and Losers: how sectors shape the developmental prospects of states. Ithaca: Cornell University Press, 1994. p. 11. 
regular e dirigir a atividade econômica, de tal forma que incapacitam os líderes de formular e implementar políticas adequadas para a reestruturação necessária.

A mineração é considerada por Shafer ${ }^{8}$ em setor inflexível, porque requer infraestrutura própria (estradas, portos, energia, eletrificação etc.) e investimentos especializados em capital físico e em capital humano, que, posteriormente, não podem ser diretamente empregados em outras atividades produtivas. Shafer ${ }^{9}$ afirma que inflexibilidade para reestruturar a economia mineral, inserida em uma economia global e volátil, conduz à incapacidade governamental para responder rapidamente às crises de mercado que ocorrem por causa da flutuação dos preços das commodities minerais.

Isso faz com que, frequentemente, o Estado tenha que prestar socorro às companhias mineradoras, por causa da inaptidão do setor mineral para administrar esses riscos. Portanto, considerando-se que a natureza da atividade mineraria não é infinita e sim exaurível, ficam demonstrados pelas análises abordadas que os impactos sociais nas economias minerárias são significativos se não houver por parte do Estado políticas para a continuidade do desenvolvimento econômico futuro nos países ou regiões onde a atividade extrativista se extinguir.

\section{Danos causados pela mineração no meio ambiente}

A mineração causa impactos devastadores ao meio ambiente e são de difícil reparação. Como as mineradoras ficam geralmente distantes dos grandes centros urbanos, poucas pessoas testemunham ou se dão conta da grandiosidade dos seus efeitos maléficos, apesar dos benefícios econômicos trazidos inicialmente nas regiões onde estão instaladas. Os minérios, tanto metálicos como não metálicos, são utilizados em uma infinidade de produtos humanos, da construção civil a bens industriais. Contudo, o certo é que, se a humanidade quer manter um nível elevado de conforto material, é inevitável a atividade mineral.

Importantes informações sobre a mineração são trazidas por Penna ${ }^{10}$, relatando que a produção mundial de ouro, em 2000, foi de 2,5 mil toneladas (Worldwatch Institute), mas os resíduos gerados (estéreis ${ }^{11}$ e rejei$\left.\operatorname{tos}^{12}\right)$ não foram inferiores a 745 milhões de toneladas. Uma razão de quase 300 mil quilos de resíduos para um quilo de ouro, significando que $99,99967 \%$ da mineração de ouro eram puro descarte, obrigatoriamente, disposto em algum lugar. É verdade que, com o avanço tecnológico, já é possível, atualmente, o processamento de minério com teores de ouro ainda mais baixos.

O minério de ferro é um dos que apresenta maior rendimento, tem o metal em menos da metade da sua massa. Embora 40\% tenham sido aproveitados como matéria-prima, 2 (dois) bilhões e 113 milhões de toneladas foram descartados apenas no ano de 2000 (Worldwatch Institute). Outros metais, como alumínio, chumbo ou prata, oferecem igualmente pequenos percentuais de aproveitamento no minério.

Segundo Penna ${ }^{13}$, em 1999, cerca de 9,6 bilhões de toneladas de minerais foram retirados da terra, quase o dobro do total explorado em 1970. Na superfície ou no subsolo, a mineração modifica intensamente a

8 SHAFER, David Michael. Winners and Losers: how sectors shape the developmental prospects of states. Ithaca: Cornell University Press, 1994.

9 SHAFER, David Michael. Winners and Losers: how sectors shape the developmental prospects of states. Ithaca: Cornell University Press, 1994.

10 PENNA, Carlos Gabaglia. Efeitos da mineração no meio ambiente, 2009. Disponível em:

< http://www.oeco.org.br/carlos-gabaglia-penna/20837-efeitos-da-mineracao-no-meio-ambiente>. Acesso em: 06 maio 2015.

11 Termo usado em geologia econômica para as substâncias minerais que não têm aproveitamento econômico.

12 Rochas ou minerais inaproveitáveis presentes no minério e que são separadas deste, total ou

parcialmente, durante o beneficiamento.

13 PENNA, Carlos Gabaglia. Efeitos da mineração no meio ambiente, 2009. Disponível em:

<http://www.oeco.org.br/carlos-gabaglia-penna/20837-efeitos-da-mineracao-no-meio-ambiente>. Acesso em: 06 maio 2015. 
paisagem tanto na extração como na deposição de seus estéreis e rejeitos. Estéreis, entenda-se, no sentido de inócuos, porém é o que esses resíduos não são para o meio ambiente.

A mineração constitui a atividade econômica com menos cuidados no que concerne aos problemas ambientais. Ainda, conforme Penna ${ }^{14}$, a distância dos centros urbanos e de pessoas conscientes favorece tal desleixo, embora algumas mineradoras tenham progredido nesse sentido.

Essa atividade consome volumes extraordinários de água: na pesquisa mineral (sondas rotativas e amostragens), na lavra (desmonte hidráulico, bombeamento de água de minas subterrâneas etc.), no beneficiamento (britagem, moagem, flotação, lixiviação etc.), no transporte por mineroduto e na infraestrutura (pessoal, laboratórios, etc.). Existem casos em que é necessário o rebaixamento do lençol freático para o desenvolvimento da lavra, prejudicando outros possíveis consumidores.

Nesse aspecto, uma série de impactos pode ocorrer: aumento da turbidez e consequente variação na qualidade da água e na penetração da luz solar no interior do corpo hídrico; alteração do pH da água, tornando-a, geralmente, mais ácida; derrame de óleos, graxas e metais pesados (altamente tóxicos, com sérios danos aos seres vivos do meio receptor); redução do oxigênio dissolvido dos ecossistemas aquáticos; assoreamento de rios; poluição do ar, principalmente por material particulado; perdas de grandes áreas de ecossistemas nativos ou de uso humano etc.

Nos Estados Unidos (EUA), a mineração é a atividade econômica líder de poluição tóxica, responsável por quase metade da poluição industrial relatada no país ${ }^{15}$. No Brasil, a participação da mineração na poluição total é possivelmente maior, em função da posição relativa dessa atividade na produção econômica nacional e de uma fiscalização mais frouxa. Basta ver o intenso grau de degradação ambiental causado por minas de ferro, como na cidade de Itabirito, em Minas Gerais. A gipsita, mineral abundante na natureza, quando parcialmente desidratada (calcinada), dá origem ao gesso, um produto muito usado na construção civil, entre outras aplicações. No Brasil, é explorada principalmente na Bacia do Rio Araripe, na fronteira comum de Pernambuco com Piauí e o Ceará. Nessa região, a fonte energética usada no processo de calcinação é a lenha da Caatinga. As calcinadoras de gesso são as principais consumidoras de energéticos florestais da região do Araripe ${ }^{16}$.

Por esse prisma, Beatriz Souza Costa e Celso Antônio Pacheco Fiorillo ${ }^{17}$ ressaltam que "O Princípio da Dignidade Humana sem um ambiente ecologicamente equilibrado não é possível, assim como proteger esse meio ambiente é fundamental." Portanto, é necessário que, antecipadamente, haja formas de prevenção aos impactos provenientes da atividade mineradora, procurando minimizar os efeitos negativos para a população e para o meio ambiente em sua volta, posto que trata-se de atividade econômica pouco atenta aos danos gerados por suas ações.

\subsection{Impactos Locais da Mineração}

O impacto ambiental em locais de mineração é facilmente observado com o decurso do tempo, tanto que na Resolução CONAMA Nº 001/1986, em seu artigo 1º, expõe-se a seguinte definição:

Art. $1^{\circ}$ - Para efeito desta Resolução considera-se impacto ambiental qualquer alteração das propriedades físicas, químicas e biológicas do meio ambiente, causada por qualquer forma de matéria ou energia resultante das atividades humanas que, direta ou indiretamente, afetam: I - a saúde, a segurança e o bemestar da população; II - as atividades sociais e econômicas; III - a biota (a flora e a fauna de uma região);

14 PENNA, Carlos Gabaglia. Efeitos da mineração no meio ambiente, 2009. Disponível em:

< http://www.oeco.org.br/carlos-gabaglia-penna/20837-efeitos-da-mineracao-no-meio-ambiente>. Acesso em: 06 maio 2015.

15 COSTA, Beatriz Souza; FIORILLO, Celso Antônio Pacheco. Tutela jurídica dos recursos ambientais minerais vinculada ao conceito democrático de segurança nacional. Revista Veredas do Direito, Belo Horizonte, v. 9, n. 18, p. 9-35, jul./dez. 2012 . p. 32.

16 COSTA, Beatriz Souza; FIORILLO, Celso Antônio Pacheco. Tutela jurídica dos recursos ambientais minerais vinculada ao conceito democrático de segurança nacional. Revista Veredas do Direito, Belo Horizonte, v. 9, n. 18, p. 9-35, jul./dez. 2012 . p. 32.

17 COSTA, Beatriz Souza; FIORILLO, Celso Antônio Pacheco. Tutela jurídica dos recursos ambientais minerais vinculada ao conceito democrático de segurança nacional. Revista Veredas do Direito, Belo Horizonte, v. 9, n. 18, p. 9-35, jul./dez. 2012 . p. 32. 
IV - as condições estéticas e sanitárias do meio ambiente; $\mathrm{V}$ - a qualidade dos recursos ambientais ${ }^{18}$.

Estas alterações no ambiente urbano são notadas, conforme Assis, Barbosa e Mota ${ }^{19}$, pelas mudanças das paisagens naturais para as paisagens modificadas por meio da atividade antrópica, ou seja, ocorrem em relação às atividades desenvolvidas pelo homem no local ou município.

O desenvolvimento desse processo $3 / 4$ mineração $3 / 4$ vem causando enormes malefícios à população do local como: conflito do uso do solo, quando, muitas vezes, resíduos e rejeitos de minerais são depositados ou abandonados em locais impróprios, o que muitas vezes serviria para agricultura; depredação de imóvel pela proximidade das minas; geração de áreas degradadas e também transtornos do tráfego urbano, que alteraria toda a rotina do local ou cidade pelo aumento do tráfego de transportes de grande porte, como treminhão e carretas.

Outros impactos são constatados no município além das enormes perfurações no solo, são as detonações por explosivos que vem comprometendo o sossego da população local, os estrondos provocados são alarmantes e os abalos que eles vêm causando nas residências são inevitáveis pela proximidade das minas. A não prevenção desses problemas, uma vez que podem também comprometer a qualidade do ar que é influenciada pela produção de pó no manejo dos minerais causando danos a flora, ao solo e aos recursos hídricos ${ }^{20}$.

Ademais, de acordo com Assis, Barbosa e Mota, evidenciam-se, portanto, os seguintes impactos negativos da atividade mineradora local:

a) impactos visuais;

b) perda de banco de sementes;

c) perda de vegetação da biota local;

d) comprometimento das áreas de recarga de aquíferos;

e) disposição inadequada dos rejeitos em áreas de bota-fora;

f) poluição do solo;

g) poluição sonora;

h) degradação do entorno;

i) compactação do solo;

j) estradas mal planejadas;

k) poluição atmosférica;

l) assoreamento de corpos hídricos;

m) obstrução do leito suplementar dos córregos e calhas de drenagem;

n) vulnerabilidade da área ao surgimento de "desertos de pedra" ${ }^{21}$.

18 BRASIL. Conselho Nacional do Meio Ambiente - CONAMA. Resolução n 001, de 23 de janeiro de 1986. Disponível em: <http:// www.mma.gov.br/port/conama/res/res86/res0186.html>. Acesso em: 13 maio 2015.

19 ASSIS, Heline Fernanda Silva de; BARBOSA, José Aécio Alves; MOTA, Tércio de Sousa. Avaliação dos impactos ambientais provocados pela atividade mineradora no município de Pedra Lavrada-PB. Revista Ámbito Jurídico, Rio Grande, v. 14, n. 90 , jul. 2011. Disponível em: <http://www.ambitojuridico.com.br/site/?n_link=revista_artigos_leitura\&artigo_id=9925\&revista_caderno=5>. Acesso em: 6 maio 2015.

20 ASSIS, Heline Fernanda Silva de; BARBOSA, José Aécio Alves; MOTA, Tércio de Sousa. Avaliação dos impactos ambientais provocados pela atividade mineradora no município de Pedra Lavrada-PB. Revista Ámbito Jurídico, Rio Grande, v. 14, n. 90, jul. 2011. Disponível em: <http://www.ambitojuridico.com.br/site/?n_link=revista_artigos_leitura\&artigo_id=9925\&revista_caderno=5>. Acesso em: 6 maio 2015.

21 ASSIS, Heline Fernanda Silva de; BARBOSA, José Aécio Alves; MOTA, Tércio de Sousa. Avaliação dos impactos ambientais provocados pela atividade mineradora no município de Pedra Lavrada-PB. Revista Ámbito Jurídico, Rio Grande, v. 14, n. 90, jul. 2011. Disponível em: <http://www.ambitojuridico.com.br/site/?n_link=revista_artigos_leitura\&artigo_id=9925\&revista_caderno=5>. Acesso em: 6 maio 2015. 


\subsection{Análise, prevenção e minimização dos impactos negativos}

Para melhor compreensão de alguns dos significativos dos impactos da atividade minerária no meio ambiente, faz-se necessário que sejam analisados, individualmente, bem como apontados os aspectos de prevenção e minimização. Os impactos que merecem abordagem mais específica são da degradação da paisagem, ruídos e vibrações, poeira, disposição de rejeito e estéril, poluição das águas e tráfego de veículos²2.

Degradação da paisagem - o principal e mais característico impacto causado pela atividade minerária é o que se refere à degradação visual da paisagem. Os efeitos da degradação ambiental constituem: focos de erosão, escorregamento de massas de solo/rochas; assoreamento de vales e cursos d'água; poluição visual e poluição sonora.

Existem duas diretrizes básicas que podem ser aplicadas na luta contra os efeitos nocivos causados pela mineração: prevenção e minimização dos impactos, bem como restauração e eliminação dos danos. A tendência atual consiste em atribuir à prevenção o caráter primordial e às atividades de recuperação o caráter complementar.

A recuperação reveste-se de importância para a reconstituição do ambiente primitivo, o que demanda inventário completo dos sistemas ecológicos existentes antes da instalação da mineração, o que tem sido exigido em muitos países, para atividades de mineração em locais de equilíbrio ecológico específico.

A erosão, por exemplo, é um processo de desgaste das rochas ou do solo que se manifesta em virtude de vários fatores como topografia, vegetação, tipo de rocha, clima ou pela intervenção humana (atividade antrópica). A extração mineral adotada a céu aberto, para praticamente todos os minérios provoca, no seu desenvolvimento, a remoção da cobertura vegetal e cortes na topografia, realizados em geral sem nenhuma técnica, deixando as áreas já mineradas muitas vezes ao abandono, sem vegetação e expostas aos efeitos climáticos.

Os terrenos nessas condições, sob intensa precipitação pluviométrica, são submetidos a processos que, uma vez iniciados, se repetem ciclicamente. Os efeitos da erosão podem ser controlados pela execução de cortes com taludes (superfície inclinada de escavação) adequados na topografia, reaterro das áreas já mineradas, feito com o próprio material estéril removido à medida que a extração avança, e implantação de cobertura vegetal nas áreas já aterradas.

A atividade mineral a céu aberto ocasiona também na sua totalidade a remoção do material estéril que recobre ou envolve o minério, sendo acumulado, via de regra, sem nenhuma técnica, ao lado ou nas vizinhanças da mina. Quando esses depósitos ficam muito volumosos, tornam-se, por si mesmos, instáveis e sujeitos a escorregamentos localizados. No período de chuvas, são removidos e transportados continuamente até as regiões mais baixas e, em muitos casos, para cursos de água. A repetição contínua do processo provoca o transporte considerável desse material, ocasionando, gradativamente, o assoreamento dos cursos d' água.

Além do volume provindo do material estéril, devem ser consideradas as quantidades advindas da área das próprias jazidas e o material produzido pela decomposição das rochas e erosão do solo. No caso da extração de areia e caulim, o problema do assoreamento chega a ser significativo. O problema pode ser minimizado por meio do adequado armazenamento do material estéril e sua posterior utilização para reaterro de áreas já mineradas e de tanques de decantação que retenham os sedimentos finos na própria área, preservando a hidrografia.

A poluição visual constitui o primeiro efeito visível da mineração ao meio ambiente. Grandes crateras e lagos, paredões e áreas devastadas são produtos da mineração em numerosos casos, impedindo a posterior utilização. Nas grandes jazidas, a reconstituição da paisagem, conforme ocorria anteriormente ao processo

22 AGÊNCIA AMBIENTAL PICK-UPAU. As consequências da mineração no meio ambiente. São Paulo, 2003. Disponível em: <http:// www.pick-upau.org.br/mundo/mineracao_meio_ambiente/mineracao.htm>. Acesso em: 06 maio 2015. 
da extração, é difícil. Porém, por meio de condução adequada das operações de lavra e de um projeto de recuperação que leve em conta o destino a ser dado à área futuramente, a degradação ambiental pode ser reduzida e até eliminada.

Ruídos e vibrações - nas pedreiras, o desmonte de material consolidado é feito por meio de explosivos, resultando, por consequência, ruídos quase sempre prejudiciais à tranquilidade pública. Não obstante o desejo de locar-se tais empreendimentos em regiões mais afastadas dos centros urbanos, existem locais onde esse objetivo não pôde ser atingido e certas jazidas ou pedreiras que foram gradualmente envolvidas pela urbanização.

Nesses casos, o deslocamento de ar causado pelas detonações, bem como a intensidade da onda de choque, que se propaga por toda a massa rochosa, pode colocar em risco as construções situadas nas vizinhanças. Para minimizar esses impactos podem ser adotadas certas medidas, tais como: orientação da frente da lavra e o controle da detonação.

Os aspectos relativos à altura das bancadas e ao planejamento de desmonte e de fogo são de grande importância no que se referem à segurança, custos e danos, merecendo, pois, estudos específicos. A onda de choque gerada por explosivos apresenta comportamentos distintos, de acordo com a distância e o tipo de material. Um método para suavizar os impactos causados pela detonação consiste em provocar descontinuidade física no maciço rochoso.

Fazendo-se uma série de furos subverticais e paralelos a um mesmo plano e detonando-os com pequena quantidade de explosivos de força elevada, pode-se criar uma falha artificial que limita a propagação das ondas de choque. Esse método apresenta-se muito eficaz quando existem habitações, monumentos históricos ou grandes obras de engenharia nas proximidades das pedreiras.

Para evitar ruídos decorrentes dos equipamentos de beneficiamento, deve-se aproveitar ao máximo os obstáculos naturais ou então criar barreiras artificiais, colocando o estoque de material beneficiado ou a ser tratado entre as instalações e as zonas a proteger. Os trabalhos, tanto nas frentes de lavra com nas etapas de beneficiamento, devem ter periodicidade e horários rígidos, devendo as comunidades vizinhas serem, devida e previamente, avisadas sobre quaisquer eventuais mudanças.

Poeira - um dos maiores transtornos sofridos pelos habitantes próximos às minerações relaciona-se com a poeira. Esta pode ter origem tanto nos trabalhos de perfuração da rocha como nas etapas de beneficiamento e do transporte da produção. Essa poeira apresenta uma fração muito fina, que permanece, durante muitas horas, em suspensão no ar, espalhando-se por extensas áreas.

O pó oriundo da perfuração da rocha é de pequena monta, não sendo, pois, computado como poluente em grande escala. Entretanto, esse pó é nocivo aos trabalhadores que operam nas frentes. As perfuratrizes devem ser equipadas com dispositivos adequados de controle de pó, seja sistema de injeção de água, seja por sistema de aspiração.

As instalações de beneficiamento (britagem, peneiramento, moagem e ensacamento), por sua vez, produzem quantidades muito grandes de poeira e de finos. O despoeiramento das instalações de pedreiras pode ser feito de diversas maneiras, de acordo com cada caso, mas, de um modo geral, existem as seguintes possibilidades: eliminação do pó através de nebulização ${ }^{23}$ de água e despoeiramento através da renovação do ar.

Poluição das águas - a atividade mineradora provoca poluição por lama e por metais pesados que geralmente são descartados no fundo de rios, lagos e mares, onde permanecem inalterados por muitos anos. Dentre os mais nocivos, estão o chumbo, mercúrio, cádmio, cromo e níquel. Se ingeridos, podem causar diversas disfunções pulmonares, cardíacas, renais e do sistema nervoso central, entre outras. Um mais tóxico é o mercúrio, comumente descartado por garimpeiros após ser empregado na separação do ouro.

23 Gotículas provenientes da condensação do vapor de água, e que flutuam na atmosfera sob as formas de nevoeiro e de nuvem. 
Em sua obra "Direito das águas" Maria Luiza M. Granziera ${ }^{24}$ afirma que "a atividade de mineração equipara-se à indústria no que se refere ao uso dos recursos hídricos." Ademais, a autora chama a atenção para a Lei $\mathrm{n}^{\circ}$ 9.433/1997, que atualizou o tratamento conferido aos recursos hídricos no plano federal, para garantir a continuidade do uso da água para as presentes e futuras gerações, além de todas as outras normas que compõem o ordenamento jurídico pátrio, e que, direta ou indiretamente, repercutam no uso dos recursos hídricos.

Nesse sentido, o art. $1^{\circ}$ da Lei $n^{\circ} 9.433 / 1997$ declara o seguinte:

Art. $1^{\circ}$ - "A Política Nacional de Recursos Hídricos baseia-se nos seguintes fundamentos: I - a água é um bem de domínio público; II - a água é um recurso natural limitado, dotado de valor econômico; III - em situações de escassez, o uso prioritário dos recursos hídricos é o consumo humano e a dessedentação de animais; IV - a gestão dos recursos hídricos deve sempre proporcionar o uso múltiplo das águas; V - a bacia hidrográfica é a unidade territorial para implementação da Política Nacional de Recursos Hídricos e atuação do Sistema Nacional de Gerenciamento de Recursos Hídricos; VI - a gestão dos recursos hídricos deve ser descentralizada e contar com a participação do Poder Público, dos usuários e das comunidades ${ }^{25}$.

Por outro lado, Everton de Oliveira, em sua participação no X Congresso Brasileiro de Águas Subterrâneas, aduz, introdutoriamente, na sua abordagem quanto à atividade mineral, que:

Empreendimentos de exploração mineral, por alterarem a configuração natural dos terrenos, interferem na circulação hídrica ou são afetados pela presença das águas superficiais ou subterrâneas. A mineração pode alterar direta ou indiretamente um grande volume de água, tanto em relação a sua quantidade como qualidade. Pode influir, por exemplo, no escoamento superficial, fluxo subterrâneo, rebaixamento de níveis d'água subterrânea, na poluição de águas e outros. O aproveitamento dos grandes volumes de água produzidos, muitas vezes muito além do consumido pela própria atividade mineradora, é realizado em diversas minas, sendo utilizado para abastecimento público, irrigação, indústrias etc. No caso da poluição de águas subterrâneas, a área de hidrografia de contaminação tem tido destaque crescente e ocupado espaços do mercado de água subterrânea. Embora aparentemente a contaminação de aquíferos se mostre contra o uso da água subterrânea, sua descontaminação é possível e fortalece o mercado pela compreensão que o estudo do comportamento dos contaminantes trouxe à ciência da hidrografia como um todo. Para o adequado manejo da água da mina, é importante avaliar os aspectos de quantidade e qualidade. Principalmente para o aproveitamento da água útil nas diversas utilizações dos empreendimentos, as demandas devem ser quantificadas e cotejadas com as reais disponibilidades dos mananciais, evitando o racionamento ou paralisações na produção. Com o desenvolvimento do conhecimento na área da qualidade de água subterrânea, pode-se optar por atitudes proativas em relação a problemas de meio ambiente ${ }^{26}$.

Entretanto, em minerações subterrâneas, pode haver a necessidade de modificar o curso natural de um lençol freático para alcançar locais no subsolo onde se encontra o minério. Os rios que são desviados e que se alimentam do lençol podem sofrer redução no volume de água ou podem secar. O controle da poluição nos cursos d'água pode ser efetivado com drenagens convenientes. Ademais, segundo Oliveiraa ${ }^{27}$, a poluição de águas em mineração está muito ligada à produção de drenagem ácida pela disposição de rejeitos.

24 GRANZIERA, Maria Luiza Machado. Direito das águas: disciplina jurídica das águas doces. 3. ed. São Paulo: Atlas, 2006. p. 139-140.

25 BRASIL. Lei n. 9.433, de 8 de janeiro de 1997. Institui a Política Nacional de Recursos Hídricos, cria o Sistema Nacional de Gerenciamento de Recursos Hídricos, regulamenta o inciso XIX do art. 21 da Constituição Federal, e altera o $\operatorname{art.~}^{\circ}{ }^{\circ}$ da Lei no 8.001 , de 13 de março de 1990, que modificou a Lei no 7.990, de 28 de dezembro de 1989. Disponível em: <http://www.planalto.gov.br/ CCivil_03/Leis/L9433.htm>. Acesso em: 15 maio 2015.

26 OLIVEIRA, Everton de. Água subterrânea e mineração. In: CONGRESSO BRASILEIRO DE ÁGUAS SUBTERRÂNEAS, 5., 1998, São Paulo. Anais... São Paulo: ABAS, 1998. p. 1-5. Disponível em: < http://aguassubterraneas.abas.org/asubterraneas/ article/view/22326/14669>. Acesso em: 14 maio 2015.

27 OLIVEIRA, Everton de. Água subterrânea e mineração. In: CONGRESSO BRASILEIRO DE ÁGUAS SUBTERRÂNEAS, 5., 1998, São Paulo. Anais... São Paulo: ABAS, 1998. p. 1-5. Disponível em: < http://aguassubterraneas.abas.org/asubterraneas/ article/view/22326/14669>. Acesso em: 14 maio 2015. 
A fonte de contaminação deve ser eliminada ou atenuada de forma que ela cesse sua atividade de geração de contaminação para as águas subterrâneas. Sua remoção ou impermeabilização são formas comumente utilizadas. A impermeabilização, opção de menor custo, evita o contato do rejeito com a atmosfera, evitando assim sua oxidação e geração de drenagem ácida, que propicia ambiente de maior mobilidade para metais. Evita também que o material disposto seja lixiviado e levado para a água subterrânea.

Tráfego de veículos - o tráfego intenso de veículos pesados, carregados de minério, causa uma série de transtornos à comunidade, especialmente naquela situação mais próxima às áreas de mineração, como: poeira, emissão de ruídos, frequente deterioração do sistema viário da região. Embora alguns itens do problema sejam de fácil resolução, como no caso da poeira, a solução global é difícil e só poderá ser minimizada após o estabelecimento de áreas específicas à atividade de mineração.

Alguns cuidados especiais devem, entretanto, ser desde logo exigidos dos mineradores ou das empresas transportadoras, tais como: estudo minucioso de toras específicas para o tráfego pesado, controle rigoroso da velocidade dos caminhões, limpeza cuidadosa e manutenção constante destes e a instalação de amortecedores acústicos especiais.

Diante de tais impactos negativos provenientes da atividade minerária sobre o meio ambiente, constata-se que existem algumas ações preventivas ou pelo menos que propiciam minimizar seus efeitos nefastos. Entretanto, se não houver fiscalização adequada, vontade do Poder Público (municipal, estadual e federal) para implementá-las, bem como a conscientização de toda sociedade, os danos tendem a aumentar de maneira substancial e de difícil ou impossível reparação.

\section{Compensação financeira pela eXPloração mineral28 (CFEM)}

Após sua criação, pela Lei no 7.990/1989, a Compensação Financeira pela Exploração Mineral (CFEM), constitui ferramenta de enorme potencial para buscar amenizar os problemas gerados aos municípios pela atividade minerária, tendo como objetivo as melhorias para as áreas afetadas no que diz respeito à qualidade de vida, meio ambiente e distribuição de outros benefícios. No início da referida norma, em seu artigo $1^{\circ}$, aponta o seguinte:

Art. $1^{\circ} \mathrm{O}$ aproveitamento de recursos hídricos, para fins de geração de energia elétrica e dos recursos minerais, por quaisquer dos regimes previstos em lei, ensejará compensação financeira aos Estados, Distrito Federal e Municípios, a ser calculada, distribuída e aplicada na forma estabelecida nesta lei ${ }^{29}$.

A respeito desse mecanismo jurídico de compensação, introdutoriamente, Enríquez, afirma o seguinte:

A CFEM é um instrumento de grande potencial para contornar os problemas que os municípios mineradores enfrentam e, se bem aplicada, pode contribuir para a melhoria da equidade intergeração na distribuição dos benefícios da extração mineral. O Brasil, acompanhando a evolução internacional das questões ligadas ao meio ambiente, elaborou importantes marcos regulatórios ambientais, com amplos efeitos sobre o setor mineral. No entanto, para a dimensão socioeconômica não há o mesmo tratamento. [...] Considerando-se que é o bom uso da renda mineira a ponte para viabilizar a distribuição equitativa dos benefícios minerais entre as gerações, a CFEM assume um papel central. Não obstante representar apenas uma pequena porção da renda mineira, a CFEM tem a vantagem de beneficiar majoritariamente o município produtor e de não estar vinculada a gasto específico, o que permite ampla flexibilidade para o gestor público usá-la a partir de uma perspectiva de sustentabilidade. Convém ressaltar que, embora a legislação minerária brasileira tenha abrangência nacional, o uso dessas rendas varia muito entre as cidades mineradoras ${ }^{30}$.

28 Para Compensação Financeira pela Exploração Mineral, utiliza-se a sigla CFEM.

29 BRASIL. Lei n. 7.990, de 28 de dezembro de 1989. Institui, para os Estados, Distrito Federal e Municípios, compensação financeira pelo resultado da exploração de petróleo ou gás natural, de recursos hídricos para fins de geração de energia elétrica, de recursos minerais em seus respectivos territórios, plataformas continental, mar territorial ou zona econômica exclusiva, e dá outras providências (Art. 21, XIX da CF). Disponível em: <http://www.planalto.gov.br/CCivil_03/leis/L7990.htm>. Acesso em: 15 maio 2015.

30 ENRÍQUEZ, Maria Amélia. Mineração: maldição ou dádiva? Os dilemas do desenvolvimento sustentável a partir de uma base 
Assim, segundo a autora, a CFEM deve ser paga por todos aqueles que exercem a atividade de mineração em virtude da exploração ou extração de recursos minerais. De acordo com o Código Mineral, a exploração de recursos minerais consiste na retirada de substâncias minerais da jazida, mina, salina ou outro depósito mineral, para fins de aproveitamento produtivo.

Dessa forma, o fato gerador da CFEM é a saída do produto mineral, por venda, das áreas de incidência. O fato gerador pode também tomar as formas de utilização, de transformação industrial do produto mineral ou mesmo do seu consumo por parte do próprio minerador (Departamento Nacional da Produção Mineral $\left.^{31}-\mathrm{DNPM}\right)^{32}$.

\subsection{0 uso sustentável e responsável da CFEM}

Os recursos provenientes da CFEM chegam ao caixa dos municípios mineradores e são direcionados, no total ou parcialmente, para determinados fins já definidos antecipadamente. Entretanto, conforme Enríquez $^{33}$, sendo levados ao padrão da "armadilha do caixa único", os gestores públicos (municipais) ainda não foram capazes de perceber o potencial da CFEM enquanto recurso extra que, se utilizado produtivamente e responsavelmente, desenvolva oportunidades de geração de emprego e renda, atacando um dos mais sérios problemas que as municipalidades de base mineradora enfrentam e, dessa forma, reduza a pobreza e amplie a base de arrecadação. Os recursos da CFEM entram nos caixas únicos das prefeituras e são dissipados pelas necessidades imediatas e ilimitadas que todos os municípios apresentam tais como folha de pagamento dos funcionários, manutenção da máquina pública, obras etc.

O padrão "uso sustentado", por sua vez, não tem ocorrido de maneira espontânea, a partir de uma atitude consciente e voluntária do gestor público em prol da diversificação produtiva local. Faz enorme diferença entre gastar os recursos em despesas correntes e assistencialismo ou investir na diversificação produtiva e formação de capital humano. Um real $(\mathrm{R} \$ 1,00)$ empregado em novas alternativas para criação de emprego e renda tem a capacidade de se multiplicar. Por outro lado, um real empregado em despesas correntes simplesmente se consome na hora do gasto, ou seja, não tem a capacidade de se propagar pela economia. Ao contrário, por vezes ele cria novas obrigações que onerarão a receita futura. Essa é a grande distinção entre gastar a CFEM com consumo ou responsavelmente com investimento ${ }^{34}$.

Do lado do poder público dos municípios mineradores, existe generalizado e profundo desconhecimento dos princípios norteadores, dos fundamentos e do significado da CFEM. Os gestores municipais atentam bem mais para o montante recebido, sempre considerado insuficiente para custear as despesas crescentes. Por outro lado, em relação aos representantes da sociedade local, é ainda maior a ignorância sobre a mineração em geral, e da CFEM, em particular, pois não há debates que esclareçam a população sobre o significado da renda mineira e, especificadamente, da $\mathrm{CFEM}^{35}$.

Por falta de planejamento e relutância dos gestores públicos em compreender que o extrativismo mineral é uma atividade exaurível, não existe a preocupação em materializar iniciativas para o futuro incremento do desenvolvimento econômico nos municípios mineradores, justamente para livrarem-se da dependência econômica gerada pela arrecadação dos recursos advindos da CFEM. Tal dependência gera um ônus para a

mineira. São Paulo: Signus, 2008. p. 28-29.

31 Para Departamento Nacional da Produção Mineral, utiliza-se a sigla DNPM.

32 ENRÍQUEZ, Maria Amélia. Mineração: maldição ou dádiva? Os dilemas do desenvolvimento

sustentável a partir de uma base mineira. São Paulo: Signus, 2008. p. 338.

33 ENRÍQUEZ, Maria Amélia. Mineração: maldição ou dádiva? Os dilemas do desenvolvimento sustentável a partir de uma base mineira. São Paulo: Signus, 2008.

34 ENRÍQUEZ, Maria Amélia. Mineração: maldição ou dádiva? Os dilemas do desenvolvimento sustentável a partir de uma base mineira. São Paulo: Signus, 2008. p. 346-347.

35 ENRÍQUEZ, Maria Amélia. Mineração: maldição ou dádiva? Os dilemas do desenvolvimento sustentável a partir de uma base mineira. São Paulo: Signus, 2008. p. 349-350. 
sociedade, posto que as receitas extinguir-se-ão a partir do momento em que o empreendimento minerário cessar suas atividades na região. Restará enorme contingente de mão de obra desempregada e sem qualificação profissional, a não ser aquela exercida no extrativismo mineral, criando, assim, enormes problemas socioeconômicos.

\section{Considerações finais}

Os danos causados pela atividade mineradora sobre o meio ambiente e o passivo socioeconômico deixado para as gerações futuras são enormes. Pela exposição das análises doutrinárias e legais, bem como pelos estudos elaborados sobre tal atividade, conclui-se, primeiramente, que a mineração constitui, sem sombra de dúvida, atividade indispensável à sobrevivência do mundo moderno em virtude da importância dos bens oriundos dos minérios e de seu uso prático em todo cotidiano humano. Entretanto, também é pacífico que a mineração consiste numa atividade altamente predatória ao meio ambiente apesar das normas que versam sobre tal empreendimento. As regiões que são exploradas sofrem e não escapam de modificações irreversíveis.

Mesmo a extração mineral trazendo desenvolvimento econômico para as regiões onde se encontram as jazidas, os prejuízos são notados com o passar do tempo. Cria-se, inicialmente, nos municípios e nos gestores públicos em geral, uma dependência econômica quanto aos recursos advindos da Compensação Financeira pela Exploração Mineral (CFEM), típico das regiões de base mineradora, causando pouca diversificação econômica além de gerar mercado de trabalho monopsônico, ou seja, uma única companhia é responsável direta ou indiretamente pela absorção de força de trabalho dependente e sem qualificação profissional para ser absorvida em outras atividades laborais depois que o empreendimento cessar as atividades de extração.

Além disso, a atividade minerária causa prejuízos devastadores ao meio ambiente e são de difícil reparação, tais como impactos visuais, perdas de grandes áreas de ecossistemas nativos ou de uso humano, poluição das águas e assoreamento de corpos hídricos, poluição do solo, surgimento dos chamados "desertos de pedra”, disposição inadequada de rejeitos, poluição sonora, dentre outros analisados neste estudo.

Urge a necessidade imperiosa do planejamento adequado por parte dos gestores públicos antes da implementação de qualquer atividade minerária no município, objetivando o desenvolvimento sustentável e no que tange ao fomento e à implementação de políticas que visem à diversificação da economia na região e ao reaproveitamento da mão de obra alijada de qualificação adequada para exercer outras profissões depois da extinção do extrativismo na região, evitando-se, assim, a decadência da sociedade local. Ademais, a importância de iniciativas sérias e fiscalização constante, colocadas em prática, que busquem a minimização dos impactos ambientais nas áreas degradadas para as gerações futuras.

\section{REFERÊNCIAS}

AGÊNCIA AMBIENTAL PICK-UPAU. As consequências da mineração no meio ambiente, 2003. Disponível em: $<$ http://www.pick-upau.org.br/mundo/mineracao_meio_ambiente/mineracao.htm>. Acesso em: 06 maio 2015.

AMBIENTE BRASIL. Poluição da Água. Disponível em: < http://ambientes.ambientebrasil.com.br/agua/ artigos_agua_doce/poluicao_da_agua.html>. Acesso em: 14 maio 2015.

ASSIS, Heline Fernanda Silva de; BARBOSA, José Aécio Alves; MOTA, Tércio de Sousa. Avaliação dos impactos ambientais provocados pela atividade mineradora no município de Pedra Lavrada-PB. Revista Âmbito 
Jurídico, Rio Grande, v. 14, n. 90, jul. 2011. Disponível em: <http://www.ambitojuridico.com.br/site/?n_ link=revista_artig os_leitura\&artigo_id=9925\&revista_caderno=5>. Acesso em: 6 maio 2015.

BRASIL. Lei n. 9.433, de 8 de janeiro de 1997. Institui a Política Nacional de Recursos Hídricos, cria o Sistema Nacional de Gerenciamento de Recursos Hídricos, regulamenta o inciso XIX do art. 21 da Constituição Federal e altera o art. $1^{\circ}$ da Lei no 8.001, de 13 de março de 1990, que modificou a Lei n. 7.990, de 28 de dezembro de 1989. Disponível em: <http://www.planalto.gov.br/CCivil_03/Leis/L9433.htm>. Acesso em: 15 maio 2015.

BRASIL. Lei n. 7.990, de 28 de dezembro de 1989. Institui, para os Estados, Distrito Federal e Municípios, compensação financeira pelo resultado da exploração de petróleo ou gás natural, de recursos hídricos para fins de geração de energia elétrica, de recursos minerais em seus respectivos territórios, plataformas continental, mar territorial ou zona econômica exclusiva, e dá outras providências (Art. 21, XIX da CF). Disponível em: <http://www.planalto.gov.br/CCivil_03/leis/L7990.htm>. Acesso em: 15 maio 2015.

BRASIL. Conselho Nacional do Meio Ambiente - CONAMA. Resolução n 001, de 23 de janeiro de 1986. Disponível em: <http://www.mma.gov.br/port/conama/res/res86/res0186.html>. Acesso em: 13 maio 2015.

COSTA, Beatriz Souza; FIORILLO, Celso Antônio Pacheco. Tutela jurídica dos recursos ambientais minerais vinculada ao conceito democrático de segurança nacional. Revista Veredas do Direito, Belo Horizonte, v. 9, n. 18, p. 32, jul./dez. 2012.

DAVIS, Graham A. The mineral sector, sectorial analysis and economic development. Resources Policy, v. 24, n. 4, p. 217-228, Dec. 1998.

DIAMOND, Jared. Colapso: como as sociedades escolhem o fracasso ou o sucesso. Rio de Janeiro: Record, 2005.

ENRÍQUEZ, Maria Amélia. Mineração: maldição ou dádiva? Os dilemas do desenvolvimento sustentável a partir de uma base mineira. São Paulo: Signus, 2008.

GRANZIERA, Maria Luiza Machado. Direito das águas: disciplina jurídica das águas doces. 3. ed. São Paulo: Atlas, 2006.

GUERRA, Sidney. Legislação de direito ambiental. Rio de Janeiro: América Jurídica, 2002.

LEWIS JUNIOR, Stephen. Development problems of the mineral-rich countries. In: SYRQUIN, Moshe; TAYLOR, Lance; WESTPHAL, Larry E. (Eds.). Economic structure and performance: essays ind the honor of Hollis B. Chenery. Orlando: Academic Press, 1984.

OLIVEIRA, Everton de. Água subterrânea e mineração. In: CONGRESSO BRASILEIRO DE ÁGUAS SUBTERRÂNEAS, 5., 1998, São Paulo. Anais... São Paulo: ABAS, 1998. p. 1-5. Disponível em: <http:// aguassubterraneas.abas.org/asubterraneas/article/view/22326/14669>. Acesso em: 14 maio 2015.

PENNA, Carlos Gabaglia. Efeitos da mineração no meio ambiente, 2009. Disponível em: < http://www.oeco. org.br/carlos-gabaglia-penna/20837-efeitos-da-mineracao-no-meio-ambiente>. Acesso em: 06 maio 2015.

SHAFER, David Michael. Winners and Losers: how sectors shape the developmental prospects of states. Ithaca: Cornell University Press, 1994. 


\title{
Participação popular e acesso à informação ambiental para preservação do meio ambiente ecologicamente equilibrado*
}

\section{Popular participation and access to environmental information to ecologically balanced environment preservation}

Luciano Marcos Paes**

\section{Resumo}

A partir da Constituição Federal Brasileira de 1988, são colocados à disposição da população mecanismos de participação para que se possa exercer a cidadania e, assim, fortalecer o regime democrático por meio da participação popular, inclusive, nas questões que envolvam a proteção e a preservação do meio ambiente. No presente artigo, pretende-se, por meio de revisão bibliográfica, realizar breve análise da possibilidade e da necessidade de participação do cidadão, por meio do acesso à informação ambiental, em relação à preservação do meio ambiente ecologicamente equilibrado.

Palavras-chave: Participação popular. Acesso à informação. Meio ambiente.

\begin{abstract}
Since Brazilian Federal Constitution of 1998 mechanisms for participation are made available to population so that the citizenship can be exercised and than the democratic regime gain strength through popular participation including questions that envolve the environment protection and preservation. In the present study intends, through a bibliographic review, to perform a brief analysis of the possibility and the need for citizen participation, by accessing to environment information, in the ecologically balanced environment preservation.
\end{abstract}

Keywords: Popular participation. Access to information. Environment.

* Recebido em 20/09/2015 Aprovado em 15/11/2015

** Possui graduação em Direito pela Universidade de Caxias do Sul - UCS (2014). Mestrando em Direito pela Universidade de Caxias do Sul__UCS (2015). E-mail: lmpaes@ucs.br

\section{SUMÁRIO}

1 Introdução. 2 Participação popular e acesso à informação ambiental. 3 Preservação do meio ambiente ecologicamente equilibrado. 4 Considerações finais. 5 Referências. 


\section{INTRODUÇÃO}

É dever dos órgãos e entidades públicas incentivar a divulgação de informações de interesse coletivo ou geral por eles produzidas. O artigo 19 da Declaração Universal dos Direitos Humanos, o artigo 19 do Pacto Internacional sobre Direitos Civis e Políticos, o artigo 13 da Convenção Interamericana sobre Direitos Humanos, o artigo 9 da Carta Africana sobre Direitos Humanos e dos Povos e o artigo 10 da Convenção Europeia sobre Direitos Humanos reconhecem o acesso às informações públicas como direito humano fundamental, pois a vida democrática em sociedade é marcada por um elemento essencial: a necessidade de o indivíduo fazer escolhas, ou seja, "a informação serve para o processo de educação de cada pessoa e da comunidade, mas a informação visa também dar a chance à pessoa informada de tomar posição ou pronunciar-se sobre a matéria informada ${ }^{1 "}$.

Igualmente, a Convenção de Aarhus de 1998 é um dos mais importantes instrumentos do Direito Internacional do Ambiente, pois traz a ideia de que o desenvolvimento sustentável só poderá ser alcançado por meio do envolvimento de todas as partes interessadas, ou melhor, todos os cidadãos passam a ser detentores do direito de acesso à informação relativa ao meio ambiente; do direito de participação nos procedimentos de tomada de decisão em matérias ambientais e do direito de acesso à justiça nessas matérias. ${ }^{2}$

$\mathrm{O}$ acesso à informação, além de ser um direito de qualquer indivíduo, também é um direito difuso pertencente a toda a coletividade eis que o acesso amplo às informações públicas resulta em ganhos para a comunidade de maneira geral ${ }^{3}$.

Durante o regime militar, no Brasil, dos anos 1964 até 1985, o direito de acesso às informações públicas foi um dos direitos formal ou informalmente suspensos.

A Constituição Federal de 1988, em seu artigo 1º, parágrafo único, refere expressamente que "todo o poder emana do povo, que o exerce por meio de representantes eleitos ou diretamente, nos termos desta Constituição” e, assim, o Estado Democrático de Direito traz consigo a ideia de cidadania como princípio fundamental.

Com a promulgação da Constituição Federal Brasileira de 1988, são colocados à disposição da população mecanismos de participação para que se possa exercer a cidadania e, assim, fortalecer o regime democrático por meio da participação popular, inclusive, nas questões que envolvam a proteção e a preservação do meio ambiente.

Uma das melhores maneiras de tratar essas questões é assegurar a participação dos cidadãos e disponibilizar informações com o objetivo de preservação ambiental, seja na esfera administrativa, legislativa ou judicial, uma vez que "a pluralidade de sujeitos que se utiliza do meio ambiente é capaz de trazer argumentos, opiniões e soluções mais eficientes para sua proteção, pois quem vive o problema tem uma visão diferente do que quem está de fora"»".

Este texto construído com base em revisão bibliográfica tem como objetivo, sem a pretensão de esgotar o assunto, analisar e fomentar a possibilidade de participação do cidadão, por meio do acesso à informação e da necessidade de utilização dessas informações para auxiliar nas ações que visem à proteção e à preservação do meio ambiente ecologicamente equilibrado.

1 MACHADO, Paulo Afonso Leme. Direito ambiental brasileiro. 21. ed. São Paulo: Malheiros, 2013. p. 123.

2 LANCEIRO, Rui Tavares. O direito de acesso à informação ambiental em Portugal: alguns problemas. In: CONFERÊNCIA DO INSTITUTO DE CIÊNCIAS JURÍDICO-POLÍTICAS, 2014, Lisboa. A trilogia de Aarbus: os direitos à informação, à participação e à justiça ambiental. Lisboa: Faculdade de Direito Universidade de Lisboa, 2015. p. 29-61. p. 30-31.

3 AGÊNCIA DE NOTÍCIAS DOS DIREITOS DA INFÂNCIA. Acesso à informação e controle social das politicas públicas. Brasília: ANDI, 2009. Disponível em: <http://www.fesmedia-latin america.org/uploads/media/Acceso_a_informacao.pdf>. Acesso em: 05 ago. 2015.

4 SOUZA, Leonardo da Rocha de. Direito ambiental e democracia deliberativa. Jundiaí: Paco, 2013. p. 112. 


\section{Participação popular e ACESSo À informação Ambiental}

A Constituição Federal Brasileira no artigo $5^{\circ}$, inciso XIV, prevê que "é assegurado a todos o acesso à informação e resguardado o sigilo da fonte, quando necessário ao exercício profissional" 5 bem como refere ainda, no inciso XXXIII, que os cidadãos "têm direito de receber dos órgãos públicos informações de seu interesse particular, ou de interesse coletivo ou geral"'.

De outro lado, a participação popular caracteriza-se pela luta na conquista de espaços para aumentar a participação social, ou seja, é um dos aspectos mais desafiadores sobre os quais se posta a democracia participativa uma vez que

não se pode pensar na preservação, conservação e gestão da qualidade ambiental fora de um regime de democracia participativa, em que se garanta às pessoas em geral - individualmente, reunidas em grupos ou representadas por entes habilitados - a possibilidade de tomar parte nas instâncias de decisão relacionadas à matéria e de exercer o controle sobre as atividades e omissões públicas e privadas potencial ou efetivamente lesivas. ${ }^{7}$

A participação popular surge como elemento que traz mecanismos que buscam renovar e dar maior oportunidade à democratização da sociedade e, em contrapartida, o acesso à informação é uma precondição para a participação do cidadão e dos grupos organizados da sociedade afim de servir aos interesses mais amplos da coletividade.

De fato,

a participação popular transforma-se no referencial de ampliação de possibilidades de acesso dos setores populares dentro de uma perspectiva de desenvolvimento da sociedade civil e de fortalecimento dos mecanismos democráticos, mas também para garantir a execução eficiente de programas de compensação social no contexto das políticas de ajuste estrutural e de deliberação da economia e privatização do patrimônio do Estado. ${ }^{8}$

A participação popular visando à preservação e à proteção do meio ambiente insere-se num quadro mais amplo da participação diante dos interesses difusos e coletivos da sociedade, o que faz um desafio maior ensejar participação pois o termo participar significa que a opinião de uma pessoa pode ser levada em conta. ${ }^{9}$

Como bem refere Machado10 “quem estiver mal informado nem por isso estará impedido de participar, mas a qualidade de sua participação será prejudicada. A ignorância gera apatia ou inércia dos que teriam legitimidade para participar".

Igualmente no âmbito internacional, a Convenção de Aarhus busca garantir o acesso do público à informação em matéria de ambiente, sem que se tenha que provar interesse na questão, além de fomentar deveres de recolha e difusão de informação em matéria de ambiente (art. $4^{\circ}$ e $5^{\circ}$ da Convenção de Aarhus). ${ }^{11}$

É indiscutível a importância do direito de acesso à informação nos estados democráticos modernos como uma forma de o cidadão entender o funcionamento do Estado e participar da execução e fiscalização de suas políticas públicas.

5 BRASIL. Constituição (1988). Constituição da República Federativa do Brasil. Disponível em: < http://www.planalto.gov.br/ccivil_03/constituicao/ConstituicaoCompilado.htm>. Acesso em: 10 dez. 2015.

6 BRASIL. Constituição (1988). Constituição da República Federativa do Brasil. Disponível em: <http://www.planalto.gov.br/ccivil_03/constituicao/ConstituicaoCompilado.htm>. Acesso em: 10 dez. 2015.

7 MIRRA, Álvaro Luiz Valery. Participação, processo civil e defesa do meio ambiente no direito brasileiro. 2010. 346 f. Tese (Doutorado) Faculdade de Direito da Universidade de São Paulo, São Paulo, 2010. p. 60.

8 JACOBI, Pedro Roberto. Espaços públicos e práticas participativas na gestão do meio ambiente no Brasil. Sociedade e Estado, Brasília, v. 18, n. 1-2, p. 315-338, jan./dez. 2003. p. 317.

9 MACHADO, Paulo Afonso Leme. Direito ambiental brasileiro. 21. ed. São Paulo: Malheiros, 2013. p. 126.

10 MACHADO, Paulo Afonso Leme. Direito à informação e meio ambiente. São Paulo: Malheiros, 2006. p. 34.

11 LANCEIRO, Rui Tavares. O direito de acesso à informação ambiental em Portugal: alguns problemas. In: CONFERÊNCIA DO INSTITUTO DE CIÊNCIAS JURÍDICO-POLÍTICAS, 2014, Lisboa. A trilogia de Aarbus: os direitos à informação, à participação e à justiça ambiental. Lisboa: Faculdade de Direito Universidade de Lisboa, 2015. p. 29-61. p. 31. 
Nessa mesma esteira, a Lei de Acesso à Informação - Lei 12.527/11 traduz as condições para o acesso às informações governamentais no Brasil, desde que essas condições possam ser incorporadas a uma política pública capaz de assegurar e instrumentalizar o exercício desses direitos, bem como a proteção à destruição e manipulação indevidas dessas informações.

É dever dos órgãos e entidades públicas incentivar, independentemente de requerimentos, a divulgação em local de fácil acesso, informações de interesse coletivo ou geral produzidas ou mantidas por eles.

No entanto, o direito de acesso à informação tem outra característica importante que é a de instrumento ou ferramenta de trabalho para a realização de outros direitos, visto que, só munidos de informações relevantes, as organizações e os indivíduos podem exigir os mais diversos direitos pois a informação permite o monitoramento e a participação.

Quando se trata de matéria ambiental além da proteção dada pela Constituição de 1988 e das garantias asseguradas pela Lei Geral de Acesso à Informação - Lei 12.527/11 importante referir, também, a Lei 10.650/03 que dispõe sobre o acesso público aos dados e informações existentes nos órgãos e entidades integrantes do SISNAMA (Sistema Nacional do Meio Ambiente) por meio de contato com os diferentes órgãos ambientais do Estado (federal, estadual ou municipal), assegurando a possibilidade de acesso à informação ambiental de forma genérica.

São exemplos de informação ambiental os relatórios sobre atuação de agências ambientais, instruções normativas, resoluções, relatórios de impacto ao meio ambiente, atas, outros documentos de reuniões de órgãos ambientais etc.

Todos os órgãos ligados ao SISNAMA têm o prazo de trinta dias, a partir da data do pedido, para entregar as informações solicitadas, todavia, a definição de tal prazo foi superada pela edição da Lei Geral de Acesso à Informação ao dispor em seu artigo 11 que o órgão ou entidade pública deverá autorizar ou conceder o acesso imediato à informação disponível e, não sendo possível conceder de imediato, o órgão ou entidade que receber o pedido deverá conceder a informação no prazo de vinte dias prorrogáveis por mais dez, mediante justificativa expressa, da qual será cientificado o requerente.

Ainda, a Lei 10.650/03 também estabelece que informações sobre temas relacionados à questão ambiental ${ }^{12}$ devem ser disponibilizas à população obrigatoriamente e independente de requisição.

São características da informação ambiental: (a) a tecnicidade da informação ambiental; (b) a compreensibilidade da informação ambiental; (c) a tempestividade da informação ambiental; (d) a imprescindibilidade da informação ambiental em situação de emergência e, (e) a prestação da informação independe de interesse pessoal do informado. ${ }^{13}$

Por outro lado, a Administração Pública não é o único canal para a obtenção da informação ambiental já que a informação se torna pública não porque está em poder do Poder Público, mas porque sua natureza é de interesse público ou social, assim, mesmo estando em mãos de pessoas ou das empresas privadas, havendo esse tipo de interesse na informação, ela se torna de natureza pública. ${ }^{14}$

12 Lei 10.650/03 - Art. 2: Os órgãos e entidades da Administração Pública, direta, indireta e fundacional, integrantes do Sisnama, ficam obrigados a permitir o acesso público aos documentos, expedientes e processos administrativos que tratem de matéria ambiental e a fornecer todas as informações ambientais que estejam sob sua guarda, em meio escrito, visual, sonoro ou eletrônico, especialmente as relativas a: I - qualidade do meio ambiente; II - políticas, planos e programas potencialmente causadores de impacto ambiental; III - resultados de monitoramento e auditoria nos sistemas de controle de poluição e de atividades potencialmente poluidoras, bem como de planos e ações de recuperação de áreas degradadas; IV - acidentes, situações de risco ou de emergência ambientais; V - emissões de efluentes líquidos e gasosos, e produção de resíduos sólidos; VI - substâncias tóxicas e perigosas; VII diversidade biológica; VIII - organismos geneticamente modificados. BRASIL. Lei ñ 10.650, de 16 de abril de 2003. Dispõe sobre o acesso público aos dados e informações nos órgãos e entidades integrantes do Sisnama. Disponível em: <http://www.planalto.gov. br/ccivil_03/Leis/2003/L10.650.htm>. Acesso em: 10 dez. 2015.

13 MACHADO, Paulo Afonso Leme. Direito à informação e meio ambiente. São Paulo: Malheiros, 2006. p. 91-95

14 MACHADO, Paulo Afonso Leme. Direito à informação e meio ambiente. São Paulo: Malheiros, 2006. p. 104-105. 
Ademais,

a informação ambiental não tem o fim exclusivo de formar a opinião pública [...] o grande destinatário da informação - o povo, em todos os seus segmentos, incluindo o científico não governamental - tem o que dizer e opinar ${ }^{15}$.

Segundo a resenha apresentada por Michel Delnoy, ligeiramente adaptada por Álavo Mirra, neste artigo, a participação pública em matéria ambiental tem como finalidades:

(a) suprir as insuficiências estruturais ou conjunturais da democracia representativa, permitindo aos cidadãos recuperar sua parcela de poder de controle sobre os destinos da sociedade, com a instituição de um regime de democracia participativa;

(b) melhorar a qualidade das decisões públicas, a partir das informações obtidas pelas autoridades junto à sociedade e das intervenções de indivíduos e grupos nos processos decisórios;

(c) aumentar a efetividade das decisões públicas, pelo apoio recebido da população que delas participou;

(d) reforçar o espaço do exercício do direito de todos à proteção do meio ambiente, como contrapartida ao alargamento do campo de atuação técnico-burocrática do Poder Público e ao desenvolvimento mal controlado das atividades privadas degradadoras;

(e) permitir aos cidadãos em geral cumprir seu dever de proteger o meio ambiente;

(f) favorecer a tomada de consciência por parte do setor privado a respeito das consequências ambientais das decisões que ele próprio toma. ${ }^{16}$

Aliás, um dos desafios que contém a democracia é a implementação de iniciativas para permitir o acesso da população a informações públicas, acolher espaços de participação que podem e devem ser criados, efetivados e alargados, com base nos valores democráticos e participativos que fundamentam a Constituição Federal Brasileira, fomentando, assim, a participação cidadã que pode tanto assumir a forma de contribuição nos debates como de intervenção propriamente dita nos processos decisórios, seja em âmbito administrativo, seja no judicial. ${ }^{17}$

\section{Preservação do meio ambiente ecologicamente gQuilibrado}

A atual Constituição Federal Brasileira traz o meio ambiente como bem jurídico constitucional integrando assim a categoria daqueles valores fundamentais da nossa sociedade, pois, com a proteção do meio ambiente, salvaguardamos não só a vida nas suas várias dimensões (individual, coletiva e até das gerações futuras), mas as próprias bases da vida. ${ }^{18}$

Com efeito tal objetivo exige:

pleno exercício da cidadania participativa e dos mecanismos da democracia. E é nesse sentido que o texto constitucional impõe inúmeros instrumentos de efetivação da ordem constitucional ambiental, ampliando a participação popular, por meios administrativos e judiciais, exigindo educação ambiental, amplitude e transparência de informações e de acesso à justiça, bem como inúmeros deveres de gestão ambiental aos poderes públicos, pois a solidariedade é pressuposto para a conquista da sustentabilidade ambiental. ${ }^{19}$

15 MACHADO, Paulo Afonso Leme. Direito ambiental brasileiro. 21. ed. São Paulo: Malheiros, 2013. p. 125.

16 MIRRA, Álvaro Luiz Valery. Participação, processo civil e defesa do meio ambiente no direito brasileiro. 2010. 346 f. Tese (Doutorado) Faculdade de Direito da Universidade de São Paulo, São Paulo, 2010. p. 62.

17 SILVEIRA, Clóvis Eduardo Malinverni. Risco ecológico abusivo: a tutela do patrimônio ambiental nos processos coletivos em face do risco socialmente intolerável. Caxias do Sul: Educs, 2014. p. 264.

18 ROTHENBURG, Walter Cláudios. A constituição ecológica. In: KISHI, Sandra Akemi Shimada; SILVA, Solange Teles da; SOARES, Inês Virgínia Prado (Org.). Desafios do direito ambiental no século XXI. São Paulo: Malheiros, 2005. p. 813-831. p. 814-815.

19 PADILHA, Norma Sueli. Fundamentos constitucionais do direito ambiental brasileiro. São Paulo: Elsevier, 2010. p. 160. 
A partir da inclusão do tema "meio ambiente" na Constituição Federal de 1988, transformações começaram e, assim, não somente se afirmou o direito a um meio ambiente sadio ou equilibrado como foram sendo inseridos instrumentos jurídicos para sua manutenção. ${ }^{20}$

No direito ambiental brasileiro, o artigo 225 da Constituição Federal de 1988 estabelece uma série de deveres direcionados à efetivação da participação, tais como o dever de cooperação entre estado e sociedade (art. 225, caput), o dever de educação ambiental (art. 225, $\int 1^{\circ}$, inc. VI) e o dever de publicidade dos estudos prévios de impacto ambiental (art. 225, $₫ 1^{\circ}$, inc. IV).

Certamente, é necessário entender a dinâmica entre as legislações que estabelecem direitos sociais e as políticas públicas que buscam garantir esses direitos, de modo que muitas das políticas públicas desenhadas pelo texto constitucional permanecem apenas como um conjunto de intenções.

Participar significa que a opinião de uma pessoa pode ser levada em conta e "portanto, permite que interessados proponham formas de prevenção das agressões ambientais e participem dessa prevenção" 21 .

É um desafio permanente ensejar participação e, nesse contexto, vários documentos internacionais reconhecem o direito à informação, dentre os quais podemos citar a Declaração do Rio de Janeiro, da Conferência das Nações Unidas para o Meio Ambiente e o Desenvolvimento de 1992, em seu princípio 10 que diz:

a melhor maneira de tratar as questões ambientais é assegurar a participação, no nível apropriado, de todos os cidadãos interessados. No nível nacional, cada indivíduo terá acesso adequado às informações relativas ao meio ambiente de que disponham as autoridades públicas, inclusive informações acerca de materiais e atividades perigosas em suas comunidades, bem como a oportunidade de participar dos processos decisórios. Os Estados irão facilitar e estimular a conscientização e a participação popular, colocando as informações à disposição de todos. Será proporcionado o acesso efetivo a mecanismos judiciais e administrativos, inclusive no que se refere à compensação e reparação de danos.

A Convenção de Aarhus ${ }^{22}$ também refere o acesso à informação como um dos pilares para a promoção do envolvimento dos cidadãos nas questões ambientais bem como para a aplicação da legislação ambiental, consagrando, assim, os posicionamentos legislativos de muitos países e colocando a saúde humana, os sítios culturais e as construções como objeto de consideração quando esses bens forem vulnerados, ou puderem ser lesados. ${ }^{23}$

Nesse sentido, é reflexo a importância da informação ambiental na forma como é cultuada pelo direito luso, especialmente ao tratar dos princípios do direito do ambiente, ao mencionar que

o princípio (e o correlativo direito) de participação está fortemente ligado a um outro direito que em geral vem sendo reconhecido em termos cada vez mais amplos aos cidadãos: o direito à informação. Só quando os cidadãos estão devidamente informados é que podem ter oportunidade de exercer convenientemente o seu direito de participação.

Com reflexo da importância que a informação - também enquanto pressuposto indeclinável de uma participação responsável e efectiva - assume em matéria ambiental [...] garantir o direito de acesso à informação sobre o ambiente detida pelas autoridades públicas, assegurar que a informação sobre

20 MACHADO, Paulo Afonso Leme. Direito à informação e meio ambiente. São Paulo: Malheiros, 2006. p. 88.

21 SOUZA, Leonardo da Rocha de. Direito ambiental e democracia deliberativa. Jundiaí: Paco, 2013. p. 115.

22 No Artigo $2^{\circ}$, item 3 da Convenção de Aarhus está dito que: entende-se por «informação em matéria de ambiente» qualquer informação disponível sob forma escrita, visual, oral, electrónica ou de qualquer outra forma sobre: a) O estado dos elementos do ambiente, tais como o ar e a atmosfera, a água, o solo, a terra, a paisagem e os sítios naturais, a diversidade biológica e as suas componentes, incluindo, genericamente, organismos modificados e a interação entre estes elementos; b) Fatores, tais como substâncias, energia, ruído e radiação, e atividades ou medidas, incluindo medidas administrativas, acordos, políticas, legislação, planos e programas em matéria de ambiente que afetem ou possam afetar os elementos do ambiente, no âmbito do acima mencionado subparágrafo a), e custo-benefício e outros pressupostos e análises económicas utilizados no processo de tomada de decisão em matéria de ambiente. ORGANIZAÇÃO DAS NAÇÕES UNIDAS. Resolução da Assembleia da República n 11/2003. Convenção sobre Acesso à Informação, Participação do Público no Processo de Tomada de Decisão e Acesso à Justiça em Matéria de Ambiente. Disponível em: <http://www.gddc.pt/siii/docs/rar11-2003.pdf>. Acesso em: 20 jul. 2015.

23 MACHADO, Paulo Afonso Leme. Direito à informação e meio ambiente. São Paulo: Malheiros, 2006. p. 79. 
ambiente seja divulgada e disponibilizada ao público e promover o acesso à informação através da utilização de tecnologias telemáticas ou electrónicas, responsabilizando as autoridades públicas por uma série de medidas necessárias para assegurar a informação ambiental e garantindo aos cidadãos o direito de acesso à informação sobre ambiente, independente do seu interesse na matéria. ${ }^{24}$

Portanto, as sujeições às obrigações de prestação de informação ambiental estão vinculadas quer pelo direito internacional como pelo direito pátrio de forma muito abrangente, sem que se tenha que provar ter um interesse específico na questão para obtenção de informações em matéria de ambiente.

Além disso, a definição de informação em matéria de ambiente engloba conteúdos informativos sob qualquer forma, sobre o estado do ambiente, sobre os fatores e medidas destinados a sua proteção, inclusive as análises de custos/benefícios econômicos e sobre a segurança das pessoas, as condições de vida, os locais de interesse cultural e as construções, na medida em que possam afetar o meio ambiente por um desses fatores ou atividades. ${ }^{25}$

Todavia um ponto de maior conflitualidade coloca-se na delimitação das situações em que é admissível o indeferimento do pedido de informação sem caracterizar recusa abusiva de prestação de informações especialmente quando há uma relação triangular composta pelo direito de obtenção da informação, interesse púbico e o interesse privado econômico, cuja a atividade é potencialmente agressora de determinados bens ambientais. ${ }^{26}$

A obtenção da informação não é por si só causa de atraso de um determinado projeto da inciativa econômica privada, porém poderá ocorrer situação diferente quando a informação pretendida colidir com a confidencialidade inerente ao segredo comercial ou industrial ou com a confidencialidade de dados pessoais sem o consentimento dos terceiros afetados.

$\mathrm{O}$ acesso à informação "nesse plano, atua como mecanismo de equalização das relações jurídicas, possibilitando ao cidadão (ou associação civil) titular do direito ao ambiente de, em um patamar mais igualitário, reivindicar o respeito ao seu direito fundamental ao ambiente ${ }^{27}$ ", pois o direito de acesso à informação possui uma dupla dimensão:

subjetiva, na medida em que a informação e o acesso às suas fontes são essenciais para que o cidadão compreenda o fundamento e o limite dos seus direitos em face dos poderes públicos; objetiva, porquanto o controle da transparência da decisão administrativa depende da possibilidade de os cidadãos se informarem e serem informados sobre os passos do iter procedimental. ${ }^{28}$

Igualmente, ao levamos em conta a preservação do meio ambiente,

formar uma consciência ambiental ética é a alternativa mais viável para garantir a perpetuação da vida num planeta vitimado por tantas agressões. A tutela da qualidade do meio ambiente é uma questão que não pode figurar em segundo plano, por que, por meio dela, o bem protegido é a vida como um valor maior da existência do ser. Em face disso, em que pese a questão do acesso à informação ter seu caráter utópico, mostra-se evidente a sua importância, inclusive para a compreensão sistêmica das questões ambientais atuais. Sua dinamização e disseminação por meio de um processo educativo mais amplo e dentro da cultura política existente apontam para a garantia da supremacia do direito coletivo sobre o individual. ${ }^{29}$

24 DIAS, José Eduardo Figueiredo. Direito constitucional e administrativo do ambiente. 2. ed. Coimbra: Almedina, 2007. p. 24.

25 LANCEIRO, Rui Tavares. O direito de acesso à informação ambiental em Portugal: alguns problemas. In: CONFERÊNCIA DO INSTITUTO DE CIÊNCIAS JURÍDICO-POLÍTICAS, 2014, Lisboa. A trilogia de Aarbus: os direitos à informação, à participação e à justiça ambiental. Lisboa: Faculdade de Direito Universidade de Lisboa, 2015. p. 29-61. p. 42.

26 MARQUES, Francisco Paes. A convecção de Aarhus e as relações jurídicas multipolares. . In: CONFERÊNCIA DO INSTITUTO DE CIÊNCIAS JURÍDICO-POLÍTICAS, 2014, Lisboa. A trilogia de Aarbus: os direitos à informação, à participação e à justiça ambiental. Lisboa: Faculdade de Direito Universidade de Lisboa, 2015. p. 61-75. p. 61.

27 FENSTERSEIFER, Tiago. Direitos fundamentais e proteção do ambiente: a dimensão ecológica da dignidade humana no marco jurídico constitucional do estado socioambiental de direito. Porto Alegre: Livraria do Advogado, 2008. p. 127.

28 PORTUGAL. Tribunal Constitucional. Acordão n. 136. Segunda Secção. Relator: Conselheiro Paulo Mota Pinto. Lisboa, 15 de março de 2005. A caminho de uma ecocidadania: notas sobre o direito à informação ambiental. Disponível em: <http://www. tribunalconstitucional.pt/tc/acordaos/20050136.html>. Acesso em: 20 jul. 2015.

29 BARROS, Lucivaldo Vasconcelos. O Estado (in)transparente: limites do direito à informação socioambiental do Brasil. 2008. 368 f. Tese (Doutorado) - Centro de Desenvolvimento Sustentável, Universidade de Brasília, Brasília, 2008. p. 340. 
Assim, o acesso à informação não só representa inversão na lógica de segredo tradicionalmente associada ao funcionamento da máquina administrativa, como e, sobretudo, acresce legitimidade da decisão por força da potencial abertura a um contraditório público, pois a partilha do "poder" que está associada à posse da informação representa um estágio de evolução superior do Estado Democrático de Direito provando que há democracia para além do sufrágio ${ }^{30}$.

Os estados democráticos têm a obrigação de implementar sistemas legais para facilitar o acesso à informações, pois o direito de ter acesso ao seu passado e a conhecer o seu presente aumenta as noções de cidadania, a boa governança, a eficiência da administração pública, a fiscalização, o combate à corrupção, o desenvolvimento humano, a inclusão social bem como o êxito de outros direitos socioeconômicos, civis e políticos $^{31}$.

\section{Considerações finais}

Parece indiscutível que tão importante quanto a norma legal é a necessidade de uma política pública que operacionalize o direito de acesso à informação, pois é por meio da qualidade e da quantidade de informação que irá se traduzir a intensidade da participação na vida social e política. ${ }^{32}$

A informação é uma ferramenta de controle democrático e, nesse sentido, o direito à informação está intimamente ligado ao conceito de democracia participativa e respeito aos direitos fundamentais de proteção do ambiente consistentemente equilibrado.

De fato a obtenção da informação ambiental mostra-se necessária e adequada à defesa do ambiente, porém a possibilidade de obtenção da informação não é por si só garantia de preservação, ademais quando em jogo outros interesses de ordem econômica.

O direito de acesso à informação, à participação e o acesso à justiça em sede ambiental (Trilogia de Aarhus) no sentido de incrementar a transparência na tomada de decisões com a possibilidade de seu controle não obsta contudo a análise judicial da questão.

Se a democracia participativa depende do nível de informação dos cidadãos (e da capacidade de aprender e analisar criticamente), o acesso à informação e a sustentabilidade ambiental têm íntima ligação, uma vez que a informação não é algo neutro que deva ser trabalhado, apenas, como um mero dado ou registro e, sim, a informação trabalhada em sua dimensão política pode auxiliar nos processos decisórios, especialmente aqueles em que o interesse coletivo difuso é predominante.

Partilhar a proteção ambiental por meio de um esforço solidário entre entidades públicas e privadas é um dever que reverte em favor de todos os membros da comunidade, existentes e futuros, e o direito de acesso à informação provoca um magnetismo especial sobre a tutela ambiental, gerando e alimentando um sentimento de responsabilidade partilhada. ${ }^{33}$

Por certo "cabe fomentar a invenção de novas formas democrático-participativas - não como panaceia,

30 PORTUGAL. Tribunal Constitucional. Acordão n. 136. Segunda Secção. Relator: Conselheiro Paulo Mota Pinto. Lisboa, 15 de março de 2005. A caminho de uma ecocidadania: notas sobre o direito à informação ambiental. p. 62. Disponível em: <http://www. tribunalconstitucional.pt/tc/acordaos/20050136.html>. Acesso em: 20 jul. 2015.

31 AGÊNCIA DE NOTÍCIAS DOS DIREITOS DA INFÂNCIA. Acesso à informação e controle social das políticas públicas. Brasília: ANDI, 2009. Disponível em: <http://www.fesmedia-latin america.org/uploads/media/Acceso_a_informacao.pdf>. Acesso em: 05 ago. 2015.

32 MACHADO, Paulo Afonso Leme. Direito à informação e meio ambiente. São Paulo: Malheiros, 2006. p. 34.

33 PORTUGAL. Tribunal Constitucional. Acordão n. 136. Segunda Secção. Relator: Conselheiro Paulo Mota Pinto. Lisboa, 15 de março de 2005. A caminho de uma ecocidadania: notas sobre o direito à informação ambiental. p. 63. Disponível em: <http://www. tribunalconstitucional.pt/tc/acordaos/20050136.html>. Acesso em: 20 jul. 2015. 
mas como desafio e como exigência histórica a povos que pretendem ser democráticos" ${ }^{34}$, uma vez que o debate público bem informado permite que o cidadão conheça e participe dos processos decisórios e monitore as ações do governo fazendo uso das informações públicas ambientais em ações específicas, utilizando dados oficiais para formulação de ações de monitoramento e defesa do meio ambiente ecologicamente equilibrado, possibilitando, assim, a conciliação de interesses privados divergentes e o adequado balanceamento do risco ambiental a ser assumido por toda coletividade, uma vez que "num primeiro momento foi dada a oportunidade ao homem para dominar, controlar e dispor de todas as coisas oferecidas pela natureza e agora ele descobre que deve voltar a sua atenção para controlar e dominar as suas próprias ações ${ }^{35}$ ".

\section{REFERÊNCIAS}

AGÊNCIA DE NOTÍCIAS DOS DIREITOS DA INFÂNCIA. Acesso à informação e controle social das políticas públicas. Brasília: ANDI, 2009. Disponível em: <http://www.fesmedia-latin america.org/uploads/media/ Acceso_a_informacao.pdf>. Acesso em: 05 ago. 2015.

BARROS, Lucivaldo Vasconcelos. O Estado (in)transparente: limites do direito à informação socioambiental do Brasil. 2008. 368 f. Tese (Doutorado) - Centro de Desenvolvimento Sustentável, Universidade de Brasília, Brasilia, 2008.

BRASIL. Constituição (1988). Constituição da República Federativa do Brasil. Disponível em: <http://www.planalto.gov.br/ccivil_03/constituicao/ConstituicaoCompilado.htm>. Acesso em: 10 dez. 2015.

BRASIL. Decreto $n^{\circ}$ 592, de 6 de julho de 1992. Atos Internacionais. Pacto Internacional sobre Direitos Civis e Políticos. Promulgação. Disponível em: <http://www.planalto.gov.br/ccivil_03/decreto/1990-1994/ D0592.htm>. Acesso em: 10 dez. 2015.

BRASIL. Lei $n^{\circ}$ 10.650, de 16 de abril de 2003. Dispõe sobre o acesso público aos dados e informações nos órgãos e entidades integrantes do Sisnama. Disponível em: < http://www.planalto.gov.br/ccivil_03/ Leis/2003/L10.650.htm>. Acesso em: 10 dez. 2015.

BRASIL. Lei $n^{\circ} 12.527$, de 18 de novembro de 2011. Regula o acesso a informações previsto no inciso XXXIII do art. $5^{\circ}$, no inciso II do $\int 3^{\circ}$ do art. 37 e no $\int 2^{\circ}$ do art. 216 da Constituição Federal; altera a Lei no 8.112, de 11 de dezembro de 1990; revoga a Lei $n^{\circ}$ 11.111, de 5 de maio de 2005, e dispositivos da Lei $\mathrm{n}^{\circ}$ 8.159, de 8 de janeiro de 1991; e dá outras providências. Disponível em: <http://www.planalto.gov.br/ccivil_03/_ ato2011-2014/2011/lei/112527.htm>. Acesso em: 10 dez. 2015.

CONSELHO DA EUROPA. Convenção Europeia sobre Direitos Humanos. Disponível em: < http://www.gddc. pt/direitos-humanos/textos-internacionais-dh/tidhregionais/conv-tratados-04-11-950-ets-5.html>. Acesso em: 05 ago. 2015.

CONVENÇÃO INTERAMERICANA SOBRE DIREIOTS HUMANOS. Pacto de San José da Costa Rica. Disponível em: <http://www.pge.sp.gov.br/centrodeestudos/bibliotecavirtual/instrumentos/sanjose. htm>. Acesso em: 05 ago. 2015.

DIAS, José Eduardo Figueiredo. Direito constitucional e administrativo do ambiente. 2. ed. Coimbra: Almedina, 2007.

FENSTERSEIFER, Tiago. Direitos Fundamentais e proteção do ambiente: a dimensão ecológica da dignidade

34 SILVEIRA, Clóvis Eduardo Malinverni. Risco ecológico abusivo: a tutela do patrimônio ambiental nos processos coletivos em face do risco socialmente intolerável. Caxias do Sul: Educs, 2014. p. 265.

35 BARROS, Lucivaldo Vasconcelos. O Estado (in)transparente: limites do direito à informação socioambiental do Brasil. 2008. 368 f. Tese (Doutorado) - Centro de Desenvolvimento Sustentável, Universidade de Brasília, Brasília, 2008. p. 341. 
humana no marco jurídico constitucional do estado socioambiental de direito. Porto Alegre: Livraria do Advogado, 2008.

JACOBI, Pedro Roberto. Espaços públicos e práticas participativas na gestão do meio ambiente no Brasil. Sociedade e Estado, Brasília, v. 18, n. 1-2, p. 315-338, jan./dez. 2003.

LANCEIRO, Rui Tavares. O direito de acesso à informação ambiental em Portugal: alguns problemas. In: CONFERÊNCIA DO INSTITUTO DE CIÊNCIAS JURÍDICO-POLÍTICAS, 2014, Lisboa. $A$ trilogia de Aarbus: os direitos à informação, à participação e à justiça ambiental. Lisboa: Faculdade de Direito Universidade de Lisboa, 2015. p. 29-61.

MACHADO, Paulo Afonso Leme. Direito à informação e meio ambiente. São Paulo: Malheiros, 2006.

MACHADO, Paulo Afonso Leme. Direito ambiental brasileiro. 21. ed. São Paulo: Malheiros, 2013.

MARQUES, Francisco Paes. A convecção de Aarhus e as relações jurídicas multipolares. . In: CONFERÊNCIA DO INSTITUTO DE CIÊNCIAS JURÍDICO-POLÍTICAS, 2014, Lisboa. A trilogia de Aarbus: os direitos à informação, à participação e à justiça ambiental. Lisboa: Faculdade de Direito Universidade de Lisboa, 2015. p. 61-75.

MIRRA, Álvaro Luiz Valery. Participação, processo civil e defesa do meio ambiente no direito brasileiro. 2010. 346 f. Tese (Doutorado) - Faculdade de Direito da Universidade de São Paulo, São Paulo, 2010.

ORGANIZAÇÃO DAS NAÇÕES UNIDAS. Resolução da Assembleia da República ñ 11/2003. Convenção sobre Acesso à Informação, Participação do Público no Processo de Tomada de Decisão e Acesso à Justiça em Matéria de Ambiente. Disponível em: <http://www.gddc.pt/siii/docs/rar11-2003.pdf>. Acesso em: 20 jul. 2015.

ORGANIZAÇÃO DAS NAÇÕES UNIDAS. Declaração do rio sobre meio ambiente e desenvolvimento. Disponível em: <http://www.onu.org.br/rio20/img/2012/01/rio92.pdf>. Acesso em: 20 jul. 2015.

ORGANIZAÇÃO DAS NAÇÕES UNIDAS. Declaração Universal dos Direitos Humanos. Disponível em: <http://www.ohchr.org/EN/UDHR/Documents/UDHR_Translations/por.pdf>. Acesso em: 05 ago. 2015.

PADILHA, Norma Sueli. Fundamentos constitucionais do direito ambiental brasileiro. São Paulo: Elsevier, 2010.

PORTUGAL. Tribunal Constitucional. Acordão n. 136. Segunda Secção. Relator: Conselheiro Paulo Mota Pinto. Lisboa, 15 de março de 2005. A caminho de uma ecocidadania: notas sobre o direito à informação ambiental. Disponível em: <http://www.tribunalconstitucional.pt/tc/acordaos/20050136.html>. Acesso em: 20 jul. 2015.

ROTHENBURG, Walter Cláudios. A constituição ecológica. In: KISHI, Sandra Akemi Shimada; SILVA, Solange Teles da; SOARES, Inês Virgínia Prado (Org.). Desafios do direito ambiental no século XXI. São Paulo: Malheiros, 2005. p. 813-831.

SILVEIRA, Clóvis Eduardo Malinverni. Risco ecológico abusivo: a tutela do patrimônio ambiental nos processos coletivos em face do risco socialmente intolerável. Caxias do Sul: Educs, 2014.

SISTEMA AFRICANO DE PROTEÇÃO DOS DIREITOS HUMANOS. Carta Africana sobre Direitos Humanos e dos Povos. Disponível em: <http://www.gddc.pt/direitos-humanos/textos-internacionais-dh/tidhregionais/carta-africa.html>. Acesso em: 05 ago. 2015.

SOUZA, Leonardo da Rocha de. Direito ambiental e democracia deliberativa. Jundiaí: Paco, 2013.

UNIVERSIDADE DE CAXIAS DO SUL. Guia para elaboração de trabalhos acadêmicos. 3. ed. Caxias do Sul: UCS, 2015. Disponível em: <https://www.ucs.br/site/midia/arquivos/guia_2015.pdf>. Acesso em: 10 dez. 2015. 


\section{Políticas públicas para a formação e avaliação de magistrados: a contribuição da educação judicial através das escolas de magistratura*}

\author{
Public policy relating to magistrate training \\ and evaluation: judicial education contribution \\ through judiciary schools
}

Flávio José Moreira Gonçalves**

\section{Resumo}

A avaliação nos cursos de formação de juízes é marcada pela inexistência de diretrizes e parâmetros a partir dos quais seja possível aferir em que medida as competências, habilidades e atitudes pressupostas para o exercício da função judicante foram incorporadas a atividade jurisdicional. Entrevistas e grupos focais realizados com cinquenta e cinco juízes que frequentaram, no período de 2006 a 2014, os cursos da Escola Superior da Magistratura do Estado do Ceará revelaram unidades de significado que, categorizadas, indicam a existência de vários problemas nos cursos de formação, mas apontam também algumas soluções. Os resultados obtidos refletem as fragilidades da formação de magistrados, realidade que talvez não seja muito diferente em outras escolas de magistratura brasileiras e mesmo estrangeiras. Em 2015, a Escola Nacional de Formação e Aperfeiçoamento de Magistrados (Enfam) criou grupo de trabalho para estudos e pesquisas com vista à produção de material teórico-prático para subsidiar os processos avaliativos das escolas judiciais e de magistratura. Ainda há necessidade, contudo, de estabelecer políticas públicas especificamente voltadas à formação e avaliação de magistrados, garantindo investimento, pelos tribunais, em capacitação. Não é possível deixar a educação judicial à margem dos processos de monitoramento e avaliação aplicáveis em outros níveis de formação profissional, haja vista que da perícia, segurança e justiça das decisões judiciais depende toda a sociedade. Este artigo apresenta alguns resultados da pesquisa fenomenológica e etnográfica realizada, com vistas a orientar tais políticas de capacitação, bem como subsidiar possíveis planejamentos de cursos de formação voltados à educação judicial.

Palavras-chave: Formação. Avaliação. Magistrados. Políticas Públicas. Educação Judicial. 


\section{AbStRACT:}

Evaluation on judges training courses is traced by guidelines and parementers absence from which it is possible to assess to what extent the skills, abilities and attitudes assumed to pursue adjudicative function that were incorporated into the judicial activity. Interviews and focus groups conducted with fifty five judges who attended, from 2006 to 2014, the Ceará's State Superior Magistrate School courses revealed meaning units, that categorized, indicate the existence of several problems in training courses, but also point out some solutions. The results reflect training weaknesses on judiciary education, a reality that may not be very different in other Brazilian Magistrates Schools and even foreign Judiciary Schools. In 2015, the National Magistrates School for Training and Improvement (ENFAM) created working group to study and research for the production of theoretical and practical material to support the evaluation processes of judicial schools and judiciary. There is a need, however, to establish public policies specifically aimed at judges training and judges evaluation, ensuring investment by the courts in training. You can not leave the judicial education monitoring and evaluation process off applicable in other training levels, given that judgments expertise, security and justice depends on all society. This article presents some results on phenomenological and ethnographic research conducted in order to guide such training policies and support possible planning of training courses aimed at judicial education.

Keywords: Training. Evaluation. Magistrates. Public policy. Judicial education.

\section{INTROdUÇÃo AO TEMA E À PROBLEMÁtICA: Estado dA ARTE}

Nunca foi tão necessário estabelecer princípios comuns e parâmetros norteadores da educação judicial, embora saibamos que, em tempos como estes nos quais vivemos, de pós-modernidade ou de modernidade líquida, esta tarefa tornou-se bastante difícil e, por que não dizer, complexa.

O que a sociedade gostaria que os magistrados aprendessem? O que os próprios juízes precisariam saber, de fato? Que conhecimentos, habilidades e atitudes espera-se de um magistrado? É importante que saibam como se portar em um tribunal? Deve-se priorizar na formação de juízes questões de ordem ética ou aquelas relacionadas à aplicação da lei aos casos concretos? Com quais dificuldades práticas os próprios magistrados se deparam em seu trabalho e o que esperam dos cursos de formação inicial e continuada ofertados pelas escolas de magistratura? Os juízes têm obtido, dos cursos ofertados, os resultados esperados? Tais cursos têm, de fato, alcançado seus objetivos?

A ideia, difundida entre os estudiosos, de que a educação judicial deve ser liderada e conduzida por magistrados, desde o planejamento, até as discussões sobre o currículo e os conteúdos a serem aprendidos, é permeada pelas concepções de imparcialidade e independência, as quais caracterizam a atividade jurisdicional. Entretanto, a educação judicial precisa levar em consideração, além destes aspectos, também uma série de outros fatores que entram em jogo quando se pensa em estabelecer políticas públicas para a educação de juízes, assunto do maior interesse de toda a sociedade, destinatária direta das decisões judiciais e pelas quais é constantemente afetada.

Como destaca Piragibe,

O direito à imparcialidade do julgador insere-se no âmbito dos direitos humanos e como tal vem sendo construído nas normas internacionais de proteção e em processo contíguo vem o ordenamento pátrio buscando assegurar a efetividade dessas normas no plano interno, onde os conflitos indivíduo/estado se estabelecem ${ }^{1}$.

1 PIRAGIBE, Marcelo. Imparcialidade Judicial: direito fundamental implícito - implicações filosóficas, sociológicas e dificuldades práticas no exercício da jurisdição. Saarbrücken: Verlag Editora, 2015, p. 116. 
Há quem entenda que os juízes, por constituírem em sua maior parte um seleto grupo, destacado da sociedade e recrutado entre pessoas de classe média ou alta em sua grande maioria, teriam dificuldade em compreender quais os vínculos a serem estabelecidos com a comunidade, já que não representariam a diversidade de segmentos e grupos existentes na população, argumento que, de certo modo, é contrariado por algumas pesquisas de cunho sociológico, realizadas no Brasil, haja vista a inexistência de homogeneidade no perfil do juiz brasileiro.

Entretanto, a necessidade de aproximar os magistrados da realidade e dos contextos de alguns segmentos sociais, cuja existência às vezes é até ignorada, exigiria uma educação judicial que possibilitasse a estes magistrados em formação o contato com grupos sociais diferenciados, sobretudo minorias, grupos estes dos quais raramente provêm os candidatos à magistratura.

O certo é que, apesar das preocupações recentes, em grande parte decorrentes da criação das escolas de magistratura, que culminaram na instituição da Escola Nacional da Magistratura (ENM), fruto da própria atividade associativa dos juízes e da Escola Nacional de Formação e Aperfeiçoamento de Magistrados (ENFAM), criada pela Emenda Constitucional no 45, como órgão vinculado ao Superior Tribunal de Justiça (STJ), a formação e avaliação de magistrados nem sempre foi objeto de preocupação específica no Brasil.

Convém lembrar que, embora desde o Brasil Colônia houvesse interesse na formação superior das elites nacionais, ela ainda ocorria inteiramente na metrópole. Somente com a vinda da família real, surgiram os primeiros cursos jurídicos, ainda completamente voltados a fornecer quadros autóctones destinados a servir aos interesses da coroa.

O ensino jurídico como um todo, por sua vez, marcado pelo tradicionalismo, passou por diversas reformas e sempre foi objeto de muitas críticas, sobretudo devido ao formalismo, tecnicismo e dogmatismo que o caracterizavam. Com a Proclamação da República, uma nova classe de intelectuais, ávida por ocupar cargos e funções públicas e exercer atividades políticas, constituía-se. Os bacharéis, graduados nestas instituições tradicionais, apresentavam-se como os principais quadros, dentre os quais era possível recrutar os juízes brasileiros.

A implantação dos cursos jurídicos no Brasil e as sucessivas reformas do ensino jurídico, entretanto, não foram capazes de dar conta das exigências de uma formação que propiciasse aos bacharéis em Direito conhecimentos, habilidades e atitudes que os preparasse para o exercício de funções judicantes, muito menos as funções atípicas de administração das unidades jurisdicionais. Somente na década de setenta do século $\mathrm{XX}$, visando suprir esta lacuna, começou a surgir entre nós brasileiros a ideia de criação das escolas judiciais (associativas) e, após a redemocratização do país, depois de quase vinte anos de Ditadura Civil-Militar, surgiram as escolas judiciárias (oficiais) com a finalidade de melhor preparar os quadros da magistratura.

Antes de prosseguir nesta reflexão, não se pode ignorar a importância de algumas pesquisas anteriores, fundamentais para conhecer a magistratura brasileira e as tendências de transformação do Judiciário, entre as quais destacam-se aquelas que procuraram traçar o perfil da magistratura brasileira, demonstrando que há uma crescente juvenização, femininização e abertura dos novos magistrados para falar sobre questões sociais e políticas, conforme constatam pesquisas realizadas em $1997^{2}$ e $2006^{3}$, bem como outras pesquisas realizadas em $2004^{4}$, tendo esta última como principal finalidade avaliar os objetivos esperados e alcançados em cursos de aperfeiçoamento e especialização ofertados pela Escola Superior da Magistratura do Estado do Ceará (Esmec) de 1995 a 2002. Tal pesquisa já apontava deficiências pedagógicas nos cursos ofertados

2 Refiro-me às pesquisas realizadas por Luiz Werneck Vianna e que foram publicadas em sua obra: VIANNA, Luiz Werneck. Corpo e Alma da Magistratura Brasileira. $3^{a}$ edição. Rio de Janeiro: Revan,1997.

3 Neste caso, refiro-me ao trabalho da pesquisadora Maria Tereza Sadek, publicado em seu livro: SADEK, Maria Tereza; BENETI, Sidnei Agostinho e FALCÃO, Joaquim. Magistrados: uma imagem em movimento. Rio de Janeiro: Editora FGV, 2006.

4 Trata-se da tese de doutorado do professor Raimundo Hélio Leite: LEITE, Raimundo Hélio. Aperfeiçoamento e Especialização: o esperado e o alcançado na visão dos alunos que frequentaram os cursos da Escola da Magistratura do Ceará, nos anos de 1995 a 2002. Tese de Doutorado. Fortaleza: UFC, 2004. 
pela instituição. Ambas as pesquisas constituem referências indispensáveis para compreender as transformações pelas quais passa atualmente a carreira da magistratura e, por conseguinte, a própria educação judicial.

Há também, nos dados oriundos do Censo Judiciário divulgado em 20145 , informações detalhadas acerca do perfil dos magistrados brasileiros e sobre o que pensam sobre variados temas. Entre os dados coletados pelo referido Censo, é possível constatar que 75,1\% dos magistrados brasileiros até avaliam positivamente as políticas de qualificação, concordando com a afirmação de que os cursos de aperfeiçoamento promovidos pelos tribunais e conselhos contribuem para a sua atuação no trabalho, mas inexistem informações detalhadas sobre como os juízes que frequentam as escolas de magistratura avaliam a aprendizagem nos cursos ofertados pelas escolas judiciais e judiciárias e qual o impacto real destes cursos em suas atividades profissionais. Este aspecto não teria como ser ignorado numa pesquisa qualitativa da natureza daquela cujos resultados preliminares são aqui apresentados, embora tal pesquisa tenha procurado também dialogar com outras investigações já realizadas no país, tanto de natureza qualitativa como de natureza quantitativa, a fim de comparar os resultados obtidos com os dados já existentes.

A NCR1000:2011, documento elaborado pela Red Iberoamericana de Escuelas Judiciales (RIAEJ), que sugere normas de qualidade a serem adotadas pelas escolas da magistratura, trata de vários aspectos relacionados aos paradigmas curriculares adotados por estas instituições. Algumas das recomendações contidas neste documento apontam, entre outros aspectos a serem considerados, os seguintes:

La institución debe assumir um marco conceptual que sirva de critério orientador de todos los processos, iniciativas, programas y proyectos que hagan parte de las dinâmica educativas que se implementen. Este marco es el Modelo Pedagógico Institucional y el Proyecto Educativo Institucional. La institución debe promover um processo de indagación permanente com la participación de las e los discentes, formadores, expertos temáticos, personalidades de los âmbitos juridico y sociales, representantes de asociaciones $u$ otras organizaciones sociales sobre el momento que vive el sistema judicial y que representa el contexto em el actúa la Institución6.

Como se observa, além de auscultar a comunidade, é preciso ouvir também os próprios magistrados, principais interessados em receber uma formação de qualidade que os capacite para o trabalho que desempenham ou desempenharão. Como destaca José Eduardo Sapateiro, na obra Ser Juiz Hoje, organizada por Rui Rangel:

Os juízes, porque aí têm a última palavra, que é decisória e definitiva, constituem o rosto mais visível desse mundo complexo, muito técnico e, para muitos, enigmático, que é o da justiça e dos tribunais. Mas nenhum juiz é uma ilha. Cercada de cidadãos. Ou sequer um Robson Crusoé. Civilizando Sextas-Feiras. Partilha antes, ombro a ombro, com a comunidade onde se encontra inserido, o sentir e devir coletivos. É um cidadão entre os demais, com a específica função de julgar, em nome de todos e para todos ${ }^{7}$.

Neste sentido, a contextualização dos programas de formação, voltando-os para o mundo do trabalho, para o fazer diário dos juízes é o que muitos propõem, sob o argumento de que a formação precisa ser prática e não meramente teórica, embora haja sempre os riscos de que os programas estejam sujeitos a incorrer também no outro extremo, isto é, no tecnicismo e pragmatismo que não permitiriam aos magistrados em formação refletir sobre o seu próprio percurso formativo e suas práticas judiciárias, corrigir rumos, traçar outros objetivos e seguir distintos caminhos.

Atualmente, os documentos produzidos pela Escola Nacional de Formação e Aperfeiçoamento de Magistrados (Enfam) têm orientado para que a formação de magistrados persiga uma concepção humanista, pragmática e interdisciplinar e vários cursos de formação de formadores têm sido realizados na perspectiva de alinhar as escolas de magistratura do país inteiro a estas diretrizes pedagógicas, o que se afigura louvável iniciativa da instituição.

5 BRASIL. Conselho Nacional de Justiça. Censo Judiciário 2014. Disponível em <http://www.cnj.jus.br/images/dpj/CensoJudiciario.final.pdf>, Acesso em 01/06/2015. págs. 32 a 85.

6 RIAEJ. NCR 1000:2011. Escuela de Estudios Judiciales. "Formación para la Justicia y la Paz". Acreditación Internacional Norma de Calidad. Disponível em <http://www.oj.gob.gt/uci/images/convocatorias/Metodologia_educativa_uci_2013/proyecto_educativo_institucional_2_unio_2014.pdf> Acesso em 16/11/2015

7 RANGEL. Ruy (Coord.). Ser Juiz Hoje. Coimbra: Almedina, 2008, p. 28. 
Entretanto, ainda se indaga acerca do que seria esta formação humanista, pragmática e interdisciplinar e como a avaliação, nos cursos de formação inicial e continuada, poderia constituir elemento regulatório desta formação, garantindo a qualidade necessária e exigida, além de favorecer a aprendizagem, respeitando a autonomia das escolas de magistratura e a independência dos juízes.

Estas são as questões que inquietam e que, apresentadas neste artigo, abrem caminhos para uma reflexão mais ampla a ser desenvolvida posteriormente, sobre a necessidade de política pública específica voltada à formação e avaliação de magistrados, discutindo a quem competiria estabelecê-la e como fazer isto sem interferir na independência e imparcialidade que devem ser respeitadas e preservadas, por caracterizarem estas duas a própria atividade judicante no Estado Democrático de Direito.

\subsection{A formação e avaliação de juízes como objeto de preocupação mundial e as condições históricas de surgimento das escolas judiciais e judiciárias no Brasil}

As escolas de magistratura são instituições relativamente novas. Surgiram na segunda metade do século $\mathrm{XX}$, pois nem sempre ficou clara a necessidade de formar magistrados, de prepará-los para a atividade que iriam desempenhar ${ }^{8}$.

O contexto era este: fim da Segunda Guerra Mundial. Tribunal de Nuremberg. Juízes sendo julgados por haver cumprido as leis sanitárias de Nuremberg, votadas e aprovadas na Alemanha, sob governo nazista. Leis que autorizavam toda sorte de discriminação negativa e perseguição a minorias.

Havia necessidade de resgatar valores fundamentais de uma formação jurídica que pudesse ir além do positivismo normativista e do tecnicismo legalista. Este foi o cenário mundial que ensejou, não por acaso, a criação das primeiras escolas de magistratura no mundo.

Em 1947, não por acaso após a Segunda Guerra Mundial e as consequências práticas com que se defrontaram os juízes do Tribunal de Nuremberg, tendo de julgar, inclusive, os magistrados alemães que aplicaram cegamente as chamadas "leis sanitárias" da Alemanha nazista, foi possível repensar seriamente a questão da educação judicial e, neste contexto, adveio a primeira instituição especificamente destinada a formação de juízes a qual surgiu no Japão naquele mesmo ano, vinculada a Suprema Corte daquele país.

O I Congresso Internacional de Magistrados, realizado em Roma no ano de 1958, passou a recomendar que os países criassem centros de educação judicial, despertando o interesse na problemática relacionada à formação dos juízes e configurando importante marco histórico para o desenvolvimento da educação judicial, a ponto da França fundar, naquele mesmo ano, a École Nationale de Magistrature, fato que influenciou a criação de escolas semelhantes em outros países europeus?

As escolas da magistratura pioneiras foram, portanto, a Escola Judicial do Japão e, logo em seguida, a Escola Nacional da Magistratura, na França, países que se encontravam durante a guerra em polos opostos do conflito. Bem se vê que as condições históricas do surgimento das primeiras escolas destinadas à formação de juízes coincidem exatamente com um contexto no qual era preciso ensinar e aprender, como lição decorrente daquele julgamento célebre no qual juízes ocuparam pela primeira vez na história a posição de réus, a insuficiência da legalidade e da técnica jurídica, sendo necessário que as decisões também atendessem a parâmetros de eticidade, justiça e legitimidade.

No Brasil, somente na década de setenta surgem as primeiras escolas judiciais, ainda de forma muito tímida, pois num contexto adverso, de Ditadura Civil-Militar, sendo o tema da educação judicial um assunto

8 Cf. NAVES, Nilson. Prefácio in BRASIL. Superior Tribunal de Justiça (STJ). Bibliografia Básica para o Ensino e Pesquisa nas Escolas de Magistratura. Brasília: ENFAM, 2008, p. 7.

9 Cf. BRASIL. Superior Tribunal de Justiça (STJ). Bibliografia Básica para o Ensino e Pesquisa nas Escolas de Magistratura. Brasília: ENFAM, 2008, p. 7. 
bastante novo na área da investigação acadêmica, território quase inexplorado de pesquisa, no qual encontramos férteis indagações que podem dar ensejo a muitas pesquisas, tantos empíricas quanto teóricas, tanto de natureza quantitativa quanto qualitativa.

Na onda desta preocupação mundial com a educação judicial, após a criação das escolas de magistratura no Japão e na França, foi a vez do Brasil voltar-se para esta questão, quando foram criadas a Escola Superior da Magistratura (Esm), vinculada à Associação de Juízes do Rio Grande do Sul (Ajuris) e a Escola Judiciária Desembargador Edésio Fernandes (Ejef), em Minas Gerais, ainda na década de setenta do século XX.

A eficiência técnica da máquina de matar construída por alguns alemães e azeitada pela tinta das decisões judiciais, ajudou a humanidade a compreender que o tecnicismo decisório conduz à irracionalidade e põe em risco o próprio sistema normativo, para não falar nas ameaças que pode representar o legalismo estrito à humanidade, por incorporar uma visão do direito desvinculada de qualquer compromisso com a democracia e os direitos humanos.

Havia dois argumentos que durante muito tempo prevaleceram e dificultaram que se pensasse em centros de formação de magistrados. Um deles, que remonta a Escola da Exegese e de larga predominância no século XIX, sustentava que não caberia ao juiz interpretar a lei, obra do legislador, mas apenas aplicá-la ao caso concreto.

Entre nós, argumento mais recente destacava a alegada desnecessidade de preparar juízes que já foram bem recrutados em razão de concorrido concurso. Este argumento, de certo modo, ainda persiste na mentalidade de alguns dirigentes de tribunais e escolas da magistratura, mas se configura um manifesto equívoco, seja pelo que afirmavam experientes magistrados na época de criação das escolas de magistratura, seja pelo que se tem revelado nas próprias afirmações dos magistrados neófitos que participaram voluntariamente desta pesquisa, como se verá adiante.

A insuficiência do modelo de recrutamento, no qual são examinados aspectos primordialmente cognitivos dos candidatos à magistratura, fato já evidenciado pelos próprios entrevistados, colaborou para que ampliássemos o horizonte de observação, lançando luzes sobre a necessidade de uma formação mais completa e de formas de seleção mais criteriosas para recrutar aqueles que decidirão sobre a liberdade, a vida e o patrimônio das pessoas.

A necessidade de preparar magistrados para o bom desempenho de suas atividades tem relação direta, portanto, com o desenvolvimento das escolas hermenêuticas no âmbito do Direito e com a própria visão de Ciência do Direito predominante nos meios jurídicos. Enquanto se achou que o magistrado era a mera "boca da lei", não se justificava a existência de escolas para formar aqueles que se limitavam a fazer incidir os ditames do legislador sobre os casos concretos que estavam sob seu julgamento.

Do mesmo modo, a persistência do mito de que, aprovado em concurso, o candidato a qualquer cargo ou função pública estaria plenamente habilitado ao exercício de suas atribuições, deixou que durante muitos anos a formação de juízes não fosse objeto de qualquer preocupação da sociedade ou do legislador.

Enquanto se concebeu o trabalho do juiz como o de um mero aplicador do texto das normas, como se este não necessitasse desenvolver qualquer operação intelectual mais complexa para interpretá-la ou preocupar-se com os impactos econômicos, políticos, sociais, culturais e ambientais de suas decisões, não se vislumbrava a necessidade de escolas de magistratura.

O surgimento das escolas de magistratura, enquanto instituições destinadas a preparar e dar formação continuada aos quadros que exercem a jurisdição, tem relação direta com a mudança de perspectiva hermenêutica, quando se desenvolvem melhor as diversas escolas de interpretação jurídica e os juízes despontam como intérpretes por excelência da obra elaborada pelo legislador (a lei), obra que se revela imperfeita, repleta de lacunas e de antinomias, a exigir do intérprete muito mais do que a simples atividade mecânica de subsunção, até mesmo pela evidente inexistência de isomorfia entre texto e norma ${ }^{10}$.

10 Cf. GRAU, Eros Roberto. Por que tenho medo dos juízes: a intepretação/aplicação do direito e os princípios. $\sigma^{\mathrm{a}}$ edição 
O velho brocardo "faço justiça, embora pereça o mundo" te aplicar as normas vigentes sem se preocupar com as suas consequências e sem a dimensão da responsabilidade do aplicador tornava desnecessária a existência de escolas de magistratura.

De modo mais recente, a preocupação com a formação de juízes refletiu-se também em documento produzido pelo Banco Mundial, intitulado O Setor Judiciário na América Latina e no Caribe: elementos para a reforma (1996), conhecido como "Documento Técnico 319”. Em tal documento, está prevista, inclusive, a criação daquilo que viria a ser mais tarde o Conselho Nacional de Justiça (CNJ), nos seguintes termos:

Como parte de um sistema de nomeação e avaliação, diversos países da América Latina estabeleceram conselhos judiciais, geralmente detentores das seguintes competências: administração de cortes, recursos humanos e mau procedimento individual e das Cortes. Também podendo ter jurisdição tanto sobre as Cortes Inferiores, quanto sobre a Corte Suprema. Na Província de Tucuman, na Argentina, a criação do Conselho para o processo de nomeação tem assegurado a indicação de advogados mais qualificados, em todas as instâncias jurídicas. É importante ainda que os membros do conselho sejam independentes e não estejam concorrendo a nenhum cargo político nos partidos. A Argentina, Equador e Peru criaram recentemente esses organismos. Os Conselhos devem incluir a participação de membros do Judiciário, conselhos profissionais de advogados, cidadãos e o Executivo, quando estabelecido de forma similar ao proposto no Chile, devendo ser presidido por um magistrado, como no modelo boliviano. Na formação do conselho torna-se relevante considerar se os membros terão dedicação parcial ou integral ${ }^{12}$.

Ademais, em referido documento técnico há recomendações expressas do Banco Mundial sobre o ensino jurídico e treinamento de magistrados, o que restou explicitado no item 3.5 do mesmo, destacando a importância de um sistema de avaliação da atividade judicial:

Para que qualquer sistema proporcione justiça, seus membros devem ser altamente qualificados, competentes e respeitar os indivíduos na sociedade. Consequentemente, mecanismos institucionais adequados devem existir para selecionar e manter estes indivíduos na estrutura do judiciário. Tais mecanismos institucionais incluem os processos de nomeação, o período de investidura, os níveis salariais e o sistema de avaliação. Todos esses elementos devem estar adequadamente dispostos a fim de proporcionar os devidos incentivos para que os operadores jurídicos prestem serviços de qualidade. Em outras palavras, o processo de nomeação deve ser talhado visando encontrar os indivíduos mais qualificados, as condições do cargo não devem oferecer incentivos indevidos que reforcem interesses pessoais, os salários devem ser suficientes para atrair e manter elevada a qualidade dos profissionais, e, finalmente, um sistema de avaliação deve permitir a seus membros e ao público em geral, o monitoramento da atividade judicial ${ }^{13}$.

Bastante criticado por alguns setores, interpretado como uma tentativa ingerência indevida do Banco Mundial na soberania dos seus países e uma interferência indevida na independência do Poder Judiciário nacional, este documento acaba por refletir uma mentalidade neoliberal, própria da década de noventa do século XX, presente claramente na recomendação de que o Judiciário de cada país procurasse colaborar para garantir um ambiente de segurança jurídica e previsibilidade das decisões para os investidores internacionais, incorporando o discurso da eficiência que está na base do modelo gerencial de Estado. ${ }^{14}$

refundida do Ensaio e Discurso sobre a Intepretação/Aplicação do Direito. Malheiros: São Paulo, 2014.

11 Crítica bem elaborada a este antigo brocardo e suas consequências pode ser lida em Hans Jonas, defensor de uma ética da responsabilidade, que inspirou boa parte das ideais relacionadas ao direito ambiental e ao biodireito no século XX. Recomenda-se a leitura de sua obra máxima: JONAS, Hans. O Princípio Responsabilidade: ensaio de uma ética para a civilização tecnológica. Rio de Janeiro: Contraponto e PUC-Rio, 2006.

12 BANCO Internacional para Reconstrução e Desenvolvimento/Banco Mundial. O Setor Judiciário na América Latina e no Caribe: elementos para a reforma. Nova York/ Washington, $1^{a}$ edição, junho de 1996. Disponível em <http://www.anamatra.org. br/uploads/document/00003439.pdf > Acesso em 16/11/2015.

13 BANCO Internacional para Reconstrução e Desenvolvimento/Banco Mundial. O Setor Judiciário na América Latina e no Caribe: elementos para a reforma. Nova York/ Washington, $1^{a}$ edição, junho de 1996. Disponível em <http://www.anamatra.org. br/uploads/document/00003439.pdf> Acesso em 16/11/2015.

14 É possível ler, no Documento Técnico n 319, o seguinte: “O Poder Judiciário é uma instituição pública e necessária que deve proporcionar resoluções de conflitos transparentes e igualitária aos cidadãos, aos agentes econômicos e ao estado. Não obstante, em muitos países da região, existe uma necessidade de reformas para aprimorar a qualidade e eficiência da Justiça, fomentando um 
Apesar das críticas, o Documento Técnico no 319 fez importantes considerações sobre ensino jurídico e a educação judicial que não devem ser ignoradas, recomendações que resvalam na formação de magistrados e nos mecanismos de avaliação, importantes instrumentos para a garantia da própria independência judicial:

Além disso, a forma pela qual os juízes são nomeados, avaliados e promovidos revestem-se de importante função na independência do Judiciário, bem como na manutenção de juízes qualificados para exercer a magistratura. Uma parte importante da qualidade da magistratura depende de um sistema disciplinar e de avaliação. A independência do judiciário requer um sistema de nomeações baseado no merecimento, podendo envolver um conselho de justiça na participação desse processo ${ }^{15}$.

$\mathrm{Na}$ atualidade, há várias pesquisas internacionais sobre o tema, conduzidas por Adele Kent (Canadá), Livingston Armytage (Austrália) e outros, destacando-se o trabalho realizado pela IOJT (International Organization for Judicial Training), que promove anualmente o principal congresso mundial na área da educação judicial e edita o periódico Judicial Education and Training.

\subsection{Especificidades da educação judicial}

Há uma discussão em curso, no âmbito dos debates acerca da educação judicial, sobre as suas especificidades como educação de adultos (andragogia), altamente qualificados e dotados da autonomia intelectual necessária para definir seus próprios percursos formativos (heutagogia). Neste aspecto, o papel das escolas de magistratura seria menos o de direcionar e mais o de orientar e fornecer subsídios para a formação de magistrados.

Como acentua Piragibe,

O papel da escola, consiste em oferecer, não impor, aos magistrados, todo o material possível para que o mesmo alcance o convencimento propício e necessário ao bem julgar. Há, portanto, mudança de paradigmas no que concerne a filosofia atual a ser adotada. Ao invés do método clássico e tradicional de educação em que se utiliza uma exposição basicamente unilateral por parte expositor, a Escola passa a atuar como agente facilitador de acesso ao conhecimento, e não de transmissora exclusiva e obrigatória deste, como ocorre com a educação no sentido genérico. Uma das boas formas complementares e coadjuvante nesse processo de livre escolha por parte do juiz, relativas aos conteúdos a serem estudados, surgiu no início deste milênio e denomina-se Heutagogia, categoria da ciência andragógica (espécie da pedagogia), e é expressão usada pela UNESCO. Neste novo modelo educacional, a própria pessoa determina o que e como a aprendizagem deve ocorrer, proporcionando, assim, uma forma idiossincrática de valorizar as experiências pessoais e que traduz em rapidez na assimilação do conhecimento e maior habilidade e segurança nas decisões ${ }^{16}$.

Sem pretender tomar partido nestes debates, é importante reconhecer que há realmente aspectos próprios da educação judicial que não podem ser ignorados quando tratamos da temática, enquanto há outros aspectos gerais que permitem compreender a formação dos juízes como parte da educação em geral.

Os formadores que atuam nas escolas de magistratura, sejam elas associativas ou públicas-estatais, precisam considerar tais aspectos e não podem de modo algum ignorá-los. Alguns destes aspectos comuns, como a zona de desenvolvimento proximal, referida por Vigotsky ${ }^{17}$, puderam ser identificados na pesquisa realizada, cujos resultados são apresentados a seguir.

ambiente propício ao comércio, financiamentos e investimentos" (1996, p. 7)

15 BANCO Internacional para Reconstrução e Desenvolvimento/Banco Mundial. O Setor Judiciário na América Latina e no Caribe: elementos para a reforma. Nova York/ Washington, $1^{a}$ edição, junho de 1996. Disponível em < http://www.anamatra.org. br/uploads/document/00003439.pdf> Acesso em 16/11/2015, p. 19.

16 PIRAGIBE, Marcelo. Equilíbrio entre influência e independência na formação judiciária in IOJT. 7th International Conference on the Training of the Judiciary. Recife, 2015, p. 4.

17 Cf. VIGOTSKY, Lev Semenovich. A Formação Social da Mente: o desenvolvimento dos processos psicológicos superiores. Trad. José Cipolla Neto, Luís Silveira Menna Barreto, Solange Castro Afeche. 7 ed. São Paulo: Martins Fontes, 2007. 


\section{Achados da PESQUisa Realizada com JuÍzes na ESMEC}

A magistratura é uma das mais desafiadoras profissões que alguém pode ter a pretensão de exercer. Protegidos por garantias institucionais (inamovibilidade, irredutibilidade de vencimentos, vitaliciedade), os juízes exercem suas atividades sob a cobrança e os olhares de toda a sociedade, que exige deles, constantemente, virtudes e poderes que ora se afiguram razoáveis e, por vezes, parecem muito acima da nossa condição humana.

Avaliar se alguém tem competências, habilidades e atitudes para exercer a função de juiz e está apto para conviver de forma saudável com os poderes que assumirá deve mesmo ser questão que interesse a todo cidadão, seja ele magistrado ou não, pois da qualidade dos juízes e de suas virtudes depende a proteção dos direitos de todos. Deve-se sempre lembrar que os magistrados são aqueles dos quais mais se espera ${ }^{18}$ a imparcialidade e independência necessárias para garantir direitos ameaçados ou violados.

Há sempre a expectativa de que os magistrados sejam garantes do direito nas circunstâncias, por mais difíceis que estas sejam, nas quais este se encontre ameaçado ou violado. Como consequência, deles costuma-se esperar muito mais qualidades intelectuais e morais para o exercício da profissão do que de qualquer outro cidadão. E nisto não há nenhuma novidade, pois desde o Direito Romano, o jurista Paulo afirma prevalecer tal entendimento, como constata Böttche:

Em suma, na definição de Paulo, podemos inferir alguns elementos tendentes ao menos a uma delimitação de magistratus como aquele que deve ter um cuidado precípuo, mais diligência e solicitude em relação às coisas (públicas) do que os outros cidadãos ${ }^{19}$.

Da pesquisa realizada com os magistrados entrevistados, foram recolhidos alguns achados que são apresentados neste artigo. Tais achados poderiam servir de subsídio para o estabelecimento de políticas públicas voltadas à formação e à avaliação de juízes, pois o que se pode perceber é que os resultados da pesquisa confirmam, de forma significativa, pesquisas já realizadas também por outros estudiosos, trazendo como elemento de inovação um maior desejo de participação democrática dos juízes na administração do tribunal e nos processos de tomada de decisão que afetam a todos.

Por outro lado, a literatura sobre educação judicial e muitas das intervenções dos palestrantes na 7 th International Conference on the Training of the Judiciary, realizada em Recife-PE de 8 a 12 de novembro de 2015, parecem corroborar os resultados desta pesquisa. Embora não possamos generalizar todas as dificuldades identificadas na formação de magistrados, haja vista existirem muitas diferenças nas formas de recrutamento nos sistemas do common law e no civil law e, neste último, variações muito significativas entre as diversas jurisdições, apresentaremos a seguir os resultados da pesquisa realizada com os juízes estatuais de carreira do Estado do Ceará, no período de 2006 a 2014.

\subsection{Metodologia e Dados Gerais da Amostra}

O estudo utilizou a técnica da entrevista aberta e também, sempre que possível, o grupo focal, com atividades que envolveram magistrados que frequentaram cursos da ESMEC no período compreendido entre 2006 e 2014, além de um grupo menor, que não frequentou o curso de formação, por não ser exigência legal para o vitaliciamento na época de seu ingresso nos quadros do Judiciário.

18 Nas palavras do jurista Paulo: Cui praecipua cura rerum incumbit, et qui magis quam ceteri diligentiam et sollicitudinem rebus quibus praesunt debent, hi 'magistri' appellantur; quin etiam magistratus per deriuationem a magistrais cognominantur. Unde etiam cuiuslibet disciplinae praeceptores magistros appelari a monendo uel mostrando. Em vernáculo: "Aquele a quem incumbe o cuidado principal das coisas e aqueles que mais (magis) do que os outros devem (ter) diligência e solicitude em relação às coisas, que presidem, são chamados mestres (magistri); porque também os próprios magistrados são assim denominados por derivação de magister. Por isso, também os preceptores de qualquer disciplina chamam-se os mestres de admoestar ou de mostrar” (Cf. Böttcher, 2011, p. 24)

19 BÖTTCHER, Carlos Alexandre. História da Magistratura: o pretor no Direito Romano. São Paulo: LTCE Editora, 2011 , p. 25. 
Participaram voluntariamente da pesquisa 55 (cinquenta e cinco) magistrados, os quais representavam 13,68\% dos magistrados estaduais de carreira do Estado do Ceará.

No decorrer do trabalho, utilizamos a seguinte nomenclatura: JV para entrevista de juiz vitaliciado; JS para entrevista de juiz substituto e JGF para participação de juiz em grupo focal, seja vitaliciado ou substituto, já que os grupos tiveram composição heterogênea.

Foram realizadas entrevistas semiestruturadas.

As entrevistas iniciavam-se com perguntas gerais, que indagavam em que instituição o magistrado graduou-se, o ano de ingresso na magistratura e o período em que frequentou o curso de formação inicial na escola da magistratura. Em seguida, eram formuladas perguntas mais subjetivas sobre o que o levou a fazer o referido curso e se este melhorou, de algum modo, a sua atuação profissional, bem como se este curso o enriqueceu como pessoa. Por último, o entrevistado era incentivado a sugerir algo para melhorar a formação e a avaliação de magistrados no Brasil, mas sempre deixando o entrevistado à vontade para tecer seus próprios comentários, além de solicitar aprofundamento das respostas naqueles pontos sobre os quais o pesquisador entendesse necessários maiores esclarecimentos.

As respostas dos entrevistados foram gravadas em áudio, transcritas e analisadas atentamente, a fim de revisá-las e identificar, na própria fala dos juízes entrevistados, as unidades de significado que permitissem articular algumas respostas aos problemas inicialmente apresentados pelo pesquisador. Para tanto, não foram eleitas hipóteses, mas deixamos que "as coisas mesmas" se revelassem, a partir da fala dos participantes, tomando como referencial teórico para esta análise a fenomenologia existencial, para a qual inexiste sujeito desprovido de mundo, isto é, desprovido de uma pré-compreensão, não cabendo também definições metodológicas a priori, como esclareceu o próprio Heidegger:

A expressão "fenomenologia" tem a significação primária de um conceito-de-método. Não caracteriza o que de conteúdo-de-coisa dos objetos da pesquisa filosófica, mas o seu como. Quanto mais autenticamente um conceito de método se desenvolve e quanto mais abrangente é sua determinação dos princípios condutores de uma ciência, tanto mais originalmente ele se enraíza na confrontação com as coisas elas mesmas e tanto mais ele se afasta do que denominamos um manejo técnico, algo que ocorre, e muito, nas disciplinas teóricas também. O termo "fenomenológica" exprime uma máxima que pode ser assim formulada: “às coisas elas mesmas!", em oposição a todas as construções que flutuam no ar, aos achados fortuitos, à assunção de conceitos só em aparência demonstradas, às perguntas só aparentemente feitas e que são transmitidas com frequência ao longo das gerações como "problemas" 20

As reuniões dos grupos focais também foram gravadas em áudio, transcritas e cuidadosamente analisadas, a fim de identificar os pontos mais comuns e as afirmações semelhantes relacionadas à forma como os magistrados percebiam a sua própria formação e avaliação.

Algumas visitas foram realizadas a comarcas do interior, procurando desvelar o ser-juiz ali mesmo onde este exerce o seu labor, as suas atividades cotidianas, nas quais se encontra imerso.

O objetivo fundamental da pesquisa, com a coleta destes dados, foi compreender e sistematizar as falas dos depoentes, visando a melhoria qualitativa no processo de formação e avaliação de magistrados no Brasil.

Antes de participar da entrevista ou dos grupos focais, o magistrado era convidado a ler e assinar o Termo de Consentimento Livre e Esclarecido (TCLE), além de preencher um pequeno Questionário Sócio-Econômico, a partir do qual foi possível estratificar e revelar um maior detalhamento das características gerais da amostra.

Desde o início, os participantes estavam cientes dos principais riscos e benefícios que poderiam advir de sua participação na pesquisa. O principal risco, como apresentado no projeto de pesquisa enviado ao

20 HEIDEGGER, Martin. Ser e Tempo. Trad. Fausto Castilho. Campinas, SP: Editora da Unicamp; Petrópolis-RJ: Editora Vozes, 2012, p. 101. 
Comitê de Ética em Pesquisa era a dificuldade de contar com tempo disponível dos sujeitos para participar das entrevistas e dos grupos focais, além da complexidade que naturalmente envolveu a análise das falas dos depoentes e o principal desconforto para os participantes, desconforto este mencionado no TCLE, consistiu no fato das entrevistas e reuniões dos grupos focais serem gravadas em áudio, com alguns registros do pesquisador em diário de bordo.

Porém, os riscos foram minimizados com o compromisso do pesquisador e seus bolsistas colaboradores assumiram no sentido de somente utilizar os dados para fins da pesquisa, sem qualquer identificação nominal dos participantes, os quais participaram da pesquisa como voluntários, sem nenhuma contraprestação, vantagem ou pagamento de qualquer natureza.

Todos os participantes também foram informados de que, a qualquer momento, poderiam recusar a continuar participando da pesquisa e até retirar seu consentimento, sem que isto lhes trouxesse qualquer prejuízo.

Portanto, as informações obtidas e aqui apresentadas, seguindo as normas da ética científica, não permitem a identificação dos sujeitos participantes.

\subsection{Principais Achados da Pesquisa}

\subsubsection{Ausência de preparo adequado para o exercício da magistratura}

O fato da maioria dos entrevistados terem frequentado o curso de formação já exercendo as suas funções, sendo lotados nas comarcas do interior logo após a posse, sem qualquer orientação prévia ou acompanhamento específico para o exercício da judicatura, ainda aparece de forma muito forte nas falas dos sujeitos entrevistados, refletindo de modo geral, uma ausência de preparação adequada para exercer suas funções.

Embora não tenham tanta intensidade quanto nas falas dos juízes vitaliciados, os quais sequer tiveram a oportunidade de realizar o curso, por inexistente na sua época, os depoimentos dos atuais juízes substitutos, também compelidos, por força das circunstâncias, a tomar posse e entrar imediatamente em exercício em suas respectivas comarcas, são bastante contundentes no sentido de apontar a sensação e falta de preparo adequado para o exercício da magistratura.

A mera aprovação em concurso público, bastante concorrido e com várias etapas, é insuficiente para investir o magistrado neófito das competências, habilidades e atitudes indispensáveis a quem exerce o dificílimo ofício de julgar.

Por outras palavras, a instrumentalidade (Zeughaftigkeit) própria e necessária para o exercício da função judicatória deixou muito a desejar. Faltava-lhes exatamente a perspectiva maior do saber fazer e, por que não dizer, do saber ser. Munidos de um volume extraordinário de conhecimentos técnicos e muitas informações teóricas (saber), faltava-lhes a vivência e a experiência.

Antigamente, a situação parecia muito pior, quando não existia sequer a exigência de cursos de formação inicial para o vitaliciamento, o que se depreende das unidades de significado identificáveis nas falas de JV01, JV02, JV05, JV10, JGF02 e de vários outros. Para os juízes mais antigos, não havia a exigência legal do curso de formação inicial para o vitaliciamento. Eram simplesmente abandonados nas comarcas, entregues à sua própria sorte e sem nenhum acompanhamento, podendo ser vítimas de todo tipo de assédio político, econômico ou moral, estando sujeitos a cometer vários erros judiciários que somente uma orientação segura de um magistrado mais experiente poderia ajudá-los a evitar. 
A fala do magistrado JV1, um dos primeiros magistrados vitaliciados que se dispuseram a participar da pesquisa, é bem reveladora desta situação, de completo abandono dos novos juízes pelo tribunal, sem que houvesse qualquer política de formação, fosse ela inicial ou continuada:

Naquela época não existia. [...] Assim, naquela época nos causou muita surpresa porque você era 'jogado' na comarca. $\mathrm{O}$ tribunal [...] durante muito tempo nunca teve essa preparação para a formação dos juízes. E eu senti uma dificuldade muito grande porque eu assumi muito jovem, 24 anos. (JV01).

Em decorrência dessa falha na formação dos juízes, a mesma situação, de completa ausência de preparo para exercer a função de julgar, também se evidencia nas falas de JV02, JV05, JV10 e JGF02, sendo comum e mais frequente entre os juízes mais antigos, que não passavam por qualquer curso de formação.

Alguns destes juízes mais antigos, preocupados com este aspecto, acabaram exercendo importante atividade na Escola de Magistratura, na condição de juízes formadores, acompanhando o desenvolvimento dos módulos práticos do Curso de Formação Inicial de Juízes e, assim, podendo fazer pelos seus colegas aquilo que não foi feito em favor deles próprios, largados à sorte nas comarcas quando assumiram o cargo.

Convém observar que a exigência de frequência e aproveitamento em curso oficial de formação é relativamente recente, oriunda da Constituição Federal de 1988. Antes disto, poucas eram as iniciativas, muitas delas isoladas, que revelavam preocupação com a formação e o aperfeiçoamento de magistrados no Brasil, havendo mesmo uma mentalidade equivocada de alguns dirigentes dos tribunais, segundo a qual a mera aprovação no concurso ungiria os aprovados com a legitimidade de um saber incontestável, até mesmo concebendo como desnecessário qualquer tipo de curso para juízes que, já saídos dos bancos das faculdades de Direito, enfrentaram concurso para ingresso na magistratura no qual lograram aprovação.

A literatura relata muito bem este problema que, antes da exigência legal de obrigatoriedade do curso de formação, era recorrente nos tribunais brasileiros.

Aliás, este é um mito que precisa ainda ser desconstituído, o mito da sabedoria decorrente da aprovação em concurso público, como se esta aprovação por si só, garantisse a qualidade dos atos praticados no exercício da função e as habilidades, competências e atitudes de todos os aprovados, não somente em relação à categoria profissional dos magistrados, mas também em todas as outras, nas quais se exige atualização permanente e formação continuada.

Questionando a forma como foram recrutados, muitos magistrados substitutos entrevistados nesta pesquisa vislumbram a importância do curso de formação inicial de juízes, inclusive reconhecendo um imenso descompasso entre o conteúdo exigido para a aprovação nos concursos e o exigido pela prática cotidiana, descompasso que poderia ser diminuído pela oferta do curso de formação prévio ao exercício do cargo.

Neste sentido, as falas dos sujeitos em entrevistas e grupos focais, são denunciadoras de um descompasso entre o "saber" (exigido deles no concurso público) e o "saber fazer", cobrado pelo dia a dia da jurisdição. Vejamos como os sujeitos JGF05 e JGF02 caracterizam esta situação:

A formação e a avaliação dos juízes no Brasil deveria focar menos na teoria e mais na prática, explico: ao invés de concursos longos e estafantes, com perguntas dificílimas de teorias da moda, nada utilizadas na profissão, dever-se-ia fazer um concurso mais sucinto, mais objetivo e mesmo com maior número de aprovados. E aí, criar o gargalo para valer no estágio probatório, com um Curso de Formação completo, eliminatório, e avaliação contínua e rigorosa da atuação prática do novel magistrado (JGF05)

Infelizmente, acredito que a seleção de Magistrados no Brasil se dá de maneira inadequada e que não seleciona pessoas com base nas suas vocações. O processo seletivo chega a ser cruel, com diversas etapas, concorrência alta e mecanismos de avaliação que não necessariamente selecionam bons profissionais (JGF02)

Parece haver um visível despreparo humanístico dos novos magistrados, haja vista os concursos estarem muito voltados à cobrança de conteúdos muito pontuais ou específicos de determinadas áreas do Direito. Explora-se excessivamente a dimensão técnica da aprendizagem jurídica, cobrando especificidades raramen- 
te encontradas em processos reais que o magistrado terá de decidir, em detrimento do conteúdo técnico-humanístico ou mesmo humanístico mais amplo.

O concurso público, como processo de recrutamento, embora necessário para evitar práticas nefastas que atentem contra a moralidade ou a impessoalidade, acaba por não se revelar apto a selecionar os mais preparados ao exercício da função, mesmo considerando critérios técnico-jurídicos, haja vista privilegiar a capacidade de memorização em detrimento dos conteúdos humanísticos ou mesmo da capacidade de fundamentação, argumentação e raciocínio jurídico.

Para que não se acuse esta pesquisa de introduzir elementos extraídos da própria subjetividade do pesquisador, o que se observa são os próprios magistrados entrevistados reconhecendo esta necessidade de formação humanística, como se percebe nas falas de JV01 e JS15:

Então acho que essa preparação voltada para formação humanista ali é essencial, a questão psicológica, noções, aprofundamento do estudo da psicologia, da sociologia, da própria filosofia a gente precisa aprofundar mais o estudo nessas ciências aí. (JV01).

Eu acredito que ponto positivo seja o fato de o CNJ abrir essa parte humanística, sociológica, da relevância de sua decisão na sociedade, no aspecto econômico, do que você pode fazer para impulsionar a economia daquela cidade. Eu acho que quanto mais o Tribunal puder dar essa visão ampla de que aquela sentença não é só para aquela parte, mas é para um conjunto social inteiro, eu acho que abre a visão principalmente dos colegas que são mais jovens, que eu acredito que estão muito naquela do jurídico, do legalismo, dos princípios e acaba que você se distancia um pouco que o processo também é um contato humano. Eu acho que essa visão pode ser sempre aprimorada com mais tempo dedicado a esse tema. (JS17).

$\mathrm{O}$ apego às novidades legais e jurisprudenciais acaba fazendo com que o concurso funcione como uma espécie de estreitamento de visão, ao invés de oportunizar um alargamento dos horizontes. Mesmo quando se resolveu explorar conteúdos de formação humanística nos concursos, como recentemente aconteceu através das exigências da Resolução $n^{\circ} 75$, do CNJ, de 12 de maio de 2009, o que se verificou foi uma deformação do espírito original da proposta. Isto pode ser melhor compreendido pela análise das falas dos novos juízes entrevistados, que embora não pareçam discordar da necessidade de tais conhecimentos, questionam o modo como eles aparecem nas avaliações dos concursos, sem falar das críticas que já aparecem na literatura jurídica a este modelo cognitivista e tecnicista de recrutamento dos magistrados ${ }^{21}$.

A insistência dos depoentes sobre a necessidade de visão mais ampla de suas atividades revela a compreensão de que há um elemento humano envolvido no fazer judicante, o que exige o exercício da cura (Sorge) no seu espaço ôntico diante das inúmeras possibilidades que se apresentam na sua função de solucionar litígios. Para tanto, os depoentes sentem necessidade de estabelecer um relacionamento (Beżiehung) mais humano com aqueles que vão julgar, pois irão lidar com questões e problemáticas humanas as mais diversas.

Neste sentido, as falas dos sujeitos em entrevistas e grupos focais, são denunciadoras de um descompasso entre o "saber" exigido deles no concurso público e o "saber fazer", cobrado pelo dia a dia da jurisdição. Veja-se, por exemplo, como os sujeitos JGF05 e JGF02 caracterizam esta situação nos trechos já transcritos de suas falas. Este elemento também chegou a ser apontado por outros sujeitos da pesquisa.

O modelo de seleção por meio do concurso está tão aferrado às novidades legais e jurisprudenciais, que mesmo quando se resolveu, como recentemente aconteceu através das exigências da Resolução no 75, do CNJ, cobrar conteúdos de formação humanística nos concursos, o que se verificou foi uma deformação do

21 No Brasil, um dos maiores críticos deste processo de recrutamento tem sido o professor Luiz Lênio Streck, autor de obras importantíssimas nas quais questiona vários aspectos da fundamentação das decisões jurídicas e as distorções promovidas pela indústria dos concursos públicos, incentivadora e difusora de um "senso comum teórico" dos juristas brasileiros. Para conhecer melhor algumas de suas ideias sobre jurisdição, decisão e interpretação jurídica, recomenda-se: STRECK, Luiz Lenio. O que é isto - decido conforme minha consciência? $2^{a}$ edição revista e ampliada. Porto Alegre: Livraria do Advogado Editora, 2010 e STRECK, Luiz Lenio. Verdade e Consenso: constituição, hermenêutica e teorias discursivas. $4^{a}$ edição. São Paulo: Saraiva, 2011. 
espírito da proposta. Isto pode ser melhor compreendido pela análise das falas dos novos juízes entrevistados, que embora não pareçam discordar da necessidade de tais conhecimentos, questionam o modo como eles aparecem nas avaliações a que se submeteram para ingresso na carreira.

É importante ressaltar que a democratização do modelo judiciário latino-americano, após as ditaduras que assolaram os países do continente, poderia servir de parâmetro para exigir dos recrutados uma compreensão mais ampla de seu papel e dos problemas sociais com os quais se defrontarão, o que parece não ocorrer. Acerca disto, vale citar Mendes e Streck:

A Constituição de 1988 institucionalizou um modelo democrático de Poder Judiciário, para além de qualquer resquício daquilo que Eugênio Raul Zaffaroni (Poder Judiciário, cit., p. 102 e s.) chamou "modelo tecnoburocrático", que caracterizava os poderes judiciários da América Latina nos anos de autoritarismo. Com efeito, a Constituição do Estado Democrático de Direito proporciona o surgimento de uma nova magistratura, agora revestida de garantias formais e materiais, aptas a transformar os juízes em garantes do processo democrático, circunstância, aliás, repetida pelo constituinte brasileiro na parte em que trata do Ministério Público. ${ }^{22}$

Uma indagação desponta evidente após constatar que os concursos públicos para a magistratura continuam a privilegiar, no recrutamento dos candidatos, conhecimentos técnico-jurídicos em detrimento de uma formação mais ampla: estaremos criando as condições para que esta nova magistratura surja?

Muitos dos juízes vitaliciados entrevistados, entretanto, são oriundos de uma época autoritária, na qual não se exigia da magistratura este compromisso com a guarda das instituições democráticas e inexistia um modelo teórico-constitucional que respaldasse posturas menos exegéticas em relação às normas legais. Atualmente, despontam modelos hermenêuticos, argumentativos e metodologias de decisão mais consentâneas com o Estado Democrático de Direito. Sobre isto, convém citar mais uma vez Mendes e Streck:

Este "modelo" de juiz forjado no ancién regime passa, então, por uma transição. De uma Constituição sem qualquer perfil compromissório, a magistratura se encontra, após 5 de outubro de 1988, frente a frente com uma Constituição que alberga, em seu texto, um conjunto de "promessas incumpridas de modernidade". De todo modo, o processo de alteração do perfil da magistratura - fenômeno que pode ser estendido às demais funções que, de um modo ou de outro, estão ligadas às práticas jurídicas - ocorre lentamente, pela falta de uma nova teoria das fontes (veja-se, até hoje, as dificuldades para a compreensão da dicotomia texto-norma), pela falta de condições para a construção de uma nova teoria da norma, uma vez que a Constituição de 1988 seguiu o nítido perfil principiológico próprio das Constituições do segundo pós-guerra e, por último, pela fragilidade da teoria do direito até então existente, ainda refratária aos novos paradigmas epistemofenomenológicos, em especial, as teorias hermenêuticas e discursivas ${ }^{23}$.

Há ainda, portanto, dificuldades que persistem na formação desta nova magistratura, muitas delas oriundas da incompatibilidade entre a mentalidade autoritária que predominava no regime político anterior, da qual ainda há resquícios que se verificam nos dias de hoje, e o novo perfil da magistratura que se delineou a partir da Constituição de 1988.

O surgimento das escolas judiciais e de magistratura, notadamente após a criação da Escola Nacional de Formação e Aperfeiçoamento de Magistrados (ENFAM), colaborou para que se possa buscar uma formação compatível com estas novas demandas de uma sociedade plural e democrática, levando os magistrados a compreender o seu papel de agentes políticos, garantidores dos direitos fundamentais e concretizadores das promessas oriundas da Assembleia Nacional Constituinte.

22 CANOTILHO, J. J. Gomes; MENDES, Gilmar Ferreira; SARLET, Ingo Wolfgang e STRECK, Lênio. Comentários à Constituição do Brasil. São Paulo: Saraiva/Almedina, 2013, p, 1320.

23 CANOTILHO, J. J. Gomes; MENDES, Gilmar Ferreira; SARLET, Ingo Wolfgang e STRECK, Lênio. Comentários à Constituição do Brasil. São Paulo: Saraiva/Almedina, 2013, p, 1320. 


\subsubsection{Críticas ao atual modelo de recrutamento}

Apesar de recém-aprovados no concurso para o cargo de magistrado, alguns juízes entrevistados não pouparam críticas ao método de recrutamento, corroborando com suas falas muitas das críticas que também se encontram na literatura pesquisada acerca dos equívocos existentes. Neste sentido, o já citado depoimento de JGF02, durante a realização de um dos grupos focais é bem contundente:

Infelizmente, acredito que a seleção de Magistrados no Brasil se dá de maneira inadequada e que não seleciona pessoas com base nas suas vocações. O processo seletivo chega a ser cruel, com diversas etapas, concorrência alta e mecanismos de avaliação que não necessariamente selecionam bons profissionais (JGF02)

Instado pelo colega, no grupo focal, a debater esta questão, JGF03 concordou com as críticas feitas ao modelo de recrutamento e acrescentou que o concurso público para selecionar pessoas aptas a exercer o cargo de juiz acabou explorando e exigindo muitos conteúdos que, embora necessários para a aprovação do candidato, não seriam utilizados na prática forense:

Como já conversamos outrora, tenho que a forma de realização do concurso público das carreiras no Brasil não tem foco na afinidade, mas na capacidade de aglomerar conhecimento (...) Há muito ouvi de um (...) amigo, que estudou muito para passar e, depois que passou, não utilizou dez por cento do conhecimento acumulado (JFGF03)

Este descompasso que ainda subsiste no Brasil entre os conteúdos cobrados nas provas de concursos e aqueles necessários ao exercício profissional não acontece apenas em relação à magistratura, sendo vOz corrente entre os críticos dos sistemas de recrutamento a desnecessidade de alguns conteúdos exigidos dos candidatos a outros cargos públicos.

Evidentemente, confrontar esta realidade exigiria da Administração Pública, no âmbito dos três poderes do Estado, uma atuação mais eficaz, eficiente e efetiva na tomada de decisão quanto à contratação de empresas ou institutos encarregados de executar o concurso público. Não se concebe deixar a cargo de entes privados a seleção de servidores públicos, principalmente o recrutamento de agentes políticos do Estado, os quais desempenharão um papel tão importante na sociedade. Sem o estabelecimento de diretrizes fundamentais mínimas quanto às competências, habilidades e atitudes que devem estar presentes nos aprovados, as quais devem estar voltadas às especificidades daquela atividade a ser exercida, todo recrutamento será um mero exame e não pode se constituir em uma avaliação propriamente dita, que precisa alcançar aspectos mais amplos.

Como destaca Luckesi, há "conduta que se tornou habitual em nosso dia a dia escolar - confundir os atos de examinar com os de avaliar a aprendizagem como se fossem equivalentes" ${ }^{24}$.

No Brasil, a terceirização dos concursos públicos tem gerado distorções extremas que precisam ser objeto de correção de rumo. Embora se constitua importante mecanismo para garantia da impessoalidade e moralidade do certame, a terceirização sem especificação deste conteúdo mínimo de competências, habilidades e atitudes acaba levando as empresas e instituições especializadas em concurso a exigir nos exames dos candidatos conteúdos que em nada estão relacionados ao saber fazer daquela atividade específica para a qual estão selecionando candidatos.

Este descompasso entre o exigido nos exames e aquilo que é necessário para pensar juridicamente resolvendo problemas concretos da jurisdição sempre se revelou como um aspecto problemático dos concursos públicos. Warat detectou esta dificuldade entre os magistrados que participaram de seus seminários, nos seguintes termos:

Vivemos hoje um paradigma da modernidade jurídica muito elaborado em termos da verdade ou falsidade, mas cada vez mais humanamente atrasado: juízes despreparados para articular seus processos decisórios. Os juízes ainda não estão prontos para fazer do jurídico um processo de humanização.

24 LUCKESI, Carlos Cipriano. Avaliação da aprendizagem componente do ato pedagógico. São Paulo: Cortez, 2011 , p. 179. 
Atualmente, grande parte deles decidem com uma cabeça cheia de normas e cada dia mais atrofiada em termos de criatividade e articulação. Juízes cada vez mais mal informados, sem capacidade para organizar e muito menos transformar o conhecimento em sabedoria. As informações que chegam ao juiz não são mais que fragmentos do saber, não dispõem de nenhum princípio humanista de seleção, nenhuma pauta que lhes permita superar as estruturas de dependência simbólica. Os juízes começam em nossos seminários a se dar conta de que são dependentes, cheios de um saber fragmentado que serve exclusivamente para uso técnico. Um conhecimento que não pode ajudá-los na condução de suas próprias vidas, nem nas decisões dos conflitos dos outros ${ }^{25}$.

Apesar da terceirização desmedida dos concursos e da inexistência de parâmetros claros, estabelecidos pelos tribunais e escolas de magistratura sobre as competências, habilidades e atitudes que desejam ver privilegiadas no recrutamento dos magistrados, ainda é possível perceber que vários dos entrevistados não perderam de vista a dimensão da cura, do cuidado e preocupação com o outro. Neste sentido, o sintomático depoimento de JGF39, ao afirmar que o magistrado "tem que lembrar sempre o seguinte, se uma pessoa chegou ali a presença de um juiz, trouxe um processo, é porque tudo antes falhou", revelando que nem tudo está perdido nas possibilidades de uma educação judicial que contemple a dimensão pragmática, mas sem descurar a dimensão humanística.

\subsubsection{Sugestões para as Escolas de Magistratura}

Os entrevistados apresentaram inúmeras sugestões para que as Escolas de Magistratura aprimorem os cursos de formação e demais atividades realizadas por estes importantes centros de formação profissional.

O que ficou evidenciado, seja nas reuniões dos grupos focais, nas visitas às comarcas do interior do Estado ou mesmo nas entrevistas individuais com os magistrados é que, se houver oportunidade das escolas judiciais e de magistratura ouvir os juízes, destinatários imediatos de seus serviços, estabelecendo gestão democrática e participativa, além de contar com a almejada autonomia financeira para concretizar seus projetos, talvez possamos realmente aprimorar a formação e avaliação de magistrados.

Isto é o que pode ser percebido, tanto no depoimento dos entrevistados quanto na convivência direta com a realidade pesquisada.

Subdividimos as sugestões apresentadas pelos magistrados entrevistados em três grupos, a seguir apresentados, quais sejam: 2.2.3.1 Sugestões para melhorar cursos de formação de juízes; 2.2.3.2 Sugestões para melhorar os métodos de avaliação de juízes e 2.2.3.3 Sugestão de novas disciplinas ou de conteúdos a serem abordados.

\subsubsection{Sugestões para melhorar cursos de formação de juízes}

Uma das unidades de significado mais recorrentes nas falas dos magistrados entrevistados foi a dificuldade de realizar um curso de formação paralelamente às atividades judicantes, premidos duplamente por responsabilidades e prazos com as disciplinas do curso e com os processos que tramitavam em suas comarcas, considerando ainda o fato de que a ausência de juízes em quantidade suficiente nas comarcas levou muitos deles a assumir sua comarca e responder por outras tantas.

Neste sentido, a sugestão do magistrado JS04, no sentido de que fosse realizado um curso de iniciação à magistratura intensivo e com dedicação exclusiva dos cursistas, traduz muito bem o sentimento e a percepção do grupo de juízes substitutos entrevistados:

[...] eu reforço a necessidade de fazer um curso preparatório, um curso de iniciação à magistratura, intensivo, com dedicação exclusiva, com prejuízo ao exercício jurisdicional, para só assim, pegar esse

25 WARAT, Luis Alberto. Cidadania e Direitos Humanos. Revista da Escola da Magistratura do Estado de Rondônia. Ano 2004, no 2. Porto Velho, 2004, p. 101-2 
jurisdicionado (magistrado) já nomeado, já com exercício, pra colocar na comarca. Ele vai entrar um pouco mais preparado pra questão prática, desmistificar de muitas coisas, já com uma boa rede de trabalho com os colegas, uma boa rede de contato, troca de informações e experiências, troca até de modelos de peças e tudo, que é outra coisa bastante interessante (JS04)

Observa-se ainda a valorização dos contatos com os colegas e a troca de informações como fontes privilegiadas de aprendizagem, importante aspecto a ser considerado para o estabelecimento daquilo que o pedagogo Vigotsky denominava “zona de desenvolvimento proximal”. Esta interação entre os juízes recém-aprovados no concurso, durante o curso de formação, talvez seja um dos principais aspectos a ser observado para o aprimoramento destes cursos, não podendo ser ignorado pelas escolas de magistratura, como aprofundaremos em outro trabalho.

A mesma percepção de JS04 quanto à necessidade de um período de adaptação antes do exercício profissional, no qual o novo magistrado deveria realizar o curso de formação encontra-se na fala de JS15, que chega a sugerir uma espécie de estágio, no qual o novel juiz seria acompanhado por outro magistrado de carreira, mais experiente e a descentralização/interiorização das atividades da escola, inclusive com a melhoria das condições de oferta da EaD. Vejamos:

[...] o que eu penso é que dever-se-ia evitar o máximo possível essa coisa de colocar o magistrado pra atuar diretamente na comarca de início. Acho que deveria se pensar num período mínimo de uma espécie de estágio, com outro magistrado de carreira, já mais antigo pra você ter esse tipo de vivência [...] Além disso, uma outra sugestão seria que, no Estado do Ceará, não sei em outros, pensar em centros descentralizados desses polos, pra passar esse conhecimento, né? Interiorizar. Também precisa melhorar a Educação a Distância (JS15)

\subsubsection{Sugestões para melhorar os métodos de avaliação de juízes}

No que concerne aos métodos de avaliação de juízes, tanto para ingresso na carreira, quanto no curso de formação e nas promoções por antiguidade e merecimento, pude observar que alguns juízes substitutos simplesmente silenciaram a respeito, talvez por temer as consequências que poderiam advir de uma entrevista gravada, haja vista encontrarem-se em pleno curso de formação, quando são avaliados para fins de vitaliciamento.

Apesar dos receios geradores de certo silêncio entre os entrevistados neste ponto, ainda foi possível colher valiosos depoimentos que apontam para a necessidade de aprimorar e tornar mais transparentes e seguros os critérios de recrutamento e, principalmente, de avaliação na carreira.

Os depoimentos mais contundentes neste sentido vieram, exatamente, de magistrados vitaliciados, como é o caso de JV01, que criticou abertamente os atuais requisitos supostamente objetivos de promoção na carreira, ao afirmar:

Eu acho que houve um retrocesso [...] O conselho nacional ao editar aquela resolução que estabelece supostos requisitos objetivos [...] Mas hoje o que você percebe são mecanismos que os desembargadores utilizam certo, de desvio, descumprindo rigorosamente a resolução e estão colocando realmente quem eles querem [...] Então isso é muito ruim, o Ceará tem uma péssima...precisa realmente uma revisão nessa Resolução para realmente buscar o mérito no processo de ascensão de promoção” (JV01)

Para o entrevistado JS19, é imprescindível que o Tribunal leve em consideração os aspectos infraestruturais na avaliação de cada magistrado. Os juízes sentem-se excessivamente cobrados para atingir fins para os quais não foram fornecidos os meios. Muitas vezes, é exigido deles o cumprimento de metas nacionais, mas sem que sejam dadas condições para viabilizar que tais metas sejam alcançadas. Senão, vejamos o que afirma JS19:

Eu creio que a avaliação do magistrado... um ponto primordial é tomar como parâmetro também dessa avaliação a estrutura oferecida para o magistrado desenvolver seu trabalho. Eu acho crucial, porque o que a gente vê é só cobrança, mas não se vê a estrutura, quais os instrumentos que eu vou ter para chegar àquele fim que o Tribunal tá cobrando. Então, eu acho essencial nessa avaliação, colocar como 
critério ali a questão da estrutura, dos meios que aquele magistrado tem para desenvolver suas atividades. Tá produzindo isto? Certo. Mas o que ele tem na Secretaria? Quantos servidores? Então, eu acho isso fundamental, essa questão de você colocar intrinsecamente esse critério de estrutura (JS19)

Para situar melhor a fala do magistrado JS19, convém destacar que após a reforma administrativa, que acrescentou o princípio da eficiência no art. 37 da Constituição Federal, exigindo-o da Administração Pública nos três poderes do Estado, exigência esta reforçada pela reforma do Judiciário, que criou o Conselho Nacional de Justiça (CNJ), os juízes passaram a conviver com uma realidade bem diferente daquela a que estavam acostumados. $\mathrm{Na}$ atividade de fiscalização administrativa atribuída constitucionalmente ao CNJ, cada vez mais, ampliam-se as exigências no que concerne ao cumprimento de metas e ao atendimento a resoluções baixadas pelo órgão, numa espécie de accountability mensal.

Hoje, são exigidos relatórios estatísticos periódicos para o CNJ e para as corregedorias dos tribunais, o que toma boa parte do tempo de atividade dos magistrados, sobretudo daqueles que têm poucos servidores sob seu comando, realidade comum em muitas comarcas do interior do Estado do Ceará.

\subsubsection{Sugestões de novas disciplinas ou de conteúdos a serem abordados}

Durante as entrevistas, surgiram interessantes ideias que nos levam a perceber o tipo de dificuldade com a qual se depara o juiz neófito e que tipos de conteúdos eles julgariam necessários para aprimorar sua formação.

Neste sentido, o depoimento de JGF01 durante o grupo focal expressa a necessidade de uma disciplina que trabalhasse o lado psicológico e emocional do magistrado, submetido a uma exaustiva e estressante atividade intelectual, sem falar nas exigências sociais e dos órgãos fiscalizatórios:

Noto, em geral nos cursos de formação, a falta de uma disciplina que nos ensinasse/orientasse/ajudasse a equilibrar a mente, após um dia exaustivo de serviço (predominantemente intelectual). A cobrança da sociedade, do Tribunal que fazemos parte e do CNJ é grande e nós precisamos estar muito bem preparados física e mentalmente para prestarmos uma tutela jurisdicional efetiva (JGF01)

O magistrado, sob cujos ombros pesa o fardo de tomar a decisão final em processos que envolvem a vida, a liberdade e o patrimônio das pessoas, acaba muitas vezes sofrendo as agruras de decidir de modo absolutamente solitário. Por mais que passeiem nos autos do processo argumentos dos advogados das partes e pareceres ministeriais, a angústia da decisão é sempre sua e a responsabilidade por ela também. Vejam-se, apenas a título de exemplificação, as questões que envolvem a judicialização do direito à saúde no Brasil e as escolhas trágicas que por vezes precisam ser feitas pelo magistrado. A este respeito especificamente, como ressaltam Pottumati e Meirelles, observe-se que

A judicialização da saúde teve um papel relevante para romper a inércia do Estado, no que tange à concessão de novos medicamentos e tratamentos. Contudo, aos poucos esta participação do judiciário foi se tornando tão frequente que, a continuar no mesmo ritmo, o controle judicial de políticas públicas pode ocasionar um verdadeiro colapso no sistema ${ }^{26}$.

Decidir não é fácil e um mesmo problema tem de ser examinado sob diferentes ângulos. Este fardo impõe aos juízes muitas horas de leitura, exame atento das provas e a capacidade de fazer uma adequada compreensão do mundo vivido, a fim de valorá-las de forma correta. Sem este horizonte ampliado, suas decisões podem tornar-se desastrosas, com sérios impactos econômicos, políticos, sociais e ambientais para a sociedade na qual está inserido, afigurando-se teratológicos os seus atos decisórios.

Há necessidade de uma formação contínua, orientada por um planejamento pedagógico eficaz, além de um currículo nos cursos de formação que permita ao juiz ampliar sua circunvisão, muitas vezes estreitada pela formação acadêmica recebida nas faculdades, formação esta incapaz de preparar o bacharel, fazendo com que este chegue muitas vezes inseguro e inexperiente ao momento da tomada de decisão.

26 POTTUMATI, Eduardo Carlos e MEIRELLES, Jussara Maria Leal de. A Judicialização da Saúde e seus Desafios. Revista Opinião Jurídica, n 16 . Fortaleza: Unichristus, 2015, p. 142. 
Neste sentido os currículos dos cursos de formação de magistrados precisariam contemplar três dimensões que deveriam estar presentes em todo processo de aprendizagem: a dimensão do saber (conhecimento), a dimensão do saber fazer (prática/habilidade) e a dimensão do saber ser (atitude), o que lamentavelmente não tem ocorrido, pelo que se depreende das falas dos entrevistados. E o mais grave é que isto não tem ocorrido nem na faculdade (bacharelado) nem nos cursos de formação ofertados pelas escolas judiciais e de magistratura, os quais muitas vezes aderem à tentação do reprodutivismo e do tecnicismo, replicando as mesmas mazelas de que se ressente o ensino superior universitário na área jurídica.

Pelo que se observa, são imensos os desafios da educação judicial em nosso país, sendo necessário uma presença cada vez mais efetiva da Escola Nacional de Formação e Aperfeiçoamento de Magistrados (Enfam), não apenas no credenciamento dos cursos de formação inicial e aperfeiçoamento, mas durante todo o processo de planejamento e execução dos cursos, bem como em todas as etapas da avaliação dos magistrados.

Respeitada a autonomia e as especificidades de cada escola de magistratura, a Enfam tem procurado, desde a sua fundação, tratar diretrizes gerais a serem observadas nas atividades destinadas à formação e avaliação de magistrados. As escolas de magistratura, principalmente aquelas que não dispõem de estrutura, pessoal e orçamento próprio, sentem grande dificuldade em cumprir a maioria destas exigências, mas o papel regulamentador e instigador da Enfam, de instituição propulsora da educação judicial no Brasil, não pode ser ignorado. Tornando-se parceira das escolas de magistratura, que poderiam atuar em rede para minimizar suas fraquezas e maximizar suas forças, a Enfam pode perfeitamente cumprir sua missão constitucional e, ouvindo as próprias escolas, os magistrados e os servidores diretamente envolvidos nas atividades de formação, construir um futuro mais promissor para a educação judicial no Brasil.

Substituir os atuais modelos avaliativos na carreira, modelos eminentemente classificatórios e punitivos, por uma avaliação que promova a aprendizagem, inclusive organizacional/institucional é uma demanda que não pode ser negligenciada.

\subsubsection{Dificuldades em fazer o curso sem afastar-se das funções judicantes, ante a sobrecarga de trabalho}

Conciliar a sobrecarga de trabalho nas varas com a realização do curso de formação inicial não foi tarefa fácil para os magistrados depoentes. Muitos deles queixaram-se de dificuldades exatamente neste sentido. É o caso de JGF 10, JGF13 e JGF06:

Particularmente senti dificuldade de fazer o curso de formação, com a sobrecarga de trabalho. Penso que o juiz deve se afastar, com prejuízo da atividade jurisdicional, para se dedicar na íntegra à formação (JGF10)

O magistrado brasileiro, especialmente o juiz estadual, está extremamente sobrecarregado de trabalho que o ideal realmente é conjugar ensino a distância com presencial (JGF13)

[...] diversas disciplinas, me proporcionaram um conhecimento global do direito - ainda que superficialmente -, de maneira que, pelo menos em teoria, eu sabia, de antemão, a solução de boa parte das ações que tramitam nas minhas comarcas - o que me falta é tempo (JGF06)

Administrar o tempo parece ser uma dificuldade inerente ao exercício da atividade judicante, que mais do que qualquer outra função exige a formação continuada. O juiz lida diretamente com prazos e a sua desídia em relação ao gerenciamento dos prazos processuais pelo impulso oficial que precisa empregar na tramitação dos feitos sob julgamento pode representar danos irreversíveis à sociedade. Em muitos casos, a falta de celeridade ou a demora na prestação jurisdicional pode causar grave lesão ao direito das partes ou mesmo ser fatal para a prescrição do processo. Como destaca Marden, 
Tempo e processo mantêm uma relação simbiótica. Na medida em que o processo é composto por uma sequência de atos que se desenvolve no tempo, não há como se pensar em processo sem que isso implique pensar em qual prazo será estabelecido para a prática dos atos ou em quanto tempo o processo chegará até a sua conclusão ${ }^{27}$.

A formação inicial poderia ser feita em um curso com dedicação exclusiva, para propiciar também a melhor qualidade desta mesma formação. Não se concebe que a formação de magistrados seja apenas um arremedo, nem tampouco a sociedade pode esperar muito tempo para que os tribunais preparem juízes para assumir suas demandas, cada vez mais urgentes, sendo necessário encontrar um ponto de equilíbrio, verdadeiro meio-termo entre necessidade de formação e exercício da jurisdição. A sociedade precisa de mais juízes, mas é necessário que estes estejam suficiente e adequadamente capacitados para tomar suas decisões com segurança e justiça.

Em qualquer caso, há sempre a necessidade de planejamento, seja o planejamento administrativo por parte dos tribunais, para realizar concursos periodicamente e não deixar na vacância função tão essencial, seja o planejamento pedagógico por parte das escolas de magistratura.

Atualmente, mercê do surgimento do CNJ e de suas exigências cada vez maiores de profissionalização e transparência administrativa no Judiciário, os tribunais são cobrados na elaboração de planejamentos estratégicos participativos, a exemplo do que dispõe a Resolução no 198/2014, do CNJ que prevê o planejamento e a gestão estratégica do Judiciário para o período 2015-2020, estabelecendo em seu art. $6^{\circ}$ a exigência de participação democrática dos interessados na elaboração e discussão deste planejamento, nos seguintes termos:

Art. $6^{\circ}$. Os órgãos do Poder Judiciário devem promover a participação efetiva de magistrados de primeiro e segundo graus, ministros, serventuários e demais integrantes do sistema judiciário e das entidades de classe, na elaboração de suas propostas orçamentárias e de seus planos estratégicos, garantida a contribuição da sociedade.

Nesta perspectiva, abre-se um canal de diálogo permanente com todos aqueles interessados na qualidade e celeridade da prestação jurisdicional, mostrando-se alvissareira a possibilidade de participação democrática na administração dos tribunais, algo bem distante daquela imagem negativa que se tinha no passado, do Poder Judiciário como uma instância decisória hermética, impermeável à vontade ou aos anseios populares de justiça, por mais legítimos que estes fossem. Tal fato é salutar na efetivação do Estado Democrático de Direito do qual trata a Constituição Federal e garante a transparência maior nos atos praticados pela administração pública, haja vista submetê-la a uma crítica de todos os que dela participam ou são por ela afetados.

\subsubsection{Possibilidades de uso de metodologias de EaD e sua receptividade}

A possibilidade de uso das modernas tecnologias da informação e da comunicação para ministrar cursos de aperfeiçoamento utilizando a metodologia da educação a distância $(\mathrm{EaD})$ tem boa receptividade entre os novos magistrados, muitos deles bastante afeitos ao uso destas novas tecnologias, até pela idade média do grupo de entrevistados.

Já entre os magistrados vitaliciados mais antigos, embora não haja exatamente uma resistência a este tipo de metodologia de ensino a distância, são evidentes as dificuldades que apresentam quando se deparam com os desafios de um ambiente virtual de aprendizagem.

Nos módulos práticos de um dos cursos de formação inicial de juízes substitutos ministrado na Esmec, alguns módulos foram cursados pelos juízes nas próprias comarcas do interior. Tais magistrados foram acompanhados à distância por magistrados formadores mais experientes, os quais ficavam na capital, mas

27 MARDEN, Carlos. A Razoável Duração do Processo: o fenômeno temporal e o modelo constitucional processual. Curitiba: Juruá, 2015, p. 17. 
discutiam com os cursistas em fóruns virtuais, esclarecendo dúvidas e debatendo estudos de caso propostos pelo formador.

O ambiente virtual de aprendizagem utilizado foi o Moodle (Modular Object-Oriented Dynamic Learning Environment), tendo esta plataforma servido também para troca de experiências e para discutir sobre a formação e avaliação de magistrados.

Neste aspecto, os depoimentos de JGF12, JGF13 e JGF17, são ilustrativos do entusiasmo destes novos juízes com a educação a distância.

Acredito que o uso da tecnologia permite o estudo à distância, de modo que a metodologia do curso de formação adotado pela Esmec tem caráter inovador e fez com que os colegas pudessem dialogar sobre os casos propostos que podem vir a ocorrer na prática do exercício da judicatura. Além de permitir a troca de ideias, o acesso virtual dá maior liberdade quanto ao horário que a disciplina pode ser cursada, haja vista a rotina diária do Fórum. (JGF12)

$\mathrm{O}$ atual curso conseguiu mesclar essas duas modalidades de ensino (presencial e EaD), dentro da realidade atual do judiciário cearense, com enorme carência de magistrados, e a opção da Presidência do TJ/CE em nos confiar a judicatura logo de início. (JGF13)

A utilização da tecnologia na formação de juízes inaugura uma nova era no Poder Judiciário. A perspectiva de formação/atualização de juízes à distância - ao tempo em que comprometida com a prestação jurisdicional adequada - contempla a otimização de tempo e recursos financeiros tanto da instituição quanto do aluno (JGF17).

A educação a distância é uma tendência irreversível na formação continuada de profissionais e, em relação à formação de juízes, não será diferente. As exigências que recaem sobre os magistrados, no que concerne ao cumprimento de prazos e metas, aliadas ao pouco tempo de que dispõem para deslocar-se de suas comarcas até a sede da escola para acompanhar aulas presenciais, tornará uma necessidade estabelecer que parte da carga horária dos cursos seja na modalidade EaD, embora ainda haja restrições da Enfam quanto a sua utilização em cursos de formação inicial de juízes, admitida apenas em cursos de aperfeiçoamento para fins de vitaliciamento, promoção e de formação continuada na carreira da magistratura, pelo que se depreende da leitura de seus atos normativos.

Outra realidade que se descortina, paralela à expansão do ensino superior público de qualidade para o interior do Estado do Ceará, é a oferta de cursos presenciais para os juízes de determinada região, sem que os magistrados cursistas tenham de deslocar-se até Fortaleza para realizá-los. Para tanto, a possibilidade que se abre de formação inicial ou continuada nos próprios polos de aprendizagem no interior do Estado pode representar um marco significativo no desenvolvimento de atividades de ensino por parte da Esmec, que atualmente possui quatro polos de aprendizagem funcionando em diferentes comarcas do interior do Estado.

\subsubsection{Valorização da troca de experiência - a Zona de Desenvolvimento Proximal (ZDP)}

Vygotsky desenvolveu o importante conceito de "zona de desenvolvimento proximal", em língua inglesa representado pela sigla ZPD (zone of proximal development), o qual é apresentado do seguinte modo em suas obras:

Is the distance between the actual developmental as determined by independent problem solving ant the level of potential development as determined throught problem solving under adult guidance or in collaboration with more capable peers 28

Ela é a distância entre o nível de desenvolvimento real, que se costuma determinar através da solução independente de problemas, e o nível de desenvolvimento potencial, determinado através da solução de problemas sob a orientação de um adulto ou em colaboração com companheiros mais capazes ${ }^{29}$

28 VYGOTSKY, L. S. Mind in Society - The Development of Hight Psychological Processes. Cambridge MA: Harvard University Press, 1978, p. 86.

29 VIGOTSKY, Lev Semenovich. A Formação Social da Mente: o desenvolvimento dos processos psicológicos superiores. 
Por meio deste conceito, é possível afirmar que a interação entre sujeitos no processo de aprendizagem pode contribuir de modo significativo para que dificuldades de aprendizagem sejam superadas.

Na turma de magistrados do IV Curso de Formação Inicial de Juízes Substitutos, ofertado pela ESMEC, por força das circunstâncias de existirem alguns juízes do concurso anterior com vários anos de magistratura os quais ainda não haviam realizado o curso para obter vitaliciamento, a escola teve de ofertar o curso para estes juízes em conjunto com aqueles que tinham acabado de assumir suas funções judicantes. Isto permitiu valiosa troca de experiência entre eles, como se depreende do depoimento de JGF09, para o qual deveria ser utilizada inclusive a EaD pela escola para potencializar este objetivo de troca de experiências:

Arrisco-me a dizer que os aspectos mais proveitosos têm surgido a partir da troca de experiências entre colegas, do compartilhamento de boas práticas e boas ideias implementadas por outros magistrados, claro, sempre com a preocupação de adaptar-se a cada realidade distinta. Penso que a formação poderia explorar ainda mais esse aspecto, priorizando mais a troca de experiências, o contato direto e in loco com inciativas bem sucedidas de outros magistrados. Há que se pensar a formação como algo permanente, daí a importância da criação de espaços virtuais $(\mathrm{EaD})$ para essas trocas de experiências e compartilhamento de conhecimentos teóricos e práticos (...) exploram-se pouco as ferramentas de aprendizagem à distância, que podem em muito contribuir para uma cultura de constante intercâmbio de ideias entre os juízes. (JGF09).

Pode-se perceber, portanto, os aspectos heutagógicos envolvidos na aprendizagem de adultos em contato com colegas mais experientes, fenômeno que pode ser mais explorado para potencializar esta aprendizagem, sobretudo quando se trata de educação judicial.

\section{Considerações finais}

O objetivo deste artigo foi apresentar o resultado de pesquisa que avaliou o que pensam e como pensam os juízes acerca de sua própria formação e avaliação, aquilatando em que medida estes cursos de formação têm, de fato, cumprido o seu papel, colaborando para desenvolver o saber, o saber fazer e o saber ser, dimensões que não podem ser negligenciadas em qualquer processo formativo, mormente na educação judicial.

A pesquisa teve como referencial teórico a fenomenologia existencial de Heidegger e a metodologia aplicada consistiu na realização de entrevistas semiestruturadas, além de grupos focais com os magistrados, observação e aplicação de questionários para aferir o perfil geral dos participantes. Os resultados obtidos, decorrentes da identificação das unidades de significado contidas nos depoimentos e sua categorização, apontaram para a consolidação de tendências já observadas em pesquisas anteriores acerca do perfil dos novos juízes e trouxeram à tona outros aspectos problemáticos, como a falta de preparação adequada para o exercício da magistratura, decorrente das deficiências da formação recebida na graduação e do modelo de recrutamento, além das dificuldades em conciliar trabalho e formação. Surgiram, porém, valiosas e inéditas sugestões para a melhoria da qualidade dos cursos de formação de juízes e dos métodos de avaliação de magistrados, evidenciando-se a valorização da zona de desenvolvimento proximal e da experiência anterior dos magistrados.

Depois da realização desta pesquisa, é possível afirmar, a partir das falas dos cinquenta e cinco magistrados entrevistados e da participação de alguns deles nas oito reuniões de grupos focais realizadas na Escola Superior da Magistratura do Estado do Ceará (ESMEC), que a formação e avaliação de magistrados estaduais de carreira ainda precisa ser aprimorada a fim de atingir seus objetivos.

A educação jurídica formal no Brasil, bastante influenciada pelas nossas raízes coloniais, patrimonialistas e elitistas, começa com a necessidade de formar quadros para ocupar as funções de Estado, mais a serviço da coroa portuguesa do que com o propósito de aplicar o direito e realizar a justiça.

Trad. José Cipolla Neto, Luís Silveira Menna Barreto, Solange Castro Afeche. 7 ed. São Paulo: Martins Fontes, 2007 , p. 97. 
Com a proclamação da República, o bacharelismo passou a ocupar espaço de destaque, embora apenas os filhos de famílias ilustres tivessem acesso à educação formal e pudessem dar continuidade a seus estudos em nível de graduação.

Na história brasileira, a exclusão de consideráveis contingentes populacionais, sobretudo de negros, índios e mulheres do acesso à educação formal, permitiu durante muito tempo a reprodução de uma lógica de exclusão e distanciamento do Judiciário em relação às necessidades dos grupos sociais excluídos, ainda que Gilberto Freire ${ }^{30}$ identifique certa ascensão social do bacharel mestiço e mulato, ocorrida quando da decadência do patriarcado rural e do desenvolvimento urbano do país, propiciando naquela ocasião a inserção social de alguns elementos dos grupos excluídos, sobretudo do bacharel mulato.

Recentemente, a política de expansão do ensino superior, inicialmente com a ampliação da oferta de vagas nas instituições privadas, ocorrida na década de noventa e, mais recentemente, com a estipulação de políticas de inclusão das minorias (ações afirmativas e cotas) nas universidades, ainda não se refletiu na incorporação dos bacharéis beneficiários de tais políticas públicas nos quadros da magistratura. Dados do Censo Judiciário (2014) e da própria pesquisa revelam sub-representação destas minorias na atividade judicante.

Por outro lado, os novos magistrados continuam a se ressentir do tecnicismo e dogmatismo que ainda predominam no ensino jurídico ofertado pelas faculdades de Direito. Confrontados com as necessidades práticas de uma atuação mais pautada por conhecimentos, habilidades e atitudes que reflitam os três aspectos indissociáveis na atividade profissional: o saber, o saber fazer e o saber ser, acabam por deparar-se com dificuldades decorrentes da desconsideração destes três aspectos em sua formação, inclusive por parte das escolas de magistratura.

As múltiplas dimensões da atividade jurisdicional e administrativa não são suficientemente exploradas no recrutamento dos juízes, havendo uma ênfase exclusiva na exigência de domínio de aspectos conteudísticos (cognitivos), pouco ou quase nada examinando os candidatos em relação aos aspectos emocionais ou atitudinais (psicológicos).

A avaliação do candidato à magistratura no que concerne a seu equilíbrio psicológico e a sua aptidão para tomada de decisões céleres é uma necessidade que contrasta com a realização de concursos que não exploram adequadamente estes aspectos, limitando-se a exigir o conhecimento das mais recentes alterações legais e jurisprudenciais, a despeito do que já dispõe a Resolução no 75 do Conselho Nacional de Justiça (CNJ) acerca da necessidade de o concurso explorar conteúdos de formação humanística.

Embora saibamos da necessidade de equilíbrio emocional e formação humanística mais ampla para exercer o cargo de juiz, do qual se exigem, atualmente, também conhecimentos gerenciais, mormente de gestão de pessoas e gestão de processos, estes requisitos são completamente negligenciados, tanto na graduação quanto no concurso a que se submeteram.

Os novos magistrados reconhecem as dificuldades decorrentes da formação deficiente que receberam e, embora enalteçam o concurso público como critério adequado, republicano e impessoal de recrutamento, compreendem claramente a incapacidade de se identificar e eliminar, durante os certames, perfis psicológicos inadequados para o exercício da magistratura.

Tanto os juízes vitaliciados quanto os juízes substitutos entrevistados destacam as dificuldades enfrentadas no início da carreira, reflexos da ausência de um estágio de prática ou residência judicial, atividade na qual os juízes neófitos fossem acompanhados e supervisionados por magistrados mais experientes.

A necessidade de enviar os juízes imediatamente para as comarcas logo após a aprovação no concurso torna dificultosa a tarefa das Escolas da Magistratura. Ficam os juízes divididos entre as exigências do cur-

30 Cf. FREIRE, Gilberto. Sobrados e Mucambos: decadência do patriarcado rural e desenvolvimento urbano. $5^{a}$ edição. Rio de Janeiro: José Olimpio, Brasília: INL, 1977. 
so e as atividades profissionais nas comarcas, sendo difícil realizar o curso de formação com qualidade e conciliá-lo com as atividades profissionais. Neste sentido, muitos dos entrevistados opinaram pela realização do referido estágio, na capital ou mesmo em comarcas de entrância final, antes do exercício das funções judicantes e administrativas em suas próprias comarcas.

Ademais, a ausência de determinados conteúdos mais práticos e humanísticos no curso de formação inicial foi sentida pelos juízes substitutos e destacada pelos entrevistados, os quais enfatizaram também o quanto seria interessante a maior utilização de metodologias ativas de aprendizagem, com cada professor ou formador propondo estudos de casos e atividades que tivessem relação direta com os conhecimentos, habilidades e atitudes exigidos pela atividade profissional nas comarcas.

Os juízes, entretanto, reconheceram a importância do curso de formação inicial como espaço de interação e troca de experiência com os colegas, principalmente com aqueles que contavam com mais tempo na magistratura, bem como com os juízes formadores, evidenciando-se aqui o conceito de zona de desenvolvimento proximal, desenvolvido por Vigotsky.

Além do mais, mostram-se receptivos ao uso das modernas tecnologias da informação e da comunicação e propõem às Escola da Magistraturas uma intensificação na utilização da metodologia de ensino a distância (EaD) como forma de alcançar suas necessidades de formação continuada.

Do ponto de vista pedagógico, os magistrados entrevistados em sua grande maioria revelaram-se abertos a uma compreensão mais ampla do Direito, reconhecem que o concurso que fizeram e a formação que receberam na graduação não colaborou para ampliar seus horizontes, antes os estreitou devido ao direcionamento específico que os levou a explorar muito mais aspectos de atualidade legal e jurisprudencial do que seu senso de julgamento e tomada de decisão.

Sob o aspecto político, denunciam a necessidade de democratização interna do Poder Judiciário, ressentem-se da falta de legitimidade dos dirigentes do Tribunal, escolhidos sem a sua participação e vislumbram na mudança desta perspectiva um caminho para a transparência e garantia de sua independência. Este caminho conduziria também ao estabelecimento de critérios mais objetivos de avaliação na carreira, critérios que dependam menos da afinidade do avaliado com quem o avalia ou de outras injunções de natureza política.

Muitos dos magistrados entrevistados sentem-se excessivamente cobrados pela sociedade e pelos órgãos correicionais, especialmente pelo Conselho Nacional de Justiça (CNJ) e esforçam-se por atender as suas metas e exigências, mesmo diante de dificuldades estruturais e de pessoal.

As escolas da magistratura, surgidas no Brasil como resultado do movimento associativista dos juízes, muitas vezes não conseguem atender a contento a demanda de formação inicial e continuada de juízes. A ausência de dotação orçamentária própria ou de sua execução, a inexistência de corpo docente próprio, a não-oferta de curso de formação de formadores, a baixa profissionalização dos servidores administrativos e a falta de continuidade administrativa são alguns dos fatores que acabam dificultando pensar as escolas de magistratura como espaços de formação e qualificação continuada, inviabilizando inclusive o planejamento educacional, o que se reflete diretamente na qualidade dos serviços prestados por estas instituições.

Nas sugestões das falas dos juízes entrevistados, evidenciam-se aspectos que não devem ser negligenciados pelas escolas de magistratura, dos quais destacaria: a valorização das dimensões técnica, humanística e técnico-humanista da atividade judicante durante o percurso formativo, a necessidade de refletir séria e criticamente sobre o atual modelo de recrutamento de juízes, a importância de explorar na educação judicial a construção da autoimagem do Juiz e sua representação, a possibilidade do magistrado afastar-se completamente das funções judicantes, para dedicar-se exclusivamente à formação, a ampliação das possibilidades de uso de metodologias de EaD e o redimensionamento dos cursos, com a valorização curricular da troca de experiência e contatos com colegas mais experientes. 


\section{REFERÊNCIAS}

BANCO Internacional para Reconstrução e Desenvolvimento/Banco Mundial. O Setor Judiciário na América Latina e no Caribe: elementos para a reforma. Nova York/ Washington, $1^{a}$ edição, junho de 1996. Disponível em <http://www.anamatra.org.br/uploads/document/00003439.pdf>

BÖTTCHER, Carlos Alexandre. História da Magistratura: o pretor no Direito Romano. São Paulo: LTCE Editora, 2011.

BRASIL. Conselho Nacional de Justiça (CNJ). Censo Judiciário 2014. Disponível em < http://www.cnj. jus.br/images/dpj/CensoJudiciario.final.pdf>

BRASIL. Superior Tribunal de Justiça (STJ). Bibliografia Básica para o Ensino e Pesquisa nas Escolas de Magistratura. Brasília: ENFAM, 2008.

CANOTILHO, J. J. Gomes; MENDES, Gilmar Ferreira; SARLET, Ingo Wolfgang e STRECK, Lênio. Comentários à Constituição do Brasil. São Paulo: Saraiva/Almedina, 2013.

FREIRE, Gilberto. Sobrados e Mucambos: decadência do patriarcado rural e desenvolvimento urbano. $5^{\mathrm{a}}$ edição. Rio de Janeiro: José Olimpio, Brasília: INL, 1977.

GRAU, Eros Roberto. Por que tenho medo dos juízes: a intepretação/aplicação do direito e os princípios. $\sigma^{a}$ edição refundida do Ensaio e Discurso sobre a Intepretação/Aplicação do Direito. Malheiros: São Paulo, 2014.

HEIDEGGER, Martin. Ser e Tempo. Trad. Fausto Castilho. Campinas, SP: Editora da Unicamp; Petrópolis-RJ: Editora Vozes, 2012.

IOJT. Judicial Education and Training: Jornal of the International Organization for Judicial Training. Austrália: National Center for State Courts (NCSC), 2015.

LEAL, Rogério Gesta. Impactos Econômicos e Sociais das Decisões Judiciais: aspectos introdutórios. Brasília: Escola Nacional de Formação e Aperfeiçoamento de Magistrados (ENFAM), 2010.

LEITE, Raimundo Hélio. Aperfeiçoamento e Especialização: o esperado e o alcançado na visão dos alunos que frequentaram os cursos da Escola da Magistratura do Ceará, nos anos de 1995 a 2002. Tese de Doutorado. Fortaleza: UFC, 2004.

LUCKESI, Cipriano Carlos. Avaliação da Aprendizagem: componente do ato pedagógico. São Paulo: Cortez, 2011.

MARDEN, Carlos. A Razoável Duração do Processo: o fenômeno temporal e o modelo constitucional processual. Curitiba: Juruá, 2015.

PIRAGIBE, Marcelo. Equilíbrio entre influência e independência na formação judiciária in IOJT. Anais da 7th International Conference on the Training of the Judiciary. Recife, 2015.

PIRAGIBE, Marcelo. Imparcialidade Judicial: direito fundamental implícito - implicações filosóficas, sociológicas e dificuldades práticas no exercício da jurisdição. Saarbrücken: Verlag Editora, 2015.

POTTTUMATI, Eduardo Carlos e MEIRELLES, Jussara Maria Leal de. A Judicialização da Saúde e seus Desafios. Revista Opinião Jurídica, no ${ }^{\circ}$. Fortaleza: Unichristus, 2015.

RANGEL. Ruy (Coord.). Ser Juiz Hoje. Coimbra: Almedina, 2008.

RIAEJ. NCR 1000:2011. Escuela de Estudios Judiciales. "Formación para la Justicia y la Paz". Acreditación Internacional Norma de Calidad. Disponível em < http://www.oj.gob.gt/uci/images/convocatorias/Metodologia_educativa_uci_2013/proyecto_educativo_institucional_2_junio_2014.pdf> 
SADEK, Maria Tereza; BENETI, Sidnei Agostinho e FALCÃO, Joaquim. Magistrados: uma imagem em movimento. Rio de Janeiro: Editora FGV, 2006.

STRECK, Luiz Lenio. O que é isto - decido conforme minha consciência? $2^{a}$ edição revista e ampliada. Porto Alegre: Livraria do Advogado Editora, 2010.

STRECK, Luiz Lenio. Verdade e Consenso: constituição, hermenêutica e teorias discursivas. $4^{\mathrm{a}}$ edição. São Paulo: Saraiva, 2011.

VIANNA, Luiz Werneck. Corpo e Alma da Magistratura Brasileira. $3^{a}$ edição. Rio de Janeiro: Revan,1997.

VIGOTSKY, Lev Semenovich. A Formação Social da Mente: o desenvolvimento dos processos psicológicos superiores. Trad. José Cipolla Neto, Luís Silveira Menna Barreto, Solange Castro Afeche. 7 ed. São Paulo: Martins Fontes, 2007.

VYGOTSKY, L. S. Mind in Society - The Development of Hight Psychological Processes. Cambridge MA: Harvard University Press, 1978.

WARAT, Luís Alberto. Cidadania e Direitos Humanos. Revista da Escola da Magistratura do Estado de Rondônia. Ano 2004, no 2. Porto Velho, 2004. 


\section{REVISTA BRASILEIRA DE POLÍTICAS PÚBLICAS BRAZILIAN JOURNAL OF PUBLIC POLICY}
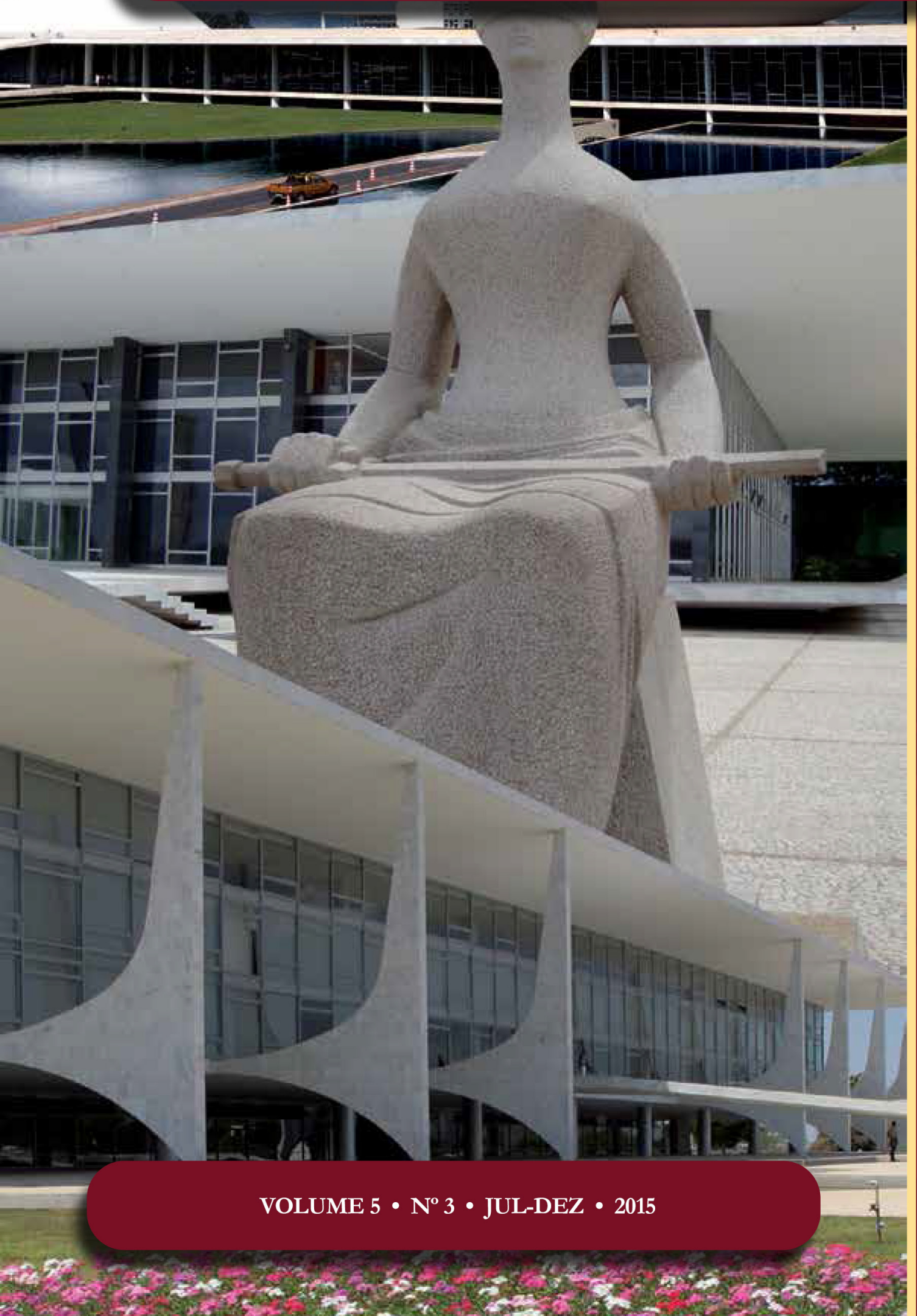

\section{Resenhas}

Simpler: the future of government, de Cass Sustein 


\title{
Simpler: the future of government, de Cass Sustein*
}

\author{
Veyzon Campos Muniz**
}

\section{Resumo}

A presente recensão constitui uma síntese dos principais pontos da obra Simpler: the future of government de Cass R. Sunstein. Nesse sentir, confere-se ênfase à exposição sintética dos argumentos trazidos pelo autor em sua defesa de procedimentos regulatórios mais simples. Por fim, assevera-se a contribuição científica da obra na afirmação do bem-estar do cidadão como elemento central das relações regulatórias.

Palavras-chave: Direito. Administração Pública. Regulação.

\section{Abstract}

This book review constitutes a synthesis of the main points of Cass R. Sunstein's Simpler: the future of government. In this sense, it gives emphasis to the summary of the arguments brought by the author in his defense of simpler regulatory procedures. Lastly, it asserts to relevant scientific contribution of the book on affirmation of citizens' welfare as a central element of regulatory relations.

Keywords: Law. Public Administration. Regulation.

I - Cass R. Sunstein é Professor na Universidade de Harvard, onde é responsável pelo Programa de Economia Comportamental e Políticas Públicas na Escola de Direito. Atua nas áreas de direito constitucional, direito administrativo e economia aplicada, ele é autor de diversas obras de grande vendagem e notável expressão acadêmico-científica, tais como: The Parcial Constitution (1993), Republic.com (2001), Risk and Reason (2002), The Second Bill of Rights (2004) e Nudge: Improving Decisoins about Health, Wealth and Happiness (com Richard H. Thaler, 2008).

Sunstein, entre os anos de 2009 e 2012, foi diretor do Office of Information

* Recebido em 09/06/2015 Aprovado em 20/09/2015

** Doutorando junto ao Programa de Doutoramento em Direito Público - Estado Social, Constituição e Pobreza do Instituto Jurídico da Universidade de Coimbra (Portugal). Mestre em Direito, com voto de distinção e louvor, e bacharel laureado em Ciências Jurídicas e Sociais pela PUCRS. Advogado. Contato: veyzon_muniz@yahoo.com.br and Regulatoru Affairs - OIRA, o Gabinete de Informação e Assuntos Regulatórios da Casa Branca, experiência que deu origem a Simpler: the future of government (2013). Nesse livro, ele compartilha as lições decorrentes do período em que esteve a serviço da gestão de Barack Obama, conduzindo e avaliando políticas públicas implementadas pelo governo norte-americano.

II - A obra recensionada tem por escopo delinear que o futuro de um governo corresponde a sua capacidade de tornar suas escolhas públicas mais simples. O autor é propositivo ao afirmar que os governantes devem "fazer as coisas mais simples". Nessa perspectiva, aduz que gestores públicos 
precisam aperfeiçoar suas decisões, práticas e escolhas, sob o signo da eliminação da "complexidade desnecessária". A tese central de Simpler pode, assim, ser sintetizada na máxima: "a simplicidade é amigável, a complexidade não".

Desde sua exposição introdutória, Sunstein retoma as ideias de nudge e arquitetura de decisões (explicitadas em suas obras anteriores $)^{1}$ para, assim, demonstrar quais foram as políticas que ele auxiliou a colocar em prática junto à administração Obama. Destacam-se então: esforços criativos para facilitar a escolha das pessoas, permitindo-lhes o acesso à universidade, a poupança para a aposentadoria, o recebimento de uma boa alimentação na escola e a obtenção de cobertura de saúde; dever de informação e publicidade, concebida para a proteção de estudantes, consumidores e investidores, garantindo-lhes segurança nas relações; ênfase na liberdade de escolha, promovendo uma regulação que maximizasse a liberdade; formas de colaboração público-privada destinadas a reduzir danos causados pelo tabaco, por distrações ao volante e pela obesidade; atenção especial na análise de custos e benefícios, sublinhando que os benefícios devem justificar os custos; ênfase na importância da dignidade humana, sobretudo, para reduzir o nível de violações em prisão e proibir a discriminação em razão de deficiência e orientação sexual; análise retrospectiva das normas existentes com vista a eliminar ou racionalizar centenas de obrigações atualmente desnecessárias; e esforços feitos para promover a cooperação internacional em matéria de regulação, eliminando divergências desnecessárias sobre as obrigações transfronteiriças.

No que se refere, especificamente, ao âmbito regulatório, propõe-se a valoração crítica do que funcionou (e o que não funcionou) nas tomadas de decisão passadas. Nesse sentido, indicam-se dois aspectos a serem observados: a análise cuidadosa de custos e benefícios dos atos regulatórios e o constante exame das normas em vigor. Defende-se que as políticas públicas sejam realizadas sob novo enfoque, isto é, que o "trabalho" do governo corresponda à geração de automatismos com fulcro na simplicidade. Desse modo, produtos e serviços públicos passam a ser identificados de modo natural e intuitivo pelos cidadãos destinatários.

O fundamento da tese de Sunstein é a redução dos custos inerentes a uma atividade regulatória excessiva. A simplicidade, nesses termos, seria efetiva com base na utilização eficiente da discricionariedade e da adoção de regras claras. A obra defende veementemente que, para os usuários das políticas públicas, os atos regulatórios devem ser simples e intuitivamente fáceis de ser internalizados. Logo, no futuro, almejado pelo autor, o governo, independentemente do seu tamanho, deverá ser muito mais simples na condução de sua atividade normativa.

III - No primeiro capítulo da obra, o autor questiona se a regulação é algo se deva evitar, indicando que não pode a regulação obstaculizar o crescimento econômico e a criação de emprego, sob pena de tornar-se prejudicial. O que vem, no segundo capítulo, ao encontro da explicitação do sistema dual (automático/ reflexivo) pela qual o ser humano procede em suas escolhas habituais, possibilitando o juízo crítico acerca da pertinência de atos regulatórios e políticas públicas. Entretanto, no terceiro capítulo, registra que a diversidade de juízos privados acerca da aplicação de certas políticas é irrelevante para sua implementação. A escolha pública deve ser orientada de modo eficaz. Em termos de regulação, a informação constitui mecanismo de regulação barato que pode ter grande impacto na integração entre o que o governo e os governados esperam acerca em matéria de bem-estar, como se nota no quarto capítulo. Assim, no quinto capítulo, indica-se que o Estado deve garantir, na medida do possível, que os cidadãos desenvolvam o sistema mental automático de modo rápido e fácil, no sentido de tomarem decisões privadas melhores.

Trazendo como exemplos medidas de visibilidade sobre a nocividade de certos produtos e serviços (tais como: identificação e advertências em cigarros, impostos sobre o álcool, campanha contra a obesidade infantil), no sexto capítulo da obra, o autor é pragmático ao pontuar que se o objetivo de uma ação consiste em

1 A saber, o primeiro conceito se refere aos impulsos e vieses que afetam a liberdade de escolha das pessoas e, por esse motivo, têm a capacidade de torná-las mais saudáveis, mais ricas e mais felizes. E o segundo, ao seu turno, corresponde ao ambiente social no qual as decisões são tomadas e as escolhas são feitas. 
salvar vidas ou economizar dinheiro, a melhor opção é o estabelecimento da parceria público-privada focada em diretrizes concretas, com a minimização ou mesmo a exclusão da regulação. A regulação analítica, abordada nos capítulos seguintes (sétimo e oitavo), é justamente o tipo de escolha pública que Sunstein defende que seja obsoleta. Para se regular uma determinada matéria, nesse sentido, não importaria predisposições e intuições de reguladores ou do próprio setor regulado. A regulação, assim, dependeria essencialmente da análise de custos e benefícios, balizada na simetria de informações e na ciência retrospectiva de normas e ações estatais.

Cumpre referir que Sunstein, antes de dirigir a OIRA, já defendia um controle político das agências reguladoras, a partir da atuação complementar e simultânea dos três poderes sobre elas, sem suprimir, contudo, a sua flexibilidade, especialização e autonomia. ${ }^{2}$ Em sua experiência junto ao Executivo norte-americano, o autor promoveu processo de simplificação de rotinas dessas agências, incluindo o uso de linguagem mais simples, a redução na burocracia, a adoção de resumos legíveis de regras complexas e a eliminação de exigências injustificadas. De fato, ele consolidou sua crítica ao que denomina, no penúltimo capítulo da obra, paternalismo estatal, advogando pela ideia de que o Estado não pode cometer erros emocionais em suas previsões e ações. Tal doutrina ensejaria impacto negativo sobre o bem-estar dos cidadãos, de sua autonomia pessoal e também sobre o mercado e a livre concorrência.

Simpler encerra sua reflexão com uma proposta de simplificação da arquitetura de decisões, afirmando que o setor público deve observar as experiências bem-sucedidas de simplificação de processos do setor privado, grifa-se que: uma boa regulação opera em conjunto com as normas sociais ajudando a salvar vidas e economizar dinheiro, gerando maior cumprimento das leis. Às vežes isso acontece sem qualquer regulação. A parceria público-privada, graças à criatividade do setor privado, pode ser a melhor e mais simples abordagem. [...] Se queremos melhorar em relação à obesidade ou a distrações ao volante [ou qualquer outra demanda social] isso ocorrerá graças a boas normas, uma arquitetura de decisão inteligente e a colaboração público-privada. ${ }^{3}$

Em epílogo, o autor sintetiza as seguintes lições: a) a análise de custos e benefícios, mesmo não sendo simples por si só, possibilita processo de simplificação, sobremaneira, pelo fato de os nudges oferecerem grandes benefícios à tomada de decisão, sem impor custos elevados; b) o serviço e os servidores públicos, sobretudo, aqueles que redigem as normas, devem se orientar pelo sistema mental reflexivo e reduzir a pressão do sistema automático dos cidadãos; e c) uma maior simplificação das normas favorece o entendimento da população acerca da informação prestada pela autoridade pública, estabelecendo-se um devido processo regulador. Por conseguinte, finaliza aduzindo que aqueles que têm o privilégio de servir o povo norte-americano deveriam prestar muita atenção sobre aqueles que têm privilégio de servir.

Sunstein, em derradeiro, apresenta, como apêndice à obra, a Ordem Executiva no 13563, de 18 de janeiro de 2011, pelo qual o governo de Barack Obama sistematizou princípios à ordem regulatória. A proteção à saúde pública, ao bem-estar, à segurança e ao meio ambiente, a promoção do crescimento econômico, da inovação, da competitividade e a criação de empregos são alçados a objetivos da atividade regulatória, deve ser baseada no melhor conhecimento científico disponível, permitir a participação popular e dialogar com agentes privados. Afirma-se, nesse sentido, a busca pela previsibilidade e a redução de incertezas, reconhecendo a dificuldade, mas também a necessidade de se determinar custos e benefícios nas relações regulatórias.

IV - O modelo de Administração Pública defendido em Simpler contribui indubitavelmente para a afirmação do cidadão como destinatário essencial de políticas públicas, apresentando, de modo contundente, a noção de simplicidade enquanto redução de custos e aumento de qualidade. Ao fazer isso, com o auxílio das "cutucadas", que buscam melhorar as escolhas individuais, Sunstein justifica, com veemência, por que e

2 Como se depreende de: SUNSTEIN, Cass R. Constitucionalismo após o New Deal. In: STIGLER, G. J. (Coord.). Regulação econômica e democracia: o debate norte-americano. São Paulo: 34, 2004. p. 131-242.

3 Tradução nossa. SUNSTEIN, Cass R. Simpler: The Future of Governmet. Nova York: Simon \& Schuster, 2013. p. 222. 
em que medida a sua passagem pela OIRA foi relevante para a efetividade de uma regulação mais inteligente nos Estados Unidos.

Filiando-se ao modelo proposto pela Organização para a Cooperação e Desenvolvimento Econômico ${ }^{4}$, a defesa de uma necessária análise de impacto regulatório é apresentada como instrumento fundamental para mensurar benefícios, custos e efeitos prováveis de uma regulação específica, sendo assim, um instrumento analítico indispensável à arquitetura de escolhas do gestor público. Sunstein, sem dúvidas, agrega a sua densa bibliografia, viés diferenciado pelo qual sua experiência prática indica novas perspectivas para a Administração Pública e sua atividade normativa. 


\section{Normas Editoriais}

1. Serão aceitas colaborações inéditas e a publicação de um artigo está condicionada à sua adequação às normas editoriais, e seu simples recebimento desobriga a sua publicação. A revista Prismas: Direito, Políticas Públicas e Mundialização classificará as colaborações de acordo com as seguintes seções:

1.1 Artigos: compreende textos que contenham relatos completos de estudos ou pesquisas concluídas, matérias de caráter opinativo, revisões da literatura e colaborações assemelhadas.

1.2 Resenhas: compreende análises críticas de livros, de periódicos recentemente publicados, dissertações e teses.

2. Excepcionalmente, a equipe editorial poderá aceitar a submissão de trabalhos que já tenham sido publicados e caso isso ocorra, serão submetidos ao mesmo processo de avaliação pelos pares que aqueles inéditos. $\mathrm{O}$ autor deverá apresentar autorização por escrito do editor da revista na qual seu trabalho tenha sido originalmente publicado, acompanhado de cópia do mesmo.

3. O processo de avaliação dos artigos e resenhas compreende duas fases: a primeira destinada à análise da adequação do trabalho à linha editorial da revista (Equipe Editorial) e a segunda referente à avaliação do conteúdo e qualidade dos trabalhos. Esta segunda fase é realizada mediante o processo de avaliação pelos pares, ou seja, os artigos serão submetidos à aprovação de no mínimo 2 pareceristas adhoc.

4. Os trabalhos serão enviados para a avaliação sem a identificação de autoria

5. Os trabalhos devem ser enviados no seguinte padrão:

$1^{a}$ Página: Começar com o título do título do trabalho, seguido do texto. Não inseriro nome dos autores ou outros elementos queidentifiquem a autoria. A autoria do artigo e a qualificação dos autores são inseridas nos campos específicos do formulário eletrônico. O objetivo aqui é garantir uma avaliação cega por pares. Os textos deverão ser digitados em Arial 12, espaço 1,5 margem de 2,5 $\mathrm{cm}$, numeração arábica das páginas no ângulo superior direito, em programa compatível com o Word para Windows.

Título do trabalho: o título deve ser breve e suficientemente específico e descritivo para representar o conteúdo do texto e deverá ter a sua tradução para o inglês.

Resumo: em todos os artigos submetidos deve ser incluído um resumo informativo com o máximo de 250 palavras e espaço entre linhas simples. O resumo deve ser estruturado com as seguintes informações:

Objetivo do artigo (obrigatório);

Metodologia (obrigatório);

Conclusões (obrigatório);

Limitações da pesquisa e suas implicações (se aplicável);

Limitações práticas (se aplicável)

Originalidade ou valor (obrigatório); 
A evolução da comunicação científica e da transmissão de conhecimentos possibilitou ao UniCEUB a criação de meios para o intercâmbio de idéias entre pares e a disseminação de informações.

As novas tecnologias da informação produzem sensíveis alterações nos processos de comunicação científica. Atualmente, a editoração das publicações acadêmicas do UniCEUB é informatizada em todas as suas etapas, com a utilização da plataforma SEER, Sistema de Editoração Eletrônico de Revistas. A aplicação do SEER permitiu acrescentar, no processo editorial, a avaliação dos pareceristas ad hoc e deu aos membros dos comitês editoriais e aos editores condições para consolidar a produção científica no UniCEUB e difundi-la por meio dos periódicos acadêmicos em mídia impressa e eletrônica.

Todas as edições das publicações científicas do UniCEUB estão disponíveis no site www.publicacoesacademicas.uniceub.br, com infraestrutura para acesso livre.

O UniCEUB publica as seguintes revistas:

- Revista Brasileira de Políticas Públicas

- Revista de Direito Internacional

- Universitas Arquitetura e Comunicação Social

- Universitas Ciências da Saúde

- Universitas Gestão e TI

- Universitas Humanas

- Universitas JUS

- Universitas Relações Internacionais

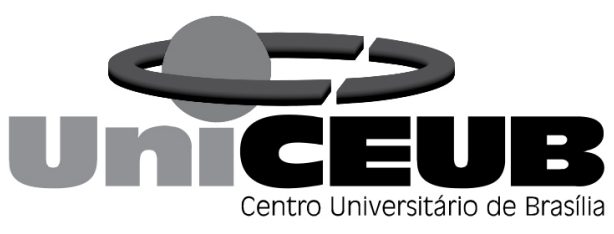


Destacar no mínimo três e no máximo seis palavraschave que representem o conteúdo do texto. O resumo e as palavras-chave deverão ter a sua tradução para o inglês.

Agradecimentos: agradecimentos a auxílios recebidos para a elaboração do trabalho deverão ser mencionados no final do artigo.

Notas: notas referentes ao corpo do artigo deverão vir no rodapé do texto.

Apêndices: apêndices podem ser empregados no caso de listagens extensivas, estatísticas e outros elementos de suporte.

Materiais gráficos: fotografias nítidas e gráficos (estritamente indispensáveis à clareza do texto) poderão ser aceitos e cada fotografia ou gráfico deverá vir no texto e além disso cada um deverá ser enviado em arquivo separado. Se as ilustrações enviadas já tiverem sido publicadas, mencionar a fonte e a permissão para reprodução.

Quadros: os quadros deverão ser acompanhados de cabeçalho que permita compreender o significado dos dados reunidos, sem necessidade de referência ao texto. Assinalar, no texto, pelo seu número de ordem, os locais onde os quadros devem ser intercalados.

Referências: as referências redigidas segundo a norma NBR 6023/2002 da Associação Brasileira de Normas Técnicas (ABNT), deverão ser apresentadas por ordem alfabética e constituir uma lista única no final do artigo. A exatidão e adequação das referências a trabalhos que tenham sido consultados e mencionados no texto do artigo são da responsabilidade do autor. Informações procedentes de comunicação pessoal, de trabalhos em andamento ou não publicados não devem ser incluídas na lista de referências, mas indicada em nota de rodapé. Não utilizar o sistema Autor data para citações. O formato utilizado pela revista é o sistema numérico, onde a citação é indicada por número sobrescrito e a referência mencionada em nota de rodapé.

Recomendações: recomenda-se que se observem as normas da ABNT referentes à apresentação de artigos em publicações periódicas (NBR 6022/2002), apresentação de citações em documentos (NBR 10520/2002), apresentação de originais (NBR 12256), norma para datar (NBR 892), numeração progressiva das seções de um documento (NBR 6024/2003) e resumos (NBR $6028 / 2003)$.

A revista se reserva o direito de efetuar nos originais alterações de ordem normativa, ortográfica e gramatical, com vistas a manter o padrão culto da língua, respeitando, porém, o estilo dos autores.

A partir de 2009, consideramos útil formular algumas sugestões (não obrigatórias) aos autores, com base nos principais motivos por recusa de artigos nos anos anteriores.

8. Responsabilidades e conflitos de interesse: A responsabilidade pelas informações e opiniões indicadas nos artigos é exclusiva dos autores. Eventuais conflitos de interesse serão de responsabilidade dos próprios autores e não do periódico.

\section{Envio dos trabalhos:}

1. Os trabalhos deverão ser enviados para a equipe editorial da revista no endereço eletrônico www.rdi.uniceub.br

2. Cada autor deve enviar declaração de responsabilidade nos termos abaixo:

“Eu XXXX certifico que participei da concepção do trabalho tornar pública minha responsabilidade pelo seu conteúdo, que não omiti quaisquer ligações ou acordos de financiamento entre os autores e companhias que possam ter interesse na publicação deste artigo."

3. Para as colaborações inéditas, cada autor deve enviar a transferência de direitos autorais nos termos abaixo:

"Eu XXXX declaro que em caso de aceitação do artigo inédito, a revista Revista Brasileira de Políticas Públicas passa a ter os direitos autorais a ele referentes. 


\section{REVISTA BRASILEIRA DE POLÍTICAS PÚBLICAS \\ V. $5, n \circ 3$}

Crimes de responsabilidade do Presidente da República

Carlos Ayres Britto

Perda de mandato parlamentar por força de condenação criminal na jurisprudência do Supremo Tribunal Federal

José Levi Mello do Amaral Júnior

Poder normativo das cortes constitucionais: o caso brasileiro

Inocêncio Mártires Coelho

Processo Legislativo Municipal

José Levi Mello do Amaral Júnior

Primeiras linhas sobre a opção político-criminal da deserção militar: a necessária contribuição das Políticas Públicas

Antonio Henrique Graciano Suxberger e Danilo Gustavo Vieira Martins

Implicações do direito ao voto aos imigrantes: ameaça à soberania nacional ou efetivação de um direito fundamental?

Juliana Cleto

Crimen, Desempleo y Actividad Económica en Chile

Sergio Zuñiga-Jara, Sofía Ruiz Campo e Karla Soria-Barreto

O impacto de diferentes tipos de repressão legal sobre as taxas de homicídio entre os estados brasileiros

Adolfo Sachsida, Mário Jorge Cardoso de Mendonça e Tito Belchior Silva Moreira

Análise dos impactos diretos e indiretos do Programa de P\&D da ANEEL no setor elétrico: diferenças com os EUA

Igor Polezi Munhz, Alessandra Cristina Santos Akkari e Neusa Maria Bastos Fernandes dos Santos

Shango Unchained? State In(Capacity), Urban Bias, and the Power Africa Initiative

Tom Brower

Levando o orçamento a sério como instrumento de controle de políticas públicas

Andre Bogossian

Estimativa de demanda pela formalização da economia informal no agreste pernambucano: uma aplicação do método de valoraçắo contingente

Monaliza de Oliveira Ferreira, Kelly Samá Lopes de Vasconcelos

Implicações do Programa Nacional de Alimentação Escolar (PNAE) na renda e organização de agricultores familiares

Nádia Kunkel Sziwelski, Carla Rosane Paz Arruda Teo, Luciara de Souza Gallina, Fabiula Grahl e Cimara Filippi Desenvolvimento das famílias e a pobreza no nordeste do Brasil

Nadja Simone Menezes Nery de Oliveira, Solange de Cassia Inforzato de Souza e Aricieri Devidé Junior Efeitos colaterais da mineração no meio ambiente

Márcio Oliveira Portella

Participação popular e acesso à informação ambiental para preservação do meio ambiente ecologicamente equilibrado

Luciano Marcos Paes

Políticas públicas para a formação e avaliação de magistrados: a contribuição da educação judicial através das escolas de magistratura

Flávio José Moreira Gonçalves

Resenhas

Simpler: the future of government, de Cass Sustein

Veyzon Campos Muniz 